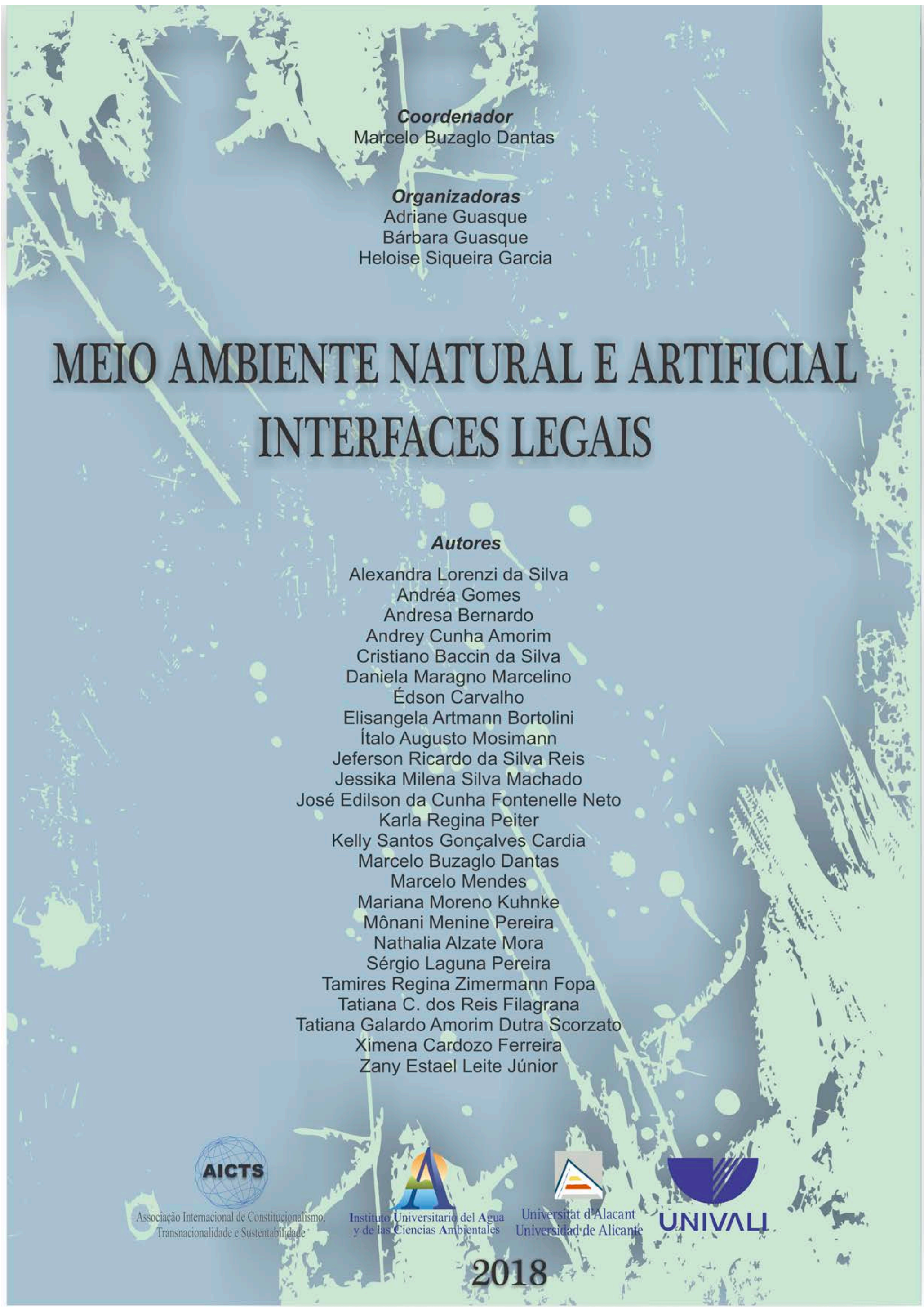




\author{
COORDENADOR \\ Marcelo Buzaglo Dantas \\ ORGANIZADORAS \\ Adriane Guasque \\ Bárbara Guasque \\ Heloise Siqueira Garcia
}

\title{
MEIO AMBIENTE NATURAL E ARTIFICIAL INTERFACES LEGAIS
}

\author{
AUTORES \\ Alexandra Lorenzi da Silva \\ Andréa Gomes \\ Andresa Bernardo \\ Andrey Cunha Amorim \\ Cristiano Baccin da Silva \\ Daniela Maragno Marcelino \\ Édson Carvalho \\ Elisangela Artmann Bortolini \\ Ítalo Augusto Mosimann \\ Jeferson Ricardo da Silva Reis \\ Jessika Milena Silva Machado \\ José Edilson da Cunha Fontenelle Neto \\ Kelly Santos Gonçalves Cardia \\ Marcelo Buzaglo Dantas \\ Marcelo Mendes \\ Mariana Moreno Kuhnke \\ Mônani Menine Pereira \\ Nathalia Alzate Mora \\ Sérgio Laguna Pereira \\ Tamires Regina Zimermann Fopa \\ Tatiana C. dos Reis Filagrana \\ Tatiana Galardo Amorim Dutra Scorzato \\ Ximena Cardozo Ferreira \\ Zany Estael Leite Júnior \\ Karla Regina Peiter
}

\section{ISBN:}

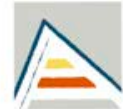

Universitat d'Alacant Universidad de Alicante

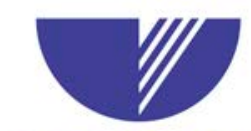

UNIVALI 
ORGANIZADORAS

Adriane Guasque

Bárbara Guasque

Heloise Siqueira Garcia

COORDENADOR

Marcelo Buzaglo Dantas

\section{Autores}

Alexandra Lorenzi da Silva Andréa Gomes

Andresa Bernardo Andrey Cunha Amorim Cristiano Baccin da Silva

Daniela Maragno Marcelino Édson Carvalho

Elisangela Artmann Bortolini Ítalo Augusto Mosimann Jeferson Ricardo da Silva Reis Jessika Milena Silva Machado José Edilson da Cunha Fontenelle Neto Karla Regina Peiter Kelly Santos Gonçalves Cardia

Marcelo Buzaglo Dantas

Marcelo Mendes

Mariana Moreno Kuhnke

Mônani Menine Pereira

Nathalia Alzate Mora

Sérgio Laguna Pereira

Tamires Regina Zimermann Fopa

Tatiana C. dos Reis Filagrana

Tatiana Galardo Amorim Dutra Scorzato Ximena Cardozo Ferreira

Zany Estael Leite Júnior

\section{Diagramação}

Heloise Siqueira Garcia

\section{Capa}

Alexandre Zarske de Mello

\section{Foto Capa}

Arroio do Engenho - Urubici/SC

Matheus Oliveira de Souza

\section{Créditos}

Este e-book foi possível por conta da Comissão Organizadora E-books/PPCJ composta pelos Professores Doutores: Paulo Márcio Cruz e Alexandre Morais da Rosa e pelo Editor Executivo Alexandre Zarske de Mello.

\section{Projeto de Fomento}

Obra com fomento da Associação Internacional de Constitucionalismo, Transnacionalidade e Sustentabilidade AICTS.

\section{AICTS}

Associação Internacional de Constitucionalismo, Transnacionalidade e Sustentabilidade

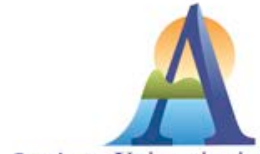

Instituto Universitario del Agua y de las Ciencias Ambientales

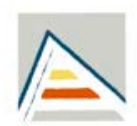

Universitat d'Alacant Universidad de Alicante

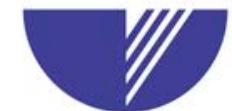

UNIVALI 


\section{SUMÁRIO}

APRESENTAÇÃO .6

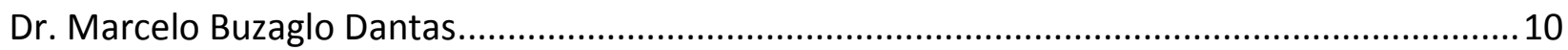

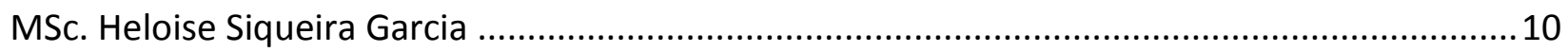

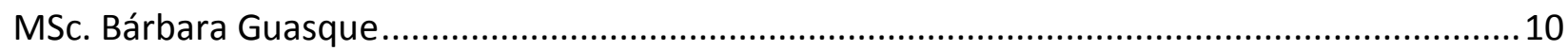

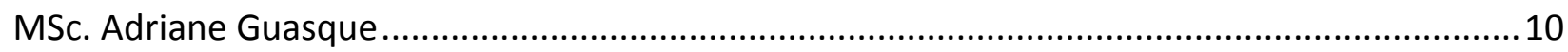

A QUESTÃO DA EXTRAFISCALIDADE NO DIREITO AMBIENTAL................................................11

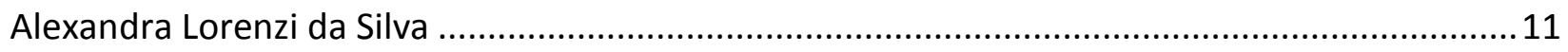

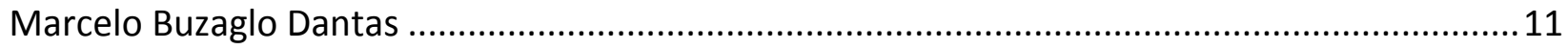

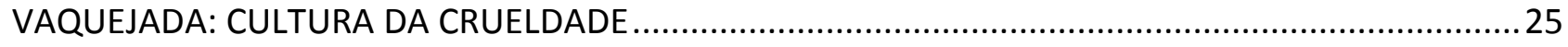

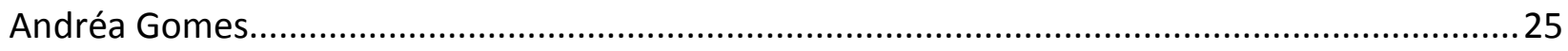

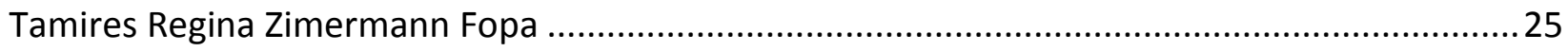

PELOS PODERES DE GRAYSKULL: O SOFRIMENTO DE PACATO E A ELETROCUSSÃO DA VAQUEJADA

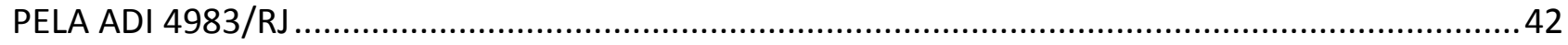

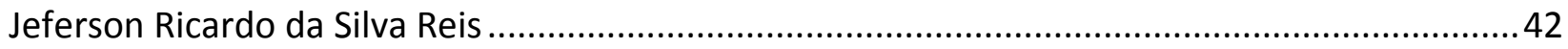

O DESAFIO DE TRANSFORMAR A EDUCAÇÃO AMBIENTAL PARTE DA CULTURA POPULAR..............67

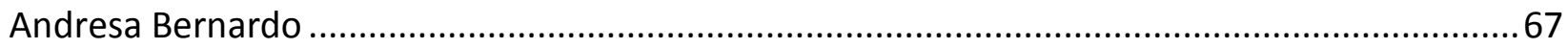

EDUCAÇÃO AMBIENTAL COMO INSTRUMENTO PARA A SUSTENTABILIDADE SOCIAL NO SISTEMA

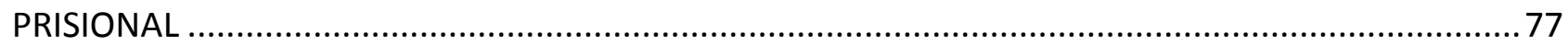

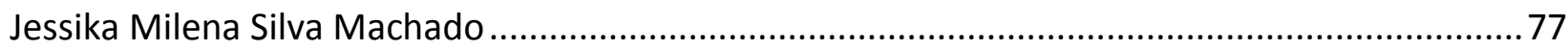

A FUNÇÃO SOCIOAMBIENTAL COMO PRESSUPOSTO PARA O EXERCÍCIO DA PROPRIEDADE URBANA A

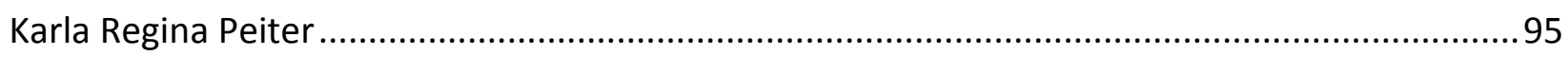

MEIO AMBIENTE PROTEGIDO E A PROPRIEDADE - A CONFLITUOSA RELAÇÃO ENTRE DIREITOS FUNDAMENTAIS E O LEADING CASE PORTUGUÊS “QUINTA DO TAIPAL" .................................107

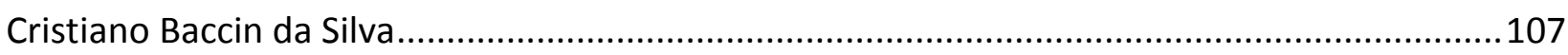

OPERAÇÕES URBANAS CONSORCIADAS E DESENVOLVIMENTO URBANO: ASPECTOS POSITIVOS E

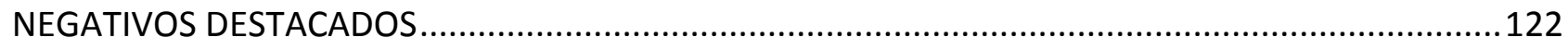

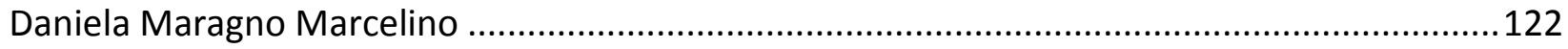

O DIREITO FUNDAMENTAL AO DESENVOLVIMENTO URBANO SUSTENTÁVEL E OS LIMITES AO

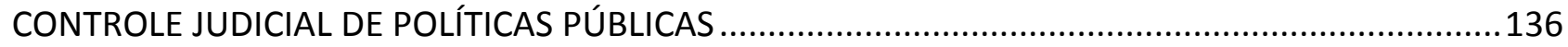

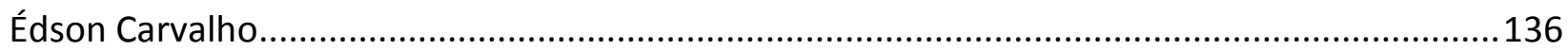

O PRINCÍPIO DO NÃO RETROCESSO AMBIENTAL COMO GARANTIA DO MÍNIMO EXISTENCIAL .... 151

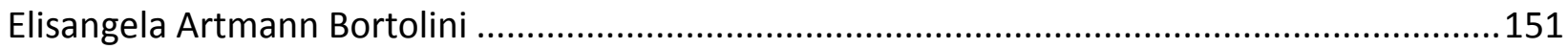


A PROTEÇÃO LEGAL DA VEGETAÇÃO DE RESTINGA PARA FINS DE CARACTERIZAÇÃO COMO ÁREA DE PRESERVAÇÃO PERMANENTE À LUZ DO NOVO CÓDIGO FLORESTAL BRASILEIRO (LEI

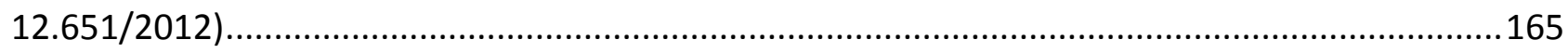

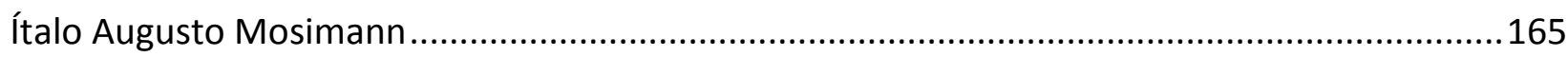

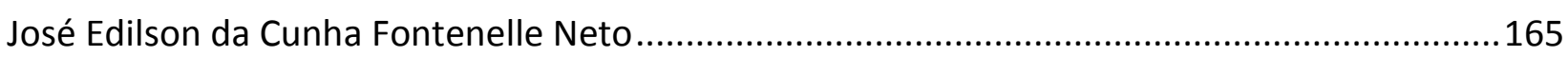

OS LOTEAMENTOS FECHADOS E A QUALIFICAÇÃO NO SISTEMA REGISTRAL BRASILEIRO ..............185

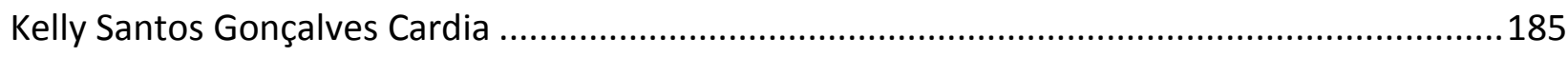

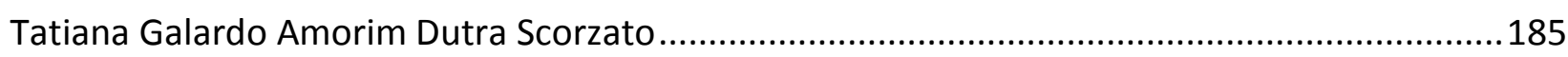

O PATRIMÔNIO HISTÓRICO COMO DIREITO TRANSNACIONAL À CULTURA ..................................200

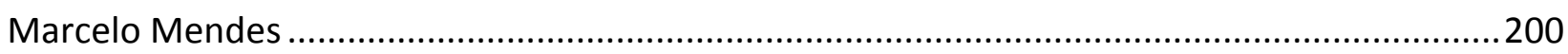

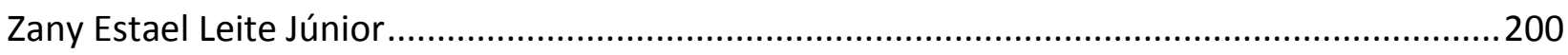

EL MODELO AGROINDUSTRIAL DE PRODUCCIÓN DE ALIMENTOS POST-MODERNO Y SUS PROBLEMAS SOCIOAMBIENTALES. HACIA UN CAMBIO DE PARADIGMA ..................................215

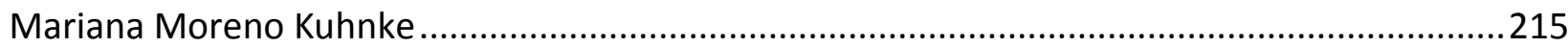

A CONCESSÃO DE USO ESPECIAL PARA FINS DE MORADIA NA COMPETÊNCIA LEGISLATIVA E OS

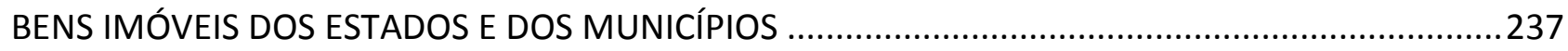

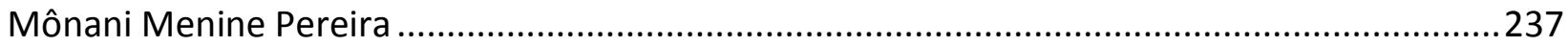

LA PARTICIPACIÓN CIUDADANA COMO ELEMENTO NECESARIO PARA UNA GESTIÓN SOSTENIBLE DEL RECURSO HÍDRICO. ACERCAMIENTO A LAS LEGISLACIONES BRASILEÑA Y COLOMBIANA ......260

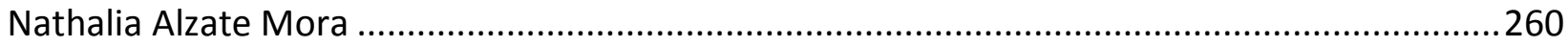

O STATUS JURÍDICO DIFERENCIADO DA LEI DO PLANO DIRETOR .................................................274

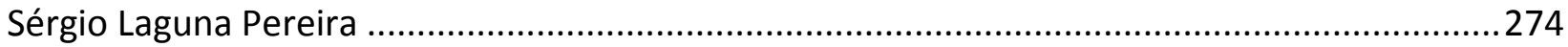

OS DESASTRES AMBIENTAIS: DICOTOMIA ENTRE OS FATORES NATURAIS E ANTROPOGÊNICOS.. 295

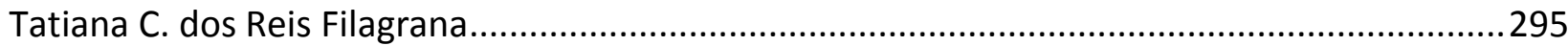

SISTEMAS URBANOS DE DRENAGEM SUSTENTÁVEL COMO ALTERNATIVAS DE CONTROLE DE

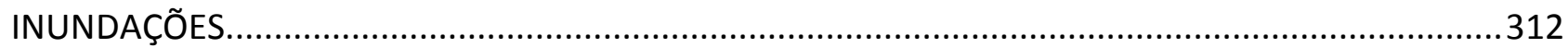

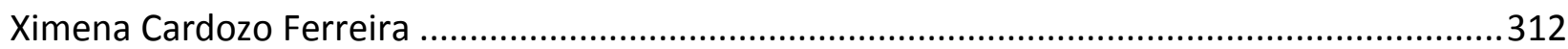

A RELATIVIZAÇÃO DA COISA JULGADA EM MATÉRIA AMBIENTAL...............................................330

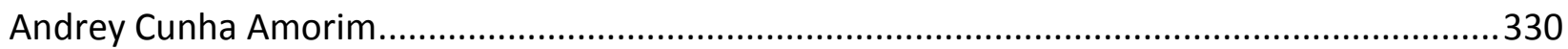




\section{APRESENTAÇÃO}

Os Cursos de Mestrado e Doutorado em Ciência Jurídica do Programa de Pós-Graduação Stricto Sensu da Universidade do Vale do Itajaí possuem como característica intrínseca a produção científica de qualidade corroborada sempre que possível com a internacionalização, de modo que a troca de conhecimento entre as teorias estudadas no Programa possa também ser ventiladas em programas de instituições não só Nacionais como Internacionais. Acredita-se que isso possibilita o engrandecimento e melhor disseminação do conhecimento.

Nesse diapasão, a produção realizada nos cursos busca sempre o aprimoramento científico de conteúdos de relevância mundial, entre estes, um dos mais relevantes, foco de duas linhas de pesquisa do curso de Mestrado diz respeito ao Direito Ambiental e à Sustentabilidade e suas interfaces, quais sejam a linha "Direito Ambiental, Transnacionalidade e Sustentabilidade" e a linha "Direito, Desenvolvimento Urbano e Meio Ambiente".

A partir de tais prerrogativas, é com grande satisfação que apresentamos a presente obra que reflete todas essas características intrínsecas buscadas pelo Programa e vem contribuir para a pesquisa científica nacional e internacional sobre as interfaces legais do Meio Ambiente Natural e Artificial.

A obra é composta por artigos de discentes do Curso de Mestrado em Ciência Jurídica do Programa de Pós-Graduação Stricto Sensu da Universidade do Vale do Itajaí e seus temas estão interligados com as linhas de pesquisa Direito, Desenvolvimento Urbano e Meio Ambiente dos Cursos de Mestrado da Universidade do Vale do Itajaí.

Importante ressaltar, ainda, que esta obra só teve sua realização possível devido aos fomentos e apoios garantidos pela Associação Internacional de Constitucionalismo, Transnacionalidade e Sustentabilidade - AICTS (https://www.aicts.com.br/).

As discussões tratadas em cada um dos capítulos são, então, reflexo do tema proposto e exarado no título do livro "MEIO AMBIENTE NATURAL E ARTIFICIAL INTERFACES LEGAIS".

Nesse ínterim, o primeiro capítulo escrito por Alexandra Lorenzi da Silva e pelo Professor Marcelo Buzaglo Dantas, trata da extrafiscalidade no Direito AMBIENTAL, que busca compreender o Direito Tributário Ambiental e a questão da extrafiscalidade, verificando as suas principais características, a clássica tripartição dos tributos, as funções fiscal, parafiscal e extrafiscal e as 
questões da capacidade tributária.

Na sequência, Andréa Gomes e Tamires Regina Zimermann Fopa trabalham com um tema bastante atual nas discussões judiciais brasileiras, que é a Vaquejada, realizando-se uma análise da Lei da Vaquejada como patrimônio cultural e a sua possível colisão com outros direitos ambientais, averiguando frente a decisão de inconstitucionalidade declarada pelo Supremo Tribunal Federal.

Na mesma esteira, no capítulo seguinte, Jeferson Ricardo da Silva Reis trabalha sobre o tema da Vaquejada fazendo uma interessante análise a partir do famoso desenho infantil "HeMan", onde o autor busca contextualizar a vaquejada como prática desportiva nascida da busca e pega do boi, que era criado livremente nos campos abertos e não demarcados do semiárido nordestino, para depois descrever que a dupla de vaqueiro de hoje, montada em seus cavalos, não têm como desafio apenas o boi indômito, mas os campos inóspitos de um alta Corte e de um Ministério Público encastelados, por vezes tão desertos quanto o sertão nordestino, porém sem o charme do juazeiro ou do umbuzeiro.

O quarto capítulo, escrito por Andresa Bernardo, trabalha com o tema da educação ambiental, focando a pesquisa no desafio de transformar a educação ambiental como parte da chamada cultura popular.

Na mesma linha de discussão, Jessila Milena Silva Machado trata sobre a Educação Ambiental a partir da análise desta como instrumento para a sustentabilidade social no sistema prisional.

No sexto capítulo, Karla Regina Peiter trabalha com a função socioambiental como pressuposto para o exercício da propriedade urbana, apresentando a evolução conceitual do direito de propriedade, deixando ele de estar apenas condicionado ao interesse individual, tornando-se um direito-dever, objeto de diversas restrições.

Nesse diapasão, Cristiano Baccin da Silva escreve o sétimo capítulo com o tema do meio ambiente protegido versus propriedade, analisando a conflituosa relação entre direitos fundamentais e o leading case português "Quinta do Taipal". A partir deste caso emblemático português que envolve, de um lado, o direito à preservação e proteção de um meio ambiente compreendido como um habitat natural, e do outro, o direito dos proprietários dessa área (rural) em dar a ela o devido aproveitamento econômico, e teve um desfecho judicial que criou um 
importante precedente para as demais questões envolvendo bens de mesma natureza e importância, o autor desenrola a discussão destes dois temas conflituosos na esfera ambiental.

No oitavo capítulo Daniela Maragno Marcelino trabalha com o tema "Operações Urbanas consorciadas e desenvolvimento urbano: aspectos positivos e negativos destacados", traçando como foco de pesquisa o destaque dos aspectos positivos e negativos da utilização do instituto das operações urbanas consorciadas nos processos de recuperação de áreas urbanas degradadas.

Após, no nono capítulo, Édson Carvalho fala sobre o direito fundamental ao desenvolvimento urbano sustentável e os limites do controle judicial de políticas públicas, que busca fomentar a reflexão sobre a formulação de políticas públicas e a problemática envolvendo a eficácia do direito fundamental ao desenvolvimento urbano sustentável, analisando as premissas a serem observadas para a definição de política pública apta a enfrentar os problemas públicos com ela relacionados, bem como o órgão estatal que se encontra em melhores condições para desempenhar essa tarefa, quer sob o prisma constitucional, quer sobre a competência técnica.

O décimo capítulo, de autoria de Elisangela Artmann Bortolini, trata do Princípio do não retrocesso ambiental como garantia do mínimo existencial, buscando analisar o princípio do não retrocesso ambiental com ênfase na garantia do mínimo existencial, com base em discussões já alavancadas por estudiosos da temática.

Na sequência Ítalo Augusto Mosimann e José Edilson da Cunha Fontenelle Neto trabalham com a proteção legal da vegetação de restinga para fins de caracterização como Área de Preservação Permanente à luz do Novo Código Florestal Brasileiro, Lei 12.651 de 2012, visando analisar as interpretações existentes acerca da proteção legal da vegetação de restinga para fins de caracterização como área de preservação permanente, realizando exame descritivo sobre o tema pesquisado a partir de análise legal e jurisprudencial acerca da evolução normativa e doutrinária da matéria.

O décimo segundo capítulo Kelly Santos Gonçalves Cardia e Tatiana Galardo Amorim Dutra Scorzato tratam do tema "Loteamento Fechados" a partir da sua qualificação no sistema registral brasileiro, buscando refletir sobre a possibilidade de os Registros de Imóveis recepcionarem uma nova forma de ordenação do solo urbano, intitulada de loteamento fechado ou loteamento de acesso controlado, e o seu ingresso no Sistema Registral Brasileiro.

Marcelo Mendes e Zany Estael Leite Júnior, na sequência, tratam com o tema "Patrimônio 
Histórico como Direito Transnacional à cultura" objetivando fazer uma breve análise dogmática e crítica dos sistemas espanhol e brasileiro de proteção e promoção ao patrimônio cultural, e a partir da premissa resultante trazer algumas elucubrações sobre o fenômeno da transnacionalidade.

Mariana Moreno Kuhnke, mestranda da Universidade de Alicante - ES, trata da temática da agroindústria, trabalhando com o modelo agroindustrial de produção de alimentos pós-moderno e seus problemas socioambientais, buscando uma discussão para mudança do paradigma atual.

O décimo quinto capítulo, de autoria de Mônani Menine Pereira, trata da concessão de uso especial para fins de moradia na competência legislativa e os bens imóveis dos estados e dos municípios, trazendo breve reflexão acerca da regulamentação da concessão de uso especial para fins moradia e a competência legislativa em face dos imóveis dos Estados e dos Municípios.

Nathalia Alzate Mora, mestranda da Universidade Externado da Colômbia e da Universidade de Alicante - Espanha, trata sobre a participação cidadã como elemento necessário para uma gestão sustentável dos recursos hídricos, estabelecendo relações entre as legislações brasileira e colombiana.

Na sequência, Sérgio Laguna Pereira trata do status jurídico diferenciado da Lei do Plano diretor, buscando demonstrar qual o status jurídico-normativo do plano diretor, e de que modo ele se inter-relaciona com as demais leis municipais de direito urbanístico.

O décimo oitavo capítulo, escrito por Tatiana dos Reis Filagrana, trata dos desastres ambientais a partir da dicotomia entre os fatores naturais e antropogênicos, analisando de uma forma mais precisa a ocorrência dos desastres e a ligação destes com os atos praticados pela sociedade.

Ximena Cardozo Ferreira, autora do décimo nono capítulo, trabalha com os sistemas urbanos de drenagem sustentável como alternativas de controle de inundações, buscando apresentar uma visão geral de algumas tipologias mais conhecidas e utilizadas ao redor do mundo do que aqui chamaremos de Sistemas Urbanos de Drenagem Sustentável (SUDS), apontando para sua possível contribuição à sustentabilidade das cidades.

E, por fim, mas não menos importante, Andrey Cunha Amorim, trabalha com o tema da relativização da coisa julgada em matéria ambiental, apresentando uma análise sobre a possibilidade da relativização da coisa julgada material quando o julgado versa sobre matéria 
ambiental.

Pelo brevemente exposto nesta apresentação já se pode perceber que o conteúdo do presente livro possui uma discussão valiosíssima, relacionando os temas de maior importância na área do direito atualmente, o que nos deixa extremamente felizes e honrados pela coordenação e organização desta produção, que ela repercuta no mundo acadêmico da mesma maneira.

Itajaí, setembro de 2018.

Dr. Marcelo Buzaglo Dantas

MSc. Heloise Siqueira Garcia

MSc. Bárbara Guasque

MSc. Adriane Guasque 


\title{
A QUESTÃO DA EXTRAFISCALIDADE NO DIREITO AMBIENTAL
}

\author{
Alexandra Lorenzi da Silva ${ }^{1}$ \\ Marcelo Buzaglo Dantas ${ }^{2}$
}

\section{INTRODUÇÃO}

Desfrutar de um meio ambiente equilibrado é essencial à sadia qualidade de vida, não apenas dessa geração como das próximas. Partiu-se dessa premissa para a realização do presente trabalho, assim como da ideia de que meio ambiente é bem jurídico a ser tutelado pelas mais diversas áreas do direito, inclusive, o Direito Tributário.

Pode-se afirmar, então, que o Direito Tributário, além de ser um instrumento arrecadatório, também funciona como uma ferramenta de atuação estatal na ordem socioeconômica e ambiental. Isso porque a repercussão econômica do tributo interfere na equação custo-benefício - ela estimula ou desestimula condutas dos contribuintes. Ao uso interventivo, através das espécies tributárias, denominou-se função extrafiscal.

O Direito Tributário, portanto, está a serviço dos objetivos fundamentais do Brasil, dos quais, em especial, se destaca o desenvolvimento sustentável e, em especial, a imperiosa necessidade de proteção ao meio ambiente (artigo $3^{\circ}$, inciso III e artigo 225, ambos da Constituição). Nesse contexto, surge o Direito Tributário Ambiental como um instrumento de proteção ambiental tanto por meio de tributos fiscais, quanto parafiscais e extrafiscais.

Se o controle vai ser realizado sobre a tributação extrafiscal ambiental é importante saber identificar a tributação extrafiscal, caso contrário o controle pode não ser realizado. A questão é: quando se está diante de tributação extrafiscal? Esse problema decorre, dentre outros fatores, da dificuldade de se trabalhar com as finalidades dos tributos, sobretudo os impostos, cuja finalidade sequer compõe sua definição tradicional. Ainda que o imposto represente uma receita

\footnotetext{
${ }^{1}$ Aluna da disciplina Meio Ambiente Natural e Artificial: Interfaces Legais, do curso de Mestrado em Ciência Jurídica, Linha de Pesquisa: Direito, Desenvolvimento Urbano e Meio Ambiente, da Universidade do Vale do Itajaí - UNIVALI, em Florianópolis - SC. E-mail: alexandra@tjsc.jus.br

${ }^{2}$ Professor Orientador da disciplina Meio Ambiente Natural e Artificial: Interfaces Legais, do curso de Mestrado em Ciência Jurídica, Linha de Pesquisa: Direito, Desenvolvimento Urbano e Meio Ambiente, da Universidade do Vale do Itajaí - UNIVALI, em Florianópolis - SC.
} 
importantíssima ao Estado, e por mais que a própria Lei $4.320 / 1964^{3}$ também o defina como receita, tradicionalmente ele é visto apenas sob a perspectiva de se tratar de um tributo cuja materialidade da norma de incidência não tem ligação com ação estatal.

Desta forma, o objetivo principal da pesquisa é compreender o Direito Tributário Ambiental e a questão da extrafiscalidade. Os objetivos específicos são verificar as principais características do Direito Tributário Ambiental, estudar a clássica tripartição dos tributos, analisando as funções fiscal, parafiscal e extrafiscal, e identificar a questão da capacidade tributária. A metodologia utilizada é a revisão de literatura, através da pesquisa bibliográfica.

\title{
1. O DIREITO TRIBUTÁRIO AMBIENTAL
}

Enquanto o plano semântico abre o Direito para as significações, o plano pragmático, ademais disso, impõe o enfoque sob a ótica da função e da finalidade do instituto jurídico em questão. E é principalmente daí que o Direito Tributário Ambiental surge.

Em síntese, pode-se definir o Direito Tributário como sendo a disciplina jurídica do tributo 4 . Já o Direito Ambiental é composto pelas normas jurídicas voltadas à proteção do meio ambiente. Segundo Paulo Affonso Leme Machado 5 :

\begin{abstract}
O Direito Ambiental é um Direito sistematizador, que faz a articulação da legislação, da doutrina e da jurisprudência concernentes aos elementos que integram o ambiente. Procura evitar o isolamento dos temas ambientais e sua abordagem antagônica. Não se trata mais de construir um Direito das águas, um Direito da atmosfera, um Direito do solo, um Direito florestal, um Direito da fauna ou um Direito da biodiversidade. O Direito Ambiental não ignora o que cada matéria tem de específico, mas busca interligar estes temas com a argamassa da identidade dos instrumentos jurídicos de prevenção e de reparação, de informação, de monitoramento e de participação.
\end{abstract}

Do encontro entre a necessidade e o instrumento, surge o Direito Tributário Ambiental que, segundo Regina Helena Costa ${ }^{6}$ :

[...] pode ser singelamente conceituada como o emprego de instrumentos tributários para gerar os recursos necessários à prestação de serviços públicos de natureza ambiental (aspecto fiscal ou arrecadatório), bem como para orientar o comportamento dos contribuintes à proteção do meio ambiente (aspecto extrafiscal ou regulatório).

\footnotetext{
${ }^{3}$ BRASIL. Lei n. 4.320, de 17 de março de 1964. Disponível em http://www.planalto.gov.br/ccivil_03/leis/L4320.htm. Acesso em 2017.

${ }^{4}$ AMARO, Luciano. Direito tributário brasileiro. 13. ed. São Paulo: Saraiva, 2007. p. 02.

${ }^{5}$ MACHADO, Paulo Affonso Leme. Direito ambiental brasileiro. 12. ed. rev. atual. e ampl. São Paulo: Malheiros, 2004. p. 139-140.

${ }^{6}$ COSTA, Regina Helena. Apontamentos sobre a tributação ambiental no Brasil. In: TÔRRES, Heleno Taveira. Direito tributário ambiental. São Paulo: Malheiros, 2005. p. 313.
} 
O que diferencia as normas tributárias ambientais das demais normas tributárias é a sua finalidade. Por exemplo, o imposto sobre produtos industrializado ambiental tem a mesma estrutura da norma de incidência do imposto sobre produtos industrializados sem essa função. 0 que distingue um do outro é o seu conteúdo e, principalmente, sua finalidade.

A dogmática nacional tem vasto campo de produção acerca da análise do plano sintático das regras tributárias. A Teoria Geral do Direito Tributário, de Alfredo Augusto Becker ${ }^{7}$, a Hipótese de Incidência Tributária, de Geraldo Ataliba ${ }^{8}$, e a Regra-Matriz de Incidência Tributária, de Paulo de Barros Carvalho ${ }^{9}$, sem excluir outros, demonstram o desenvolvimento da ciência do Direito Tributário nesse campo.

No entanto, ainda são escassos os estudos acerca da função e finalidade tributária. No Brasil, até então, estudou-se muito os tributos, mas pouco a tributação. E no Direito Tributário Ambiental, além de estudar o tributo, estuda-se a tributação, enquanto política pública voltada à proteção ao meio ambiente.

\section{FISCALIDADE, PARAFISCALIDADE E EXTRAFISCALIDADE}

Dentre outras perspectivas, o direito também é visto como um instrumento de regulação de condutas intersubjetivas. Mediante a sua juridicização, o Estado impõe aos destinatários comportamentos positivos, negativos ou permissivos, em vista a atender determinadas finalidades. Normas jurídicas têm funções e finalidades, um campo ainda pouco estudado pela ciência do direito. José Souto Maior Borges ${ }^{10}$ escreve:

As normas de estrutura acabam por regular, também elas, determinados comportamentos. Um órgão, enquanto centro de imputação normativa, não pode por si só produzir normas. Mesmo quando destinatário expresso de uma competência, por hipótese, tributária, não pode exercitá-la senão pela intermediação dos seus titulares e agentes. Logo as normas de estrutura regulam comportamentos dos titulares e agentes dos órgãos.

Tradicionalmente o Direito Tributário é um instrumento que tem servido ao Estado para garantir os ingressos financeiros, com os quais o mesmo faz frente ao pagamento de suas despesas. Esse subsistema passou a ganhar maior destaque a partir do momento em que a Administração Pública percebeu que era mais vantajoso arrecadar em espécie a confiscar o

\footnotetext{
${ }^{7}$ BECKER, Alfredo Augusto. Teoria geral do Direito Tributário. 4. ed. São Paulo: Noeses, 2007.

${ }^{8}$ ATALIBA, Geraldo. Hipótese de incidência tributária. 6. ed. São Paulo: Malheiros, 2004.

${ }^{9}$ CARVALHO, Paulo de Barros. Teoria da norma tributária. 5. ed. São Paulo: Quartier Latin do Brasil, 2009.

${ }^{10}$ BORGES, José Souto Maior. Teoria geral da isenção tributária. 3. ed. São Paulo: Malheiros, 2007. p. 377.
} 
patrimônio de seus súditos. Com o passar do tempo, aperfeiçoou-se este poderoso instrumento de obtenção de ingressos financeiros. ${ }^{11}$

No entanto, abastecer o erário não é a única finalidade da tributação, pois esta também pode ser utilizada para atender a outras finalidades estatais. A esse fenômeno, de utilização da tributação com fins diversos do arrecadatório, se atribuiu o nome de função extrafiscal do tributo. Fiscalidade, extrafiscalidade e parafiscalidade representam metas a serem alcançados pela ação estatal de impor tributos. ${ }^{12}$

Trata-se de uma classificação cujo critério é a finalidade da tributação: tributação instituída para arrecadar; induzir condutas (positiva ou negativamente); ou abastecer de recursos entidade da Administração Pública indireta ou paraestatal.

Luís Eduardo Schoueri ${ }^{13}$, por sua vez, apresenta proposta distinta ao classificar a finalidade da norma tributária. Segundo o autor, as normas tributárias teriam função simplificadora, extrafiscal (divididas entre as extrafiscais em sentido estrito e as de política social) e as normas de função fiscal.

Para Luís Eduardo Schoueri ${ }^{14}$, portanto, a extrafiscalidade, que está ao lado das funções simplificadora e fiscal, é gênero, das quais são espécies a norma indutora (extrafiscalidade em sentido estrito) e as normas de política social:

O gênero "extrafiscalidade" inclui os casos não vinculados nem à distribuição eqüitativa da carga tributária, nem à simplificação do sistema tributário. No dizer de José Marcos Domingues de Oliveira, a tributação extrafiscal é aquela orientada para fins outros que não a captação de dinheiro para o Erário, tais como a redistribuição de renda e da terra, a defesa da indústria nacional, a orientação dos investimentos para setores produtivos ou mais adequados ao interesse público, a promoção do desenvolvimento regional ou setorial etc. Inclui, neste sentido, além de normas com função indutora (que seria a extrafiscalidade em sentido estrito, como se verá abaixo), outras que também se move por razões não fiscais, mas desvinculadas da busca do impulsionamento econômico por parte do Estado.

A classificação que toma por objeto a finalidade da tributação é realizada a partir da prevalência de uma função sobre a outra, em um determinado tributo. Vale lembrar que, por mais que determinadas espécies tributárias tenham maior aptidão fiscal ou extrafiscal, por exemplo,

\footnotetext{
${ }^{11}$ HARADA, Kiyoshi. Direito financeiro e tributário. 14. ed. São Paulo: Atlas, 2005. p. 309-310.

${ }^{12}$ CARVALHO, Paulo de Barros. Curso de Direito Tributário. 24. ed. São Paulo: Saraiva, 2012. p. 289-294.

${ }^{13}$ SCHOUERI, Luís Eduardo. Normas tributárias indutoras e intervenção econômica. Rio de Janeiro: Forense, 2005. p. 32-33.

${ }^{14}$ SCHOUERI, Luís Eduardo. Normas tributárias indutoras e intervenção econômica. Rio de Janeiro: Forense, 2005. p. 33.
} 
nenhuma espécie será pura, como observa Paulo de Barros Carvalho ${ }^{15}$, afirmando que não existe "entidade tributária que se possa dizer pura, no sentido de realizar tão só a fiscalidade, ou, unicamente, a extrafiscalidade. Os dois objetivos convivem, harmônicos, na mesma figura impositiva, sendo apenas lícito verificar que, por vezes, um predomina sobre o outro".

Fiscal é o tributo cuja função é arrecadar. Parafiscal é o tributo cuja função é abastecer os cofres de entidades da Administração Pública indireta ou paraestatal, para que elas possam cumprir seu mister. Por fim, extrafiscal é o tributo cuja função é diversa da arrecadatória. Essa classificação leva em conta a finalidade do tributo e é vista, por parte da doutrina do Direito Tributário, como matéria da ciência das finanças. Ricardo Berzosa Saliba ${ }^{16}$, comentando a classificação que toma os tributos como fiscais, extrafiscais e parafiscais, escreve:

Ainda que se admitindo tais identificações para não desmerecê-las por completo, entendemos que elas no máximo se aplicam sob a ótica do Direito Financeiro e não Tributário, quando da organização de gastos públicos na medida do quanto ingressou a título de receita pública e seu efetivo reflexo na sociedade, e no que diz respeito ao nosso estudo, no direcionamento em face da defesa e preservação do meio ambiente. Trata-se de signos estranhos quer à estrutura da norma tributária, quer à motivação constitucional.

No entanto, é difícil conceber o uso do Direito, assim como seu efeito, como algo totalmente alheio ao próprio direito. Ademais, a criação do Direito é um fenômeno jurídico, que se realiza de acordo com as normas de competência. ${ }^{17}$

O tributo será fiscal, parafiscal ou extrafiscal conforme sua organização jurídica desvendar finalidade de arrecadar, de abastecer de receita tributária pessoa jurídica distinta do Ente Político que instituiu o tributo, ou quando tiver por fim objetivo distinto da arrecadação, como a orientação de condutas ambientalmente adequadas, por exemplo. Sendo assim, o aumento de um tributo visando desestimular conduta não pode ser tomado como um fenômeno fora do jurídico.

Pelo contrário, a criação de tributo é intensamente regulada pela Constituição de 1988 e se insere no âmbito das normas de competência. Ocorre que, as normas de competência trazem para o universo jurídico os conceitos de outros subsistemas sociais. Talvez, por isso, parte da doutrina tributária coloque a função do tributo fora do contexto jurídico. ${ }^{18}$

\footnotetext{
${ }^{15}$ CARVALHO, Paulo de Barros. Curso de Direito Tributário. 24. ed. São Paulo: Saraiva, 2012. p. 291.

${ }^{16}$ SALIBA, Ricardo Berzosa. Fundamentos do Direito Tributário Ambiental. São Paulo: Quartier Latin, 2005. p. 271.

${ }^{17}$ MACHADO, Hugo de Brito. Curso de Direito Tributário. 25. ed. rev. atual. e ampl. São Paulo: Malheiros, 2004. p. 79.

${ }^{18}$ MACHADO, Hugo de Brito. Curso de Direito Tributário. 25. ed. rev. atual. e ampl. São Paulo: Malheiros, 2004. p. 80.
} 
James Marins e Jeferson Teodorovicz ${ }^{19}$, comentando a escassez de estudos em torno da extrafiscalidade, escrevem:

[...] se o Direito Tributário pode ser entendido enquanto instrumento para a adoção dessas políticas, também aos estudiosos do Direito Tributário interessa conhecer as novas concepções que vão surgindo, possibilitando assim o progressivo avanço e atualidade da matéria frente às inovações trazidas da realidade e que logo estarão impressas em seus ordenamentos.

Inegável, portanto, a juridicidade de tal tema. Sobre a função fiscal, Simone Martins Sebastião ${ }^{20}$ escreve: "[...] a finalidade precípua da instituição de tributos é a fiscal ou arrecadatória, consiste na transferência de recursos financeiros do particular para o Estado, com vistas à consecução dos objetivos eleitos pelo Poder Público e o cumprimento de sua finalidade institucional (bem-estar comum e paz social)."

Criar um Direito Tributário para arrecadar ou para induzir conduta é, no mínimo, exercitar a competência tributária constitucionalmente prevista, isso sem contar os objetivos fundamentais do Brasil, que vinculam toda a atuação estatal.

\section{A QUESTÃO DA CAPACIDADE TRIBUTÁRIA}

As primeiras Constituições nacionais foram concebidas em pleno liberalismo econômico e, por isso, se limitaram a estruturar o Estado e a conceder alguns poucos direitos, na maioria, relativos à liberdade, à igualdade e à propriedade. Com o Estado do bem-estar social uma série de direitos e garantias fundamentais passaram a ser inseridos nas Constituições. Tal forma de Estado se caracterizou pelo intervencionismo, pela instituição de sistemas previdenciários, pela tutela aos direitos à saúde, educação, segurança etc., e nesse contexto está inserida a Constituição de 1988, que criou muitos deveres ao Estado. ${ }^{21}$

As constituições atuais, incluindo a brasileira, de 1988, não podem ser vistas como cartas de boas intenções; pelo contrário, já que é inegável sua força normativa. Ocorre, porém, que saúde, educação, segurança, previdência, lazer, são direitos que, para serem garantidos, necessitam de atuação concreta do Estado - eis que as promessas da modernidade somente serão cumpridas mediante a implantação de políticas públicas, as quais exigem o dispêndio de recursos

\footnotetext{
${ }^{19}$ MARINS, James; TEODOROVICZ, Jeferson. Extrafiscalidade socioambiental. Revista Tributária e de Finanças Públicas, São Paulo, ano 18, n. 90, p. 73-123, jan./fev. 2010. p. 108.

${ }^{20}$ SEBASTIÃO, Simone Martins. Tributo ambiental: extrafiscalidade e função promocional do Direito. Curitiba: Juruá, 2007. p. 132133.

${ }^{21}$ SOUZA, Carlos Frederico Marés de. A função social da terra. Porto Alegre: Sergio Fabris Editor, 2003. p. 15-20.
} 
públicos que, no Estado moderno, em sua maioria são de natureza tributária. ${ }^{22}$

O Estado moderno vê no tributo a principal forma de se financiar. No Brasil, esse fenômeno fica ainda mais nítido com a reforma estatal realizada, dentre outras normas, pela Emenda Constitucional 19/1998. Tem-se, com isso, uma diminuição do tamanho do Estado, notadamente em relação à exploração direta de atividade econômica. O tributo passa a figurar praticamente sozinho como o grande instrumento de financiamento estatal. ${ }^{23}$

Luís Eduardo Schoueri ${ }^{24}$ escreve:

Apenas para que se complete o quadro da evolução dos modelos de financiamento do Estado, importa ressaltar que o agigantamento do Estado passou a ser questionado quando se passou a considerar que seu crescimento já não era garantia de melhor distribuição de renda ou de eficiência econômica. Estes objetivos, conquanto permanentes, não se alcançam sem o concurso da iniciativa privada, a quem há de ser reservado um espaço para atuação. O Estado Fiscal social cede espaço para o Estado do século XXI, denominado “Estado Democrático e Social de Direito" (ou Estado Subsidiário, ou Estado da Sociedade de Risco, ou Estado de Segurança). Marcam-no uma diminuição de tamanho e restrição a seu intervencionismo. É Estado Fiscal, ainda de maneira mais marcante, uma vez que as privatizações diminuem os recursos provenientes de seus esforços.

Sob o ponto de vista de geração de riquezas, o Estado diminuiu seu tamanho. Empresas estatais foram alienadas ao setor privado, o mesmo aconteceu em relação aos serviços públicos com aptidão para geração de riquezas, os quais, em grande parte, foram concedidos ao setor privado. Fernando Facury Scaff e Lise Vieira da Costa Tupiassu ${ }^{25}$ identificam esse fenômeno:

No âmbito político estamos frente a uma transformação do modelo de Estado, que antes era de bem-estar e hoje é marcado pelo neoliberalismo. A declarada intenção é reduzir o tamanho do Estado, a fim de que sua participação econômica ocorra muito mais pela atuação sobre o domínio econômico, como agente normatizador de mercados, do que como agente de produção/comercialização de bens ou serviços, ao atuar no domínio econômico. O neoliberalismo, portanto, necessita de manutenção do Estado fiscalizador, a fim de que as regras do jogo econômico sejam asseguradas e o "livre mercado" possa atuar. Resta saber, atuar em prol de quem?

Atualmente se não é dada ao Estado a exploração direta de atividade econômica (caput, do artigo 173), a não ser em caráter excepcional, da mesma forma é vedado o confisco de bens particulares (inciso IV, do artigo 150). Assim, a receita tributária ganha papel de destaque nas finanças públicas. O tributo é, portanto, o grande instrumento das finanças estatais do Estado

\footnotetext{
${ }^{22}$ MINGATI, Vinícius Secafen. Reclamação (neo)constitucional: precedentes, segurança jurídica e os juizados especiais. Brasília: Gazeta Jurídica, 2013. p. 11

${ }^{23}$ MINGATI, Vinícius Secafen. Reclamação (neo)constitucional: precedentes, segurança jurídica e os juizados especiais. Brasília: Gazeta Jurídica, 2013. p. 11

${ }^{24}$ SCHOUERI, Luís Eduardo. Direito tributário. 3. ed. São Paulo: Saraiva, 2013. p. 30.

${ }^{25}$ SCAFF, Fernando Facury; TUPIASSU, Lise Vieira da Costa. Tributação e políticas públicas: o ICMS ecológico. In: TÔRRES, Heleno Taveira (Org.). Direito tributário ambiental. São Paulo: Malheiros, 2005. p. 725.
} 
contemporâneo, servindo para fazer frente a boa parte das despesas estatais, dentre elas a realização dos direitos e garantias fundamentais. Daí a relevância da função fiscal do tributo. ${ }^{26}$

A função parafiscal também está relacionada à atividade de arrecadação de recursos. Sob esse prisma, tributo parafiscal igualmente é fiscal. A propósito, a dimensão fiscal dos tributos parafiscais serve para demonstrar que a classificação tríade da função dos tributos se faz por preponderância de uma finalidade sobre outra. A distinção que se faz entre a fiscalidade e a parafiscalidade é que, nessa, os recursos são dirigidos a entidade distinta do Ente Político com competência para criar o tributo em questão. Assim, tributos parafiscais são instrumentos de financiamento, em geral, de entidades da Administração Pública indireta e entidades paraestatais.

Por isso, comumente é feita a distinção entre competência tributária e capacidade tributária ativa. Aquela é consectário do pacto federativo, manifestação da autonomia dos entes federados, limitada pelas disposições constitucionais, consistindo na prerrogativa de, visando atingir os objetivos fundamentais da República, criar tributos e, por conseguinte, aumentar, ou diminuir sua incidência e, até mesmo, isentá-lo. ${ }^{27}$

Já a capacidade tributária ativa é a capacidade que o sujeito tem de ocupar o polo ativo da relação jurídica tributária. Quando a norma que impõe o tributo se silenciar a respeito do sujeito ativo, será ele o Ente Político que instituiu o respectivo tributo. Caso contrário, será aquele pela norma indicado.

Para Simone dos Santos Lemos Fernandes ${ }^{28}$, "a parafiscalidade corresponde à delegação da capacidade tributária ativa sem retorno, para os cofres da pessoa tributante, da receita arrecadada, que não figura no orçamento estatal". Quando não há coincidência entre o titular da competência tributária e o sujeito que dispõe de capacidade tributária ativa, diz-se que o tributo é utilizado em sua função parafiscal, ou seja, serve de instrumento de abastecimento de fonte de receita tributária a ente diverso do Ente Político que criou o tributo.

O estudo da parafiscalidade deixa claro que a classificação tríade das funções dos tributos é feita por preponderância, pois, servindo para dotar de receita tributária entidade da Administração Pública indireta ou entidade paraestatal, o tributo, por mais que seja parafiscal,

\footnotetext{
${ }^{26}$ SCHOUERI, Luís Eduardo. Direito tributário. 3. ed. São Paulo: Saraiva, 2013. p. 33.

${ }^{27}$ CARRAZZA, Roque Antonio. Curso de direito constitucional tributário. 19. ed. rev. ampl. e atual. até a Emenda Constitucional $n$. 39/2002. São Paulo: Malheiros, 2003. p. 437.

${ }^{28}$ FERNANDES, Simone dos Santos Lemos. Teoria da Parafiscalidade brasileira. Revista Dialética de Direito Tributário, São Paulo, $\mathrm{n}$. 112, p. 127-133, jan. 2005. p. 133.
} 
também é fiscal, já que tem finalidade de arrecadar.

Se for criada, por exemplo, uma contribuição interventiva no domínio econômico a ser arrecadada por uma autarquia, o tributo será, ao mesmo tempo, e talvez em igual medida, fiscal, extrafiscal e parafiscal. Fiscal porque será instrumento financeiro da respectiva autarquia. Como não será arrecadada pela União, igualmente, será parafiscal. E, por fim, servindo como ferramenta de intervenção no domínio econômico, da mesma forma, terá função extrafiscal. ${ }^{29}$

Não obstante o alerta acima, pode-se dizer que, havendo coincidência entre as posições de titular da competência e da capacidade tributária ativa, o tributo será fiscal ou extrafiscal. Não existindo tal coincidência, o tributo será parafiscal e, igualmente, poderá ser extrafiscal ou fiscal.

A fiscalidade é a função do tributo ligada ao aspecto arrecadatório da atividade tributária. A parafiscalidade demonstra que o Direito Tributário também tem condições de abastecer de recursos tributários sujeitos distintos daqueles representados pela Administração Pública direta. A extrafiscalidade, por sua vez, é o emprego das espécies tributárias para se alcançar finalidades distintas da meramente arrecadatória. ${ }^{30}$

Função, finalidade, objetivo, são palavras-chave no direito. Alfredo Augusto Becker ${ }^{31}$ identifica tal importância:

O Direito Tributário não tem objetivo (imperativo econômico-social) próprio; ou melhor, como todo o Direito Positivo, o Direito Tributário tem natureza instrumental e seu "objetivo próprio" (razão de existir) é ser um instrumento a serviço de uma política. Esta (a política) é que tem os seus próprios e específicos objetivos econômico-sociais. Por isso, cumpre lembrar que a tributação extrafiscal serve tanto para a reforma social, como para impedi-la.

O tema extrafiscalidade não é novo. James Marins e Jeferson Teodorovicz ${ }^{32}$ identificam três fases no reconhecimento da extrafiscalidade:

[...] o liberalismo econômico não apresentava ideias sólidas para o aspecto social que estava ligado inexoravelmente à ordem econômica. Assim, entre Adam Smith, representante maior o liberalismo econômico, e Karl Marx, cujas ideias socialistas manifestavam a antítese à doutrina liberal, surgiam aqueles autores que procuravam alcançar um "meio termo", um equilíbrio entre as duas posições, angariando os pontos positivos de ambas as escolas, nessa esteira podemos citar Adolph Wagner, que no século XIX, propôs incluir na atividade financeira preocupações de natureza social, o que, no âmbito da tributação, significava aplicar os tributos a finalidades alheias a mera arrecadação, como a

\footnotetext{
${ }^{29}$ BECKER, Alfredo Augusto. Teoria geral do Direito Tributário. 4. ed. São Paulo: Noeses, 2007. p. 631.

${ }^{30}$ BECKER, Alfredo Augusto. Teoria geral do Direito Tributário. 4. ed. São Paulo: Noeses, 2007. p. 632.

${ }^{31}$ BECKER, Alfredo Augusto. Teoria geral do Direito Tributário. 4. ed. São Paulo: Noeses, 2007. p. 632.

${ }^{32}$ MARINS, James; TEODOROVICZ, Jeferson. Extrafiscalidade socioambiental. Revista Tributária e de Finanças Públicas, São Paulo, ano 18, n. 90, p. 73-123, jan./fev. 2010. p. 78.
} 
função de redistribuição de riquezas. Podemos afirmar que nesse período (a partir das ideias de Keynes) poderia ser fixado o marco inicial para a "segunda fase" do reconhecimento da extrafiscalidade, porque a partir daí a extrafiscalidade atinge pleno reconhecimento pelos teóricos e políticos sobre a sua utilidade no combate às situações hostis vivenciadas naquele período.

[...] De qualquer modo, podemos afirmar que a extrafiscalidade socioambiental estará inevitavelmente inserida nos próximos anos com maior força no sistema tributário nacional. Isso porque a socioambientalidade está prevista nos atuais projetos de Reforma Tributária. Muito embora seja improvável a veiculação da Reforma Tributária para este ano e, provavelmente, para 2011, podemos confirmar, pela leitura desses projetos, que já existem importantes alterações a serem realizadas no regime tributário das Green Taxes brasileiras, e, consequentemente, representando o passo adiante no que diz respeito à extrafiscalidade socioambiental. Ademais, também vinculam conceitos à Constituição Tributária que, por sua vez, apontam o caminho para o reconhecimento da terceira fase da tributação extrafiscal no sistema tributário brasileiro.

O tributo passa a ser uma excepcional ferramenta de implementação de políticas públicas, nas mais variadas áreas. Fabiana Del Padre Tomé $^{33}$ destaca que o Direito Tributário tem dupla função em matéria de políticas públicas: serve tanto como instrumento de obtenção de recursos, como nas contribuições sociais, por exemplo, ou como ferramenta de indução de condutas.

Alfredo Augusto Becker ${ }^{34}$ dispõe que "na construção de cada tributo não mais será ignorado o finalismo extrafiscal, nem será esquecido o fiscal". Ou seja, segundo o autor, a tendência é a de que os tributos passem a ser dotado dessa dupla característica: fiscalidade e extrafiscalidade. Hugo de Brito Machado ${ }^{35}$ afirma que "no estágio atual das finanças públicas, dificilmente um tributo é utilizado apenas como instrumento de arrecadação".

\section{Para José Souto Maior Borges ${ }^{36}$ :}

A doutrina da extrafiscalidade - ao contrário da concepção da finança "neutra" - não considera a atividade financeira um simples instrumento ou meio de obtenção de receita, utilizável para o custeio da despesa pública. Através dela, o Estado provoca modificações deliberadas nas estruturas sociais. É, portanto, um fator importantíssimo na dinâmica socioestrutural.

Os objetivos fundamentais da República Federativa do Brasil (artigo 3. ${ }^{\circ}$, da Constituição), os princípios que fundam e orientam a ordem econômica (artigo 170, caput e incisos, da Constituição), a política urbana e fundiária (artigos 182 e 184, da Constituição), a proteção ao meio ambiente (artigo 225, da Constituição), são alguns dos muitos campos de atuação da tributação extrafiscal.

\footnotetext{
${ }^{33}$ TOMÉ, Fabiana Del Padre. A extrafiscalidade tributária como instrumento para concretizar políticas públicas. In: SANTI, Eurico Marcos Diniz (Org.). Tributação e desenvolvimento: homenagem ao Professor Aires Barreto. São Paulo: Quartier Latin, 2011. p. 193.

${ }^{34}$ BECKER, Alfredo Augusto. Teoria geral do Direito Tributário. 4. ed. São Paulo: Noeses, 2007. p. 623-624.

${ }^{35}$ MACHADO, Hugo de Brito. Curso de Direito Tributário. 25. ed. rev. atual. e ampl. São Paulo: Malheiros, 2004. p. 79.

${ }^{36}$ BORGES, José Souto Maior. Introdução ao direito financeiro. São Paulo: Max Limonad, 1998. p. 47.
} 
Isso sem contar previsões expressas de utilização extrafiscal do tributo, como nas contribuições de intervenção no domínio econômico (caput, do artigo 149 e $\S 4 .^{\circ}$, do artigo 177 , da Constituição) e na progressividade extrafiscal do imposto sobre propriedade territorial rural (artigo 153, § $4 .^{\circ}$, I e II, da Constituição) e do imposto sobre propriedade predial e territorial urbana (artigo 182, $\S 4 .^{\circ}$, II, da Constituição). Para Renato Lopes Becho ${ }^{37}$, a extrafiscalidade é o exercício da competência tributária, não em busca de arrecadação, mas visando atingir objetivos constitucionalmente previstos.

Sem sair das lições de Luís Eduardo Schoueri ${ }^{38}$, citado anteriormente, mas indo além de suas ponderações, talvez também seja possível relacionar a função extrafiscal do tributo ao Estado moderno - assim como o autor faze em relação à função fiscal.

Das várias características do Estado moderno, destacam-se duas: (a) é um Estado mais enxuto, em especial relativamente à intervenção direta na economia; (b) é um Estado com mais atribuições perante os cidadãos, aos quais são concedidos diversos direitos e garantias fundamentais que, para serem realizados, exigem ações positivas por parte do Estado.

Essas características fazem do Estado moderno um Estado fiscal. Primeiro porque o tributo é a principal receita estatal. Segundo porque, com o aumento de atribuições no que toca a tutela dos cidadãos, a receita tributária é a principal forma, sob a perspectiva financeira, de desempenhar suas funções. ${ }^{39}$

Luís Eduardo Schoueri, diz que o Estado moderno é um Estado fiscal. Porém, o mesmo neoliberalismo que acentuou a característica fiscal, também pode ter acentuado a importância da função extrafiscal da tributação. O fato de o Estado moderno ter, em certa medida, deixado de lado a atuação direta na ordem econômica faz com que a intervenção, via tributação, ganhe ainda mais importância.

Por isso, a afirmação de que o Estado moderno, ademais de ser um Estado fiscal, também é um Estado extrafiscal, parece ser verdadeira, o que torna o estudo da extrafiscalidade ainda mais relevante. $^{40}$

\footnotetext{
${ }^{37}$ BECHO, Renato Lopes. Competência tributária, extrafiscalidade e novos desafios para o Direito Tributário. Revista Dialética de Direito Tributário, São Paulo, n. 216, p. 123-131, 2013. p. 129.

${ }^{38}$ SCHOUERI, Luís Eduardo. Direito tributário. 3. ed. São Paulo: Saraiva, 2013.

${ }^{39}$ SCHOUERI, Luís Eduardo. Direito tributário. 3. ed. São Paulo: Saraiva, 2013, p. 42.

${ }^{40}$ SCHOUERI, Luís Eduardo. Direito tributário. 3. ed. São Paulo: Saraiva, 2013, p. 43.
} 


\section{CONSIDERAÇÕES FINAIS}

O Direito Tributário Ambiental é um ramo do direito pouco trabalhado pela doutrina tributarista. Partindo de premissas clássicas, nem poderia ser visto como uma disciplina autônoma. No entanto, espalhados entre os fundamentos e os objetivos da República, bem como entre os sistemas tributário e ambiental, existem preceitos constitucionais que justificam a existência de um Direito Tributário Ambiental. O Estado deve proteger o meio ambiente e quando o faz por meio de tributos está a aplicar as normas de Direito Tributário Ambiental.

Conclui-se que, por meio da tributação, é possível contribuir com a proteção do meio ambiente. Isso pode ser feito tanto mediante a obtenção de recursos tributários, como por meio da indução de condutas. No primeiro caso, o Direito Tributário Ambiental está a se valer das funções fiscal e parafiscal e, no segundo caso, da função extrafiscal dos tributos.

Separar os tributos entre fiscais, parafiscais e extrafiscais é classificá-los tomando como critério a função que se sobressai no tributo. Os tributos são, portanto, preponderantemente fiscais, parafiscais ou extrafiscais. Ademais, há tributos que apresentam mais de uma função, sem que uma se sobressaia sobre a outra.

Ponto bastante sensível é a identificação da tributação extrafiscal, que visa estudar as limitações impostas pela isonomia tributária à tributação extrafiscal ambiental. Sobre isso, inexiste um critério único e totalmente seguro para a identificação da tributação extrafiscal. Por mais que se tenha dado maior importância para a identificação da função a partir da análise do sistema do direito positivo como um todo - diferenciando finalidade de resultado - é inegável que a eficácia da norma pode repercutir no modo de sua aplicação e, a partir daí, de sua identificação como norma indutora. Propôs-se, assim, um critério que concilie tanto as prescrições sistêmicas do direito como, eventualmente, o efeito que aquela norma já tenha produzido.

O Direito Tributário Ambiental torna-se instrumento de realização de políticas públicas voltadas à proteção ambiental, dentre outros fatores, por conta de seu potencial indutor de condutas. Diminuição ou majoração de tributos, criação de faixas de isenção, benefícios fiscais etc. podem influenciar a conduta do contribuinte e, com isso, orientá-los a tomar o caminho ambientalmente mais adequado. Ocorre que, criando políticas extrafiscais ambientais de tributação, contribuintes são desequiparados, tendo em vista critérios ambientais. 


\section{REFERÊNCIAS DAS FONTES CITADAS}

AMARO, Luciano. Direito tributário brasileiro. 13. ed. São Paulo: Saraiva, 2007.

ATALIBA, Geraldo. Hipótese de incidência tributária. 6. ed. São Paulo: Malheiros, 2004.

BECHO, Renato Lopes. Competência tributária, extrafiscalidade e novos desafios para o Direito Tributário. Revista Dialética de Direito Tributário, São Paulo, n. 216, p. 123-131, 2013.

BECKER, Alfredo Augusto. Teoria geral do Direito Tributário. 4. ed. São Paulo: Noeses, 2007. BORGES, José Souto Maior. Introdução ao direito financeiro. São Paulo: Max Limonad, 1998. BORGES, José Souto Maior. Teoria geral da isenção tributária. 3. ed. São Paulo: Malheiros, 2007. BRASIL. Lei n. 4.320, de 17 de março de 1964. Disponível em http://www.planalto.gov.br/ccivil_03/leis/L4320.htm. Acesso em 2017.

CARRAZZA, Roque Antonio. Curso de direito constitucional tributário. 19. ed. rev. ampl. e atual. até a Emenda Constitucional n. 39/2002. São Paulo: Malheiros, 2003.

CARVALHO, Paulo de Barros. Curso de Direito Tributário. 24. ed. São Paulo: Saraiva, 2012

CARVALHO, Paulo de Barros. Teoria da norma tributária. 5. ed. São Paulo: Quartier Latin do Brasil, 2009.

COSTA, Regina Helena. Apontamentos sobre a tributação ambiental no Brasil. In: TÔRRES, Heleno Taveira. Direito tributário ambiental. São Paulo: Malheiros, 2005.

FERNANDES, Simone dos Santos Lemos. Teoria da Parafiscalidade brasileira. Revista Dialética de Direito Tributário, São Paulo, n. 112, p. 127-133, jan. 2005.

HARADA, Kiyoshi. Direito financeiro e tributário. 14. ed. São Paulo: Atlas, 2005.

MACHADO, Hugo de Brito. Curso de Direito Tributário. 25. ed. rev. atual. e ampl. São Paulo: Malheiros, 2004.

MACHADO, Paulo Affonso Leme. Direito ambiental brasileiro. 12. ed. rev. atual. e ampl. São Paulo: Malheiros, 2004.

MARINS, James; TEODOROVICZ, Jeferson. Extrafiscalidade socioambiental. Revista Tributária e de Finanças Públicas, São Paulo, ano 18, n. 90, p. 73-123, jan./fev. 2010.

MINGATI, Vinícius Secafen. Reclamação (neo)constitucional: precedentes, segurança jurídica e os 
juizados especiais. Brasília: Gazeta Jurídica, 2013.

SALIBA, Ricardo Berzosa. Fundamentos do Direito Tributário Ambiental. São Paulo: Quartier Latin, 2005.

SCAFF, Fernando Facury; TUPIASSU, Lise Vieira da Costa. Tributação e políticas públicas: o ICMS ecológico. In: TÔRRES, Heleno Taveira (Org.). Direito tributário ambiental. São Paulo: Malheiros, 2005.

SCHOUERI, Luís Eduardo. Direito tributário. 3. ed. São Paulo: Saraiva, 2013.

SCHOUERI, Luís Eduardo. Normas tributárias indutoras e intervenção econômica. Rio de Janeiro: Forense, 2005.

SEBASTIÃO, Simone Martins. Tributo ambiental: extrafiscalidade e função promocional do Direito. Curitiba: Juruá, 2007.

SOUZA, Carlos Frederico Marés de. A função social da terra. Porto Alegre: Sergio Fabris Editor, 2003.

TOMÉ, Fabiana Del Padre. A extrafiscalidade tributária como instrumento para concretizar políticas públicas. In: SANTI, Eurico Marcos Diniz (Org.). Tributação e desenvolvimento: homenagem ao Professor Aires Barreto. São Paulo: Quartier Latin, 2011. 


\section{VAQUEJADA: CULTURA DA CRUELDADE}

Andréa Gomes ${ }^{1}$

Tamires Regina Zimermann Fopa ${ }^{2}$

\section{INTRODUÇÃO}

A tradicional festa da apartação, culturalmente praticada pelos peões nordestinos, conhecida atualmente como vaquejada, é uma modalidade um tanto intrigante, pois faz parte da cultura brasileira já há alguns anos, mas tem causado grandes problemas aos animais envolvidos na prática dessa modalidade desportiva.

Observou-se que existe certo grau, inaceitável, de maus tratos e de crueldade com os animais, sejam os bois, os quais os vaqueiros correm para derrubá-los, com uma violenta puxada pelo rabo, sejam os cavalos que também sofrem alguns traumas em decorrência da brutalidade do esporte.

Uma lei do Estado do Ceará buscou regulamentar a vaquejada como patrimônio cultural brasileiro, no entanto, foi declarada inconstitucional pelo Supremo Tribunal Federal, por entender que existe uma colisão de direitos fundamentais, vez que a Constituição protege o patrimônio cultural e da mesma forma protege a fauna, vedando as práticas que submetam os animais a crueldade.

Pretende-se analisar se a lei da vaquejada, como patrimônio cultural, colide com outros direitos ambientais, e ainda, averiguar frente a decisão de inconstitucionalidade declarada pelo Supremo.

Logo, o objeto da presente pesquisa é uma analise da lei da vaquejada, e como Objetivo Geral examinar sua compatibilidade com o artigo 225, §1으, inciso VII da Constituição de 1988. Os Objetivos Específicos são: a) estudar a prática da vaquejada; b) analisar a decisão de

\footnotetext{
${ }^{1}$ Mestranda em Ciências Jurídicas na linha de pesquisa Direito, Desenvolvimento Urbano e Meio Ambiente, pela Universidade do Vale de Itajaí - UNIVALI, Pós-Graduada em Direito Penal e Direito Processual Penal, pela Escola do Ministério Público de Santa Catarina e Univali, Pós-Graduanda em Direito Público pela Escola da Magistratura de Santa Catarina - ESMESC e Advogada. Email dheiagomes@uol.com.br.

${ }^{2}$ Mestranda em Ciências Jurídicas pela Universidade do Vale de Itajaí - UNIVALI. Pós-Graduada em Direito Civil pela Universidade Anhanguera - Uniderp. Advogada na Cidade de Brusque - SC. Endereço eletrônico: tamiresrz@msn.com.
} 
inconstitucionalidade da lei cearense; e c) verificar se existe colisão entre direitos.

Para construção do presente trabalho, foram utilizadas várias obras, mas de grande importância a Ação Direta de Inconstitucionalidade n. 4983, de relatoria do Ministro Marco Aurélio.

O presente artigo esta dividido em quatro momentos: no primeiro, aborda-se acerca da proteção ao patrimônio cultural e a fauna; no segundo, discorre sobre a prática da vaquejada no Brasil; na terceira etapa, analisa-se a decisão proferida pelo Supremo Tribunal Federal, sobre a inconstitucionalidade da vaquejada, e por fim, expõe sobre o projeto de emenda constitucional.

A metodologia empregada foi a Indutiva $^{3}$ e no decorrer da pesquisa serão utilizadas as seguintes Técnicas: Referente ${ }^{4}$, da Categoria $^{5}$, do Conceito Operacional ${ }^{6}$ e Pesquisa Bibliográfica ${ }^{7}$.

\section{PATRIMÔNIO CULTURAL BRASILEIRO E A PROTEÇÃO À FAUNA}

Ao analisar o meio ambiente em sua totalidade, definido como bem de uso comum do povo, deve-se considerar o seu caráter social, que é ao mesmo tempo histórico considerando que "o meio ambiente resulta das relações do ser humano com o mundo natural no decorrer do tempo". Isso faz com que se inclua no conceito de ambiente, além dos ecossistemas naturais, as criações do homem que se traduzem nas suas múltiplas obras. Destarte, as políticas ambientais dão ênfase a preocupação com o patrimônio cultural, "expresso em realizações significativas que caracterizam de maneira particular, os assentamentos humanos e as paisagens de seu entorno". ${ }^{8}$

A proteção ao patrimônio cultural teve início com a Constituição de 1934 e um dos primeiros conceitos foi trazido pelo art. 10 do Decreto Lei n. 25/37.

Hodiernamente, na Constituição Federal de 1988, o patrimônio cultural recebe tratamento

\footnotetext{
3 "[...] pesquisar e identificar as partes de um fenômeno e coleciona-las de modo a ter uma percepção ou conclusão geral [..]" PASOLD, Cesar Luiz. Metodologia da pesquisa jurídica: teoria e prática. 13. ed. rev., atual. e ampl. Florianópolis: 2015. p. 91.

4 '[...] a explicitação previa do(s) motivo(s), do(s) objetivo(s) e do produto desejado, delimitando o alcance temático e de abordagem para uma atividade intelectual, especialmente para uma pesquisa." PASOLD, Cesar Luiz. Metodologia da pesquisa jurídica: teoria e prática. 13. ed. rev., atual. e ampl. Florianópolis: 2015. p. 58.

5 “[...] palavra ou expressão estratégica à elaboração e/ou à expressão de uma ideia. " PASOLD, Cesar Luiz. Metodologia da pesquisa jurídica: teoria e prática. 13. ed. rev., atual. e ampl. Florianópolis: 2015. p. 27.

6 “[...] estabelecemos ou propomos uma definição para uma palavra ou expressão, com o desejo de que tal definição seja aceita para os efeitos das ideias que expomos [...]" PASOLD, Cesar Luiz. Metodologia da pesquisa jurídica: teoria e prática. 13. ed. rev., atual. e ampl. Florianópolis: 2015. p. 91.

7 “Técnica de investigação em livros, repertórios jurisprudenciais e coletâneas legais. " PASOLD, Cesar Luiz. Metodologia da pesquisa jurídica: teoria e prática. 13. ed. rev., atual. e ampl. Florianópolis: 2015. p. 91.

${ }^{8}$ MILARÉ, Édis. Direito do Ambiente. 8. ed. São Paulo: Revista dos Tribunais, 2013. p. 564.
} 
através dos arts. 215 e 216, cujo conceito está disposto no caput e incisos I a V do art. 216, in verbis:

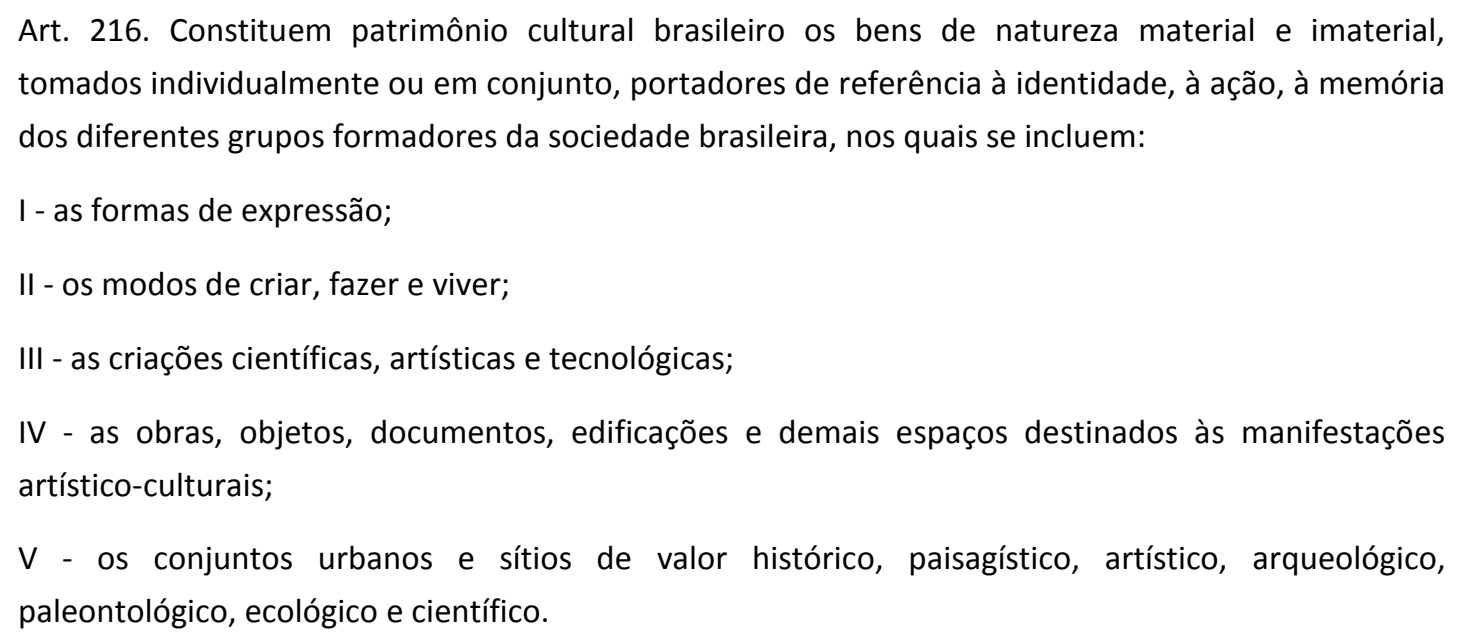

Percebe-se que a Constituição, ao conceituar patrimônio cultural, estabelece como sendo brasileiro e inclui bens tangíveis, sendo obras, objetos, edificações e bens intangíveis, que são conhecimentos técnicos. Podendo ser tomados individualmente ou em conjunto sendo necessária a existência da vinculação com a identidade, a ação e a memória dos diferentes grupos formadores da sociedade brasileira.

O rol disposto pelo art. 216 é exemplificativo, nos incisos I e II tem-se o patrimônio cultural intangível, o inciso III traz as criações científicas, artísticas e tecnológicas podendo ser tangíveis ou intangíveis, já o inciso IV aborda os locais onde ocorrem manifestações culturais, e o inciso V protege os valores histórico, paisagístico, artístico, arqueológico, paleontológico, ecológico e científico." $^{9}$

Como se pode perceber, a Constituição não restringe qualquer tipo de bem, podendo ser materiais ou imateriais, singulares ou coletivos, móveis ou imóveis, independentemente de terem sido criados por intervenção do homem. Resta claro que uma diversidade de bens podem ser considerados culturais, mas, para tanto, é necessária a existência do nexo vinculante entre o bem e a identidade, a ação e a memória dos grupos formadores da sociedade. ${ }^{10}$

Com a Constituição Federal de 1988 houve a consagração no direito positivo do pluralismo cultural, reconhecendo que a cultura brasileira não é única, ela "resulta da atuação de interação dinâmica de todos os grupos e classes sociais de todas as regiões". Pretende-se assim, preservar "a

\footnotetext{
${ }^{9}$ MILARÉ, Édis. Direito do Ambiente. 8. ed. São Paulo: Revista dos Tribunais, 2013. p. 568.

${ }^{10}$ FIORILO, Celso Antonio Pacheco. Curso de Direito Ambiental Brasileiro. 14. ed. São Paulo: Saraiva, 2013. p. 454.
} 
diversidade de riqueza de bens culturais, construídas incessantemente num país de dimensões continentais a variada formação étnica". ${ }^{11}$

A preservação do patrimônio cultural é atribuída a diversos entes de acordo com as regras de competência trazidas pela Constituição Federal. $\mathrm{O}$ art. 23 estabelece a competência comum da União, dos Estados, do Distrito Federal e dos Municípios para:

III - proteger os documentos, as obras e outros bens de valor histórico, artístico e cultural, os monumentos, as paisagens naturais notáveis e os sítios arqueológicos;

IV - impedir a evasão, a destruição e a descaracterização de obras de arte e de outros bens de valor histórico, artístico ou cultural;

Já o artigo 24 prevê a competência concorrente entre os Entes para legislar sobre o assunto.

Cumpre ressaltar que a identificação do valor cultural de um bem compete igualmente aos Poderes administrativo, legislativo e judiciário, podendo partir da cada um deles os meios de atuação para promoção dos bens culturais ambientais. ${ }^{12}$

Indaga-se então como identificar um bem cultural uma vez que a conceituação de patrimônio cultural pode abranger toda atividade humana. Na visão de Milaré ${ }^{13}$, a solução estaria na atuação da comunidade, que, de acordo com art. 216, § 1으, deve colaborar com o Poder Público, promovendo e protegendo o patrimônio cultural brasileiro. $O$ autor leciona que:

A atuação da comunidade é fundamental, pois ela, como legítima produtora e beneficiária dos bens culturais, mais do que ninguém tem legitimidade para identificar um valor cultural, que não precisa ser apenas artístico, arquitetônico ou histórico, mas também estético ou simplesmente afetivo. A identificação ou simpatia da comunidade por determinado bem pode representar uma prova de valor cultural bastante superior àquela obtida através de dezenas de laudos técnicos plenos de erudição, mas muitas vezes vazio de sensibilidade. Além de significar, por si só, uma maior garantia para a sua efetiva conservação.

Da mesma forma que a Constituição Federal protege o Patrimônio Cultura, ela também o faz com a Fauna, conforme disposto no art. $225, \S 1^{\circ}, \mathrm{VII}$ :

Art. 225. Todos têm direito ao meio ambiente ecologicamente equilibrado, bem de uso comum do povo e essencial à sadia qualidade de vida, impondo-se ao Poder Público e à coletividade o dever de defendê-lo e preservá-lo para as presentes e futuras gerações.

$\S 1$ 을 Para assegurar a efetividade desse direito, incumbe ao Poder Público: (...)

\footnotetext{
${ }^{11}$ MILARÉ, Édis. Direito do Ambiente. 8. ed. São Paulo: Revista dos Tribunais, 2013. p. 565.

${ }^{12}$ MILARÉ, Édis. Direito do Ambiente. 8. ed. São Paulo: Revista dos Tribunais, 2013. p. 568.

${ }^{13}$ MILARÉ, Édis. Direito do Ambiente. 8. ed. São Paulo: Revista dos Tribunais, 2013. p. 567.
} 
VII - proteger a fauna e a flora, vedadas, na forma da lei, as práticas que coloquem em risco sua função ecológica, provoquem a extinção de espécies ou submetam os animais a crueldade.

Percebe-se que o dispositivo supramencionado não apresenta um conceito para Fauna. Destarte ficou a cargo do legislador infraconstitucional faze-lo. A Lei $n^{\circ} 5.197 / 67$ que dispõe sobre à proteção à fauna, determina que:

Art. 1‥ Os animais de quaisquer espécies, em qualquer fase do seu desenvolvimento e que vivem naturalmente fora do cativeiro, constituindo a fauna silvestre, bem como seus ninhos, abrigos e criadouros naturais são propriedades do Estado, sendo proibida a sua utilização, perseguição, destruição, caça ou apanha.

O artigo mencionado restringiu o conteúdo direcionando a proteção da lei à fauna silvestre, porém, Fiorilo ${ }^{14}$ explica que:

O legislador constituinte não pretendeu delimitar a fauna a ser tutelada, porquanto objetiva-se que a lei busque preservá-la, colocando-a a salvo das práticas que representem risco a sua função ecológica e à extinção das espécies e que submetam os animais a crueldade. Aceitar que a única fauna a ser tutelada é a silvestre é distanciar-se do comando constitucional, porque, se assim fosse, os animais domésticos não seriam objeto de tutela. Deve-se observar em relação a estes que, embora não possuam função ecológica e não corram risco de extinção (porquanto são domesticados), na condição de integrantes do coletivo fauna, devem ser protegidos contra as práticas que lhe sejam cruéis, de acordo com a senso da coletividade.

Vale destacar também a Lei $n^{\circ} 9.605 / 98$ que dispõe sobre as sanções penais $e$ administrativas derivadas de condutas e atividades lesivas ao meio ambiente, no art. 32 caracteriza como crime a prática de ato de abuso, maus-tratos, que ferem ou mutilam animais silvestres, domésticos ou domesticados, nativos ou exóticos.

\section{SOBRE A VAQUEJADA NO BRASIL}

Antiga tradição nordestina, a vaquejada é uma festa tradicional que vem sendo passada ao longo dos anos de geração para geração, e que atualmente se tornou uma espécie de esporte, o qual consiste na derrubada do boi pela puxada de cauda, por dois vaqueiros a cavalo, dentro de um espaço previamente delimitado, na arena da vaquejada. ${ }^{15}$

Essa prática surgiu entre os séculos XVII e XVIII, com o nome, inicialmente de apartação que

\footnotetext{
${ }^{14}$ FIORILO, Celso Antonio Pacheco. Curso de Direito Ambiental Brasileiro. 16. ed. São Paulo: Saraiva, 2015. p. 313-314.

${ }^{15}$ SILVA, Thomas de Carvalho. A prática da vaquejada à luz da constituição federal. In: Âmbito Jurídico, Rio Grande, XII, n. 63, abr. 2009. Disponível em: < http://www.ambito-juridico.com.br/site/index.php?n_link=revista_artigos_leitura\&artigo_id=5922 >. Acesso em 08. Nov. 2016.
} 
consistia na pegada do boi no mato, segundo Bezerra: ${ }^{16}$

Na verdade, tudo começou aqui pelo Nordeste com o Ciclo dos Currais. É onde entram as apartações. Os campos de criar não eram cercados. O gado, criado em vastos campos abertos, distanciava-se em busca de alimentação mais abundante nos fundos dos pastos. Para juntar gado disperso pelas serras, caatingas e tabuleiros, foi que surgiu a apartação.

Escolhia-se antecipadamente uma determinada fazenda e, no dia marcado para o início da apartação, numerosos fazendeiros e vaqueiros devidamente encourados partiam para o campo, guiados pelo fazendeiro anfitrião, divididos em grupos espalhados em todas as direções à procura da gadaria solta pelos "campos tão bonitos", no dizer do poeta dos vaqueiros, que em vida se chamou Fabião das Queimadas.

Naquela época os fazendeiros, trabalhavam nos campos, e corriam os mesmos riscos que o os profissionais das vaquejadas correm hoje. Eles reuniam e buscavam o gado, que estavam espalhados pelo campo, conduzindo-os através de caminhos abertos até as fazendas.

No entanto, haviam aqueles animais que chamavam de "barbatões" eram touros e novilhos que se tinham criado no mato, mais relutantes e não seguiam os demais, necessitando de serem derrubados e algemados, com uma espécie de algema, de maneira que não os permita que saíssem correndo. ${ }^{17}$

O trabalho de apartação, como o próprio nome indica, começou pela separação e contagem do gado da conta de um vaqueiro de uma determinada fazenda. Terminada a separação do gado de acordo com a letra da ribeira (T para Trairi, $\mathrm{P}$ para Potengi, S para Seridó), os fazendeiros ou vaqueiros mais idosos retiravam-se conduzindo seus animais. Do gado separado ficavam ainda muitas cabeças cujos respectivos donos ou representantes estavam ausentes. "[...] A apartação, nos dias que correm, caiu em desuso, passando a ser chamada junta de gado. ${ }^{18}$

Assim, a prática foi ganhando mais adeptos, destaca-se ainda que na antiga tradição da "pega de boi no mato", que acontecia em meio a vegetação de característica do Nordeste brasileiro, os peões, para adentrar, necessitavam de roupas de couro para não se machucarem. ${ }^{19}$

Desta forma, a vaquejada, era comemorada como encerramento de uma fase de trabalho, ou seja, reunir o gado, tratar os doentes, marcar, castrar, entre outras tarefas. Depois de separados os animais faziam a vaquejada, chamada de festa da apartação, onde eram realizadas provas para demonstrar a capacidade e as habilidades dos peões na lida com o gado e com os

\footnotetext{
${ }^{16}$ BEZZERA, José Euzébio Fernandes. No mundo do vaqueiro: apartação. Barcelona Portal virtual Barcelona - RN Brasil. Disponível em : <http://www.barcelona.educ.ufrn.br/mundo.htm>. Acesso em 08.nov. 2016.

${ }^{17}$ BEZZERA, José Euzébio Fernandes. No mundo do vaqueiro: apartação. Barcelona Portal virtual Barcelona - RN Brasil. Disponível em : <http://www.barcelona.educ.ufrn.br/mundo.htm>. Acesso em 08.nov. 2016.

${ }^{18}$ BEZZERA, José Euzébio Fernandes. No mundo do vaqueiro: apartação. Barcelona Portal virtual Barcelona - RN Brasil. Disponível em : <http://www.barcelona.educ.ufrn.br/mundo.htm>. Acesso em 08.nov. 2016.

${ }^{19}$ MEDEIROS, Rostand. Pega de boi no mato: tradição e cultura do nordeste. Tok de História. 2014. Disponível em: <https://tokdehistoria.com.br/2014/07/16/pega-de-boi-no-mato-tradicao-e-cultura-do-nordeste/>. Acesso em 08.nov. 2016.
} 
cavalos. $^{20}$

Por volta de 1940, os vaqueiros de várias partes do Nordeste começaram a tornar público suas habilidades na Corrida do Mourão.

Os coronéis e os senhores de engenho passaram a organizar torneios de vaquejadas, onde os participantes eram os vaqueiros, e os patrões faziam apostas entre si, mas ainda não existiam premiações para os campeões. Os coronéis davam apenas um "agrado" para os vaqueiros que venciam. A festa se tornou um bom passatempo para os patrões, suas mulheres e seus filhos. ${ }^{21}$

No entanto, relatos de que muito antes já havia a prática da vaquejada, como descreve a ABVAQ - Associação Brasileira de Vaquejada:

Somente em 1874 apareceu o primeiro registro de informação sobre vaquejada. O escritor José de Alencar escreveu a respeito da "puxada de rabo de boi" no Ceará, mas não como sendo algo novo, ele deixou claro que a prática já ocorria anteriormente. E se existia no Ceará, era indiscutível que pudesse existir em estados vizinhos como, Rio Grande do Norte, Paraíba e Piauí, já que eram regiões tão semelhantes nos hábitos, atividade econômica e social, e ambiente físico. Foi isso que levantou a suspeita dos pesquisadores. Eles descobriram pela tradição falada que muito antes de 1870 já se praticava vaquejada no Seridó Potiguar. Uma indicação para isso era a existência dos currais de apartação de bois, que deram origem ao nome da cidade de CURRAIS NOVOS, também no Rio Grande do Norte. Esses currais foram feitos em 1760. E era entre 1760 e 1790 que acontecia em Currais Novos a apartação e feira de gado. Foram dessas apartações que surgiram as vaquejadas. O pátio de apartação de São Bento, no município de Currais Novos foi construído em $1830{ }^{22}$

$\mathrm{Na}$ atualidade a vaquejada, considerada como modalidade esportiva cultural, tomou grandes proporções que contam com grandes competições, regulamentos e calendários de programação, além de movimentar em milhões a economia.

"Viraram "indústrias" milionárias, que oferecem verdadeiras fortunas em prêmios. Hoje, há dezenas de parques de vaquejada no Nordeste. Vaqueiros de todas as partes se reúnem para as disputas, pela glória e pelos prêmios, cada vez mais atrativos." ${ }^{23}$

A Associação Brasileira de Vaquejada - Abvaq, em seu regulamento, define no art. 3으, alínea "a", a vaquejada:

Art. 3ㅇ - Para fins de entendimento, ficam definidos os seguintes conceitos:

\footnotetext{
${ }^{20}$ SILVA, Thomas de Carvalho. A prática da vaquejada à luz da constituição federal. In: Âmbito Jurídico, Rio Grande, XII, n. 63, abr. 2009. Disponível em: < http://www.ambito-juridico.com.br/site/index.php?n_link=revista_artigos_leitura\&artigo_id=5922 >. Acesso em 08. Nov. 2016.

${ }^{21}$ SILVA, Thomas de Carvalho. A prática da vaquejada à luz da constituição federal. In: Âmbito Jurídico, Rio Grande, XII, n. 63, abr. 2009. Disponível em: < http://www.ambito-juridico.com.br/site/index.php?n_link=revista_artigos_leitura\&artigo_id=5922 >. Acesso em 08. Nov. 2016.

${ }^{22}$ ABVAQ - Associação Brasileira de Vaquejada. A vaquejada. 2014. Disponível em: <http://www.abvaq.com.br/telas/4>.Acesso em 08.nov.2016.

${ }^{23}$ Vaquejadas manifestações das culturas populares ou crimes de crueldade e maus tratos contra os animais? Disponível em: <http://www.proanima.org.br/ProAnima/www.proanima.org.br/o-que-fazemos/proanima-na-midia/vaquejadas-manifestacoesdas-culturas-populares-ou-crime-de-crueldade-e-maus-tratos-contra-os-animais/>. Acesso em 10 nov. 2016.
} 
a) Vaquejada - atividade cultural - competitiva, com características de esporte, praticado em uma pista sobre colchão de areia com espessura mínima não inferior a 50 (cinquenta) centímetros, no qual dois vaqueiros tem o objetivo de alcançar e emparelhar o boi entre os cavalos, conduzi-lo até o local indicado, onde o animal deve ser deitado; $[\ldots]^{24}$

O referido regulamento, em seus arts. 30, 31, 32 e 33, fez previsão quanto ao bem estar dos animais, dispondo que em se tratando de prática de atividade esportiva cultural, deve-se proteger os animais, contra maus tratos, necessitando estes, serem tratados de forma humanitária, com respeito e compaixão, impondo-se aos participantes regras rígidas, bem como a responsabilização para quem não as cumprir: ${ }^{25}$

Art.30 - A ABVAQ fomenta a prática da atividade cultural - esportiva da vaquejada, protegendo os animais envolvidos ativamente através do estabelecimento e imposição de regras rígidas, as quais regem todo e qualquer evento oficializado pela $A B V A Q$.

Art.31- Os promotores dos eventos, suas equipes de apoio e organização, assim como os competidores, tem obrigação de preservar os animais envolvidos no esporte. Qualquer maltrato proposital aos bois e cavalos, acarretará a responsabilização daquele diretamente envolvido na ocorrência.

Art.32 - É terminantemente proibida a realização de Vaquejada sem o uso do protetor de cauda.

Art.33 - Todos os animais (bovinos e equinos) deverão em qualquer ocasião ser tratados de modo humanitário, com dignidade, respeito e compaixão. ${ }^{26}$

Assim, tem-se a prática da vaquejada, como patrimônio Cultural Brasileiro, no entanto, existem opiniões que divergem sobre a questão da proteção aos animais, por entenderem que é afronta ao disposto no art. 225, §1으, VII, da Carta Constitucional.

\subsection{Lei do Estado do Ceará que Regulamentou a Prática da Vaquejada}

Trata-se da Lei $n^{\circ} 15.299$ de 08 de janeiro de 2013 do Estado do Ceará, que regulamenta a vaquejada como prática desportiva e cultural.

$\mathrm{O}$ art. $2^{\circ}$ da Lei conceitua a vaquejada como "todo evento de natureza competitiva, no qual uma dupla de vaqueiro a cavalo persegue animal bovino, objetivando dominá-lo".

Dentre as regulamentações sobre a prática, que se diga, não são muito detalhadas, 0 art. $4^{\circ}$

\footnotetext{
24 ABVAQ - Associação Brasileiras de Vaquejada. Regulamento geral de vaquejada: 2017.Disponível em: <http://www.abvaq.com.br/images/institucional/Regulamento_ABVAQ_novo_28.10.pdf>. Acesso em 10. Nov. 2016.

25 ABVAQ - Associação Brasileiras de Vaquejada. Regulamento geral de vaquejada: 2017. Disponível em: <http://www.abvaq.com.br/telas/12>. Acesso em 10. Nov. 2016.

26 ABVAQ - Associação Brasileiras de Vaquejada. Regulamento geral de vaquejada: 2017. Disponível em: <http://www.abvaq.com.br/telas/12>. Acesso em 10. Nov. 2016.
} 
estabelece a obrigação aos organizadores de "adotar medidas de proteção à saúde e à integridade física do público, dos vaqueiros e dos animais. " O § 1ㅇ dispõe que "o transporte, o trato, o manejo e a montaria do animal utilizado na vaquejada devem ser feitos de forma adequada para não prejudicar a saúde do mesmo. " E ainda o $\S 3^{\circ}$ prevê punição de exclusão da prova ao vaqueiro que se exceder no trato com o animal ferindo-o ou maltratando-o de forma intencional.

Referida Lei foi objeto da Ação Direta de Inconstitucionalidade $n^{\circ} 4983$, que foi ajuizada pelo Procurador Geral da República, por entender que existe uma colisão de normas de direitos fundamentais, não sendo possível coexistir uma norma de proteção ao patrimônio cultural que fere o direito ambiental, mais precisamente, conivente com maus tratos aos animais.

\section{DECISÃO DO STF - INCONSTITUCIONALIDADE}

A Lei. no 15.299/2013 do Estado de Ceará, regulamentava a vaquejada como uma prática esportiva e cultural do Estado Cearense, foi declara inconstitucional pelo Supremo Tribunal Federal - STF.

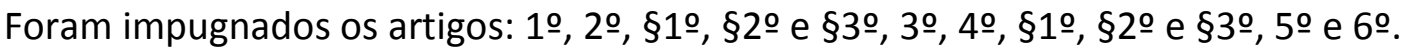

Segundo a decisão do STF, a prática da vaquejada expõe os animais a maus tratos e crueldade, caracterizando um conflito entre normas constitucionais, ou seja, entre o art. 225 (assegura o direito ao meio ambiente) e art. 215 (garante o direito as manifestações culturais, expressão da pluralidade). ${ }^{27}$

Assim, como definição breve de vaquejada tem-se:

Essa modalidade de espetáculo é praticada por dois vaqueiros, montados em seus cavalos, os quais perseguem o boi desde a saída da sangra (boxe feito para a largada das reses) até a faixa de julgamento. Neste local os vaqueiros devem tombar o boi ao chão, arrastando-o brutalmente, ate que mostre as quatro patas. Esses animais, geralmente, sofrem luxações e hemorragias internas, devido ao tombo. ${ }^{28}$

Portanto a lei impugnada não encontra guarida na Constituição, vez que viola o artigo 225, $\S 10$, inciso VII:

\footnotetext{
${ }^{27}$ BRASIL. Supremo Tribunal Federal. Ação Direta de Inconstitucionalidade n. 4983 CE, Relator: Min. MARCO AURÉLIO, Data de Julgamento: 27/07/2013, Data de Publicação: DJe-150 DIVULG 02/08/2013 PUBLIC 05/08/2013. Disponível em: http:<//stf.jusbrasil.com.br/jurisprudencia/23889398/acao-direta-de-inconstitucionalidade-adi-4983-ce-stf>. Acesso em: 02 . Fev. 2017.

${ }^{28}$ SIRVINSKAS, Luis Paulo. Manual de direito ambiental. 13. ed. São Paulo: Saraiva, 2015. p. 647.
} 
Art. 225. Todos têm direito ao meio ambiente ecologicamente equilibrado, bem de uso comum do povo e essencial à sadia qualidade de vida, impondo-se ao poder público e à coletividade o dever de defendê-lo e preservá-lo para as presentes e futuras gerações.

$\S 1$ 으 - Para assegurar a efetividade desse direito, incumbe ao poder público:

VII - proteger a fauna e a flora, vedadas, na forma da lei, as práticas que coloquem em risco sua função ecológica, provoquem a extinção de espécies ou submetam os animais a crueldade. ${ }^{29}$

Por outro lado, tem-se pelo mesmo diploma legal, a proteção quanto as manifestações culturais: "Art. 215. O Estado garantirá a todos o pleno exercício dos direitos culturais e acesso às fontes da cultura nacional, e apoiará e incentivará a valorização e a difusão das manifestações culturais". 30

Nota-se uma colisão entre direitos, a preservação do meio ambiente e a proteção a manifestações culturais, no entanto, a posição do STF defende que frente a essa "via de mão dupla" não se pode ter espaços para dúvidas, pois quando se trata de meio ambiente, não podem haver disputas. ${ }^{31}$

Sobre crueldade pode-se destacar: conotação de severo, desumano, tirano, consiste em satisfação em fazer algum tipo de mal, pode-se dizer que crueldade com os animais seria em submete-los a algum tipo de mal "além do absolutamente desnecessário" ${ }^{32}$, a palavra ferir sugere machucar, causar ferimentos, e mutilar compreende a prática de arrancar, destruir alguma parte do corpo. ${ }^{33}$

Tem se ainda a lei $9.605 / 98$ de Crimes ambientais que cuida da proteção aos animais conta maus tratos:

Art. 32. Praticar ato de abuso, maus-tratos, ferir ou mutilar animais silvestres, domésticos ou domesticados, nativos ou exóticos:

Pena - detenção, de três meses a um ano, e multa.

$\S 10$ Incorre nas mesmas penas quem realiza experiência dolorosa ou cruel em animal vivo, ainda que para fins didáticos ou científicos, quando existirem recursos alternativos.

\footnotetext{
${ }^{29}$ BRASIL. Constituição (1988). Constituição da República Federativa do Brasil. Brasília, DF: Senado Federal: Centro Gráfico, 1988.

${ }^{30}$ BRASIL. Constituição (1988). Constituição da República Federativa do Brasil. 1988.

${ }^{31}$ BRASIL. Supremo Tribunal Federal. Ação Direta de Inconstitucionalidade n. 4983 CE, Relator: Min. MARCO AURÉLIO, Data de Julgamento: 27/07/2013, Data de Publicação: DJe-150 DIVULG 02/08/2013 PUBLIC 05/08/2013. Disponível em: http:<//stf.jusbrasil.com.br/jurisprudencia/23889398/acao-direta-de-inconstitucionalidade-adi-4983-ce-stf >. Acesso em: 02. Fev. 2017.

32 FIORILO, Celso Antônio Pacheco. Curso de Direito Ambiental Brasileiro. 16. ed. São Paulo: Saraiva, 2015. p. 327-328.

${ }^{33}$ CALAHU, Lélio Braga. Meio ambiente e tutela penal nos maus tratos a animais. PROANIMA - Associação Protetora dos Animais do DF. Disponível em: < http://www.proanima.org.br/animais-tem-direitos/meio-ambiente-e-tutela-penal-nos-maus-tratoscontra-animais.html>. Acesso em 06. Fev. 2017.
} 
§ 2o A pena é aumentada de um sexto a um terço, se ocorre morte do animal. ${ }^{34}$

Assim, demonstrado o que se entende por maus tratos, pode-se observar o laudo técnico, relatado pela Dr. Irvênia Luíza de Santis Prada, o qual instruiu a petição inicial da Ação Direta de Inconstitucionalidade 4983, demonstrando claramente situações de maus tratos:

Ao perseguirem o bovino, os peões acabam por segurá-lo fortemente pela cauda (rabo), fazendo com que ele estanque e seja contido. A cauda dos animais é composta, em sua estrutura óssea, por uma sequência de vertebras, chamadas coccígeas ou caudais, que se articulam umas com as outras. Nesse gesto brusco de tracionar violentamente o animal pelo rabo, é muito provável que disto resulte luxações das vértebras, ou seja, perda da condição anatômica de contato de uma com outra. Com essa ocorrência, existe a ruptura de ligamentos e de vasos sanguíneos, portanto, estabelecendo-se lesões traumáticas. Não deve ser rara a desinserção (arranchamento) da cauda, de sua conexão com o tronco. Como a porção caudal da coluna vertebral, representa continuação dos outros segmentos da coluna vertebral, particularmente na região sacral, afecções que ocorrem primeiramente nas vertebras caudais podem repercutir mais para frente, comprometendo inclusive a medula espinhal que se acha contida dentro do canal vertebral. Esses processos patológicos são muito dolorosos, dada a conexão da medula espinhal com as raízes dos nervos espinhais, por onde trafegam inclusive os estímulos nociceptivos (causadores de dor). Volto a repetir que além de dor física, os animais submetidos a esses procedimentos vivenciam sofrimento mental. ${ }^{35}$

Demonstra-se assim, que a prática de tal modalidade, causam lesões traumáticas nos animais envolvidos, ainda, acarretam graves danos nos cavalos utilizados em tal atividade, em percentual relevante. ${ }^{36}$

O STF tem firmado precedente, baseados na ponderação, para dirimir conflitos entre a proteção ao meio ambiente (animais) e as manifestações culturais. Destaca-se duas importantes decisões no mesmo sentido, que foram as declarações de inconstitucionalidades da manifestações culturais de "farra do boi" e "brigas de galo". ${ }^{37}$

A farra do boi consiste em "submeter o animal à fobia do público, que o persegue e o machuca durante o trajeto. O animal, cortado e ensanguentado, é sacrificado no final da brincadeira.". A briga de galo, não é muito diferente, "os animais (galos, passarinhos, cachorros, etc.) são levados ao confronto mortal. Esses animais, geralmente, saem da rinha bastante ferido,

\footnotetext{
${ }^{34}$ BRASIL. Lei 9.605/1998 - Crimes ambientais. Disponível em: < http://www.planalto.gov.br/ccivil_03/leis/L9605.htm>. Acesso em 06 fev. 2017.

${ }^{35}$ BRASIL. Supremo Tribunal Federal. Ação Direta de Inconsticionalidade n. 4983 CE, Relator: Min. MARCO AURÉLIO, Data de Julgamento: 27/07/2013, Data de Publicação: DJe-150 DIVULG 02/08/2013 PUBLIC 05/08/2013. Disponível em: http:</ http://www.stf.jus.br/portal/geral/verPdfPaginado.asp?id=4027060\&tipo=TP\&descricao=ADI\%2F4983>. Acesso em: 04 . Fev. 2017.

${ }^{36}$ BRASIL. Supremo Tribunal Federal. Ação Direta de Inconsticionalidade n. 4983 CE.

${ }^{37}$ BRASIL. Supremo Tribunal Federal. Ação Direta de Inconsticionalidade n. 4983 CE.
} 
sangrando e, às vezes, cegos." ${ }^{38}$

Segundo entendimento do Ministro Marco Aurélio, quando se trata do artigo 225 da Constituição de 88, em "todos tem direito ao meio ambiente ecologicamente equilibrado, bem de uso comum do povo e essencial a sadia qualidade de vida", ${ }^{39}$ o dever de defender e preservar, cabe tanto ao poder público, quanto a coletividade, visando a proteção para também as futuras gerações. $^{40}$

Ocorre que muitas vezes os direitos fundamentais individuais e os difusos entram em confronto, cabe ao Supremo Tribunal, baseado em princípios constitucionais, dirimir e harmonizar tais conflitos, muitas vezes inevitáveis. ${ }^{41}$

Havendo, portanto, "conflito entre os interesses individual e coletivo resolve-se a favor deste ultimo". Segundo entendimento do Supremo, dá-se preferencia aos interesses coletivos aos individuais, quando se tratar de ponderar direito ao meio ambiente de natureza individual diversa, como no presente caso. ${ }^{42}$

Quando uma manifestação cultural, abrange largamente a crueldade com os animais, não merece guarida da Constituição:

Ante os dados empíricos evidenciados pelas pesquisas, tem-se como indiscutível o tratamento cruel dispensado às espécies animais envolvidas. $\mathrm{O}$ ato repentino e violento de tracionar o boi pelo rabo, assim como a verdadeira tortura prévia - inclusive por meio de estocadas de choques elétricos - à qual é submetido o animal, para que saia do estado de mansidão e dispare em fuga a fim de viabilizar a perseguição, consubstanciam atuação a implicar descompasso com o que preconizado no art. 225, §1으, inciso VII, da Carta da República. ${ }^{43}$

Portanto, pela forma como é desenvolvida a prática da vaquejada, não restam duvidas quanto a existência de crueldade e maus tratos ao animais envolvidos, assim, não pode ser protegida em detrimento dos interesses fundamentais de proteção ao meio ambiente. ${ }^{44}$

\section{LEI № 13.364 DE 29 DE NOVEMBRO DE 2016}

A Lei 13.364/16 foi aprovada e sancionada em meio a decisão do STF. Referida Lei "eleva o

\footnotetext{
${ }^{38}$ SIRVINSKAS, Luís Paulo. Manual de direito ambiental. 13. ed. São Paulo: Saraiva, 2015. p. 645-647.

${ }^{39}$ BRASIL. Constituição (1988). Constituição da República Federativa do Brasil. 1988.

${ }^{40}$ BRASIL. Supremo Tribunal Federal. Ação Direta de Inconsticionalidade n. 4983 CE.

${ }^{41}$ BRASIL. Supremo Tribunal Federal. Ação Direta de Inconsticionalidade n. 4983 CE.

${ }^{42}$ BRASIL. Supremo Tribunal Federal. Ação Direta de Inconsticionalidade n. 4983 CE

${ }^{43}$ BRASIL. Supremo Tribunal Federal. Ação Direta de Inconsticionalidade n. 4983 CE.

${ }^{44}$ BRASIL. Supremo Tribunal Federal. Ação Direta de Inconsticionalidade n. 4983 CE.
} 
Rodeio, a Vaquejada, bem como as respectivas expressões artístico-culturais, à condição de manifestação cultural nacional e de patrimônio cultural imaterial".

0 art. $3^{\circ}$ estabelece que:

Art. $3^{\circ}$ Consideram-se patrimônio cultural imaterial do Brasil o Rodeio, a Vaquejada e expressões decorrentes, como:

I - montarias;

II - provas de laço;

III - apartação;

IV - bulldog;

$\mathrm{V}$ - provas de rédeas;

VI - provas dos Três Tambores, Team Penning e Work Penning;

VII - paleteadas; e

VIII - outras provas típicas, tais como Queima do Alho e concurso do berrante, bem como apresentações folclóricas e de músicas de raiz.

O que se indaga nesse caso é quanto a participação da comunidade, pois como já exposto, deveria ser fundamental para qualificação ou não como um bem cultural. Conforme consulta ao site do Senado Federal ${ }^{45}$ Projeto de Lei $n^{\circ} 24$, que restou aprovado e elevou a vaquejada como manifestação cultural, a consulta pública teve 69.335 votantes, desses 51.490 votaram contra a aprovação da lei.

\subsection{Projeto de Emenda a Constituição Federal}

Apesar da nobre decisão do Supremo Tribunal Federal, após a aprovação da Lei supra mencionada, o Senado criou uma Proposta de Emenda à Constituição, de n. 50/2016 ${ }^{46}$, que visa permitir a realização de manifestações culturais que sejam registradas como patrimônio cultural e não atentem contra o bem estar do animal, para isso a proposta busca acrescentar o $\S 7^{\circ}$ ao art. 225 da Constituição Federal:

Art. 1ㅇ. O art. 225 da Constituição passa a vigorar acrescido do seguinte § 7ㅇ․

“Art. 225

\footnotetext{
${ }^{45}$ http://www25.senado.leg.br/web/atividade/materias/-/materia/125802. Consulta em: 01 fev. 2017.

${ }^{46}$ https://www12.senado.leg.br/ecidadania/visualizacaomateria?id=127262. Consulta em: 01 fev. 2017.
} 
$\S 70$ Para fins do disposto na parte final do inciso VII do $\S 1$ 10 deste artigo, não se consideram cruéis as manifestações culturais previstas no $\S 1$ 으 do art. 215 e registradas como bem de natureza imaterial integrante do patrimônio cultural brasileiro, desde que regulamentadas em lei específica que assegure o bem-estar dos animais envolvidos."

A proposta apresenta como justificativa o fato de a CF/88 assegurar tanto o direito as manifestações culturais como a proteção aos animais contra crueldade. E recentemente o STF declarou a inconstitucionalidade da prática por meio da ADI 4.983/13 e argumentou que "é permitida a regulamentação de manifestações culturais que envolvam animais, desde que ela seja capaz de evitar a crueldade sem a descaracterização da própria prática".

Referida decisão provocou polêmica entre os apoiadores da prática e defensores dos direitos dos animais. Assim, o projeto propõe consignar a Lei Maior com clareza e permitir que as "práticas culturais de natureza imaterial que integram o patrimônio cultural brasileiro e comprovadamente não submetam os animais à crueldade possam se realizar sem óbices". Destarte a vaquejada, reconhecida como patrimônio, se regulamentada de forma a garantir a integridade física e mental dos animais envolvidos sem descaracterizar a própria prática, atenderá aos mandamentos exarados pelo Tribunal Constitucional. ${ }^{47}$

\section{CONSIDERAÇÕES FINAIS}

A Constituição Federal garante a proteção ao patrimônio cultural, a fim de resguardar certas práticas e acontecimentos para as futuras gerações, incentivando a valorização das manifestações culturais, também assegura a proteção a fauna e veda as práticas que submetam os animais a crueldade.

A prática da vaquejada que consiste na derrubada do boi, através da puxada pelo rabo, até cair com as patas para cima, de forma violenta e traumática, que muitas vezes causam gravíssimas lesões (mutilação) físicas e psicológicas a estes animais, vem sendo praticada atualmente como grandes espetáculos, que movimentam a economia e oferecem prêmios milionários.

A lei cearense, por sua vez, regulamentou essa prática como bem cultural, delimitando algumas normas sancionatórias para evitar maus tratos aos animais.

Em seguida o STF, declarou a Lei 15.299/2013, inconstitucional, pois a forma como ocorre a

\footnotetext{
${ }^{47}$ Disponível em: file:///C:/Users/Tamires/Downloads/sf-sistema-sedol2-id-documento-composto-59373.pdf. Acesso em 01 fev. 2017.
} 
vaquejada submete os animais a crueldade, pois é inerente a tal pratica, afrontando o art. 225, $\S 1$, inciso VII da Constituição.

Resultando em colisão entre direitos fundamentais, ou seja, entre a proteção ao patrimônio cultural e a proteção a fauna, destaca-se ainda que se tratam de direitos individuais colidindo com direitos coletivos, sendo que estes últimos devem prevalecer sobre aqueles.

Em meio a decisão do STF foi aprovada a Lei Federal n. 13.364/16, elevando a vaqueja a condição de patrimônio cultural imaterial, no então, prevalecendo a decisão de inconstitucionalidade do STF, pois o fato de ser considerado bem que integre o patrimônio cultural, não autoriza a crueldade com os animais.

Diante desse quadro foi proposta pelo Senado Federal um Projeto de emenda Constitucional que visa permitir a realização da vaquejada, por ser registrada como patrimônio cultural e que não atente contra o bem-estar do animal.

A dúvida ainda persiste se existe a possibilidade da pratica da vaquejada, sem causar sofrimento aos animais, e sem descaracteriza-la.

Parece quase impossível, pois mesmo com a melhoria da pratica, com a exigência de usar uma proteção caudal, ainda não se tem uma forma de derrubar o animal sem que cause algum dano.

Portanto, consistente a decisão do Supremo, em elevar a proteção ambiental da fauna, a crueldade intrínseca à vaquejada não permite a prevalência do valor cultural como resultado desejado pelo sistema de direitos fundamentais da Carta de 1988.

\section{REFERÊNCIAS DAS FONTES CITADAS}

ABVAQ - Associação Brasileira de Vaquejada. A vaquejada. 2014. Disponível em: <http://www.abvaq.com.br/telas/4>.

Regulamento geral de vaquejada: 2017. Disponível em:

<http://www.abvaq.com.br/telas/12>.

Regulamento geral de vaquejada: 2017. Disponível em:

<http://www.abvaq.com.br/images/institucional/Regulamento_ABVAQ_novo_28.10.pdf>. 
BEZZERA, José Euzébio Fernandes. No mundo do vaqueiro: apartação. Barcelona Portal virtual Barcelona - RN Brasil. Disponível em: <http://www.barcelona.educ.ufrn.br/mundo.htm>.

BRASIL. Constituição (1988). Constituição da República Federativa do Brasil. Brasília, DF: Senado Federal: Centro Gráfico, 1988.

BRASIL. Supremo Tribunal Federal. Ação Direta de Inconsticionalidade n. 4983 CE, Relator: Min. MARCO AURÉLIO, Data de Julgamento: 27/07/2013, Data de Publicação: DJe-150 DIVULG 02/08/2013 PUBLIC 05/08/2013. Disponível em:

http:<//stf.jusbrasil.com.br/jurisprudencia/23889398/acao-direta-de-inconstitucionalidade-adi4983-ce-stf>.

BRASIL. Lei no 13.364, de 29 de novembro de 2016. Eleva o Rodeio, a Vaquejada, bem como as respectivas expressões artístico-culturais, à condição de manifestação cultural nacional e de patrimônio cultural imaterial. Disponível em:<http://www.planalto.gov.br/ccivil_03/_ato20152018/2016/Lei/L13364.htm>. Acesso em: 02 fev. 2017.

BRASIL (Estado). Lei no 15.299, de 08 de janeiro de 2013. Regulamenta a vaquejada como prática desportiva e cultural no Estado do Ceará. Disponível em:

<https://www.legisweb.com.br/legislacao/?id=250070>. Acesso em: 02 fev. 2017.

CALAHU, Lélio Braga. Meio ambiente e tutela penal nos maus tratos a animais. PROANIMA Associação Protetora dos Animais do DF. Disponível em: < http://www.proanima.org.br/animaistem-direitos/meio-ambiente-e-tutela-penal-nos-maus-tratos-contra-animais.html>.

FIORILO, Celso Antônio Pacheco. Curso de Direito Ambiental Brasileiro. 14. ed. São Paulo: Saraiva, 2013. $961 \mathrm{p}$.

. Curso de Direito Ambiental Brasileiro. 16. ed. São Paulo: Saraiva, 2015. 1035 p.

MEDEIROS, Rostand. Pega de boi no mato: tradição e cultura do nordeste. Tok de História. 2014. Disponível em: <https://tokdehistoria.com.br/2014/07/16/pega-de-boi-no-mato-tradicao-ecultura-do-nordeste/>.

MILARÉ, Édis. Direito do Ambiente. 8. ed. São Paulo: Revista dos Tribunais, 2013. 1614 p.

SILVA, Thomas de Carvalho. A prática da vaquejada à luz da constituição federal. In: Âmbito Jurídico, Rio Grande, XII, n. 63, abr. 2009. Disponível em: < http://www.ambitojuridico.com.br/site/index.php?n_link=revista_artigos_leitura\&artigo_id=5922 >. 
SIRVINSKAS, Luís Paulo. Manual de direito ambiental. 13. ed. São Paulo: Saraiva, 2015.

. Manual de Direito Ambiental. 8. ed. São Paulo: Saraiva, 2010. 914 p.

VAQUEJADAS manifestações das culturas populares ou crimes de crueldade e maus tratos contra os animais? Disponível em: <http://www.proanima.org.br/ProAnima/www.proanima.org.br/oque-fazemos/proanima-na-midia/vaquejadas-manifestacoes-das-culturas-populares-ou-crime-decrueldade-e-maus-tratos-contra-os-animais/>. 


\title{
PELOS PODERES DE GRAYSKULL: O SOFRIMENTO DE PACATO E A ELETROCUSSÃO DA VAQUEJADA PELA ADI 4983/RJ
}

\author{
Jeferson Ricardo da Silva Reis ${ }^{1}$
}

\section{INTRODUÇÃO}

A vaquejada, enquanto prática desportiva é uma das festas de maior referência do Nordeste brasileiro, foi considerada pelo STF como violadora do direito ao meio ambiente ecologicamente equilibrado no âmbito da ADI 4983/CE, por transgredir a vedação constitucional ao tratamento cruel de animais.

Como o esporte não tem nenhuma regra ou objetivo sadista, que sujeite cavalos e bovinos participantes do evento a um tratamento cruel, durante o no qual não se fere ou não se mata propositalmente, a questão passou a ser analisada pelo viés do preconceito que acomete as expressões culturais nordestinas.

Para tanto, o ensaio tem o propósito inicial de contextualizar a vaquejada como prática desportiva nascida da busca e pega do boi, que era criado livremente nos campos abertos e não demarcados do semiárido nordestino, para depois descrever que a dupla de vaqueiro de hoje, montada em seus cavalos, não têm como desafio apenas o boi indômito, mas os campos inóspitos de um alta Corte e de um Ministério Público encastelados, por vezes tão desertos quanto o sertão nordestino, porém sem o charme do juazeiro ou do umbuzeiro.

A proposta é tentar identificar se a equiparação da vaquejada com práticas já consideradas sadistas pelo STF, a exemplo da rinha de galo e da pega do boi, é um excesso e, por isso, estaria contaminada pelo preconceito, aproveitando para, quem sabe, ressignificar a imagem do esporte ao final, distanciando-o de outras manifestações indiscutivelmente cruéis.

E para ilustrar a questão, optou-se por fazer referência a uma animação de grande sucesso nos anos 1980. He-Man e os Defensores do Universo foi utilizado como recurso lúdico e ao mesmo

\footnotetext{
${ }^{1}$ Aluno regular do Mestrado em Ciência Jurídica pela Universidade do Vale do Itajaí. Aluno regular do Máster en Territorio, Urbanismo y Sostenibilidad Ambiental en el Marco de La Economia Circular pela Universidad de Alicant. Pós-graduado em Direito Público pela Escola Damásio. Bacharel em Direito pela Universidade Estadual de Feira de Santana/UEFS. Analista Judiciário - Área Judiciária na Justiça Federal em Florianópolis/SC.
} 
tempo sarcástico. A escolha deu-se pelo fato de a relação do protagonista da série com o seu amigo Pacato representar bem aquela entre o vaqueiro e o cavalo, estrelas do Parque de Vaquejada ao lado dos bovinos.

As tentativas de esclarecimentos também estão centradas na participação pessoal do autor em vaquejadas, ainda quando residia no estado da Bahia, o que facilita a explicação das regras para quem não esteja familiarizado com o esporte.

Quanto à metodologia empregada, utilizou-se o método indutivo ${ }^{2}$ na fase de investigação ${ }^{3}$, o método cartesiano ${ }^{4}$ na fase de tratamento de dados, com as considerações finais sendo construída a partir de uma base lógica indutiva.

Ressalte-se, ainda, que nas diversas fases da pesquisa foram acionadas as técnicas do referente $^{5}$, da categoria $^{6}$, do conceito operacional ${ }^{7}$ e da pesquisa bibliográfica ${ }^{8}$.

\section{HE-MAN E O ART. 225 DA CONSTITUIÇÃO FEDERAL}

O jovem Adam é o protagonista da série animada de televisão americana He-Man and the Masters of the Universe, conhecida no Brasil como He-Man e os Defensores do Universo.

Vivendo no planeta Etérnia, onde seu pai Randor é o regente máximo, Adam transforma-se constantemente no poderoso He-Man para proteger seu mundo e o Castelo de Grayskull, sempre que ameaçados pelo vilão Esqueleto (Skeletor no idioma original).

Concluído o processo de transformação em He-Man, que se inicia com Adam empunhando sua 'Espada do Poder', gritando "Pelos poderes de Grayskull" e termina com o protagonista da cena recebendo uma forte descarga elétrica, o agora personagem He-Man aponta a mesma arma

\footnotetext{
2 “[...] pesquisar e identificar as partes de um fenômeno e colecioná-las de modo a ter uma percepção ou conclusão geral [...]". PASOLD, Cesar Luiz. Metodologia da Pesquisa Jurídica: teoria e prática. 13. ed. rev. São Paulo: Conceito Editorial, 2015, p. 91.

3 "[...] momento no qual o Pesquisador busca e recolhe os dados, sob a moldura do Referente estabelecido [...]." PASOLD, Cesar Luiz. Metodologia da pesquisa jurídica: teoria e prática. 13 ed. Florianópolis: Conceito Editorial, 2015. p. 87.

${ }^{4}$ Sobre as quatro regras do Método Cartesiano (evidência, dividir, ordenar e avaliar) veja LEITE, Eduardo de oliveira. A monografia jurídica. 5 ed. São Paulo: Revista dos Tribunais, 2001. p. 22-26.

5 “[...] explicitação prévia do(s) motivo(s), do(s) objetivo(s) e do produto desejado, delimitando o alcance temático e de abordagem para a atividade intelectual, especialmente para uma pesquisa." PASOLD, Cesar Luiz. Metodologia da pesquisa jurídica: teoria e prática. p. 58.

6 “[...] palavra ou expressão estratégica à elaboração e/ou à expressão de uma ideia." PASOLD, Cesar Luiz. Metodologia da pesquisa jurídica: teoria e prática. p. 27.

7 “[...] uma definição para uma palavra ou expressão, com o desejo de que tal definição seja aceita para os efeitos das ideias que expomos [...]". PASOLD, Cesar Luiz. Metodologia da pesquisa jurídica: teoria e prática. p. 39.

8 "Técnica de investigação em livros, repertórios jurisprudenciais e coletâneas legais". PASOLD, Cesar Luiz. Metodologia da pesquisa jurídica: teoria e prática. p. 215.
} 
de guerra para Pacato, seu melhor amigo, descarregando neste uma parte considerável da descarga elétrica recebida e transformando-o, ao final, em um tigre poderoso, que assume o nome de Gato-Guerreiro.

O episódio é descrito com precisão pela música He-Man, do grupo infantil 'Trem da Alegria', na seguinte passagem:

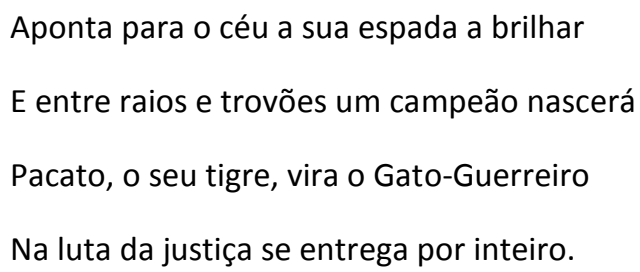

Mesmo recebendo uma inacreditável quantidade de descarga elétrica, He-Man não hesita em apontar a 'Espada do Poder' para Pacato, impingindo-Ihe angustia e sofrimento.

O felino, ciente de seu infortúnio, treme de tal forma que não consegue sequer sair do lugar e escapar da chamuscada. Pacato, então, é eletrocutado em tamanha intensidade que, a exemplo do que aconteceu com Adam, transforma-se em um ser poderoso e diferente do que era, que serve de montaria para o próprio He-Man e tem uma participação relevante na trama dos episódios.

Mas algo denuncia que a eletrocussão de Pacato ainda é mais violenta do que aquela recebida por Adam. Enquanto que em Adam o raio mágico apenas acrescenta força e altera o figurino, em Pacato, além desses dois efeitos, percebe-se que sua personalidade é fortemente afetada.

Com a eletrocussão, sai de cena um felino tímido e medroso, sem expressividade, para surgir um tigre destemido e autoconfiante, com um timbre de voz que, por si só, já é capaz de intimidar a maioria dos comparsas de Esqueleto.

Apesar da boa intenção, a conduta do Príncipe Adam gera desdobramentos quando analisada à luz da Constituição Federal da República Federativa do Brasil.

O art. 225 da Constituição prevê que todos têm direito ao meio ambiente ecologicamente equilibrado, bem de uso comum do povo e essencial à sadia qualidade de vida, impondo-se ao Poder Público e à coletividade o dever de defendê-lo e preservá-lo para as presentes e futuras gerações.

Já o inciso VII do $§ 1$ 으 prevê que para assegurar a efetividade desse direito, incumbe ao 
Poder Público proteger a fauna e a flora, vedadas, na forma da lei, as práticas que coloquem em risco sua função ecológica, provoquem a extinção de espécies ou submetam os animais a crueldade.

Considerando-se as disposições do art. 225, § 10, VII, da Constituição Federal, a utilização da 'Espada do Poder' com o propósito de eletrocutar Pacato seria um típico exemplo de submissão de animal a tratamento cruel, devendo o utensílio ou a animação em si serem proibidas?

Embora a pergunta seja inusitada, ela faz sentido porque não é apenas em animações da década de 1980 que tal discussão gera polêmicas. Não tão longe quanto o planeta Etérnia e acalorando os debates aqui na Terra, o estado do Ceará regulamentou a vaquejada como prática desportiva e cultural por meio da Lei 15.299, de 8.1.2013, nos seguintes moldes:

Art. 1‥ Fica regulamentada a vaquejada como atividade desportiva e cultural no Estado do Ceará.

Art. 2․ Para efeitos desta Lei, considera-se vaquejada todo evento de natureza competitiva, no qual uma dupla de vaqueiro a cavalo persegue animal bovino, objetivando dominá-lo.

$\S 1$ 1ㅇ Os competidores são julgados na competição pela destreza e perícia, denominados vaqueiros ou peões de vaquejada, no dominar animal.

§ 2ㅇ A competição dever ser realizada em espaço físico apropriado, com dimensões e formato que propiciem segurança aos vaqueiros, animais e ao público em geral.

§ 3으 A pista onde ocorre a competição deve, obrigatoriamente, permanecer isolada por alambrado, não farpado, contendo placas de aviso e sinalização informando os locais apropriados para acomodação do público.

Art. 3․ A vaquejada poderá ser organizada nas modalidades amadora e profissional, mediante inscrição dos vaqueiros em torneio patrocinado por entidade pública ou privada.

Art. 4ㅇ. Fica obrigado aos organizadores da vaquejada adotar medidas de proteção à saúde e à integridade física do público, dos vaqueiros e dos animais.

§ 1으 0 transporte, o trato, o manejo e a montaria do animal utilizado na vaquejada devem ser feitos de forma adequada para não prejudicar a saúde do mesmo.

$\S 2$ 2 Na vaquejada profissional, fica obrigatória a presença de uma equipe de paramédicos de plantão no local durante a realização das provas.

$\S 3$ ㅇ 0 vaqueiro que, por motivo injustificado, se exceder no trato com o animal, ferindo-o ou maltratando-o de forma intencional, deverá ser excluído da prova.

Art. 5‥ Esta Lei entra em vigor na data de sua publicação.

Art. 6‥ Revogam-se as disposições em contrário.

O esporte é definido pelo art. 20 da Lei n. 15.299/2013 como todo evento de natureza competitiva, no qual uma dupla de vaqueiros a cavalo persegue um bovino, objetivando dominá- 
lo.

Antes de continuar com a discussão legal e com a tentativa de eletrocussão da vaquejada pela Procuradoria Geral da República, com sua declaração de inconstitucionalidade via Supremo Tribunal Federal, passa-se à uma breve contextualização histórica sobre essa manifestação cultural e sua prática, regras e características, deixando-se claro que não será utilizada o ordenamento jurídico de Etérnia no decorrer do estudo.

\section{BREVE HISTÓRICO}

A vaquejada tradicional em si remonta às festas de apartação, divisão do boi ou, ainda, pega do boi, em um período no qual as propriedades rurais não tinham cercas e, por isso, os gados da região Nordeste eram criados soltos. Tratava-se de um ritual de simples captura do boi pelos vaqueiros na caatinga, vegetação típica do semiárido nordestino, descrito com precisão na seguinte passagem:

Apesar de ser uma atividade importante, até a metade do século XX a pecuária se apresentava ainda pouco intensiva, e os bovinos criados soltos, pouco modificando a vegetação nativa do sertão. $O$ gado, resistente ao clima semi-árido e à vegetação da caatinga, era denominado de "crioulo" ou "péduro", devido a sua rusticidade e ao fato de não pertencer a uma raça específica. Para adentrarem na caatinga, os vaqueiros, montados em seus cavalos, usavam chapéu e guardapeito de couro, gibão, perneiras. Para proteger o cavalo, também, da vegetação nativa, utilizavam nos animais os largos peitorais e cabeçadas protetoras. Isso não era um mero ato rotineiro do dia de trabalho, mas um momento que os vaqueiros tinham para demonstrar a sua coragem, força e agilidade. Refletindo a respeito da destreza e fortaleza dos sertanejos na lida com o gado na caatinga, autores como Euclides da Cunha (1999), em Os Sertões, e José de Alencar (1969), no romance O Sertanejo, abordaram essa representação sertaneja. Como não havia demarcações nas fazendas, as chamadas cercas de arame farpado, quando o gado se embrenhava na caatinga, misturava-se aos de outros fazendeiros. Assim, no período das chuvas ou no momento da comercialização, o fazendeiro proporcionava festejos, para reaver as reses perdidas. Convocava vaqueiros da própria fazenda e de outras circunvizinhas, objetivando aproveitar o conhecimento decorrente da lida diária e reaver e selecionar o seu gado ${ }^{9}$.

Conclui a autora: "Essas investidas, posteriormente, transformaram-se em rituais festivos, atraindo, no sertão, as comunidades próximas e as distantes. Da apartação do gado, nasceu uma festa rural que dominava em todo o sertão nordestino." ${ }^{10}$.

\footnotetext{
${ }^{9}$ MENEZES, Sônia de Souza Mendonça. ALMEIDA, Maria Geralda de. VAQUEJADA: a pega de boi na caatinga resiste no sertão sergipano. p. 3-4.

${ }^{10}$ MENEZES, Sônia de Souza Mendonça. ALMEIDA, Maria Geralda de. VAQUEJADA: a pega de boi na caatinga resiste no sertão sergipano. p. 4.
} 
Segundo as autoras, a vaquejada tradicional também pode ser considerada uma estratégia conservacionista, uma vez que a criação extensiva do boi impede o desmatamento de vastas áreas de caatinga para o plantio de capim, evita a utilização de madeira para construção de cercas e, ainda, o esgotamento do solo.

Atualmente, a prática da vaquejada é definida pela Associação Brasileira de Vaquejada (ABVAQ) como uma atividade cultural-competitiva, com características de esporte, praticado em uma pista sobre um colchão de areia com espessura mínima não inferior a $40 \mathrm{~cm}$, no qual dois vaqueiros montados a cavalo têm o objetivo de alcançar e emparelhar o boi entre os cavalos, conduzi-lo até o local indicado, onde o bovino deve ser deitado.

Tal conceito é extraído do art. 3ำ do Regulamento Geral da Vaquejada 2017-2018, da própria $A B V A Q$, aprovado com o propósito de unificar as regras do esporte em todo o Brasil, estabelecendo normas de realização dos eventos, de bem-estar animal, além de definir procedimentos e estabelecer diretrizes garantidoras do bom andamento do esporte, por meio do controle e prevenção sanitário-ambientais, higiênico-sanitárias e de segurança em geral.

A partir da leitura do Regulamento Geral da Vaquejada, identifica-se que o objetivo do esporte é puxar o bovino pelo protetor de cauda com o objetivo de deitá-lo no colchão de areia, dentro de uma área específica demarcada no solo por duas linhas paralelas de cal denominadas faixas.

Embora fortemente inspirada nas festas de apartação, a vaquejada evoluiu para transformar-se em uma importante atividade desportiva com DNA genuinamente nordestino, frequentemente realizado em conjunto com grandes festejos e eventos locais em um local denominado Parque de Vaquejadas ${ }^{11}$.

Durante a competição, uma dupla de vaqueiros, cada qual em sua respectiva montaria, persegue um boi ou touro que corre em disparada por uma pista de corrida, cuja a largura pode ou não aumentar conforme os competidores se aproximem da reta final (o que dá à pista um formato próximo a de um trapézio isósceles).

Ambos largam lado a lado do início da pista, que corresponderia à base menor do trapézio, precisamente do brete ${ }^{12}$ (porteira ou mourão), sempre com o boi ou touro ao centro.

\footnotetext{
${ }^{11}$ Parque de vaquejada - As instalações de acesso ao público, competidores e a arena onde acontece a vaquejada. Conceito extraído do Regulamento Geral de Vaquejada da ABVAQ.

12 11. Brete - Local de ordenamento e liberação dos bovinos para a pista de vaquejada. Conceito extraído do Regulamento Geral de
} 
Cada vaqueiro posiciona-se e corre com seu cavalo ao lado do animal e tem funções bastantes diferentes durante a prova. 0 vaqueiro-esteiro ${ }^{13}$ ou 'bate-esteira' tem por função alinhar o boi o mais próximo possível do vaqueiro-puxador ${ }^{14}$ ou 'derrubador'. É essencial que ambos corram de tal forma que impeça o retorno do boi, mantendo-o em velocidade e em direção à faixa de pontuação.

Alinhado o boi, o vaqueiro-esteiro pega o protetor de cauda e a entrega ao vaqueiropuxador (movimento este chamado de passagem de cauda), que tentará derrubá-lo dentro da faixa de pontuação ${ }^{15}$ de uma forma tal que este seja deitado no colchão de areia. Além da passagem da cauda, o vaqueiro-esteiro tem que evitar que o boi saia da área de pontuação após se levantar, dando tempo ao juiz de pista de avaliar o movimento.

Com relação à pista de areia, há normalmente nela uma disposição de três faixas paralelas entre si (marcas de cal) por toda sua extensão, podendo tais dimensões variarem de uma pista para outra, que juntas delineiam quatro áreas bem definidas e fundamentais para o propósito da prova.

Entre o brete e a primeira marca de cal ou faixa (faixa de tolerância) ${ }^{16}$ disposta na areia tem-se a primeira área, conhecida como 'área de tolerância'. Com um cumprimento médio de 10 metros, na hipótese de o boi virar a cabeça em direção ao ponto de partida (brete), o movimento não é considerado retorno, a prova segue normalmente e a dupla de vaqueiros não é penalizada, daí a referência ao termo tolerância.

Entre a primeira faixa e a segunda há uma distância média de 90 metros, delimitando a segunda área da pista. É esta a distância que os vaqueiros, em alta velocidade, têm para ajustar o boi, evitando o seu retorno, e para realizarem a passagem de cauda, sendo conhecida como 'área de ajuste do boi'.

Se durante a corrida o boi mudar de direção ou virar a cabeça em direção ao brete, fica caracterizado o retorno e a dupla de vaqueiros pode ser penalizada, ocasião em que o árbitro da

\footnotetext{
Vaquejada da ABVAQ.

${ }^{13}$ 3. Vaqueiro-esteireiro - Competidor responsável por direcionar o boi e condicioná-lo até o local da faixa, emparelhando-o com o vaqueiro-puxador, além de entregar o protetor de caudas do boi ao vaqueiro-puxador. Conceito extraído do Regulamento Geral de Vaquejada da ABVAQ.

${ }^{14}$ 2. Vaqueiro-puxador - Competidor responsável por entrelaçar o protetor de caudas do boi entre as mãos e deitar o bovino na faixa demarcada no colchão de areia. Conceito extraído do Regulamento Geral de Vaquejada da ABVAQ.

${ }^{15}$ 4. Faixa de pontuação - Linhas paralelas, com distância de $9 m$ entre uma e outra, demarcadas sobre o colchão de areia, onde o boi deve ser deitado. Conceito extraído do Regulamento Geral de Vaquejada da ABVAQ.

${ }^{16}$ 5. Faixa de tolerância - Imediações do local de partida do boi para iniciar a corrida, demarcada com uma linha perpendicular à pista de competição. Conceito extraído do Regulamento Geral de Vaquejada da ABVAQ.
} 
corrida não atribui pontos, anunciando como resultado: 'Zero' ${ }^{17}$.

Entre a segunda e a terceira faixas, também com uma extensão média de 10 metros, encontra-se a terceira área, chamada de 'faixa de pontuação'. Corresponde à área onde o animal precisa ser deitado. Caso o animal caia dentro das faixas, o árbitro valida o movimento, a dupla pontua e o resultado é anunciado aos competidores e ao público presente ao Parque de Vaquejada com a expressão: 'Valeu o boi' ${ }^{18}$.

A última área da pista tem um cumprimento médio de 50 metros, sendo conhecida como área de desaceleração, e estende-se até a base maior do trapézio, completando as quatro áreas mencionadas (área de tolerância; área de ajuste do boi; faixa de pontuação; e área de desaceleração).

Nas vaquejadas atuais existem duas fases: classificatória e disputa. De acordo com o art. 6으, item 1, a, do Regulamento do esporte, a fase classificatória pode ocorrer com a puxada de 02 (dois), 03 (três), 04 (quatro), 05 (cinco) ou 06 (seis) bois, o que representa a quantidade de animais que cada dupla terá para pontuar. Cada boi, quando deitado no colchão de areia, possui uma pontuação diferente, sendo normalmente corrido em ordem crescente de pontuação e de dificuldade, variando de 7 até 13 pontos por animal.

Não há nenhuma modalidade de vaquejada na qual a submissão do boi ou do cavalo a tratamento cruel, sofrimento ou dor física renda pontos aos vaqueiros e leve o público ao delírio.

O próprio art. 32 do Regulamento Geral de Vaquejada proíbe o uso de tapas, chicotes/tacas ou de qualquer outro objeto que possa causar sofrimento ao animal, esteja ele correndo ou não. A proibição é tão rigorosa que se estende a toda a área do Parque de Vaquejada, impondo-se fiscalização dentro e fora da arena.

Em relação aos bois, o caput do art. 33 do Regulamento proíbe os vaqueiros de agredi-los, de tocarem suas faces ou apoiarem-se em seus lombos. Além do mais, a norma possui toda uma preocupação com os equipamentos de segurança obrigatórios, que não podem causar danos ou lesões aos animais, além de uma Seção VII, inteiramente dedicada ao bem-estar dos animais.

Os bovinos utilizados na vaquejada são denominados popularmente de boi-mobral ou boi-

\footnotetext{
${ }^{17}$ 7. Zero - Expressão que caracteriza a ausência de êxito do competidor. Conceito extraído do Regulamento Geral de Vaquejada da ABVAQ.

${ }^{18} 6$. Valeu o boi - Expressão que caracteriza o êxito do competidor. Conceito extraído do Regulamento Geral de Vaquejada da ABVAQ.
} 
letrado. Os primeiros assim são chamados para identificar aqueles que nunca correram uma vaquejada, sendo inexperientes e mais fáceis de derrubar.

Tal denominação, inclusive, pode ser encontrada na dissertação de mestrado "O 'espetáculo do cabra macho': um estudo sobre os vaqueiros nas vaquejadas no Rio Grande do Norte", apresentada por Francisco Jânio Filgera Aires ao Programa de Pós-Graduação em Antropologia Social da Universidade Federal do Rio Grade do Norte, como requisito parcial à obtenção do título de mestre em Antropologia Social.

Já o termo 'boi letrado' refere-se aos habituados com o esporte, de maior porte físico e, por isso, mais difíceis de serem derrubados.

Os primeiros bois corridos são os inexperientes, mais leves e de menor pontuação, por representarem reduzidos riscos e dificuldades aos vaqueiros em termos de força, velocidade e equilíbrio. Assim, o final das provas tende a ser mais emocionante para os competidores e público.

$\mathrm{O}$ art. 49 do Regulamento fixa um peso mínimo de 12 (doze) arrobas médias para classificação e de 16 (dezesseis) arrobas médias para a disputa final.

As provas exigem velocidade, equilíbrio, coragem, concentração e sincronismo entre as duplas cavalos, além de muita força e precisão do vaqueiro puxador.

A falta ou perda momentânea de tais atributos, inclusive, pode comprometer o desempenho da dupla, conforme retratado na música Saga de um vaqueiro, um dos hinos do esporte, de autoria da compositora Rita de Cássia e eternizadas pelas bandas de forró eletrônico Mastruz com Leite e Catuaba com Amendoim.

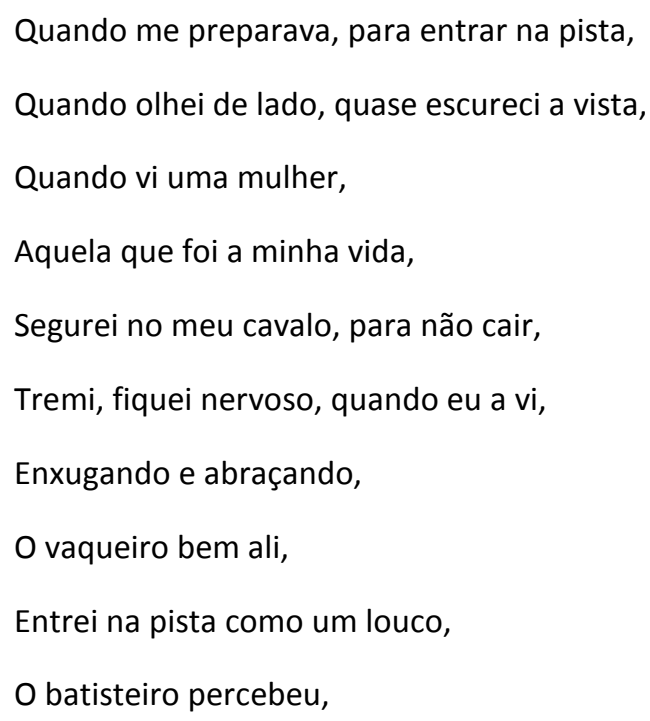


Andei foi longe do boi,

"Há isso nunca aconteceu!"

O Vaqueiro entrou na pista, e eu fiquei a observar

Ela acenava, ela aplaudia

E ele, o boi a derrubar

Derrubou o boi na faixa

Ganhou o primeiro lugar...

Fiquei desconsolado,

Envergonhado eu fiquei

Por tudo que foi visto, pode-se afirmar que a prática do esporte está relacionada a aspectos culturais que remontam ao início do povoamento e da exploração econômica da pecuária no sertão nordestino, notadamente a pecuária extensiva. ${ }^{19}$

Em razão disso, a vaquejada não pode ser considerada apenas como uma atividade desportiva, cuja supressão representaria a mera exclusão de uma forma de lazer lúdica, vazia de significado, mas como algo que decorre do próprio direito à cultura a que se refere o art. 216, caput, da Constituição Federal.

Tal característica é negligenciada em razão tanto do preconceito que cerca o esporte, quanto pela má compreensão da atividade, associada injustamente a práticas sádicas e de maus tratos que caracterizavam outros festejos populares centrados na figura bovina.

O boi não é visto como uma ameaça, nem o foco principal do evento é seu sofrimento ou angustia. Embora possa eventualmente acontecer um acidente, não há qualquer intenção de submeter os animais participantes da vaquejada (equinos e bovinos) a sofrimentos. Quando acontecem, precisam ser compreendidos como acidentes, passíveis de ocorrer com seres humanos e animais envolvidos em atividades desportivas.

Além disso, é comum a desclassificação de vaqueiros que causem danos aos cavalos ou aos bovinos durante as provas, mesmo que não intencionais, não se aceitando qualquer evento dentre ou no entorno dos Parques de Vaquejadas que incitem a violência ou maus tratos aos animais, indiscutíveis estrelas do evento, conforme previsto no próprio Regulamento Geral de Vaquejada.

Para além de contribuir para o desenvolvimento econômico e oferecer uma experiência

\footnotetext{
${ }^{19}$ MENEZES, Sônia de Souza Mendonça. ALMEIDA, Maria Geralda de. VAQUEJADA: a pega de boi na caatinga resiste no sertão sergipano.
} 
lúdica, a vaquejada possui contornos afetivos para o nordestino e está presente nas artes, letras, tradições e crenças do povo, inspirando tanta a música, quanto a literatura e a poesia regionais.

Não se pode acabar com o regime democrático pelo fato de os representantes escolhidos pelo povo desviarem-se do propósito para o qual foram eleitos e passam a locupletar-se, corromper-se ou beneficiar uma pequena parte da população ou mesmo instituições bancárias. A crueldade contra animais pode ser observada em diversas ocasiões, a exemplo da forma como são criados e abatidos, e precisam ser inibidas com rigor.

O discurso utilizado contra a vaquejada precisaria ser ampliado para alcançar outras práticas desportivas e, ainda, incluir todas as demais formas de incorporação da vida animal à lógica de mercado, voltado para a obtenção de lucro por meio da exploração de seus corpos e vidas (a exemplo do consumo de carne), para o fornecimento de produtos (leite e derivados, artigos de vestuário, calçados de couro, roupas de lã, estofados, etc) ou, então, para servir de cobaias em pesquisas científicas realizadas pelas indústrias farmacêutica e cosmética (OLIVEIRA, PINZANI).

Se a proibição da vaquejada decorresse tão somente de uma análise de ordem legal ou moral, e não de um preconceito incontido, tais desdobramentos deveriam forçar a diminuição de todo tipo de ação ou interesse econômico que alcançasse qualquer animal, a considerar injustificável, por exemplo, o comércio de produtos cuja matéria prima ou forma de produção implicasse algum sofrimento ou abate.

A posição assumida pelo STF no julgamento da ADI 4983/CE, proibindo a vaquejada sem lhe conceder qualquer chance de adaptação, contrasta com o seu silencio e o da PGR diante dos inúmeros exemplos acima mencionados e que provocam a transformação de animais em mercadorias com valor instrumental, além de chocar-se com o compromisso que o estado brasileiro tem de adotar medidas de proteção às diversas expressões culturais existentes em seu território, a que está obrigado por ratificar inúmeros tratados e convenções internacionais com esta temática, o que será visto oportunamente.

\section{A CURTINA CONSTITUCIONAL NO ÂMBITO DA ADIN 4983/CE}

Nos termos do art. 216, caput, da Constituição Federal, constitui patrimônio cultural brasileiro os bens de natureza material e imaterial, tomados individualmente ou em conjunto, 
portadores de referência à identidade, à ação, à memória dos diferentes grupos formadores da sociedade brasileira.

Já o art. 215 da Constituição prevê que o estado garantirá a todos o pleno exercício dos direitos culturais e acesso às fontes da cultura nacional, e apoiará e incentivará a valorização e a difusão das manifestações culturais, cabendo, ainda, proteger as manifestações culturais populares, indígenas e afro-brasileiras, e das de outros grupos participantes do processo civilizatório nacional.

Do ponto de vista da constitucionalidade formal, o art. 24, caput, XI, §§ 1으 a 3 으, todos da Constituição Federal, estabelece que compete à União, aos estados e ao Distrito Federal legislarem concorrentemente sobre educação, cultura, ensino e desporto, cabendo à União estabelecer normas de caráter gerais e aos estados suplementá-las.

Inexistindo lei federal sobre normas gerais, os estados poderão exercer a competência legislativa plena e, com isso, atender às suas peculiaridades.

Assim considerado, o estado do Ceará detinha competência para legislar sobre a matéria e, por isso, a Lei 15.299/2013 não padecia de qualquer vício de constitucionalidade formal.

Após a sua entrada em vigor, contudo, o Procurador-Geral da República Roberto Monteiro Gurgel Santos, acolhendo representação formulada pela Procuradoria da República no Estado do Ceará, ingressou no Supremo Tribunal Federal, em 17.6.2013, com uma Ação Direta de Inconstitucionalidade, questionando a constitucionalidade material da lei cearense. ${ }^{\mathbf{2 0}}$

A peça inaugural, também subscrita pela então Vice-Procuradora-Geral da República Déborah Macedo Duprat de Britto Pereira, defendia que a Lei n. 15.299/2013 violava o disposto no art. $225, \S 1^{\circ}$, VII, da Constituição da República, por submeter os animais a tratamento cruel.

Na peça, a Procuradoria-Geral da República argumentava que o direito ao meio ambiente insere-se nos denominados direitos de fraternidade ou de solidariedade, conhecidos como direitos de 3 a geração ou de novíssima dimensão, e que a concepção de meio ambiente, no âmbito do Supremo Tribunal Federal, superava a dicotomia cultura/natureza; reconhecia a necessária harmonia entre a construção social do ser humano e a convivência com o ambiente em que está inserido; e, por fim, que a Corte alçava o direito das futuras gerações à condição de direito fundamental. A relatoria da ADIM 4983/CE coube ao Ministro Marco Aurélio.

\footnotetext{
${ }^{20}$ ADIN 4983/CE, Relator Min. Marco Aurélio.
} 
Em resumo, a ação se apresenta pela necessidade de preservação do meio ambiente, dentro da concepção do STF sobre o tema, o que afastaria do ordenamento jurídico as práticas que resultassem em tratamento inadequado aos animais, ainda que estas ocorram dentro de um contexto cultural, em razão da antinomia destas com a Constituição Federal.

Citou-se, como exemplo, a declaração de inconstitucionalidade de leis estaduais que permitiam as sádicas Rinha de Galo, no Rio de Janeiro, e a Farra do Boi, em Santa Catarina, nos termos das ADIs 1856 e 2.514, cujas ementas transcreve-se abaixo:

E M E N T A: AÇÃO DIRETA DE INCONSTITUCIONALIDADE - BRIGA DE GALOS (LEI FLUMINENSE № 2.895/98) - LEGISLAÇÃO ESTADUAL QUE, PERTINENTE A EXPOSIÇÕES E A COMPETIÇÕES ENTRE AVES DAS RAÇAS COMBATENTES, FAVORECE ESSA PRÁTICA CRIMINOSA - DIPLOMA LEGISLATIVO QUE ESTIMULA O COMETIMENTO DE ATOS DE CRUELDADE CONTRA GALOS DE BRIGA - CRIME AMBIENTAL (LEI № 9.605/98, ART. 32) - MEIO AMBIENTE - DIREITO À PRESERVAÇÃO DE SUA INTEGRIDADE (CF, ART. 225) - PRERROGATIVA QUALIFICADA POR SEU CARÁTER DE METAINDIVIDUALIDADE - DIREITO DE TERCEIRA GERAÇÃO (OU DE NOVÍSSIMA DIMENSÃO) QUE CONSAGRA O POSTULADO DA SOLIDARIEDADE - PROTEÇÃO CONSTITUCIONAL DA FAUNA (CF, ART. 225, § 10, VII) - DESCARACTERIZAÇÃO DA BRIGA DE GALO COMO MANIFESTAÇÃO CULTURAL RECONHECIMENTO DA INCONSTITUIONALIDADE DA LEI ESTADUAL IMPUGNADA - AÇÃO DIRETA PROCEDENTE. LEGISLAÇÃO ESTADUAL QUE AUTORIZA A REALIZAÇÃO DE EXPOSIÇÕES E COMPETIÇÕES ENTRE AVES DAS RAÇAS COMBATENTES - NORMA QUE INSTITUCIONALIZA A PRÁTICA DE CRUELDADE CONTRA A FAUNA - INCONSTITUCIONALIDADE. - A promoção de briga de galos, além de caracterizar prática criminosa tipificada na legislação ambiental, configura conduta atentatória à Constituição da República, que veda a submissão de animais a atos de crueldade, cuja natureza perversa, à semelhança da "farra do boi" (RE 153.531/SC), não permite sejam eles qualificados como inocente manifestação cultural, de caráter meramente folclórico. Precedentes. - A proteção jurídicoconstitucional dispensada à fauna abrange tanto os animais silvestres quanto os domésticos ou domesticados, nesta classe incluídos os galos utilizados em rinhas, pois o texto da Lei Fundamental vedou, em cláusula genérica, qualquer forma de submissão de animais a atos de crueldade. - Essa especial tutela, que tem por fundamento legitimador a autoridade da Constituição da República, é motivada pela necessidade de impedir a ocorrência de situações de risco que ameacem ou que façam periclitar todas as formas de vida, não só a do gênero humano, mas, também, a própria vida animal, cuja integridade restaria comprometida, não fora a vedação constitucional, por práticas aviltantes, perversas e violentas contra os seres irracionais, como os galos de briga ("gallus-gallus"). Magistério da doutrina. ALEGAÇÃO DE INÉPCIA DA PETIÇÃO INICIAL. - Não se revela inepta a petição inicial, que, ao impugnar a validade constitucional de lei estadual, (a) indica, de forma adequada, a norma de parâmetro, cuja autoridade teria sido desrespeitada, (b) estabelece, de maneira clara, a relação de antagonismo entre essa legislação de menor positividade jurídica e o texto da Constituição da República, (c) fundamenta, de modo inteligível, as razões consubstanciadoras da pretensão de inconstitucionalidade deduzida pelo autor e (d) postula, com objetividade, o reconhecimento da procedência do pedido, com a conseqüente declaração de ilegitimidade constitucional da lei questionada em sede de controle normativo abstrato, delimitando, assim, o âmbito material do julgamento a ser proferido pelo Supremo Tribunal Federal. Precedentes. (ADI 1856, Relator Min. CELSO DE MELLO, Tribunal Pleno, julgado em 26/05/2011, DJe-198 DIVULG 13- 
10-2011 PUBLIC 14-10-2011 EMENT VOL-02607-02 PP-00275 RTJ VOL-00220-01 PP-00018 RT v. 101, n. 915,2012 , p. 379-413).

EMENTA: AÇÃO DIRETA DE INCONSTITUCIONALIDADE. LEI N. 11.366/00 DO ESTADO DE SANTA CATARINA. ATO NORMATIVO QUE AUTORIZA E REGULAMENTA A CRIAÇÃO E A EXPOSIÇÃO DE AVES DE RAÇA E A REALIZAÇÃO DE "BRIGAS DE GALO". A sujeição da vida animal a experiências de crueldade não é compatível com a Constituição do Brasil. Precedentes da Corte. Pedido de declaração de inconstitucionalidade julgado procedente. (ADI 2514, Relator Min. EROS GRAU, Tribunal Pleno, julgado em 29/06/2005, DJ 09-12-2005 PP-00004 EMENT VOL-02217-01 PP-00163 LEXSTF v. 27, n. 324, 2005, 42-47).

A conclusão do STF, ao julgar o mérito da ADI 4983/CE, em 6.10.2016, foi semelhante ao decido nos processos acima referenciados (ou seja, pela declaração de sua inconstitucionalidade material), em uma votação bastante apertada (6X5):

Decisão: O Tribunal, por maioria e nos termos do voto do Relator, julgou procedente o pedido formulado para declarar a inconstitucionalidade da Lei no 15.299/2013, do Estado do Ceará, vencidos os Ministros Edson Fachin, Gilmar Mendes, Teori Zavascki, Luiz Fux e Dias Toffoli. Ausentes, justificadamente, os Ministros Celso de Mello e Gilmar Mendes, que proferiram votos em assentada anterior. Presidiu o julgamento a Ministra Cármen Lúcia. Plenário, 06.10.2016.

No seu voto, o Ministro Marco Aurélio consignou que a crueldade era intrínseca à vaquejada pelo fato de o boi ser enclausurado, açoitado e instigado a sair em disparada, sendo derrubado após o seu rabo ser torcido.

O Ministro apoiou-se, outrossim, nos laudos técnicos disponibilizados pelo PGR, relatando as consequências danosas à integridade física e mental dos animais, para, ao final de seu voto, considerar inconstitucional a Lei 15.299/2013.

Em seguida, o Ministro Edson Fachin inaugurou a divergência ao entender que o próprio Ministério Público reconheceu, na petição inicial, a vaquejada como manifestação cultural, a provocar na espécie a incidência do art. 215, § 1으, da Constituição Federal.

Infelizmente, com exceção do voto do Min. Relator Marco Aurélio, os demais posicionamentos dos Ministros do STF não foram, até a presente data, disponibilizados pelo sítio eletrônico do Tribunal.

Importante destacar que a Resolução n. 536, de 16.10.2014, que dispõe sobre a publicação de acórdão pela Secretaria Judiciária do Supremo Tribunal Federal, prevê em seus arts. 1ํ e 3으, caput e parágrafo único, um prazo de sessenta dias, a partir da sessão em que tenha sido proclamado o resultado de julgamento, para a publicação dos acórdãos proferidos pelo Plenário e 
pelas Turmas, com possibilidade de sucessivas prorrogações.

Com isso, a indisponibilidade dos votos impediu a realização de uma análise sobre o enfrentamento da ponderação dos direitos fundamentais em conflito na visão de cada um dos Ministros, o que seria enriquecedor pelo fato de a composição do STF não ter sido a mesma da época em que a Corte julgou as ADIs 1856 e 2514.

Até que os votos sejam disponibilizados, não será possível saber, por exemplo, se a nova composição da Corte foi o que contribuiu para que a votação fosse apertada (6x5 a favor da declaração de inconstitucionalidade) ou se, no caso da Vaquejada, a ponderação aplicada pela corte no julgamento das ADIs 1856 e 2514 sofreu uma leve inclinação em seu entendimento.

Uma terceira questão que padece de esclarecimentos e espera-se que tenha sido objeto de um intenso debate durante o julgamento da ADI 4983/CE diz respeito a lógica do entendimento do Supremo que proibiu a vaquejada cearense, quando a lei declarada inconstitucional trazia em seu bojo a obrigação de os organizadores da vaquejada adotarem medidas de proteção à saúde e à integridade física do público, dos vaqueiros e dos animais e, ainda, a obrigação de o transporte, o trato, o manejo e a montaria dos animais utilizados serem feitos de forma a não prejudicar a saúde daqueles (art. 4으, caput e § 1으, Lei 15.299/2013).

Como a vaquejada seria indissociável de práticas cruéis, se a realização da modalidade profissional do esporte estava condicionada à obrigatória presença de uma equipe de paramédicos de plantão no local, durante a realização das provas, e à eliminação do vaqueiro que excedesse no trato com o animal, vindo a feri-lo ou maltratá-lo (art. 4으, §§ 2ㅇ e 3ㅇ da Lei 15.299/2016), são outras questões cujas respostas são aguardadas com grande ansiedade para saber de que forma foram abordadas pela ADI 4983/CE.

Aparentemente encerrada a discussão pelo STF, embora ainda incipiente no campo acadêmico, o tema sofreu nova e surpreendente reviravolta com a entrada no jogo do Congresso Nacional e com a promulgação da Lei 13.364, de 29.11.2016, temas do próximo tópico.

\section{A PROMULGAÇÃO DA LEI 13.364/2016}

Pouco tempo após a declaração de inconstitucionalidade da Lei 15.299/13, o Presidente da República Michel Temer sancionou a Lei 13.364, de 29.11.2016, que elevou o Rodeio, a Vaquejada e as respectivas expressões artístico-culturais à condição de manifestação cultural nacional e de 
patrimônio cultural imaterial:

Art. 10 Esta Lei eleva o Rodeio, a Vaquejada, bem como as respectivas expressões artístico-culturais, à condição de manifestações da cultura nacional e de patrimônio cultural imaterial.

Art. 2ㅇ O Rodeio, a Vaquejada, bem como as respectivas expressões artístico-culturais, passam a ser considerados manifestações da cultura nacional.

Art. 30 Consideram-se patrimônio cultural imaterial do Brasil o Rodeio, a Vaquejada e expressões decorrentes, como:

I - montarias;

II - provas de laço;

III - apartação;

IV - bulldog;

$\checkmark$ - provas de rédeas;

VI - provas dos Três Tambores, Team Penning e Work Penning;

VII - paleteadas; e

VIII - outras provas típicas, tais como Queima do Alho e concurso do berrante, bem como apresentações folclóricas e de músicas de raiz.

Art. 4을sta Lei entra em vigor na data de sua publicação.

Mesmo antes da declaração de inconstitucionalidade da lei cearense, o Congresso Nacional antecipou-se ao provável desfecho do julgamento da ADI 4983/CE, conduzindo dois projetos de lei a toque de caixa, a despeito de o regime de tramitação ter sido o ordinário e de o cenário de forte instabilidade política pelo qual passava o país não colaborar. ${ }^{21}$

O primeiro deles foi o Projeto de Lei n. 1767/2015, apresentado em 1.6.2015, de autoria do Deputado Federal Capitão Augusto, filiado ao Partido da República. Em 10.6.2015, a Mesa Diretora da Câmara dos Deputados determinou o apensamento de um segundo Projeto de Lei (PL), que reconhecia o Rodeio Crioulo como patrimônio cultural imaterial do Brasil, de autoria do Deputado Pompeo de Mattos.

Após circular por diversas vezes pela Mesa Diretora (cinco vezes), pela Comissão de Cultura (uma vez) e, ainda, pela Constituição e Justiça e Cidadania (mais cinco vezes), a redação final do projeto foi aprovada em 10.5.2016, sendo encaminho ao Senado Federal.

Em 18.5.2016, o projeto foi entregue no Serviço de Protocolo Legislativo do Senado Federal, sendo autuado como Projeto de Lei da Câmara n. 24, de 2016, e vindo a ser lida em

\footnotetext{
${ }^{21}$ Fortemente deteriorado pela aceitação do pedido de impedimento da Presidenta da República Dilma Rousseff, em 2.12.2015, e pela perda definitiva do cargo na sequência, em 31.08.2016.
} 
Plenário no dia seguinte para, na sequência, ser encaminhada à Comissão de Educação, Cultura e Esporte daquela Casa.

Em seu parecer, o Senador Otto Alencar, relator do PL junto à Comissão de Educação, Cultura e Esporte, consignou que o rodeio e a vaquejada eram manifestações esportivas, recreativas e culturais difundidas por diversas regiões do país, sugerindo que ambas possuíam uma dimensão que transcendia a uma prática regionalista, dedicando à vaquejada o seguinte comentário:

No que se refere à vaquejada, além das leis estaduais que têm tratado sobre o mesmo tema, verifica-se uma ampla e difundida preocupação em garantir o máximo de segurança aos animais, por meio de práticas tais quais a utilização exclusiva de bois adultos, o uso de cauda artificial, a abolição de esporas e tacas e a disposição de três palmos de areia lavada no local das provas, para amortecer a queda dos animais. ${ }^{22}$

Em 1.11.2016, o PLC 24/2016 foi aprovado pela Plenário do Senado Federal e encaminhado à sanção presidencial, após a qual foi convertido na Lei 13.364/2016.

É bem verdade que a lei em questão não tratou de garantir o máximo de segurança aos animais, a exemplo da necessidade de utilização exclusiva de bois adultos, de garantir a assistência veterinária, a segurança sanitária nos eventos, o uso da cauda artificial, proibição de esporas e tacas nas montarias ou, ainda, sobre a quantidade mínima de areia nas pistas de corrida, a fim de suavizar as quedas.

No exercício de sua competência concorrentemente para legislar sobre educação, cultura, ensino e desporto, alhures já comentada, cabia à União estabelecer normas de caráter gerais sobre a vaquejada e aos estados suplementá-las.

Assim, pode-se até dizer que o Congresso perdeu uma excelente oportunidade para, no bojo da Lei 13.364/2016, estabelecer exigências mínimas que inibissem práticas cruéis, garantissem o respeito às integridades físico-mental dos vaqueiros e dos animais participantes, a segurança sanitária e a assistência médico-veterinária nos eventos, a exemplo da tentativa do art. 4으 da Lei cearense 15.299/2013, com um evidente viés humanizador do esporte, e do próprio Regulamento Geral de Vaquejada da ABVAQ.

É possível atribuir ao curto espaço de tempo, que o próprio Congresso Nacional se impôs para votar e concluir a tramitação dos projetos que resultaram na promulgação da Lei

\footnotetext{
${ }^{22}$ Disponível em: https://www25.senado.leg.br/web/atividade/materias/-/materia/125802. Acesso em 15 jan 2017.
} 
$13.364 / 2016$, o papel de grande vilão, que impediu a feitura de uma norma que desse uma maior segurança jurídica à vaquejada.

Tal deficiência legislativa acabou por despejar grande responsabilidade sobre os estados que, no exercício de sua competência suplementar, não poderão negligenciar tais questões em matéria de cultura e desporto.

É importante constar que a Lei 10.519, de 17 de julho de 2002, que dispõe sobre a promoção e a fiscalização da defesa sanitária animal quando da realização de rodeio, previu inúmeras medidas de proteção aos animais participantes das provas, a exemplo da assistência médico-veterinária, transporte adequado e utilização de apetrechos que não causem injúrias ou ferimentos, a demonstrar que a Lei 13.364/2016 poderia muito bem, em caráter geral, fazer o mesmo em relação à vaquejada e, com isso, disciplinar medidas de segurança e de salvaguarda aos vaqueiros, cavalos e bovinos participantes.

Esvaziada neste sentido, aparentemente o propósito que remanesce na Lei 13.364 é o de desdizer, de forma republicana, a conclusão do STF por ocasião do julgamento da ADI 4983, ratificando a vaquejada como indiscutível patrimônio cultural do Brasil.

Longe de se querer resumir a atuação do Congresso à agenda do STF, a entrada do Poder Legislativo no cenário pode ser vista como uma resposta positiva aos diversos compromissos assumidos pelo Brasil no âmbito do direito internacional público em matéria de manifestação e preservação da diversidade cultural.

\section{DIREITO A MANIFESTAÇÃO E À DIVERSIDADE CULTURAL E O COMPROMISSO DO ESTADO BRASILEIRO DIANTE DA COMUNIDADE INTERNACIONAL}

A preservação dos aspectos culturais de uma dada população é importante por refletirem um estilo próprio de vida, cuja existência e legado dependem da garantia de se poder exercer e desfrutar de toda a produção cultural e artística por ela produzida.

Como se não bastasse a previsão constitucional da matéria, o estado brasileiro assumiu o compromisso perante a comunidade internacional de apoiar e proteger as diversas manifestações culturais, em seu território e fora dele, ao participar e ratificar diversas convenções e tratados supranacionais. 
No âmbito internacional, o direito à livre manifestação cultural tem arrimo no art. $27^{23}$ da Declaração Universal dos Direitos Humanos, de 10.12.1948, assinada pelo Brasil naquela mesma data, e no art. $15^{\mathbf{2 4}}$ do Pacto Internacional dos Direitos Econômicos, Sociais e Culturais, de 16.12.1976, incorporado ao ordenamento jurídico brasileiro pelo Decreto presidencial n. 591, de 6.7.1992.

O direito aos benefícios da cultura também foi previsto pelo art. $14^{25}$ do Protocolo Adicional à Convenção Americana sobre Direitos Humanos, promulgado no Brasil pelo Decreto presidencial n. 3.321, de 30.12.1999.

Nos termos do art. 4ำ da Declaração Universal sobre a Diversidade Cultural, de 2.11.2001, a cultura é considerada um imperativo ético, inseparável do respeito à dignidade humana. A diversidade cultural, inclusive, implica compromisso de respeitar os direitos humanos e as liberdades fundamentais, em particular os direitos das pessoas que pertencem a minorias e os dos povos autóctones.

Nesse contexto, o Congresso Nacional percebeu que a vaquejada, mesmo diante das modificações sofridas com o tempo e com a sua difusão, a despeito das inúmeras críticas que lhe são direcionadas, é portadora de uma identidade cultura rica e repleta de símbolos, dando início a uma processo de reconhecimento e aceitação da prática, que ainda carece de marcos reguladores

\footnotetext{
${ }^{23}$ Artigo 27

$\S 1$. Toda pessoa tem o direito de participar livremente da vida cultural da comunidade, de fruir as artes e de participar do processo científico e de seus benefícios.

§2. Toda pessoa tem direito à proteção dos interesses morais e materiais decorrentes de qualquer produção científica, literária ou artística da qual seja autor.

${ }^{24}$ Artigo 15

1. Os Estados Partes do presente Pacto reconhecem a cada indivíduo o direito de:

a) Participar da vida cultural;

b) Desfrutar o processo cientifico e suas aplicações;

c) Beneficiar-se da proteção dos interesses morais e materiais decorrentes de toda a produção cientifica, literária ou artística de que seja autor.

2. As Medidas que os Estados Partes do Presente Pacto deverão adotar com a finalidade de assegurar o pleno exercício desse direito incluirão aquelas necessárias à convenção, ao desenvolvimento e à difusão da ciência e da cultura.

${ }^{25}$ Artigo 14

Direito aos benefícios da cultura

1. Os Estados Partes neste Protocolo reconhecem o direito de toda pessoa a:

a) Participar na vida cultural e artística da comunidade;

b) Gozar dos benefícios do progresso científico e tecnológico;

c) Beneficiar-se da proteç̧ão dos interesses morais e materiais que lhe caibam em virtude das produções científicas, literárias ou artísticas de que for autora.

2. Entre as medidas que os Estados Partes neste Protocolo deverão adoptar para assegurar o pleno exercício deste direito, figurarão as necessárias para a conservação, desenvolvimento e divulgação da ciência, da cultura e da arte.

3. Os Estados Partes neste Protocolo comprometem-se a respeitar a liberdade indispensável para a pesquisa científica e a atividade criadora.

4. Os Estados Partes neste Protocolo reconhecem os benefícios que decorrem da promoção e desenvolvimento da cooperação e das relações internacionais em assuntos científicos, artísticos e culturais e, nesse sentido, comprometem-se a propiciar maior cooperação internacional nesse campo.
} 
próprios, de forma a superar as situações que geram questionamento ético-jurídico e, com isso, consolidar uma indústria turística e cultural ao seu redor, em atenção ao princípio da complementariedade dos aspectos econômicos e culturais do desenvolvimento.

Percebe-se que boa parte das instituições brasileiras precisam aprender ou melhor compreender o conteúdo cultural da vaquejada e que há um grande caminho a ser percorrido na tentativa de difundir uma consciência acerca de seu valor positivo, diante do foco demasiado que se dá a acidentes ou a eventos nos quais o respeito aos animais fora negligenciado.

Criar condições para que a vaquejada floresça, construindo-se pontes entre a integridade dos animais envolvidos (bois e cavalos) e a livre circulação da sua prática, reconhecendo-se o autêntico valor que esta encerra em si, nada mais é do que honrar os compromissos assumidos pelo Brasil junto à comunidade internacional e o Congresso que, nesse ponto, prestou uma importante colaboração em direção a um caminho alternativo àquele imposto pelo STF e perseguido pelo Ministério Público Federal.

\section{CONSIDERAÇÕES FINAIS}

A prevalecer o posicionamento do STF e do MPF, há um risco real de extinção ou grave deterioração de uma das mais expressivas, genuínas e legítimas manifestações culturais do Brasil, cujos reflexos poderão, a longo prazo, refletir até mesmo na frágil coesão social do país, agravando a instabilidade nacional ${ }^{26}$.

Não se busca defender a prática de maus-tratos aos animais ao se focar na viabilidade constitucional das normas que a alçam a vaquejada ao posto de esporte e de manifestação cultural, mas de assentar que é uma visão reducionista e extremamente preconceituosa aquela que enxerga e associa a sua prática a um esporte sadista e cruel.

O STF não é o foro adequado para discutir-se medidas regulatórias capazes de proteger e promover a vaquejada. A tentativa açodada do MPF em interromper precocemente sua prática por meio de uma ADI, além de um viés elitista, menospreza toda a riqueza e complexidade desse universo cultural em franca expansão, inteiramente capaz de adaptar-se às exigências sobre o bem-estar dos animais envolvidos, e cujos esforços de preservação foram consignados pelo Brasil

\footnotetext{
${ }^{26}$ Dentre as inúmeras manifestações, destacam-se os atos de protestos em 11 estados e no Distrito Federal, realizados conjuntamente no dia 11.10.2016, e a ocupação da Esplanada dos Ministérios, em Brasília, ocorrida no dia 25.10.2016, ambas amplamente noticiados pelos meios de comunicação impressos e digitais.
} 
perante a comunidade internacional.

No que pese a salvaguarda constitucional da vaquejada e o compromisso do Brasil em fomentar e garantir a diversidade cultural, previsto em convenções e tratados internacionais, é de chamar atenção ao fato de a Procuradoria-Geral da República e de o Supremo Tribunal Federal não terem feito qualquer incursão em relação à regularização do hipismo, do pólo e das corridas de cavalos, permitidas no Brasil desde 1984 pela Lei 7.291, de 19.12.

Infelizmente não há informações oficiais de quantos ministros de Tribunais Superiores no Brasil e membros do MPF são associados, coproprietários ou frequentadores assíduos de aras e de quantos assistem ou participam de vaquejadas, o que permitiria uma correlação de causa e efeito entre o tratamento direcionado à vaquejada, no âmbito dos tribunais e das procuradorias, e a tolerância silenciosa com as várias modalidades de hipismo, com farta doutrina veterinária estrangeira a respeito, abordando os maus-tratos e os processos doloroso e traumático suportados pelos animais durante a doma e o adestramento ${ }^{27}$.

A superveniente declaração de inconstitucionalidade da Lei 13.364/2016 justificaria a comunicação do fato ao Comitê Intergovernamental da UNESCO para a Proteção e Promoção da Diversidade das Expressões Culturais, a que faz referência o art. 23 da Convenção sobre a Proteção e Promoção da Diversidade das Expressões Culturais, promulgada pelo Brasil pelo Decreto $\mathrm{n}$. 6.177, de 1ㅇ․8.2007.

É provável que, se o príncipe Adam desembarcasse no Brasil acompanhando por seu fiel amigo Pacato, não poderia mais ser o defensor do Universo e eletrocutar livremente o felino, sem correr o sério risco de ter a 'Espada do Poder' confiscada e de ser acusado de crueldade.

Nos episódios de He Man and the Masters of the Universe, o protagonista não demonstra qualquer ânimo de maltratar ou sujeitar Pacato a um tratamento violento durante a eletrocussão. Na metamorfose sofrida por Pacato, o objetivo é tirar de cena um ser frágil e indefeso, que seria facilmente vítima dos poderosos vilões que He Man enfrenta, embora se possa, no ato em si, haver quem o julgue como forçado, agressivo e cruel.

Na lúdica hipótese de uma outra lei cearense alçar a metamorfose de Pacato (em Gato Guerreiro) à condição de manifestação cultural, ainda que limitando a voltagem da descarga

\footnotetext{
27 Recomenda-se o fragmento do vídeo The Horse Crucified and Risen, disponível na plataforma Youtube: http://hauteecole.ru/en/anthology.php
} 
elétrica e evitando-se dor e sofrimento, He Man não poderia contar com a ajuda de Gato Guerreiro.

Pela primeira vez, com muitíssimas risadas tenebrosas, Esqueleto sairia vitorioso no único episódio da série gravado no Brasil (com produção do STF e direção da PRG) que, para alívio de todos, nunca foi ao ar.

\section{REFERÊNCIAS DAS FONTES CITADAS}

AIRES, F. J.F. O "espetáculo do cabra-macho": um estudo sobre os vaqueiros nas vaquejadas no

Rio Grande do Norte. Dissertação (Dissertação em Antropologia) - UFRN. Natal, p. 45. 2008.

Disponível em: https://repositorio.ufrn.br/jspui/bitstream/123456789/12253/1/FranciscoJFA.pdf. Acesso em 01 ago. 2018.

ALEGRIA, Trem da. He-man. Trem da Alegria [1986]. Disponível em:

<https://www.youtube.com/watch?v=6C1owkSGWOI. >. Acesso em: 01 ago. 2018.

AMENDOIM, Catuaba com. Saga de um vaqueiro. Catuaba com Amendoim ao vivo, v. 2. [1999].

Disponível em:< https://www.letras.mus.br/catuaba-com-amendoin/66155/>. Acesso em 01 ago. 2018.

BRASIL. Constituição da República Federativa do Brasil de 1988. Texto consolidado até a EC n. 91, de 18 de fevereiro de 2016. Disponível em:

<http://www.planalto.gov.br/ccivil_03/constituicao/Emendas/Emc/emc91.htm>. Acesso em 20 ago. 2016.

. Decreto no 591, de 6 de julho de 1992. Atos Internacionais. Pacto Internacional sobre Direitos Econômicos, Sociais e Culturais. Promulgação. Disponível em: <http://www.planalto.gov.br/ccivil_03/leis/2002/L10519.htm>. Acesso em 20 ago. 2016.

. Decreto no 3.321, de 30 de dezembro de 1999. Promulga o Protocolo Adicional à

Convenção Americana sobre Direitos Humanos em Matéria de Direitos Econômicos, Sociais e Culturais "Protocolo de São Salvador", concluído em 17 de novembro de 1988, em São Salvador, El Salvador. Disponível em: <http://www.planalto.gov.br/ccivil_03/decreto/D3321.htm>. Acesso em 20 ago. 2016.

. Lei no 7.291, de 19 de dezembro de 1984. Dispõe sobre as atividades da equideocultura 
no País, e dá outras providências. Disponível em:

<http://www.planalto.gov.br/ccivil_03/Leis/L7291.htm>. Acesso em 20 ago. 2016.

. Lei no 10.519 , de 17 de julho de 2012. Dispõe sobre a promoção e a fiscalização da defesa sanitária animal quando da realização de rodeio e dá outras providências. Disponível em: <http://www.planalto.gov.br/ccivil_03/leis/2002/L10519.htm>. Acesso em 20 ago. 2016.

. Lei no 13.364, de 29 de novembro de 2016. Eleva o Rodeio, a Vaquejada, bem como as respectivas expressões artístico-culturais, à condição de manifestação cultural nacional e de patrimônio cultural imaterial. Disponível em: < http://www.planalto.gov.br/ccivil_03/_ato20152018/2016/lei/L13364.htm>. Acesso em 20 ago. 2016.

. Supremo Tribunal Federal. ADI n. 2514/SC. Relator: Min. Eros Grau, Brasília/DF, 09 de dezembro de 2005. Disponível em:

<http://www.stf.jus.br/portal/jurisprudencia/listarJurisprudencia.asp?s1=\%28ADI\%24\%2ESCLA\%2 $\mathrm{E}+\mathrm{E}+2514 \% 2 \mathrm{ENUME} \% 2 \mathrm{E} \% 29+\mathrm{OU}+\% 28 \mathrm{ADI} \% 2 \mathrm{EACMS} \% 2 \mathrm{E}+\mathrm{ADJ} 2+2514 \% 2 \mathrm{EACMS} \% 2 \mathrm{E} \% 29 \&$ base=ba seAcordaos\&url=http://tinyurl.com/a6hp5ln>. Acesso em: 20 Nov. 2016.

. Supremo Tribunal Federal. ADI n. 1856/RJ. Relator: Min. Celso de Mello, Brasília, DF, 26 de maio de 2011. Disponível em:

<http://www.stf.jus.br/portal/jurisprudencia/listarJurisprudencia.asp?s1=\%28ADI\%24\%2ESCLA\%2 $\mathrm{E}+\mathrm{E}+1856 \% 2 \mathrm{ENUME} \% 2 \mathrm{E} \% 29+\mathrm{OU}+\% 28 \mathrm{ADI} \% 2 \mathrm{EACMS} \% 2 \mathrm{E}+\mathrm{ADJ} 2+1856 \% 2 \mathrm{EACMS} \% 2 \mathrm{E} \% 29 \&$ base $=$ ba seAcordaos\&url=http://tinyurl.com/a3d5|9e>. Acesso em: 20 Nov. 2016.

. Supremo Tribunal Federal. ADI n. 4983/CE. Relator: Min. Marco Aurélio, Brasília/DF, 16 de outubro de 2016. Disponível em:

<http://www.stf.jus.br/portal/diarioJustica/verDiarioProcesso.asp?numDj=119\&dataPublicacaoDj $=10 / 06 / 2016 \&$ incidente $=4425243 \&$ codCapitulo=2\&numMateria $=16 \&$ codMateria $=4>$. Acesso em: 20 Nov. 2016.

. Supremo Tribunal Federal. Resolução n. 536, de 16.10.2014. Dispõe sobre a publicação de acórdãos pela Secretaria Judiciária do Supremo Tribunal Federal. DJE/STF, n. 205, p. 1. de 20.10.2014.

CAMARA DE DEPUTADOS FEDERAL. Projeto de Lei $\mathbf{n} . \mathbf{1 7 6 7 / 2 0 1 5}$. Eleva o Rodeio, bem como suas manifestações artístico-culturais, à condição de patrimônio cultural imaterial do Brasil. Disponível em: < http://www.camara.gov.br/proposicoesWeb/fichadetramitacao?idProposicao=1301384>. 
Aceso em 20 ago. 2016.

CANOTILHO, José Joaquim Gomes. Direito Constitucional e Teoria da Constituição. 7.ed. Coimbra: Almedina, 2003.

CASSIA, Rita de. A saga de um Vaqueiro.

CEARÁ. Lei n. 15.299/2013. Regulamenta a vaquejada como prática desportiva e cultural no Estado do Ceará. Disponível em:

<http://www.al.ce.gov.br/legislativo/legislacao5/leis2013/15299.htm>. Acesso em 20 ago. 2016

COSTA, Rodrigo Vieira. Cultura e patrimônio cultural na Constituição da República de 1988 - a autonomia dos direitos culturais. Revista CPC, São Paulo: n.6, p. 21-46, maio/ out 2008.

DE OLIVEIRA, Wesley Felipe; PINZANI, Alessandro. O que o mercado não mata: uma análise da moralidade especista e a economia. Revista Internacional Interdisciplinar INTERthesis, Florianópolis, v. 12, n. 1, p. 01-15, jul. 2015. ISSN 1807-1384. Disponível em: <https://periodicos.ufsc.br/index.php/interthesis/article/view/1807-1384.2015v12n1p1>. Acesso em: 31 jul. 2018. doi: https://doi.org/10.5007/1807-1384.2015v12n1p1.

Declaração Universal sobre a Diversidade Cultural. Disponível em: http://unesdoc.unesco.org/images/0012/001271/127160por.pdf. Acesso em 20 ago. 2016 DIAS, Edna Cardozo. Direitos dos Animais e isonomia jurídica. Revista Brasileira de Direito Animal, Bahia: n.3, p. 107-117, jul/dez. 2007. Disponível em:

<http://vvww.animallaw.info/journals/jo_pdf/brazilvol3.pdf\#page=107>. Acesso em: 10 Nov 2016. FREITAS, Vladimir Passos de. A Constituição Federal e a efetividade das normas ambientais. São Paulo: Revista dos Tribunais, 2000.

LOURENÇO, Daniel Braga. A liberdade de culto e o direito dos animais. Revista Brasileira de Direito Animal, Bahia: n.3, p. 271-288, jul/dez. 2007. Disponível em: <http://www.animallaw.info/journals/jo_pdf/brazilvol3.pdf\#page=107>. Acesso em: 10 Jan 2017. Manifestação do Procurador Geral da República, Rodrigo Janot, no âmbito da ADI 4983, protocolada em 07 de outubro de 2013.

MENEZES, Sônia de Souza Mendonça. ALMEIDA, Maria Geralda de. VAQUEJADA: a pega de boi na caatinga resiste no sertão sergipano. Disponível em:<http://www.cchla.ufrn.br/vivencia/sumarios/34/PDF\%20para\%20INTERNET_34/13_S\%C3\%B 
4nia\%20de\%20Souza\%20e\%20Maria\%20Geralda.pdf>. Acesso em 22 fev. 2017.

PASOLD, Cesar Luiz. Metodologia da Pesquisa Jurídica: teoria e prática. 13. ed. rev. São Paulo: Conceito Editorial, 2015.

Regulamento geral de vaquejada: 2017-2018. Associação Brasileira de Vaquejada. Disponível em <http://abvaq.com.br/app/webroot/documentos/regulamentogeraldevaquejada20172018.pdf>. Acesso em 29 jul. 2018.

SENADO FEDERAL. Projeto de Lei da Câmara no 24, de 2016. Eleva o Rodeio, a Vaquejada, bem como as respectivas expressões artístico-culturais, à condição de manifestação cultural nacional e de patrimônio cultural imaterial. Disponível em:< https://www25.senado.leg.br/web/atividade/materias/-/materia/125802>. Acesso em 22 fev. 2017.

STEINMETZ, Wilson. Farra do Boi, fauna e manifestação cultural: uma colisão de princípios constitucionais? Estudo de um acórdão do Supremo Tribunal Federal. Direitos Fundamentais e Justiça, Rio Grande do Sul: n.9, p.260-273, Out./Dez. 2009.

NEVZOROV, Alexander. The horse crucified and risen. Nevzorov Haute Ecole, 2011, p. 82-83.

Notas da sessão oral do julgamento da ADI 4.983, disponível em <http://www.stf.jus.br/portal/cms/verNoticiaDetalhe. asp?idConteudo=297502>. Acesso: 20 nov. 2015. 21.

Notas da sessão oral do julgamento da ADI 4.983, disponível em <http://noticias.pgr.mpf.mp.br/noticias/noticias-do-site/copy_of_constitucional/stf-pgr-reforcaentendimento-contra-vaquejada>. Acesso: 20 nov. 2015.

Voto do Ministro Relator Marco Aurélio Mello, no julgamento da ADI 4.983, em 12 de agosto de 2015, p. 4-5. Disponível em <http://www.stf.jus.br/ arquivo/cms/noticiaNoticiaStf/anexo/ADI_4983.pdf>. Acesso: 10 Jan 2016. 


\title{
O DESAFIO DE TRANSFORMAR A EDUCAÇÃO AMBIENTAL PARTE DA CULTURA POPULAR
}

\author{
Andresa Bernardo ${ }^{1}$
}

\section{INTRODUÇÃO}

O discurso da sustentabilidade se intensifica diariamente. Todavia, apesar da crescente regulamentação de ferramentas legais em prol do desenvolvimento sustentável, poucas ações práticas realmente são consideradas pela sociedade como protetivas de um direito fundamental que lhes é garantido constitucionalmente.

E esse desconhecimento/ignorância decorre da visão ainda estreita do que verdadeiramente representa a proteção ambiental. Não se trata de mero combate a cultura capitalista, mas de efetiva transformação do pensamento, inclusive fomentando o desenvolvimento econômico, tão necessário à diminuição da violência e desigualdades sociais, mas de forma mais humana e consciente.

Esse artigo tem por objetivo a demonstração de que seria possível a transmutação da "sociedade de risco" ${ }^{2}$, como concebida pelo sociólogo alemão Ulrich Beck, reflexo de nossa "irresponsabilidade organizada", em uma "sociedade sustentável", desde que a ordem social se endereçasse à internalização individual de uma cultura ambiental participativa.

O Método utilizado na fase de Investigação foi o indutivo; na fase de Tratamento dos Dados o cartesiano, utilizando-se, ainda, a técnica da Pesquisa Bibliográfica.

\section{EDUCAÇÃO AMBIENTAL}

Em 1972 foi realizada na capital da Suécia, a Conferência das Nações sobre o Ambiente Humano, denominada Conferência de Estocolmo, com o objetivo de conscientizar a sociedade a melhorar a relação com o meio ambiente e assim atender as necessidades da população presente

\footnotetext{
${ }^{1}$ Mestranda no Programa de Pós-Graduação stricto sensu em Ciência Jurídica da Universidade do Vale do Itajaí - Univali/SC. Juíza Estadual em Santa Catarina.

${ }^{2}$ BECK, Ulrich. Sociedade de risco: rumo a uma outra modernidade. 2 ed. São Paulo: Editora 34, 2011.
} 
sem comprometer as gerações futuras.

A Conferência de Estocolmo serviu de marco à Educação Ambiental (EA), ao menos no que se refere à especial atenção atribuída ao tema em praticamente todos os fóruns que a posteriori se dedicaram ao meio ambiente.

A própria Conferência de Estocolmo estabeleceu um plano de trabalho com 110 recomendações, destacando-se a de implantar a EA de caráter interdisciplinar com o objetivo de preparar o ser humano para viver em harmonia com o meio ambiente.

A esse respeito, o princípio 19 da declaração da Conferência de Estocolmo:

É indispensável um esforço para a educação em questões ambientais, dirigida tanto às gerações jovens como aos adultos e que preste a devida atenção ao setor da população menos privilegiado, para fundamentar as bases de uma opinião pública bem informada, e de uma conduta dos indivíduos, das empresas e das coletividades inspirada no sentido de sua responsabilidade sobre a proteção e melhoramento do meio ambiente em toda sua dimensão humana. É igualmente essencial que os meios de comunicação de massas evitem contribuir para a deterioração do meio ambiente humano e, ao contrário, difundam informação de caráter educativo sobre a necessidade de protegê-lo e melhorá-lo, a fim de que o homem possa desenvolver-se em todos os aspectos ${ }^{3}$ (grifamos).

E para cumprir as recomendações da Conferência de Estocolmo, especialmente no quesito EA, a Unesco e o Pnuma criaram o Programa Internacional de Educação Ambiental (Piea).

Esse programa admitiu que no ano de 1975 fosse realizado o Seminário Internacional sobre Educação Ambiental, oportunidade em que se aprovou a Carta de Belgrado ${ }^{4}$, documento direcionado ao desenvolvimento sustentável em muitos de seus termos ratificado em 1977 pela Conferência Intergovernamental da Geórgia sobre Educação Ambiental de Tbilisi ${ }^{5}$.

\footnotetext{
${ }^{3}$ Princípio original em inglês: Education in environmental matters, for the younger generation as well as adults, giving due consideration to the underprivileged, is essential in order to broaden the basis for an enlightened opinion and responsible conduct by individuals, enterprises and communities in protecting and improving the environment in its full human dimension. It is also essential that mass media of communications avoid contributing to the deterioration of the environment, but, on the contrary, disseminates information of an educational nature on the need to project and improve the environment in order to enable mal to develop in every respect.

${ }^{4}$ Carta de Belgrado. Item D. "Objetivos da Educação Ambiental. Tomada de consciência. Ajudar às pessoas e aos grupos sociais a adquirir maior sensibilidade e consciência do meio ambiente em geral e dos problemas. Conhecimentos. Ajudar às pessoas e aos grupos sociais a adquirir uma compreensão básica do meio ambiente em sua totalidade, dos problemas associados e da presença e função da humanidade neles, o que necessita uma responsabilidade crítica. Atitudes. Ajudar às pessoas e aos grupos sociais a adquirir valores sociais e um profundo interesse pelo meio ambiente que os impulsione a participar ativamente na sua proteção e melhoria. Aptidões. Ajudar às pessoas e aos grupos sociais a adquirir as aptidões necessárias para resolver os problemas ambientais. Capacidade de avaliação. Ajudar às pessoas e aos grupos sociais a avaliar as medidas e os programas de educação ambiental em função dos fatores ecológicos, políticos, sociais, estéticos e educativos. Participação. Ajudar às pessoas e aos grupos sociais a desenvolver seu sentido de responsabilidade e a tomar consciência da urgente necessidade de prestar atenção aos problemas ambientais, para assegurar que sejam adotadas medidas adequadas".

${ }^{5}$ Baseado na Conferência de Tbilisi são finalidades da EA: 1 -Promover a compreensão da existência e da importância da interdependência econômica, social, política e ecológica. 2- Proporcionar a todas as pessoas a possibilidade de adquirir os
} 


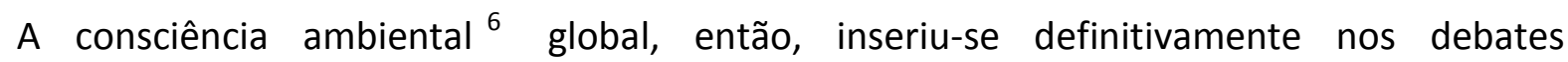
internacionais.

Faltam, entretanto, proposições concretas para adequação dos objetivos, metas e diretrizes dos "compromissos" 7 de EA assumidos nacional e internacionalmente.

E na "sociedade de risco" 8 em que vivemos, as ameaças decorrem do crescimento dos sistemas produtivos e recaem sobre as próprias organizações e comunidades, num efeito bumerangue decorrente da modernidade reflexiva ${ }^{9}$, onde os problemas socioambientais são disseminados em escala global: injusta distribuição de recursos, os efeitos da poluição, o desmatamento, a degradação dos recursos hídricos, a destruição da camada de ozônio.

Diante da necessidade de mudança de comportamento da sociedade como um todo, faz-se necessário o desenvolvimento de práticas específicas, que afastem as cegueiras do conhecimento $^{10}$, tornando a educação ambiental parte de sua cultura e, sob essa ótica, defendida na qualidade de direito fundamental.

No que pertine à educação como conscientização e participação, não se pode deixar de fazer referência à obra de István Mészarós, "A educação para além do capital”, texto escrito para a conferência de abertura do Fórum Mundial de Educação em 2004, em Porto Alegre, onde o autor defende a existência de práticas educacionais que permitam a construção de uma sociedade na

conhecimentos, o sentido dos valores, o interesse ativo e as atitudes necessárias para protegerem e melhorarem o meio ambiente. 3- Induzir novas formas de conduta, nos indivíduos e na sociedade, a respeito do meio ambiente.

"'A consciência ambiental aponta para a conjugação de quatro elementos: (i) o momento intelectual; (ii) o momento afetivoexistencial; (iii) o momento ético; (iiii) o momento voluntarista. A consciência destes momentos da consciência ambiental é importante se quisermos ter uma compreensão razoável da própria formação da vontade política na área ambiental. O momento intelectual aponta para o saber; o momento afetivo-existencial liga-se ao viver; o momento ético transporta-nos para o valer; o momento voluntarista exige o agir. Saber, viver, dar valor e agir, eis os verbos de consciência ambiental" (VIERHAUS, 1994, apud CANOTILHO, José Joaquim Gomes. Recensão, democracia e ambiente: em torno da formação da consciência ambiental. Revista do Centro de Direito e Ordenamento do Urbanismo e do ambiente, Coimbra, v. 1, p. 93-95, 1998).

${ }^{7}$ Declaração de Tbilisi, Geórgia, 1977; Conferência das Nações Unidas para o Desenvolvimento e Meio Ambiente (Cnumad), realizada no Rio de Janeiro, em 1992; Conferência Internacional sobre Meio Ambiente e Sociedade, em Tessalônica, Grécia, 1997; Cúpula Mundial sobre Desenvolvimento Sustentável (CMDS), em Johannesburgo, em 2002, conhecida como Rio+10, entre outras.

${ }^{8}$ A sociedade de risco é aquela que, em função de seu contínuo crescimento econômico, pode sofrer a qualquer tempo as consequências de uma catástrofe ambiental. Nota-se, portanto, a evolução e o agravamento dos problemas, seguidos de uma evolução da sociedade (da sociedade industrial para a sociedade de risco), sem, contudo, uma adequação dos mecanismos jurídicos de solução dos problemas dessa nova sociedade. Há consciência da existência dos riscos, desacompanhada, contudo, de políticas de gestão, fenômeno denominado irresponsabilidade organizada. (LEITE, José Rubens Morato. Sociedade de risco e estado. In: CANOTILHO, José Joaquim Gomes; Leite, José Rubens Morato (orgs.). Direito constitucional ambiental brasileiro. 6 ed. São Paulo: Saraiva, 2015. p. 158).

"'A modernização reflexiva entendida do ponto de vista dos efeitos sobre o sujeito indica que uma ação promovida por este recai novamente sobre ele mesmo, tal como um bumerangue. Os próprios agentes responsáveis pelo processo de contaminação são igualmente afetados por ela". (DEMAJOROVIC, Jacques. Sociedade de risco e responsabilidade socioambiental: perspectivas para a educação corporativa. p. 40-41).

${ }^{10}$ MORIN, Edgar. Os sete saberes necessários à educação do futuro. 3 ed. São Paulo: Cortez. 2001. 
qual o capital não explore mais o tempo de lazer (crítica ao trabalho alienante), trazendo reflexões acerca da necessidade de se constituir uma educação que tenha como principal referência o ser humano, em detrimento do capital, uma educação que realize as transformações políticas, econômicas, culturais e sociais necessárias à construção de um outro mundo e, porque não dizer, necessárias à construção de "sociedades sustentáveis".

Na obra citada, Mészáros aborda a educação em sentido amplo, compreendendo todo o processo vital de existência do homem, sua capacidade de conhecer, de ter ciência do real e de transformar-se de forma consciente em ser social.

Para Mészáros, a perpectiva de uma educação emancipadora não se trata apenas de uma mudança educacional, mas de uma mudança objetiva de toda a forma de vida, de todo o modo de ser da humanidade na produção/reprodução de sua existência, de forma que a educação não seja mais um momento específico da vida das pessoas, mas a sua própria vida.

Faz-se necessário, como já se disse, tirar a Educação Ambiental do papel, estabelecer uma reorientação e compatibilidade de diferentes disciplinas e experiências educacionais que facilitem uma percepção integrada dos problemas ambientais, proporcionando capacitação para ações suficientes às necessidades socioambientais, assim como previsto nas recomendações de Tbilisi ${ }^{11}$.

Ao analisar a questão da educação especificamente para o desenvolvimento de sociedades sustentáveis, Victor Novick $^{12}$, citando Marx, explica que:

Em seu conjunto, a adoção do item " $c$ " da Recomendação no 1 de Tbilisi implica refletir sobre categorias analíticas que consideramos centrais para compreender e transformar a realidade socioambiental: (a) superar a alienação do Homem em relação à natureza e à sociedade, através da consciência de que somos "naturalmente humanos ou humanamente naturais" (MARX, 2004) ou da consciência de nossa dupla (e inalienável) determinação: natural e social, (b) conquistar na sociedade civil a participação no processo decisório de formulação/implementação de políticas públicas e práticas sociais que visem o pleno exercício da cidadania.

No Rio de Janeiro, no ano de 1992, em evento paralelo à ECO 92, na I Jornada Internacional de Educação Ambiental, elaborou-se o Tratado de Educação Ambiental para Sociedades Sustentáveis e Responsabilidade Global, documento que se tornou referência para a Educação

\footnotetext{
${ }^{11}$ Segundo a recomendação no 1, item "c" da Conferência de Tbilisi: “Um objetivo fundamental da educação ambiental é lograr que os indivíduos e a coletividade compreendam a natureza complexa do meio ambiente natural e do meio ambiente criado pelo homem, resultante da integração de seus aspectos biológicos, físicos, sociais, econômicos e culturais, e adquiram os conhecimentos, os valores, os comportamentos e as habilidades práticas para participar responsável e eficazmente da prevenção e solução dos problemas ambientais, e da gestão da questão da qualidade do meio ambiente".

${ }^{12}$ NOVICKI, Victor. Educação para o desenvolvimento sustentável ou sociedades sustentáveis?. Linhas Críticas (Online), v. 15, p. 215-232, 2009
} 
Ambiental na qualidade de processo educativo transformador, orientando ao envolvimento pessoal das comunidades e nações para criar sociedades sustentáveis e equitativas ${ }^{13}$.

Esse tratado, que pode ser lido na íntegra na página do Ministério do Meio Ambiente, é essencial para compreensão da educação ambiental voltada ao desenvolvimento de sociedades sustentáveis.

A mesma importância se atribui à Política Nacional de Educação Ambiental, instituída na Lei 9.795/99, especialmente o artigo 4우 que reforça o caráter interdisciplinar da educação ambiental.

O art. 40 da Lei 9.795/99 define a EA como uma prática que deve considerar o aspecto ecológico e, no particular, a concepção de ambiente em sua totalidade, as relações de interdependência entre o meio natural, socioeconômico e cultural sob a ideia de sustentabilidade.

Oportuna, ainda, a referência ao art. 5ㅇ da Lei 9.795/99, relativo aos objetivos fundamentais da EA: "o desenvolvimento de uma compreensão integrada do meio, ambiente em suas múltiplas e complexas relações, envolvendo aspectos, ecológicos, psicológicos, legais, políticos, sociais, econômicos, científicos, culturais e éticos ${ }^{14}$

Finalmente, um aspecto importante da implantação da Educação Ambiental diz respeito às contribuições das instituições de ensino superior (IES) em cumprimento às recomendações das conferências internacionais.

No Brasil, em 2001, criou-se a Rede Universitária de Programas de EA para Sociedades Sustentáveis (RUPEA) que tem por objetivos principais: reunir, articular, fortalecer e divulgar princípios, iniciativas, reflexões e propostas em EA comprometidos com a construção de sociedades sustentáveis; promover a formação de agentes locais de sustentabilidade socioambiental; constituir-se em um fórum permanente de intercâmbio, debate e aprofundamento teóricometodológico; debater, propor, promover e/ou apoiar políticas públicas, pesquisas, projetos, experiências e outras iniciativas em EA; estabelecer intercâmbios com grupos, redes e instituições de caráter socioambiental e/ou educacional, em especial na perspectiva da interlocução ibero-

\footnotetext{
${ }^{13}$ Segundo se extrai da introdução do TEASS: “Consideramos que a educação ambiental para uma sustentabilidade equitativa é um processo de aprendizagem permanente, baseado no respeito a todas as formas de vida. Tal educação afirma valores e acções que contribuem para a transformação humana e social e para a preservação ecológica. Ela estimula a formação de sociedades socialmente justas e ecologicamente equilibradas, que conservam entre si uma relação de interdependência e diversidade. Isto requer responsabilidade individual e colectiva a nível local, nacional e planetário".

14 BRASIL. Lei n. 9.795, de 27 de abril de 1999. Institui a Política Nacional de Educação Ambiental. Disponível em: https://www.planalto.gov.br/ccivil_03/LEIS/L9795.htm: acesso em 26.01.2017. p. 2.
} 
americana $^{15}$.

O desenvolvimento de uma política ambiental participativa, no sentido de tornar nossa sociedade verdadeiramente sustentável depende, hoje, exclusivamente da implementação das políticas já previstas nacional e internacionalmente, não se podendo reduzir a educação ambiental a mera "conscientização" das pessoas acerca dos riscos produzidos.

\section{A CULTURA COMO PILAR DO DESENVOLVIMENTO SUSTENTÁVEL}

Conforme acima destacado, Estocolmo, em 1972, sediou a Conferência das Nações Unidas sobre o Meio Ambiente Humano, oportunidade em que se lançou as bases do nominado "desenvolvimento sustentável".

A locução se difundiu na Comissão Brundtland porque cunhou o documento final intitulado de "Nosso Futuro Comum"16 em que se definiu que desenvolvimento sustentável "é aquele que atende às necessidades do presente sem comprometer a possibilidade de as gerações futuras atenderem a suas próprias necessidades".

Sustentável é, assim, o desenvolvimento que não esgota os recursos para o futuro, harmonizando a expansão econômica e a conservação ambiental ${ }^{17}$.

Segundo a União Internacional para a Conservação da Natureza (UICN), o desenvolvimento sustentável tem como princípios: integrar conservação da natureza e desenvolvimento; satisfazer as necessidades humanas fundamentais; perseguir a equidade e a justiça social; buscar a autodeterminação social e respeitar a diversidade cultural; manter a integridade ecológica.

E conforme se consignou na Declaração de Hangzhou ${ }^{18}$, a cultura ocupa importante papel para concretização de todos os princípios acima citados, sendo ela fonte de energia, criatividade e inovação.

A cultura, como capital de conhecimento e como recurso, provê as necessidades dos indivíduos e reduz a pobreza, na medida em que agrupa e, consequentemente, reduz a violência e facilita a implementação de políticas na defesa dos interesses do grupo/sociedade.

\footnotetext{
${ }^{15}$ Disponível em: http://www2.uefs.br/rupea/carta.htm: acesso em 26.01.2017.

${ }^{16}$ COMISSÃO MUNDIAL SOBRE MEIO AMBIENTE E DESENVOLVIMENTO (CMMAD). Nosso futuro comum. Rio de Janeiro: Fundação Getulio Vargas, 1991.

${ }^{17} \mathrm{O}$ conceito de desenvolvimento sustentável foi ratificado na Agenda 21, documento desenvolvido na Conferência "Rio 92", e incorporado em outras agendas mundiais de desenvolvimento e de direitos humanos.

${ }^{18}$ Aprovada em Hangzhou (República Popular da China), no dia 17 de maio de 2013.
} 
Neste sentido também constou do relatório final da Rio+20, a intenção de se considerar a cultura o quarto pilar do desenvolvimento sustentável, considerada uma dimensão chave da sustentabilidade ${ }^{19}$.

Este artigo, entretanto, procura ir um pouco além. Tanto a cultura quanto o direito ao meio ambiente equilibrado aparecem em nossa Constituição Federal sob o status de Direito Fundamental.

Todavia, o direito ao meio ambiente ainda é visto pela grande massa como limitador de liberdades e não na condição de direito. O grande desafio, dessa forma, encontra-se em, por meio da educação, mudar a visão social.

A "cultura do meio ambiente" fará com que a sociedade naturalmente passe a defendê-lo, por meio de práticas naturais da condição humana, com a mesma força dos direitos à saúde, à vida, à educação, à moradia, ao lazer etc.

Todos esses direitos fazem parte do meio ambiente e com ele encontram-se alinhados, fazendo-se necessário apenas a utilização de ferramentas legais para disseminação desse conhecimento, introduzindo-o na cultura popular.

\section{CONSIDERAÇÕES FINAIS}

A preservação dos recursos naturais e mesmo sua recuperação passou a ser essencial para afastamento dos riscos criados pela sociedade moderna e transmutá-la em uma sociedade sustentável, afastando-se o perigo de autodestruição.

A criação de uma cultura da sustentabilidade é peça chave ao engajamento dos indivíduos na construção dessa sociedade sustentável, uma vez que somente a consciência ambiental global será bastante à erradicação do reflexo negativo.

Com esse objetivo, a Educação Ambiental ganhou espaço definitivo nos debates internacionais - Declarações, Tratados, Conferências, Seminários, faltando, entretanto, ordens concretas para sua execução, metas e diretrizes adequadas.

Reitera-se, assim, a necessidade de se tirar a Educação Ambiental do papel, apoiando-se e

\footnotetext{
${ }^{19}$ http://www.cultura.gov.br/documents/10901/689246/Cultura+e+Sustentabilidade+na+Rio\%2B20++RELAT\%C3\%93RIO+FINAL/87fa7f40-99c1-495d-8b16-b6557afb4323?version=1.0: acesso em 12.02.2017.
} 
incentivando-se ações sociais que, por meio de uma reorientação educacional, capacite o homem para o desenvolvimento socioambiental sustentável.

A velha máxima de que o discurso não implica na ação ${ }^{20}$ seria substituída pelo ditado latino que diz: "As palavras movem e os exemplos arrastam". É improdutivo falar o tempo todo sobre a mesma coisa. É pelo exemplo que se consegue que as coisas sejam feitas.

É preciso criar uma ordem social/cultural que obrigue na consciência ambiental e ponha em prática os objetivos, metas e diretrizes já traçados. Enfim, conclui-se, a consciência ambiental se encontra intimamente ligada a ordens sociais que consolidem nos indivíduos práticas inconscientes de atos de preservação.

Faz-se necessário o enraizamento da cultura ambiental.

\section{REFERÊNCIAS DAS FONTES CITADAS}

ARAGÃO, Alexandra. Direito constitucional do ambiente da união europeia. In: CANOTILHO, José Joaquim Gomes; Leite, José Rubens Morato (orgs.). Direito constitucional ambiental brasileiro. 6 ed. São Paulo: Saraiva, 2015.

BECK, Ulrich. Sociedade de risco: rumo a uma outra modernidade. Tradução de Sebastião Nascimento. São Paulo: editora 34, 2010. Título original: Rsikogesellschaft: Aufdem Weg in eine andre Modern.

BRASIL. Ministério do Meio Ambiente. In: http://www.mma.gov.br/ acesso em: 26.014.2017.

BRASIL. Lei n. 9.795, de 27 de abril de 1999. Institui a Política Nacional de Educação Ambiental. In: https://www.planalto.gov.br/ccivil_03/LEIS/L9795.htm: acesso em 26.01.2017.

CARTA DE BELGRADO. In: http://www.mma.gov.br/educacao-ambiental/politica-de-educacaoambiental/documentos-referenciais/item/8066: acesso em 26.01.2017.

COMISSÃO MUNDIAL SOBRE MEIO AMBIENTE E DESENVOLVIMENTO (CMMAD). Nosso futuro comum. Rio de Janeiro: Fundação Getulio Vargas, 1991.

CONFERÊNCIA DAS NAÇÕES UNIDAS SOBRE MEIO AMBIENTE E DESENVOLVIMENTO (CNUMAD). Agenda 21. São Paulo: Secretaria de Estado do Meio Ambiente, 1992.

\footnotetext{
20 "Faça o que eu digo, não faça o que eu faço".
} 
DECLARAÇÃO DE TBILISI. In: http://www.mma.gov.br/port/sdi/ea/deds/pdfs/decltbilisi.pdf: acesso em 26.01.2017.

DEMAJOROVIC, Jacques. Sociedade de risco e responsabilidade socioambiental: perspectivas para a educação corporativa.

DIEGUES, Antonio Carlos. Sociedades e comunidades sustentáveis.

In: http://nupaub.fflch.usp.br/sites/nupaub.fflch.usp.br/files/color/comsust.pdf: acesso em 26/01/2017.

GIDDENS, Anthony; BECK, Ulrich; LASH, Scott. Modernização reflexiva: política, tradição e estética na ordem social moderna. Tradução de Magda Lopes. São Paulo: Editora da Universidade Estadual Paulista, 1997.

HANSE, Cláudia Maria; CALGARO, Cleide. Modernidade reflexiva e a sociedade de risco: o futuro da nova era social. In: http://huespedes.cica.es/gimadus/21/07_modernidade_reflexiva.html: acesso em 26.01.2017.

LEFF, Enrique. Saber ambiental: sustentabilidade, racionalidade, complexidade, poder. Traduzido por Lúcia Mathilde Endlich Orth. Petrópolis: Vozes, 2001.

LEITE, José Rubens Morato. Sociedade de risco e estado. In: CANOTILHO, José Joaquim Gomes; Leite, José Rubens Morato (orgs.). Direito constitucional ambiental brasileiro. 6 ed. São Paulo: Saraiva, 2015.

LEITE, José Rubens Morato; BELCHIOR, Germana Parente Neiva. Dano ambiental na sociedade de risco: uma visão introdutória. In: FERREIRA, Heline Sivini; FERREIRA, Maria Leonor Paes Cavalcanti (Org.). Dano ambiental na sociedade de risco. São Paulo: Saraiva, 2012.

MÉSZÁROS, Istvan. A educação para além do capital. São Paulo: Boitempo, 2005.

MORIN, Edgar. Os sete saberes necessários à educação do futuro. 3 ed. São Paulo: Cortez. 2001. NOVICKI, Victor. Educação para o desenvolvimento sustentável ou sociedades sustentáveis?. Linhas Críticas (Online), v. 15, p. 215-232, 2009.

PIMENTA, Carlos. Enquadramento geral da problemática do ambiente. In: AMARAL, Diogo Freitas do (org.). Direito do ambiente. Oeiras: INA, 1994.

ROCHA, Heverthon Jeronimo da. $\mathbf{O}$ desenvolvimento sustentável e a sociedade sustentável. 
In: http://culturadigital.br/jornal2010/2010/12/07/o-desenvolvimento-sustentavel-e-a-sociedadesustentavel/ acesso em 26.01.2017.

TRATADO DE EDUCAÇÃO AMBIENTAL PARA SOCIEDADES SUSTENTÁVEIS E RESPONSABILIDADE GLOBAL. In: http://www.mma.gov.br/educacao-ambiental/politica-de-educacaoambiental/documentos-referenciais/item/8068: acesso em 26.01.2017.

VIERHAUS, 1994, apud CANOTILHO, José Joaquim Gomes. Recensão, democracia e ambiente: em torno da formação da consciência ambiental. Revista do Centro de Direito e Ordenamento do Urbanismo e do ambiente, Coimbra, v. 1, p. 93-95, 1998. 


\title{
EDUCAÇÃO AMBIENTAL COMO INSTRUMENTO PARA A SUSTENTABILIDADE SOCIAL NO SISTEMA PRISIONAL
}

\author{
Jessika Milena Silva Machado ${ }^{1}$
}

\section{INTRODUÇÃO}

Em razão do desenvolvimento econômico abundante e desmedido, a utilização dos recursos naturais e a poluição aumentaram significativamente, gerando desequilíbrio ecológico, degradações e devastações ambientais descomunais. Diante desse quadro, surge a problemática ambiental e, com ela, a necessidade de conscientização e reparação dessas assolações.

Para tanto, inicia-se o item $1 \mathrm{com}$ a análise da origem e o conceito da sustentabilidade, mencionando quais as suas dimensões e, por fim, conceitua-se a sustentabilidade social, um dos pilares do presente artigo.

Após, aborda-se o tema educação ambiental, elencando os dispositivos jurídicos nos quais ela se encontra disciplinada e descrevendo o seu conceito e a sua importância.

Já no item 3, verifica-se se a educação ambiental, consubstancia-se instrumento de efetivação da sustentabilidade social, no sistema prisional.

Quanto à metodologia, registra-se que o tratamento dos dados e a elaboração da pesquisa sob a forma de artigo científico foram realizados com base no método indutivo, e as técnicas utilizadas são a do referente, das categorias, dos conceitos operacionais e da pesquisa bibliográfica.

\section{SUSTENTABILIDADE}

Não existe dúvida acerca da importância do tema sustentabilidade, o qual vem sendo, nas últimas décadas, amplamente discutido.

\footnotetext{
${ }^{1}$ Mestranda do Programa de Pós-Graduação Stricto Sensu em Ciência Jurídica da Universidade do Vale do Itajaí (UNIVALI). Pósgraduada lato sensu em Direito Público e Direito Aplicado pela Fundação Universidade Regional de Blumenau (FURB). Pósgraduanda em Direito Ambiental, pela Universidade do Sul de Santa Catarina (UNISUL). Bacharel em Direito pela UNISUL. E-mail: jessikamsm@gmail.com. Currículo Lattes: http://lattes.cnpq.br/0553965900431491.
} 
Dessa forma, passa-se a descrever a origem e o conceito de sustentabilidade, mencionando quais as suas dimensões e, por fim, conceitua-se a sustentabilidade social, um dos pilares do presente artigo.

\subsection{Origem e Conceito}

É cediço que o tema sustentabilidade vem sendo defendido com afinco pela sociedade, porém sua origem se remota a tempos pretéritos.

Senão, veja-se o que evidencia Leonardo Boff²:

[...] foi na Alemanha, em 1560, na Província da Saxônia, que irrompeu, pela primeira vez, a preocupação pelo o uso racional das florestas, de forma que elas pudessem se regenerar e se manter permanentemente. Neste contexto surgiu a palavra alemã Nachhaltingkeit que traduzida significa "sustentabilidade". (itálico no original)

Na Província supracitada, anos mais tarde, especificamente em 1713, o Capitão Hans Carl von Carlowitz escreveu um tratado em latim sobre a sustentabilidade das florestas, intitulado "[...] Silvicultura oeconomica", cujo lema era: "devemos tratar a madeira com cuidado" ${ }^{3}$. Isso porque, "Haviam se criado fornos de mineração que demandavam muito carvão vegetal, extraído da madeira. Florestas eram abatidas para atender esta nova frente do progresso". 4

Naquela época já se incentivava o reflorestamento, objetivando a utilização sustentável da madeira, com intuito de não exterminar os negócios, e em consequência, não cessar o lucro. ${ }^{5}$

Com o advento da Revolução Industrial, a partir do ano de 1760, a população e os ecossistemas foram ameaçados, tendo em vista que os avanços tecnológicos e científicos implementados intensificaram a exploração e utilização dos recursos naturais.

Ulrich Beck ${ }^{6}$ afirma:

Ao longo de sua transformação tecnológico-industrial e de sua comercialização global, a natureza foi absorvida pelo sistema industrial. Dessa forma, ela se converteu, ao mesmo tempo, em pré-requisito indispensável do modo de vida no sistema industrial. Dependência do consumo e do mercado agora também significam um novo tipo de dependência da 'natureza', e essa dependência imanente da 'natureza' em relação ao sistema mercantil se converte, no e com o sistema mercantil, em lei do modo de vida na civilização industrial.

\footnotetext{
${ }^{2}$ BOFF, Leonardo. Sustentabilidade: o que é - o que não é. 4. ed. Rio de Janeiro: Vozes, 2015. p. 32-33.

${ }^{3}$ BOFF, Leonardo. Sustentabilidade: o que é - o que não é. 4. ed. Rio de Janeiro: Vozes, 2015. p. 33.

${ }^{4}$ BOFF, Leonardo. Sustentabilidade: o que é - o que não é. 4. ed. Rio de Janeiro: Vozes, 2015. p. 33.

${ }^{5}$ BOFF, Leonardo. Sustentabilidade: o que é - o que não é. 4. ed. Rio de Janeiro: Vozes, 2015. p. 33.

${ }^{6}$ BECK, Ulrich. Sociedade de risco: rumo a uma outra modernidade. Trad. Sebastião Nascimento. São Paulo: ed. 34, 2016. p. 09.
} 


\section{Complementa Juliana Gallina Badalotti:}

Após a Revolução Industrial, verifica-se a massificação na produção dos bens de consumo, a produção em série, aumentando a quantidade e a diversidade dos produtos oferecidos no mercado de consumo. O avanço tecnológico proporcionou um aumento quantitativo de produtos no mercado, determinando novos meios de produção, criando novas funções para objetos desconhecidos, facilitando o dia a dia e aumento a oportunidade de escolha do consumidor, que a cada dia se depara com um objeto diferente para a sua lista de necessidades criadas.

A partir de então, pode-se dizer que surge uma nova forma de modelo social, que é ditada pelos padrões de consumo, na qual se busca satisfazer desenfreadamente os anseios dos consumidores, ainda que para isso haja prejuízos ambientais irreparáveis e, até mesmo, ameaças à vida humana.

O homem extasiado com o avanço da tecnologia passa a ser uma espécie capaz de se autodestruir, bem como de aniquilar, gradativamente, todo o meio ambiente. ${ }^{8}$

Elucidando, Reinaldo Dias ${ }^{9}$ informa:

Entre os muitos problemas ambientais que a industrialização trouxe estão: a alta concentração populacional devida à urbanização acelerada; consumo excessivo de recursos naturais, sendo que alguns não renováveis (petróleo e carvão mineral, por exemplo); contaminação do ar, do solo, das águas; e desflorestamento entre outros.

Ademais, importa salientar que a industrialização trouxe consigo também problemas humanitários, cuja consequência maior foi a Segunda Guerra Mundial, que terminou em 1945. Com ela, ocorreram também desastres ambientais.

[...] Os bombardeios, a necessidade de alimentação e abrigo, as exigências estratégicas de cada lado do conflito alteraram o meio ambiente humano de forma significativa. Só para destacar um dos aspectos mais conhecidos, nos estágios finais da guerra, ocorreram as explosões atômicas de Hiroshima e Nagasaki, que, além de enorme número de vítimas, provocaram consequências danosas ao meio ambiente natural que perduraram durante anos, sendo que seus efeitos se sentem ainda hoje. $^{10}$

Outros acontecimentos ambientais de grandes proporções ocorreram na mesma época, os quais contribuíram para que o alarme da crise e preocupação ambiental fossem ligados. Cita-se: a poluição de Londres de 1952, na qual milhares de pessoas morreram em razão da fumaça

\footnotetext{
${ }^{7}$ BADALOTTI, Juliana Gallina. Sociedade de consumo versus sociedade sustentável. Instrumentos de tutela ambiental no direito brasileiro, Chapecó: Argos, 2009. p. 49.

${ }^{8}$ WINCKLER, Silvana; PEREIRA, Reginaldo. O novo meio ambiente e o direito ambiental. Instrumentos de tutela ambiental no direito brasileiro, Chapecó: Argos, 2009. p. 19-20.

${ }^{9}$ DIAS, Reinaldo. Sustentabilidade: origem e fundamentos; educação e governança global; modelo de desenvolvimento. São Paulo: Atlas, 2015. p. 86.

${ }^{10}$ DIAS, Reinaldo. Sustentabilidade: origem e fundamentos; educação e governança global; modelo de desenvolvimento. São Paulo: Atlas, 2015. p. 86-87.
} 
originada da combustão do carvão e a intoxicação por mercúrio de um grupo de pescadores e suas famílias em Minamata, no Japão. ${ }^{11}$

Cumpre ainda mencionar que, em 1962, ocorreu a publicação do livro Primavera Silenciosa (Silent Spring), de autoria da bióloga Rachel Carson, o qual despertou a atenção da opinião pública sobre as ameaças ao meio ambiente.

E são exatamente as consequências das mudanças ambientais destrutivas que fizeram com que o tema passasse a ser discutido em âmbito internacional. Especificadamente em 1972, a Organização das Nações Unidas (ONU), na Cidade de Estocolmo, realizou a Primeira Conferência Mundial sobre o Homem e o Meio Ambiente, a qual estabeleceu:

O homem é ao mesmo tempo obra e construtor do meio ambiente que o cerca, o qual lhe dá sustento material e the oferece oportunidade para desenvolver-se intelectual, moral, social e espiritualmente. Em larga e tortuosa evolução da raça humana neste planeta chegou-se a uma etapa em que, graças à rápida aceleração da ciência e da tecnologia, o homem adquiriu o poder de transformar, de inúmeras maneiras e em uma escala sem precedentes, tudo que o cerca. Os dois aspectos do meio ambiente humano, o natural e o artificial, são essenciais para o bem-estar do homem e para o gozo dos direitos humanos fundamentais, inclusive o direito à vida mesma. ${ }^{12}$

Ou seja, a proteção e preservação do meio ambiente é um direito fundamental de todos, essencial para manutenção da vida humana e desenvolvimento econômico sadio.

Cumpre destacar que a supracitada Conferência criou o Programa das Nações Unidas para o Meio Ambiente (Pnuma), entrando para a história como "[...] a inauguração da agenda ambiental e o surgimento do direito ambiental internacional, elevando a cultura política mundial de respeito à ecologia, e como o primeiro convite para a elaboração de um novo paradigma econômico e civilizatório para os países." ${ }^{13}$

Após a referida Conferência, foi realizado outro encontro, o qual originou a Comissão Mundial sobre Meio Ambiente e Desenvolvimento, na qual foi produzido um documento denominado Relatório Brundtland ou Nosso Futuro Comum, cuja elaboração foi coordenada pela

\footnotetext{
${ }^{11}$ DIAS, Reinaldo. Sustentabilidade: origem e fundamentos; educação e governança global; modelo de desenvolvimento. São Paulo: Atlas, 2015. p. 88-90.

12 ONU. Declaração de Estocolmo. Estocolmo: $_{1972 .}$ Disponível em http://www.onu.org.br/rio20/img/2012/01/estocolmo1972.pdf>. Acesso em: 25 jul. 2017.

${ }^{13}$ SENADO FEDERAL. Da Conferência das Nações Unidas para o Meio Ambiente Humano, em Estocolmo, à Rio-92: agenda ambiental para os países e elaboração de documentos por Comissão Mundial sobre Meio Ambiente e Desenvolvimento. Revista em discussão. Disponível em: http://www.senado.gov.br/noticias/Jornal/emdiscussao/rio20/a-rio20/conferencia-das-nacoesunidas-parao-meio-ambiente-humano-estocolmo-rio-92-agenda-ambiental-paises-elaboracao-documentos-comissaomundialsobre-meio-ambiente-e-desenvolvimento.aspx. Acesso em: 25 jul. 2017.
} 
Primeira-ministra norueguesa Gro Harlem Brundtland. ${ }^{14}$

Acerca do Relatório Brundtland, Maria Claudia da Silva Antunes de Souza e Kamilla Pavan informam: "Em seu contexto, podem-se anunciar características marcantes, das quais resultaram novos enfoques ambientais e, principalmente, conceituação do que vem a ser o desenvolvimento sustentável, objetivando o equilíbrio sobre três pilares: as dimensão sociais, econômicas e ambientais." $^{15}$

Sendo assim, desenvolvimento sustentável é definido como "aquele que atende as necessidades das gerações atuais sem comprometer a capacidade das gerações futuras de atenderem a suas necessidades e aspirações" (itálico no original). ${ }^{16}$

O Relatório traz a necessidade de se estabelecer uma nova relação do ser humano com o meio ambiente. Isso não quer dizer que o crescimento econômico deva estagnar, apenas que ele deve ser congruente aos padrões de sustentabilidade, conciliando-se, dessa forma, com as questões ambientais e sociais.

Aliás, em relação às questões sociais, Brundtland ressalta que um fator considerado como causador da degradação do meio ambiente é a pobreza. Esta "[...] reduz a capacidade das pessoas de usar recursos de uma maneira sustentável, ela intensifica a pressão sobre o meio ambiente". ${ }^{17}$

Em razão do relatório supracitado, em 1992, a Assembleia das Nações Unidas convocou a Conferência das Nações Unidas sobre o Meio Ambiente e Desenvolvimento, chamada também de Cúpula da Terra, realizada no Rio de Janeiro. Nesta Conferência, foram produzidos muitos documentos de relevância global, dentre os quais: Agenda 21: Programas de Ação Global e a Carta do Rio de Janeiro. ${ }^{18}$

Em suma,

A Conferência do Rio 92 consagrou o conceito de desenvolvimento sustentável e contribuiu para a conscientização de que os danos ao meio ambiente eram, na sua maioria, de responsabilidade dos

\footnotetext{
${ }^{14}$ BOFF, Leonardo. Sustentabilidade: o que é - o que não é. 4. ed. Rio de Janeiro: Vozes, 2015. p. 34.

${ }^{15}$ SOUZA, Maria Claudia da Silva Antunes de; PAVAN, Kamilla. Sustentabilidade, meio ambiente e água: uma questão de sobrevivência. Direito e Sustentabilidade II: XXV Encontro Nacional do CONPEDI. Brasília: CONPEDI, 2016, p.319-337,. Disponível em: <https://www.conpedi.org.br/publicacoes/y0ii48h0/dzoq9f77/4aF1HOT08DIXm7Cl.pdf>. Acesso em: 26 jul 2017. p. 326.

${ }_{16}^{16}$ BOFF, Leonardo. Sustentabilidade: o que é - o que não é. 4. ed. Rio de Janeiro: Vozes, 2015. p. 34.

${ }^{17}$ SOUZA, Maria Claudia da Silva Antunes de; PAVAN, Kamilla. Sustentabilidade, meio ambiente e água: uma questão de sobrevivência. Direito e Sustentabilidade II: XXV Encontro Nacional do CONPEDI. Brasília: CONPEDI, 2016, p.319-337,. Disponível em: <https://www.conpedi.org.br/publicacoes/y0ii48h0/dzoq9f77/4aF1HOT08DIXm7Cl.pdf>. Acesso em: 26 jul 2017. p. 326.

${ }^{18}$ BOFF, Leonardo. Sustentabilidade: o que é - o que não é. 4. ed. Rio de Janeiro: Vozes, 2015. p. 35.
} 
países desenvolvidos. Ressaltou-se a importância quanto ao reconhecimento dos países desenvolvidos receberem apoio financeiro e tecnológico para avançarem na direção do desenvolvimento sustentável, sendo sua premissa o progresso sustentável. ${ }^{19}$

Já em 2002, a ONU provocou uma convocação da Cúpula da Terra sobre Sustentabilidade e Desenvolvimento, a qual foi realizada em Joanesburgo, na África do Sul, ocasião em que "[...] A questão da salvaguarda do planeta e da preservação de nossa civilização foi apenas referida marginalmente", assim como a sustentabilidade. ${ }^{20}$

Ocorre que, em 2012, no Rio de Janeiro, aconteceu outra Cúpula da terra, também promovida pela ONU, intitulada Rio+20, cujos temas geradores foram sustentabilidade, economia verde e governança global do ambiente. ${ }^{21}$

Antes, contudo, vale contextualizar, nas palavras de Enrique Leff, o exposto acerca da origem da sustentabilidade, a qual "[...] surge do limite de um mundo levado pela busca de uma unidade da diversidade submetida ao jugo da ideia absoluta, da racionalidade tecnológica e da globalização do mercado." 22

Analisada a origem da sustentabilidade, passa-se à delimitação do seu conceito.

Segue, de acordo com Leonardo Boff ${ }^{23}$, uma definição integradora de sustentabilidade:

Sustentabilidade é toda ação destinada a manter as condições energéticas, informacionais, físicoquímicas que sustentam todos os seres, especialmente a Terra viva, a comunidade de vida, a sociedade e a vida humana, visando sua continuidade e ainda atender as necessidades da geração presente e das futuras, de tal forma que os bens e serviços naturais sejam mantidos e enriquecidos em sua capacidade de regeneração, reprodução e coevolução. (itálico no original)

Em síntese, pode-se dizer que a sustentabilidade consiste em encontrar meios de produção e consumos dos recursos existentes de forma harmoniosa, economicamente eficaz e ecologicamente correta.

Por fim, cumpre mencionar que "A sustentabilidade aponta para um futuro, para uma solidariedade transgeracional e um compromisso com as gerações futuras", sendo que "O futuro é

\footnotetext{
${ }^{19}$ SOUZA, Maria Claudia da Silva Antunes de; PAVAN, Kamilla. Sustentabilidade, meio ambiente e água: uma questão de sobrevivência. Direito e Sustentabilidade II: XXV Encontro Nacional do CONPEDI. Brasília: CONPEDI, 2016, p.319-337,. Disponível em: <https://www.conpedi.org.br/publicacoes/y0ii48h0/dzoq9f77/4aF1HOT08DIXm7Cl.pdf>. Acesso em: 26 jul 2017. p. 327.

${ }^{20}$ BOFF, Leonardo. Sustentabilidade: o que é - o que não é. 4. ed. Rio de Janeiro: Vozes, 2015. p. 36.

${ }^{21}$ BOFF, Leonardo. Sustentabilidade: o que é - o que não é. 4. ed. Rio de Janeiro: Vozes, 2015. p. 37.

${ }^{22}$ LEFF, Enrique. Saber ambiental: sustentabilidade, racionalidade, complexidade, poder. 11. ed. Petrópolis: Vozes, 2015. p. 412.

${ }^{23}$ BOFF, Leonardo. Sustentabilidade: o que é - o que não é. 4. ed. Rio de Janeiro: Vozes, 2015. p. 107.
} 
uma exigência de sobrevivência e um instinto de conservação." 24

\subsection{Sustentabilidade social}

A sustentabilidade se consubstancia essencial para a preservação do meio ambiente, e consequente proteção da qualidade e manutenção da vida humana. Sendo assim, ela deve ser abordada sob vários aspectos, tais como: o ambiental, o econômico, o social, o cultural, o político, o tecnológico.

Passa-se a abordar a sustentabilidade social, um dos pilares do presente artigo, conforme abordado na sequência.

A sustentabilidade social tem seu fundamento no Relatório Brundtland, o qual possui como premissa o afirmativo de que a desigualdade social é um dos problemas enfrentados pela questão ambiental. Isso porque os danos ambientais são sentidos de maneiras diversas por aqueles que possuem e aqueles que não possuem recursos.

Ao tratar da sustentabilidade social, Aloísio Ruscheinsky ${ }^{25}$ afirma que:

[...] compreende-se que a emergência da sociedade sustentável compreende o desenvolvimento de ações coletivas que venham a enfrentara as desigualdades sociais ou emerge como resultado de mudanças sociais e econômicas contemporâneas que permitem novo formato organizativo da sociedade. É a ênfase que privilegia os atores sociais, o reordenamento jurídico, o Estado de compromisso, as alterações dos condicionamentos sociais e as bases de sustentação material da vida.

Complementa Antônio Márcio Buainain ${ }^{26}$ :

A noção de sustentabilidade incorpora uma clara dimensão social e implica atender também as necessidades dos mais pobres de hoje, outra dimensão ambiental abrangente, uma vez que busca garantir que a satisfação das necessidades de hoje não podem comprometer o meio ambiente e criar dificuldades para as gerações futuras. Nesse sentido, a idéia de desenvolvimento sustentável carrega um forte conteúdo ambiental e um apelo claro à preservação e à recuperação dos ecossistemas e dos recursos naturais.

Percebe-se que a sustentabilidade social busca, conforme propõe Zygmunt Bauman ${ }^{27}$, "[...]

\footnotetext{
${ }^{24}$ LEFF, Enrique. Saber ambiental: sustentabilidade, racionalidade, complexidade, poder. 11. ed. Petrópolis: Vozes, 2015. p. 412.

${ }^{25}$ RUSCHEINSKY, Aloísio. No conflito das interpretações: o enredo da sustentabilidade. Revista eletrônica do Mestrado em Educação Ambiental, Fundação Universidade Federal do Rio Grande, v. 10, jan./set 2003. Disponível em: $<$ http://files.manualdesustentabilidade.webnode.com.br/200000010-

9b3fa9c39a/RUSCHEINSKY,\%20A.\%20\%20No\%20conflito\%20das\%20interpreta\%C3\%A7\%C3\%B5es\%20o\%20enredo\%20da\%20su stentabilidade.\%20\%20In\%20RUSCHEINSKY,\%20A\%20(org.)\%20Sustentabilidade\%20uma\%20paix\%C3\%A30\%20em\%20movimen to.\%201a\%20ed.\%20Porto\%20Alegre\%20Sulina,\%202004..pdf>. Acesso em: 26 jul 2017. p. 42.

${ }^{26}$ BUAINAIN, Antônio Márcio. Agricultura Familiar, Agroecologia e Desenvolvimento Sustentável: questões para debate. v. 5. Brasília: IICA, 2006. p. 25. Disponível em: < http://www.iicabr.iica.org.br/wp-content/uploads/2014/03/Serie-DRS-vol-5Agricultura-familiar-agroecologica-e-desenvol-sustentavel.pdf>. Acesso em: 26 jul 2017.

${ }^{27}$ BAUMAN, Zygmunt. Confiança e medo na cidade. Rio de Janeiro: Zahar, 2009. p. 89.
} 
tornar mais humana a comunidade dos homens".

Em suma, pode-se dizer que "[...] Sustentabilidade Social, implica em construir uma sociedade (civilização) do ser, em que exista maior equidade na distribuição do ter." 28 Ou seja, busca melhorar a qualidade de vida da população, através de políticas distributivas e atendimento a direitos fundamentais como saúde, educação, moradia e seguridade social.

\section{A EDUCAÇÃO AMBIENTAL}

Inicialmente, cumpre ressaltar que a educação é um direito fundamental de todos e se encontra positivada na Constituição da República Federativa do Brasil. Veja-se:

Art. 205. A educação, direito de todos e dever do Estado e da família, será promovida e incentivada com a colaboração da sociedade, visando ao pleno desenvolvimento da pessoa, seu preparo para o exercício da cidadania e sua qualificação para o trabalho. ${ }^{29}$

Ademais, a educação ambiental foi tratada logo em seguida, pela carta constitucional.

Art. 225. Todos têm direito ao meio ambiente ecologicamente equilibrado, bem de uso comum do povo e essencial à sadia qualidade de vida, impondo-se ao Poder Público e à coletividade o dever de defendê-lo e preserva-lo para as presentes e futuras gerações.

$\S 1$ 을 Para assegurar a efetividade desse direito, incumbe ao Poder Público:

$[\ldots]$

VI - promover a educação ambiental em todos os níveis de ensino e a conscientização pública para a preservação do meio ambiente; ${ }^{30}$

Além do diploma constitucional supracitado, existe a Lei de Educação Ambiental (Lei Federal no 9.795/1999), a qual determina as diretrizes para o desenvolvimento da política de educação ambiental, preconizando no artigo 1ㅇ:

Entendem-se por educação ambiental os processos por meio dos quais o indivíduo e a coletividade constroem valores sociais, conhecimentos, habilidades, atitudes e competências voltadas para a conservação do meio ambiente, bem de uso comum do povo, essencial à sadia qualidade de vida e sua sustentabilidade. ${ }^{31}$

\footnotetext{
${ }^{27}$ BAUMAN, Zygmunt. Confiança e medo na cidade. Rio de Janeiro: Zahar, 2009. p. 89.

${ }^{28}$ DUARTE, Maria Raquel. Aplicação do princípio constitucional da sustentabilidade como forma de efetivação dos princípios dos Juizados Especiais Federais. Revista Eletrônica Direito e Política, Programa de Pós-Graduação Stricto Sensu em Ciência Jurídica da UNIVALI, Itajaí, v.8, n.1, 10 quadrimestre de 2013. Disponível em: <www.univali.br/direitoepolitica>. Acesso em: 26 jul 2017.

29 BRASIL. Constituição da República Federativa do Brasil. Disponível em: <http://www.planalto.gov.br/ccivil_03/constituicao/constituicaocompilado.htm>. Acesso em: 27 jul. 2017.

30 BRASIL. Constituição da República Federativa do Brasil. Disponível em: <http://www.planalto.gov.br/ccivil_03/constituicao/constituicaocompilado.htm>. Acesso em: 27 jul. 2017.

${ }^{31}$ BRASIL. Lei no 9.795, de 27 de abril de 1999. Dispõe sobre a educação ambiental, institui a Política Nacional de Educação Ambiental e dá outras providências. Disponível em: <http://www.planalto.gov.br/ccivil_03/leis/L9795.htm>. Acesso em: 27 jul.
} 
Dessa forma, pode-se dizer que as referidas atividades normativas objetivam a promoção da educação ambiental e a sua conscientização pública, com intuito de preservar o meio ambiente e utilizar de maneira sustentável os recursos naturais.

Há de se destacar, desde já, que a educação ambiental também se fundamenta na ética ambiental. Explica Luis Paulo Sirvinskas ${ }^{32}$ :

A educação ambiental deve estar fundamentada na ética ambiental. Entende-se por ética ambiental o estudo dos juízos de valor da conduta humana em relação ao meio ambiente. É, em outras palavras, a compreensão que o homem tem da necessidade de preservar ou conservar os recursos naturais essenciais à perpetuação de todas as espécies de vida existentes no planeta Terra. Essa compreensão está relacionada com a modificação das condições físicas, químicas e biológicas do meio ambiente, ocasionada pela intervenção de atividades comunitárias e industriais, que pode colocar em risco todas as formas de vida do planeta. O risco de extinção de todas as formas de vida deve ser uma das preocupações do estudo da ética ambiental. [...] A ética ambiental está amparada pela Constituição Federal, ao consignar que todos têm direito ao meio ambiente ecologicamente equilibrado, bem de uso comum do povo e essencial à sadia qualidade de vida, impondo-se ao Poder Público e à coletividade o dever de defendê-lo e preservá-lo e para as presentes e futuras gerações (art. 225, caput, da CF). É o exercício efetivo da cidadania que poderá resolver parte dos grandes problemas ambientais do mundo através da ética transmitida pela educação ambiental. Para se entender as causas da degradação ambiental é necessário compreender os problemas socioeconômicos e políticos-culturais e, a partir desses conhecimentos, tentar alterar as atitudes comportamentais das pessoas na sua fase inicial por meio de uma ética ambiental.

Oportuno elencar os objetivos fundamentais da educação ambiental (artigo 5ํ):

I - o desenvolvimento de uma compreensão integrada do meio ambiente em suas múltiplas e complexas relações, envolvendo aspectos ecológicos, psicológicos, legais, políticos, sociais, econômicos, científicos, culturais e éticos;

II - a garantia de democratização das informações ambientais;

III - o estímulo e o fortalecimento de uma consciência crítica sobre a problemática ambiental e social;

IV - o incentivo à participação individual e coletiva, permanente e responsável, na preservação do equilíbrio do meio ambiente, entendendo-se a defesa da qualidade ambiental como um valor inseparável do exercício da cidadania;

V - o estímulo à cooperação entre as diversas regiões do País, em níveis micro e macrorregionais, com vistas à construção de uma sociedade ambientalmente equilibrada, fundada nos princípios da liberdade, igualdade, solidariedade, democracia, justiça social, responsabilidade e sustentabilidade;

VI - o fomento e o fortalecimento da integração com a ciência e a tecnologia;

2017.

${ }^{32}$ SIRVINSKAS, Luis Paulo. Manual de direito ambiental. 15. ed. São Paulo: Saraiva, 2017. p. 93-94. 
VII - o fortalecimento da cidadania, autodeterminação dos povos e solidariedade como fundamentos para o futuro da humanidade. ${ }^{33}$

A doutrina também trata do tema educação ambiental, elucidando sabiamente:

A educação ambiental é um processo no qual todos somos aprendizes e mestres. Os bons mestres sempre foram aprendizes até alcançarem a maestria de artes e ofícios. Mas esse processo de transmissão de saberes sempre se deu no âmbito de relações de poder daquele que detém um saber; de relações de dominação professor-aluno; de relações de autoridade e de prestígio exercidas na busca de apropriação de um saber codificado, certificado. [...] Trata-se de uma educação que permite que os indivíduos se preparem para a construção de uma nova racionalidade; não para uma cultura de desesperança e alienação, mas, pelo contrário, para um processo de emancipação que permita o surgimento de novas formas de reapropriação do mundo. ${ }^{34}$

\section{Segundo Thiago Braga Dantas e Enoque Feitosa ${ }^{35}$ :}

[...] explicita-se a educação ambiental como ferramenta política de conscientização do cidadão ambiental, não como sinônimo de ecologia, de ambiente natural, mas redimensionada ao aspecto humano, ao ambiente construído. A educação é uma ferramenta política e pode ser direcionada, tanto para um aspecto conservador, como crítico. A educação ambiental conservadora se pauta por ações individuais para a resolução dos problemas ambientais, fomentando o individualismo, a desigualdade. Já a educação ambiental crítica concebe o ser como inacabado, primando por ações coletivas, verdadeira fonte de resolução dos problemas ambientais. A educação tem o poder de transformar a consciência dos indivíduos, ensejando o início de novas práticas.

Portanto, pode-se dizer que a educação ambiental "[...] afirma valores e ações que contribuem para a transformação humana e social e para a preservação ecológica" ${ }^{36}$, requerendo, para tanto, responsabilidade individual e coletiva em nível planetário. A partir disto, tem-se sociedades socialmente justas e ecologicamente equilibradas, cujo comprometimento é voltado não apenas à preservação ambiental, mas também ao cuidado com o meio social.

\section{Ainda, assevera Karoline de Lucena Araújo ${ }^{37}$ :}

[...] que a educação ambiental sempre foi e é mencionada como meio de grande eficácia para a formação de uma postura responsável no consumo. A mudança na postura consumerista se tornou imprescindível para a sustentação da produção pelos recursos naturais, e, o mais importante, para a preservação dos mesmos. É relevante destacar que a preservação do bem ambiental não é apenas

\footnotetext{
${ }^{33}$ BRASIL. Lei no 9.795, de 27 de abril de 1999. Dispõe sobre a educação ambiental, institui a Política Nacional de Educação Ambiental e dá outras providências. Disponível em: <http://www.planalto.gov.br/ccivil_03/leis/L9795.htm>. Acesso em: 27 jul. 2017.

${ }^{34}$ LEFF, Enrique. Epistemologia ambiental. São Paulo: Cortez, 2001. p.218-219.

${ }^{35}$ DANTAS, Thiago Braga; FEITOSA, Enoque. Os princípios ambientais e o conceito de sustentabilidade: Gerações futuras diante dos recursos naturais do brasil. São Paulo: CONPEDI, 2009. p. 2919.

${ }^{36}$ LOUREIRO, Carlos Frederico B. Sustentabilidade e educação ambiental: controvérsias e caminhos do caso brasileiro. Sinais Sociais, Rio de Janeiro, v.9, n. 26, p. 1-160, set.-dez. 2014. p. 47.

${ }^{37}$ ARAÚJO, Karoline de Lucena. Consumo, meio ambiente e sustentabilidade: um olhar sobre o saber ambiental segundo Leff. Os saberes ambientais, sustentabilidade e olhar jurídico [recurso eletrônico] : visitando a obra de Enrique Leff. Caxias do Sul: Educs, 2015. Disponível em:< https://www.conpedi.org.br/wp-content/uploads/2015/09/saberes_ambientais_ebook-1.pdf>. Acesso em: 27 jul, 2017. p. 273.
} 
para que o sistema de produção continue, mas para que o meio ambiente seja protegido e preservado para as futuras gerações, como reza o dispositivo constitucional. A educação ambiental é um instrumento de grande eficácia para que o consumo sustentável não seja um processo falacioso.

É papel da educação ambiental, portanto, modificar a racionalidade humana vigente, proporcionando ao individuo a consciência da problemática "meio ambiente" e ensinando-lhe formas de implementar sua preservação, amenizando, assim, as desigualdades sociais já instaladas na sociedade.

Ainda, frisa-se que a educação ambiental pode ser formal, não formal e informal. Acerca do tema, Elida Séguin ${ }^{38}$ prevê:

Na primeira, realizada nas escolas de forma sistemática, introduz a matéria como disciplina a ser ministrada obrigatoriamente nas escolas públicas e particulares, é fundamental que o docente tenha sensibilidade para captar as implicações ambientais, induzindo o aluno a uma reflexão ética do tema, com abertura para aceitar as diversas manifestações étnico culturais. Na segunda, tem-se o acesso à informação através de campanhas públicas; pode decorrer de Campanhas, governamentais ou privadas, ou ainda, da atuação individual. É sabido que uma ação vale por mil palavras. O simples fato de divulgar que o Código Nacional de Trânsito, no art. 172, proíbe que se lance objetos e detritos de veículos, já é uma forma de educar ambientalmente. A terceira, partindo do grupo familiar e da sociedade em geral, criam-se comportamentos que são imitados pelos demais. No terreno nebuloso da educação informal estão enraizados os problemas que afligem a humanidade, em especial os preconceitos, a intolerância e a discriminação.

Sobre todo o exposto até aqui, percebe-se que o tamanho da ignorância do homem quanto à importância da preservação do meio ambiente é proporcional à sua capacidade de destruição deste. Sendo assim, a educação ambiental se consubstancia não só como direito fundamental, mas também como forma de demonstrar que o ser humano necessita do meio ambiente para sobreviver, e, portanto, deve preservá-lo, constituindo, assim, uma mudança social.

\section{Acentua Leonardo Boff ${ }^{39}$ :}

A sustentabilidade não acontece mecanicamente. Ela é fruto de um processo de educação pela qual o ser humano redefine o feixe de relações que entretém com o universo, com a Terra, com a natureza, com a sociedade e consigo mesmo dentro dos critérios assinalados de equilíbrio e ecológico, de respeito e amor à Terra e à comunidade de vida, de solidariedade para com as gerações futuras e da construção de uma democracia socioecológica.

Até porque, nas palavras de José Renato Nalini ${ }^{40}$ :

\footnotetext{
${ }^{38}$ SÉGUIN, Elida. O Direito Ambiental: nossa casa planetária. 2. ed. Rio de Janeiro: Forense, 2002. p. 105.

${ }^{39}$ BOFF, Leonardo. Sustentabilidade: o que é - o que não é. 4. ed. Rio de Janeiro: Vozes, 2015. p. 149.

${ }^{40}$ NALINI, José Renato. Direitos que a cidade esqueceu. São Paulo: Editora Revista dos Tribunais, 2011. p. 179.
} 
A construção de uma nova mentalidade ecológica precisa ter esperança de mudar o comportamento das novas gerações, eis que as atuais foram cegas e surdas aos clamores da Terra vilipendiada. É mais do que urgente recuperar o tempo pedido e aceitar a verdade do novo paradigma ecológico.

Portanto, percebe-se que a educação ambiental está necessariamente no caminho para se alcançar a sustentabilidade, tendo em vista que apenas essa nova construção mental pode modificar a racionalidade produtiva, fazendo com que se amenize o consumo desenfreado, pautado na exploração desmedida dos recursos naturais e na poluição excessiva, para que se alcance a máxima da preservação ambiental.

Esse será o foco do último item deste trabalho, mais especificamente quanto à importância da educação ambiental para a efetivação da sustentabilidade social no sistema prisional.

\section{EDUCAÇÃO AMBIENTAL COMO INSTRUMENTO PARA A SUSTENTABILIDADE SOCIAL NO SISTEMA PRISIONAL}

Em primeiro lugar, deve-se mencionar que quando se trata do assunto "sistema prisional", ainda perduram inúmeras discriminações e prejulgamentos, o que gera uma abordagem ainda embrionária deste sistema como parte integrante do meio ambiente.

Contudo, não há como ignorar a existência desta parcela da sociedade. Por esse motivo, deve-se buscar, cada vez mais, inseri-la na comunidade como um todo.

Conforme já mencionado neste trabalho, a ação do homem, aliada ao desenvolvimento econômico desenfreado, irresponsável e não planejado, é responsável pela crise ambiental, em um cenário com tendências atuais e previsões futuras desesperadoras. Portanto, para garantir a utilização dos recursos naturais e sustentar as presentes e futuras gerações, é imprescindível que sejam adotadas medidas de sustentabilidade. ${ }^{41}$

Diante de tal panorama, cumpre ressaltar que as medidas de sustentabilidade devem ser acatadas e adotadas por todos, tanto Poder Público como cidadãos comuns, assim como pelo sistema prisional.

Dessa forma, os Estados devem promover políticas públicas sociais e ambientas também nos estabelecimentos prisionais, capazes de minimizar os efeitos dos danos que o meio ambiente vem sofrendo, isso porque, conforme já mencionado, todos os seres humanos são responsáveis

\footnotetext{
${ }^{41}$ PERALTA, Carlos E. A justiça ecológica como novo paradigma da sociedade de risco contemporânea. Direito e justiça ambiental: diálogos interdisciplinares sobre a crise ecológica, Caxias do Sul, RS: Educs, 2014. p. 15.
} 
pela recuperação da devastadora degradação ambiental, conforme bem acentua o artigo 225, caput, da Constituição Federal. ${ }^{42}$

Ademais, é visível que os números de apenados no sistema prisional nacional só aumentam e, consequentemente, cresce também o consumo de recursos naturais, a produção de lixo e diversos outros fatores que prejudicam o meio ambiente.

De acordo com dados levantados pelo Ministério da Justiça, através do Departamento Penitenciário Nacional (DEPEN), em dezembro de 2014, a população carcerária brasileira era de 622.202 pessoas. Com este elevado número, o Brasil ocupa o quarto lugar no ranking de países com maior número de presos, perdendo apenas para os Estados Unidos, China e Rússia. Ocorre que: "[...] esses países estão reduzindo as suas taxas de encarceramento nos últimos anos, o Brasil segue em trajetória diametralmente oposta, incrementando sua população prisional na ordem de $7 \%$ ao ano, aproximadamente" ${ }^{43}$.

Paralelamente, a preservação ambiental e a sustentabilidade possuem evidentes importâncias para toda a sociedade, tendo em vista que as questões ambientais podem ser percebidas não só por aqueles que estão em liberdade, mas também pelos encarcerados.

Nas palavras de Brisa Arnoud Silva ${ }^{44}$ :

O paradigma da sustentabilidade significa coordenar providências de modo não apenas no sentido de suprir as necessidades do presente sem comprometer o futuro (como introduziu o Relatório de Brundtland, no documento Nosso Futuro Comum, da Comissão Mundial sobre o Meio Ambiente em 1987), mas para garantir o máximo de qualidade possível, material e imaterial, à vida de todos, superando o individualismo, assumindo o princípio de solidariedade, e convergindo para a salvaguarda e promoção de um mínimo existencial socioambiental, hoje e amanhã.

Ou seja, "[...] os valores ambientais exigem do Estado e da coletividade a preservação do que ainda existe, e recuperar o que deixou de existir [...]" ${ }^{15}$.

Sendo assim, importa mencionar que a consciência e a responsabilidade socioambiental devem ser implementadas nos estabelecimentos prisionais através da educação. Isso porque a

42 BRASIL. Constituição da República Federativa do Brasil. Disponível em: <http://www.planalto.gov.br/ccivil_03/constituicao/constituicaocompilado.htm>. Acesso em: 15 fev. 2017.

${ }^{43}$ BRASIL. Ministério da Justiça e Cidadania. Levantamento Nacional de informações penitenciárias. INFOPEN - dezembro 2014. Disponível em: <http://www.justica.gov.br/seus-direitos/politica-penal/infopen_dez14.pdf>. Acesso em: 15 fev. 2017.

${ }^{44}$ SILVA, Brisa Arnoud. Uma análise sobre a modernidade reflexiva e a complexidade ambiental no estado socioambiental de direito para o compromisso do desenvolvimento sustentável. Cadernos do Programa de Pós-Graduação em Direito PPGDir/UGRGS. Porto Alegre, v. X, n. 2, p. 101-131, 2015. Disponível em: <http://seer.ufrgs.br/index.php/ppgdir/article/view/54612>. Acesso em: 15 fev. 2017. p. 120.

${ }^{45}$ CANOTILHO, José Joaquim Gomes; LEITE, José Rubens Morato. Direito constitucional ambiental brasileiro. 6 ed. rev. São Paulo: Saraiva, 2015. p. 196. 
educação "[...] é um instrumento de defesa ambiental. Ela funciona como ponto de partida para a conscientização e a necessidade do ser humano de se aperfeiçoar, numa valorização do contexto natural em que a pessoa vive" ${ }^{46}$.

Infelizmente, conforme acentua Carlos Eduardo Iponema ${ }^{47}$ :

Atualmente não se encontra registros referentes a artigos científicos relacionados à Educação Ambiental no Sistema Penitenciário. Os dados encontrados fazem referência apenas à Educação do preso em relação à ressocialização, não fazendo qualquer menção às questões do meio ambiente, tais como: impactos ambientais, reciclagem e coletas de lixos.

Importante ressaltar que a educação ambiental no sistema prisional almeja proporcionar a igualdade social, cumprindo com o que preconiza a sustentabilidade social, pois visa expor aos presos conhecimentos quanto à proteção dos recursos naturais e preservação do meio ambiente, deixando-os sensíveis para com as questões ambientais.

Até porque, a educação ambiental se traduz exatamente como um mecanismo de preservação do meio ambiente, tendo em vista que uma população carcerária esclarecida "[...] dificilmente vai permitir que o meio ambiente ao qual tem direito, mas com qualidade, seja agredido por um sistema que põe em risco os recursos naturais e a saúde da população." ${ }^{48}$

Portanto, é importante que as políticas públicas prisionais implementem cada vez mais a educação ambiental nas prisões, objetivando a efetivação da sustentabilidade social, o aumento da participação social dos detentos na construção de um futuro mais justo e igualitário, e, em consequência, a preservação do meio ambiente e a qualidade de vida de todos.

\section{CONSIDERAÇÕES FINAIS}

É irrefutável que a preservação do meio ambiente ecologicamente equilibrado e a sustentabilidade se constituem de suma importância para a manutenção da vida humana e de todo o ecossistema.

O conceito de sustentabilidade, conforme exaustivamente afirmado, implica no dever de

\footnotetext{
${ }^{46}$ SÉGUIN, Elida. Direito ambiental: nossa casa planetária. Rio de Janeiro: Forense, 2006. p. 110.

47 IPONEMA, Carlos Eduardo. Percepção ambiental dos presos no sistema prisional. Disponível em: < https://canalcienciascriminais.com.br/percepcao-ambiental/ >. Acesso em: 15 jan. 2017.

${ }^{48}$ ARAÚJO, Karoline de Lucena. Consumo, meio ambiente e sustentabilidade: um olhar sobre o saber ambiental segundo Leff. Os saberes ambientais, sustentabilidade e olhar jurídico [recurso eletrônico] : visitando a obra de Enrique Leff. Caxias do Sul: Educs, 2015. Disponível em:< https://www.conpedi.org.br/wp-content/uploads/2015/09/saberes_ambientais_ebook-1.pdf>. Acesso em: 27 jul, 2017. p. 272.
} 
proteger e restaurar a integridade e a vitalidade dos sistemas da Mãe Terra, incluídos seus elementos físicos, químicos e ecológicos que possibilitam a existência e a reprodução da vida, o atendimento das necessidades da presente e das futuras gerações, sendo que o novo foco, através do paradigma da sustentabilidade, deve ser a comunidade mais ampla da vida (além da vida humana).

Nesse sentido, a educação ambiental, além de propiciar uma mudança de mentalidade para a implementação das políticas sustentáveis, sejam econômicas, sociais ou ecológicas, deve apresentar uma dimensão ética que garanta a solidariedade intergeracional, cuja relevância é nítida em toda a sociedade, mas especialmente no sistema carcerário, tratado no último tópico deste trabalho.

Através da análise desse ambiente específico, é possível vislumbrar a contribuição que a educação ambiental pode exercer nas relações da sociedade como um todo: indivíduos conscientes de si e do meio ambiente que os rodeia - suas riquezas e seus desastres iminentes são mais capazes de ser fraternos, solidários e compreensivos com os outros.

Um ser humano sustentável consegue solucionar seus conflitos internos e externos. A sociedade atual, na contramão da sustentabilidade, está adoecendo - começando pelas doenças de causas emocionais. Faz-se, portanto, um chamado urgente à cooperação e à esperança, de modo que a sustentabilidade seja posicionada como um denominador comum de todas as formas de vida.

\section{REFERÊNCIAS DAS FONTES CITADAS}

ARAÚJO, Karoline de Lucena. Consumo, meio ambiente e sustentabilidade: um olhar sobre o saber ambiental segundo Leff. Os saberes ambientais, sustentabilidade e olhar jurídico [recurso eletrônico] : visitando a obra de Enrique Leff. Caxias do Sul: Educs, 2015. Disponível em:< https://www.conpedi.org.br/wp-content/uploads/2015/09/saberes_ambientais_ebook-1.pdf>. Acesso em: 27 jul. 2017.

BADALOTTI, Juliana Gallina. Sociedade de consumo versus sociedade sustentável. Instrumentos de tutela ambiental no direito brasileiro, Chapecó: Argos, 2009.

BAUMAN, Zygmunt. Confiança e medo na cidade. Rio de Janeiro: Zahar, 2009. 
BECK, Ulrich. Sociedade de risco: rumo a uma outra modernidade. Trad. Sebastião Nascimento. São Paulo: ed. 34, 2016.

BRASIL. Constituição da República Federativa do Brasil. Disponível em: <http://www.planalto.gov.br/ccivil_03/constituicao/constituicaocompilado.htm>. Acesso em: 27 jul. 2017.

BRASIL. Lei no 9.795, de 27 de abril de 1999. Dispõe sobre a educação ambiental, institui a Política Nacional de Educação Ambiental e dá outras providências. Disponível em: <http://www.planalto.gov.br/ccivil_03/leis/L9795.htm>. Acesso em: 27 jul. 2017.

BRASIL. Ministério da Justiça e Cidadania. Levantamento Nacional de informações penitenciárias. INFOPEN - dezembro 2014. Disponível em: <http://www.justica.gov.br/seus-direitos/politicapenal/infopen_dez14.pdf>. Acesso em: 28 jul. 2017.

BOFF, Leonardo. Sustentabilidade: o que é - o que não é. 4. ed. Rio de Janeiro: Vozes, 2015. BUAINAIN, Antônio Márcio. Agricultura Familiar, Agroecologia e Desenvolvimento Sustentável: questões para debate. v. 5. Brasília: IICA, 2006. p. 25. Disponível em: < http://www.iicabr.iica.org.br/wp-content/uploads/2014/03/Serie-DRS-vol-5-Agricultura-familiaragroecologica-e-desenvol-sustentavel.pdf>. Acesso em: 26 jul 2017.

CANOTILHO, José Joaquim Gomes; LEITE, José Rubens Morato. Direito constitucional ambiental brasileiro. 6 ed. rev. São Paulo: Saraiva, 2015.

DANTAS, Thiago Braga; FEITOSA, Enoque. Os princípios ambientais e o conceito de sustentabilidade: Gerações futuras diante dos recursos naturais do brasil. São Paulo: CONPEDI, 2009.

DIAS, Reinaldo. Sustentabilidade: origem e fundamentos; educação e governança global; modelo de desenvolvimento. São Paulo: Atlas, 2015.

DUARTE, Maria Raquel. Aplicação do princípio constitucional da sustentabilidade como forma de efetivação dos princípios dos Juizados Especiais Federais. Revista Eletrônica Direito e Política, Programa de Pós-Graduação Stricto Sensu em Ciência Jurídica da UNIVALI, Itajaí, v.8, n.1, 10 quadrimestre de 2013. Disponível em: <www.univali.br/direitoepolitica>. Acesso em: 26 jul 2017. IPONEMA, Carlos Eduardo. Percepção ambiental dos presos no sistema prisional. Disponível em: < https://canalcienciascriminais.com.br/percepcao-ambiental/ >. Acesso em: 28 jul. 2017. 
LEFF, Enrique. Saber ambiental: sustentabilidade, racionalidade, complexidade, poder. 11. ed. Petrópolis: Vozes, 2015.

LOUREIRO, Carlos Frederico B. Sustentabilidade e educação ambiental: controvérsias e caminhos do caso brasileiro. Sinais Sociais, Rio de Janeiro, v.9, n. 26, p. 1-160, set.-dez. 2014.

NALINI, José Renato. Direitos que a cidade esqueceu. São Paulo: Editora Revista dos Tribunais, 2011.

ONU. Declaração de Estocolmo. Estocolmo: 1972. Disponível em http://www.onu.org.br/rio20/img/2012/01/estocolmo1972.pdf>. Acesso em: 25 jul. 2017. PERALTA, Carlos E. A justiça ecológica como novo paradigma da sociedade de risco contemporânea. Direito e justiça ambiental: diálogos interdisciplinares sobre a crise ecológica, Caxias do Sul, RS: Educs, 2014.

RUSCHEINSKY, Aloísio. No conflito das interpretações: o enredo da sustentabilidade. Revista eletrônica do Mestrado em Educação Ambiental, Fundação Universidade Federal do Rio Grande, v. 10, jan./set 2003. Disponível em:

<http://files.manualdesustentabilidade.webnode.com.br/200000010-

9b3fa9c39a/RUSCHEINSKY,\%20A.\%20\%20No\%20conflito\%20das\%20interpreta\%C3\%A7\%C3\%B5es \%20o\%20enredo\%20da\%20sustentabilidade.\%20\%20In\%20RUSCHEINSKY,\%20A\%20(org.)\%20Sust entabilidade\%20uma\%20paix\%C3\%A3o\%20em\%20movimento.\%201a\%20ed.\%20Porto\%20Alegre \%20Sulina,\%202004..pdf>. Acesso em: 26 jul 2017.

SÉGUIN, Elida. O Direito Ambiental: nossa casa planetária. 2. ed. Rio de Janeiro: Forense, 2002. SENADO FEDERAL. Da Conferência das Nações Unidas para o Meio Ambiente Humano, em Estocolmo, à Rio-92: agenda ambiental para os países e elaboração de documentos por Comissão Mundial sobre Meio Ambiente e Desenvolvimento. Revista em discussão. Disponível em: http://www.senado.gov.br/noticias/Jornal/emdiscussao/rio20/a-rio20/conferencia-das-nacoesunidas-parao-meio-ambiente-humano-estocolmo-rio-92-agenda-ambiental-paises-elaboracaodocumentos-comissaomundial-sobre-meio-ambiente-e-desenvolvimento.aspx. Acesso em: 25 jul. 2017.

SILVA, Brisa Arnoud. Uma análise sobre a modernidade reflexiva e a complexidade ambiental no estado socioambiental de direito para o compromisso do desenvolvimento sustentável. Cadernos do Programa de Pós-Graduação em Direito PPGDir/UGRGS. Porto Alegre, v. X, n. 2, p. 101-131, 
2015. Disponível em: <http://seer.ufrgs.br/index.php/ppgdir/article/view/54612>. Acesso em: 28 jul. 2017.

SIRVINSKAS, Luis Paulo. Manual de direito ambiental. 15. ed. São Paulo: Saraiva, 2017.

SOUZA, Maria Claudia da Silva Antunes de; PAVAN, Kamilla. Sustentabilidade, meio ambiente e água: uma questão de sobrevivência. Direito e Sustentabilidade II: XXV Encontro Nacional do CONPEDI. Brasília: CONPEDI, 2016, p.319-337. Disponível em:

<https://www.conpedi.org.br/publicacoes/y0ii48h0/dzoq9f77/4aF1HOT08DIXm7CI.pdf>. Acesso em: 26 jul 2017.

WINCKLER, Silvana; PEREIRA, Reginaldo. O novo meio ambiente e o direito ambiental.

Instrumentos de tutela ambiental no direito brasileiro, Chapecó: Argos, 2009. 


\title{
A FUNÇÃO SOCIOAMBIENTAL COMO PRESSUPOSTO PARA O EXERCÍCIO DA PROPRIEDADE URBANA ${ }^{1}$
}

\author{
Karla Regina Peiter ${ }^{2}$
}

\section{INTRODUÇÃO}

O grande crescimento populacional, a ocupação descontrolada em detrimento do meio ambiente e a subutilização ou a utilização inadequada da propriedade tornam cogente a imposição de limites ao exercício do direito de propriedade. Perseguindo neste panorama, observa-se que o próprio conceito de propriedade sofreu transformações na medida em que deixa de lado o caráter egoístico e individualista, vertendo-se em função social e ambiental.

Desta forma, a função socioambiental pode ser vista como pressuposto para o exercício da propriedade, visto que seu cumprimento é de caráter indispensável. Todo proprietário, deve atribuir ao seu bem, uso correspondente ao fim social a que se destina, bem como atentar para a preservação dos recursos ambientais, sob pena de perda da proteção constitucional.

Para tanto, o presente artigo apresenta a evolução conceitual do direito de propriedade, deixando ele de estar apenas condicionado ao interesse individual, tornando-se um direito-dever, objeto de diversas restrições.

A partir da promulgação da Constituição da República Federativa do Brasil de 1988 a ideia de função socioambiental da propriedade foi sobremaneira intensificada e, portanto, a repercussão social e ambiental do seu exercício passou a fazer parte de sua concepção e tutela.

\section{DIREITO DE PROPRIEDADE: EVOLUÇÃO CONCEITUAL}

Desde os primórdios tempos da civilização o direito de propriedade é entendido pelas sociedades como uma instituição de caráter puramente natural. Percebe-se pelo fato de o indivíduo sempre ter visto as suas necessidades fundamentais efetivadas por meio da aquisição de

\footnotetext{
${ }^{1}$ Artigo produzido como requisito parcial para aprovação na disciplina de Política Jurídica: estudos sobre o modo de produção do direito urbanístico e ambiental no Brasil ministrada pelo Professor Doutor Davi do Espírito Santo da Linha de Pesquisa Direito, Desenvolvimento Urbano e Meio Ambiente do Programa de Mestrado em Ciência Jurídica da Universidade do Vale do Itajaí.

${ }^{2}$ Mestranda do Programa de Mestrado em Ciência Jurídica da Universidade do Vale do Itajaí. Professora Universitária.
} 
bens, sejam eles móveis ou imóveis.

Segundo Venosa ${ }^{3}$ "nas sociedades primitivas somente existia o direito a propriedade móvel, como roupas, ferramentas e utensílios, e a terra era pertencente a toda coletividade, todos os membros da gens".

Diante da grande dimensão de terras que se encontrava a dispor da sociedade o que se teve num primeiro momento da história foi a apropriação de terras de forma coletiva, com a simples finalidade de sustento e de sobrevivência. ${ }^{4}$

No mesmo sentido, Fachin ${ }^{5}$ afirma, "parece que a propriedade, nos primórdios da civilização, começou por ser coletiva, transformando-se, porém, paulatinamente em propriedade individual".

Assim, com o desenvolvimento da sociedade humana percebeu-se que a necessidade de acúmulo de riquezas tornou aquilo que se denominava coletivo em privado, aguçando a ideia de liberdade do indivíduo diante da conquista de seus bens. Neste sentido, definiram Farias e Rosenvald ${ }^{6}$ sobre a apropriação de bens:

Inicialmente, era a busca por bens de consumo imediato; com o tempo, o domínio de coisas móveis, até perfazer-se a noção de propriedade, progressivamente complexa e plural. O verbo ter marca indelevelmente o direito subjetivo de propriedade, sendo inerente a qualquer ser humano o anseio pela segurança propiciada pela aquisição de bens.

No direito romano, o instituto da propriedade era revestido de caráter absoluto, intimamente relacionado à família e à religião. O possuidor de determinado solo, não podia ser desalojado, em nenhuma hipótese, seja por deliberação ou por decisão dos governantes. Essa concepção encontrava amparo na Constituição Social, sendo impossível qualquer tipo de alteração ${ }^{7}$.

Já na Idade Média, o que se tem é o predomínio da propriedade rural sobre a urbana. O rei era o único senhor absoluto da terra. Surge aqui como cita Pereira ${ }^{8}$ a "ideia de transferência da terra aos poderosos, com juramento de submissão e vassalagem, em troca de proteção a sua

\footnotetext{
${ }^{3}$ VENOSA, Sílvio de Salvo. Direito Civil: direitos reais. 5. ed. São Paulo: Atlas, 2005. 5v. p. 174.

${ }^{4}$ DINIZ, Maria Helena. Curso de Direito Civil Brasileiro. Direito das Coisas 22. ed., São Paulo: Saraiva, 2007. 4v.

${ }^{5}$ FACHIN, Luiz Edson. A Função Social da Posse e a Propriedade Contemporânea. Porto Alegre: Sergio Antonio Fabris Editor, 1988. p. 14.

${ }^{6}$ FARIAS, C. C; ROSENVALD, N. Direitos Reais. 6. ed. Rio de Janeiro: Lumen Juris, 2009. p. 164.

7 COMPARATO, Fabio Konder. Direitos e Deveres Fundamentais em Matéria de Propriedade. Disponível em: <http://www.cjf.jus.br/revista/numero3/artigo11.htm>. Acesso em: 28 jan., 2017.

${ }^{8}$ PEREIRA, Caio Mario da Silva. Instituições de Direito Civil. 19. ed. Rio de Janeiro: Forense, 2008. 4v. p. 82.
} 
fruição". Nesta época a propriedade não era absoluta, no entanto sofria certas limitações:

Essa forma de propriedade privada das terras existentes na Idade Média sofre algumas limitações. Não se trata da mesma forma que hoje se apresenta. Nessa época a propriedade privada da terra não é plena e absoluta como o foi no direito romano, e sim tem-se a propriedade de uma mesma coisa dividida em vários domínios, isto é, um direito de propriedade que não exclui os outros da relação com a mesma amplitude e que permite a existência de possuidores de títulos de diversos sobre uma mesma coisa. ${ }^{9}$

Predominavam as figuras do senhor feudal e seus vassalos. Em síntese, o senhor feudal concedia aos seus vassalos porções de terra, as quais desenvolviam uma administração e prestação de serviço ao senhorio. A propriedade neste período é puramente vista para a economia de subsistência. Segundo Bobbio $^{10}$, "nesse mesmo sistema o imperador possuía a propriedade absoluta sobre todas as coisas, mas eram os proprietários das terras que acabavam exercendo os poderes políticos sobre os camponeses que trabalhavam em suas terras".

Um grande acontecimento que contribuiu amplamente para o conceito de propriedade foi a Revolução Francesa, que nas palavras de Pereira "11 "pretendeu democratizar a propriedade, aboliu privilégios, cancelou direitos perpétuos. Desprezando a coisa móvel, concentrou sua atenção na propriedade imobiliária".

É certo que o termo propriedade em vigor no ordenamento jurídico, não manteve teor idêntico ao de suas raízes históricas. Hoje, como definem Farias e Rosenvald ${ }^{12}$, a propriedade é concebida como:

Um direito complexo, que se instrumentaliza pelo domínio, possibilitando ao seu titular o exercício de um feixe de atributos consubstanciados nas faculdades de usar, gozar, dispor e reivindicar a coisa que the serve de objeto [...] uma relação jurídica complexa formada entre o titular do bem e a coletividade de pessoas.

O Código Civil de 2002 não estabelece um conceito exato para o instituto, limitando-se apenas a elencar os poderes concernentes àquele que se denomina proprietário, como consta no caput do art. $1.228^{13}$.

Desta forma, pode-se afirmar que são elementos constitutivos da propriedade, o direito de usar, gozar, dispor e reaver a coisa. O jus utendi consiste na faculdade atribuída ao proprietário de

\footnotetext{
${ }^{9}$ WOLKMER, Antonio Carlos. Fundamentos de História do Direito. 2. ed. Belo Horizonte: Del Rey, 2001. p. 166.

${ }^{10}$ BOBBIO, Norberto; MATTEUCCI, Nicola; PASQUINO, Gianfranco. Dicionário de Política. Tradução Carmen C. Varrialle. 4. ed. Brasília: Unb, 1992. 2v. p. 1033.

${ }^{11}$ PEREIRA, Caio Mario da Silva. Instituições de Direito Civil. 19. ed. Rio de Janeiro: Forense, 2008. 4v. p. 83.

${ }^{12}$ FARIAS, C. C; ROSENVALD, N. Direitos Reais. 6. ed. Rio de Janeiro: Lumen Juris, 2009. p. 168.

${ }^{13}$ Art. 1.228. O proprietário tem a faculdade de usar, gozar e dispor da coisa, e o direito de reavê-la do poder de quem quer que injustamente a possua ou detenha.
} 
"servir-se da coisa e de utilizá-la da maneira que entender mais conveniente, sem, no entanto alterar-Ihe a substância"14. Vale ressaltar que o uso do bem não pode acontecer de maneira arbitrária ou ilimitada, vez que o direito de propriedade, conforme preceitua o $\S 1$ o do art. 1.228 do Código Civil, é orientado pelas finalidades econômicas e sociais, respeitando-se, ainda, outras leis especiais ${ }^{15}$.

Por jus fruendi entende-se a percepção dos frutos naturais e civis, bem como seu aproveitamento econômico. Nas palavras de Pereira ${ }^{16}$ "pode-se igualmente pressupor no gozo a utilização dos produtos da coisa, além dos frutos".

A esse respeito complementam Farias e Rosenvald ${ }^{17}$ :

Quando o proprietário colhe frutos naturais (percebidos diretamente da natureza) está exercitando somente a faculdade de usar. Mas estará verdadeiramente fruindo ao obter os frutos industriais (resultantes da transformação do homem sobre a natureza) e os frutos civis (rendas oriundas da utilização da coisa por outrem).

Ao jus disponendi, atribui-se a ideia de poder de transferência, de alienação a outrem "a qualquer título", faculdade esta que melhor caracteriza o proprietário, pois o uso e o gozo podem ser exercidos por um simples possuidor ou detentor, já a disposição somente será exercida pelo proprietário. Ainda sobre este elemento, vale ressaltar, que este pode ser limitado por ato de vontade e por lei, como nas cláusulas de inalienabilidade do bem.

O quarto e último elemento é o jus reivindicatio, que consiste no direito de reaver a coisa e de reivindicá-la das mãos de quem injustamente a possua ou a detenha. Essa característica envolve a proteção ao direito de propriedade, que se satisfaz pela ação reivindicatória.

Por derradeiro, conclui-se que nem todas as definições dadas ao termo, cunhadas no ao logo da história, foram mantidas. No entanto, o direito de propriedade sempre esteve de alguma forma diretamente ligado ao direito à liberdade, consubstanciado na ideia de que aquele que é denominado proprietário da coisa possui o seu direito pleno de usar, gozar e dispor do bem. Sendo assim, considera-se a propriedade como o instituto mais completo e de maior expressão, a matriz dos direitos reais.

\footnotetext{
${ }^{14}$ GONÇALVES, Carlos Roberto. Direito Civil Brasileiro. 3. ed. São Paulo: Saraiva, 2008. 5v. p. 109.

${ }^{15}$ Art. 1.228, §1ㅇ. O direito de propriedade deve ser exercido em consonância com as suas finalidades econômicas e sociais e de modo que sejam preservados, de conformidade com o estabelecido em lei especial, a flora, a fauna, as belezas naturais, o equilíbrio ecológico e o patrimônio histórico e artístico, bem como evitada a poluição do ar e das águas.

${ }^{16}$ PEREIRA, Caio Mario da Silva. Instituições de Direito Civil. 19. ed. Rio de Janeiro: Forense, 2008. 4v. p. 94.

${ }^{17}$ FARIAS, C. C; ROSENVALD, N. Direitos Reais. 6. ed. Rio de Janeiro: Lumen Juris, 2009. p. 188.
} 


\section{RESTRIÇÕES AO DIREITO DE PROPRIEDADE}

Importa elucidar que o direito de propriedade é restringido pela ordem jurídica, posto que o seu exercício deve ser desempenhado em consonância com o interesse coletivo, com as normas ambientais e com os direitos de vizinhança.

Como elucidado acima, o direito de propriedade não mais possui caráter absoluto, visto que se encontra sujeito a diversas limitações decorrentes tanto do interesse privado como do interesse público, que impedem o proprietário de utilizá-la de forma arbitrária e ilimitada.

Essas restrições podem decorrer de ato voluntário, caso em que emana da vontade das partes, como a título ilustrativo, a presença de cláusulas de inalienabilidade, impenhorabilidade previstas em testamentos, bem como decorrentes de ato legal, que são as que "estão contidas em leis especiais que tem por objetivo proteger não só o interesse público, social ou coletivo, bem como o interesse privado ou particular considerado em função da necessidade social” ${ }^{18}$.

As restrições de caráter voluntário, para que produzam efeitos necessitam preencher determinados requisitos. Primeiramente deve emanar de testamento ou doação, visto que não "não é lícita a imposição das cláusulas em contrato de compra e venda, permuta, ou outra modalidade aquisitiva onerosa"19. E por derradeiro, deve constar no registro público, posto que determinadas restrições atingem diretamente direitos de terceiros.

As decorrentes de ato legal estão presentes em inúmeros dispositivos que restringem o exercício da propriedade, dentre os mais importantes, podem ser citadas as restrições de natureza constitucional, de natureza administrativa e por fim os de natureza civil.

Numa breve abordagem, as restrições de natureza constitucional preveem o cumprimento da função social no exercício do direito de propriedade (art. 5o, XXII, CF), a desapropriação por necessidade ou utilidade pública e por interesse social mediante prévia e justa indenização em dinheiro (art. 5ㅇ, XXIV, CF). Na mesma linha, também é prevista a utilização da propriedade particular em casos de perigo eminente (art. 5ํ, XXV, CF). Ainda, no caput do art. 184 da CRFB/88, verifica-se a desapropriação de imóvel rural que não esteja cumprindo com a função social, para fim de reforma agrária.

\footnotetext{
${ }^{18}$ DINIZ, Maria Helena. Curso de Direito Civil Brasileiro. Direito das Coisas 22. ed., São Paulo: Saraiva, 2007. 4v. p. 253.

${ }^{19}$ PEREIRA, Caio Mario da Silva. Instituições de Direito Civil. 19. ed. Rio de Janeiro: Forense, 2008. 4v. p. 109.
} 
No que se refere às restrições de natureza administrativa, por serem inúmeras, pode-se de início destacar as que protegem o patrimônio histórico e a cultura, como previsto no Decreto Lei n. 25 , de 30-11-1937 e no art. 216 , $\$ 10$ da CRFB/88. Acrescentam-se as limitações urbanísticas, como o direito de construção e, neste sentido, bem mencionou Monteiro ao dispor que "a exigência de licença prévia de edificação evidencia a ingerência do Estado no direito de propriedade, conformando-o e harmonizando-o com os da coletividade" ${ }^{20}$.

O Estatuto da Cidade (Lei 10.257/2001) também estabelece normas que regulam o uso da propriedade urbana em atendimento ao bem estar coletivo. A esse respeito, Loureiro ${ }^{21}$, comenta:

O Estatuto da Cidade trouxe importantes sanções ao mau uso da propriedade imobiliária urbana, por exemplo, a possibilidade de cobrança progressiva do Imposto Predial Territorial Urbano (IPTU), a desapropriação com pagamento em títulos da dívida pública e a usucapião coletiva em benefício de um considerável número de pessoas de baixa renda que exerçam a posse contínua, ininterrupta e sem oposição de imóvel urbano com área superior a 250 metros quadrados por mais de cinco anos.

Por fim, têm-se as limitações de natureza civil, dentre as quais podem ser destacadas as determinadas pelo direito de vizinhança. Como esclarece Gonçalves ${ }^{22}$ :

As regras que constituem o direito de vizinhança destinam-se a evitar conflitos de interesses entre proprietários de prédios contíguos. Tem sempre em mira a necessidade de conciliar o exercício do direito de propriedade com as relações de vizinhança, uma vez que sempre é possível o advento de conflitos entre os confinantes.

Neste sentido, tem-se o disposto no o art. 1277 do Código Civil, “o proprietário ou possuidor de um prédio tem o direito de fazer cessar as interferências prejudiciais à segurança, ao sossego e à saúde dos que o habitam, provocadas pela utilização de propriedade vizinha".

Desta forma, as limitações impostas entre vizinhos constituem basicamente os deveres inerentes à propriedade, impostos com a finalidade de se obter uma boa convivência social.

Por fim, salienta-se que as limitações e restrições impostas ao exercício do direito de propriedade, devem ser percebidas como aquelas que atingem seus elementos fundamentais e que tem por escopo a proteção jurídica do bem, que visa o interesse da coletividade.

\footnotetext{
${ }^{20}$ MONTEIRO, Washington de Barros. Curso de Direito Civil: Direito das Coisas. 37 ed. São Paulo: Saraiva, 2003. p. 93.

${ }^{21}$ LOUREIRO, Luiz Guilherme. Curso Completo de Direito Civil. 1. ed. São Paulo: Método, 2007. p. 799.

${ }^{22}$ GONÇALVES, Carlos Roberto. Direito Civil Brasileiro. 3. ed. São Paulo: Saraiva, 2008. 5v. p. 325.
} 


\section{A FUNÇÃO SOCIOAMBIENTAL COMO PRESSUPOSTO PARA O EXERCíCIO DA PROPRIEDADE URBANA E SUA PREVISÃO NA CONSTITUIÇÃO DA REPÚBLICA DE 1988}

Para um melhor entendimento da importância do instituto da propriedade, faz-se necessário estudar os direitos e garantias constitucionais que o permeiam. Assim, serão abordados os princípios e direitos fundamentais concernentes à pesquisa, com especial enfoque ao direito de propriedade e ao princípio da função socioambiental.

Para isso, primeiramente devem-se distinguir direitos e garantias fundamentais. De acordo com Lenza ${ }^{23}$, "os direitos são bens e vantagens prescritos na norma constitucional, enquanto as garantias são os instrumentos através dos quais se assegura o exercício dos aludidos direitos (preventivamente) ou prontamente os repara, caso violados".

Num segundo momento, importante ressaltar que a República Federativa do Brasil rege-se por alguns fundamentos e princípios, que se encontram previstos na CRFB/88, em seu art. 1으, dos quais se destaca o princípio fundamental da dignidade da pessoa humana no inciso III deste dispositivo.

A esse respeito, Sarlet ${ }^{24}$ destaca que:

[...] todos os direitos fundamentais encontram sua vertente no princípio da dignidade da pessoa humana. Basta um breve olhar sobre o nosso extenso catálogo dos direitos fundamentais para que tenhamos dúvidas fundadas a respeito da alegação de que todas as posições jurídicas ali reconhecidas possuem necessariamente um conteúdo diretamente fundado no valor maior da dignidade da pessoa humana.

Ainda, Farias e Rosenvald ${ }^{25}$ reafirmam que:

A dignidade da pessoa humana assume um papel de defesa da integridade humana em dois planos: a) tutelando as situações jurídicas da personalidade de modo a preservar estes bens jurídicos intrínsecos e essenciais; b) situando a missão de parte do patrimônio, justamente na preservação das condições materiais mínimas de humanidade, o chamado patrimônio mínimo.

Desta forma, observa-se que a dignidade da pessoa humana atua como elemento fundamental que proporciona uma exigência mínima a ser observada em qualquer produção do direito. Deste princípio se retiram, ainda, a essência de direitos e de diversos outros princípios que se aplicam tanto na esfera processual como na esfera material, dentre os quais pode se encontrar o direito fundamental a propriedade, a moradia e o princípio da função social.

\footnotetext{
${ }^{23}$ LENZA, Pedro. Direito Constitucional: esquematizado. 12. ed. São Paulo: Saraiva, 2008. p. 589.

${ }^{24}$ SARLET, Ingo Wolfgang. A Eficácia dos Direitos Fundamentais. 3. ed. Porto Alegre: Livraria do Advogado, 2003. p. 102.

${ }^{25}$ FARIAS, C. C; ROSENVALD, N. Direitos Reais. 6. ed. Rio de Janeiro: Lumen Juris, 2009. p. 182.
} 
Como corolário da dignidade humana, encontra-se o direito fundamental de acesso à moradia previsto no art. 60 da CRFB/88. Disciplinado como direito social fundamental, possui estrita vinculação com direito de propriedade, posto que é direito de todos ter um local digno para estabelecer sua moradia.

O direito de propriedade encontra amparo já no caput do art. 5 da CRFB/88, ao lado de outros direitos individuais, como à vida, à liberdade e à igualdade. Com o intuito de assegurar seu caráter, foi disciplinado em seu inciso XXII, in verbis: "é garantido o direito de propriedade". Ainda, sobre a propriedade, tem-se o disposto no art. 170 , inciso II, que elenca a propriedade privada como um dos os princípios fundamentais da ordem econômica do País.

É importante ressaltar que, num primeiro momento da história o direito de propriedade foi adotado como um direito absoluto da pessoa, no qual aquele que era proprietário do bem poderia usar, gozar, dispor da coisa, bem como reivindicá-la de quem indevidamente a possuísse.

Ocorre que, como bem mencionado por Alexandrino ${ }^{26}$, "não é mais cabível essa concepção da propriedade como um direito absoluto. Deveras, nossa Constituição consagra o Brasil como um Estado Democrático Social de Direito, o que implica afirmar que também a propriedade deve atender a uma função social”.

Ao mesmo tempo em que a $\mathrm{CRFB} / 88$ assegura os direitos do proprietário, impõe a estes certos deveres, como o uso adequado do bem. Neste sentido, tem-se que a propriedade é um direito intrínseco à pessoa e que, no entanto, se encontra condicionado a certas exigências como o cumprimento da função social, motivo pelo qual fica completamente afastada uma concepção individualista deste direito.

A CRFB/88 ao estatuir que à propriedade cabe o cumprimento da função social, deu a norma caráter de eficácia contida, pois o direito de propriedade pode sofrer limitações, como exposto no inciso XXIV do art. 50 da CRFB/88, sejam elas, por meio de "necessidade ou utilidade pública”, "interesse social” ou "perigo público iminente"27.

Neste sentido, sustenta Venosa ${ }^{28}$ :

É inevitável que no exercício do direito de propriedade, por mais amplo que seja seu âmbito, há restrições e limitações fundadas em interesses de ordem pública e de ordem privada. A coexistência

\footnotetext{
${ }^{26}$ ALEXANDRINO, Vicente Paulo Marcelo. Direito Constitucional Descomplicado. 4 ed. Método: São Paulo, 2009. p. 133.

${ }^{27}$ SILVA, José Afonso da. Curso de Direito Constitucional Positivo. 31 ed. São Paulo: Atlas, 2003. 5v.

${ }^{28}$ VENOSA, Sílvio de Salvo. Direito Civil: direitos reais. 3. ed. São Paulo: Atlas, 2003. 5v. p. 329.
} 
de vários prédios próximos, a vizinhança, a coletividade, a disciplina urbana traduzem parte dessas restrições.

Muito embora a CRFB/88 discipline o direito de propriedade como um direito fundamental da pessoa humana, este se encontra veiculado em norma constitucional de eficácia contida, no momento em que o legislador impõe certas limitações ao seu uso.

Uma dessas limitações é o cumprimento do princípio da função social, disciplinado no art. 5o, inciso XXIII e art. 170, inciso III , ambos da CRFB/88. Nas palavras de Farias e Rosenvald ${ }^{29}$ a função social é:

Princípio básico que incide no próprio conteúdo do direito de propriedade, somando-se às quatro faculdades conhecidas (usar, gozar, dispor e reivindicar) [...] converte-se em um quinto elemento da propriedade. Enquanto os quatro elementos estruturais são estáticos, o elemento funcional da propriedade é dinâmico e assume um decisivo papel de controle sobre os demais.

É também imprescindível a aproximação dos conteúdos da função socioambiental da propriedade e do dever fundamental de proteção ambiental, cuja concepção se torna possível dentro do novo modelo de Estado Socioambiental de Direito, superando a concepção absolutista do direito de propriedade ${ }^{30}$.

Ainda que de forma genérica, o § 1으 do Art. 1228 do Código Civil, estabelece diretrizes para o cumprimento da função social, quando disciplina que:

O direito de propriedade deve ser exercido em consonância com as suas finalidades econômicas e sociais e de modo que sejam preservados, de conformidade com o estabelecido em lei especial, a flora, a fauna, as belezas naturais, o equilíbrio ecológico e o patrimônio histórico e artístico, bem como evitada a poluição do ar e das águas.

Este dispositivo reafirma o contido na $\mathrm{CRFB} / 88$, uma vez que dispõe de um rol que afere à função social, e por outro lado, respalda as leis especiais que também disciplinam sobre o assunto.

Ainda sobre a função social, é válido lembrar que a CRFB/88, em seu art. 182, § 20 assim dispôs: "a propriedade urbana cumpre sua função social quando atende às exigências fundamentais de ordenação da cidade expressas no plano diretor".

Ademais, denota-se do artigo $2 \stackrel{\circ}{\circ}$, inciso I do Estatuto da Cidade que:

A política urbana tem por objetivo ordenar o pleno desenvolvimento das funções sociais da cidade e da propriedade urbana, mediante as seguintes diretrizes gerais:

\footnotetext{
${ }^{29}$ FARIAS, C. C; ROSENVALD, N. Direitos Reais. 6. ed. Rio de Janeiro: Lumen Juris, 2009. p. 207.

${ }^{30}$ FENSTERSEIFER, Tiago. Direitos Fundamentais e Proteção do Ambiente: a dimensão ecológica da dignidade humana no marco jurídico constitucional do estado socioambiental de direito. Porto Alegre: Livraria do Advogado Editora, 2008. p. 217.
} 
I - a garantia do direito as cidades sustentáveis, entendido como o direito a terra urbana, à moradia, ao saneamento ambiental, à infraestrutura urbana, ao transporte e aos serviços públicos, ao trabalho e ao lazer, para as presentes e futuras gerações.

Sobre o Estatuto da Cidade, Di Pietro ${ }^{31}$ elucida: "o princípio da função social da cidade impõe um dever ao poder público e cria para os cidadãos direito de natureza coletiva".

Desta feita, observa-se que, o princípio da função social possui a finalidade de reduzir o uso abusivo e inadequado do bem, bem como estabelece diretrizes para uma utilização correspondente à utilidade comum.

É importante lembrar, como afirma Venosa ${ }^{32}$, que:

Utilizar a propriedade adequadamente possui no mundo contemporâneo amplo espectro que desborda para aspectos como a proteção da fauna e da flora e para sublimação do patrimônio artístico e histórico. Há que se preservar a natureza e todo o seu equilíbrio com desenvolvimento sustentável, para que não coloquemos em risco as futuras gerações deste planeta.

Neste mesmo sentido, comenta Loureiro ${ }^{33}$ : "A propriedade deve ser utilizada como instrumento de produção e circulação de riquezas, para moradia ou produção econômica, não podendo servir de instrumento para a destruição de bens e valores fundamentais a toda a sociedade, como é o caso do meio ambiente sadio e equilibrado."

Fensterseifer ${ }^{34}$ acentua categoricamente que "o não-cumprimento pelo proprietário da função socioambiental do bem caracteriza forma extintiva da titularidade", ou seja, a função social somada à função social determinam o fundamento e o conteúdo da propriedade.

De tal modo, a função socioambiental pode ser compreendida como pressuposto para a propriedade, visto que tal instituto na contemporaneidade deve estar aliado ao bem-estar social e à preservação do meio ambiente, conforme demarcado no art. 225, caput, da CFRB/88

Para Comparato ${ }^{35}$, "quem não cumpre a função social da propriedade perde as garantias, judiciais e extrajudiciais, de proteção da posse, inerentes à propriedade, como o desforço privado imediato (Código Civil, art. 502) e as ações possessórias".

\footnotetext{
${ }^{31}$ DI PIETRO, Maria Sylvia Zanella. Direito Administrativo. 17. ed. São Paulo: Atlas, 2004.

${ }^{32}$ VENOSA, Sílvio de Salvo. Direito Civil: direitos reais. 5. ed. São Paulo: Atlas, 2005. 5v. p. 181.

${ }^{33}$ LOUREIRO, Luiz Guilherme. Curso Completo de Direito Civil. 1. ed. São Paulo: Método, 2007. p. 798.

${ }^{34}$ FENSTERSEIFER, Tiago. Direitos Fundamentais e Proteção do Ambiente: a dimensão ecológica da dignidade humana no marco jurídico constitucional do estado socioambiental de direito. Porto Alegre: Livraria do Advogado Editora, 2008. p. 215

35 COMPARATO, Fabio Konder. Direitos e Deveres Fundamentais em Matéria de Propriedade. Disponível em: <http://www.cjf.jus.br/revista/numero3/artigo11.htm>. Acesso em: 28 jan., 2017.
} 
Como bem mencionado por Melo ${ }^{36}$ "a função social da propriedade tornou-se exigência da vida em sociedade [...], pois é fundamental que se exija do proprietário a observância das potencialidades econômicas e sociais dos bens que deverão ser revertidos em benefício da sociedade".

Ante o exposto, inserida na categoria de princípio constitucional, que exprime valores essenciais e superiores de um Estado, tem-se que a função socioambiental não se apresenta como valor colidente com o exercício do direito de propriedade, ao contrário, trata-se de um elemento condicionante dos seus poderes constitutivos (uso, fruição, disposição e reivindicação).

\section{CONSIDERAÇÕES FINAIS}

No deslinde desta pesquisa observou-se que a clássica concepção do Direito de Propriedade cedeu espaço para um entendimento contemporâneo, alinhado às atuais necessidades e exigências da sociedade que requer um desenvolvimento urbano sustentável.

Convertida em um poder-dever, conclui-se que a Propriedade não pode ser exercida de maneira absoluta e, sim, deve ser orientada pela sua função socioambiental, adequando-se às demandas sociais, econômicas e ambientais da coletividade.

A reflexão ora proposta objetivou demonstrar a necessidade de repensar a produção do direito, especialmente no que tange ao exercício da propriedade privada sem que se comprometa a sobrevida das presentes e futuras gerações, compatibilizando o instituto com a preservação do meio ambiente.

\section{REFERÊNCIA DAS FONTES CITADAS}

ALEXANDRINO, Vicente Paulo Marcelo. Direito Constitucional Descomplicado. 4. ed. Método: São Paulo, 2009.

BOBBIO, Norberto; MATTEUCCI, Nicola; PASQUINO, Gianfranco. Dicionário de Política. Tradução Carmen C. Varrialle. 4. ed. Brasília: Unb, 1992. 2v.

COMPARATO, Fabio Konder. Direitos e Deveres Fundamentais em Matéria de Propriedade.

Disponível em: <http://www.cjf.jus.br/revista/numero3/artigo11.htm>. Acesso em: 28 jan., 2017.

\footnotetext{
${ }^{36}$ MELO, Marco Aurélio Bezerra de. Direito das Coisas. 2. ed. Rio de Janeiro: Lumen Juris, 2008. p. 89.
} 
DINIZ, Maria Helena. Curso de Direito Civil Brasileiro. Direito das Coisas 22. ed., São Paulo: Saraiva, 2007. 4v.

DI PIETRO, Maria Sylvia Zanella. Direito Administrativo. 17. ed. São Paulo: Atlas, 2004.

FACHIN, Luiz Edson. A Função Social da Posse e a Propriedade Contemporânea. 1. ed. Porto Alegre: Sergio Antonio Fabris Editor, 1988.

FARIAS, C. C; ROSENVALD, N. Direitos Reais. 6. ed. Rio de Janeiro: Lumen Juris, 2009.

FENSTERSEIFER, Tiago. Direitos fundamentais e proteção do ambiente: a dimensão ecológica da dignidade humana no marco jurídico constitucional do estado socioambiental de direito. Porto Alegre: Livraria do Advogado Editora, 2008.

GONÇALVES, Carlos Roberto. Direito Civil Brasileiro. 3. ed. São Paulo: Saraiva, 2008. 5v.

LENZA, Pedro. Direito Constitucional: esquematizado. 12. ed. São Paulo: Saraiva, 2008.

LOUREIRO, Luiz Guilherme. Curso Completo de Direito Civil. 1. ed. São Paulo: Método, 2007.

MELO, Marco Aurélio Bezerra de. Direito das Coisas. 2. ed. Rio de Janeiro: Lumen Juris, 2008.

MONTEIRO, Washington de Barros. Curso de Direito Civil: Direito das Coisas. 37. ed. São Paulo: Saraiva, 2003.

PEREIRA, Caio Mario da Silva. Instituições de Direito Civil. 19. ed. Rio de Janeiro: Forense, 2008. $4 \mathrm{v}$.

SARLET, Ingo Wolfgang. A Eficácia dos Direitos Fundamentais. 3. ed. Porto Alegre: Livraria do Advogado, 2003.

SILVA, José Afonso da. Curso de Direito Constitucional Positivo. 31. ed. São Paulo: Malheiros, 2007.

VENOSA, Sílvio de Salvo. Direito civil: direitos reais. 3. ed. São Paulo: Atlas, 2003. 5v.

. Direito Civil: direitos reais. 5. ed. São Paulo: Atlas, 2005. 5v.

WOLKMER, Antonio Carlos. Fundamentos de História do Direito. 2. ed. Belo Horizonte: Del Rey, 2001. 


\title{
MEIO AMBIENTE PROTEGIDO E A PROPRIEDADE - A CONFLITUOSA RELAÇÃO ENTRE DIREITOS FUNDAMENTAIS E O LEADING CASE PORTUGUÊS “QUINTA DO \\ TAIPAL"
}

\author{
Cristiano Baccin da Silva ${ }^{1}$
}

\section{INTRODUÇÃO}

O assunto - Meio Ambiente versus Propriedade, polêmico pela importância dos bens jurídicos envolvidos e complexo porque a solução que se apresenta está longe de ser justa, satisfatória e pacífica.

O Poder Judiciário vem, ao longo dos anos, sendo provocado a definir, nos inúmeros casos levados à sua apreciação, se no choque entre esses direitos fundamentais assegurados constitucionalmente, prevalece a propriedade ou a proteção ao meio ambiente.

O que se desenhou, até o momento, é que tais manifestações judiciais não se mostraram suficientes a bem atender (e responder) aos interesses de cada uma das partes envolvidas, existindo, ainda, grande margem de discussão e interpretações, para, a cabo e satisfatoriamente dar os contornos nítidos nesse intrincado e tumultuoso relacionamento repleto de diferenças conceituais e valores.

É inegável, que os efeitos da exploração desenfreada do Meio Ambiente já sejam sentidos pela raça humana, resultado do processo de globalização mundial, do aumento da concentração humana nos grandes centros urbanos e do avançado da fronteira agrícola sobre as reservas naturais, diante da necessidade do aumento da produção de bens de consumo e alimentos.

Preocupados com o deslinde catastrófico dessa exploração e degradação do Meio Ambiente e das reservas naturais, sem controle, políticas públicas ou consciência ecológica, os países passaram a dar o devido tratamento e importância à temática ambiental, estabelecendo,

\footnotetext{
${ }^{1}$ Mestrando em Ciências Jurídicas na Universidade do Vale do Itajaí - UNIVALI. Pós-graduado em MBA - Gestão Empresarial, pela Pós-Graduação Internacional - Devry Brasil em parceria com a Harvard Business Publishing. Especialista em Direito do Trabalho pela Universidade Cândido Mendes em parceria com o Instituto Prominas. Especialista em Direito Penal e Processo Penal pela EMAB - Escola de Magistrados da Bahia, em parceria com a Faculdade Baiana de Direito. Especialista em Processo Civil pelo Instituto de Excelência Ltda. (JusPODIVM), filiado a Rede LFG. Graduado em Direito pela Universidade de Fortaleza - UNIFOR, Ceará. Advogado. Sócio-Diretor da Reichemback Advogados Associados, com sede em Itajaí/SC. Contatos (71) 991376604 | (47) 999844037 | (47) 21253665; baccin@reichemback.adv.br | cristianobaccins@gmail.com
} 
em suas respectivas constituições, normas de preservação, sustentabilidade e proteção, vez que cumpre ao Estado e à própria coletividade a obrigação de defendê-lo e preservá-lo, como forma de garantir a manutenção da raça humana, para as presentes e futuras gerações.

Não diferentemente dos demais países, o Brasil, em sua Constituição Federal promulgada em 1988, deu ao Meio Ambiente ecologicamente equilibrado, o status de norma constitucional, reconhecendo-o como um direito fundamental assim encampado no artigo 225, onde, em seu caput, estabelece que "todos têm direito ao meio ambiente ecologicamente equilibrado, bem de uso comum do povo e essencial à sadia qualidade de vida, impondo-se ao poder público e à coletividade o dever de defendê-lo e preservá-lo para as presentes e futuras gerações." ${ }^{2}$.

Doutra via, neste mesmo patamar constitucional está o direito de propriedade, reconhecido como um direito humano, ao passo "que há uma função individual da propriedade que consiste na garantia da autonomia privada do ser humano e no desenvolvimento de sua personalidade, pois os direitos reais são outorgados a uma pessoa para a realização pessoal da posição de vantagem que exerce sobre a coisa." ${ }^{3}$.

Ocorre, que o recente panorama mostra

uma tendência atual de hostilidade franca entre aqueles que, de um lado defendem o direito fundamental à propriedade na sua feição romana, com as concepções presentes ainda nos dias de hoje, e de outros, que, por sua vez, ungidos por uma ideologia radical ambiental preconizam os esforços na busca de um mundo livre de qualquer tipo de poluição advinda daquela que o direito moderno conhece como propriedade empresarial ${ }^{4}$.

Por isto, a ocorrência de colisão de direitos fundamentais explícitos na Constituição Federal, envolvendo princípios que são "fundamentais" na composição e validação do Estado democrático de Direito, é uma realidade.

Diante deste quadro de conflito, no caso concreto, qual seria a melhor solução? Neste sentido, cinge-se em sopesar esses princípios constitucionais, de qual deles deve prevalecer em face do caso concreto, mormente o direito ao meio ambiente ecologicamente equilibrado e o direito de propriedade.

${ }^{2}$ BRASIL. Constituição (1988) Constituição da República Federativa do Brasil. Brasília, 1988. Disponível em <http://www.planalto.gov.br/ccivil_03/constituicao/constituicaocompilado.htm>. Acesso em 25 dez. 2016.

3 FARIAS, Cristiano Chaves de; ROSENVALD, Nelson. Direitos Reais. 6a. ed. São Paulo: Lumen Juris, 2010, p. 178.

4 GOULART, Leandro Henrique; FERNANDES, Josiane Livia. Direito à propriedade e ao meio ambiente ecologicamente equilibrado: a colisão de direitos fundamentais. Veredas do Direito: Direito Ambiental e Desenvolvimento Sustentável, v. 9, n. 17, p. 133, 2012. Disponível em: http://www.domhelder.edu.br/revista/index.php/veredas/article/download/200/212.> Acesso em: 02 dez. 2016. 
Contribuindo na demonstração do problema, busca-se no Direito Português, um caso emblemático - o leading case "Quinta do Taipal" -, onde, uma questão envolvendo, de um lado, o direito à preservação e proteção de um meio ambiente compreendido como um habitat natural, e do outro, o direito dos proprietários dessa área (rural) em dar a ela o devido aproveitamento econômico, teve um desfecho judicial que criou um importante precedente para as demais questões envolvendo bens de mesma natureza e importância, cuja dimensão e amplitude se deu, também, pelas brilhantes contribuições do renomado constitucionalista português, José Joaquim Gomes Canotilho, valendo-se, para tanto, do método indutivo e da técnica de pesquisa bibliográfica.

\section{A COLISÃO ENTRE DIREITOS FUNDAMENTAIS: MEIO AMBIENTE ECOLOGICAMENTE EQUILIBRADO E A PROPRIEDADE PRIVADA}

No entendimento de Antônio Herman Benjamim, "direitos fundamentais são aqueles que, reconhecidos na Constituição ou em tratados internacionais, atribuem a pessoas ou a grupos uma garantia subjetiva ou pessoal" ${ }^{5}$.

O direito ao Meio Ambiente como direito fundamental foi reconhecido pelo Supremo Tribunal Federal - STF, no julgamento do MS 22.164/DF, de relatoria do ministro Celso de Melo, cujo trecho se transcreve abaixo:

[....] A questão do direito ao meio ambiente ecologicamente equilibrado - direito de terceira geração - princípio da solidariedade. - o direito a integridade do meio ambiente - típico direito de terceira geração - constitui prerrogativa jurídica de titularidade coletiva, refletindo, dentro do processo de afirmação dos direitos humanos, a expressão significativa de um poder atribuído, não ao indivíduo identificado em sua singularidade, mas, num sentido verdadeiramente mais abrangente, a própria coletividade social. Enquanto os direitos de primeira geração (direitos civis e políticos) - que compreendem as liberdades clássicas, negativas ou formais - realçam o princípio da liberdade e os direitos de segunda geração (direitos econômicos, sociais e culturais) - que se identifica com as liberdades positivas, reais ou concretas - acentuam o princípio da igualdade, os direitos de terceira geração, que materializam poderes de titularidade coletiva atribuídos genericamente a todas as formações sociais, consagram o princípio da solidariedade e constituem um momento importante no processo de desenvolvimento, expansão e reconhecimento dos direitos humanos, caracterizados, enquanto valores fundamentais indisponíveis, pela nota de uma essencial inexauribilidade ${ }^{6}$.

${ }^{5}$ BENJAMIM, Herman Antônio. Constitucionalização do ambiente e ecologização da constituição brasileira. In: CANOTILHO, J. Joaquim Gomes, LEITE; José Rubens Morato (Orgs). Direito Constitucional brasileiro. São Paulo. Saraiva, 2007, p. 96.

6 BRASIL. Supremo Tribunal Federal. MS 22164, Relator(a): Min. CELSO DE MELLO, Tribunal Pleno, julgado em 30/10/1995, DJ 17http://redir.stf.jus.br/paginadorpub/paginador.jsp?docTP=AC\&doclD=85691>. Acesso em: 06 dez. 2016. 
Segundo Édis Milaré7, "[...] o meio ambiente ascendeu ao posto de valor supremo das sociedades contemporâneas, passando a compor o quadro de direitos fundamentais ditos de terceira geração ou dimensão incorporados aos textos constitucionais dos Estados Democráticos de Direito."

Portanto, constitui direito fundamental da pessoa humana, com expressão do direito à vida, à saúde dos seres humanos e à qualidade de vida ${ }^{8}$.

Pertinente ao direito de propriedade, a Constituição Federal de 1988, a despeito de reconhecê-lo como um legítimo direito fundamental, estabeleceu uma condicionante para o seu pleno exercício: deve necessariamente estar vinculado ao bem-estar social, atendendo com isto, a sua função social.

Tal condicionante está contemplada no artigo 182, §2으, da Carta Magna, no qual estabelece que "a propriedade urbana cumpre sua função social quando atende às exigências fundamentais de ordenação da cidade expressas no plano diretor" ${ }^{\prime 9}$.

O Código Civil brasileiro de 2002, em sintonia com a Lei Maior, trouxe expressa referência à função ambiental da propriedade, dispondo em seu artigo 1.228, §1ํ, o seguinte:

\begin{abstract}
O direito de propriedade deve ser exercido em consonância com as suas finalidades econômicas e sociais e de modo que sejam preservados, desconformidade com o estabelecido em especial, a flora, a fauna, as belezas naturais, o equilíbrio ecológico e o patrimônio histórico e artístico, bem como evitada a poluição do ar das águas ${ }^{10}$.
\end{abstract}

Novamente, Milaré entende "que a propriedade, sem deixar de ser privada, se socializou, com isso significando que deve oferecer à coletividade maior utilidade, sob a concepção de que o social orienta o individual” ${ }^{11}$.

Antônio Herman Benjamim, citado por Mary Lúcia Andrade Correia, considera que a Lei Maior, a despeito de reconhecer o direito de propriedade, impôs-lhe "limites constitucionais

\footnotetext{
7 MILARÉ, Édis. Direito do ambiente: doutrina, jurisprudência, glossário. 8. ed. São Paulo. Editora Revista dos Tribunais, 2013, p. 257.

${ }^{8}$ CORREIA, Mary Lúcia Andrade. Colisão dos direitos fundamentais: o direito ao meio ambiente ecologicamente equilibrado e o direito de propriedade à luz da hermenêutica constitucional. Disponível em: http://www.publicadireito.com.br/artigos/?cod=a85dfcdc20a09f0a. Acesso em: 20 dez. 2016.

9 BRASIL. Constituição (1988) Constituição da República Federativa do Brasil. Brasília, 1988. Disponível em <http://www.planalto.gov.br/ccivil_03/constituicao/constituicaocompilado.htm>. Acesso em 20 dez. 2016.

${ }^{10}$ BRASIL. Código Civil (2002) Lei 10.406, de 10 de janeiro de 2002. Brasília, 2002. Disponível em < http://www.planalto.gov.br/ccivil_03/Leis/2002/I10406.htm>. Acesso em 20 dez. 2016.

${ }^{11}$ MILARÉ, Édis. Direito do ambiente: doutrina, jurisprudência, glossário. 2013, p. 273.
} 
(intrínsecos e extrínsecos) de duas ordens" ${ }^{12}$, quais sejam:

Primeiro, agregando ao direito de propriedade a exigibilidade do cumprimento de uma função social. (...). Na doutrina, a função social é vista como princípio de controle da propriedade, que conforme salienta magistralmente Eros Roberto Grau: [....] impõe ao proprietário - ou a quem detém o poder de controle, na empresa- o dever de exercê-la em benefício de outrem e não, apenas, de não a exercer em prejuízo de outrem. Isso significa que a função social da propriedade atua como fonte da imposição de comportamentos positivos - prestação de fazer, portanto, e não, meramente, de não fazer - ao detentor do poder que deflui da propriedade. Segundo, e agora de modo original, o constituinte de 1988, a partir das bases da função social básica, introduziu uma função ecológica autônoma, que deve ser cumprida necessariamente pela propriedade, sob pena de perversão de seus fins, de sua legitimidade e de seus atributos ${ }^{13}$.

Desta forma, como direito fundamental a propriedade situa-se na primeira dimensão dos direitos, contemplando os direitos civis e políticos, neles inseridos os direitos à vida, à liberdade, à propriedade, à igualdade formal as liberdades de expressão coletiva e direitos de participação política.

Em linhas gerais, a função social da propriedade é a destinação economicamente útil da propriedade, em nome do interesse público. Busca limitar o exercício do direito de propriedade, otimizando sua utilização, impedindo o seu uso, em detrimento do progresso e da satisfação da comunidade.

Esse princípio autoriza a imposição, dentro de certos limites, de medidas restritivas à garantia do direito de propriedade. Pela função social, a lei pode impor encargos suportáveis, mas não excessivos ao direito de propriedade, preservando a sua essência, contribuindo, assim, por humanizar o capitalismo ${ }^{14}$, efetivar os direitos humanos, a cidadania, a solidariedade, a igualdade material e a dignidade da pessoa humana, segundo os ditames da justiça social ${ }^{15}$.

\subsection{Da colisão entre direitos fundamentais e o leading case "Quinta do Taipal”}

\footnotetext{
12 BENJAMIM, Herman Antônio. Constitucionalização do ambiente e ecologização da constituição brasileira. In: CANOTILHO, J. Joaquim Gomes, LEITE; José Rubens Morato (Orgs). Direito Constitucional brasileiro. São Paulo. Saraiva, 2007, p. 119-120.

${ }^{13}$ CORREIA, Mary Lúcia Andrade. Colisão dos direitos fundamentais: o direito ao meio ambiente ecologicamente equilibrado e o direito de propriedade à luz da hermenêutica constitucional. Disponível em: http://www.publicadireito.com.br/artigos/?cod=a85dfcdc20a09f0a. Acesso em: 20 dez. 2016.

${ }^{14}$ LIMA, Arthur Kapteinat; COVOLAN, Fernanda Cristina. O Direito de Propriedade e sua Função Social à Luz do Capitalismo Humanista: Uma Análise do Caso Pinheirinho. In: MAIA, Luciano Mariz; DE ARAÚJO, Marcelo Labanca Corrêa; DA SILVA, Lucas Gonçalves. (Org.). Direitos Fundamentais e Democracia I. Florianópolis: CONPEDI, 2014., p. 382-409. Disponível em: <http://publicadireito.com.br/artigos/?cod=a78f38f1d46f350b. . Acesso em: 28 dez. 2016.

${ }^{15}$ SERENO, Giordano Alan Barbosa. Função social da propriedade na obra de John Locke. Revista Jus Navigandi, ISSN 1518-4862, Teresina, ano 21, n. 4762, 15 jul. 2016. Disponível em: <https://jus.com.br/artigos/50562. . Acesso em: 17 dez. 2016.
} 
Assim, poder-se-ia afirmar que a colisão dos direitos fundamentais ocorre quando o exercício de um direito fundamental por parte de um titular colide com o exercício do direito fundamental por parte de outro titular.

Na lição de Gavar de Cara $^{16}$, citado por Joana de Moraes Souza Machado ${ }^{17}$, ocorre conflito entre um direito fundamental e bens jurídicos constitucionais quando o "exercício de um direito fundamental implica uma contradição ou um prejuízo de um bem jurídico protegido pelo texto constitucional".

Para Canotilho e Vital Moreira,

a ocorrência de colisão entre direitos se dá quando o exercício de um direito fundamental colide (a) com o exercício do mesmo ou de outro direito fundamental por parte de outro titular (conflito de direitos em sentido estrito); (b) com a defesa e proteção de bens da colectividade e do Estado constitucionalmente protegidos (conflito entre direitos e outros bens constitucionais) ${ }^{18}$.

Para exemplificar o conflito entre direitos fundamentais, traz-se à exposição, o leading case "Quinta do Taipal".

O Ministério Público português propôs na comarca de Montemor-o-Velho, ação ordinária contra proprietários de uma área rural - subsequente a uma providência cautelar - para a defesa do equilíbrio ecológico de região conhecida como Quinta do Taipal, buscando impedir a drenagem de 50 hectares da ponta norte da Quinta, bem como quaisquer outros atos que destruíssem ou colocassem em perigo a fauna e o habitat natural lá existente.

Alegou o membro do Ministério Público, basicamente, que a drenagem almejada pelos réus prejudicaria irremediavelmente o equilíbrio ecológico de toda a área. Por outro lado, os proprietários, então réus, argumentaram, em síntese, que sempre houve cultivo de arroz na área em causa, precedido da necessária drenagem, sem que se produzisse nenhum prejuízo ecológico.

O magistrado proferiu sentença de mérito, reconhecendo a prevalência do direito ao meio ambiente protegido, sobrepondo-se ao direito de propriedade, individual, ainda que de expressão constitucional.

A sentença fora confirmada pelo Tribunal de Relação Português, dando prevalência aos

\footnotetext{
${ }^{16}$ GAVARA DE CARA, Juan Carlos. Derechos fundamentales y desarrollo legislativo: la garantia del contenido essencial de los derechos fundamentales em la ley fundamental de Bom: Madrid: Centro de Estudios Constitucionales, 1994, p. 289.

${ }^{17}$ CARVALHO, Joana de Moraes Souza Machado. A colisão de direitos fundamentais na jurisprudência do Supremo Tribunal Federal. 2006. Tese de Doutorado. Disponível em: < http://www.repositorio.ufc.br/handle/riufc/15697>. Acesso em: 12 dez. 2016.

${ }^{18}$ CANOTILHO, J. J. Gomes, MOREIRA, Vital. Fundamentos da constituição. Coimbra: Coimbra, 1991, p. 135.
} 
direitos do dever de proteção do meio ambiente sobre o direito de propriedade, resultando em uma imposição de um vínculo definitivo, limitador do direito de propriedade e da liberdade da iniciativa econômica privada.

Canotilho, todavia, fez pertinente crítica à sentença na ponderação dos princípios vigentes no ordenamento jurídico português, ao lembrar que a existência de preceito ambiental de "privilégio agrário" não pode levar ao desprezo dos outros valores relevantes do ordenamento jurídico $^{19}$. Para ele,

uma coisa é a operação interpretativa, visando assinalar um significado aos enunciados normativos dos vários legisladores ambientais. Outra coisa é o balanceamento ou a ponderação de direitos e interesses em conflito, designadamente entre o direito do ambiente e o direito de propriedade privada. No entanto, se o procedimento metódico e interpretativo não merecem reparos relevantes, já o balacing test efetuado pelo juiz quanto aos direitos colidentes nos suscita algumas objeções. Parece-nos de que o aresto sub judice, ao interpretar as várias normas aplicáveis ao caso, partiu de uma regra fundamental: o princípio da interpretação mais amiga do ambiente (princípio da melhor proteção possível do ambiente, princípio do efeito útil ecológico). Este princípio, que como expressão ou ratio da maioria das normas jurídicas aplica ao caso, é inatacável, não goza, em termos e abstratos, de uma prevalência absoluta. A inexistência de uma ponderação mais aberta aos direitos conflituantes com o direito do ambiente conduziu o juiz a infralavorar os argumentos da parte recorrente e fundamentalmente centrados na ideia de privilégio agrário ${ }^{20}$.

Para Mukai, fazendo referência ao constitucionalista português:

[....] neste final de milênio, parece indiscutível a Canotilho que as exigências de proteção do ambiente natural ou construído (proteção da natureza, proteção do patrimônio cultural) vêm colocar ou recolocar dois problemas de particular importância: (1) O das relações recíprocas entre a garantia institucional da propriedade e do direito fundamental da propriedade por um lado, e o da proteção do ambiente por outro; (2) O da conformação jurídica dessas relações pelo legislador e pelos tribunais. A intensificação dos vínculos incidentes sobre a propriedade obriga, porém, a novos esforços dogmáticos, no sentido de saber em que casos deve o proprietário incitado suportar medidas autoritativas de compressão ecológica, sem qualquer direito a compensações patrimoniais $^{21}$.

Note-se, neste contexto, ser impreciso afirmar que o direito ao meio ambiente tem maior peso, valor ou força do que o direito de propriedade ou direito de iniciativa econômica privada. Em razão disto, Farias assegura que,

\footnotetext{
${ }^{19}$ FARIAS, Paulo José Leite. O caráter dinâmico do controle judicial sobre as normas-princípios ambientais e a sua concretização protetiva na sentença judicial. Revista de Informação Legislativa, Brasília, v. 39, n. 154, p. 155-176, 2002. Disponível em: <https://www2.senado.leg.br/bdsf/bitstream/handle/id/496885/RIL153.pdf?sequence=1\#page=93>. Acesso em: 02 dez. 2016.

${ }^{20}$ CANOTILHO, José Joaquim Gomes. Proteção do ambiente e direito de propriedade: crítica de jurisprudência ambiental. Coimbra: Coimbra, 1995, p. 78.

${ }^{21}$ MUKAI, Toshio. A proteção do meio ambiente e o direito de propriedade sob a perspectiva da Constituição Federal. Fórum de direito urbano e ambiental, 2011.
} 
as normas ambientais constitucionais de caráter principiológico fornecem matiz nova a inúmeras questões jurídicas relacionadas à proteção ambiental; entretanto, não afastam aprioristicamente a aplicação de outros princípios fundamentais que deverão ser valorados no caso concreto ${ }^{22}$.

\subsection{Da incidência do princípio da harmonização entre direitos colidentes e a unicidade da Constituição Federal}

Não resta dúvida, que na análise do caso concreto, ocorre à colisão de direitos, de um lado o direito ao meio ambiente ecologicamente equilibrado e de outro, o direito de propriedade. Em casos assim, há duas normas constitucionais de igual hierarquia jurídica capazes de resultar em soluções contraditórias para o mesmo problema.

Farias, valendo-se da lição de Canotilho,

O litígio em apreço ressalta a necessidade de ponderação de bens jurídicos muitas vezes em conflito nos litígios ambientais, seja pela complexidade do domínio normativo aplicável ao caso, seja porque as normas aparentemente são contraditórias, o que fez, por exemplo, que no presente caso existissem pronunciamentos judiciais contraditórios, pois o Supremo Tribunal de Justiça português, em Acórdão de 17/01/1995, decidiu pela revogação de Acórdão do Tribunal de Relação que havia confirmado a sentença da comarca de Montemor-o-Velho, absolvendo os réus dos pedidos, por ter entendido que a sentença não poderia ter criado uma área ambiental protegida substituindo-se aos poderes da Administração ${ }^{23}$.

Percebe-se que, no caso em estudo, existe a colisão entre dois direitos fundamentais, veiculados por disposições normativas que revestem o caráter de princípios.

De tal forma, para a aplicação dos princípios, impõem-se, em primeira abordagem, analisar as condições fáticas e jurídicas, porquanto os princípios só obrigam conforme tais condições, devendo considerar, para isto:

E como mandados de otimização os princípios são normas que ordenam que algo seja realizado na maior medida possível, conforme as possibilidades jurídicas e fáticas. Isto significa que podem ser satisfeitos em diferentes graus e que a medida da sua satisfação depende não apenas das possibilidades fáticas mas também das jurídicas, que estão determinadas não apenas por regras, mas também por princípios opostos ${ }^{24}$.

\footnotetext{
${ }^{22}$ FARIAS, Paulo José Leite. $\mathbf{O}$ caráter dinâmico do controle judicial sobre as normas-princípios ambientais e a sua concretização protetiva na sentença judicial. Revista de Informação Legislativa, Brasília, v. 39, n. 154, p. 155-176 (p. 111), 2002. Disponível em: <https://www2.senado.leg.br/bdsf/bitstream/handle/id/496885/RIL153.pdf?sequence=1\#page=93>. Acesso em: 02 dez. 2016.

${ }^{23}$ FARIAS, Paulo José Leite. $\mathbf{O}$ caráter dinâmico do controle judicial sobre as normas-princípios ambientais e a sua concretização protetiva na sentença judicial. Revista de Informação Legislativa, Brasília, v. 39, n. 154, p. 155-176 (p. 111), 2002. Disponível em: <https://www2.senado.leg.br/bdsf/bitstream/handle/id/496885/RIL153.pdf?sequence=1\#page=93>. Acesso em: 02 dez. 2016.

${ }^{24}$ ALEXY, Robert. El concepto y la validez del derecho. 2. ed. Barcelona: Gedisa, 1997, p. 162. Texto original: En tanto mandados de optimización, los princípios son normas que ordenan algo sea realizado en la mayor medida posible, de acuerdo con las posibilidades jurídicas y fácticas. Esto significa que pueden ser satisfechos en grados diferentes y que la medida ordenada de su
} 
Deve-se ter a Constituição como uma unidade, um sistema que deve ser analisado em sua totalidade como conjunto normativo, rechaçando-se interpretação que visualize oposição entre suas garantias, consagrando-se, assim, o princípio da unidade da Constituição.

Barroso, abordando o princípio da unidade da Constituição, assevera que:

Na colisão de normas constitucionais, especialmente de princípios - mas também, eventualmente, entre princípios e regras e entre regras e regras - emprega-se a técnica da ponderação. Por força do princípio da unidade, inexiste hierarquia entre normas da Constituição, cabendo ao intérprete a busca da harmonização possível, in concreto, entre os comandos que tutelam valores ou interesses que se contraponham. Conceitos como os de ponderação e concordância prática são instrumentos de preservação do princípio da unidade, também conhecido como princípio da unidade hierárquiconormativa da Constituição ${ }^{25}$.

Com efeito, conforme conhecida lição de Eros Roberto Grau, "não se interpreta a Constituição em tiras, aos pedaços", assim como "não se interpreta textos de direito, isoladamente, mas sim o direito - a Constituição - no seu todo"26.

No mesmo sentido é o escólio de Gilmar Ferreira Mendes et alii ao descrever o princípio da unidade da Constituição:

Segundo essa regra de interpretação, as normas constitucionais devem ser vistas não como normas isoladas, mas como preceitos integrados num sistema unitário de regras e princípios, que é instituído na e pela própria constituição. Em consequência, a constituição só pode ser compreendida e interpretada corretamente se nós a entendermos como unidade, do que resulta, por outro lado, que em nenhuma hipótese devemos separar uma norma do conjunto em que ela se integra, até porque relembre-se o círculo hermenêutico - o sentido da parte e o sentido do todo são interdependentes ${ }^{27}$.

Diante da colisão aparente entre bens de igual assento constitucional, o dever de pôr em prática o princípio da harmonização ou da concordância prática, que visa a equilibrar os direitos envolvidos, garantindo a existência de todos eles.

Sobre esse entendimento, José Joaquim Gomes Canotilho, já referido anteriormente, ensina que tal princípio impõe o estabelecimento de limites e condicionamentos recíprocos de forma a conseguir uma harmonização ou concordância prática entre estes bens.

satisfacción depende no solo de las posibilidades fácticas sino jurídicas, que están determinadas no solo por reglas sino también, essencilamente, por los principios opuestos.

${ }^{25}$ BARROSO, Luis Roberto. Interpretação e aplicação da Constituição, 7ạ. ed. São Paulo: Saraiva, 2009, p. 374.

${ }^{26}$ BRASIL. Supremo Tribunal Federal. Voto do Ministro Eros Roberto Grau na Ação Direta de Inconstitucionalidade (ADI) no $3685-$ 8/DF (verticalização das coligações partidárias). Requerente: Conselho Federal da Ordem dos Advogados do Brasil. Requerido: Congresso Nacional. Brasília, Distrito Federal, em 23 de março de 2006. Relator(a): Ministra Ellen Gracie Northfleet. Disponível em: <http://www.stf.jus.br/imprensa/pdf/ADI3685\%20Eros\%20Grau.pdf>. Acesso em: 27 dez. 2016.

${ }^{27}$ MENDES, Gilmar Ferreira. COELHO, Inocêncio Mártires. BRANCO, Paulo Gustavo Gonet. Curso de Direito Constitucional. São Paulo: Saraiva/IDP, 2007. p. 107. 
No contexto da hermenêutica constitucional, são definidos princípios constitucionais de interpretação, que fixam premissas para a compreensão mais adequada dos dispositivos da constituição, dentre eles, o princípio da concordância prática.

Também chamado de princípio da harmonização, determina que, no caso de colisão entre direitos fundamentais e outros bens jurídicos com garantia constitucional, a interpretação da norma não pode sacrificar nenhum em detrimento de outro. Esses bens e direitos tem o mesmo valor, logo exigem da interpretação o estabelecimento de limites recíprocos de forma a harmonizá-los.

Diante da colisão aparente entre bens de igual assento constitucional, o dever de pôr em prática o princípio da harmonização ou da concordância prática, que visa a equilibrar os direitos envolvidos, garantindo a existência de todos eles.

Sobre esse entendimento, José Joaquim Gomes Canotilho, já referido anteriormente, ensina que tal princípio impõe o estabelecimento de limites e condicionamentos recíprocos de forma a conseguir uma harmonização ou concordância prática entre estes bens.

Dirley da Cunha Júnior afirma que:

[....] é necessário, portanto, haver uma relação de conciliação ou de ponderação ou concordância prática entre os direitos fundamentais concretamente em conflito, balanceando-se, através de um juízo de proporcionalidade, os valores em disputa, num esforço de harmonização, de modo que não acarrete o sacrifício definitivo de algum deles. Isso significa que a restrição de um direito fundamental só é possível in concreto, atendendo-se a regra da máxima observância e mínima restrição dos direitos fundamentais. Não há a mínima possibilidade de se limitar um direito fundamental em abstrato. Vale dizer, os limites aos direitos fundamentais não podem ocorrer em nível abstrato, mas unicamente em nível concreto. Ademais, há uma ordem excepcional de limitações constitucionais dos direitos fundamentais, que podemos chamar de limitações circunstanciais, pois dizem respeito às restrições impostas circunstancialmente durante situações constitucionais de crise, por ocasião da decretação dos estados de sítio e de defesa ${ }^{28}$.

Neste sentido, seria possível a concordância prática entre os direitos em conflito em matéria de direito econômico e ambiental?

Em relação aos tribunais de segunda instância é possível observar, de certa forma, um amadurecimento na interpretação deste conflito, pesando-se, muito mais, pela tentativa da compatibilização de ambos os direitos e superando o absolutismo ambientalista. Isto nada mais é do que a aplicação do princípio instrumental de hermenêutica constitucional da concordância

\footnotetext{
${ }^{28}$ CUNHA JÚNIOR, Dirley da. Controle judicial das omissões do Poder Público: em busca de uma dogmática constitucional transformadora à luz do direito fundamental à efetivação da Constituição. São Paulo: Saraiva, 2004, p. 223-4.
} 


\section{prática ou harmonização.}

\section{Para Dantas ${ }^{29}$,}

[...] quando se está diante de direitos fundamentais em conflito, o ideal é que se busque harmonizálos, de modo a que ambos possam prevalecer, não sendo necessário afastar a incidência de qualquer deles no caso concreto. Curiosamente, não se encontram, na doutrina em geral, muitas referências explícitas ao tema. A maioria dos autores pesquisados e mencionados nos tópicos anteriores examina a questão envolvendo a colisão de princípios fundamentais quase que exclusivamente sob a ótica da superação de um pelo outro. É quase que uma lógica do tudo ou nada, aplicada agora aos princípios. É bem verdade que, em alguma medida, o teste da necessidade, que integra a proporcionalidade em sentido estrito, de que se irá tratar no próximo tópico, pode ser encarada como sendo uma forma de harmonização, na medida em que impede o sacrifício do direito colidente, através da adoção de uma medida alternativa. [....] Embora apresentada de maneira sutil, a máxima é clara: havendo colisão, primeiro deve se tentar harmonizar os direitos conflituosos, e somente não sendo possível isso é que parte para a prevalência de um sobre o outro, mediante ponderação.

Por outro lado, Marmelstein ao tratar sobre "a difícil arte de ponderar o imponderável: reflexões em torno da colisão de direitos fundamentais e da ponderação de valores", destaca que ocorre que há várias situações em que a harmonização será inviável, pois a proteção de um determinado valor implicará no sacrifício total do outro valor colidente. Desacordo com a doutrina constitucional dominante, se não for possível harmonizar os direitos em colisão, parte-se para um sopesamento em que será prestigiado o princípio mais importante e sacrificado o princípio "perdedor". E de fato, há várias situações em que o jurista se depara com dois princípios em rota de colisão e, para solucionar esse conflito, necessariamente precisa sacrificar um desses princípios caso não seja possível conciliá-los ${ }^{30}$.

Para o autor acima, em determinadas situações não é possível harmonizar valores de distintas e diferentes naturezas e origens:

Uma colisão de direitos fundamentais é uma batalha do direito contra o direito, mais precisamente é uma batalha do direito válido contra o direito válido, do justo contra o justo. É um problema jurídico em que as duas partes em conflito possuem um argumento de peso - com fundamento constitucional! - Que ampara as suas pretensões. Nesses casos, têm-se normas de hierarquia constitucional, publicadas ao mesmo tempo e com o mesmo grau de abstração, que, no caso concreto, fornecem consequências jurídicas opostas. Os famosos critérios de solução de antinomias (hierárquico, cronológico e da especialidade) não servem para solucionar o conflito ora previsto! Quid iuris? Como decidir entre dois valores igualmente relevantes que estão ambos contemplados na Constituição? No âmbito da teoria dos direitos fundamentais, costuma-se dizer que todas as situações envolvendo o fenômeno da colisão de direitos são de difícil solução (“hard cases”) e, por

\footnotetext{
${ }^{29}$ DANTAS, Marcelo Buzaglo. Direito ambiental de conflitos: o direito ao meio ambiente ecologicamente equilibrado e os casos de colisão com outros direitos fundamentais. 2016, p. 46.

${ }^{30}$ MARMELSTEIN, George. A difícil arte de ponderar o imponderável: reflexões em torno da colisão de direitos fundamentais e da ponderação de valores. In: LEITE, George Salomão, SARLET, Ingo Woldergang, CARBONELL, Miguel (Orgs). Direitos, deveres e garantias fundamentais. Salvador. Editora Jus Podivm. 2011, p. 452.
} 
isso, tudo vai depender das informações fornecidas pelo caso concreto, das argumentações apresentadas pelas partes do processo judicial e da percepção ética do juiz. Tornou-se quase pacífico reconhecer que, em situações assim, é preciso usar a técnica da ponderação para solucionar esse conflito, ou seja, é preciso realizar uma análise de peso e importância dos valores em jogo e decidir qual merece prevalecer ${ }^{31}$.

Assim, a aplicação do princípio não está predeterminada em seu enunciado, mas depende de ponderações a serem consideradas no momento de sua aplicação, face às possibilidades jurídicas (relações com outras regras igualmente válidas) e fáticas (condições de fato para a sua eficácia).

\section{CONSIDERAÇÕES FINAIS}

O direito de propriedade e o direito a um meio ambiente ecologicamente equilibrado são direitos fundamentais reconhecidos e protegidos pela Constituição da República Federativa do Brasil, portanto, resultados de elaborações normativas constitucionais, situadas em mesmo nível hierárquico.

Para tanto, na aplicação da hermenêutica constitucional, necessária à interpretação dos direitos fundamentais, os princípios devem ser considerados como normas jurídicas, exigindo-se o sopesamento dos princípios à disposição no ordenamento jurídico, buscando, assim, a solução mais justa e equânime.

É certo, que nenhum direito fundamental guarda em si o predicado de ser absoluto, tampouco pode ser limitado ou restringido por outro de igual status.

Por isto, o julgamento de assuntos que envolvam interesses conflitantes de matiz constitucional representa missão das mais difíceis e complexas, pois neles estão em contraste direitos de primeira dimensão, no caso, o direito de propriedade, originalmente individualista, mas que hodiernamente vinculado à concretização de valores consubstanciados constitucionalmente a uma sociedade livre, justa, solidária com imposição de atender a função social e, doutro lado, um direito de terceira dimensão, direito ao meio ambiente, em que a titularidade é difusa, centrada na coletividade, dotado de alto teor de solidariedade, tendo por fim todo gênero humano, com expressão voltada para a vida, qualidade de vida e saúde. De maneira que não há hierarquização

\footnotetext{
${ }^{31}$ MARMELSTEIN, George. A difícil arte de ponderar o imponderável: reflexões em torno da colisão de direitos fundamentais e da ponderação de valores. In: LEITE, George Salomão, SARLET, Ingo Woldergang, CARBONELL, Miguel (Orgs). Direitos, deveres e garantias fundamentais. 2011, p. 453.
} 
entre esses direitos ${ }^{32}$.

Dois ou mais princípios podem-se compor e incidir sobre um mesmo fato. Na aplicação dos princípios, verificada a colisão, deve-se, incialmente, buscar a harmonização entre eles, de forma a um não se prevalecer sobre o outro, preservando a unicidade da Constituição, vez que inexiste hierarquia entre normas de igual assento constitucional.

Na impossibilidade, procede-se, então, a ponderação de valores, atuando os dois princípios no caso concreto, com pesos distintos, sem que um retire a validade do outro, prevalecendo um sobre o outro, na impossibilidade de solução com base no princípio da harmonização.

\section{REFERÊNCIAS DAS FONTES CITADAS}

ALEXY, Robert. El concepto y la validez del derecho. 2. ed. Barcelona: Gedisa, 1997.

ÀVILA, Humberto. Teoria dos princípios: da definição à aplicação dos princípios jurídicos. 9ed. São Paulo: Malheiros, 2009.

AYALA, Patryck de Araújo. O novo paradigma constitucional e a jurisprudência ambiental do Brasil. In: CANOTILHO, José Joaquim Gomes. LEITE, José Rubens Morato (Orgs.). Direito Constitucional Ambiental brasileiro. 3. ed. São Paulo: Saraiva, 2010.

BARROSO, Luis Roberto. Interpretação e aplicação da Constituição, 7ạ. ed. São Paulo: Saraiva, 2009.

BENJAMIM, Herman Antônio. Constitucionalização do ambiente e ecologização da constituição brasileira. In: CANOTILHO, J. Joaquim Gomes, LEITE; José Rubens Morato (Orgs). Direito Constitucional brasileiro. São Paulo. Saraiva, 2007.

CANOTILHO, J. J. Gomes e MOREIRA, Vital. Fundamentos da constituição. Coimbra: Coimbra, 1991.

CANOTILHO, J. J. Gomes, LEITE, José Rubens Morato. Direito Constitucional Ambiental Brasileiro. 4. ed. São Paulo: Saraiva, 2011.

CANOTILHO, J.J. Gomes. Protecção do ambiente e direito de propriedade (crítica de

\footnotetext{
${ }^{32}$ CORREIA, Mary Lúcia Andrade. Colisão dos direitos fundamentais: o direito ao meio ambiente ecologicamente equilibrado e o direito de propriedade à luz da hermenêutica constitucional. Disponível em: http://www.publicadireito.com.br/artigos/?cod=a85dfcdc20a09f0a. Acesso em: 20 dez. 2016.
} 
jurisprudência ambiental). Coimbra: Coimbra, 1995.

CORREIA, Mary Lúcia Andrade. Colisão dos direitos fundamentais: o direito ao meio ambiente ecologicamente equilibrado e o direito de propriedade à luz da hermenêutica constitucional. Disponível em: <http://www.publicadireito.com.br/artigos/?cod=a85dfcdc20a09f0a>. Acesso em: 20 dez. 2016.

CUNHA JÚNIOR, Dirley da. Controle judicial das omissões do Poder Público: em busca de uma dogmática constitucional transformadora à luz do direito fundamental à efetivação da Constituição. São Paulo: Saraiva, 2004.

DANTAS, Marcelo Buzaglo. Direito ambiental de conflitos: o direito ao meio ambiente ecologicamente equilibrado e os casos de colisão com outros direitos fundamentais. $2 \underline{a}$ ed. (2 2 a tiragem). Rio de Janeiro: Lumen Juris, 2016.

FARIAS, Cristiano Chaves de; ROSENVALD, Nelson. Direitos Reais. 6‥ ed. São Paulo: Lumen Juris, 2010.

FARIAS, Paulo José Leite. $\mathbf{O}$ caráter dinâmico do controle judicial sobre as normas-princípios ambientais e a sua concretização protetiva na sentença judicial. Revista de Informação Legislativa, Brasília, v. 39, n. 154, p. 155-176, 2002. Disponível em:

<https://www2.senado.leg.br/bdsf/bitstream/handle/id/496885/RIL153.pdf?sequence=1\#page=9 3>. Acesso em: 02 dez. 2016.

GAVARA DE CARA, Juan Carlos. Derechos fundamentales y desarrollo legislativo: la garantia del contenido essencial de los derechos fundamentales em la ley fundamental de Bom: Madrid: Centro de Estudios Constitucionales, 1994, p. 289.

GOULART, Leandro Henrique; FERNANDES, Josiane Livia. Direito à propriedade e ao meio ambiente ecologicamente equilibrado: a colisão de direitos fundamentais. Veredas do Direito: Direito Ambiental e Desenvolvimento Sustentável, v. 9, n. 17, p. 133, 2012. Disponível em: http://www.domhelder.edu.br/revista/index.php/veredas/article/download/200/212.> Acesso em: 02 dez. 2017.

LEITE, George Salomão. SARLET, Ingo Wolfgang (Coord.). Direitos Fundamentais e Estado Constitucional. São Paulo: RT, 2009.

LIMA, Arthur Kapteinat; COVOLAN, Fernanda Cristina. O Direito de Propriedade e sua Função 
Social à Luz do Capitalismo Humanista: Uma Análise do Caso Pinheirinho. In: MAIA, Luciano Mariz; DE ARAÚJO, Marcelo Labanca Corrêa; DA SILVA, Lucas Gonçalves. (Org.). Direitos Fundamentais e Democracia I. Florianópolis: CONPEDI, 2014., p. 382-409. Disponível em: <http://publicadireito.com.br/artigos/?cod=a78f38f1d46f350b. . Acesso em: 28 dez. 2016. MACHADO, Paulo Affonso Leme. Direito Ambiental Brasileiro. 19a. ed. São Paulo: Malheiros, 2011.

MARMELSTEIN, George. A difícil arte de ponderar o imponderável: reflexões em torno da colisão de direitos fundamentais e da ponderação de valores. In: LEITE, George Salomão, SARLET, Ingo Woldergang, CARBONELL, Miguel (Orgs). Direitos, deveres e garantias fundamentais. Salvador. Editora Jus Podivm. 2011.

MENDES, Gilmar Ferreira. COELHO, Inocêncio Mártires. BRANCO, Paulo Gustavo Gonet. Curso de Direito Constitucional. São Paulo: Saraiva/IDP, 2007.

MILARÉ, Édis. Direito do ambiente: doutrina, jurisprudência, glossário. 8ạ. ed. São Paulo. Editora Revista dos Tribunais, 2013.

MUKAI, Toshio. A proteção do meio ambiente e o direito de propriedade sob a perspectiva da Constituição Federal. Fórum de direito urbano e ambiental, 2011.

PASOLD, Cesar Luiz. Metodologia da Pesquisa Jurídica: Teoria e Prática. 13a . ed. rev. São Paulo: Conceito Editorial, 2015.

SARLET, Ingo Wolfgang. FENSTERSEIFER, Tiago. Direito Constitucional Ambiental: Constituição, direitos fundamentais e proteção do ambiente. 2a. ed. São Paulo: Revista dos Tribunais, 2012. SERENO, Giordano Alan Barbosa. Função social da propriedade na obra de John Locke. Revista Jus Navigandi, ISSN 1518-4862, Teresina, ano 21, n. 4762, 15 jul. 2016. Disponível em: <https://jus.com.br/artigos/50562. . Acesso em: 17 dez. 2016. 


\title{
OPERAÇÕES URBANAS CONSORCIADAS E DESENVOLVIMENTO URBANO: ASPECTOS POSITIVOS E NEGATIVOS DESTACADOS
}

\author{
Daniela Maragno Marcelino ${ }^{1}$
}

\section{INTRODUÇÃO}

O crescimento desproporcional das cidades ocasionou grande desorganização ambiental artificial, exigindo do Poder Público excessivos investimentos e urgência na execução de medidas que promovam a eficácia do plano urbanístico, com o fim de conter o crescimento de loteamentos irregulares, favelas, a ocupação de áreas de preservação permanente e a degradação do patrimônio público.

Para enfrentar a diversidade de problemas urbanísticos, há necessidade de adoção de instrumentos de política urbana, capazes de valorizar o patrimônio das cidades, seja ele cultural, ambiental, paisagístico ou histórico, e garantir, além do desenvolvimento sustentável, a função social da cidade e da propriedade, a melhora dos centros urbanos e o direito ao meio ambiente ecologicamente equilibrado.

O instrumento da Operação Urbana Consorciada, previsto no Estatuto da Cidade, é um controverso recurso de política urbana à disposição do Poder Público para elaboração de melhorias urbanísticas. Diz-se controverso porque a implementação de tal instrumento de planejamento urbano, dependendo de como for feita, poderá melhorar o desenvolvimento urbano ou apenas agravar problemas sociais.

Deste modo, a utilização deste instituto pode ser vantajosa, por ser um meio econômico para a efetivação de programas de urbanização, mas também, se utilizada sem o cumprimento de todas as exigências legais e sem planejamento adequado, pode agravar os problemas já existentes.

$\mathrm{O}$ artigo tem por objetivo apontar aspectos positivos e negativos da utilização do instituto das operações urbanas consorciadas nos processos de recuperação de áreas urbanas degradadas.

\footnotetext{
1 Mestranda em Ciência Jurídica do Curso de Pós-Graduação Strictu Sensu em Ciência Jurídica da UNIVALI. Linha de Pesquisa: Direito, Desenvolvimento Urbano e Meio Ambiente. E-mail: danimaragno@gmail.com
} 
Neste estudo, que foi elaborado seguindo o método indutivo, procura-se enfocar os aspectos conceituais da lei e oferecer contribuições teóricas acerca do assunto.

\section{BREVES CONSIDERAÇÕES ACERCA DA POLÍTICA URBANA}

A Constituição Federal, em seus artigos 182 e 183 estabeleceu expressamente a importância da política urbana.

A redação do artigo 182 dispõe que a política de desenvolvimento urbano, executada pelo poder público municipal, conforme diretrizes gerais fixadas em lei, tem por objetivo ordenar o pleno desenvolvimento das funções sociais da cidade e garantir o bem-estar de seus habitantes, com o Plano Diretor como instrumento básico desta política.

Já o artigo 183 estabeleceu que todo aquele que possuir, como sua, área urbana de até duzentos e cinquenta metros quadrados, por cinco anos, ininterruptamente e sem oposição, utilizando-a para sua moradia ou de sua família, adquirirá o seu domínio, desde que não seja proprietário de outro imóvel urbano ou rural

A previsão de aquisição gratuita de domínio do artigo 183 da Constituição Federal, muito embora tenha instituído garantia que assegura o direito à moradia em imóveis públicos àqueles que preencham os requisitos descritos, com aplicabilidade plena, poderá sofrer restrição legal pela lei ou em razão de interesse público.

A Lei 10.257 de 10 de julho de 2001, denominada Estatuto da Cidade, regulamentou a Política Urbana prevista constitucionalmente, reunindo normas sobre o uso da propriedade urbana, a segurança e o bem estar dos cidadãos, além da proteção ao meio ambiente, tudo com base nos princípios da função social da cidade e da propriedade urbana.

O artigo $5^{\circ}$, incisos XXII e XXIII, da Constituição Federal, ao estabelecer a garantia ao direito de propriedade, fixou também que toda propriedade atenderá a sua vocação social, vocação esta que será determinada pelo Município, de acordo com os interesses públicos e privados previstos no Plano Diretor.

A autonomia dada aos Municípios pelo Estatuto da Cidade priorizou a gestão municipal por ser a esfera de governo mais próxima do cidadão, o que permite a melhor avaliação e implementação de políticas públicas, de acordo com a necessidade local. O Município estará 
incumbido de planejar e controlar o uso do território, favorecendo o desenvolvimento sustentável e garantindo direitos constitucionais mínimos aos seus habitantes.

Outro importante ponto a ser destacado do Estatuto da Cidade é o comprometimento com o desenvolvimento sustentável das cidades. As diretrizes gerais para que a política urbana alcance o pleno desenvolvimento das funções sociais da cidade e da propriedade, obrigam os Municípios a ajustarem parâmetros para produção e consumo de bens e serviços. A expansão urbana deve ser compatível com a sustentabilidade ambiental, social e econômica do Município e do território sob sua área de influência.

\subsection{As políticas de uso e ocupação do solo urbano}

As políticas de uso e ocupação do solo urbano estão regulamentadas no Plano Diretor como instrumento de gestão do espaço urbano. O Plano Diretor define também o zoneamento urbano e estabelece diretrizes para o adensamento e para a expansão territorial, além da infraestrutura a ser disponibilizada. Para TAKEDA ${ }^{2}$, “[...] sinteticamente, pode-se dizer que o termo 'uso e ocupação do solo' é definido em função das normas relativas à densificação, regime de atividades, dispositivos de controle das edificações e parcelamento do solo, que configuram o regime urbanístico."

TAKEDA ${ }^{3}$ explica, ainda, que o "[...] o que pode ou não ser construído e o tamanho das construções (uso e ocupação) nos terrenos dos municípios são definidos pela relação entre o tamanho do terreno e a quantidade de pessoas; pelas atividades (comércio, moradias, serviços, indústrias), bem como pelo tipo dos prédios e tamanho dos lotes, dentre outros."

As normas de uso e ocupação são distintas de acordo com cada área do zoneamento, que se divide em zonas industriais, comerciais, residenciais, institucionais e mistas. Como resume TAKEDA $^{4, ~ "[. . .] ~ e m ~ o u t r a s ~ p a l a v r a s, ~ a ~ l e g i s l a c ̧ a ̃ o ~ d e f i n i r a ́, ~ p a r a ~ c a d a ~ z o n a ~ e m ~ q u e ~ s e ~ d i v i d a ~ o ~}$ território do município, os usos permitidos e os índices urbanísticos de parcelamento e ocupação do solo, que incluirão, obrigatoriamente, as áreas mínimas e máximas de lotes e os coeficientes

\footnotetext{
2 TAKEDA, Tatiana. Uso e Ocupação do Solo Urbano. Disponível em: http://www.jurisway.org.br/v2/dhall.asp?id_dh=12363. Acesso em 6 de fevereiro de 2017.

3 TAKEDA, Tatiana. Uso e Ocupação do Solo Urbano. Disponível em: <http://www.jurisway.org.br/v2/dhall.asp?id_dh=12363>, acesso em 6 de fevereiro de 2017.

4 TAKEDA, Tatiana. Uso e Ocupação do Solo Urbano. Disponível em: <http://www.jurisway.org.br/v2/dhall.asp?id_dh=12363>. Acesso em 6 de fevereiro de 2017.
} 
máximos de aproveitamento."

Assim, a legislação aplicada direciona a ocupação da cidade como forma de legitimação do espaço construído e contenção ao crescimento desordenado, com a simplificação da legislação de parcelamento, uso e ocupação do solo e das normas de construção (artigo 2으, inciso XV, do Estatuto da Cidade).

Mas não só as áreas urbanas em desenvolvimento serão abarcadas pelo Plano Diretor:

\begin{abstract}
Regularização fundiária e urbanização de áreas ocupadas por população pobre também estão previstas. O poder público municipal deverá se responsabilizar pelo estabelecimento de normas especiais de urbanização, de uso e ocupação do solo e de edificação, consideradas a situação sócioeconômica da população atendida e, também, fixará, para estas áreas, as normas ambientais pertinentes. Esta recomendação vem de encontro às antigas reivindicações da população moradora de favelas, invasões, vilas ou de alagados que, em alguns casos, até já foram urbanizadas e continuam sem a regularização fundiária. Casos também existem em que a população adquiriu o terreno onde se encontra a denominada favela e, mesmo assim, continua sendo percebida como ocupante "ilegal" da área. As situações são as mais diversas, contudo, esta diretriz geral para a ação do poder público municipal, apoiada nos instrumentos previstos no Estatuto da Cidade, poderá inverter o quadro de ocupações "ilegais" e promoverá a regularização urbanística em nossas cidades. ${ }^{5}$
\end{abstract}

A desorganização ambiental artificial pode, também, ser combatida com cooperação entre os governos federal, estadual e municipal e com a iniciativa privada e os demais setores da sociedade.

Atualmente, diante da situação de crise econômica pela qual o Brasil atravessa, está em evidência a instituição de parcerias entre o setor público e a iniciativa privada. Isto porque tais parcerias visam a suprir a insuficiência de investimentos em infraestrutura por recursos próprios do Poder Público. A exemplo, temos o instituto das operações urbanas consorciadas, previsto nos artigos 32, 33 e 34 do Estatuto da Cidade, e que será abordada no próximo capítulo.

\title{
2. AS OPERAÇÕES URBANAS
}

Fundado no princípio constitucional da Função Social da Propriedade (art. 5ํ, incisos. XXII e XXIII), o instituto da Operação Urbana Consorciada está presente no Estatuto da Cidade (Lei 10.257/2001), em seus artigos 32, 33 e 34.

\footnotetext{
${ }^{5}$ FEC, Site da. Estatuto da Cidade: Para compreender. Disponível em: <http://www.fec.unicamp.br/ labinur/Estatuto_comp.html>. Acesso em 6 de fevereiro de 2017.
} 
O artigo 32, § 1ํ, da Lei 10.251/2001 (Estatuto da Cidade), define a Operação Urbana Consorciada, como "o conjunto de intervenções e medidas coordenadas pelo Poder Público municipal, com a participação dos proprietários, moradores, usuários permanentes e investidores privados". O objetivo de tal instituto é alcançar, em determinada área, transformações urbanísticas estruturais, melhorias sociais e a valorização ambiental. De acordo com a redação dos artigos 32 e 33 do Estatuto da Cidade ${ }^{6}$, as operações urbanas somente poderão ser instituídas mediante aprovação de lei específica, a qual regulamentará o plano de operação urbana consorciada, definindo a área a ser atingida, com programa básico de sua ocupação; a previsão de um programa de atendimento econômico e social para a população diretamente afetada pela operação; as finalidades da operação; um estudo prévio de impacto de vizinhança; a contrapartida a ser exigida dos proprietários, usuários permanentes e investidores privados em função da utilização dos benefícios previstos na lei; e a forma de controle da operação, obrigatoriamente compartilhada com representação da sociedade civil.

Outrossim, ficará sob encargo do Município a possibilidade de serem previstas a modificação de índices e de características do parcelamento, uso e ocupação do solo e subsolo; as alterações das normas para edificação; a regularização de construções, reformas ou ampliações

\footnotetext{
${ }^{6}$ Art. 32. Lei municipal específica, baseada no plano diretor, poderá delimitar área para aplicação de operações consorciadas.

$\S 10$ Considera-se operação urbana consorciada o conjunto de intervenções e medidas coordenadas pelo Poder Público municipal, com a participação dos proprietários, moradores, usuários permanentes e investidores privados, com o objetivo de alcançar em uma área transformações urbanísticas estruturais, melhorias sociais e a valorização ambiental.

$\S 20$ Poderão ser previstas nas operações urbanas consorciadas, entre outras medidas:

I - a modificação de índices e características de parcelamento, uso e ocupação do solo e subsolo, bem como alterações das normas edilícias, considerado o impacto ambiental delas decorrente;

II - a regularização de construções, reformas ou ampliações executadas em desacordo com a legislação vigente.

III - a concessão de incentivos a operações urbanas que utilizam tecnologias visando a redução de impactos ambientais, e que comprovem a utilização, nas construções e uso de edificações urbanas, de tecnologias que reduzam os impactos ambientais e economizem recursos naturais, especificadas as modalidades de design e de obras a serem contempladas. (Incluído pela Lei no 12.836, de 2013)

Art. 33. Da lei específica que aprovar a operação urbana consorciada constará o plano de operação urbana consorciada, contendo, no mínimo:

I- definição da área a ser atingida;

II - programa básico de ocupação da área;

III - programa de atendimento econômico e social para a população diretamente afetada pela operação;

IV - finalidades da operação;

$\mathrm{V}$ - estudo prévio de impacto de vizinhança;

VI - contrapartida a ser exigida dos proprietários, usuários permanentes e investidores privados em função da utilização dos benefícios previstos nos incisos I e II do § 20 do art. 32 desta Lei;

VI - contrapartida a ser exigida dos proprietários, usuários permanentes e investidores privados em função da utilização dos benefícios previstos nos incisos I, II e III do § 20 do art. 32 desta Lei; (Redação dada pela Lei no 12.836, de 2013)

VII - forma de controle da operação, obrigatoriamente compartilhado com representação da sociedade civil.

VIII - natureza dos incentivos a serem concedidos aos proprietários, usuários permanentes e investidores privados, uma vez atendido o disposto no inciso III do § 20 do art. 32 desta Lei. (Incluído pela Lei no 12.836, de 2013)

$\S 10$ Os recursos obtidos pelo Poder Público municipal na forma do inciso VI deste artigo serão aplicados exclusivamente na própria operação urbana consorciada.

§ 20 A partir da aprovação da lei específica de que trata o caput, são nulas as licenças e autorizações a cargo do Poder Público municipal expedidas em desacordo com o plano de operação urbana consorciada
} 
executadas em desacordo com a legislação vigente; caso julgue necessária o estabelecimento de determinada operação urbana.

Entretanto, FIORILLO ${ }^{7}$ adverte que

O Estatuto da cidade admite a possibilidade de que estas operações ocorram; entretanto exige que em cada lei municipal que aprovar uma operação com esta deva ser incluído obrigatoriamente o programa e projetos básicos para a área, o programa de atendimento econômico e social para a população diretamente afetada pela operação e o estudo de impacto de vizinhança. Com essas medidas se procura evitar que as operações sejam somente 'liberações' de índices construtivos para atender interesses particulares ou simplesmente operações de valorização imobiliária que impliquem expulsão de atividades e moradores de menor renda"

As condições impostas para aplicação do instrumento estão diretamente ligadas à dinâmica do mercado imobiliário, ao interesse dos agentes envolvidos na participação. O emprego das operações urbanas, deste modo, também estará relacionado com a maneira como é visto o espaço urbano, pois deverá ser atrativo aos investidores imobiliários, como orienta SAVELLI ${ }^{8}$

As decisões empresariais baseiam-se no grau de atratividade proveniente de indicadores da qualidade econômico-financeira do empreendimento que se analisa, construídos tanto a partir da movimentação financeira esperada no horizonte de seu desenvolvimento, como das condições de cenários que permitem avaliar os riscos envolvidos:

a) as variáveis de cenário vinculadas à receita estão relacionadas, diretamente, a fatores de mercado como velocidade de vendas e forma dos recebimentos.

b) as variáveis de cenário vinculadas aos desembolsos estão relacionadas a aspectos associados às obras civis e, em particular, ao terreno.

Não bastam, portanto, o Poder Público estabelecer parcerias e mediar negociações, bem como firmar sua competência para gerir a aplicação da operação urbana consorciada, já que a parceria precisa também ser vista como um bom investimento para o investidor privado.

No entanto, para que as operações urbanas consorciadas atraiam investimentos privados, necessária a adoção de medida que torne o negócio atrativo aos olhos do investidor, como a modificação de índices e características de parcelamento, uso e ocupação do solo e subsolo, além de alterações das normas de edificação, sem desconsiderar o impacto ambiental delas decorrente, ou, ainda, a regularização de construções, reformas ou ampliações executadas em desacordo com a legislação vigente. Em outras palavras, criam-se direitos de construir ou utilizar imóveis acima

7 FIORILLO, Celso Antonio Pacheco. Estatuto da cidade comentado: Lei 10.257/2001 - Lei do Meio Ambiente Artificial. 4. ed., rev., atual. e ampl. São Paulo, SP: Revista dos Tribunais, 2010, p. 156

8 SAVELLI, Alfredo Mario. Subsídios para a implementação de parceria público privada (PPP): operações urbanas em São Paulo. 2003. Tese de Doutorado. Universidade de São Paulo. Disponível em: http://www.teses.usp.br/teses/disponiveis/3/3146/tde03032004-134908/en.php. Acesso em: 20 de janeiro de 2016. 
dos padrões previstos pelo Plano Diretor, conhecidos como Certificados de Potencial Adicional de Construção (CEPAC).

\subsection{Certificados de Potencial Adicional de Construção - CEPAC}

Os Certificados de Potencial Adicional de Construção, conhecidos como CEPAC, estão previstos no Estatuto da Cidade, na redação do seu artigo 34.

Trata-se de um direito adicional de construção criado pelo município para conceder aos investidores interessados direitos adicionais de construção, representados pelo certificado, mas delimitados na lei específica que instituir a operação urbana consorciada, que poderão, mediante prévio registro na Comissão de Valores Mobiliários $^{9}$, serem comercializados no mercado. 0 Município, em contrapartida, recebe investimentos de revitalização ou reestruturação de determinada área da cidade.

Conforme previsto na Instrução 401 da $\mathrm{CVM}^{10}$, nenhum CEPAC circulará no mercado sem o prévio registro na CVM da operação a que estiver vinculado. Com o registro, haverá a emissão de prospecto, contendo os dados básicos da operação e a quantidade de CEPAC para alienação. $\mathrm{O}$ Município poderá requerer o registro de distribuição pública para realização do leilão de CEPAC.

Frisa-se que os CEPACs geram tão somente o direito inerente ao certificado, que pode ser repassado ou utilizado dentro das condições do plano que o criou. Não são títulos de dívida ou de capital, mas sim valores mobiliários específicos.

Há quem critique os CEPACS, como é o caso de FERREIRA e FIX: ${ }^{11}$

Um primeiro problema dos CEPACs é a desvinculação que o título cria entre a compra do potencial construtivo e a posse do lote. Como qualquer um pode comprar o título, tendo ou não lote na região, e seu valor - como com qualquer título financeiro - pode variar, gera-se um novo tipo de especulação imobiliária, "financeirizada". Os defensores dessa idéia dizem que tal dinâmica não está à mercê do mercado, já que os CEPACs serão lançados em operações específicas, sob controle do Poder Público. Além disso, os CEPACs teriam um "forte componente social", pois poderiam ser

\footnotetext{
9 BRASIL. Instrução de número 401: dispõe sobre os registros de negociação e de distribuição pública de Certificados de Potencial Adicional de Construção - CEPAC. Comissão de Valores Mobiliários. Disponível em: <http://www.cvm.gov.br/legislacao/inst/inst401.html>. Acesso em 6 de fevereiro de 2017.

${ }^{10}$ Informação obtida na Instrução de número 401, que dispõe sobre os registros de negociação e de distribuição pública de Certificados de Potencial Adicional de Construção - CEPAC. Disponível em <http://www.cvm.gov.br/legislacao/inst/inst401.html>. Acesso em 6 de fevereiro de 2017.

${ }^{11}$ FERREIRA, João S. W. e FIX, Mariana. A urbanização e o falso milagre do CEPAC. Disponível em: <http://www.fau.usp.br/depprojeto/labhab/biblioteca/textos/ferreira_cepacfalsomilagre.pdf>. Acesso em: 6 de fevereiro de 2017.
} 
vendidos para alavancar a reurbanização de favelas ou recuperações de cortiços, e seus recursos poderiam ser utilizados em melhorias na cidade toda. $\mathrm{O}$ "controle" do Poder Público é relativo, pois os CEPACs - e consequentemente as operações urbanas em que serão lançados - são encarados apenas como uma fonte de recursos. Como a Prefeitura precisa de dinheiro, buscará, se adotar essa lógica, multiplicar ao máximo as operações urbanas. Nesse caso, institucionaliza-se a especulação imobiliária como elemento motivador da renovação urbana na cidade. A conformação de seu desenho não se dá em função da ação planejada do Poder Público e das prioridades urbanas que ele estabeleça a partir da demanda participativa da população (sobretudo dos $70 \%$ excluídos), mas se subordina ao interesse do mercado, que justificará ou não as operações. Ora, parcerias com a iniciativa privada devem ser parte de um plano maior, em que o Poder Público e a população estabeleçam as necessidades da área a ser renovada - habitações, parques públicos, passeios - e somente a partir daí se definam as contrapartidas a oferecer à iniciativa privada. Quando as áreas são escolhidas apenas pelo potencial de gerar dinheiro através dos CEPACs, esquecem-se as condicionantes urbanísticas do espaço público. Quanto aos recursos arrecadados com os CEPACs, eles servirão para investimentos públicos essencialmente nas áreas de interesse do mercado, em detrimento da periferia. Essa já é a lógica das operações urbanas: fazer a iniciativa privada financiar a recuperação da própria área da operação, vendendo-lhe o direito adicional de construção. É evidente que o mercado só se interessa por áreas nas quais vislumbrem certa valorização que justifique a compra do potencial construtivo adicional. O CEPAC exacerba essa lógica, pois sendo um título, ele só funciona se for valorizado. Senão, torna-se um "mico". Ou seja, os títulos só podem ser lançados em áreas que interessem ao mercado, ou alguém imagina que a iniciativa privada compraria CEPACs no Jd. Ângela ou em Guaianazes? Além disso, a prefeitura terá que investir pesadamente em obras que potencializem sempre mais a valorização dessas áreas, e portanto dos CEPACs a elas relacionados.

Os autores acima citados criticam o uso dos CEPACs por serem encarados apenas como uma fonte de recursos ao Município, já que propiciam arrecadação rápida de fundos oriundos da venda dos certificados. Os titulares dos CEPACS estarão autorizados a construírem imóveis com metragens acima daquelas permitidas pelo Plano Diretor. Na prática, para a iniciativa privada e para o setor imobiliário, esses títulos deixam um terreno mais produtivo, pois é possível construir torres mais altas e mais lucrativas. Haverá o crescimento de determinada região.

Contudo, em que pese os aspectos negativos levantados, não há como negar que a aplicação do instituto das operações urbanas é uma tendência inovadora que ajuda o processo de urbanização, considerando a complexidade da vida urbana, a participação popular e a descentralização.

Necessário colocar em evidência a obrigatoriedade de ajuste de todos os instrumentos de gestão financeira da administração municipal ao objetivo do desenvolvimento urbano construído pelo Poder Público e pelos diferentes setores sociais. Cabe lembrar que este princípio se integra aos artigos da denominada Lei de Responsabilidade Fiscal. 


\subsection{Gentrificação}

Por um lado, o sucesso da operação urbana acarreta na produção de novos espaços e beneficia a imagem da cidade.

Lado outro, o insucesso de uma operação urbana consorciada pode acarretar processo de gentrificação, conceituado por BATALLER ${ }^{12}$ como

[...] uma série de melhorias físicas ou materiais e mudanças imateriais - econômicas, sociais e culturais - que ocorrem em alguns centros urbanos antigos, os quais experimentam uma apreciável elevação de seu status. Este processo tem se desenvolvido nos países industrializados basicamente ao longo da etapa chamada pós-industrial ou pós-moderna, iniciada com o declínio do modelo socioeconômico industrial tradicional a partir dos anos de 1970. Caracteriza-se normalmente pela ocupação dos centros das cidades por uma parte da classe média, de elevada remuneração, que desloca os habitantes da classe baixa, de menor remuneração, que viviam no centro urbano.

Na opinião de BATALLER ${ }^{13}$, a ocupação de determinada área da cidade por pessoas de poder aquisitivo mais elevado, provocará melhorias e valorização do local, expulsando para áreas periféricas a população de baixa renda anteriormente ocupante da localidade.

O deslocamento vem acompanhado de investimentos e melhorias tanto nas moradias (que são renovadas ou reabilitadas) quanto em toda área afetada, tais como comércio, equipamentos e serviços. Isto implica, portanto, mudanças no mercado de solo e habitacional, de modo que desempenham um papel decisivo os agentes do solo: os proprietários, os promotores, os governos locais, estaduais - e as instituições financeiras, assim como também os moradores - em regime de propriedade ou de aluguel. Em conjunto, o fenômeno proporciona uma maior estima das áreas renovadas e, inclusive, uma recuperação do valor simbólico dos centros urbanos. De fato, tal como tem assinalado J. Van Weesep, atualmente considera-se a gentrificação como expressão espacial de uma profunda mudança social.

O fenômeno da gentrificação também pode ser facilmente visualizado nos casos em que os índices de uso e ocupação do solo, alterados em razão da realização de determinada operação urbana, beneficiam altos investidores que enobrecem o local e expulsam os moradores que não dispõem de condições financeiras para arcarem com os custos da construção adicional de seus imóveis.

O paradoxo do desenvolvimento urbano e o aumento da desigualdade social pode ser evitado, desde que o Poder Público faça um estudo prévio, íntegro e completo, com o fim de

\footnotetext{
${ }^{12}$ BATALLER, Maria Alba Sargatal. O Estudo da Gentrificação. Disponível em: http://r1.ufrrj.br/revistaconti/pdfs/1/ART1.pdf.. Acesso em 6 de fevereiro de 2017.

${ }^{13}$ BATALLER, Maria Alba Sargatal. O Estudo da Gentrificação. Disponível em: http://r1.ufrrj.br/revistaconti/pdfs/1/ART1.pdf.. Acesso em 6 de fevereiro de 2017.
} 
verificar se a operação urbana a ser efetivada poderá forçar os moradores daquele local a migrarem para áreas marginalizadas e sem infraestrutura adequada.

O fato é que, se o Poder Público não ter cautela ao propor a operação urbana, grande segregação socioespacial poderá ser consequência. Uma operação urbana que, a princípio, pode parecer um grande passo para o desenvolvimento, na prática, poderá trazer sim benefícios para uma determinada área, mas, por outro lado, poderá resultar na expansão da desigualdade social e na supervalorização de áreas nobres.

É certo que a migração das pessoas ocorrerá para as áreas marginalizadas e sem infraestrutura. Isto afetará significativamente e de forma negativa a cidade como um todo, ante o crescimento das chamadas periferias.

\subsection{Os recursos obtidos e a responsabilidade do Poder Público}

O parágrafo primeiro do art. 33, do Estatuto da Cidade (Lei 10.257/2001), estabelece expressamente que "os recursos obtidos pelo Poder Público municipal na forma do inciso VI deste artigo serão aplicados exclusivamente na própria operação urbana consorciada". Tais recursos podem ser obtidos pelo município em razão da contrapartida exigida aos proprietários, usuários permanentes e investidores privados que serão beneficiados pela operação urbana (art. 33, §1으, da Lei $10.257 / 2001)$.

E ainda:

A contrapartida pode ser através de pagamento pela regularização de construções, reforma ou ampliação executada em desacordo com a legislação vigente. A contrapartida também pode ser exigida quando as modificações de parcelamento, uso e ocupação do solo e subsolo forem alteradas pela lei da operação urbana beneficiando os proprietários e investidores privados.

Uma forma de contrapartida dos beneficiários é através da aplicação do instituto da contribuição de melhoria, podendo também esta contrapartida incidir no instituto do IPTU progressivo. Com base nos princípios da Administração Pública da moralidade, da igualdade, da razoabilidade, da publicidade e eficiência, a contrapartida deve ser proporcional ao benefício. ${ }^{14}$

Obviamente, a definição da contrapartida deverá ser proporcional entre os investidores e habitantes daquele local, pois

\footnotetext{
${ }^{14}$ INSTITUTO PÓLIS. Estatuto da Cidade - Guia para implementação pelos municípios e cidadãos, coord. por Raquel Rolnik. Brasília: Câmara dos Deputados, 2001. Disponível em: <http://polis.org.br/publicacoes/estatuto-da-cidade-guia-para-implementacaopelos-municipios-e-cidadaos/.> Acesso em 3 de fevereiro de 2017. p. 131.
} 
A justa distribuição dos benefícios e ônus decorrentes do processo de urbanização e a recuperação dos investimentos do Poder Público de que tenha resultado a valorização dos imóveis urbanos definidas como diretrizes da política urbana nos incisos IX e XI do artigo $2^{\circ}$ do Estatuto devem ser observadas na definição da contrapartida, que não pode resultar nem em privilégios ou prejuízos para os sujeitos envolvidos diretamente nas operações, proprietários, moradores, usuários permanentes e investidores privados.Os recursos obtidos pelo Poder Público municipal na operação urbana devem ser aplicados exclusivamente na própria operação urbana nos termos do $\S 1$ 잉 do artigo 33. Estes recursos devem ser priorizados para a execução do programa de atendimento econômico e social para a população diretamente afetada pela operação. Esta prioridade deve ser definida na própria lei da operação urbana, de modo que se evite o desvio de recursos para outras finalidades que não sejam as melhorias sociais e a valorização ambiental definidas no artigo 32 do Estatuto da Cidade.

Cabe portanto à lei municipal da operação urbana definir como deverão ser utilizados os recursos de modo que possa ocorrer um controle social sobre a utilização dos recursos e evitar lesão à ordem urbanística. A utilização dos recursos para outras finalidades implicará em responsabilidade administrativa dos agentes públicos responsáveis pela operação. ${ }^{15}$

Há, portanto, a vedação expressa de utilização dos recursos para investimentos diversos. O descumprimento da determinação pelo Prefeito caracterizará crime de responsabilidade administrativa, como prevê o inciso V do art. 52 do Estatuto da Cidade ${ }^{16}$ :

O desvio indevido dos recursos obtidos ofende os princípios da administração púbica, notadamente porque, ainda que de forma indireta, afetará negativamente o patrimônio público, já que a condição importará na utilização de outros recursos na operação consorciada, ou no enriquecimento ilícito, caso o Prefeito receba bens ou valores para a prática do desvio.

Oportuna a lição colacionada da obra Estatuto da Cidade - Guia para implementação pelos Municípios e cidadãos ${ }^{17}$

A improbidade administrativa do Prefeito e demais agentes públicos fica configurada pela não utilização dos recursos na área urbana objeto da operação urbana nos termos da lei municipal que instituiu a operação. Estão também sujeitos às sanções decorrentes da configuração da improbidade administrativa, os indivíduos e agentes privados que sejam membros de órgãos colegiados que tenham aprovado a destinação dos recursos da operação urbana consorciada para outras finalidades não previstas no artigo 32 do Estatuto.

\footnotetext{
${ }^{15}$ INSTITUTO PÓLIS. Estatuto da Cidade - Guia para implementação pelos municípios e cidadãos, coord. por Raquel Rolnik. Brasília: Câmara dos Deputados, 2001. Disponível em: <http://polis.org.br/publicacoes/estatuto-da-cidade-guia-para-implementacaopelos-municipios-e-cidadaos/.> Acesso em 3 de fevereiro de 2017. p. 132.

${ }^{16}$ Art. 52. Sem prejuízo da punição de outros agentes públicos envolvidos e da aplicação de outras sanções cabíveis, o Prefeito incorre em improbidade administrativa, nos termos da Lei no 8.429, de 2 de junho de 1992, quando: $V$ - aplicar os recursos auferidos com operações consorciadas em desacordo com o previsto no § 10 do art. 33 desta Lei;

${ }^{17}$ INSTITUTO PÓLIS. Estatuto da Cidade - Guia para implementação pelos municípios e cidadãos, coord. por Raquel Rolnik. Brasília: Câmara dos Deputados, 2001. Disponível em: <http://polis.org.br/publicacoes/estatuto-da-cidade-guia-para-implementacaopelos-municipios-e-cidadaos/.> Acesso em 3 de fevereiro de 2017. p. 133-134.
} 
O Prefeito e demais agentes públicos que utilizarem os recursos de forma indevida estarão lesando o patrimônio público. Por esta configuração, estes agentes estão sujeitos a uma ação popular. Outra situação que se configura é a lesão à ordem urbanística pela não aplicação de recursos na área objeto da operação urbana. A não execução do programa de atendimento econômico e social para a população diretamente afetada pela ausência de recursos que foram desviados para outros fins, caracteriza a lesão à ordem urbanística. Por meio da ação civil pública poderá ser exigido no Judiciário o cumprimento de obrigação de executar o programa nos termos estabelecidos na lei municipal da operação.

A utilização ilegal dos recursos é desvio de finalidade e também implicará na nulidade do ato administrativo que o concluiu.

\section{CONSIDERAÇÕES FINAIS}

A Política Urbana foi instituída com o objetivo de propiciar o desenvolvimento urbano, que consiste em ordenar o pleno desenvolvimento das funções sociais da cidade e garantir o bemestar de seus habitantes.

A implementação da Política Urbana, além de buscar o progresso e o desenvolvimento, atribuiu diretamente ao Município a responsabilidade pelo estabelecimento da função de gestor, haja vista a sua autonomia na elaboração do Plano Diretor. Importante consignar que, ainda que Constituição Federal tenha dado ao Município responsabilidade normativa e para a execução de obras de interesse local, sempre deverá respeitar os planos urbanísticos nacionais, estabelecidos pela União.

O Poder Público para efetivar projetos de desenvolvimento urbano, pode valer-se de alguns instrumentos previstos no Estatuto da Cidade, como é o caso das operações urbanas consorciadas, que, sem dúvida, trata-se de um importante instrumento na luta pela urbanização das cidades e pela implantação de planejamento urbano adequado. Isto porque tal instituto possibilita ao ente municipal a captação de recursos, como a venda dos CEPACs, por exemplo. A desoneração dos cofres públicos é um ponto positivo relevante, diante do cenário nacional de crise.

Os municípios, no entanto, deverão ter cautela na instituição das operações urbanas, já que o aumento da desigualdade social e da especulação imobiliária são as duas principais críticas ao instrumento. Para que ela seja caracterizada como uma alternativa para a recuperação de áreas degradadas, o município deverá realizar um estudo prévio íntegro, além de cuidar para não estabelecer contrapartidas desproporcionais. 
Outrossim, ao elaborar um projeto de operação urbana, o Poder Público Municipal deverá também planejar e elaborar política pública que propicie à população de baixa renda uma readequação dos locais onde vive, pois, somente assim a operação urbana representará um grande recurso para o desenvolvimento das cidades brasileiras.

\section{REFERÊNCIAS DAS FONTES CITADAS}

BATALLER, Maria Alba Sargatal. O Estudo da Gentrificação. Disponível em: <://r1.ufrrj.br/revistaconti/pdfs/1/ART1.pdf.>. Acesso em: 6 de fevereiro de 2017.

BRASIL. Constituição (1988). Constituição da República Federativa do Brasil. Brasília, DF:

Disponível em: <http://www.planalto.gov.br/ccivil_03/constituicao/constituicao.htm>. Acesso em: 10 de março de 2017.

BRASIL. Estatuto da Cidade: Lei 10.257/2001 que estabelece diretrizes gerais da política urbana. Brasília, Câmara dos Deputados, 2001, $1^{\text {a }}$ Edição. Disponível em: <http://www.planalto.gov.br/ccivil_03/leis/LEIS_2001/L10257.htm>. Acesso em 6 de fevereiro de 2017.

BRASIL. Instrução de número 401: dispõe sobre os registros de negociação e de distribuição pública de Certificados de Potencial Adicional de Construção - CEPAC. Comissão de Valores Mobiliários. Disponível em <http://www.cvm.gov.br/legislacao/inst/inst401.html>. Acesso em 6 de fevereiro de 2017.

FEC, Site da. Estatuto da Cidade: Para compreender. Disponível em: <http://www.fec.unicamp.br/ labinur/Estatuto_comp.html>. Acesso em 6 de fevereiro de 2017. FERREIRA, João S. W. e FIX, Mariana. A urbanização e o falso milagre do CEPAC. Disponível em: <http://www.fau.usp.br/depprojeto/labhab/biblioteca/textos/ferreira_cepacfalsomilagre.pdf>. Acesso em 6 de fevereiro de 2017.

FIORILLO, Celso Antonio Pacheco. Estatuto da cidade comentado: Lei 10.257/2001 - Lei do Meio Ambiente Artificial. 4. ed., rev., atual. e ampl. São Paulo, SP: Revista dos Tribunais, 2010.

INSTITUTO PÓLIS. Estatuto da Cidade - Guia para implementação pelos municípios e cidadãos, coord. por Raquel Rolnik. Brasília: Câmara dos Deputados, 2001. Disponível em: <http://polis.org.br/publicacoes/estatuto-da-cidade-guia-para-implementacao-pelos-municipios- 
e-cidadaos/>. Acesso em 3 de fevereiro de 2017.

MARICATO, Erminia; FERREIRA, João Sette Whitaker. Operação urbana consorciada: diversificação urbanística participativa ou aprofundamento da desigualdade. Estatuto da Cidade e Reforma Urbana, novas perspectivas para as cidades brasileiras. Porto Alegre: Sergio Fabris Editora, 2002. Disponível em:

<http://www6.fau.usp.br/depprojeto/labhab/biblioteca/textos/ferreira_operacoesurbanasconsor c.pdf.> Acesso em 20 de janeiro de 2017.

MOBILIÁRIOS, Comissão de Valores. Instrução CVM 401. Disponível em <http://www.cvm.gov.br/legislacao/inst/inst401.html.> Acesso em 6 de fevereiro de 2017. SAVELLI, Alfredo Mario. Subsídios para a implementação de parceria público privada (PPP): operações urbanas em São Paulo. 2003. Tese de Doutorado. Universidade de São Paulo. Disponível em: <http://www.teses.usp.br/teses/disponiveis/3/3146/tde-03032004-134908/en.php.>. Acesso em: 20 de janeiro de 2016.

TAKEDA, Tatiana. Uso e Ocupação do Solo Urbano. Disponível em: <http://www.jurisway.org.br/v2/dhall.asp?id_dh=12363>, acesso em 6 de fevereiro de 2017. 


\title{
O DIREITO FUNDAMENTAL AO DESENVOLVIMENTO URBANO SUSTENTÁVEL E OS LIMITES AO CONTROLE JUDICIAL DE POLÍTICAS PÚBLICAS
}

\author{
Édson Carvalho ${ }^{1}$
}

\section{INTRODUÇÃO}

O Poder Público se vê diante de grandes problemas que afetam a organização das cidades e comprometem o desenvolvimento social, o bem-estar da população e a sustentabilidade urbana.

Problemas como mobilidade urbana, desemprego, segurança pública, gestão dos recursos naturais, destinação de resíduos sólidos, vazios urbanos dentre outros, aliados à falta de planejamento e de políticas de desenvolvimento urbano adequadas, criam um cenário desolador e contribuem para a expansão insustentável das cidades, agravando os problemas já existentes e criando outros mais.

Em matéria de políticas públicas, mormente as voltadas ao desenvolvimento urbano, o Poder Judiciário é chamado em muitas oportunidades para decidir questões sensíveis que em última análise comprometem a atuação dos Poderes Legislativo e Executivo.

As cidades são o centro da vida moderna e sua criação e desenvolvimento requer muito mais que apenas edifícios e moradores, a exigir planejamento e gestão eficiente de diversos elementos que escapam do domínio do Poder Judiciário. Esta circunstância aponta para a impossibilidade de intervenção Judicial ampla nos assuntos que envolvam as políticas de desenvolvimento urbano.

O presente artigo tem por objetivo fomentar a reflexão sobre a formulação de políticas públicas e a problemática envolvendo a eficácia do direito fundamental ao desenvolvimento urbano sustentável.

Para tanto, serão analisadas as premissas a serem observadas para a definição de política pública apta a enfrentar os problemas públicos com ela relacionados, bem como o órgão estatal

\footnotetext{
${ }^{1}$ Édson Carvalho, graduado pela Universidade do Vale do Itajaí. Especialista em Direito Público pela Escola da Magistratura Federal de Santa Catarina. Advogado militante, professor da UNIVALI, das cadeiras de Direito Constitucional, Direito Administrativo e Direito Tributário. Mestrando em Ciências Jurídicas da UNIVALI. O presente artigo foi elaborado como trabalho de conclusão da disciplina de Meio Ambiente Natural e Artificial: Interfaces Legais. edsoncarvalho@floripa.com.br
} 
que se encontra em melhores condições para desempenhar essa tarefa, quer sob o prisma constitucional, quer sobre a competência técnica.

Depois será estabelecido o conceito de desenvolvimento sustentável e verificada a sua influência para o desenvolvimento urbano, bem como sua implicação jurídica como direito fundamental.

Por fim, será analisado se a intervenção do Poder Judiciário em políticas de desenvolvimento urbano pode ocorrer de forma ampla, com o escopo de colmatar todos os interesses em conflito e viabilizar o desenvolvimento urbano sustentável.

Para o desenvolvimento deste trabalho foi realizada pesquisa bibliográfica e adotado o método de abordagem dedutivo.

\section{POLÍTICAS PÚBLICAS DE DESENVOLVIMENTO URBANO}

A Constituição da República não define diretamente o conteúdo da política pública de desenvolvimento urbano. Mas a necessidade de sua formulação e implementação decorre da previsão contida no art. 182 do texto constitucional, que estabelece:

Art. 182. A política de desenvolvimento urbano, executada pelo Poder Público municipal, conforme diretrizes gerais fixadas em lei, tem por objetivo ordenar o pleno desenvolvimento das funções sociais da cidade e garantir o bem-estar de seus habitantes.

Como se pode perceber, não apenas a implementação de política pública é tarefa atribuída ao Poder Público municipal, mas também a sua formulação, que deverá ocorrer de acordo com as diretrizes fixadas em lei de competência da União².

Os Poderes Executivo municipal e Legislativo federal têm papel fundamental no cumprimento desse mandamento constitucional. Este definindo as diretrizes a serem observadas, e aquele atuando materialmente para dar corpo aos anseios constitucionais de ordenação e desenvolvimento urbano adequados.

$\mathrm{SECCHI}^{3}$ leciona que há dois conceitos fundamentais para se compreender o campo da política pública: o problema público e a política pública. O primeiro conceito se refere ao fim ou à

\footnotetext{
${ }^{2} \mathrm{O}$ art. 21, inciso $\mathrm{XX}$, da Constituição da República estabelece competir à União: "instituir diretrizes para o desenvolvimento urbano, inclusive habitação, saneamento básico e transportes urbanos".

${ }^{3}$ SECCHI, Leonardo. Análise de políticas públicas: diagnóstico de problemas, recomendação de soluções. São Paulo: Cengage Learning, 2016. p. 5.
} 
intenção de resolução, enquanto o segundo diz respeito ao meio ou mecanismo para levar a termo tal intenção.

O problema público é verificável comparando a distância que separa o status quo de uma situação reputada como ideal e possível para a realidade pública sendo, portanto, um conceito intersubjetivo ${ }^{4}$.

A política pública, por outro lado, “[...] é um conceito abstrato que se materializa com instrumentos concretos como, por exemplo, leis, programas, campanhas, obras, prestação de serviços, subsídios, impostos e taxas, decisões judiciais, entre muitos" ${ }^{5}$.

Os instrumentos citados não são autossuficientes, devendo ser utilizados conjuntamente, possibilitando a análise apropriada do problema público a ser enfrentado e das alternativas que possam viabilizar as ações estatais eficientes.

O ponto mais sensível na formulação de políticas públicas não é a identificação de sua necessidade prática, tampouco os parâmetros jurídicos a serem observados pelo Poder Público pois isso já está estabelecido no plano normativo -, mas sim a definição e investigação do problema a ser solucionado e a sua relação com outros problemas e aspectos da realidade social.

De pouco adianta definir uma política pública voltada para o desenvolvimento urbano sem considerar os seus impactos no meio ambiente, na economia, no desenvolvimento social. A formulação de políticas públicas de forma desarticulada tende a ser mais prejudicial do que benéfica ${ }^{6}$, além de desconsiderar que a organização social é um sistema complexo na forma de rede, cujas consequências de uma ação estatal não podem ser apuradas de forma linear ${ }^{7}$.

Para se tomar boas decisões públicas, elas devem estar embasadas em informações e análises confiáveis. Além disso, pondera $\mathrm{SECCHI}^{8}$, elas devem se pautar por princípios e valores

\footnotetext{
${ }^{4}$ Cf. SECCHI, Leonardo. Análise de políticas públicas: diagnóstico de problemas, recomendação de soluções, p. 5. Para o autor, o problema público é um conceito intersubjetivo porque "[...] ele só existe se incomoda uma quantidade ou qualidade considerável de atores [...]".

${ }^{5}$ SECCHI, Leonardo. Análise de políticas públicas: diagnóstico de problemas, recomendação de soluções, p. 5.

${ }^{6}$ Em artigo publicado na Folha de S.Paulo, edição online de 18/08/2016, o economista da EESP-FGV, Bernardo Guimarães, fez uma análise da política pública de realocação de crédito por meio do BNDES no governo de Dilma Rouseff lançando, logo de início, uma afirmação e um questionamento: "Com políticas públicas adequadas, o Brasil seria um país muito mais próspero. Bons governos nos países mais pobres teriam reduzido bastante a pobreza e o subdesenvolvimento. Por que freqüentemente adotamos políticas públicas ruins?".

${ }^{7}$ Os sistemas não-vivos interagem com o ambiente segundo as leis de causa e efeito da física. Ou seja, a relação é linear e nos permite prover o futuro mediante a análise das ações e as conseqüências que decorrem delas. Por sua vez, os sistemas vivos reagem de forma não linear com o ambiente, tornando imprevisível o comportamento resultante de uma influência externa. CF. CAPRA, Fritjof. As conexões ocultas: ciência para uma vida sustentável. trad. Marcelo Brandão Cipolla. São Paulo: Cultrix. p. 51.

${ }^{8} \mathrm{Cf}$. SECCHI, Leonardo. Análise de políticas públicas: diagnóstico de problemas, recomendação de soluções, p. 1.
} 
compartilhados pela sociedade e serem capazes de produzir efeitos favoráveis à melhoria do bemestar coletivo.

Para o referido autor,

[...] A análise, portanto, serve para aumentar as chances de uma boa formulação, decisão e posterior implementação de um curso de ação. Fazer análise com finalidade prática, prescritiva e de resolução de problemas públicos exige trabalho de pesquisa aprofundada, conversa com atores políticos, reuniões com a participação dos potenciais destinatários da política pública, coleta de documentos em repartições públicas, leitura de notícias dos meios de comunicação. Uma análise de política pública também depende de uma delimitação clara e precisa do problema público, de geração de alternativas tecnicamente consistentes, de projeção de custos e benefícios com a implementação, de antecipação e dissolução de conflitos de interesses. Fazer análise de política pública significa gerar informações, argumentos e consensos que forneçam uma base mais sólida à tomada de decisão pública. As decisões que exigem níveis mais elevados de sofisticação e profissionalismo são aquelas que usam métodos, evidências, critérios e parâmetros, ou seja, baseiam-se numa análise consistente do problema público e da política pública ${ }^{9}$ [...]

Política pública adequada ao enfrentamento de problemas públicos é incompatível com decisões açodadas, sem fundamentação e pautadas em informações e dados não confiáveis. A política pública deve considerar diversos outros fatores e não somente o problema principal, conforme apontado por SECCHI.

Essa constatação sugere a insuficiência da descrição das políticas públicas no texto constitucional, no que tange ao desenvolvimento urbano. A exigência constitucional de polícia pública de desenvolvimento urbano não vem acompanhada da especificação do seu conteúdo e forma de implementação, porque isso depende de análises técnicas e fáticas, bem como de ponderações políticas atribuídas aos Poderes Executivo municipal e Legislativo federal.

$\mathrm{O}$ art. 182 da Constituição da República aponta a necessidade de a política pública ser instituída conforme diretrizes gerais fixadas em lei, com o escopo de alcançar os objetivos definidos no referido dispositivo constitucional. Seguindo as diretrizes fixadas em lei, é legítimo ao Poder Público municipal definir de diversas formas o caminho a trilhar para satisfazer os objetivos constitucionais. E aqui surgem algumas hipóteses que exigem reflexão.

A primeira se refere à inércia do Poder Público em termos de formulação e implementação de política pública voltada para o desenvolvimento urbano, apesar de haver regra constitucional impondo um dever de ação.

\footnotetext{
${ }^{9}$ SECCHI, Leonardo. Análise de políticas públicas: diagnóstico de problemas, recomendação de soluções, p. 1-2.
} 
A segunda se configura pela definição de política pública inadequada ou insuficiente para promover o desenvolvimento urbano, nos termos da previsão constitucional.

A terceira e última hipótese se refere à formulação e implementação de política pública adequada à promoção do desenvolvimento urbano nos moldes idealizados pelo constituinte.

As duas primeiras hipóteses nos remetem à questão sobre o que fazer para assegurar a máxima eficácia da constituição e garantir o direito fundamental ao desenvolvimento urbano ${ }^{10}$.

O enfrentamento desta questão é fundamental, porque a formulação e a implementação de política pública envolvem mais do que a seleção de alternativas para resolver os problemas públicos. Ela é permeada pela disputa de poder, conforme nos adverte SUNDFELD ${ }^{11}$ :

[...] Talvez um dos mais graves equívocos em que se possa incidir na elaboração de políticas públicas - correndo-se, inclusive, o risco de frustrar seus objetivos - é não levar em conta os perigos escondidos no Direito, ligados, como não poderia deixar de ser, ao seu valor e ao modo pelo qual é construído. Tanto os formuladores de políticas quanto os responsáveis pela execução devem tê-los em mente - se não para evitá-los, ao menos para minimizá-los.

O primeiro deles consubstancia-se no fato de que o mundo do Direito (os profissionais do Direito e os órgãos de controle jurídico) disputa espaço de poder com o mundo da Política. As políticas públicas, disciplinadas por normas e atos jurídicos, costumam ser, ao mesmo tempo, o objeto e o ambiente de disputa por poder. [...]

Embora as políticas públicas sejam definidas por meio de normas jurídicas ${ }^{12}$, não se pode desconsiderar a necessidade de se demarcar, a partir da Constituição da República, o espaço de atuação dos Poderes Executivo municipal, Legislativo federal e Judiciário, no que diz respeito às políticas de desenvolvimento urbano e o seu controle judicial, limitando este se necessário, para resguardar a atuação e o fortalecimento daqueles.

A este ponto se voltará no terceiro tópico deste artigo, quando se analisará a legitimidade do Poder Judiciário para controlar políticas públicas de desenvolvimento urbano.

\footnotetext{
${ }^{10}$ No próximo tópico será abordada a relação existente entre o desenvolvimento urbano sustentável e a realização de direitos fundamentais, com base em Gisi. Cf. CLÈVE, Clèmerson Merlin; PEREIRA, Ana Lucia Pretto (coordenadores). Direito constitucional brasileiro: constituições econômica e social. vol. III. São Paulo: RT, 2014. p. 539-540.

${ }^{11}$ SUNDFELD, Carlos Ari; ROSILHO, André (org.). Direito da regulação e políticas públicas. São Paulo: Malheiros, 2014. p. 64.

${ }^{12}$ Cf. SUNDFELD, Carlos Ari; ROSILHO, André (org.). Direito da regulação e políticas públicas, p. 48: “O primeiro elemento que desde logo deve ser ressaltado diz respeito ao fato de que as medidas de política pública são definidas por meio de normas e de atos jurídicos. Esta afirmação, apesar de aparentemente singela, nada tem de trivial. Afinal de contas, equivale a dizer que o DNA das políticas públicas é escrito em códigos jurídicos. Dito de outro modo: as políticas públicas dependem do Direito para a construção da sua estrutura, valendo-se, para tanto, dos mecanismos que lhe são próprios (lembram-se das tais noções básicas que estão na cabeça do jurista?)".
} 


\section{O DIREITO FUNDAMENTAL AO DESENVOLVIMENTO URBANO SUSTENTÁVEL}

A Constituição da República delineia o marco normativo a partir do qual as políticas de desenvolvimento urbano devem ser definidas e implementadas. Tais normas possuem natureza jurídica diversa, ora estando definidas na forma de princípios, em outras passagens com a roupagem de regras.

Mas talvez o mais importante a se extrair dessas normas constitucionais que informam o desenvolvimento urbano seja a sua intima relação com a promoção dos direitos fundamentais plasmados em seu texto.

Seria simplista compreender que o desenvolvimento urbano tem por objetivo apenas ordenar a ocupação das áreas urbanas, a partir de uma leitura rasa dos art. 182 e 183 do texto constitucional.

Certamente que o objetivo a ser alcançado pelas políticas públicas voltadas para o desenvolvimento urbano tem seu locus normativo no caput do art. 182, segundo o qual o Poder Público municipal, delimitado pelas diretrizes gerais fixadas pela União, deve buscar o "pleno desenvolvimento das funções sociais da cidade e garantir o bem-estar de seus habitantes".

Escrevendo sobre o direito ao desenvolvimento, CLÉVE e PEREIRA ${ }^{13}$ destacam que:

[...] A concepção do direito ao desenvolvimento envolve as noções de: livre determinação dos povos; direito à soberania sobre os recursos naturais; eliminação de violações massivas de direitos humanos; indivisibilidade e interdependência dos direitos humanos; paz e segurança internacionais; a pessoa humana como principal sujeito (participante e beneficiário) do desenvolvimento; igualdade de oportunidades tanto para as nações quanto para as pessoas e que os recursos obtidos do desarmamento sejam investidos no bem-estar das pessoas, especialmente do terceiro mundo; esforços para uma nova ordem econômica internacional. Define-se como "o direito de todas as pessoas humanas em todas as partes, e a humanidade como um todo, de realizar seu potencial, segundo Upendra Baxi e registrado por lima. [...]

Se o direito ao desenvolvimento está intimamente ligado à promoção de direitos fundamentais de diversos matizes, é possível afirmar com GISI que ele tem suporte também no preâmbulo do texto constitucional, no seu art. 3ำ e nas disposições da ordem econômica e social, das disposições que disciplinam a cidadania, a dignidade da pessoa humana, os valores sociais do trabalho e da livre-iniciativa, do pluralismo cultural e político, na construção de uma sociedade livre, justa e solidária, na busca pela erradicação da pobreza e da marginalização, na redução das

\footnotetext{
${ }^{13}$ CLÈVE, Clèmerson Merlin; PEREIRA, Ana Lucia Pretto (coordenadores). Direito constitucional brasileiro: constituições econômica e social. vol. III. São Paulo: RT, 2014. p. 539-540.
} 
desigualdades sociais e regionais dentre outros ${ }^{14}$.

Percebe-se que o conceito de desenvolvimento aqui adotado não se restringe ao econômico, por ser muito restrito e insuficiente para explicar as diversas vertentes em que o desenvolvimento deve ocorrer para propiciar o bem-estar das pessoas.

Nesse sentido, para os fins deste artigo, deve-se entender o desenvolvimento enquanto direito em sua mais ampla acepção, de modo a abarcar, além do aspecto econômico, o social, o ambiental, o cultural, o urbano, sem excluir outras dimensões. Esse sentido amplo deve ser considerado quando se fala em desenvolvimento urbano, especialmente quando se tem em mira sua conexão com os direitos fundamentais.

Adverte $\mathrm{GISI}{ }^{15}$ que,

[...] O desenvolvimento, descolado da perspectiva meramente econômica, sem naturalmente excluíla, possibilita olhares em dimensões interessantes para o resgate ou construção de uma sociedade que propicie a seus indivíduos ou grupos integrantes autonomia e proteção jurídica suficiente para garantir a criação e a manutenção de formas de produzir e reproduzir em escalas individuais, familiares e comunitárias, sem ser solapado por um mercado autorregulável e suas gigantescas demandas para a satisfação de suas ilimitadas necessidades. [...]

A Lei federal no 10.257/2001, regulamentando o art. 182 do texto constitucional, reproduziu aquela regra em seu art. 20 e estabeleceu, em seguida, diversas diretrizes a serem observadas com o escopo de alcançar o objetivo constitucional de desenvolvimento urbano.

Tratando do assunto, MEDAUAR ${ }^{16}$ destaca que

[...] O caput do art. 2o fixa como objetivo da política urbana o pleno desenvolvimento das funções sociais e da propriedade urbana. Nas funções sociais da cidade se entrevê a cidade como locus não somente geográfico e de mera reunião de pessoas, mas como o espaço destinado à habitação, ao trabalho, à circulação, ao lazer, à integração entre os seres humanos, ao crescimento educacional e cultural. Ao mencionar as funções sociais da propriedade urbana, com base certamente no art. 50, XXIII, da Constituição Federal, o dispositivo ressalta o direcionamento da propriedade urbana a finalidades de interesse geral, com as quais há de se conformar ou conciliar o direito individual de propriedade, não mais dotado de caráter absoluto. [...]

As cidades não devem se manter estagnadas. Ao contrário, como condição para o desenvolvimento humano e para a realização dos fins inerentes a sua condição, as cidades devem

\footnotetext{
${ }^{14}$ CLÈVE, Clèmerson Merlin; PEREIRA, Ana Lucia Pretto (coordenadores). Direito constitucional brasileiro: constituições econômica e social, p. 540

${ }^{15}$ CLÈVE, Clèmerson Merlin; PEREIRA, Ana Lucia Pretto (coordenadores). Direito constitucional brasileiro: constituições econômica e social, p. 538

${ }^{16}$ MEDAUAR, Odete; ALMEIDA, Fernando Dias Menezes de. Estatuto da cidade: Lei 10.257, de 10.07.2001, comentários. 2. ed. rev., atual. eampl. São Paulo: RT, 2004. p. 25-26.
} 
se desenvolver, incorporando tecnologias e inovações que permitam a todos desempenhar suas atividades, perseguir seus objetivos individuais e coletivos, se desenvolver intelectual e culturalmente enfim, viver plenamente suas vidas.

Atualmente muitas são as cidades espalhadas pelo mundo, em tamanhos diversos e estruturadas de forma diversificada. Mas o desenvolvimento das cidades a qualquer custo atende aos anseios de seus habitantes e significa o cumprimento das obrigações constitucionais pelo Poder Público?

\section{LEITE $^{17}$ destaca que}

[...] A maioria das megacidades tem concentração de pobreza e graves problemas socioambientais decorrentes da falta de maciços investimentos em infraestrutura e saneamento. Sua importância na economia nacional e global é desproporcionalmente elevada. Segundo a Organização das Nações Unidas para a Educação, a Ciência e a Cultura (Unesco), no futuro teremos muitas megacidades que estarão localizadas em novos endereços - das 16 existentes em 1996, passarão a 25 em 2025, muitas delas fora dos países desenvolvidos. [...]

Essa constatação demonstra a urgência no planejamento adequado das cidades, com o estabelecimento e implementação de políticas públicas aptas a viabilizar o desenvolvimento urbano e capazes de realizar os fins estabelecidos pelo texto constitucional e almejados por seus habitantes. O desenvolvimento capaz de atender a essas expectativas é o qualificado pela sustentabilidade.

Para MILARÉ, a sustentabilidade pressupõe o equilíbrio entre a oferta e a demanda, de modo a possibilitar que uma realidade possa manter-se continuamente com suas características essenciais ${ }^{18}$.

LEITE $^{19}$ conceitua o desenvolvimento sustentável como aquele que "satisfaz as necessidades presentes, sem comprometer a capacidade das gerações futuras de suprir suas

\footnotetext{
${ }^{17}$ LEITE, Carlos; AWAD, Juliana diCesare. Cidades sustentáveis, cidades inteligentes: desenvolvimento sustentável num planeta urbano. Porto Alegre: Bookman, 2012. p. 23.

${ }^{18}$ Cf. MILARÉ, Milaré. Direito ambiental: a gestão ambiental em foco: doutrina, jurisprudência, glossário. 7. ed. rev., atual. erefom. São Paulo: RT, 2011. p. 1643. "SUSTENTABILIDADE - Qualidade, característica ou requisito do que é sustentável. Num processo ou num sistema, a sustentabilidade pressupõe o equilíbrio entre "entradas" e "saídas", de modo que uma dada realidade possa manter-se continuamente com suas características essenciais. Na abordagem ambiental, a sustentabilidade é um requisito para que os ecossistemas permaneçam iguais a si mesmos, assim como os recursos podem ser utilizados somente com reposição e/ou substituição, evitando-se a sua depleção, de maneira a manter o equilíbrio ecológico, uma relação adequada entre recursos e produção, e entre produção e consumo. A sustentabilidade é um objetivo a ser alcançado na gestão ambiental; para a consecução desse objetivo contribui o processo do desenvolvimento sustentável, que inclui a produção e o consumo sustentáveis. Fala-se também de sociedade e de cidades sustentáveis. Em última análise, o que se procura é a sustentabilidade do planeta Terra, sem o que não será possível atingir o objetivo de uma sociedade humana sustentável".

${ }^{19}$ LEITE, Carlos; AWAD, Juliana diCesare. Cidades sustentáveis, cidades inteligentes: desenvolvimento sustentável num planeta urbano, p. 29.
} 
próprias necessidades".

Para o referido autor, a sustentabilidade possui por fundamento a percepção de que os recursos naturais são finitos e que eles não estão sendo utilizados de maneira adequada. Esta concepção, ainda segundo o autor, possui caráter normativo muito abstrato, a exigir o aprofundamento do conhecimento sobre os impactos da ação humana nos ambientes em que estão inseridos, destacando-se as cadeias produtivas, as cidades e o meio natural, possibilitando a orientação sobre a forma como as questões decorrentes devem ser enfrentadas ${ }^{20}$.

Com esteio em Paul Krugman, LEITE ${ }^{21}$ destaca que

[...] o crescimento das cidades será o modelo econômico de desenvolvimento no futuro. Isso porque é nas megacidades que acontecem as maiores transformações, gerando uma demanda inédita por serviços públicos, matérias-primas, produtos, moradias, transportes e empregos. Trata-se de um grande desafio para os governos e a sociedade civil, que exige mudanças na gestão pública e nas formas de governança, obrigando o mundo a rever padrões de conforto típicos da vida urbana - do uso excessivo do carro à emissão de gases. [...]

Ao formular políticas públicas voltadas para o desenvolvimento urbano, como se percebe, o Poder Público deve ponderar diversos interesses, buscando a definição de metas e objetivos que os conciliem ao invés de optar por soluções que causem a ruptura da sociedade ou acarretem o enfrentamento desconectado dos problemas públicos.

As políticas públicas devem contemplar, a um só tempo, instrumentos de superação das crises que afetam áreas sensíveis como saúde, moradia, lazer, emprego, mobilidade, saneamento, dentre outros, além de impedir o engessamento das cidades, tudo isso sem agravar os problemas existentes e sem criar outros novos.

O desenvolvimento urbano sustentável, parece intuitivo, não será alcançado apenas pela previsão normativa de objetivos, metas e instrumentos a serem utilizados. Entre o plano normativo e a atuação prática das disposições constitucionais e legais há um considerável espaço que deve ser preenchido com análises, planejamentos e ações efetivas dos Poderes Públicos.

Antes mesmo da definição normativa, o planejamento a ser levado a termo pelo Poder Executivo mostra-se fator essencial para a formulação adequada de política pública urbanística.

\footnotetext{
${ }^{20}$ LEITE, Carlos; AWAD, Juliana diCesare. Cidades sustentáveis, cidades inteligentes: desenvolvimento sustentável num planeta urbano, p. 29. O autor destaca que para a realização de avaliação do contexto global, devem ser observados três pilares da sustentabilidade a saber: ambientais, econômicos e sociais.

${ }^{21}$ LEITE, Carlos; AWAD, Juliana di Cesare. Cidades sustentáveis, cidades inteligentes: desenvolvimento sustentável num planeta urbano, p. 23.
} 
Sem ele, por mais que no plano normativo esteja bem definido o objetivo a ser alcançado e os instrumentos a serem utilizados, dificilmente se alcançará resultado satisfatório, por falta de rumo a seguir 22 .

O planejamento e a definição de políticas públicas, em todas as áreas, é tarefa atribuída aos Poderes Executivo e Legislativo, conforme transparece em diversos dispositivos constitucionais ${ }^{23}$, cabendo ao Poder Judiciário, em linhas gerais, o controle da legalidade e a tutela dos direitos violados ou ameaçados.

Neste ponto, deve-se refletir sobre o alcance desse controle exercido pelo Poder Judiciário. Essa questão será analisada no próximo tópico.

\section{O CONTROLE JUDICIAL DE POLÍTICA PÚBLICA DE DESENVOLVIMENTO URBANO}

Parece intuitivo que o Poder Judiciário possui ampla legitimidade constitucional para interferir em políticas públicas, incluindo aquelas voltadas para o desenvolvimento urbano, especialmente se considerarmos o desenvolvimento sustentável como direito fundamental.

Há jurisprudência formada no âmbito do Supremo Tribunal Federal nesse sentido, sendo exemplificativa a decisão proferida quando do julgamento do RE no 488208/SC, rel. Min. Celso de Melo, de cujo acórdão se extrai os seguintes excetos:

\section{$[\ldots]$}

Impende assinalar, no entanto, que a incumbência de fazer implementar políticas públicas fundadas na Constituição poderá atribuir-se, ainda que excepcionalmente, ao Judiciário, se e quando os entes e órgãos estatais competentes (como os Municípios, p. ex.), por descumprirem os encargos políticojurídicos que sobre eles incidem em caráter vinculante, vierem a comprometer, com tal comportamento, a eficácia e a integridade de direitos individuais e/ou coletivos impregnados de estatura constitucional, como sucede na espécie ora em exame.

$[\ldots]$

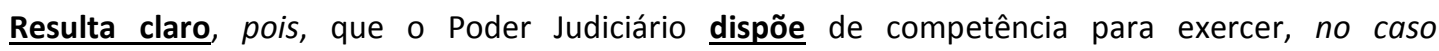
concreto, controle de legitimidade sobre a omissão do Estado na implementação de políticas

\footnotetext{
${ }^{22}$ Há um trecho no desenho "Alice no País das Maravilhas" em que Alice, caminhando pela floresta, se depara com uma encruzilhada, onde diversos caminhos se colocam à sua frente. Indecisa e sem saber qual caminho tomar, Alice fica ali pensativa. Então surge o mestre gato. Em tom jocoso e misterioso, ele pergunta para Alice se pode ajudá-la. Segue o diálogo: - Eu só queria saber que caminho tomar, disse Alice. - Isso depende do lugar aonde você queira ir, respondeu o gato. - Realmente não importa, retorquiu Alice, ao que obteve como resposta do gato: - então não importa o caminho a tomar.

${ }^{23}$ Pode-se mencionar, exemplificativamente, os art. 21, 22, 23, 24, 25, 30, 182, 184, 194, 196, 203, 205, 215, 217,218 além de diversos outros que prescrevem obrigações prestacionais aos entes políticos.
} 
públicas cuja efetivação lhe incumbe por efeito de expressa determinação constitucional, sendo certo, ainda, que, ao assim proceder, o órgão judiciário competente estará agindo dentro dos limites de suas atribuições institucionais, sem incidir em ofensa ao princípio da separação de poderes, tal como tem sido reconhecido, por esta Suprema Corte, em sucessivos julgamentos (RE 367.432AgR/PR, Rel. Min. EROS GRAU - RE 543.397/PR, Rel. Min. EROS GRAU - RE 556.556/PR, Rel. Min. ELLEN GRACIE, v.g.): ${ }^{24}$

[...] (destaques no original)

Para que se possa avaliar adequadamente o âmbito de atuação do Poder Judiciário nessa seara, mormente considerando o desenvolvimento urbano sustentável como direito fundamental, é recomendável partir da análise da eficácia das normas constitucionais ${ }^{25}$. Nesse sentido, SILVA ${ }^{26}$ propõe a seguinte classificação: a) normas constitucionais de eficácia plena; b) normas constitucionais de eficácia contida; e, c) normas constitucionais de eficácia limitada.

Nas palavras do referido autor,

[...] As normas de eficácia plena incidem diretamente sobre os interesses a que o constituinte quis dar expressão normativa. São de aplicabilidade imediata, porque dotadas de todos os meios e elementos necessários à sua executoriedade. No dizer clássico, são auto-aplicáveis. As condições gerais para essa aplicabilidade são a existência apenas do aparalho jurisdicional, o que significa: aplicam-se só pelo fato de serem normas jurídicas, que pressupõem, no caso, a existência do Estado e de seus órgãos ${ }^{27}$. [...]

Percebe-se que as normas definidoras de direitos fundamentais dotadas de eficácia plena e aplicabilidade imediata contêm todos os elementos necessários para a sua incidência dispensando, por isso mesmo, a interposição legislativa para conferir densidade normativa ao preceito constitucional utilizado para tutelar o direito ou garantia fundamental.

\footnotetext{
${ }^{24}$ Não se compartilha desse entendimento, sob diversos aspectos. O mais relevante deles diz respeito ao fato de que a formulação e implementação de política pública exige diversas providências prévias, as quais não podem ser cumpridas por meio de decisão judicial que determine a adoção de medidas tendentes a cumprir formalmente o texto constitucional. Como resultado tem-se que as políticas públicas, via de regra, são formuladas e implementadas para enfrentar determinados problemas como se fossem ilhas. Exemplo disso é a Lei no $12.318 / 2010$, que dispõe sobre a alienação parental. Essa lei se insere na política pública voltada para a proteção integral da criança e do adolescente, conforme preconizado pelo art. 227 da CR/88, mas suas disposições deixam evidentes as suas deficiências. Da forma como o assunto foi tratado, é como se a alienação parental ocorresse apenas quando os pais estivessem separados. Ou seja, os problemas acarretados ao desenvolvimento da criança e do adolescente na constância do casamento ou da união estável, e os efeitos advindos após decisão judicial enfrentando a questão com base no referido diploma legal, ao que parece, não merece a atenção do Estado.

${ }^{25}$ Não se vai aprofundar essa análise da eficácia das normas constitucionais neste artigo. Mas se pode avaliar que as normas definidoras de direitos e garantias fundamentais de primeira geração ou dimensão, em sua maioria são normas constitucionais de eficácia plena e aplicabilidade imediata. Alguns direitos fundamentais dessa natureza podem ser veiculados por meio de normas constitucionais de eficácia condita e aplicabilidade imediata. Por outro lado, as normas constitucionais que veiculam direitos prestacionais possuem eficácia limitada e aplicabilidade mediata, por exigirem a implementação da norma constitucional pelo estabelecimentos dos elementos faltantes no plano Constitucional.

${ }^{26}$ SILVA, José Afonso da. Aplicabilidade das normas constitucionais. 3. ed., 3. triag., rev., atual. e ampl. São Paulo: Malheiros, 1999. p. 101-102.

${ }^{27}$ SILVA, José Afonso da. Aplicabilidade das normas constitucionais. 3. ed., 3. triag., rev., atual. e ampl. São Paulo: Malheiros, 1999. p. 101-102.
} 
Para o referido autor, as normas constitucionais de eficácia contida

[...] São elas normas de aplicabilidade imediata e direta. Tendo eficácia independente da interferência do legislador ordinário, sua aplicabilidade não fica condicionada a uma normação ulterior, mas fica dependente dos limites (daí: eficácia condita) que ulteriormente se lhe estabeleçam mediante lei, ou de que as circunstâncias restritivas, constitucionalmente admitidas, ocorram (atuação do Poder Público para manter a ordem, a segurança pública, a defesa nacional, a integridade nacional etc., na forma permitida pelo direito objetivo) ${ }^{28}$. [...]

Por fim, tem-se as normas constitucionais de eficácia limitada, assim conceituadas por SILVA $^{29}$ :

[...] Como normas de eficácia limitada, sua aplicação plena, relativamente aos interesses essenciais que exprimem os princípios genéricos e esquemáticos, depende da emissão de uma normatividade futura, em que o legislador ordinário, integrando-lhe a eficácia, mediante lei ordinária (a Constituição vigente, pelo menos nesse aspecto, foi sábia em não exigir a integração por meio de lei complementar, sem sentido próprio), Ihe dê capacidade de execução em termos de regulamentação daqueles interesses visados. Muitas, contudo, podem ser aplicadas independentemente de lei, mas por meio de outras providências, como aquela que visa ao amparo da cultura pelo Estado. [...]

Essa classificação nos coloca frente ao problema de como tornar efetivos os direitos fundamentais veiculados por meio de normas constitucionais de eficácia limitada, face ao disposto no art. 5으, § 1으, da Constituição da República, e o papel desempenhado pelo Poder Judiciário nesse cenário.

Os direitos fundamentais veiculados por meio de normas de eficácia plena e contida, mas de aplicabilidade imediata, não acarretam maiores transtornos. Ameaçado ou violado um direito, o seu titular poderá vindicar a sua proteção ao Poder Judiciário, fundando o seu pleito diretamente no preceito constitucional.

O problema reside em relação às normas constitucionais de eficácia limitada, especialmente sobre o papel desempenhado por sua eficácia mínima ${ }^{30}$ e a possibilidade de imposição do dever de agir ao legislador e ao administrador pelo Poder Judiciário.

Considerando o desenvolvimento urbano sustentável um direito fundamental, não se pode

\footnotetext{
${ }^{28}$ SILVA, José Afonso da. Aplicabilidade das normas constitucionais, p. 116.

${ }^{29}$ SILVA, José Afonso da. Aplicabilidade das normas constitucionais, p. 165-166.

${ }^{30} \mathrm{Cf}$. SILVA, José Afonso da. Aplicabilidade das normas constitucionais. P. 164. O autor afirma que essas normas são dotadas de um mínimo de eficácia. Portanto, elas possuem "eficácia jurídica imediata, direta e vinculante nos seguintes casos: I estabelecem um dever para o legislador ordinário; II - condicionam a legislação futura, com a consequência de serem inconstitucionais as leis ou atos que as ferirem; III - informam a concepção do Estado e da sociedade e inspiram sua ordenação jurídica, mediante a atribuição de fins sociais, proteção dos valores da justiça social e revelação dos componentes do bem comum; IV - constituem sentido teleológico para a interpretação, integração e aplicação das normas jurídicas; $V$ - condicionam a atividade discricionária da Administração e do Judiciário; VI - criam situações jurídicas subjetivas, de vantagem ou de desvantagem [...]".
} 
desprezar que ele vem veiculado por norma constitucional de eficácia limitada. Vale dizer, o reconhecimento constitucional ao desenvolvimento urbano se dá por meio de norma que não permite, sozinha, pautar a atuação do Poder Público municipal.

Há a necessidade de edição de lei definindo as diretrizes gerais de desenvolvimento urbano e que balizarão a definição das políticas voltadas para essa área. O conteúdo da legislação e das políticas públicas de desenvolvimento urbano será definido mediante o desenvolvimento de diversas atividades de planejamento e estudos, bem como de ponderações políticas, que não podem ser realizadas adequadamente e de forma eficaz pelo Poder Judiciário.

O controle judicial de política pública de desenvolvimento urbano envolve, como visto no primeiro tópico deste artigo, omissão do Poder Público. Não há, com fundamento na Constituição da República, a possibilidade de o Poder Judiciário constranger os outros poderes a atuar e, o que seria de tamanha gravidade, definir o conteúdo de sua atuação.

A grande questão que se coloca é: não sendo legítimo e suficiente a intervenção do Poder Judiciário em políticas públicas de desenvolvimento urbano e havendo incompetência dos atores políticos nessa seara, como conciliar as necessidades sociais com as promessas decorrentes do Estado de Direito?

STRECK $^{31}$ aponta o paradoxo brasileiro representado, por um lado, pela sociedade carente de realização de direitos e, de outro, uma Constituição da República que garante esses mesmos direitos, da forma mais ampla possível. Nesse cenário, o direito assume a função de instrumento de ação concreta do Estado, a demandar maior responsabilidade dos atores políticos na concretização das promessas constitucionais. E acrescentamos: sem prescindir de agentes públicos sérios e comprometidos com a efetivação da Constituição, por meio de ações voltadas para a realização dos anseios sociais.

O Poder Judiciário poderá controlar as políticas públicas de desenvolvimento urbano sob o aspecto da conformidade constitucional ${ }^{32}$, infirmando aquelas que se mostrem incompatíveis com os fins visados pela Constituição e devolvendo a matéria para ser tratada no âmbito próprio qual seja, o político.

\footnotetext{
${ }^{31}$ Cf. STRECK, Lenio. Hermenêutica jurídica e(m) crise: uma exploração hermenêutica da construção do Direito. 10. ed. rev., atual. eampl. Porto Alegre: Livraria do Advogado Editora, 2011. p. 47.

${ }^{32}$ Cf. CANOTILHO, JJ Gomes. Direito constitucional e teoria da constituição. 7. ed., 2. reimpr. Coimbra: Edições Almedina, 2003. p. 246, especialmente na passagem em que ao se referir ao princípio da conformidade dos atos do estado com a constituição, o autor afirma ser ele mais amplo que o princípio da constitucionalidade das leis, por exigir a conformidade intrínseca e formal de todos os atos dos poderes públicos, em sentido amplo, com a constituição.
} 


\section{CONSIDERAÇÕES FINAIS}

A complexidade da organização social aponta a necessidade de repensar como se formula e se implementa política pública para promover o desenvolvimento urbano sustentável.

As políticas públicas, em última análise, decorrem todas do texto constitucional que, ao estabelecer as competências materiais dos entes políticos, impõe obrigações que devem ser cumpridas, sob pena de caracterizar omissão inconstitucional.

A Constituição da República estabelece, em seu art. 182, caber ao Poder Público municipal promover o desenvolvimento urbano, mediante políticas públicas formuladas de acordo com as diretrizes gerais estabelecidas em lei federal.

Políticas públicas de desenvolvimento urbano devem ser pensadas considerando a sustentabilidade e a complexidade da organização social. Nesse sentido, para que sejam eficazes e cumpram o papel a que se destinam, elas devem ser precedidas de pesquisas, estudos e análise de documentos e informações confiáveis, além de contemplar soluções interconectadas com outras políticas públicas, pois os problemas públicos não podem ser enfrentados de forma desconectada.

A complexidade da organização social acarreta a complexidade dos problemas públicos os quais, por sua vez, exigem políticas públicas também marcadas pela complexidade.

Enquanto direito fundamental, o desenvolvimento urbano sustentável encontra assento constitucional por meio de norma de eficácia limitada, o que requer a atuação do legislador federal e do executivo municipal para conferir densidade à determinação constitucional.

Essa constatação aponta para a impossibilidade de intervenção ampla e irrestrita do Poder Judiciário no controle de políticas públicas, mostrando-se um dos limites imanentes à sua atuação. Não convence a alegação de que em políticas públicas estabelecidas na Constituição da República haveria a legitimação da intervenção judicial, porque além de todas as políticas públicas terem fundamento constitucional, faltam ao Poder Judiciário conhecimentos específicos que Ihe permitam investigar diversos outros aspectos que condicionam a definição de planos de ação adequados.

A atuação do Poder Judiciário, nesse sentido, deve se limitar ao controle da conformidade 
constitucional da política pública. Infirmada determinada política pública, compete aos Poderes Legislativo e Executivo a sua reformulação.

\section{REFERÊNCIAS DAS FONTES CITADAS}

CANOTILHO, JJ Gomes. Direito constitucional e teoria da constituição. 7. ed., 2. reimpr. Coimbra: Edições Almedina, 2003.

CAPRA, Fritjof. As conexões ocultas: ciência para uma vida sustentável. trad. Marcelo Brandão Cipolla. São Paulo: Cultrix, 2005.

CLÈVE, Clèmerson Merlin; PEREIRA, Ana Lucia Pretto (coordenadores). Direito constitucional brasileiro: constituições econômica e social. vol. III. São Paulo: RT, 2014.

LEITE, Carlos; AWAD, Juliana diCesare. Cidades sustentáveis, cidades inteligentes: desenvolvimento sustentável num planeta urbano. Porto Alegre: Bookman, 2012. MEDAUAR, Odete; ALMEIDA, Fernando Dias Menezes de. Estatuto da cidade: Lei 10.257, de 10.07.2001, comentários. 2. ed. rev., atual. eampl. São Paulo: RT, 2004.

MILARÉ, Milaré. Direito ambiental: a gestão ambiental em foco: doutrina, jurisprudência, glossário. 7. ed. rev., atual. erefom. São Paulo: RT, 2011.

SECCHI, Leonardo. Análise de políticas públicas: diagnóstico de problemas, recomendação de soluções. São Paulo: Cengage Learning, 2016.

SILVA, José Afonso da. Aplicabilidade das normas constitucionais. 3. ed., 3. triag., rev., atual. e ampl. São Paulo: Malheiros, 1999.

STRECK, Lenio. Hermenêutica jurídica e(m) crise: uma exploração hermenêutica da construção do Direito. 10. ed. rev., atual. eampl. Porto Alegre: Livraria do Advogado Editora, 2011.

SUNDFELD, Carlos Ari; ROSILHO, André (org.). Direito da regulação e políticas públicas. São Paulo: Malheiros, 2014. 


\title{
O PRINCÍPIO DO NÃO RETROCESSO AMBIENTAL COMO GARANTIA DO MÍNIMO EXISTENCIAL
}

\author{
Elisangela Artmann Bortolini ${ }^{1}$
}

\section{INTRODUÇÃO}

De acordo com vários autores a relação entre o homem e o meio ambiente até meados do século XX foi baseada apenas em sistemas de exploração, sendo que somente na década de 70 deste mesmo século é que a questão ambiental passou a fazer parte das agendas internacionais e a integrar os fóruns mundiais de discussão ambiental.

O presente estudo tem por escopo a análise do princípio do não retrocesso ambiental com ênfase no direito fundamental que trata da garantia de um meio ambiente ecologicamente equilibrado como o mínimo existencial.

Importante salientar que tal princípio fundamenta-se nos dispositivos constitucionais e ocorre na medida em que é voltado a assegurar a vida e a dignidade da pessoa humana, preservando sua saúde e outros valores, sem os quais não se pode falar em vida humana digna, conforme preconizado pelos artigos 225 e 170, inciso $\mathrm{VI}$, e demais disposições gerais em matéria ambiental elencados na Constituição Federal de 1988.

Diante do exposto, o objetivo deste estudo é analisar o princípio do não retrocesso ambiental com ênfase na garantia do mínimo existencial, com base em discussões já alavancadas por estudiosos da temática.

A metodologia utilizada para o alcance dos objetivos foi a pesquisa bibliográfica, conceituada por $\mathrm{Gil}^{2}$ como sendo aquela obtida através de livros, revistas, trabalhos acadêmicos já publicados e quaisquer outros tipos de fontes escritas. Utilizou-se também o método indutivo na fase de investigação e o método cartesiano na fase de tratamento dos dados, enquanto que no relatório da pesquisa, foi empregada a base indutiva. Foram ainda utilizadas técnicas de

\footnotetext{
${ }^{1}$ Acadêmica do Curso de Mestrado Acadêmico em Ciência Jurídica da Universidade do Vale do Itajaí - UNIVALI, 2016. elisangela.artman@hotmail.com

${ }^{2}$ GIL, Antônio Carlos. Como elaborar projeto de pesquisa. 13. ed. São Paulo: Atlas, 2010.
} 
fichamento para apreensão dos conceitos e organização da discussão dos temas abordados.

O método indutivo é um processo mental que, para chegar ao conhecimento ou demonstração da verdade, parte de fatos particulares, comprovados, e tira uma conclusão genérica.

O método cartesiano, criado por René Descartes, consiste no Ceticismo Metodológico, ou seja, duvida-se de cada ideia que pode ser duvidada.

O estudo sobre o princípio do não retrocesso ambiental como garantia do mínimo existencial encontra-se estruturado em tópicos temáticos, que pontuam os principais conceitos e sua simultânea discussão; considerações finais e referências bibliográficas de autores e estudiosos que debatem sobre as questões ambientais, princípios básicos de dignidade humana, dentre outros que subsidiaram a pesquisa.

\section{PRESERVAÇÃO AMBIENTAL E DIGNIDADE HUMANA}

Como já mencionado a relação entre o homem e o meio ambiente até bem pouco tempo era baseada apenas em sistemas de exploração.

Segundo Milaré $^{3}$ esse paradigma exploratório passou a ser vislumbrado sob uma ótica diversa, a partir do século XX, uma vez que houve a percepção de que a devastação ambiental poderia colocar em risco a própria existência do homem.

Contudo, os diplomas que versavam sobre questões ambientais existentes até esta década, em sua grande maioria, apenas se preocupavam com as formas de exploração sob uma ótica utilitarista e não preservacionista, pontua o autor.

\subsection{Meio ambiente sustentável}

Como acima descrito, a forma como o homem sempre utilizou os recursos naturais e os danos causados ao ambiente, tanto pela extração como pela utilização desses recursos, nem sempre foram motivos de preocupação.

\footnotetext{
${ }^{3}$ MILARÉ, E. Direito do ambiente. A gestão ambiental em foco. 7. ed. São Paulo: Revista dos Tribunais, 2011. p. 61.
} 
Segundo Moradillo ${ }^{4}$, o conjunto de eventos degradativos, potencializados pelos avanços tecnológicos, são os principais fatores nas mudanças ocorridas no ecossistema global, dentre eles o clima, a poluição e a extinção.

A partir desta percepção, preocupados com o futuro do planeta, a Organização das Nações Unidas (ONU), juntamente com os Estados e a comunidade científica, realizou na década de setenta a primeira Conferência das Nações Unidas, sobre o Meio Ambiente Humano. Também conhecida como "Conferência de Estocolmo", o evento teve como objetivo tratar das questões relacionadas à degradação do meio ambiente. Realizada em junho de 1972, em Estocolmo capital da Suécia, a Conferência contou com a presença de chefes de estado de vários países, e é considerada um marco nas tentativas de melhorar as relações do homem com o meio ambiente, além de ter inaugurado a busca por equilíbrio entre desenvolvimento econômico e redução da degradação ambiental.

Em termos gerais, este foi o primeiro protocolo em nível mundial em defesa da sustentabilidade do meio ambiente, que o elevou à condição de direito fundamental, ou seja, "bem indispensável à vida". Esta condição de direito essencial foi abrigada e reinterada por outros documentos da ONU e, assim, o meio ambiente passou a ser reconhecido internacionalmente como objeto de proteção como condição sinequa non para a vida.

Assim, protegendo o meio ambiente através da prática correta do desenvolvimento sustentável, supostamente o homem poderia vivenciar uma melhor qualidade de vida paralelamente a um ambiente saudável e equilibrado, conforme enfatizado por vários autores, dentre estes Geraldo Eulálio do Nascimento Silva ${ }^{5}$.

Um ambiente sadio implica em ar e águas puras, isto é, atmosfera, rios, lagos e mares livres de poluição. A poluição dos rios e dos mares pela descarga de esgoto é sério atentado às populações e aos seus direitos, não só de desfrutar de um ambiente sadio, mas também contra o direito ao lazer, direito este de que ricos e pobres não abrem mão.

De acordo com o autor para se ter um meio ambiente ecologicamente equilibrado todos, sem exceção, devem tomar consciência de que a proteção ambiental é extremamente necessária para uma vida humana digna.

Entretanto, Prieur $^{6}$ adverte que,

\footnotetext{
${ }^{4}$ MORADILLO, E. F \& OKI, M. C. M. Educação ambiental na universidade: construindo possibilidades. Quim. Nova, Vol. $27,2004$.

${ }^{5}$ SILVA, Geraldo Eulálio do Nascimento e. Direito Ambiental Internacional. 2 ed. Rio de Janeiro: Thex, 2002. Pag.146.

${ }^{6}$ PRIEUR. Michel. O Princípio de Proibição de Retrocesso Ambiental. In: ROLLEMBERG, Rodrigo. (Org.) Princípio da Proibição de
} 
O objetivo principal do Direito Ambiental é o de contribuir à diminuição da poluição e à preservação da diversidade biológica. Contudo, no momento em que o Direito Ambiental é consagrado por um grande número de constituições como um novo direito humano, ele é paradoxalmente ameaçado em sua essência.

Significa dizer que a sustentabilidade ambiental ou ecológica, mesmo considerando um forte impacto nas atividades econômicas, tornou-se imprescindível para resolver problemas ambientais gerados pelo próprio ser humano, de modo que o planeta possa prover as necessidades do presente sem comprometer a capacidade de subsistência das gerações futuras. Para sua efetividade, não só os meios de produção devem mudar, mas toda a sociedade precisa educar suas ações, estabelecendo limites de consumo de modo a minimizar as agressões ao meio ambiente.

\subsection{Da dignidade da pessoa humana}

O princípio da dignidade da pessoa humana é um valor moral e espiritual inerente à pessoa, ou seja, todo ser humano é dotado desse preceito, e tal constitui o princípio máximo do estado democrático de direito.

Segundo Andrade ${ }^{7}$ a dignidade da pessoa humana é um conceito extremamente abrangente, com definição e delimitação amplas, haja vista englobar diversas concepções e significados.

Plácido e Silva ${ }^{8}$ define dignidade humana como sendo:

Dignidade, palavra derivada do latim dignitas (virtude, honra, consideração), em regra se entende a qualidade moral, que, possuída por uma pessoa serve de base ao próprio respeito em que é tida: compreende-se também como o próprio procedimento da pessoa pelo qual se faz merecedor do conceito público; em sentido jurídico, também se estende como a dignidade a distinção ou a honraria conferida a uma pessoa, consistente em cargo ou título de alta graduação; no Direito Canônico, indica o benefício ou prerrogativa de um cargo eclesiástico.

Assim sendo, ao tratar da proteção à vida, do direito à saúde, à moradia digna, garantindo a liberdade, a igualdade, o acesso à justiça, bem como quando trata do meio ambiente sustentável, capaz de atender às necessidades sociais presentes e futuras, o estado assegura a dignidade da pessoa humana. 
Nesse sentido, ao ser tratada como direito fundamental, a dignidade da pessoa humana reflete um valor inestimável, que constitui um dos pilares que sustenta a legitimação de atuação do Estado, coibindo qualquer ato que de alguma forma possa restringir essa atuação, em qualquer que seja a dimensão.

No Brasil, a Constituição de 1988 é considerada o marco legal de garantia da dignidade humana. Em diversos artigos, a Carta Magna referenda tal princípio como norteador do Estado Democrático de Direito, conforme apresentado a seguir, nas principais legislações do país.

\subsection{As principais legislações brasileiras de proteção ao meio ambiente}

Segundo Jacovine ${ }^{9}$ a criação das principais legislações ambientais e seu aperfeiçoamento se deram com o objetivo maior de proteger o meio ambiente.

“No Brasil, quer fosse como colônia, império ou república, sempre houve a prevalência de uma percepção intervencionista do Poder Público sobre a propriedade das florestas. Em sua história recente, o Brasil contou com dois Códigos Florestais: o de 1934, e o instituído em 1965." ${ }^{10}$

Criado em 1934, o primeiro código florestal foi instituído pelo governo de Getúlio Vargas, e concebia as primeiras disposições legais a respeito da preservação e utilização de áreas florestais brasileiras. $^{11}$

Pelo código florestal de 1934, instituído por meio do Decreto no 23.793, de 23-01-1934, reconheceu-se que as florestas eram de interesse da sociedade, sendo parte integrante da paisagem natural, portanto, a partir de então os proprietários de terras deveriam manter ao menos $25 \%$ da área de seus imóveis com a cobertura de mata original. Porém, não havia qualquer orientação sobre em qual parte das terras (margens dos rios ou outras) a floresta deveria ser preservada.

Importante enfatizar que nessa época o legislador já demonstrava preocupação com a preservação ambiental, ao criar a figura das florestas protetoras, para garantir a saúde de rios e lagos e áreas de risco (encostas íngremes e dunas), sendo que mais tarde, esse conceito deu

\footnotetext{
${ }^{9}$ JACOVINE, L.A.G. et al. Quantificação das áreas de preservação permanente e de reserva legal em propriedades da bacia do Rio Pomba-MG. R. Árvore, Viçosa-MG, v.32, n.2, 2008.

10 PRIOSTE, F.G.V; AVANCI, J; PACHER, L; VIEIRA,J. Mudanças na legislação ambiental e os reflexos na agricultura familiar camponesa e povos e comunidades tradicionais: subsídios técnicos e políticos para o debate. Curitiba, 2009. P. 4.

${ }^{11}$ MILARÉ, E. Direito do ambiente: doutrina, prática, jurisprudência. R. Atual e Ampliada. São Paulo-SP, v.22, n.2, 2001.
} 
origem às áreas de preservação permanente (APPs), inclusive localizadas em imóveis rurais.

Entretanto, devido às dificuldades encontradas para a efetiva implementação do Código Florestal de 1934, foi elaborado um novo código, instituído pela Lei no 4.771, publicado em 1965.

Em decorrência das imensas dificuldades verificadas para a efetiva implementação do Código Florestal de 1934, seja em decorrência da mentalidade exploratória do desenvolvimento empreendido até então, seja pela inércia, displicência ou resistência passiva ou deliberada das autoridades estaduais e municipais, elaborou-se a proposta para um novo diploma legal que pudesse normatizar adequadamente a proteção jurídica do patrimônio florestal brasileiro. ${ }^{12}$

O novo Código Florestal, editado em 1965 estabeleceu normas mais claras e bem definidas no que tange à preservação e conservação das florestas, definiu as Áreas de Preservação Permanente (APPs) e o conceito de Reserva Legal (RL) na manutenção da biodiversidade. ${ }^{13}$

Conforme enfatizado por Ahrens ${ }^{14}$ :

O novo projeto incorporou percepções bastante avançadas para a época, e que ainda perseveram na atualidade, refletindo numa política intervencionista do Estado sobre a propriedade imóvel agrária privada na medida em que "as florestas existentes no território nacional e as demais formas de vegetação, são bens de interesse comum a todos os habitantes do País".

Importante salientar que desde sua publicação o Código Florestal de 1965 passou por várias alterações, retificações e complementações por uma série de leis, decretos e resoluções do Conselho Nacional do Meio Ambiente (CONAMA).

“A situação dos últimos anos, em que uma parcela do setor ligado à produção agrícola, representado pela bancada ruralista, exerce pressão no Congresso para "flexibilizar" o Código Florestal, já ocorreu diversas vezes em formatos diferentes." ${ }^{15}$

Dessa forma, as duas primeiras edições do Código Florestal Brasileiro mesmo tendo a preocupação com a preservação ambiental não conseguiram atingir efetivamente, seus objetivos. O Primeiro editado em 1934, por não trazer orientações necessárias à determinação das áreas a serem preservadas e o segundo editado em 1965 por sofrer pressões, principalmente políticas,

\footnotetext{
${ }^{12}$ AHRENS, S. O “novo" código florestal brasileiro: conceitos jurídicos fundamentais. In: VIII Congresso Florestal Brasileiro, 25 a $28-$ 08-2003, São Paulo, SP. São Paulo: Sociedade Brasileira de Silvicultura; Brasília: Sociedade Brasileira de Engenheiros Florestais, 2003. P. 6

${ }^{13}$ GUIMARÃES, V.M.B.; CHIMENES, M,M.; ANDRADE, C.S.; BEZERRA, R.A.; LEMKE. A.P. II Congresso Brasileiro de Gestão Ambiental. Instituto Brasileiro de estudos ambientais. Londrina-PR, 2011. p. 37

${ }^{14}$ AHRENS, S. O “novo" código florestal brasileiro: conceitos jurídicos fundamentais. In: VIII Congresso Florestal Brasileiro, 25 a $28-$ 08-2003, São Paulo, SP. São Paulo: Sociedade Brasileira de Silvicultura; Brasília: Sociedade Brasileira de Engenheiros Florestais, 2003. P. 6

${ }^{15}$ MERCADANTE, M. As novas regras do Código Florestal: repercussão sobre a gestão dos recursos naturais na propriedade rural. In Seminário Interno sobre "Dilemas y Perspectivas para el Desarrollo Regional en Brasil, con Énfasis en El Agrícola y lo Rural en Brasil en la Primera Década del Siglo XXI". [S.I.]: Oficina Regional de la FAO para América Latina y el Caribe; 2001.
} 
que culminou em inúmeras alterações durante sua vigência. Em 2012 é editado um novo Código Florestal, ainda vigente.

Ressalta-se que na década de setenta a Conferência de Estocolmo, realizada em junho de 1972 que tratou das questões ambientais que passaram a fazer parte das agendas de vários países, dentre estes o Brasil, ao integrar os fóruns nacionais e internacionais de discussão ambiental, alavancou uma série de eventos relacionados à conscientização sobre a necessidade de preservação do meio ambiente como requisito primordial para a sobrevivência das espécies, inclusive a humana.

Dessa forma, considerado como um direito fundamental, a proteção ao meio ambiente foi inserida em várias Constituições passando a representar um direito constitucional, em que o meio ambiente ficaria tutelado ao poder público.

A Constituição Federal de 1988 trata da defesa do meio ambiente, em capítulo específico. A Carta Magna visa à proteção do meio ambiente, para que se resguarde, em última análise, a própria dignidade da pessoa humana, já que reconhece ser um meio ambiente ecologicamente equilibrado capaz de oferecer melhores condições de vida a todos os seres humanos.

Nesse sentido, o Jurista Celso Ribeiro Bastos nos lembra de que foi a partir da Constituição de 1988 que o meio ambiente passou a ser tratado como um princípio constitucional, o que para ele pode ser explicado em face de uma maior conscientização da humanidade para os problemas gerados pelo descaso com o meio ambiente, sendo imperativa a utilização de forma racional do mesmo, já que a humanidade necessita de um ambiente equilibrado e saudável para sua própria sobrevivência.

\footnotetext{
A defesa do meio ambiente é sem dúvida, um dos problemas mais cruciais da época moderna. Os níveis de desenvolvimento econômico, acompanhados da adoção de práticas que desprezam a preservação do meio ambiente, têm levado a uma gradativa deteriorização deste, a ponto de colocar em perigo a própria sobrevivência do homem. ${ }^{16}$
}

Legalmente, o art. 225 da Constituição Federal de 1988 trata da responsabilidade do Poder Público (em qualquer instância), no tocante às práticas ambientais ilícitas e danosas, ao incumbir o Poder Público de assegurar que todos tenham a possibilidade de usufruir de um ambiente ecologicamente equilibrado, em face de ser este de uso comum do povo, além de essencial à qualidade de vida sadia e, portanto, imprescindível para a efetividade da dignidade da pessoa

\footnotetext{
${ }^{16}$ BASTOS, Celso Ribeiro. Curso de Direito econômico. São Paulo: Celso Bastos, 2004. p. 156
} 
humana.

O direito ao meio ambiente ecologicamente equilibrado é um direito fundamental na medida em que é voltado a assegurar a vida e a dignidade da pessoa humana, preservando a saúde, a segurança, o sossego, o bem-estar da coletividade, e outros valores, sem os quais não se pode falar em vida humana digna ${ }^{17}$.

Assim sendo, ao regulamentar a matéria ambiental a Constituição Federal de 1988 assegura que: "Todos têm direito ao meio ambiente ecologicamente equilibrado" ${ }^{18}$. Ou seja, sob a ótica da Constituição Brasileira há expressa garantia de que todo o cidadão possa usufruir de um meio ambiente saudável.

Para tanto, os dispositivos constitucionais asseguram que cabe ao Poder Público garantir o controle da produção, a comercialização e a utilização de técnicas e métodos de produção de modo a não comprometer a preservação do meio ambiente. Nas palavras de Sodré ${ }^{19}$ : "Para assegurar a efetividade do direito a um meio ambiente ecologicamente equilibrado o Poder Público deverá 'controlar a produção, comercialização e o emprego de técnicas, métodos e substâncias que comportem risco para a vida, a qualidade de vida e o meio ambiente'."

Vale ressaltar que as leis pátrias promulgadas a partir da Constituição de 1988 deveriam atender a esse preceito legal estabelecido, passando a regulamentar a exploração e, principalmente, a conservação da natureza. Por isto, o meio ambiente passou, em razão da importância conferida a partir do texto constitucional, a condição de bem fundamental para a manutenção da vida, ganhando, desta forma, tutela especial no ordenamento nacional.

Ao elevar o meio ambiente à qualidade de bem de uso do povo e essencial para uma vida sadia, a Constituição de 1988 relaciona esse direito a um princípio básico, que é a dignidade da pessoa humana, previsto no artigo 1으 do mesmo diploma. Assim, o constituinte de 1988 equiparou o meio ambiente aos demais bens indispensáveis à vida tais como: saúde, educação, trabalho, lazer, previstos no artigo 6ㅇq que dispõe sobre a ordem social.

Todavia, em se tratando do meio ambiente ecologicamente equilibrado como direito

\footnotetext{
${ }^{17}$ YOSHIDA, Consuelo Moromizato Yatsuda. A proteção do Meio Ambiente e dos Direitos Fundamentais Correlatos no Sistema Constitucional Brasileiro. (IN): Temas Fundamentais de Direitos Difusos e Coletivos: Desafios e Perspectivas. Rio de Janeiro: Editora Lumen Juris, 2013. p. 3.

18 BRASIL. Constituição (1988). Constituição da República Federativa do Brasil. Brasília, DF: Senado Federal. $<$ www.planalto.gov.br/ccivil_03/constituicao/constituicaocompilado.htm>.Jan. 2017

${ }^{19}$ SODRÉ, Marcelo Gomes. Dignidade Planetária: O direito e o consumo sustentável. In: MIRANDA, Jorge; SILVA, Marco Antonio Marques da (coordenação). Tratado Luso-Brasileiro da Dignidade Humana. São Paulo: Quartier Latin, 2008. p. 1171.
} 
fundamental de todos, Silva ${ }^{20}$ nos ensina que: "O meio ambiente demanda uma proteção especial, já que versa sobre a qualidade de vida e também sobre a dignidade humana. Essa não só deve ser respeitada, mas principalmente protegida, de modo que a estabilidade seja garantida, independentemente de qualquer questão."

O Novo Código Florestal editado em 2012 estabelece normas gerais sobre a proteção da vegetação, áreas de Preservação Permanente e as áreas de Reserva Legal; a exploração florestal, o suprimento de matéria-prima florestal, o controle da origem dos produtos florestais e o controle e prevenção dos incêndios florestais, e prevê instrumentos econômicos e financeiros para o alcance de seus objetivos ${ }^{21}$.

O artigo 4ำ do referido código florestal atribui responsabilidade comum da União, Estados, Distrito Federal e Municípios, em colaboração com a sociedade civil, na criação de políticas para a preservação e restauração da vegetação nativa e de suas funções ecológicas e sociais nas áreas urbanas e rurais.

Dessa forma, pode-se afirmar que na atualidade há uma maior preocupação com a preservação do meio ambiente, ao se estabelecer leis mais rígidas que tratam da proteção ambiental, através de normas gerais com o fundamento central da proteção e uso sustentável das florestas e demais formas de vegetação nativa em harmonia com a promoção do desenvolvimento econômico, reconhecendo o meio ambiente como um bem de interesse comum a todos os habitantes do País.

Nesse contexto, como direito fundamental de todos, o meio ambiente demanda uma proteção especial, já que um meio ambiente ecologicamente equilibrado está associado a dignidade humana, posto que tende a propiciar uma melhor qualidade de vida.

Pelos motivos já elencados no decorrer do estudo observa-se que o meio ambiente deve ser protegido, de modo a garantir, independentemente de qualquer questão, uma melhor qualidade de vida aos seres humanos.

Partindo desse pressuposto, surge então o Princípio do Não retrocesso Ambiental estritamente relacionado ao princípio da segurança jurídica, que garante proteção aos direitos fundamentais contra a atuação do legislador que vise à supressão ou à redução dos níveis de

\footnotetext{
${ }^{20}$ SILVA. José Afonso. Direito ambiental constitucional. 4ạ ed. São Paulo: Malheiros. 2013. p. 43

${ }^{21}$ BRASIL. Lei n ${ }^{\circ}$ 12.727. Código Florestal. DF: Presidência da República Brasília, 2012.
} 
tutela desses direitos, conforme pontuado no item 2.

\section{DO PRINCÍPIO DO NÃO RETROCESSO AMBIENTAL}

O Princípio do Não Retrocesso Ambiental configura-se como garantia do mínimo existencial, ou seja, um meio ambiente ecologicamente equilibrado é um direito fundamental do ser humano visto que de sua efetividade dependerá a qualidade de vida das gerações atuais e também futuras.

“O Princípio do Não Retrocesso surgiu na Alemanha e em Portugal simultaneamente, tendo tratamento bem diferenciado em cada um destes países, em função da diversidade originária de cada região e dos problemas que deram início à sua aplicação." ${ }^{22}$

Pelo princípio do não retrocesso uma lei ao regulamentar um mandamento constitucional, instituir determinado direito, faz com que este se incorpore ao patrimônio jurídico da cidadania e não pode ser absolutamente suprimido ${ }^{23}$.

Desse modo, a proibição do retrocesso se fundamenta no princípio da segurança jurídica e em seus respectivos desdobramentos, guardando conexão com os limites materiais a emendas constitucionais, uma vez que tais institutos também guardam relação com a proibição de atos e medidas de caráter retroativo que venham, de algum modo, a afetar situações e posições jurídicas consolidadas.

Nesse contexto, o princípio do não retrocesso diz respeito mais especificamente a uma garantia de proteção dos direitos fundamentais (e da própria dignidade da pessoa humana) contra a atuação do legislador, tanto no âmbito constitucional quanto - e de modo especial infraconstitucional (quando estão em causa medidas legislativas que impliquem supressão ou restrição no plano das garantias e dos níveis de tutela dos direitos já existentes), mas também proteção em face da atuação da própria administração pública.

\footnotetext{
A proibição do retrocesso, de acordo com o entendimento consolidado na doutrina, consiste em um princípio constitucional implícito, tendo como fundamento constitucional, entre outros, o princípio da dignidade da pessoa humana, de direitos fundamentais, da segurança jurídica e seus desdobramentos, o dever de progressividade dos direitos sociais, econômicos, culturais e ambientais, apenas para citar os mais relevantes fundamentos jurídico-constitucionais invocados. ${ }^{24}$
}

\footnotetext{
${ }^{22}$ SARLET, Ingo Wolfgang. A Eficácia dos Direitos Fundamentais. 11a. ed. Porto Alegre: Livraria do Advogado, 2007. p. 37.

${ }^{23}$ BARROSO, L. R. O direito constitucional e a efetividade de suas normas. 5. ed. Rio de Janeiro: Renovar, 2001. p. 158.

${ }^{24}$ SARLET, I. W.; FENSTERSEIFER, T. Direito constitucional ambiental: constituição, direitos fundamentais e proteção do ambiente.
} 
Ou seja, Ingo Sarlet ${ }^{25}$ vê nos direitos fundamentais e na divisão dos poderes uma garantia aos cidadãos contra o arbítrio do Poder Público, pois aqueles direitos atribuem um conjunto de direitos subjetivos aos cidadãos contra os possíveis abusos realizados pelo Estado e esta separação constrói uma garantia orgânica que impossibilita o autoritarismo em virtude da autonomia entre Executivo, Legislativo e Judiciário.

Enquanto George Marmelstein ${ }^{26}$ destaca uma concepção mais ideológica dos Direitos Fundamentais, mas também com viés de limitação dos poderes.

[...] os direitos fundamentais são normas jurídicas, intimamente ligadas à ideia de dignidade da pessoa humana e de limitação de poder, positivadas no plano constitucional de determinado Estado Democrático de Direito, que, por sua importância axiológica, fundamentam e legitimam todo o ordenamento jurídico.

Nas palavras de Ferrajoli ${ }^{27}$, o sistema constitucional brasileiro, graças a positivação dos direitos fundamentais como normas supraordenadas a todo o ordenamento, apresenta uma certa funcionalização das instituições políticas em relação às pessoas, posto que no momento da positivação das garantias estas se tornaram a razão social dos direitos do cidadão. Estes direitos, ao mesmo tempo que são atribuídos a todos os cidadãos, são também imposições para sua garantia, além de representarem limites e vínculos a todos os poderes governantes.

Assim, observa-se que a efetividade da proteção ambiental depende não só da associação de medidas de desestímulo à degradação ambiental, ou seja, da relação homem x natureza, mas depende, sobretudo, do reconhecimento da proibição do retrocesso como princípio basilar do direito ambiental. Somente por meio da conscientização ecológica e de uma segurança jurídica será possível criar condições para um meio ambiente sustentável e assim galgar melhor qualidade de vida no planeta.

Desse modo, não raramente se observa tanto na literatura quanto na prática, doutrinadores e ambientalistas consagrados apelarem a toda comunidade internacional, para que busquem o desenvolvimento sustentável, já que somente assim poderá se ter uma sociedade

2. ed. São Paulo: Revista dos Tribunais, 2012. p. 197.

${ }^{25}$ SARLET, Ingo Wolfgang. A Eficácia do direito fundamental à segurança jurídica: dignidade da pessoa humana, direitos fundamentais e proibição de retrocesso social no direito constitucional brasileiro. Disponível em: <http://www.mundojuridico.adv.br>. Acesso em: 3 out. 2009. p. 33.

${ }^{26}$ MARMELSTEIN, George. Curso de Direitos Fundamentais. p. 17, apud DEMARCHI, Clovis, et al. Ativismo Judicial e Judicialização de Políticas Públicas: A teoria da Separação dos Poderes no Ambiente Transnacional Assimétrico. Da possibilidade de angariar efetividade aos direitos fundamentais através do ativismo judicial. Livraria Eletrônica Univali. 2016. Página 13

${ }^{27}$ FERRAJOLI, Luigi. A democracia através dos direitos. O constitucionalismo garantista como modelo teórico e como projeto político. Tradução de Alexandre Araujo de Souza et al. São Paulo. Revista dos Tribunais. 2015.p. 82. 
evoluída, em termos de economia e ambiente equilibrado.

Assim sendo, um recuo na proteção ambiental, regressão esta totalmente repelida pelo Princípio do não retrocesso, consistiria numa retroação não somente ambiental, mas, principalmente, jurídico e cultural, já que tal atitude iria na contramão a todas as conquistas jurídicas já consolidadas em prol do ambiente sustentável.

\section{CONSIDERAÇÕES FINAIS}

Considerando que a evolução do pensamento ecológico no decorrer do século XX culminou, no Brasil, no reconhecimento do direito fundamental a um meio ambiente ecologicamente equilibrado e na constitucionalização da tutela ambiental a partir de uma série de princípios e regras voltados para a manutenção da qualidade do meio ambiente em níveis compatíveis com a dignidade humana e com o pleno desenvolvimento do indivíduo.

Considerando que, a partir desses pressupostos, o presente artigo buscou trazer uma visão geral das questões ambientais e a implicação da não preservação do meio ambiente na qualidade de vida humana, mostrando a importância das leis ambientais, em especial ao princípio do não retrocesso ambiental como garantia do mínimo existencial.

Considerando que o objetivo da pesquisa não foi esgotar a discussão dos temas abordados pelo estudo e sim de enfatizar a importância do não retrocesso dos direitos adquiridos, especialmente em relação ao meio ambiente, entende-se que na atualidade o direito ambiental encontra-se alçado à categoria de direito fundamental, e, portanto, a proibição do retrocesso tornou-se um princípio geral do direito do direito ambiental, provocando a necessidade de maior comprometimento de todos com as questões ambientais para que se possa almejar um meio ambiente ecologicamente equilibrado, a fim de garantir uma melhor qualidade de vida, preservando assim a dignidade da pessoa humana, preconizada pelo Estado democrático de direito.

Dessa forma conclui-se que apesar de ser de responsabilidade do poder público garantir a preservação do meio ambiente e consequentemente uma melhor qualidade de vida à população, esta é uma missão de todos nós restando-nos o despertar de uma consciência ecológica de preservação ambiental, ao percebermos a importância da relação harmoniosa entre homem e 
meio ambiente para a sobrevivência humana.

\section{REFERÊNCIA DAS FONTES CITADAS}

ANDRADE, Vander Ferreira. A dignidade da pessoa humana. São Paulo: Cautela, 2007.

BASTOS, Celso Ribeiro. Curso de Direito econômico. São Paulo: Celso Bastos, 2004.

BARROSO, L. R. O direito constitucional e a efetividade de suas normas. 5. ed. Rio de Janeiro: Renovar, 2001.

BRASIL. Código Florestal de 1934. Brasília: Senado Federal, 1934.

. Lei no 4771, de 15 de setembro de 1965. Institui o Código Florestal. Brasília: Senado Federal. 1965.

. Lei $\mathbf{n}^{\circ} \mathbf{1 2 . 7 2 7}$, de 17 de outubro de 2012. Altera a Lei no 12.651, de 25 de maio de 2012, que dispõe sobre a proteção da vegetação nativa; altera as Leis nos 6.938, de 31 de agosto de 1981, 9.393, de 19 de dezembro de 1996, e 11.428, de 22 de dezembro de 2006; e revoga as Leis nos 4.771, de 15 de setembro de 1965, e 7.754, de 14 de abril de 1989, a Medida Provisória no 2.166-67, de 24 de agosto de 2001, o item 22 do inciso II do art. 167 da Lei no 6.015, de 31 de dezembro de 1973, e o § 20 do art. 4 o da Lei no 12.651, de 25 de maio de 2012. Diário Oficial União. República Federativa do Brasil, Brasília, DF, 18 out 2012.

BRASIL. Constituição (1988). Constituição da República Federativa do Brasil. Brasília, DF: Senado Federal. <www.planalto.gov.br/ccivil_03/constituicao/constituicaocompilado.htm>. Acesso em jan. 2017

GIL, Antônio Carlos. Como elaborar projeto de pesquisa. 13. ed. São Paulo: Atlas, 2010.

GUIMARÃES, V.M.B.; CHIMENES, M,M.; ANDRADE, C.S.; BEZERRA, R.A.; LEMKE. A.P. II Congresso Brasileiro de Gestão Ambiental. Instituto Brasileiro de estudos ambientais. Londrina-PR, 2011.

JORGE. Frederico Welington, et al. Princípio da proibição do retrocesso em matéria socioambiental: Estudo das teorias de Michel Prieur. (Não) Podemos retroagir às leis ambientais. Livro Eletrônico. Itajaí: UNIVALI, 2015. - v. 1.

MERCADANTE, M. As novas regras do Código Florestal: repercussão sobre a gestão dos recursos 
naturais na propriedade rural. In Seminário Interno sobre "Dilemas y Perspectivas para el Desarrollo Regional en Brasil, con Énfasis en El Agrícola y lo Rural en Brasil en la Primera Década del Siglo XXI". [S.I.]: Oficina Regional de la FAO para América Latina y el Caribe; 2001.

MILARÉ, E. Direito do ambiente. A gestão ambiental em foco. 7. ed. São Paulo: Revista dos Tribunais, 2011.

MORADILLO, E. F \& OKI, M. C. M. Educação ambiental na universidade: construindo possibilidades. Quim. Nova, Vol. 27, 2004.

SARLET, Ingo Wolfgang. A Eficácia dos Direitos Fundamentais. 11a.. ed. Porto Alegre: Livraria do Advogado, 2007.

SARLET, I. W.; FENSTERSEIFER, T. Direito constitucional ambiental: constituição, direitos fundamentais e proteção do ambiente. 2. ed. São Paulo: Revista dos Tribunais, 2012.

SILVA. José Afonso. Direito ambiental constitucional. 4. ed. São Paulo: Malheiros. 2013.

SODRÉ, Marcelo Gomes. Dignidade Planetária: O direito e o consumo sustentável. In: MIRANDA, Jorge; SILVA, Marco Antonio Marques da (coordenação). Tratado Luso-Brasileiro da Dignidade Humana. São Paulo: Quartier Latin, 2008.

YOSHIDA, Consuelo Moromizato Yatsuda. A proteção do Meio Ambiente e dos Direitos Fundamentais Correlatos no Sistema Constitucional Brasileiro. (IN): Temas Fundamentais de Direitos Difusos e Coletivos: Desafios e Perspectivas. Rio de Janeiro: Editora Lumen juris, 2013. 


\title{
A PROTEÇÃO LEGAL DA VEGETAÇÃO DE RESTINGA PARA FINS DE CARACTERIZAÇÃO COMO ÁREA DE PRESERVAÇÃO PERMANENTE À LUZ DO NOVO CÓDIGO FLORESTAL BRASILEIRO (LEI 12.651/2012)
}

\author{
Ítalo Augusto Mosimann ${ }^{1}$ \\ José Edilson da Cunha Fontenelle Neto²
}

INTRODUÇÃO

Este artigo científico tem por escopo analisar as interpretações existentes acerca da proteção legal da vegetação de restinga para fins de caracterização como área de preservação permanente, realizando exame descritivo sobre o tema pesquisado a partir de análise legal e jurisprudencial acerca da evolução normativa e doutrinária da matéria.

A questão a que este trabalho se propõe a investigar e equacionar, portanto, está umbilicalmente vinculada à seguinte indagação: Considerando o conceito legal de restinga para fins de caracterização como área de preservação permanente protegida no Código Florestal Brasileiro (Lei 12.651/2012), qual a interpretação deve prevalecer acerca da proteção deste bioma para fins de tutela ambiental? Considera-se de preservação permanente a restinga apenas enquanto vegetação fixadora de dunas e estabilizadora de mangue (conjugando, assim, o aspecto da flora com o geológico), ou se pode considerar protegido qualquer local onde se apresente a vegetação típica de restinga, independentemente da existência ou não do acidente geográfico 'restinga'?

O tema mostra-se relevante e atual, pois, até recentemente, havia consenso que apenas poderia ser considerada de preservação permanente a 'vegetação de restinga' que exercesse a função de fixadora de dunas ou de estabilizadora de mangues, de modo a aliar os conceitos do tipo de vegetação e ocorrência de formação geológica (dunas ou mangue). A própria Lei da Mata Atlântica permite que a 'vegetação de restinga' seja suprimida dentro de certos critérios definidos

\footnotetext{
${ }^{1}$ Mestrando em ciência jurídica pela Universidade do Vale do Itajaí - UNIVALI, na linha de pesquisa Direito, Desenvolvimento Urbano e Meio Ambiente. Advogado inscrito na OAB/SC sob o n.o 16.498. E-mail: italo@mh.adv.br

${ }^{2}$ Mestrando em ciência jurídica pela Universidade do Vale do Itajaí - UNIVALI, na linha de pesquisa Direito, Desenvolvimento Urbano e Meio Ambiente. Advogado inscrito na OAB/SC sob o n.o OAB/SC sob o n. 45658. E-mail: jedneto2@hotmail.com
} 
de preservação.

Após a edição do atual Código Ambiental Brasileiro e, principalmente, após o voto do Ministro Herman Benjamin, do Superior Tribunal de Justiça, no Recurso Especial 945.898/SC, órgãos ambientais, magistrados e membros do Ministério Público passaram a interpretar que o termo 'restinga' constante do art. $3^{\circ}, \mathrm{XVI}$, da $12.651 / 12$, teria sido concebido para proteger a 'vegetação de restinga' como fixadora de dunas ou estabilizadora de mangues, independentemente de ela (restinga) ocorrer ou não sobre um acidente geográfico 'restinga', associando a vegetação (de restinga) com o acidente geográfico duna ou mangue.

Os defensores deste entendimento, utilizando-se de conceitos de proteção ambiental (princípio da precaução, utilidade social, segurança jurídica, supremacia do interesse público sobre o privado) conferem interpretação ampliativa que representa mudança efetiva de enfrentamento da questão sob o ponto de vista hermenêutico e ao espectro da proteção legal da restinga.

Eventual mudança de orientação sobre a questão, entretanto, deve ser analisada de forma cautelosa, dada à ausência de consenso legislativo e, principalmente, tendo em vista a repercussão e efeitos em toda a região litorânea do Brasil, devendo-se ponderar, ainda, com o devido critério, outras vertentes que não somente a literal disposição de lei acerca da matéria, como a preservação de direitos e garantias fundamentais, bem como princípios jurídicos que não somente os de proteção ambiental, como os princípios constitucionais da segurança jurídica, da legalidade, da proporcionalidade, da razoabilidade, da independência dos poderes, entre outros.

Para a realização deste trabalho adotou-se, metodologicamente, a pesquisa bibliográfica, cujo método de abordagem foi o dedutivo, partindo de premissas gerais e culminando na análise de modo específico.

\section{A PROTEÇÃO DA VEGETAÇÃO DE RESTINGA NA VIGÊNCIA DO CÓDIGO FLORESTAL DE 1965 (LEI}

\subsection{1/65)}

$\mathrm{O}$ art. $2^{\circ}$, ' $f$ ', do Código Florestal de 1965 (Lei 4.771/65) estabelecia que "consideram-se de preservação permanente, pelo só efeito desta Lei, as florestas e demais formas de vegetação natural situadas: [...] f) nas restingas, como fixadoras de dunas ou estabilizadoras de mangues" ${ }^{3}$.

\footnotetext{
${ }^{3}$ BRASIL. Lei no 4.771 de 31 de agosto de 1965. Disponível em: <www.planalto.gov.br/ccivil_03/leis/L6938.htm>. Acesso em: 14 de janeiro de 2017.
} 
Da análise do dispositivo legal exsurge claramente a intenção do legislador em proteger a vegetação existente em locais específicos (e não a própria vegetação em si), tanto que se refere a "formas de vegetação situadas [...] ao longo dos rios [...] ao redor das lagoas [...] nas nascentes [...] nas encostas [...] nas restingas [...] nas bordas das chapadas" ${ }^{4}$, etc.

Assim, a interpretação correta para o dispositivo parece ser a que considera área de preservação permanente (APP) tão somente a vegetação que ocorre sobre o acidente geográfico 'restinga', e mesmo assim, somente quando possui (a vegetação ali existente) a função de 'fixar dunas' ou 'estabilizar mangues', levando-se em consideração que 'dunas' e 'mangues' são ocorrências possíveis no ecossistema denominado de 'restinga' que merecem ter a sua proteção vegetal resguardada.

Inclusive, historicamente, para que uma vegetação fosse considerada área de preservação permanente para efeito da aplicação do art. $2^{\circ}$, ' f', da revogada Lei 4.771/65, a mesma deveria: (a) ocorrer sobre um acidente geográfico denominado 'restinga' (que possui contornos próprios); (b) ocorrer em uma restinga que tivesse a presença ou de dunas (que também possui conceito próprio) ou de mangue (conceito próprio); (c) que tivesse a função de fixar as dunas existentes ou estabilizar o mangue existente.

Esta sempre foi a interpretação predominante acerca da proteção da vegetação de restinga durante décadas de vigência da Lei 4.771/65, como bem salienta Joel de Menezes Niebuhr, em artigo cientifico intitulado "As restingas como áreas de preservação permanente"

O fundamental é perceber que a alínea ' $f$ ' do artigo $2^{\circ}$ da Lei 4.771/65 protege apenas a vegetação que se situa sobre o acidente geográfico restinga. A Lei não protege a vegetação por si só. Ou seja, se a vegetação, que costuma encobrir restinga, encobrir outros tipos de acidentes geográficos, como planícies marinhas, rampas de dissipação, etc., ela não é por si só protegida. Repita-se: pela dicção unívoca da alínea ' $f$ ' do artigo $2^{\circ}$ da Lei $n^{\circ} 4.771 / 65$, a vegetação só é protegida se encobre o acidente geográfico restinga.

Ora, a vegetação que não encobre restinga não pode ser reputada como de preservação permanente. Se a vegetação encobre outros acidentes geográficos, tais como planícies marinhas ou rampas de dissipação, ela não se qualifica como de preservação permanente, ainda que apresente espécies que também costumam encobrir restingas. A Lei $n^{\circ} 4.771 / 65$ não protege vegetação que encobre planície marinha, rampa de dissipação ou outros acidentes geográficos: ela protege

\footnotetext{
${ }^{4}$ BRASIL. Lei no 6.938 de 31 de agosto de 1981. Disponível em:<www.planalto.gov.br/ccivil_03/leis/L6938.htm>. Acesso em: 18 de agosto de 2016.

${ }^{5}$ NIEBUHR, Joel de Menezes. As restingas como áreas de preservação permanente. In: Revista da Escola Superior da Magistratura do Estado de Santa Catarina. v. 15 (jun. 2003), p. 41-50. Florianópolis. Escola Superior da Magistratura do Estado de Santa Catarina, 2003.
} 
somente a vegetação que encobre restinga. Essa conclusão é óbvia, deflui da singela leitura do artigo $2^{\circ}$ da Lei $n^{\circ} 4.771 / 65$. Negá-la é o mesmo que negar a lei!

Interpretação diversa, além de gritantemente contra legem, levaria ao incomensurável absurdo de se considerar área de preservação permanente praticamente toda a costa brasileira, haja vista que a vegetação que costuma encobrir a restinga se estende por toda a extensão dela.

[...] Soma-se a isso o fato de que a vegetação de restinga somente é qualificada como de preservação permanente se prestante a fixar dunas ou a estabilizar mangues. Quer dizer que nem a vegetação situada na restinga é por si só merecedora da proteção legal. Só o será se evidenciada a funcionalidade dela em relação às dunas e aos mangues e, por obséquio, ao princípio da proporcionalidade, na medida em que realmente for útil a tal propósito".

No mesmo sentido, Márcio Silva Pereira e Renata O. P. Castanho, em 'A restinga na Resolução CONAMA 303/02' ${ }^{6}$ consideram que:

Desde 1965, a vegetação existente nas restingas é considerada de preservação permanente pelo só efeito da Lei 4.771/65 (Código Florestal, art. 2ํ, alínea "f").

De lá pra cá, a força e efetividade desse indiscutível avanço legal, em matéria de proteção florestal, têm sido reforçadas por sucessivos atos regulamentares. Não obstante, ainda persiste dúvida na caracterização dessa situação de preservação permanente, em razão da falta de precisão técnica na sua regulamentação.

De fato, tem-se vivido uma situação de insegurança jurídica por conta de atos regulamentares editados em desacordo com a lei e aplicados em flagrante descompasso com a própria realidade do litoral brasileiro.

O maior equívoco consiste no emprego do conceito de restinga, pelas Resoluções do CONSELHO NACIONAL DO MEIO AMBIENTE, ora para designar uma formação geológica, ora para formação vegetal de domínio de mata atlântica, como o fez a Resolução 303/02.

[...] O que se considera de preservação permanente é a vegetação que encobre a formação geológica denominada restinga.

Neste sentido, vale citar, a título de esclarecimento, a definição de restinga: “1. Geog. Faixa ou língua de areia, depositada paralelamente ao litoral, devido ao dinamismo destrutivo e construtivo das águas oceânicas. Esses depósitos são feitos com apoio em pontas ou cabos, podendo barrar uma série de pequenas lagoas. P.ex., a restinga da Marambaia, ao sul do Município do Rio de Janeiro. 2. A vegetação típica desses ecossistemas".

[...] Todavia, embora esse tipo de vegetação também ocorra sobre outros acidentes geográficos, como planícies marinhas, é bom esclarecer que, nestes casos, não se caracterizará como de preservação permanente.

No mesmo sentido, a Resolução n. 04 do Conselho Nacional do Meio Ambiente - CONAMA, em $1985^{7}$, conceituou 'restinga', para efeito da aplicação da Lei 4.771/65, como:

6 PEREIRA, Marcio Silva. CASTANHO, Renata O. P. A Restinga na Resolução CONAMA 303/02. In:

http://www.milare.adv.br/artigos/conama302.htm>. Acesso em 14 de janeiro de 2017.

BRASIL. CONAMA, Resolução 04 , de 18 
Art. 2o - Para efeitos desta Resolução são estabelecidas as seguintes definiç̧̃̃es:

$[\ldots]$

2. restinga - acumulação arenosa litorânea, paralela à linha da costa, de forma geralmente alongada, produzida por sedimentos transportados pelo mar, onde se encontram associações vegetais mistas características, comumente conhecidas como 'vegetação de restingas.

Vê-se claramente que o conceito de restinga proposto pelo CONAMA para efeito da aplicação do art. $2^{\circ}$, 'f', da Lei $4.771 / 65$, é totalmente adequado ao escopo da lei então vigente, caracterizado como acidente geográfico, dispondo, ainda, que no acidente geográfico se encontram, normalmente, espécies comumente conhecidas como 'vegetação de restinga'.

Avançando na evolução legal e regulamentar, a Resolução $n^{\circ} 303 / 2002$ do CONAMA $^{8}$ também não se afastou da conceituação de 'restinga' como formação geológica para efeito de regulamentar a proteção conferida pela Lei 4.771/65:

Art. 2ํ Para os efeitos desta Resolução, são adotadas as seguintes definições:

$[\ldots]$

VIII - restinga: depósito arenoso paralelo a linha da costa, de forma geralmente alongada, produzido por processos de sedimentação, onde se encontram diferentes comunidades que recebem influência marinha, também consideradas comunidades edáficas por dependerem mais da natureza do substrato do que do clima. A cobertura vegetal nas restingas ocorrem mosaico, e encontra-se em praias, cordões arenosos, dunas e depressões, apresentando, de acordo com o estágio sucessional, estrato herbáceo, arbustivos e arbóreo, este último mais interiorizado

Não há dúvida, portanto, que, desde sempre, a proteção volta-se ao acidente geográfico e não à vegetação em si que ali costuma se manifestar. E mais, que a vegetação que costuma ocorrer sobre a restinga não se confunde com o acidente geográfico restinga, sendo certo que 0 art. $2^{\circ}$, ' $f$ ', da Lei $4.771 / 65$, protegeu apenas a vegetação porventura existente sobre 0 acidente geográfico restinga e tão somente quando essa vegetação tenha a função de fixar dunas ou estabilizar mangues (ecossistemas que podem ocorrer em um acidente geográfico como a 'restinga'). E nem poderia se imaginar algo diferente, eis que a ocorrência da comumente chamada 'vegetação de restinga' está disseminada em praticamente todo o litoral brasileiro, sendo impossível a ocupação do solo caso simplesmente se determinasse, genericamente, que toda a 'vegetação de restinga' é de preservação permanente.

Isto não significa, no entanto, que a proteção da vegetação de restinga tenha ficado à

\footnotetext{
http://www.mma.gov.br/port/conama/legiabre.cfm?codlegi=21. Acesso em: 18 de janeiro de 2017.

8 CONAMA, Resolução 303 de 20 de março de 2002. Disponível em: http://www.mma.gov.br/port/conama/legiano1.cfm?codlegitipo=3\&ano=todos. Acesso em: 18 de janeiro de 2017.
} 
margem da lei, vez que albergada pelo Decreto $n^{\circ} 750 / 93$, que trata da proteção da mata atlântica. Ocorre que a vegetação caracterizada como 'mata atlântica' para efeito da aplicação da legislação não é considerada, por si só, como de preservação permanente, sendo possível a sua supressão em casos específicos, com a autorização dos órgãos ambientais competentes, considerados, principalmente, as características e os estágios de regeneração ('vegetação primária' ou 'secundária', em 'estágio de regeneração - inicial, médio ou avançado').

Nesse sentido, a Resolução CONAMA $n^{\circ} 10 / 1993^{9}$, visando a estabelecer parâmetros básicos para a análise dos estágios de sucessão da Mata Atlântica e aplicabilidade aos arts. $3^{\circ}, 6^{\circ} \mathrm{e}$ $7^{\circ}$, do Decreto $n^{\circ} 750 / 93$, estabeleceu que:

Artigo 4ㅇ - A caracterização dos estágios de regeneração da vegetação, definidos no artigo 3 desta Resolução, não é aplicável aos ecossistemas associados às formações vegetais do domínio da Mata Atlântica, tais como manguezal, restinga, campo de altitude, brejo interiorano e encrave florestal do nordeste.

Parágrafo Único - Para as formações vegetais referidas no "caput" deste artigo, à execução de manguezal, aplicam-se as disposições contidas nos parágrafos 1으 e 2 o do artigo 10 desta Resolução, respeitadas a legislação protetora pertinente, em especial a Lei 4.771, de 15 de Setembro de 1965, a Lei 5.197, de 03 de Janeiro de 1967, a Lei 6.902, de 27 de Abril de 1981, a Lei 6.938 de 31/02/91, e a Resolução/CONAMA/ 004, de 18 de Setembro de 1985.

Artigo 5ㅇ - As definições adotadas para as formações vegetais de que trata o artigo 4으, para efeito desta Resolução, são as seguintes:

$[\ldots]$

II - Restinga - vegetação que recebe influência marinha, presente ao longo do litoral brasileiro, também considerada comunidade edáfica, por depender mais da natureza do solo do que do clima. Ocorre em mosaico e encontra-se em praias, cordões arenosos, dunas e depressões, apresentando de acordo com o estágio sucessional, estrato herbáceo, arbustivo de arbóreo, este último mais interiorizado.

Posteriormente, com o fito de regulamentar os parâmetros para se definir os estágios sucessionais ('inicial', 'médio' e 'avançado') de regeneração da 'vegetação de restinga' (que não se confunde com o acidente geográfico protegido pela Lei 4.771/65!) para o Estado de Santa Catarina (associado à Mata Atlântica), para efeito de aplicação do art. $6^{\circ}$ do Decreto $n^{\circ} 750 / 93^{10}$, o CONAMA baixou a Resolução $261 / 1999^{11}$, do seguinte teor:

\footnotetext{
9 BRASIL. CONAMA, Resolução 10, de 01 de outubro de 1993. Disponível em: http://www.mma.gov.br/port/conama/res/res93/res1093.html. Acesso em: 19 de janeiro de 2017.

10 "A definição de vegetação primária e secundária nos estágios avançado, médio e inicial de regeneração da Mata Atlântica será de iniciativa do IBAMA, ouvido o órgão competente, aprovado pelo CONAMA".

11 BRASIL. CONAMA, Resolução 261, de 30 de junho de 1999 . Disponível em: http://www.mma.gov.br/port/conama/legiabre.cfm?codlegi=260. Acesso em: 19 de janeiro de 2017.
} 
“Considerando o disposto no artigo $6^{\circ}$ do Decreto n. 750, de 10 de fevereiro de 1993, resolve:

Art. $1^{\circ}$ - Aprovar, como parâmetro básico para análise dos estágios sucessionais de VEGETAÇÃO DE RESTINGA para o Estado de Santa Catarina, as diretrizes constantes no Anexo desta Resolução.

\section{ANEXO \\ INTRODUÇÃO}

Entende-se por restinga um conjunto de ecossistemas que compreende comunidades vegetais florísticas e fisionomicamente distintas, situadas em terrenos predominantemente arenosos, de origens marinha, fluvial, lagunar, eólica ou combinações destas, de idade quaternária, em geral com solos pouco desenvolvidos. Estas comunidades vegetais formam um complexo vegetacional edáfico e pioneiro, que depende mais da natureza do solo que do clima, encontrando-se em praias, cordões arenosos, dunas e depressões associadas, planícies e terraços.

A vegetação de restinga compreende formações originalmente herbáceas, subarbustivas, arbustivas ou arbóreas, que podem ocorrer em mosaicos e também possuir áreas ainda naturalmente desprovidas de vegetação; tais formações podem ter-se mantido primárias ou passado a secundárias, como resultado de processos naturais ou de intervenções humanas. Em função da fragilidade dos ecossistemas de restinga, sua vegetação exerce papel fundamental para a estabilização dos sedimentos e a manutenção da drenagem natural, bem como para a preservação da fauna residente e migratória associada à restinga e que encontra neste ambiente disponibilidade de alimentos e locais seguros para nidificar e proteger-se dos predadores.

A vegetação de ambientes rochosos associados à restinga, tais como costões e afloramentos, quando composta por espécies também encontradas nos locais citados no primeiro parágrafo, será considerada como vegetação de restinga, para efeito desta Resolução. A vegetação encontrada nas áreas de transição entre a restinga e as formações da floresta ombrófila densa, igualmente será considerada como restinga. As áreas de transição entre a restinga e o manguezal, bem como entre este e a floresta ombrófila densa, serão consideradas como manguezal, para fins de licenciamento de atividades localizadas no Domínio Mata Atlântica.

A composição florística e estrutural das três fitofisionomias originais ou primárias da restinga e de seus estágios sucessionais passa a ser caracterizada a seguir.

\section{RESTINGA HERBÁCEA E/OU SUBARBUSTIVA}

Vegetação composta por espécies predominantemente herbáceas ou subarbustivas, atingindo geralmente até cerca de 1 (um) metro de altura, apresentando uma diversidade relativamente baixa de espécies. Está presente principalmente em: praias, dunas frontais e internas (móveis, semifixas e fixas), lagunas e suas margens, planícies e terraços arenosos, banhados e depressões. Na restinga herbácea e/ou subarbustiva, em função de uma morfodinâmica intensa (causada pela instável ação de ondas, ventos, chuvas e marés), não são definidos estágios sucessionais naturais ou decorrentes de atividades humanas. 
2.1 - Vegetação de praias e dunas frontais

a) A vegetação é constituída predominantemente por plantas herbáceas geralmente providas de estolões ou rizomas, com distribuição geralmente esparsa ou formando touceiras, podendo compreender vegetação lenhosa, com subarbustos em densos agrupamentos, fixando e cobrindo totalmente o solo. Corresponde aos agrupamentos vegetais mais próximos do mar, recebendo maior influência da salinidade marinha, através de ondas e respingos levados pelo vento.

b) Predominância dos estratos herbáceo e/ou subarbustivo.

c) A altura das plantas geralmente não ultrapassa 1 (um) metro.

d) As epífitas são inexistentes ou raras.

Logo em seguida, com o mesmo objetivo da Resolução 261/1999, o CONAMA baixou a Resolução $n^{\circ} 417 / 2009^{12}$ para o âmbito nacional, deixando claro no preâmbulo

a necessidade de se definir vegetação primária e parâmetros básicos para análise dos estágios sucessionais secundários nas distintas fitofisionomias de Restinga, na Mata Atlântica, visando estabelecer critérios a fim de orientar o licenciamento e outros procedimentos administrativos relativos à autorização de atividades nessas áreas.

Ou seja, de maneira clara e inequívoca, assentou a Resolução CONAMA n. 417/2009 que a 'vegetação de restinga' efetivamente é passível de licenciamento ambiental e utilização por atividades da iniciativa privada, não podendo ser considerada área de preservação permanente, por consequência lógica.

Acontece que as Resoluções CONAMA n 10/93 e 261/1999 acabaram por utilizar conceitos distintos de acidente geográfico e de vegetação sem o cuidado de esclarecer adequadamente quanto estava a tratar de um ou de outro caso, dando a entender, erroneamente, que o termo 'restinga' poderia se referir apenas à vegetação, quando resta claro, pelo que foi explicitado, que o termo refere-se a acidente geográfico específico e delimitado.

A diferença, entretanto, entre 'restinga' e 'vegetação de restinga', restou evidenciada por trecho da própria Resolução $10 / 93^{13}$, quando prescreve que: “Em função da fragilidade dos ecossistemas de restinga, sua vegetação exerce papel fundamental para a estabilização dos sedimentos [...]". Seria um tanto melhor, no entanto, para não gerar equívocos interpretativos como os que se sucederam a esses textos, fosse feita distinção expressa entre 'restinga' e 'vegetação de restinga', extirpando, também, insegurança jurídica sobre a questão.

\footnotetext{
12 BRASIL. CONAMA, Resolução 417, de 23 de novembro de 2009 . Disponível em: www.mma.gov.br/port/conama/legiabre.cfm?codlegi=617. Acesso em: 19 de janeiro de 2017.

13 BRASIL. CONAMA, Resolução 10, de 01 de outubro de 1993. Disponível em: http://www.mma.gov.br/port/conama/res/res93/res1093.html. Acesso em: 19 de janeiro de 2017.
} 
O fato é que, a partir destes e outros equívocos na edição de atos normativos sobre a matéria, segmentos passaram a defender que o termo 'restinga' constante do art. $2^{\circ}$, ' $f$ ', Lei 4.771/65, teria sido concebido para proteger a 'vegetação de restinga' como fixadora de dunas ou estabilizadora de mangues, independentemente de ela ocorrer ou não sobre um acidente geográfico 'restinga', associando a vegetação (de restinga) com o acidente geográfico duna ou mangue. Os defensores deste entendimento (alguns membros do Ministério Público e poucos órgãos ambientais) procuraram ampliar indevidamente, sem o consenso legislativo, o espectro da proteção legal. A tese, no entanto, não seduz, por representar ampliação indevida do comando legal $^{14}$ :

Muitos dos defensores dessa tese - de que basta a vegetação típica de restinga para qualificar área como de preservação permanente, mesmo que ela não corresponda ao acidente geográfico restinga - se apegam, sobremodo, no inciso II do artigo $5^{\circ}$ da Resolução 10/93 do CONAMA [...].

Em outras palavras, o CONAMA nessa passagem, confundiu restinga, que é espécie de acidente geográfico, com a vegetação que a encobre. E o fato é que esse lapso passou a servir, indevidamente, de argumento aos defensores da tese que ora se refuta: a de que basta a presença de vegetação típica de restinga para reputar área de preservação permanente, ainda que o acidente geográfico não corresponda à restinga. Contudo, o inciso II do artigo $5^{\circ}$ da Resolução $n^{\circ} 10 / 93$, analisado a fundo, não se presta a esse tipo de argumento. Por ordem:

Em primeiro lugar, a Resolução 10/93 não se propõe a regulamentar a Lei $4.771 / 65 . .$. , que dispõe sobre as áreas de preservação permanente. Tal propósito foi o da Resolução 04/85 e, atualmente, é o da Resolução 303/02. A Resolução 10/93 pretende, na verdade, regulamentar o Decreto Federal $n^{\circ}$ 750/93, com o intuito de estabelecer parâmetros básicos para a análise dos estágios de sucessão da Mata Atlântica. Por isso é que a definição de restinga enfeixada na Resolução 10/93, referindo-se a aporte exclusivamente botânico, confunde restinga com vegetação típica de restinga. O CONAMA com a Resolução n 10/93 - não quis dizer o que se deve entender por restinga para avaliar áreas de preservação permanente; quis apenas definir o que se entende por vegetação de restinga, para o efeito de oferecer parâmetros aos órgãos ambientais na avaliação do grau de regeneração da mata porventura existente. $\mathrm{O}$ problema é que as pessoas desavisadas ou de má-fé se valeram dessa definição como parâmetro para avaliar áreas de preservação permanente, isto é, se utilizaram dela para finalidade distinta daquela visada pelo CONAMA e consignada no próprio texto da aludida Resolução.

Em segundo lugar, ad argumentandum tantum, se a Resolução 10/963 do CONAMA pudesse ser utilizada para avaliar área de preservação permanente, o conceito de restinga ofertado por ela iria para além do admitido pelo legislador, em virtude do que extravasaria os lindes da competência regulamentar, desenhando-se inconstitucional.

[...] o CONAMA não reúne competência para criar áreas de preservação permanente, pois estaria tomando para si a função legislativa. Quem pode qualificar como área de preservação permanente

\footnotetext{
${ }^{14}$ NIEBUHR, Joel de Menezes. As restingas como áreas de preservação permanente. Revista da Esmesc - Escola Superior da Magistratura do Estado de Santa Catarina Florianópolis, Escola Superior da Magistratura do Estado de SC v.15, jun. 2003, p. 4150.
} 
uma planície marinha ou uma rampa de dissipação coberta por vegetação típica de restinga é o legislador, jamais o CONAMA. E o fato é que o legislador não assumiu tal postura; para ele a vegetação que se situa em restinga é de preservação permanente; jamais a que se situa em planície marinha ou em rampa de dissipação, ainda que as espécies nelas encontradas sejam as espécies nelas encontradas sejam as mesmas que se encontram numa restinga.

Mera Resolução não basta para qualificar a área como de preservação permanente em hipótese não admitida pela lei.

Importante destacar que a 'vegetação de restinga', com a entrada em vigor da Lei $n^{\circ}$ 11.428/06 (Lei da Mata Atlântica), passou a ser protegida por lei e não mais apenas pelo Decreto $n^{\circ}$ 750/93, por se tratar de uma ocorrência possível nesse bioma. A Lei da Mata Atlântica, entretanto, não conferiu à 'vegetação de restinga' o status de área de preservação permanente. Pelo contrário, permitiu - e permite - a utilização e exploração das áreas de sua ocorrência, com algumas restrições que se aplicam a todas as vegetações integrantes do bioma Mata Atlântica.

Independente das interpretações acerca do conteúdo da proteção legal instituída pelo art. $2^{\circ}$, ' $f$ ', da Lei $4.771 / 65$, é certo que sempre houve consenso no sentido de que apenas se poderia considerar de preservação permanente a 'vegetação de restinga' que exercesse a função de fixadora de dunas ou de estabilizadora de mangues, de modo a aliar os conceitos do tipo de vegetação e ocorrência de formação geológica (dunas ou mangue).

Por fim, cabe ressaltar que, apesar de a Lei $n^{\circ}$ 6.938/81 ter conferido competência normativa ao CONAMA, a mesma foi revogada pelo art. 25 do ADCT da Constituição Federal de 1988. De modo que ao CONAMA, através de resoluções (meros atos administrativos), é vedado criar primariamente obrigações, inovando na ordem jurídica e impondo restrições à atividade e propriedade privadas, por ferir o Princípio da Legalidade (art. $5^{\circ}, \mathrm{CF} / 88$ ). As resoluções do CONAMA apenas podem ter natureza regulamentar e não normativa. A competência para a ampliação de restrições ao uso da propriedade é do legislativo.

\section{O PROBLEMA SURGIDO COM O JULGAMENTO DO RESP $945.898 / \mathrm{SC}$}

A partir de voto-vista declarado pelo Ministro Herman Benjamin, do Superior Tribunal de Justiça, no Recurso Especial $945.898 / \mathrm{SC}^{15}$, órgãos ambientais, magistrados e membros do Ministério Público passaram a interpretar que o termo 'restinga' constante do art. $3^{\circ}, \mathrm{XVI}$, da

\footnotetext{
${ }^{15}$ BRASIL. Superior Tribunal de Justiça. Recurso Especial n. 945.898 - SC. Relator: Min. Eliana Calmon. Julgado em: 24/11/2009. Diário da Justiça Eletrônico, edição 24/08/2010. Disponível em: http://www.stj.jus.br/SCON/jurisprudencia/doc.jsp?livre=945898\&b=ACOR\&p=true\&l=10\&i=4. Acesso em: 23 jan. 2017.
} 
$12.651 / 12$, teria sido concebido para proteger a 'vegetação de restinga' como fixadora de dunas ou estabilizadora de mangues, independentemente de ela ocorrer ou não sobre um acidente geográfico 'restinga', associando a vegetação (de restinga) com o acidente geográfico duna ou mangue. A conclusão do voto-vista foi nesse sentido:

Na hipótese, tendo a instância ordinária consignado que a área degradada caracteriza-se como Restinga e possui vegetação fixadora de dunas lato sensu (= dunas stricto sensu, cordões arenosos e terrenos arenosos), forçosa é sua qualificação como Área de Preservação Permanente, nos termos dos dispositivos legais em comento.

No mais, pode-se dizer que a simples existência de Vegetação de Restinga, como definida pela legislação vigente (= tipo de vegetação), basta para especificar o local como Área de Preservação Permanente, sendo irrelevante a existência ou não do acidente geográfico Restinga, na sua acepção geológico-geomorfológica, que, como explicamos neste Voto, não é o significado adotado pela legislação brasileira.

$[\ldots]$

A verdade é uma só: a adoção pelo STJ da interpretação defendida pelos recorrentes extirpará a qualificação de APP da quase totalidade do que hoje se entende, ecológica e juridicamente, por Vegetação de Restinga. Em outras palavras, de norte a sul do Brasil onde ainda sobrevivam fragmentos do mais ameaçado e crítico ecossistema dos que compõem o igualmente ameaçado bioma da Mata Atlântica, ficará facilitado o desmatamento, para que em seu lugar o proprietário possa fazer o uso que bem entender, com construções ou com a prática de outras atividades econômicas, hoje absolutamente vedadas.

Embora o objetivo jurídico-exegético seja claro, isto é, a poda do campo de aplicação do Código Florestal, sobretudo do art. $2^{\circ}$, que cuida das APPs, a conseqüência fático-ecológica é omitida: a liberação do corte raso e supressão de Vegetação de Restinga em todo o domínio da Mata Atlântica.

Em que pese o inegável brilhantismo e conhecimento jurídico do Ministro Herman Benjamin, não se pode concordar com os fundamentos do posicionamento externado, notadamente para efeito de mudança de orientação sobre a questão, dada a repercussão e efeitos em toda a região litorânea do Brasil e, principalmente, porque tal entendimento vai de encontro à literal disposição de lei acerca da questão.

A utilização de locais com 'vegetação de restinga' não é absolutamente vedada atualmente (e nem o foi nos últimos 50 anos) e a manutenção do entendimento predominante acerca da proteção deste bioma não implicará em facilitação para o desmatamento, já que o uso das áreas em que ocorre a 'vegetação de restinga' é protegido pela legislação brasileira, notadamente, pela Lei da Mata Atlântica. Essa legislação foi concebida com o objetivo de preservar aquilo que existe de importante em relação à 'vegetação de restinga' no cenário nacional (como as vegetações primárias, etc.) e, ainda, para permitir o desenvolvimento sustentável das áreas que não são mais 
relevantes para a preservação ambiental, seja pela descaracterização de seu entorno, seja pela pobreza/incipiência dos exemplares encontrados. A Lei da Mata Atlântica e legislação correlata, por certo, não permite a supressão de vegetação importante do ponto de vista ecológico, de modo que estão protegidas as áreas ainda remanescentes de relevância para a manutenção de nichos ecológicos. O contrário, tornando morta a lei e exacerbando demasiadamente a proteção da vegetação, mesmo quando não associada a biomas ou acidentes geográficos, é que gerará uma enxurrada de empreendimentos clandestinos.

Além disso, 0 art. $2^{\circ}$ da então vigente Lei $4.771 / 65$ é claro ao levar em consideração locais estratégicos (longo de rios, redor de lagoas, nascentes, topo de morros, etc.) nos quais a vegetação (qualquer tipo de vegetação, independente da importância das características botânicas) serve como forma de evitar erosão, propiciar a fauna, etc. Nas hipóteses do art. $2^{\circ}$, em momento algum é levado em consideração o tipo de vegetação (critério botânico), mas o local em que ela ocorre. Todas as previsões se referem a locais específicos e não a espécies arbóreas.

Ademais, pode-se concluir com segurança não ter havido qualquer alteração no conceito de 'restinga' ao longo do tempo. O que o ocorreu, em verdade, foi que a utilização equivocada do conceito de 'vegetação de restinga' por alguns, substituindo-o apenas por 'restinga' (confundindo o acidente geográfico com a vegetação que ocorre sobre esse acidente) acabou por confundir os operadores do direito (ainda mais em se tratando de legislação que se vale de conceitos de outras disciplinas, como a biologia, etc.). Portanto, em sentido oposto ao que dispõe o voto-vista, não se trata de 'polissemia lexical', mas sim da utilização inapropriada de um conceito, não se sustentando o entendimento de que teria havido evolução do 'sentido jurídico-ecológico do vocábulo restinga'. A "evolução" que a declaração de voto quer emprestar ao termo 'restinga' acaba encerrando inegável usurpação da competência legislativa, pois substituir o sentido de um termo técnico de uma lei é equivalente a legislar novamente.

\section{O FIM DA INSEGURANÇA COM A ENTRADA EM VIGOR DO NOVO CÓDIGO FLORESTAL (LEI N $12.651 / 2012)$}

Em 25/05/2012 foi sancionado o novo Código Florestal, que expressamente revogou a Lei 4.771/65 e as Resoluções do CONAMA que regulamentavam a matéria, extirpando imprecisões acerca de qual a extensão do termo 'restinga' para efeito de proteção como área de preservação 
permanente.

Importante destacar que a nova redação do Código Florestal em nada altera o fato de a 'vegetação de restinga' estar protegida pela Lei da Mata Atlântica. São proteções distintas, uma lei protege especificamente a vegetação que ocorre sobre o acidente geográfico 'restinga' (considerando-a como APP quando fixa dunas e estabiliza mangues) e a outra protege a 'vegetação de restinga' no contexto do Bioma Mata Atlântica (sem considerá-la APP).

Como se pode observar do novo texto normativo, o legislador expressamente incorporou à norma os conceitos técnicos a que a lei remete e também, para que não houvesse a possibilidade de deturpação ou 'evolução' dos conceitos através de meros atos administrativos (Resoluções CONAMA, por exemplo), deixou muito claro no art. 3․, XVI, da Lei $12.651 / 12^{16}$, o conceito de restinga:

XVI - RESTINGA: depósito arenoso paralelo à linha da costa, de forma geralmente alongada, produzido por processos de sedimentação, onde se encontram diferentes comunidades que recebem influência marinha, com cobertura vegetal em mosaico, encontrada em praias, cordões arenosos, dunas e depressões, apresentando, de acordo com o estágio sucessional, estrato herbáceo, arbustivo e arbóreo, este último mais interiorizado;

E para espancar qualquer ambiguidade ou equívoco interpretativo, o art. 4ํㅡ, $\mathrm{VI}$, do Novo Código Florestal ${ }^{17}$ foi taxativo ao complementar o dispositivo retro (art. 3ㅇ, XVI, Lei 12.651/12), estabelecendo que:

Art. $4^{\circ}$ Considera-se Área de Preservação Permanente, em zonas rurais ou urbanas, para os efeitos desta Lei: [...]

VI - as restingas, como fixadoras de dunas ou estabilizadoras de mangues;

No artigo 8으, § 10ำ, mais uma vez o novo Código Florestal está a se referir apenas a proteção do fenômeno 'restinga' (e não da vegetação de restinga):

Art. $8^{\circ}$. A intervenção ou a supressão de vegetação nativa em Área de Preservação Permanente somente ocorrerá nas hipóteses de utilidade pública, de interesse social ou de baixo impacto ambiental previstas nesta Lei.

$\S 1^{0}$ A supressão de vegetação nativa protetora de nascentes, dunas e restingas somente poderá ser autorizada em caso de utilidade pública.

Como se vê, é clara a diferenciação que o novo Código Florestal faz do espaço 'restinga', de

16 BRASIL. Lei 12.651, de 25 de maio de 2012. 2014/2012/lei/l12651.htm>. Acesso em: 21 de janeiro de 2017.

17 BRASIL. Lei 12.651, de 25 de maio de 2012 2014/2012/lei/l12651.htm>. Acesso em: 21 de janeiro de 2017.

18 BRASIL. Lei 12.651, de 25 de maio de 2012 2014/2012/lei/l12651.htm>. Acesso em: 21 de janeiro de 2017.
Disponível em: <www.planalto.gov.br/ccivil_03/_ato2011-

Disponível em: <www.planalto.gov.br/ccivil_03/_ato2011-

Disponível em: <www.planalto.gov.br/ccivil_03/_ato2011- 
'vegetação de restinga', confirmando se tratar de conceitos distintos, aplicados desde a criação do Código Florestal de 1965 e mantidos no atual.

Não se pode olvidar, por outro lado, que o novo Código Florestal, instituído pela Lei 12.651/2012, é resultado de mais de uma década de estudos e debates, inclusive técnicos, tratando a questão da proteção das 'restingas' e da 'vegetação de restinga' em tópico próprio. Acaso o legislador, após tanto tempo de discussão sobre o tema, quisesse proteger como APP toda a 'vegetação de restinga', assim o teria feito expressamente, não dispondo, de forma tão clara, que a proteção recai apenas sobre a vegetação que encobre o acidente geográfico 'restinga' e, mesmo assim, apenas quando fixar dunas ou estabilizar mangue, a exemplo da proteção dos manguezais (art. $\left.4^{\circ}, \mathrm{VII}\right)$.

Antomar Viegas de Carvalho de Oliveira Junior ${ }^{19}$, em obra que conta com a coordenação de Édis Milaré e Paulo Affonso Leme Machado, ao comentar o art. 3 XVI, da Lei 12.651/2012, é taxativo quanto ao escopo da norma:

1. As Restingas no novo Código Florestal

1.1 Introdução

Com a edição da Lei 4771 no ano de 1965, pelo efeito de seu art. $2^{\circ}$, f, as restingas, quando dotadas de vegetação com função de fixar dunas ou estabilizar mangues, passaram a ser consideradas áreas de preservação permanente.

Embora seja indiscutível o avanço legal na proteção dessa feição geográfica, os sucessivos atos regulamentadores e a interpretação em sentido lato conferida aos mesmos acabaram por gerar dúvidas na aplicação da Lei.

De início, a confusão estabelecida entre o conceito físico de 'restinga', de caráter geológicogeomorfológico, e 'vegetação de restinga', oportunizou, inclusive, entendimentos que levaram a considerar como restinga praticamente toda a planície costeira brasileira, em flagrante descompasso não só com o fundamento científico, mas também ao próprio comando legal.

A Lei 12.561/2012, ora aprovada e designada como Novo Código Florestal, define 'restinga' no art. $3^{\circ}, \mathrm{XVI}$, cujo enunciado representa incontestável avanço para o esclarecimento da questão e certamente, contribuirá, de um lado, para a preservação desse frágil recurso natural e, de outro lado, para o desenvolvimento sustentável de parcela considerável do litoral brasileiro.

2. As Restingas como Área de Preservação Permanente

O novo Código Florestal, acompanhando a Lei anterior, estabeleceu a delimitação das Áreas de Preservação Permanente (APP) com base em parâmetros do meio físico, conforme pode-se observar pela leitura de seu art. $4^{\circ}$.

\footnotetext{
${ }^{19}$ MILARÉ, Édis (Org.); MACHADO, Paulo Affonso Leme (Org.) Novo Código Florestal: comentários à Lei 12.651, de 25 de maio de 2012, e à Medida Provisória 571, de 25 de maio de 2012. São Paulo: RT, 2012, p. 102-108.
} 
Assim, os critérios para demarcação das APP foram designados a partir das características do meio físico, tais como: (a) largura das margens dos cursos d’água, lagoas, nascentes e reservatórios d'água; (b) encostas...(c) localização nos topos de morros...

Portanto, o legislador compôs essa relação com base em elementos de mesma natureza - físicos -, sendo certa e lógica a impossibilidade de inclusão, nesse grupo, de elementos estranhos aos adotados na definição legal das APP, como por exemplo, o 'tipo de vegetação', a 'qualidade da água', o 'tipo de solo', entre outros.

Desse modo, embora o objetivo da Lei em comento seja, em linhas gerais, a proteção das florestas e demais formas de vegetação - daí o título 'Código Florestal' -, os elementos ambientais adotados para a delimitação da proteção nos moldes das APP foram os de ordem física.

Acentuando o caráter físico adotado na delimitação das APP, o novo Código Florestal promoveu alteração discreta, porém de fundamental importância para a caracterização das Áreas de Preservação Permanente, ao suprimir no caput do art. $4^{\circ}$ a expressão '[...] as florestas e demais formas de vegetação natural situadas'.

[...] ou seja: o novo diploma estabelece categoricamente que a proteção aplica-se ao espaço territorial delimitado pelos parâmetros que estabelece, sem consideração sobre a ocorrência ou qualidade da cobertura vegetal eventualmente presente no espaço protegido.

Logo, não há mais que se falar em florestas ou demais formas de vegetação para que sejam caracterizadas as APP, sendo a única condição para tal que esse espaço físico esteja inserido nos limites expressos na Lei.

\section{Conceito de Restinga}

\section{[...] 3.2 Conceito de Restinga no novo Código Florestal}

[...] Da análise do conceito estabelecido pela nova Lei florestal, constata-se que a definição de restinga permanece bastante clara e objetiva ao destacar a necessária existência de 'depósito arenoso paralelo a linha de costa, de forma geralmente alongada, produzido por processos de sedimentação [...]', para que se identifique a ocorrência da feição 'restinga', fato que indica, também, conformidade em relação ao entendimento científico registrado na literatura especializada.

Nesse sentido, a fitofisionomia apresenta-se como aspecto complementar. Assim, a expressão 'onde se encontram diferentes comunidades que recebem influência marinha com cobertura vegetal em mosaico, encontrada em praias, cordões arenosos, dunas e depressões, apresentando, de acordo com o estágio sucessional, estrato herbáceo, arbustivo e arbóreo, este último mais interiorizado' não particulariza as restingas, pro duas razões principais. A primeira, por não corresponder aos parâmetros físicos estabelecidos para a caracterização das APP e, a segunda, por constituir-se em expressão válida para praticamente toda a costa brasileira, não distinguindo os locais onde efetivamente ocorrem as restingas.

Portanto, o aspecto que particulariza as restingas, nos termos da Nova Lei Florestal, é sua característica física, geológica e geomorfológica, e não sua fitofisionomia.

Por outro lado, cumpre ressaltar que o conceito em comento denota serem as restingas fenômenos de exceção na dinâmica costeira [...], ou seja: o conceito não é aplicável à totalidade da planície costeira brasileira, mas apenas àqueles locais...

4. Restingas e vegetação de Restingas: conceitos distintos 
O conceito de restinga foi objeto de controvérsias por seu uso, no Brasil, em diversas áreas do conhecimento, tais como, a geologia, a geografia, a geomorfologia, a botânica e a ecologia. Inicialmente adotado para caracterizar as feições geológicas e geomorfológicas, teve, posteriormente, seu significado estendido para as vegetações litorâneas, fato que gerou graves conflitos, especialmente na aplicação da legislação ambiental.

[...] Fica evidenciado de maneira cabal que a presença, em dado local, de 'vegetação de restinga', não cria, por si, APP, onde qualquer supressão é proibida.

Portanto, apenas à restinga geológica-geomorfológica está prevista a especial proteção nos termos do instituto da preservação permanente, ficando esclarecido que, do ponto de vista técnico e legal, 'restinga' e 'vegetação de restinga' são conceitos distintos e tal dualidade foi efetivamente recepcionada pelo conceito contido no novo Código Florestal.

Resta claro, consequentemente, que o novo Código Florestal (Lei 12.651/12) não alterou a concepção de 'restinga' prevista no antigo Código Florestal (Lei 4.771/65), sendo certo que o conceito de restinga para fins de caracterização de área de preservação ambiental protegida no Código Florestal se restringe à vegetação fixadora de dunas e estabilizadora de mangue, conjugando, assim, o aspecto da flora (vegetação) com o geológico (dunas ou mangue).

Referendando o entendimento ora defendido, o Tribunal de Justiça de Santa Catarina, julgando a Apelação Cível n.o 2014.079082-720 , proferiu julgado, não unânime, interpretando que apenas o acidente geográfico restinga (e não a vegetação de restinga), caso estabilize mangue ou fixe duna, é que pode ser considerado área de preservação permanente, nos termos do art. 4으, VI, da Lei 12.651/2012, verbis:

AÇÃO CIVIL PÚBLICA. APELAÇÕES CÍVEIS. MEIO AMBIENTE.

INADEQUAÇÃO DA VIA ELEITA. INCOMPETÊNCIA DO

JUÍZO. ILEGITIMIDADE ATIVA AD CAUSAM. LITISCONSÓRIO PASSIVO NECESSÁRIO. CERCEAMENTO DE DEFESA. PRELIMINARES RECHAÇADAS.

LICENCIAMENTO AMBIENTAL. DIFERENÇA ENTRE "RESTINGA" E "VEgetAÇÃO DE RESTINGA". CARACTERIZA ÁREA DE PRESERVAÇÃO PERMANENTE, NOS TERMOS DA LEI, APENAS A RESTINGA, COMO FIXADORAS DE DUNAS OU ESTABILIZADORAS DE MANGUES. INTERPRETAÇÃO LITERAL DO ART. 4으, VI, DA LEI FEDERAL N. 12.651/2012 (NOVO CÓDIGO FLORESTAL).

SENTENÇA QUE IMPEDIU A CONCESSÃO DE LICENÇA AMBIENTAL, INDEPENDENTE DA EXISTÊNCIA OU NÃO DO

ACIDENTE GEOGRÁFICO "RESTINGA". DECISÃO REFORMADA. RECURSOS CONHECIDOS E PROVIDOS.

Para os efeitos da Lei Federal n. 12.651/2012, entende-se por

\footnotetext{
${ }^{20}$ BRASIL. Tribunal de Justiça de Santa Catarina. Apelação Cível n.o 2014.079082-7. Relator: Desembargador Júlio Knoll. Julgado em: 24/11/2009. Diário da Justiça Eletrônico, edição n. 2198. Disponível em: http://busca.tjsc.jus.br/jurisprudencia/\#resultado ancora. Acesso em: 21 jan. 2017.
} 
restinga: "depósito arenoso paralelo à linha da costa, de forma

geralmente alongada, produzido por processos de sedimentação, onde se encontram diferentes comunidades que recebem influência marinha, com cobertura vegetal em mosaico, encontrada em praias, cordões arenosos, dunas e depressões, apresentando, de acordo com o estágio sucessional, estrato herbáceo, arbustivo e arbóreo, este último mais interiorizado" (art.3ํ, XVI).

Considera-se Área de Preservação Permanente, em zonas rurais ou urbanas, as restingas, como fixadoras de dunas ou

estabilizadoras de mangues (art. 4으, VI).

"A ação civil pública se sustenta no voto vencedor do Min. Herman Benjamin, nos autos do REsp. $n$. 945.898-SC, que indo além do que discutido, pois a hipótese versada contemplava restinga fixadora de dunas, fez ver, com o brilhantismo que lhe é próprio, e pelas convicções que sustenta, que já seria momento de se ampliar, para fins jurídicos, o que se deve entender por restinga, fugindo a redoma de que só seria área de preservação permanente quando protetora de dunas ou estabilizadora de mangues.

Entretanto, é a lei que assim quer (art. 2으, f da Lei 4.771/65; art. 3으, XVI, da Lei 12.651/2012; art. 20 da Lei 11.428/2006), cumprindo ao julgador se the dê concretude enquanto não alterada, caso contrário seria transformar o processo judicial em fonte legiferante." (TJSC, Órgão Especial, Agravo (§ 3으 art. 4ㅇ da Lei 8.437/92) em Pedido de Suspensão de Liminar n. 2014.028915-9/0001.00, da Capital, Relator Designado: Des. Cesar Abreu, j. 15.10.2014).

\section{CONSIDERAÇÕES FINAIS}

Não restam dúvidas de que o conceito de restinga para fins de caracterização de área de preservação ambiental protegida no Código Florestal Brasileiro, instituído pela Lei 12.651/2012, restringe-se à vegetação fixadora de dunas e estabilizadora de mangue, conjugando, assim, o aspecto da flora (vegetação) com o geológico (dunas ou mangue), na medida em que o novo regramento jurídico (Lei 12.651/12) não alterou a concepção de 'restinga' prevista no antigo Código Florestal (Lei 4.771/65).

Considerando a previsão legal expressa de que apenas podem ser consideradas de preservação permanente as áreas geológicas de restinga, não se pode conceber interpretação contra legem, que amplie indevidamente a proteção legal para toda a 'vegetação de restinga' com a função de fixar dunas e estabilizar mangue. Ampliar a proteção para tal hipótese representa evidente violação ao princípio da legalidade, obrigando cidadãos e jurisdicionados a "deixar de fazer alguma coisa" sem lei que sustente a obrigação.

Mais que interpretar a lei, é consabido que, por vezes, magistrados ativistas acabam exercendo função legislativa e criando norma inexistente, o que é inaceitável, já que: 
No Brasil, ao contrário de outros países, o juiz não cria obrigações de proteção do meio ambiente. Elas jorram da lei, após terem passado pelo crivo do Poder Legislativo. Daí não precisarmos de juízes ativistas, pois o ativismo é da lei e do texto constitucional. Felizmente nosso Judiciário não é assombrado por um oceano de lacunas ou um festival de meias-palavras legislativas. Se lacuna existe, não é por falta de lei, nem mesmo por defeito na lei; é por ausência ou deficiência de implementação administrativa e judicial dos inequívocos deveres ambientais estabelecidos pelo legislador. $^{21}$

Mudar o entendimento acerca da proteção legal sem nova lei que a discipline, por outro lado, é ferir de morte o princípio da segurança jurídica, um dos mais importantes postulados do estado democrático de direito. É absolutamente relevante, por isso, que o Poder Judiciário, notadamente os Tribunais Superiores no exercício de sua missão constitucional de uniformizar a jurisprudência, confira celeridade na interpretação final da matéria e no alcance da proteção a ser dada em relação à 'vegetação de restinga'. Esse entendimento servirá de lastro a importantes obras públicas e privadas no País.

Considerar, antecipadamente, sem que os Tribunais Superiores firmem posição final interpretativa, toda a 'vegetação de restinga' como APP, afigura-se, ainda, desproporcional e desarrazoado, na medida em que inviabilizaria a ocupação e o desenvolvimento de boa parte da região litorânea do Brasil, sem fundamentação plausível.

\section{REFERÊNCIA DAS FONTES CITADAS}

BRASIL. Constituição da República Federativa do Brasil de 1988. 37 ed. São Paulo: Saraiva, 2014.

BRASIL. Lei 12.651, de 25 de maio de 2012. Disponível em:

$<$ www.planalto.gov.br/ccivil_03/_ato2011-2014/2012/lei//12651.htm>. Acesso em: 21 de janeiro de 2017.

. Lei no 4.771 de 31 de agosto de 1965. Disponível em:

<www.planalto.gov.br/ccivil_03/leis/L6938.htm>. Acesso em: 14 de janeiro de 2017.

. Lei no 6.938 de 31 de agosto de 1981. Disponível em:

<www.planalto.gov.br/ccivil_03/leis/L6938.htm>. Acesso em: 18 de agosto de 2016.

CONAMA, Resolução 04, de 18 de setembro de 1985. Disponível em:

\footnotetext{
${ }^{21}$ BRASIL. Superior Tribunal de Justiça. Recurso Especial n. $\cong$ 650728-SC. Relator: Ministro Herman Benjamin. Julgado em: 23/10/2007. Diário da Justiça Eletrônico, edição 02/12/2009. Disponível em: $<$ http://www.stj.jus.br/SCON/jurisprudencia/toc.jsp?livre=650728\&\&b=ACOR\&thesaurus=JURIDICO\&p=truehttp://busca.tjsc.jus. br/jurisprudencia/\#resultado ancora>. Acesso em: 21 jan. 2017.
} 
http://www.mma.gov.br/port/conama/legiabre.cfm?codlegi=21. Acesso em: 18 de janeiro de 2017.

. CONAMA, Resolução 303 de 20 de março de 2002. Disponível em:

http://www.mma.gov.br/port/conama/legiano1.cfm?codlegitipo=3\&ano=todos. Acesso em: 18 de janeiro de 2017.

. CONAMA, Resolução 261, de 30 de junho de 1999. Disponível em:

http://www.mma.gov.br/port/conama/legiabre.cfm?codlegi=260. Acesso em: 19 de janeiro de 2017.

. CONAMA, Resolução 10, de 01 de outubro de 1993. Disponível em:

http://www.mma.gov.br/port/conama/res/res93/res1093.html. Acesso em: 19 de janeiro de 2017.

. CONAMA, Resolução 417 de 23 de novembro de 2009. Disponível em:

http://www.mma.gov.br/port/conama/legiabre.cfm?codlegi=617. Acesso em: 18 de janeiro de 2017.

. Decreto no 750 de 10 de fevereiro de 1993. Disponível

em: www.cprh.pe.gov.br/downloads/decreto-750-93.doc. Acesso em: 18 de janeiro de 2017

Lei no 6.938 de 31 de agosto de 1981. Disponível em:

<www.planalto.gov.br/ccivil_03/leis/L6938.htm>. Acesso em: 18 de janeiro de 2017.

. Lei 11.428, de 25 de maio de 2012. Disponível em:

<www.planalto.gov.br/ccivil_03/_ato2004-2006/2006/lei//11428.htm>. Acesso em: 18 de janeiro de 2017.

. Lei 12.651, de 25 de maio de 2012. Disponível em:

$<w w w . p l a n a l t o . g o v . b r / c c i v i l$ 03/_ato2011-2014/2012/lei/l12651.htm>. Acesso em: 18 de janeiro de 2017.

Superior Tribunal de Justiça. Recurso Especial n. 945.898 - SC. Relator: Min. Eliana

Calmon. Julgado em: 24/11/2009. Diário da Justiça Eletrônico, edição 24/08/2010. Disponível em: http://www.stj.jus.br/SCON/jurisprudencia/doc.jsp?livre=945898\&b=ACOR\&p=true\&I=10\&i=4. Acesso em: 23 jan. 2017.

. Superior Tribunal de Justiça. Recurso Especial n. 650728-SC. Relator: Ministro 
Herman Benjamin. Julgado em: 23/10/2007. Diário da Justiça Eletrônico, edição 02/12/2009.

Disponível em:

$<$ http://www.stj.jus.br/SCON/jurisprudencia/toc.jsp?livre=650728\&\&b=ACOR\&thesaurus=JURIDIC O\&p=truehttp://busca.tjsc.jus.br/jurisprudencia/\#resultado ancora>. Acesso em: 21 jan. 2017. . Tribunal de Justiça de Santa Catarina. Apelação Cível n.o 2014.079082-7. Relator: Desembargador Júlio Knoll. Julgado em: 24/11/2009. Diário da Justiça Eletrônico, edição n. 2198. Disponível em: http://busca.tjsc.jus.br/jurisprudencia/\#resultado ancora. Acesso em: 21 jan. 2017. MILARÉ, Édis (Org.); MACHADO, Paulo Affonso Leme (Org.) Novo Código Florestal: comentários à Lei 12.651, de 25 de maio de 2012, e à Medida Provisória 571, de 25 de maio de 2012. São Paulo: RT, 2012, p. 102-108.

NIEBUHR, Joel de Menezes. As restingas como áreas de preservação permanente. In: Revista da Escola Superior da Magistratura do Estado de Santa Catarina. v. 15 (jun. 2003), p. 41-50. Florianópolis. Escola Superior da Magistratura do Estado de Santa Catarina, 2003.

PASOLD, Cesar Luiz. Metodologia da Pesquisa Jurídica: Teoria e Prática. 13 ed. rev. atual. amp. Florianópolis: Conceito Editorial, 2015.

PEREIRA, Marcio Silva. CASTANHO, Renata O. P. A Restinga na Resolução CONAMA 303/02. In: http://www.milare.adv.br/artigos/conama302.htm>. Acesso em 14 de janeiro de 2017. 


\title{
OS LOTEAMENTOS FECHADOS E A QUALIFICAÇÃO NO SISTEMA REGISTRAL BRASILEIRO $^{1}$
}

\author{
Kelly Santos Gonçalves Cardia ${ }^{2}$ \\ Tatiana Galardo Amorim Dutra Scorzato ${ }^{3}$
}

\section{INTRODUÇÃO}

O presente artigo tem como objetivo refletir sobre a possibilidade de os Registros de Imóveis recepcionarem uma nova forma de ordenação do solo urbano, intitulada de loteamento fechado ou loteamento de acesso controlado, e o seu ingresso no Sistema Registral Brasileiro.

Os loteamentos fechados são empreendimentos cercados por muros e guaritas, somente sendo permitido o ingresso de moradores ou pessoas por ele autorizadas, inclusive nas áreas, a princípio, públicas. Para isso, as vias, praças, logradouros e demais bens públicos são desafetados da categoria de bem de uso comum do povo, passando à categoria de bem de uso especial e concedidos ao uso exclusivo de particulares, que, no caso, são os proprietários dos lotes.

Esse fechamento dos espaços públicos não encontra previsão expressa na Lei de Parcelamento do Solo, diploma legal utilizado pelos Oficiais Registradores nas qualificações dos empreendimentos que ingressam na Serventia. Nesse contexto, surge o seguinte questionamento: devem os Registradores qualificarem positivamente os empreendimentos dessa natureza?

Para a reflexão a essa indagação, o ensaio divide-se em duas partes.

A primeira apresenta a compreensão do Sistema Registral Brasileiro, abordando o princípio da legalidade no âmbito registral, o qual é efetivado mediante o exame de qualificação dos títulos apresentados. Nesse contexto, para ingressar no folio real, os títulos devem estar formalmente constituídos, incumbindo ao registrador examinar os princípios registrários, bem como aferir a

\footnotetext{
${ }^{1}$ Artigo produzido como trabalho final da disciplina Política Jurídica, do Curso de Mestrado em Ciência Jurídica da UNIVALI, ministrada pelo Professor Doutor Marcelo Buzaglo Dantas.

${ }^{2}$ Mestranda do Curso de Mestrado em Ciências Jurídicas da UNIVALI. Especialista em Direito Notarial e Registral e, também, em Direito Público. Graduada em Direito pela UNIVALI. Atualmente é Oficiala Registradora do 1o Ofício do Registro de Imóveis da Comarca de Mafra, Estado de Santa Catarina.

${ }^{3}$ Mestranda do Curso de Mestrado em Ciências Jurídicas da UNIVALI. Especialista em Direito Processual Penal e Direito Notarial e Registral. Graduada em Direito pelo CESUSC. Atualmente Oficiala Registradora do Ofício de Registro de Imóveis, Títulos e Documentos e Civil de Pessoa Jurídica da Comarca de Socorro, Estado de São Paulo.
} 
observância das normas jurídicas vigentes.

Após, concluído esse desiderato, pretende-se apresentar um panorama acerca dos loteamentos fechados ou loteamentos de acesso controlado, empreendimentos com características que os diferem dos loteamentos convencionais, apesar de serem aprovados nos termos da Lei de Parcelamento do Solo - Lei n. 6.766/1979 - e o exame de qualificação pelo Oficial Registrador desses títulos.

Para desenvolver o presente artigo utilizou-se como critério metodológico o método indutivo $^{4}$ e como técnicas as da pesquisa bibliográfica ${ }^{5}$, da categoria ${ }^{6}$ e do conceito operacional ${ }^{7}$.

\section{O REGISTRO DE IMÓVEIS E A QUALIFICAÇÃO DOS TÍTULOS}

Os serviços notariais e de registros no Brasil, também chamados de serviços extrajudiciais, são serviços de titularidade pública, embora exercidos em caráter privado, por delegação do Poder Público, nos termos do art. 236 da Constituição da República Federativa do Brasil.

Nos ensinamentos de Ricardo $\mathrm{Dip}^{8}$, os "serviços notariais e de registro afirmaram-se, pelo texto constitucional, como funções da soberania política, ou como ali se diz: como serviços públicos". Referido doutrinador ainda discorre que os serviços notariais e de registro são funções valiosas para a segurança jurídica e que, dessa forma, "convinha integrar, de algum modo, no complexo de atividade do Poder Público".

Os titulares das serventias, chamados de Notário ou Tabelião e Oficial de Registro ou Registrador, são profissionais do Direito, dotados de fé pública, a quem é delegado o exercício da atividade notarial e de registro. Nos termos do art. 1으 da Lei Federal n. 8.935, de 18 de novembro de 1994, que disciplinou a natureza e os fins dos serviços notariais e de registro, estes serviços podem ser conceituados como de "organização técnica e administrativa destinados a garantir a publicidade, autenticidade, segurança e eficácia dos atos jurídicos".

\footnotetext{
${ }^{4} \mathrm{O}$ método indutivo caracteriza-se por pesquisar e identificar as partes de um fenômeno e colecioná-ls de modo a ter uma percepção ou conclusão geral [...]. PASOLD, Cesar Luiz. Metodologia da pesquisa jurídica: teoria e prática. 12. ed. São Paulo: Conceito, 2011, p. 101.

${ }^{5}$ A Pesquisa Bibliográfica trata-se da "técnica de investigação em livros, repertórios jurisprudenciais e coletâneas leias". PASOLD, Cesar Luiz. Metodologia da pesquisa jurídica, p. 207.

${ }^{6}$ A Categoria trata-se "[...] da palavra ou expressão estratégica à elaboração e/ou à expressão de uma ideia”. PASOLD, Cesar Luiz. Metodologia da pesquisa jurídica, p. 34

${ }^{7}$ O Conceito Operacional consiste na "[...] definição para uma palavra ou expressão, com o desejo de que tal definição seja aceita para os efeitos das ideias que expomos". PASOLD, Cesar Luiz. Metodologia da pesquisa jurídica, p. 50.

${ }^{8}$ DIP, Ricardo. Registros Públicos: a Trilogia do Camponês de Andorra e outras reflexões. Títulos e Documentos Imóveis - Civil. Campinas: Millennium, 2003, p. 184.
} 
O Registro Imobiliário, serventia extrajudicial objeto do presente estudo, é o ofício público que tem como atribuição o registro de atos jurídicos, os quais compreendem os negócios jurídicos, bem como os atos jurídicos stricto sensu, ou mesmo registro de fatos jurídicos, em sua acepção ampla, que envolvem, nos ensinamentos de Ulysses da Silva ${ }^{9}$ :

A aquisição e a transferência da propriedade imobiliária, com efeitos constitutivos ou declaratórios, assim como a constituição e oneração de direitos a ela inerentes, em especial direitos reais, e, ainda, a averbação de atos que afetem os assentos registrais, seja em relação ao objeto ou às pessoas neles interessadas.

Conforme ensina Maria Helena Diniz ${ }^{10}$, incumbe ao Registro Imobiliário as operações registrais relativas a bens imóveis e a direitos a eles condizentes, consistindo no cadastro da propriedade imobiliária, demonstrando seu estado atual, promovendo atos de escrituração, realizando as mudanças, alterações e extinções dos direitos referentes ao imóvel, assegurando-se, assim, aos requerentes a aquisição e o exercício do direito de propriedade e a instituição de ônus reais de fruição, garantia ou de aquisição, de forma a dar proteção especial à propriedade imobiliária.

Pode-se dizer que a função precípua do Registro Imobiliário é garantir pacificação social. Para isso, o artigo 1ㅇ da Lei no 8.935, de 18 de novembro de 1994, estabelece as finalidades do Registro Público, quais sejam: a publicidade, a autenticidade, a segurança e a eficácia dos atos jurídicos. É justamente esta presunção de conhecimento que, juntamente com a presunção de veracidade e legalidade do registro, diante da fé pública do ofício imobiliário, garante a tão almejada segurança jurídica para a sociedade.

Destarte, incumbe ao Oficial do Registro, na análise dos títulos apresentados, a obediência ao ordenamento jurídico e, notadamente, aos princípios registrais, destacando-se os princípios da instância, inscrição, legalidade, continuidade, presunção de verdade e fé pública, prioridade, especialidade e publicidade registral, todos imprescindíveis de ser observados na qualificação dos títulos.

Em razão da segurança jurídica, detém o registrador a obrigação de examinar a legalidade, validade e eficácia dos títulos apresentados, permitindo o acesso ao álbum registral apenas para os títulos juridicamente válidos para esse fim e que reúnam as qualidades necessárias para gerar o

\footnotetext{
${ }^{9}$ SILVA, Ulysses da. Direito Imobiliário - O Registro de Imóveis e suas atribuições: a nova caminhada, Porto Alegre: Sergio Antônio Fabris Ed., 2008, pág. 20.

${ }^{10}$ DINIZ, Maria Helena. Sistema de Registro de Imóveis, 6ạ ed. São Paulo: Saraiva, 2006, pág.13.
} 
direito que pretende ${ }^{11}$.

Esse exame feito por parte do Registrador é denominado "qualificação do título" e efetiva o princípio da legalidade no âmbito registral. Segundo Luiz Guilherme Loureiro Camargo, todo o título que ingressa no Ofício Imobiliário deve ser previamente submetido ao exame de sua validade e autenticidade. E detalha o tema ${ }^{12}$ :

\begin{abstract}
A legalidade em matéria registral aplica-se a todo procedimento registral, mas tem seu ápice no denominado "exame de qualificação", no qual o registrador faz o controle da legalidade do título submetido a registro. No que tange ao exame do documento, o fundamento do princípio da legalidade se funda na necessidade de que os assentos registrais concordem com a realidade externa ao registro, evitando que ingressem documentos carentes de validade ou de autenticidade. 0 exame ou análise que o registrador realiza para tornar efetivo o princípio da legalidade é denominado "qualificação" e a função do registrador que examina o documento apresentado a registro é chamado de função qualificadora.
\end{abstract}

Assim, deverá o ofício imobiliário verificar se o documento apresentado para registro contém todos os requisitos jurídicos de validade e perfeição, concluindo por sua qualificação negativa ou positiva, uma vez que é a lei que determina as condições de registrabilidade.

Cristiano Chaves de Farias e Nelson Rosenvald ${ }^{13}$ acrescentam afirmando que: "[...] a presunção relativa de propriedade em favor daquele que registrou o título no RGI provém justamente do princípio da legalidade. Só há segurança jurídica perante o adquirente e aparência de legalidade em face da sociedade em virtude do exame da legalidade propiciado pelo ofício imobiliário."

Nesse contexto, a análise de um título apresentado envolve diversos elementos que precisam ser observador pelo registrador. No tocante aos loteamentos, sejam eles convencionais ou fechados, essa análise encontra respaldo na Lei de Parcelamento do Solo - Lei n. 6.766, de 19 de dezembro de 1979 -, cujos requisitos serão a seguir abordados.

\title{
2. O LOTEAMENTO FECHADO
}

Antes de iniciarmos propriamente a análise das características dos loteamentos fechados ou loteamento de acesso controlado, mister se faz delinear as espécies de parcelamento do solo,

\footnotetext{
${ }^{11}$ LOUREIRO, Luiz Guilherme. Registros Públicos: Teoria e Prática. 3. ed. São Paulo: Editora Método, 2012, p. 330.

12 LOUREIRO, Luiz Guilherme. Registros Públicos: Teoria e Prática. 3. ed. São Paulo: Editora Método, 2012, p. 330.

${ }^{13}$ FARIAS, Cristiano Chaves de; ROSENVALD, Nelson. Direitos Reais, 6ạ ed. Rio de Janeiro: Ed. Lumen Juris, 2010, pág. 263.
} 
quais sejam, o desmembramento e o loteamento, dando-se ênfase para esta última pela relevância e pertinência com o tema do presente artigo.

A Lei n. 6.766, de 19 de dezembro de 1979, com as alterações introduzidas pela Lei 9.785, de 29 de janeiro de 1999, disciplina o instituto do parcelamento do solo para fins urbanos, gênero, do qual são espécies o loteamento e o desmembramento.

O loteamento consiste na subdivisão da gleba em lotes para edificação com aberturas, prolongamento, modificação e ampliação de vias, enquanto o desmembramento é a subdivisão da gleba aproveitando-se o sistema viário existente. A diferença primordial reside, portanto, na interferência ou não do sistema viário existente.

O parcelamento do solo, notadamente na espécie de loteamento, é fundamental para o desenvolvimento das cidades, sendo necessária sua harmonização com os interesses e a função social da cidade, de modo a evitar sua utilização excessiva ou inadequada. Aliás, por essa razão que compete ao município a prévia aprovação dos loteamentos, a fim de verificar se estes estão de acordo com o conteúdo do Plano Diretor.

Nesse diapasão, Vicente Celeste Amadei elucida que três perspectivas devem ser observadas no fenômeno da modificação do solo, pelo parcelamento. Pela primeira perspectiva civilista, sob o ângulo da ordem privada, o parcelamento do solo constitui direito subjetivo do proprietário, embora não ilimitado nem absoluto. Destarte, dentre os atributos da propriedade (gozar, usar, dispor e reaver) previstos no artigo 1.228 do Código Civil, a possibilidade de fracionamento da propriedade privada encontra-se inserida no atributo dispor da coisa. Embora não ilimitada, o direito de propriedade é considerado como um direito constitucional fundamental, previsto no artigo 5으, XXII, da Constituição Federal.

Referido doutrinador, preleciona, também, sobre a análise do parcelamento do solo, notadamente na espécie loteamento, na perspectiva urbanística. Enfatiza:

De fato, o direito de propriedade urbana é conformado às diretrizes e limites legais da política de desenvolvimento urbano, com especial atenção às normas constitucionais da política urbana, às normas principiológicas do Estado da Cidade e às normas fundamentais de ordenação da cidade expressas no plano diretor, que concretizam sua função social. 
Assim, o parcelamento do solo urbano é, para além da operação civil de fracionamento do domínio privado, operação urbana que se há de atrelar à função social da cidade, ou seja, ao contexto, do desenvolvimento horizontal sustentável da cidade ${ }^{14}$

Por derradeiro, mas não menos importante, aludido doutrinador ${ }^{15}$ enfatiza que o parcelamento do solo deve ser analisado pela perspectiva ambiental, visando à observância do direito ao meio ambiente ecologicamente equilibrado (artigo 225 da CRFB), que se traduz na garantia do direito à cidade sustentável, estabelecido no artigo 2으, I, do Estatuto da Cidade. É imprescindível que haja o parcelamento sustentável da propriedade imobiliária.

Feitas tais considerações, conforme acima mencionado, no loteamento não há o aproveitamento do sistema viário existente, havendo a abertura de novas vias e logradouros públicos ou o prolongamento, a modificação ou a ampliação dos já existentes.

O loteamento "é meio de urbanização e só se efetiva por procedimento voluntário e formal do proprietário da gleba, que planeja a sua divisão e submete à aprovação da Prefeitura, para subseqüente inscrição no registro imobiliário". ${ }^{16}$

Nos ensinamentos de Vicente Celeste $\operatorname{Amadei}^{17}$, a inscrição do loteamento, no registro imobiliário competente, compreende seis etapas, quais sejam: rogação, documentação, qualificação registraria, comunicação, publicação do edital e, por fim, o registro na matrícula do imóvel. A rogação compreende a necessidade de o registro do loteamento ser provocado, requerido pelo interessado, não podendo o registrador agir de ofício. Quanto à documentação, o artigo 18 da Lei n. 6.766/79 estabelece o rol de documentos necessários a serem apresentados na serventia imobiliária. A propósito, referido doutrinador preleciona:

Nota-se, ainda, em exame conjunto dos diversos documentos de apresentação necessária, que alguns deles têm em vista o resguardo do interesse público, urbanístico e administrativo (ato de aprovação, cronograma de obras acompanhado de instrumento de garantia, termo de verificação de obras etc.); outros, o interesse privado, negocial e civil, de tutela dos futuros adquirentes de lotes (históricos dos títulos de propriedade, certidões de ações reais e pessoais, de protesto de títulos, contrato-padrão, etc.).

\footnotetext{
${ }^{14}$ AMADEI, Vicente Celeste; AMADEI Vicente de Abreu. Como lotear uma gleba: o parcelamento do solo urbano e seus aspectos essenciais (Loteamento e Desmembramento). 4.ed. Campinas, SP: Milennium Editora, 2014, p. 4-5.

${ }^{15}$ AMADEI, Vicente Celeste; AMADEI Vicente de Abreu. Como lotear uma gleba: o parcelamento do solo urbano e seus aspectos essenciais (Loteamento e Desmembramento), p. 6.

${ }^{16}$ MEIRELLES, Hely Lopes. Urbanismo e Proteção Ambiental. Revista de Direito Público n. 39/40. São Paulo: Revista dos Tribunais, 1976, p. 72.

${ }^{17}$ AMADEI, Vicente Celeste; AMADEI Vicente de Abreu. Como lotear uma gleba: o parcelamento do solo urbano e seus aspectos essenciais (Loteamento e Desmembramento), p. 287-290.
} 
Por isso se diz que o serviço de registro de imóveis exerce, e tema de registro de parcelamento do solo, função instrumental de controle urbanístico da propriedade e função instrumental protetivosocial dos adquirentes.

Para o registro do loteamento, no Ofício de Registro de Imóveis competente, são necessários os seguintes documentos: requerimento firmado pelo proprietário com firma reconhecida por autenticidade; certidão de aprovação da Prefeitura Municipal do local do empreendimento; memorial descritivo de todas as áreas (desmembradas, remanescentes, áreas verdes, áreas institucionais, etc.), assinado pelo responsável técnico, com sua firma reconhecida; apresentação da ART/CREA ou RRT/CRA quitada, assinada pelo responsável técnico e pelos proprietários. Além disso, dispõe o artigo 18 da Lei n. 6.766/79:

Art. 18. Aprovado o projeto de loteamento ou de desmembramento, o loteador deverá submetê-lo ao registro imobiliário dentro de 180 (cento e oitenta) dias, sob pena de caducidade da aprovação, acompanhado dos seguintes documentos:

I - título de propriedade do imóvel ou certidão da matrícula, ressalvado o disposto nos $\S 4^{\circ}$ e $5^{\circ}$

II - histórico dos títulos de propriedade do imóvel, abrangendo os últimos 20 (vintes anos), acompanhados dos respectivos comprovantes;

III - certidões negativas:

a) de tributos federais, estaduais e municipais incidentes sobre o imóvel;

b) de ações reais referentes ao imóvel, pelo período de 10 (dez) anos;

c) de ações penais com respeito ao crime contra o patrimônio e contra a Administração Pública.

IV - certidões:

a) dos cartórios de protestos de títulos, em nome do loteador, pelo período de 10 (dez) anos;

b) de ações pessoais relativas ao loteador, pelo período de 10 (dez) anos;

c) de ônus reais relativos ao imóvel;

d) de ações penais contra o loteador, pelo período de 10 (dez) anos.

V - cópia do ato de aprovação do loteamento e comprovante do termo de verificação pela Prefeitura Municipal ou pelo Distrito Federal, da execução das obras exigidas por legislação municipal, que incluirão, no mínimo, a execução das vias de circulação do loteamento, demarcação dos lotes, quadras e logradouros e das obras de escoamento das águas pluviais ou da aprovação de um cronograma, com a duração máxima de quatro anos, acompanhado de competente instrumento de garantia para a execução das obras;

$\mathrm{VI}$ - exemplar do contrato padrão de promessa de venda, ou de cessão ou de promessa de cessão, do qual constarão obrigatoriamente as indicações previstas no art. 26 desta Lei;

VII - declaração do cônjuge do requerente de que consente no registro do loteamento.

O registrador deve analisar rigorosamente a documentação e, se estiver em ordem, 
proceder à comunicação à Prefeitura local e, após, publicar editais do pedido de registro, por três vezes, em jornal de grande circulação, dando ciência a todos do empreendimento, conforme determina o artigo 19, caput, da lei n. 6.766/79. Ultrapassado o prazo de 15 (quinze) dias contados da última publicação e não havendo impugnação, incumbe ao registrador proceder ao registro do loteamento no Livro 2- Registro Geral, livro que é destinado às matrículas. A matrícula do imóvel parcelado, denominada matrícula-mãe, receberá o registro do empreendimento e originará as matrículas de cada um dos lotes objeto do loteamento.

Uma vez registrado o loteamento, passam a integrar ao domínio do Município as vias e praças, os espaços livres e as áreas destinadas aos edifícios públicos e outros equipamentos urbanos, constantes do projeto e do memorial descritivo, conforme previsto no artigo 22 da Lei $\mathrm{n}$. 6.766/1979, independente de título aquisitivo. Essa transferência ocorre ex lege, com a simples aprovação e, posterior, registro do projeto. Aliás, a menção a essas áreas públicas deve ser feita no registro do parcelamento, anotando-se que passam a integrar o domínio do Município.

Por outro lado, o loteamento intitulado "fechado", novo modelo de desenvolvimento urbano, caracteriza-se pela restrição ao uso dos bens públicos unicamente pelos proprietários dos lotes, moradores ou pessoas por ele autorizadas, pois o perímetro é cercado ou murado, concebido para agregar segurança e qualidade de vida.

Esse empreendimento caracteriza-se por se tratar de um loteamento, aprovado nos termos da Lei de Parcelamento do Solo - Lei n. 6.766/1979 - com a peculiaridade de a municipalidade retirar as vias, praças, logradouros e demais bens públicos, da categoria de bem de uso comum do povo e passá-lo para a categoria de bem de uso especial. Esses bens são concedidos ao uso exclusivo de particulares, que, no caso, são os proprietários do loteamento ou pessoas por eles autorizadas.

Diante disso, pode-se dizer que os loteamentos fechados foram concebidos na tentativa de fugir da violência que atinge, sobretudo, os grandes centros urbanos. Toshio Mukai ${ }^{18}$ preleciona que o controle de acesso a essas espécies de loteamento decorre da necessidade imperiosa de segurança, diante da violência que hodiernamente assola o país, sendo, pois, uma verdadeira adequação dos espaços à realidade. O autor conclui, ainda, que a liberdade de locomoção é tolhida não pelo fechamento de lotes e ruas, mas, sim, pela falta de segurança pública.

\footnotetext{
${ }^{18}$ MUKAI, Toshio. Consolidada a legalidade dos loteamentos fechados. Revista Magister de Direito Ambiental e Urbanístico, Porto Alegre, v. 11, n. 63, p. 52-63, dez. 2015/jan.2016.
} 
Destarte, conforme preleciona a doutrina ${ }^{19}$, a natureza desses empreendimentos é de verdadeiro parcelamento do solo seguindo-se, portanto, o regramento previsto na Lei $\mathrm{n}$. $6766 / 1979$, com as peculiaridades necessárias do empreendimento. Destarte, para viabilizar o uso privado dos equipamentos de natureza pública e o acesso controlado aos proprietários do lote, valem-se os Municípios de ato administrativo - contrato de concessão de uso de bem público ou permissão qualificada de uso de bem público -, corroborado por Lei Municipal que disponha acerca desses instrumentos.

Portanto, aprovado e registrado o loteamento, o proprietário tabular das áreas públicas é o município, o qual, mediante o instituto da concessão de uso de bem público, concede aos particulares o uso exclusivo dessas áreas. Sobre o tema, explica Toshio Mukai ${ }^{20}$ :

Tratar-se-á de um loteamento comum, sujeito às regas superiores da Lei $6.766 / 79$, mas cujas vias de
comunicação e espaços livres sejam objeto de fechamento mediante lei municipal, que ao mesmo
tempo autorizará o Executivo a outorgar a concessão do direito real de uso à sociedade formada
pelos adquirentes dos lotes mediante instrumento público ou particular, onde deverão constar
obrigações da sociedade visando o fechamento do loteamento e a implantação de portarias de
acesso, urbanização e conservação das vias e praças, manutenção do serviço de limpeza, permissão
e facilitação da fiscalização dos agentes públicos municipais, com a possibilidade de rescisão da
concessão em caso de desvirtuamento das condições pactuadas.

Considerando ser o registrador adstrito ao princípio da legalidade e não havendo previsão legal para esses empreendimentos, surgiram divergências acerca da legitimidade de os registradores qualificarem positivamente tais empreendimentos. Nesse contexto, houve a recusa, por parte do registro de imóveis, em registrar um loteamento fechado tendo a Corregedoria Geral da Justiça do Estado de São Paulo, no Processo CG № 933/2006 ${ }^{21}$, decido:

REGISTRO DE IMÓVEIS - PARCELAMENTO DO SOLO - LOTEAMENTO FECHADO - IMPUGNAÇÃO AO REGISTRO - EXISTÊNCIA DE LEGISLAÇÃO MUNICIPAL QUE DISCIPLINA REFERIDA MODALIDADE DE PARCELAMENTO DO SOLO - EMPREENDIMENTO, ADEMAIS, APROVADO PELOS ÓRGÃOS PÚBLICOS MUNICIPAIS E ESTADUAIS COMPETENTES - SUFICIÊNCIA PARA RECONHECIMENTO DA LEGALIDADE FORMAL DO EMPREENDIMENTO, NO ÂMBITO DA QUALIFICAÇÃO REGISTRAL - IMPOSSIBILIDADE DE NEGATIVA DE VIGÊNCIA A NORMAS MUNICIPAIS NA ESFERA ADMINISTRATIVA, SOB O ARGUMENTO DE INCONSTITUCIONALIDADE - CONTROLE DE COMPATIBILIDADE DE NORMA MUNICIPAL COM NORMA FEDERAL, À LUZ DOS CRITÉRIOS CONSTITUCIONAIS DE REPARTIÇÃO DE COMPETÊNCIAS LEGISLATIVAS, RESERVADO, COMO REGRA, NA MATÉRIA, AO PODER JUDICIÁRIO, NO EXERCíCIO DA

\footnotetext{
${ }^{19}$ TUTIKIAN, Cláudia Fonseca; TIMM, Luciano Benetti e PAIVA, João Pedro Lamana (coord.), in Novo Direito Imobiliário e Registral. 2. Ed. São Paulo: Quartier Latin, 2010, p. 55.

${ }^{20}$ MUKAI, Toshio. Temas atuais de direito urbanístico e ambiental. Belo Horizonte: Fórum, 2004, p. 92.

21 Processo CGJ/SP n. 933/2006, disponível em: https://www.extrajudicial.tjsp.jus.br/pexPtl/visualizarDetalhesPublicacao.do?cdTipopublicacao=2\&nuSeqpublicacao=10
} 
FUNÇÃO JURISDICIONAL - IMPUGNAÇÃO NÃO ACOLHIDA - REGISTRO AUTORIZADO - RECURSO NÃO PROVIDO.

Na referida decisão, adotou-se o entendimento de que havendo aprovação municipal não detém o registrador legitimidade para devolver os loteamentos que ingressarem como loteamentos fechados, já que esse controle urbanístico deve ser feito pela municipalidade.

Em recente decisão proferida pelo Supremo Tribunal Federal, no Recurso Extraordinário n. 607.940, do Distrito Federal, cujo Relator foi o Ministro Teori Zavascki, houve a consolidação do entendimento acerca da competência normativa conferida pela Constituição Federal aos Municípios e ao Distrito Federal para legislarem sobre a ocupação, a expansão e o desenvolvimento urbanos e, consequentemente, detendo os entes municipais competência normativa para tanto.

Corroborando o assunto, o doutrinador Marcelo Buzaglo Dantas ${ }^{22}$ conclui que:

\begin{abstract}
O tema é de extrema relevância porque, acima de tudo, coloca uma pá de cal na controvérsia consubstanciada na competência normativa municipal sobre a matéria. Com efeito, inúmeras situações são levadas ao conhecimento do Poder Judiciário em todo o país, relacionadas ao tema. Isso porque, normalmente, tem-se entendido que as normas municipais não são aptas a disciplinar institutos não previstos na legislação federal (caso, p.ex., dos loteamentos fechados e dos condomínios de lotes) e aí se busca a intervenção do Judiciário para a decretação de inconstitucionalidade dos respectivos diplomas municipais.

O acórdão da Suprema Corte, a nosso sentir, põe fim a celeuma. Segundo o que foi definido pelo Plenário é que o ente que detém competência legislativa para editar normas sobre uso e ocupação do solo é o Município.
\end{abstract}

Nos termos do artigo 24 , inciso $1^{23}$ e $\S 10^{24}$, combinados com o artigo $182^{25}$, ambos da Constituição Federal, a União tem competência normativa em matéria urbanística para estabelecer as diretrizes gerais, enquanto os Estados o poder normativo suplementar, nos termos do artigo $24, \S \S 2$ e $30^{26}$, da CRFB, além da clássica competência residual prevista no artigo 25, 1으, da $\mathrm{CRFB}^{27}$, bem como a competência regional para ordenar seu território, nos termos do $\S 33^{28}$, do

\footnotetext{
22 DANTAS, Marcelo Buzaglo. Considerações sobre Loteamentos Fechados - Disponível em: http://siaiapp28.univali.br/lstfree.aspx?type=ebook\&id=4.

${ }^{23}$ Art. 24. Compete à União, aos Estados e ao Distrito Federal legislar concorrentemente sobre:

I - direito tributário, financeiro, penitenciário, econômico e urbanístico;

${ }^{24} \S 1$ 은 No âmbito da legislação concorrente, a competência da União limitar-se-á a estabelecer normas gerais.

${ }^{25}$ Art. 182. A política de desenvolvimento urbano, executada pelo Poder Público municipal, conforme diretrizes gerais fixadas em lei, tem por objetivo ordenar o pleno desenvolvimento das funções sociais da cidade e garantir o bem- estar de seus habitantes

${ }^{26} \S 2$ ㅇ A competência da União para legislar sobre normas gerais não exclui a competência suplementar dos Estados.

§ 3ㅇ Inexistindo lei federal sobre normas gerais, os Estados exercerão a competência legislativa plena, para atender a suas peculiaridades.

27 Art. 25. Os Estados organizam-se e regem-se pelas Constituições e leis que adotarem, observados os princípios desta Constituição.
} 
referido dispositivo constitucional.

Por sua vez, aos municípios foi reservada a competência para legislarem sobre assunto de interesse local e o ordenamento dos espaços urbanos, o que inclui o planejamento e controle do uso, o parcelamento e a ocupação do solo urbano (artigo 30, incisos I, II e VIII, da Constituição Federal).

A propósito, Hely Lopes Meirelles ${ }^{29}$ afirma:

Interesse local não é interesse exclusivo do Município; não é interesse privativo da localidade; não é interesse único dos munícipes. Se se exigisse essa exclusividade, essa privatividade, essa unicidade, bem reduzido ficaria o âmbito da Administração local, aniquilando-se a autonomia de que faz praça a Constituição. Mesmo porque há interesse municipal que não o seja reflexamente da União e do Estado-membro, como, também, não há interesse regional ou nacional que não ressoe nos Municípios, como partes integrantes da Federação Brasileira. O que define e caracteriza o "interesse local”, inscrito como dogma constitucional, é a predominância do interesse do Município sobre o do Estado ou da União.

Destarte, a Lei n. 6.766/79 traça as linhas gerais sobre o direito de propriedade imobiliária urbana, dispondo sobre o seu fracionamento pelo parcelamento do solo, competindo aos municípios à adequação dessa legislação aos interesses e características locais, ocorrendo uma repartição de competências constitucionalmente delimitadas.

Consoante lição de Eduardo Lima de Matos ${ }^{30}$ :

O Município é a menor unidade federativa; está mais próximo dos problemas de uma determinada área e detém os instrumentos legais para atuação. Ora, estando com a competência para gerir o interesse local, poderá implementar uma política ambiental que promova o desenvolvimento e assegure a proteção ao meio ambiente, proporcionando uma melhor qualidade de vida aos munícipes. Além disso, conhecendo melhor os seus problemas, o Município pode resolver com mais agilidade o que for de interesse local.

Conforme reconhecido pela Corte Superior, essa possibilidade decorre da autonomia legislativa e administrativa conferida aos Municípios por força do artigo 30, incisos I, II e VIII, da Constituição Federal. E, em que pese a omissão legislativa sobre o tema, a legislação sobre permissões e concessões poderá ser utilizada como subsídio, pelos municípios, para compatibilizar

\footnotetext{
$\S 1$ 음 Sa reservadas aos Estados as competências que não Ihes sejam vedadas por esta Constituição.

${ }^{28}$ Art. 25. Os Estados organizam-se e regem-se pelas Constituições e leis que adotarem, observados os princípios desta Constituição.

[...]

§ 3으 Os Estados poderão, mediante lei complementar, instituir regiões metropolitanas, aglomerações urbanas e microrregiões, constituídas por agrupamentos de municípios limítrofes, para integrar a organização, o planejamento e a execução de funções públicas de interesse comum.

${ }^{29}$ MEIRELLES, Hely Lopes. Direito municipal brasileiro, p. 109.

${ }^{30}$ MATOS, Eduardo Lima de. Autonomia municipal e meio ambiente. Belo Horizonte: Del Rey, 2001, p. 132.
} 
os problemas derivados do uso privado dos equipamentos de natureza pública.

A propósito, oportuna a transcrição dos ensinamentos de Luiz Antônio Scavone Junior ${ }^{31}$, nos seguintes termos:

O loteamento fechado nada mais é que o resultado da subdivisão de uma gleba em lotes destinados à edificação, com abertura de novas vias de circulação e de logradouros púbicos, cujo perímetro da gleba original, ao final, é cercado ou murado de modo a manter aceso controlado. Nesse caso, os proprietários, mediante regulamento averbado junto à matrícula do loteamento, são obrigados a contribuir para as despesas decorrentes da manutenção e conservação dos espaços e equipamentos públicos que passam ao uso exclusivo por contrato administrativo de concessão entre o Município e uma associação criada para esse fim.

Assim, em que pese a omissão na legislação de parcelamento do solo, detém o município a competência conferida pela Constituição Federal para autorizar os particulares a utilizarem, de forma privativa, as vias, as praças, as áreas de lazer e demais bens públicos, transformando o empreendimento em loteamento fechado.

E não havendo qualquer ilegalidade nesses empreendimentos, não cabe ao Oficial registrador qualificar negativamente, exclusivamente por esse fundamento, os títulos apresentados para registro. Apesar disso, deve observar toda a lei de parcelamento do solo, notadamente os documentos exigidos pelo artigo 18 do referido diploma legal, acima já mencionados.

Oportuno ressaltar, por derradeiro, que embora constitucional os empreendimentos intitulados loteamentos fechados, não é possível ingressar no folio real o pedido de averbação de certidão emitida pelo Município noticiando a natureza desses empreendimentos. Isso porque, a concessão das áreas públicas trata-se de questão obrigacional entre o Poder Público Municipal e os particulares adquirentes dos lotes, não consistindo em mutações jurídicas reais relacionados aos imóveis.

Esse entendimento foi adotado pela Corregedoria Geral da Justiça do Estado de São Paulo, no Processo CG n² 2014/24793, datado de 16 de maio de 2014, aprovado pelo Corregedor Geral da Justiça Hamilton Elliot Akel $^{32}$. Na situação em comento, o objetivo das partes era dar conhecimento a todos os proprietários de lotes, atuais e futuros, acerca da natureza do empreendimento, notadamente em razão das responsabilidades dos particulares na manutenção

\footnotetext{
${ }^{31}$ SCAVONE JUNIOR, Luiz Antônio. Direito Imobiliário. Teoria e Prática. 3ạ ed., rev. e atual. Rio de Janeiro: Forense, 2011 , p. 111.

32 Tribunal de Justiça do Estado de São Paulo. Processo CG $n^{\circ}$ 2014/24793. Disponível em: http://www.tjsp.jus.br/cco/obterArquivo.do?cdParecer=6380. Acesso em: 09 de mar de 2017.
} 
da infraestrutura das áreas públicas. Apesar da intenção de conferir publicidade erga omnes à natureza do empreendimento e especialmente na intenção de alterar os adquirentes das eventuais despesas na conservação das áreas públicas ${ }^{33}$, não foi possível o ingresso dessa informação na matrícula do imóvel, por se tratar de questão meramente obrigacional.

\section{CONSIDERAÇÕES FINAIS}

O presente artigo teve como objetivo geral analisar a possibilidade de os Registros de Imóveis recepcionarem uma nova forma de ordenação do solo urbano, intitulada de loteamento fechado ou loteamento de acesso controlado.

Todos os títulos que são submetidos a registro passam previamente por um procedimento de qualificação por parte do Oficial Registrador, o qual faz um controle da legalidade dos documentos apresentados. Nessa qualificação é verificada a observância aos princípios registrais, bem como a obediência ao ordenamento jurídico, só adentrando à publicidade registral os títulos válidos e perfeitos para os fins a que se destinam.

Na qualificação de um parcelamento do solo, da espécie de loteamento, incumbe ao Oficial Registrador analisar os requisitos previstos na Lei n. 6.766/79, notadamente o artigo 18, que traz o rol dos documentos que o loteador deve apresentar. Entretanto, no referido Diploma Legal não existe dispositivo regulamentando os loteamentos fechados, razão pela qual surgiram questionamentos acerca da constitucionalidade e legalidade desses empreendimentos e, consequentemente, da possibilidade de recepção por parte das Serventias Imobiliárias.

Apesar de inexistente legislação federal sobre o assunto, detém o Município ou o Distrito Federal a competência legislativa para disciplinar essa espécie de ordenação do solo urbano, com base no artigo 30, incisos I e VIII, da Constituição Federal.

Nesse contexto, no julgamento do Recurso Extraordinário n. 607.940/DF, o Supremo Tribunal Federal confirmou a tese de que o município é o Ente Federativo que detém competência legislativa para editar normas sobre uso e ocupação do solo urbano e, consequente, autorizarem o fechamento dos loteamentos.

\footnotetext{
${ }^{33}$ Segundo Luiz Antônio Scavone Junior, in Direito Imobiliário. Teoria e Prática. 3a ed., rev. e atual. Rio de Janeiro: Forense, 2011, p. 111 , os proprietários dos lotes em um loteamento fechado são obrigados a contribuir para as despesas decorrentes da manutenção e conservação dos espaços e equipamentos públicos que passam ao uso exclusivo por contrato administrativo de concessão entre o Município e uma associação criada para esse fim.
} 
Assim, em que pese a omissão na legislação de parcelamento do solo, detém o município a competência conferida pela Constituição Federal para autorizar os particulares a utilizarem, de forma privativa, as vias, as praças, as áreas de lazer e demais bens públicos, transformando o empreendimento em loteamento fechado mediante a concessão/permissão das áreas públicas aos particulares.

E não havendo qualquer ilegalidade nesses empreendimentos, não compete ao Oficial registrador qualificar negativamente, exclusivamente por esse fundamento, os títulos apresentados para registro.

Por todo exposto, conclui-se que é possível ingressar, nos Registros de Imóveis, os empreendimentos denominados de loteamentos fechados ou loteamento de acesso controlado.

\section{REFERÊNCIAS DAS FONTES CITADAS}

AMADEI, Vicente Celeste; AMADEI Vicente de Abreu. Como lotear uma gleba: o parcelamento do solo urbano e seus aspectos essenciais (Loteamento e Desmembramento). 4.ed. Campinas, SP: Milennium Editora, 2014.

BRASIL. Casa Civil. Constituição da República Federativa do Brasil de 1988. Disponível em: http://www.planalto.gov.br/ccivil_03/constituicao/constituicao.htm Acesso em: 12 mar. 2017.

BRASIL. Casa Civil. Lei n. 6.766, de 19 de Dezembro de 1979. Dispõe sobre o Parcelamento do Solo Urbano e dá outras Providências. Disponível em http://www.planalto.gov.br/ccivil_03/leis/L6766.htm. Acesso em: 12 mar. 2017.

DANTAS, Marcelo Buzaglo. Considerações sobre Loteamentos Fechados - Disponível em: http://siaiapp28.univali.br/Istfree.aspx?type=ebook\&id=4.

DINIZ, Maria Helena. Sistema de Registro de Imóveis, 6ạ ed. São Paulo: Saraiva, 2006.

DIP, Ricardo. Registros Públicos: a Trilogia do Camponês de Andorra e outras reflexões. Títulos e Documentos Imóveis - Civil. Campinas: Millennium, 2003.

FARIAS, Cristiano Chaves de; ROSENVALD, Nelson. Direitos Reais, 6a ed. Rio de Janeiro: Ed. Lumen Juris, 2010. 
LOUREIRO, Luiz Guilherme. Registros Públicos: Teoria e Prática. 3. ed. São Paulo: Editora Método, 2012.

MATOS, Eduardo Lima de. Autonomia municipal e meio ambiente. Belo Horizonte: Del Rey, 2001. MEIRELLES, Hely Lopes. Direito Municipal Brasileiro, p. 109.

MEIRELLES, Hely Lopes. Urbanismo e Proteção Ambiental. Revista de Direito Público n. 39/40. São Paulo: Revista dos Tribunais, 1976.

MUKAI, Toshio. Temas atuais de direito urbanístico e ambiental. Belo Horizonte: Fórum, 2004. MUKAI, Toshio. Consolidada a legalidade dos loteamentos fechados. Revista Magister de Direito Ambiental e Urbanístico, Porto Alegre, v. 11, n. 63, p. 52-63, dez. 2015/jan.2016.

PASOLD, Cesar Luiz. Metodologia da pesquisa jurídica: teoria e prática. 12. ed. São Paulo: Conceito Editorial, 2011.

SCAVONE JUNIOR, Luiz Antônio. Direito Imobiliário. Teoria e Prática. 3ạ ed., rev. e atual. Rio de Janeiro: Forense, 2011.

TUTIKIAN, Cláudia Fonseca; TIMM, Luciano Benetti e PAIVA, João Pedro Lamana (coord.), in Novo Direito Imobiliário e Registral. 2. Ed. São Paulo: Quartier Latin, 2010.

TRIBUNAL DE JUSTIÇA DO ESTADO DE SÃO PAULO. Disponível em http://www.tjsp.jus.br/. Acesso em 10 de mar. 2017.

SILVA, Ulysses da. Direito Imobiliário - O Registro de Imóveis e suas atribuições: a nova caminhada, Porto Alegre: Sergio Antônio Fabris Ed., 2008. 


\title{
O PATRIMÔNIO HISTÓRICO COMO DIREITO TRANSNACIONAL À CULTURA
}

\author{
Marcelo Mendes ${ }^{1}$ \\ Zany Estael Leite Júnior ${ }^{2}$
}

\section{INTRODUÇÃO}

O desenvolvimento deste trabalho científico sob a forma de artigo se deu por duas razões: requisito para conclusão do curso de Mestrado em Ciência Jurídica, da Universidade do Vale do Itajaí; e a outra razão reside no desejo de analisar a transcendência jurídica do patrimônio histórico.

Muito se houve falar em direitos fundamentais, como o meio ambiente, saúde, educação etc., mas pouco se sabe sobre sua origem e a natureza, pouco se escreve sobre a perspectiva histórica dos direitos fundamentais e seus efeitos para além das barreiras dos Estados, muito menos sobre a proteção e promoção dos bens históricos que representam a identidade de um povo, bem como sua magnitude transfronteiriça, um tema fascinante que demandaria um curso inteiro e redação de monografias e teses. A relevância da perspectiva cultural dos direitos fundamentais permite perceber o rompimento do tradicional direito fundamental interno e, para além de um mecanismo de interpretação, a própria dignidade do homem.

Assim, iniciará este modesto ensaio, com o valor fundamental dos bens culturais (1a parte), advindo na sequência uma abordagem sobre a perspectiva transnacional do patrimônio cultural e histórico (2 $2^{\text {a }}$ parte), para ao arremate expor algumas considerações sobre os níveis de interesse cultural e também transnacional (3a parte).

Em relação ao conceito operacional de patrimônio cultural, a bem da delimitação semântica, no direito inglês fala-se preponderantemente herança (heritage) cultural e, por vezes, em propriedade cultural (cultural property) ${ }^{3}$, enquanto que no direito alemão se utilizada de bem

\footnotetext{
${ }^{1}$ Mestrando em Ciência Jurídica na Universidade do Vale do Itajaí (UNIVALI). Especialista em Direito Público pelo Complexo de Ensino Superior de Santa Catarina (CESUSC). Procurador do Estado de Santa Catarina. Florianópolis - Santa Catarina, Brasil. marcelo@pge.sc.gov.br

${ }^{2}$ Mestrando em Ciência Jurídicas na Universidade do Vale do Itajaí (UNIVALI). Especialista em Direito Público e Eleitoral pela Unisul. Procurador do Estado de Santa Catarina. Florianópolis - Santa Catarina, Brasil. zany@pge.sc.gov.br

${ }^{3}$ HUTT, Sherry; BLANCO, Caroline Meredith; HARRIS, Stan N. Cultural Property Law: a practitioner's guide to the management, 
cultural (Kulturgut). ${ }^{4}$

Não obstante o termo herança, do inglês, rememorar adequadamente ao legado, à transmissão, que constitui um dos aspectos essenciais do patrimônio histórico, e a expressão patrimônio cultural, como a semelhante em alemão (bem cultural), serem de fácil inteligibilidade, adiantamos desde já a adoção da locução patrimônio histórico, por ser a mais citada nos direitos brasileiro e espanhol.

Também a lei do patrimônio cultural portuguesa partilha de um conceito específico de bens culturais, que reservou a expressão para o patrimônio cultural com natureza material, denominado pela doutrina de bens culturais (materiais). ${ }^{5}$

No Brasil não é diferente. A CRFB igualmente diferenciou patrimônio de bem cultural, quando disse no $\S$ 3ㅇ do art. 215 e incisos I e $\|^{6}$ que a lei estabelecerá o plano plurianual e nacional de cultura, visando a defesa e valorização do patrimônio cultural brasileiro e a produção e promoção de bens culturais. Se fossem tidos como sinônimos, não precisariam estar em incisos distintos.

Longe de pretender exaurir o tema, ou mesmo buscar que este artigo científico se compare ao integral e complexo Direito Comparado, objetiva-se apenas fazer uma breve análise dogmática e crítica dos sistemas espanhol e brasileiro de proteção e promoção ao patrimônio cultural, e a partir da premissa resultante trazer algumas elucubrações sobre o fenômeno da transnacionalidade. Isto é, no que concerne à dimensão espacial deste trabalho acadêmico, a análise se limitará às matizes constitucionais espanhola e brasileira.

Um dos problemas que, inicial e imediatamente, se impõe é indagar sobre a categoria direito à cultura: deve ele necessariamente constar na Constituição de um país e ser considerado fundamental? E também, a perspectiva centrada no Estado, que se limita ao sistema interestadual, é uma estrutura adequada para a investigação da realidade contemporânea do patrimônio

\footnotetext{
protection, and preservation of heritage resources. Second edition. Chicago: American Bar Association, 2016.

${ }^{4}$ NABAIS, José Casalta. Introdução ao direito do património cultural. Coimbra: Almedina, 2010. p. 12.

${ }^{5}$ NABAIS, José Casalta. Introdução ao direito do património cultural. p. 15.

${ }^{6}$ Art. 215. [...]

§ 3o A lei estabelecerá o Plano Nacional de Cultura, de duração plurianual, visando ao desenvolvimento cultural do País e à integração das ações do poder público que conduzem à:

I defesa e valorização do patrimônio cultural brasileiro;

II produção, promoção e difusão de bens culturais; (BRASIL. Constituição da República Federativa. Publicada em 05 de outubro de 1988. Disponível em: <http://www.planalto.gov.br/ccivil_03/Constituicao/Constituicao.htm>, acesso em 21.jun.2018).
} 
histórico? Qual o interesse cultural na preservação de um bem? Seriam eles todos equiparáveis? As Constituições do Brasil e da Espanha abordam a temática da mesma forma?

Após buscar algumas respostas a estes problemas, e expor alguns conceitos operacionais necessários à compreensão das ideias aqui empreendidas, será introduzido o objeto desta pesquisa científica, que adotará a metodologia indutiva e as categorias, conceitos operacionais e

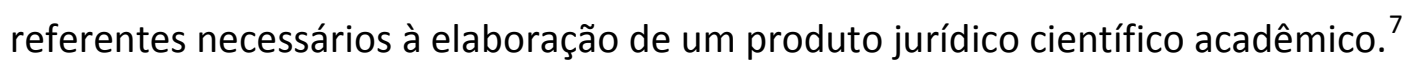

Ao final, o que se pretende, longe de exaurir o tema, é instigar a pesquisa e trazer elementos para formar conviç̧ões, em sintonia ou não com as conclusões aqui apresentadas.

\section{O VALOR (FUNDAMENTAL) DOS BENS CULTURAIS}

O século XX foi marcado por um movimento internacional, liderado pela Unesco, que trabalhou por um consenso global na produção de normas destinadas à proteção, preservação e promoção dos bens naturais. $O$ bem da vida que se almejou proteger e conscientizar a população do mundo situa-se entre os mais essenciais. ${ }^{8}$

Mas nem sempre foi assim.

A essencialidade, bem que se diga, ou o valor das coisas é dado pela população que as detém, segundo o arbítrio de seus valores históricos, sociais e econômicos. E o valor, por estas singelas razões, também varia conforme o espaço. A passagem a seguir bem retrata a mudança na persecução penal no mundo:

No fim do século XVIII e começo do XIX, a despeito de algumas grandes fogueiras, a melancólica festa de punição vai-se extinguindo. [...] O cerimonial da pena vai sendo obliterado e passa a ser apenas um novo ato de procedimento ou de administração. [...] As obras públicas que a Áustria, a Suíça e algumas províncias americanas como a Pensilvânia obrigavam a fazer em plena rua ou nas estradas - condenados com coleiras de ferro, em vestes multicores, grilhetas nos pés, trocando com o povo desafios, injúrias, zombarias, pancadas, sinais de rancor ou de cumplicidade - são eliminados mais ou menos em toda parte no fim do século XVIII, ou na primeira metade do século XIX.

A punição vai-se tornando, pois, a parte mais velada do processo penal, provocando várias consequências: deixa o campo da percepção quase diária e entra no da consciência abstrata; sua eficácia é atribuída à sua fatalidade não à sua intensidade visível; a certeza de ser punido é que deve

\footnotetext{
${ }^{7}$ O presente artigo científico é composto conforme: PASOLD, Cesar Luiz. Metodologia da Pesquisa Jurídica: teoria e prática. 13. ed. rev. São Paulo: Conceito Editorial, 2015, especialmente p. 165.

${ }^{8}$ SOARES, Inês Virgínia Prado. Direito ao (do) Patrimônio Cultural Brasileiro. Belo Horizonte: Fórum, 2009. p. 51
} 
desviar o homem do crime e não mais o abominável teatro; a mecânica exemplar da punição muda as engrenagens. ${ }^{9}$

Até o fim do século XVIII, as execuções das penas eram capitais, de trabalhos forçados, cruéis e até vexatórias. De lá pra cá, notadamente do 2 o pós-guerra mundial e as conferências das nações unidas sobre meio ambiente (Estocolmo, 1972; Rio de Janeiro, 1992; Johanesburgo 2002 e Rio de Janeiro, 2012) ${ }^{10}$ muito se transformou, em especial na evolução e desenvolvimento do direito ao meio ambiente.

O direito fundamental ao meio ambiente ecologicamente equilibrado nos remete a sua característica historicista, e tem sua origem diagnosticada pela boa doutrina a partir da:

[...] queda do regime absolutista, apregoada pelos filósofos iluministas do século XVIII e consagrada com o advento da Revolução Francesa, foi responsável por um redimensionamento da qualidade do indivíduo, que passou da condição de súdito à de cidadão. Tem-se aí os chamados direitos de 1ạ geração, que são a liberdade, a igualdade, a propriedade privada e todos aqueles que se referem ao indivíduo. $^{11}$

Se foi com a teoria contratualista, no século XVIII, que os DFs atingiram o apogeu no iluminismo, não menos verdadeira é a afirmação de que o surgimento dos DFs de 1a dimensão demarca uma zona de não intervenção, cujo limite é a liberdade do indivíduo, surgindo daí os conhecidos direitos de cunho negativo, direitos de resistência ou de oposição perante o Estado. ${ }^{12}$

Assim sendo, são direitos fundamentais de primeira dimensão, e inseridos no texto constitucional brasileiro $^{13}$ : liberdade de expressão, imprensa, manifestação, reunião, associação, direitos de participação política (voto e capacidade eleitoral passiva), a proteção contra a privação arbitrária da liberdade, a inviolabilidade do domicílio, a liberdade e segredo de correspondência, direito de igualdade, devido processo legal, habeas corpus, direito de petição, dentre outros adotados pela Republica Brasileira.

Na Constituição da Monarquia Parlamentar da Espanha ${ }^{14}$, à semelhança da brasileira, igualmente estão constitucionalizados diversos direitos fundamentais de 1 ạ dimensão, que se

\footnotetext{
${ }^{9}$ FOUCAULT, Michel. Vigiar e punir: nascimento da prisão. Trad.: Raquel Ramalhete. Petrópolis: Vozes, 1987. p. 12 e 13.

${ }^{10}$ Disponível em: <https://sustainabledevelopment.un.org/rio20>, acesso em 28.mar.2018.

${ }^{11}$ DANTAS, Marcelo Buzaglo. Direito ambiental de conflitos: o direito ao meio ambiente ecologicamente equilibrado e os casos de colisão com outros direitos fundamentais. Rio de Janeiro: Lumen Juris, 2015. p. 143.

${ }^{12}$ BONAVIDES, Paulo. Curso de Direito Constitucional. 26a ed. São Paulo: Malheiros, 2011. p. 580.

13 BRASIL. Constituição da República Federativa de 1988. Disponível em: < http://www.planalto.gov.br/ccivil_03/Constituicao/Constituicao.htm>, acesso em: 08.mar.2018.

${ }^{14}$ Assim denominamos aquele texto magno pela dicção verbalizada no item 3, artigo 1: "La forma política del Estado español es la Monarquía parlamentaria." ESPANHA. Constituição da Monarquia Parlamentar. Disponível em: < https://www. boe.es/buscar/act.php?id=BOE-A-1978-31229>, acesso em: 08.mar.2018.
} 
encontram detalhados no título I, tais como o livre desenvolvimento da personalidade, o respeito pelas leis, respeito pelos outros, igualdade perante a lei, direito à vida, religião, liberdade de expressão e demais direitos expressa e limitadamente contidos no título I.

Eis aqui uma característica distintiva da ordem constitucional espanhola, somente os direitos que estão inseridos no catálogo do texto espanhol (título I) são considerados fundamentais. Nenhum outro direito, que esteja disperso no texto, ou em outros instrumentos normativos (leis ou tratados), nem mesmo os decorrentes do regime e dos princípios adotados pela CMPE, ostentam o viés da fundamentalidade. ${ }^{15}$

Em continuidade à evolução jusfundamental, impulsionado pela revolução industrial, os graves problemas sociais e econômicos que a acompanharam, e para o bem da efetivação da liberdade e igualdade conquistadas (em sentido formal), surgem os direitos de 2 a dimensão, denominados de direitos sociais, que atribuem ao Estado o comportamento ativo na realização da justiça social. Também conhecidos pela dimensão positiva (sentido material). Foi no século XX, em particular nas Constituições do segundo pós-guerra, que estes novos direitos fundamentais foram consagrados e "...se distinguem dos clássicos direitos de liberdade e igualdade formal, uma vez que nasceram 'abraçados ao princípio da igualdade', entendida num sentido material."16

Na CRFB, os DFs de 2a dimensão estão inseridos no capítulo II, 'Dos Direitos Sociais', tais como liberdade de sindicalização, direito de greve, férias, repouso semanal remunerado, salário mínimo, limitação de jornada de trabalho, FGTS, seguro desemprego, salário família, 13o salário, licença gestante e paternidade, dentre outros tantos, e também ao longo do texto constitucional há os direitos fundamentais não catalogados como o 'Da Seguridade Social' (Título VIII, Capítulo II), por exemplo. Na CMPE estão reconhecidos o direito de greve, direito e dever de trabalhar, ${ }^{17}$ livre

\footnotetext{
${ }^{15}$ É o que nos ensina a doutrina dos Professores da Uned, na Espanha, Ignacio Gutiérrez Gutiérrez e Jorge Alguacil GonzálezAurioles (2011, p. 01): A Constituição espanhola dedica seu primeiro título (após a preliminar) aos direitos fundamentais. [...], o fato de que na Constituição outros direitos aparecem fora desse Título, nesse sentido disperso, nem sempre em óbvia conexão com os direitos reconhecidos dentro dele; e também o regime que pode corresponder a direitos reconhecidos fora da Constituição, mas dotado, em termos que poderiam ser descritos como para-constitucionais, com certa imunidade da Lei (incluindo um valor especial ao interpretar os direitos fundamentais coletados pela nossa Constituição, artigo $10.2 \mathrm{CE}$ ), ou também a qualificação precisa das faculdades jurídicas que incorporam aos direitos constitucionais as leis que, segundo os arts. 53.1 e 81 CE, regulam ou desenvolvem. (GUTIÉRREZ, Ignacio Gutiérrez; e GONZÁLEZ-AURIOLES, Jorge Alguacil. Concepto de derechos fundamentales en la Constitución española. Disponível em: < https://www2.uned.es/dpto-derechopolitico/1concepto3.pdf>, acesso em 28.ago.2018).

${ }^{16}$ SARLET, Ingo Wolfgang. A eficácia dos direitos fundamentais: uma teoria geral dos direitos fundamentais na perspectiva constitucional. p. 47.

${ }^{17}$ A CMPE erigiu o trabalho não apenas como um direito, mas também como dever fundamental de todos os espanhóis: "Artículo 35. 1. Todos los españoles tienen el deber de trabajar y el derecho al trabajo, a la libre elección de profesión u oficio, a la promoción a través del trabajo y a una remuneración suficiente para satisfacer sus necesidades y las de su familia, sin que en ningún caso pueda hacerse discriminación por razón de sexo." ESPANHA. Constituição da Monarquia Parlamentar. Disponível
} 
exercício de profissão, direito de habitação e a seguridade social também, e etc.

Por sua vez, os direitos de 3 a dimensão, também denominados direitos de fraternidade ou solidariedade, caracterizam-se pelo desprendimento do indivíduo, e pela titularidade coletiva ou difusa, como o direito do consumidor e o direito ao meio ambiente equilibrado. ${ }^{18}$

Dentre esses direitos, no texto brasileiro, situam-se: direito de reunião, a paz, a autodeterminação dos povos, o desenvolvimento, patrimônio histórico e cultural, direito de comunicação e o meio ambiente e qualidade de vida. ${ }^{19}$ Já no espanhol, há direito ao meio ambiente adequado para desenvolvimento da pessoa, direito de reunião, de associação, de participar dos assuntos políticos, preservação do patrimônio histórico, artístico e dos povos da Espanha, direito de petição dentre outros. ${ }^{20}$

Nota-se que, tanto no texto constitucional brasileiro como no espanhol, está presente o Cop de meio ambiente em sentido amplo, na medida em que ambas Constituições igualmente assentaram os recursos naturais, o patrimônio histórico e o trabalho como valores essenciais à nação. E isto se justifica pelos períodos da história por que igualmente passaram Brasil e Espanha.

Daí a observação que faz a doutrina, ao reconhecer que os direitos fundamentais projetamse em sucessivas gerações (ou dimensões), todas elas vinculadas a determinados momentos e correntes constitucionais, como o revela Paulo Bonavides que relaciona, no estudo do tema, cinco gerações de direitos fundamentais, por ele assim catalogadas: primeira geração (direitos de liberdade), segunda geração (direitos de igualdade), terceira geração (direitos de solidariedade ou de fraternidade), quarta geração (democracia, informação e pluralismo) e quinta geração (direito à paz). ${ }^{21}$

É claro que, entre nós, o landmark da fundamentalidade do direito ao meio ambiente é interpretação já pacificada, há muito tempo, e neste ponto estamos consentâneos com a doutrina de Marcelo Buzaglo Dantas ${ }^{22}$, porém no direito espanhol a interpretação não é tão pacífica assim.

\footnotetext{
em: < https://www. boe.es/buscar/act.php?id=BOE-A-1978-31229>, acesso em: 08.mar.2018.

${ }^{18}$ SARLET, Ingo Wolfgang. A eficácia dos direitos fundamentais: uma teoria geral dos direitos fundamentais na perspectiva constitucional. p. 48.

${ }^{19}$ Entre nós, há quem sustente que o direito à cultura e ao lazer por estarem consagrados ao lado dos direitos sociais e econômicos, são direitos humanos de segunda geração. (SOARES, Inês Virgínia Prado e CUREAU, Sandra. Org. Bens culturais e direitos humanos. São Paulo: Sesc, 2015. p. 333).

${ }^{20}$ ESPANHA. Constituição da Monarquia Parlamentar. Disponível em: < https://www.boe.es/buscar/act.php?id=BOE-A-197831229>, acesso em: 08.mar.2018.

${ }^{21}$ BONAVIDES, Paulo. Curso de Direito Constitucional. 26a ed. São Paulo: Malheiros, 2011. p. 560/578 e 579/593.

22 “...pode-se facilmente chegar à conclusão de que o direito ao meio ambiente ecologicamente equilibrado pode perfeitamente
} 
Como aponta Jordano Fraga, a doutrina espanhola “..está dividida entre a consideração do direito a um ambiente apropriado como direito da personalidade, como direito humano ou direito fundamental." 23

Para outra vertente doutrinária, a discussão em torno do direito ao meio ambiente ser, ou não, fundamental é irrelevante e imprópria pelo errôneo paradigma que estabelece (direito individual). Assim é que o Professor Gabriel Real Ferrer ${ }^{24}$ ensina:

\begin{abstract}
A inconsistência dos direitos nacionais em relação à sua consideração como Lei Ambiental é demonstrada no debate estéril sobre sua possível consideração como Direito Fundamental. Visto amplamente, o debate sobre a existência ou não de um direito subjetivo de desfrutar de um ambiente adequado beira o absurdo. Em primeiro lugar, porque do ponto de vista legal é insustentável, em segundo lugar, porque a abordagem está errada e precisa ser distorcida até que seja polarizada, pois do ponto de vista individual a questão chave é definir nossas obrigações com relação ao meio ambiente, não nossos direitos.
\end{abstract}

Neste prisma, não há um direito, mas sim um dever fundamental de todos com o meio ambiente, seja ele artificial, cultural e do trabalho, na medida em que não se trata de um direito oponível simplesmente contra o Estado (pessoa jurídica de direito internacional), mas um direito esférico, de todas as pessoas, indistintamente.

Eis o princípio do raciocínio que desenvolveremos no item a seguir: a transnacionalidade do patrimônio histórico.

\title{
2. O PATRIMÔNIO CULTURAL E HISTÓRICO: UM DIREITO TRANSNACIONAL
}

Para além do Direito, no sentido mais geral, falar pode-se em 'interações globais' “...como

ser considerado um direito fundamental. Embora não esteja previsto, de modo específico, no art. 5o da CF/88, isto não significa que o (sic) ele não possa ser considerado fundamental, em virtude do que estabelece o § 20 desse dispositivo..." DANTAS, Marcelo Buzaglo. Direito ambiental de conflitos: o direito ao meio ambiente ecologicamente equilibrado e os casos de colisão com outros direitos fundamentais. Rio de Janeiro: Lumen Juris, 2015. p. 147.

${ }^{23}$ Tradução livre dos autores: "la doctrina se ha dividido entre la consideración del derecho a unmedio ambiente adecuado como derecho de la personalidad, como derecho humano o como derecho fundamental." (FRAGA, Jesús Jordano. La protección del derecho a un medio ambiente adecuado. Barcelona: Bosch, 1995. Disponível em: < file:///C:/Users/mende/Downloads/RJ_19_V_3\%20(1).pdf>, acesso em: 30.mar.2018. pg 485). Aliás, o próprio Professor Gabriel Real Ferrer já defendeu que "...desde una perspectiva técnico-jurídica, ya me manifesté con relación a la Constitución española entendiendo que no lo contemplaba como un Derecho fundamental." (El Medio Ambiente en la Constitución Española, Revue Juridique de l' Environnement, 4/1.994, pags. 319).

${ }^{24}$ Tradução livre dos autores: "La inconsistencia de los derechos nacionales en cuanto a su consideración como Derecho Ambiental se demuestra en el estéril debate acerca de su posible consideración como Derecho Fundamental. Visto ampliamente, el debate sobre la existencia o no de un derecho subjetivo a disfrutar de un medio ambiente adecuado roza lo absurdo. En primer lugar, porque desde un punto de vista jurídico es insostenible, em segundo, porque el enfoque es erróneo y requiere ser retorcido hasta hacerlo polarmente opuesto, pues desde un punto de vista individual la cuestión clave es definir nuestras obligaciones respecto del medio, no nuestros derechos." (FERRER, Gabriel Real. La construcción del Derecho Ambiental. Disponível em: <https://dda.ua.es/documentos/construccion_derecho_ambiental.pdf>, acesso em: 30.mar.2018. p. 18). 
movimentos de informação, dinheiro, objetos físicos, pessoas ou outros itens tangíveis ou intangíveis através dos limites do Estado." ${ }^{25}$ Essas interações globais são classificadas por Joseph S. Nye Jr. e Robert Keohane desde 1971 em, pelo menos, quatros tipos:

1) comunicação, o movimento da informação, incluindo a transmissão de crenças, ideias e doutrinas; 2) transporte, o movimento de objetos físicos, incluindo material bélico e bens pessoais, bem como mercadorias; 3) finanças, movimentação de dinheiro e instrumentos de crédito; 4) viagem, o movimento de pessoas. $^{26}$

Para melhor compreender o que queremos dizer acima, para além do Direito, outros fatos sociais como comércio e a guerra (exemplos dos autores) “...exigem movimentos coordenados de informação, objetos físicos, dinheiro e pessoas; assim como a participação mais pessoal de indivíduos em sociedades estrangeiras..." ${ }^{27}$, que denomina de 'participação transnacional'. O que Joseph S. Nye Jr. e Robert Keohane sustentam, a partir de nossa percepção, é que algumas interações globais são encetadas e mantidas a partir de um único estado-nação. Isso vale para a maioria das guerras, comunicação internacional, comércio e finanças.

Entretanto, os efeitos das interações (são cinco os principais) têm consequências diretas ou indiretas para a sensibilidade mútua e, portanto, para a política interestatal. Joseph S. Nye Jr. e Robert Keohane resumem nos seguintes ítens:

I) mudanças de atitude, 2) pluralismo internacional, 3) aumento das restrições aos estados por meio de dependência e interdependência, 4) aumento da habilidade de certos governos em influenciar os outros e 5) surgimento de atores autônomos com políticas externas privadas que possam se opor deliberadamente ou colidir com as políticas do Estado. ${ }^{28}$

\footnotetext{
${ }^{25}$ Tradução livre: "...as movements of information, money, physical objects, people, or other tangible or intangible items across state boundaries." (NYE JR., Joseph S. and KEOHANE, Robert O. Transnational Relations and World Politics: An Introduction. Source: International Organization, Vol. 25, No. 3, Transnational Relations and World Politics (Summer, 1971), Published by: University of Wisconsin Press Stable. p. 332. Disponível em: <http://www.jstor.org/stable/2706043>, acesso em 23.mar.2018).

${ }^{26}$ Tradução livre: "1) communication, the movement of information, including the transmission of beliefs, ideas, and doctrines; 2 ) transportation, the movement of physical objects, including war matériel and personal property as well as merchandise; 3) finance, the movement of money and instruments of credit; 4) travel, the movement of persons." (NYE JR., Joseph S. and KEOHANE, Robert O. Transnational Relations and World Politics: An Introduction. Source: International Organization, Vol. 25, No. 3, Transnational Relations and World Politics (Summer, 1971), Published by: University of Wisconsin Press Stable. p. 332. Disponível em: <http://www.jstor.org/stable/2706043>, acesso em 23.mar.2018).

${ }^{27}$ Tradução livre: "Some global interactions are initiated and sustained entirely, or almost entirely, by governments of nationstates. This is true of most wars, a large amount of international communication, considerable trade, and some finance. These we consider "interstate" interactions along with conventional diplomaticac activit." (NYE JR., Joseph S. and KEOHANE, Robert O. Transnational Relations and World Politics: An Introduction. Source: International Organization, Vol. 25, No. 3, Transnational Relations and World Politics (Summer, 1971), Published by: University of Wisconsin Press Stable. p. 332. Disponível em: <http://www.jstor.org/stable/2706043>, acesso em 23.mar.2018).

${ }^{28}$ Tradução livre: “I) attitude changes, 2) international pluralism, 3) increases in constraints on states through depen- dence and interdependence, 4) increases in the ability of certain governments to influence others, and 5) the emergence of autonomous actors with private foreign policies that may deliberately oppose or impinge on state policies..." NYE JR., Joseph S. and KEOHANE, Robert O. Transnational Relations and World Politics: An Introduction. Source: International Organization, Vol. 25, No. 3, Transnational Relations and World Politics (Summer, 1971), Published by: University of Wisconsin Press Stable. p. 332. Disponível em: <http://www.jstor.org/stable/2706043>, acesso em 23.mar.2018).
} 
Estes efeitos das relações transnacionais na política interestatal, catalogados em 1971, certamente sofreram significativas mutações até hoje, tanto pela influência da revolução tecnológica incessante, quanto pelas leis mercadológicas. Certo é que, desde lá até os dias atuais, nunca se pretendeu e não seremos nós que ousaremos neste sentido, em estabelecer os efeitos definitivos da transnacionalidade.

As mudanças de atitudes, que aparecem como primeiro efeito, e o pluralismo internacional, segundo efeito acima listado, têm ligação com as crenças, estilos de vida ou práticas sociais ocidentais em outras partes do mundo. Assim, Joseph S. Nye Jr. e Robert Keohane trazem como exemplo, a atividade dos missionários e o "...pacote cultural que acompanhou o evangelho protestante..." no século XIX, bem como as atividades econômicas e evangélicas das empresas multinacionais no século $X X$.

Faz sentido a conclusão de que as interações transnacionais não dependem apenas dos estados-nação, porque não se pode ignorar a existência de outros atores. É bem verdade que os estados representam os atores mais importantes nos assuntos mundiais, atuando tanto diretamente quanto através de organizações intergovernamentais.

Até a CRFB/67, é possível diagnosticar que o Estado, a partir da identificação das características fundamentais do patrimônio cultural e histórico, concentrava em si a responsabilidade exclusiva (caráter socialista) de proteção.

Em países como o Brasil, marcados como “...culturalmente menos desenvolvidos, costumase atribuir ao Estado o papel primacial, como que se reconhecendo a inépcia da sociedade para exercer a tutela sobre o patrimônio..." ${ }^{29}$, enquanto que naqueles mais avançados, a coletividade é protagonista. E, para além de um dever comum, o patrimônio cultural pode ser visto como um direito transnacional, a depender segundo a nossa diretriz já indicada dos fatos históricos relacionados.

Não se afiança a transnacionalidade a todo e qualquer patrimônio histórico. Isto porque, para tanto é necessário que o interesse sobre aquele determinado bem ultrapasse as fronteiras de uma determinada nação e esteja identificado de alguma forma com aquele patrimônio cultural. Passaremos a detalhar o raciocínio nas próximas linhas, a partir da breve contextualização histórica. Eis aqui a resposta, ao menos sob uma perspectiva, a um dos problemas formulados na

\footnotetext{
${ }^{29}$ PIRES, Maria Coeli Simões. Da proteção ao patrimônio cultural: o tombamento como principal instituto. Belo Horizonte: Del Rey, 1994. p. 278
} 
introdução.

Muitos dos conceitos antes tidos como cláusulas pétreas, hoje estão relativizados. Assim é com a soberania, uma característica marcante do Estado Moderno que vem sendo modificada, ou aperfeiçoada, com as integrações aos blocos econômicos, e até mesmo à comunidade de Estados (União Europeia - EU). Neste contexto, a globalização, tecnologia, as imigrações exerceram um papel decisivo para a construção de uma nova acepção de nação. Na feliz formulação de Patricia Jimena Rivero e Virginia Soledad Martínez ${ }^{30}$ :

A partir dos anos 70 e 80, a abordagem objetivista foi fortemente questionada. Os processos migratórios (não tanto um produto do aumento quantitativo como do deslocamento das populações anteriormente colonizadas para os Estados Unidos e a Europa), juntamente com as mudanças tecnológicas e o papel das novas redes de comunicação, tornaram a interpretação de outras culturas inviável. mundos distantes (Beck, 2002, Hannerz, 2003, Grimson 2010, 2011). Assim, a imagem de um mundo dividido em culturas harmoniosas e estáveis tornou-se implausível e as consequências teóricas e políticas que implicavam ignorar a interconexão (desigual) entre os grupos humanos, bem como suas heterogeneidades internas, conflitos e desigualdades tornaram-se evidentes.

Segundo as autoras, as múltiplas interações globais impossibilitam pensar nas comunidades como unidades isoladas e nos conduz a repensar o conceito de 'fronteira' "[...] como uma noçãochave para a análise cultural” e que as fronteiras culturais são fronteiras de significados, identidades, de sentimentos. ${ }^{31}$

São muitas as interações globais que, como a imigração, enquanto fenômeno social transnacional, têm o poder de influenciar “...a fisionomia sócio-cultural da população de um Estado e sobre a configuração da pertinência em contextoS transnacionais e pluralistas desde o ponto de vista religioso, cultural, linguístico." ${ }^{32}$

\footnotetext{
${ }^{30}$ Tradução livre: "A partir de las décadas de los 70 y 80, el enfoque objetivista fue fuertemente cuestionado. Los procesos migratorios (no tanto producto del incremento cuantitativo como del desplazamiento de las poblaciones antiguamente colonizadas hacia los Estados Unidos y Europa), junto con los cambios tecnológicos y el papel de las nuevas redes comunicacionales, volvió inviable la interpretación de otras culturas como si fueran mundos distantes (Beck, 2002; Hannerz, 2003; Grimson 2010, 2011). Así, la imagen de un mundo dividido en culturas armónicas y estables se tornó inverosímil y se evidenciaron las consecuencias teóricas y políticas que implica desconocer la interconexión (desigual) entre los grupos humanos así como sus heterogeneidades, conflictos y desigualdades internas. (RIVERO, Patricia Jimena; e MARTíNEZ, Virginia Soledad. Cultura e identidade: Discusiones teóricas-epistemológicas para la comprensión de la contemporaneidad. Revista de Antropología Experimental Deposito legal: J-154-2003 no 16, 2016. Texto 8: 109-121. ISSN: 1578-4282. Universidad de Jaén (España). Disponível em: <http://revistaselectronicas.ujaen.es/index.php/rae>, acesso em 03.abr.2018).

${ }^{31}$ RIVERO, Patricia Jimena; e MARTíNEZ, Virginia Soledad. Cultura e identidade: Discusiones teóricas-epistemológicas para la comprensión de la contemporaneidad. Revista de Antropología Experimental Deposito legal: J-154-2003 no 16, 2016. Texto 8: 109-121. ISSN: 1578-4282. Universidad de Jaén (España). Disponível em: <http://revistaselectronicas.ujaen.es/index.php/rae>, acesso em 03.abr.2018.

32 LOCCHI, Maria Chiara. La complejidad del ius soli: una contribución al debate sobre la ciudadanía en los estados democraticopluralistas contemporáneos. Revista General de Derecho Público Comparado 15 (2014). ISSN: 1988-5091, núm. 15, Julio (2014). p. 23.
} 
E não é só a acepção de nação que está sofrendo mutação, assim como também o de 'cultura', “[...] como paradigma fundamental de compreensão da identidade individual e coletiva [...]" está sendo transformado de modo bastante intenso pela globalização, "..na medida em que os fenômenos de desterritorialização e transnacionalismo redesenham elo entre espaço, estabilidade e reprodução cultural [... $]^{\prime 33}$

Pela expressão 'direito transnacional', nos termos de Maria Chiara Locchi entendemos como as múltiplas redes globais e regionais de interação, as instituições e os regimes de governança, as interações jurídicas globais que "[...] no dia de hoje prescindem de um vínculo territorial estável e implicam no pluralismo jurídico dos ordenamentos de referência." ${ }^{34}$

Aquela realidade estatal no Brasil, constituída pela centralização no Estado de todas as obrigações culturais fundamentais, que vigorou até 1988, já foi em muito ultrapassada. Para além da coletividade (local), o dever de colaborar com a proteção à cultura transcende, como visto, as 'fronteiras'.

Do que foi até aqui exposto, a construção conceitual objetiva de Paulo Márcio Cruz e Joana Stelzer bem resume a transnacionalidade “...como aquilo que atravessa o nacional, que perpassa o Estado, que está além da concepção soberana do Estado e, por consequência, traz consigo, inclusive, a ausência da dicotomia público e privado" ${ }^{35}$ Nesta perspectiva, que se pode definir como um estágio avançado de integração entre as Nações, que rompe as fronteiras da tradicional soberania e do próprio território,

Neste sentido, também se pode afiançar, com razoável segurança, que os períodos da história que marcaram o mundo, ou ao menos mais de uma Nação, despertam interesses multiculturais que, igualmente, rompem fronteiras. Entre outras palavras, o patrimônio histórico, nesta situação, preserva em si uma história que, por vezes, não se circunscreve apenas a uma única e isolada nação, região ou comunidade, mas do mundo.

Queremos dizer, a exemplo da valoração que a Monarquia Espanhola adotou para os bens culturais - conforme o interesse cultural - e isso é um critério para diferenciar, objetivamente, o

\footnotetext{
${ }^{33}$ LOCCHI, Maria Chiara. La complejidad del ius soli: una contribución al debate sobre la ciudadanía en los estados democraticopluralistas contemporáneos. Revista General de Derecho Público Comparado 15 (2014). ISSN: 1988-5091, núm. 15, Julio (2014). p. 91.

${ }^{34}$ LOCCHI, Maria Chiara. La complejidad del ius soli: una contribución al debate sobre la ciudadanía en los estados democraticopluralistas contemporáneos. Revista General de Derecho Público Comparado 15 (2014). ISSN: 1988-5091, núm. 15, Julio (2014). p. 31.

${ }^{35}$ CRUZ, Paulo Márcio; STELZER, Joana. Direito e Transnacionalidade. Curitiba: Juruá, 2009. p. 21
} 
valor histórico de cada patrimônio. Todavia, há outra forma de, igualmente de modo utilitário, também aferir o quão é importante determinado bem, de acordo com a vinculação do fato histórico com o mundo.

Explicamos. Se o bem tem identidade com a história mundial, é possível dizer em princípio que o valor daquele patrimônio histórico não se limita àquela comunidade onde se situa, mas transcende às fronteiras do país que o detém. Daí a transnacionalidade que defendemos dos bens que fazem parte da história mundial.

Por que assim defendemos?

Parte-se da premissa que os bens culturais integram o sistema do meio ambiente (lato sensu), e segundo a exposição de motivos da Diretirva 2011/92/UE do Parlamento e do Conselho Europeus, de 13 de dezembro de 2011, “É desejável estabelecer disposições reforçadas relativas à avaliação do impacto ambiental num contexto transfronteiriço, de modo a ter em conta a evolução a nível internacional. ${ }^{36}$

Quis com isso o Conselho e Parlamento Europeus, ao 'transnacionalizar' a avaliação de impacto ambientais, portanto num contexto transfronteiriço, elevar o nível de proteção de um instrumento chave para a política do meio ambiente.

E, respeitando os limites desta espécie de pesquisa acadêmica, considerando que o direito à cultura é elemento integrante do sistema meio ambiente, é possível concluir pela sua transnacionalidade, ao menos quando se tratar de patrimônio cujo interesse social esteja desvinculado dos limites territoriais da nação que o pertença.

\section{CONSIDERAÇÕES FINAIS}

Após a exposição de todos os argumentos e citações neste artigo científico foi possível concluir, sem logicamente exaurir o objeto, que o fim foi atingido: encontrar algumas respostas para os problemas formulados na parte introdutória.

No primeiro item deste ensaio, foi analisada a concepção histórica, suas dimensões e o catálogo dos direitos fundamentais espanhóis e brasileiros. Nesta seção inicial foi possível

\footnotetext{
${ }^{36}$ Preâmbulo da Diretirva 2011/92/UE do Parlamento e do Conselho Europeus, de 13 de dezembro de 2011, relativa à avaliação dos efeitos de determinados projectos públicos e privados no ambiente. (Disponível em: <https://eur-lex.europa.eu/legalcontent/pt/TXT/?uri=CELEX:32011L0092>, acesso em: 02.abr.2018)
} 
constatar que o sistema jurídico brasileiro adotou muitos direitos como fundamentais, muitos outros além daqueles que o ordenamento espanhol adotou.

Eis a primeira distinção: o rol brasileiro é maior que o espanhol e, a segunda, o catálogo de direitos fundamentais de lá é taxativa.

Já na segunda seção, discorreu-se sobre os efeitos das interações transnacionais e, elfim, a transnacionalidade do patrimônio cultural e histórico.

Foi possível notar que as interações transnacionais não dependem apenas dos estadosnação, porque não se pode ignorar a existência de outros atores, e não menos verdade é que os estados representam os atores mais importantes nos assuntos mundiais, atuando tanto diretamente quanto através de organizações intergovernamentais.

Vimos também que, em países como o nosso, marcados como culturalmente menos desenvolvidos, o Estado assume a responsabilidade exclusiva e ao mesmo tempo reconhece a inépcia da sociedade para exercer a tutela sobre o patrimônio, enquanto que naqueles mais avançados, a coletividade é protagonista.

$E$, para além de um dever comum, o patrimônio cultural pode ser visto como um direito transnacional, a depender segundo a nossa diretriz já indicada dos fatos históricos relacionados.

Não quisemos, com isso, assegurar a transnacionalidade a todo e qualquer patrimônio histórico. Isto porque, para tanto é necessário que o interesse sobre aquele determinado bem ultrapasse as fronteiras de uma determinada nação e esteja identificado de alguma forma com aquele patrimônio cultural. Para isso foi importante delimitar a natureza jurídica do direito à cultura, no primeiro item deste artigo, e assim no segundo item estabelecer a transcendência de parte dele sobre os territórios das nações.

Vimos que os períodos da história que marcaram o mundo, ou ao menos mais de uma Nação, despertam interesses multiculturais que, igualmente, rompem fronteiras. Entre outras palavras, o patrimônio histórico, nesta situação, preserva em si uma história que, por vezes, não se circunscreve apenas a uma única e isolada nação, região ou comunidade, mas do mundo.

Partimos da premissa que os bens culturais integram o sistema do meio ambiente (lato sensu), segundo a exposição de motivos da Diretirva 2011/92/UE do Parlamento e do Conselho Europeus, de 13 de dezembro de 2011, que pretende estabelecer disposições reforçadas relativas à avaliação do impacto ambiental num contexto transfronteiriço, de modo a ter em conta a 
evolução a nível internacional.

Quis com isso, em conclusão, o Conselho e Parlamento Europeus, ao 'transnacionalizar' a avaliação de impacto ambientais, portanto num contexto transfronteiriço, elevar o nível de proteção de um instrumento chave para a política do meio ambiente: o direito à cultura.

Para finalizar a conclusão, acreditamos ter alcançado os objetivos da introdução e, com isso, estimular o leitor desta pesquisa a formular críticas e sugestões que julgar oportunas. E se este artigo científico tiver logrado provocar a reflexão, consideramos ter alcançado o objetivo.

\section{REFERÊNCIA DAS FONTES CITADAS}

BONAVIDES, Paulo. Curso de Direito Constitucional. 21. ed. São Paulo: Malheiros, 2007. BRASIL. Constituição da República Federativa. Publicada em 05 de outubro de 1988. Disponível em: <http://www.planalto.gov.br/ccivil_03/constituicao/constituicao.htm>. Acesso em: 25.jan.2018.

CRUZ, Paulo Márcio; STELZER, Joana. Direito e Transnacionalidade. Curitiba: Juruá, 2009. DANTAS, Marcelo Buzaglo. Direito ambiental de conflitos: o direito ao meio ambiente ecologicamente equilibrado e os casos de colisão com outros direitos fundamentais. Rio de Janeiro: Lumen Juris, 2015.

PARLAMENTO E DO CONSELHO EUROPEUS. Diretiva 2011/92/UE, de 13 de dezembro de 2011, relativa à avaliação dos efeitos de determinados projectos públicos e privados no ambiente. (Disponível em: <https://eur-lex.europa.eu/legal-content/pt/TXT/?uri=CELEX:32011L0092>, acesso em: 02.abr.2018).

ESPANHA. Constituição da Monarquia Parlamentar. Disponível em: < https://www. boe.es/buscar/act.php?id=BOE-A-1978-31229>, acesso em: 08.mar.2018.

FERRER, Gabriel Real. La construcción del Derecho Ambiental. Disponível em: <https://dda.ua.es/documentos/construccion_derecho_ambiental.pdf>, acesso em: 30.mar.2018. FOUCAULT, Michel. Vigiar e punir: nascimento da prisão. Trad.: Raquel Ramalhete. Petrópolis: Vozes, 1987. p. 12 e 13.

FRAGA, Jesús Jordano. La protección del derecho a un medio ambiente adecuado. Barcelona: Bosch, 1995. Disponível em: < file:///C:/Users/mende/Downloads/RJ_19_V_3\%20(1).pdf>, acesso em: 30.mar.2018.

GUTIÉRREZ, Ignacio Gutiérrez; e GONZÁLEZ-AURIOLES, Jorge Alguacil. Concepto de derechos fundamentales en la Constitución española. Disponível em: < https://www2.uned.es/dptoderecho-politico/1concepto3.pdf> 
HUTT, Sherry; BLANCO, Caroline Meredith; HARRIS, Stan N. Cultural Property Law: a practitioner's guide to the management, protection, and preservation of heritage resources. Second edition. Chicago: American Bar Association, 2016.

LOCCHI, Maria Chiara. La complejidad del ius soli: una contribución al debate sobre la ciudadanía en los estados democratico-pluralistas contemporáneos. Revista General de Derecho Público Comparado 15 (2014). ISSN: 1988-5091, núm. 15, Julio (2014).

NABAIS, José Casalta. Introdução ao direito do património cultural. Coimbra: Almedina, 2010.

NYE JR., Joseph S. and KEOHANE, Robert O. Transnational Relations and World Politics: An Introduction. Source: International Organization, Vol. 25, No. 3, Transnational Relations and World Politics (Summer, 1971), Published by: University of Wisconsin Press Stable. p. 332. Disponível em: <http://www.jstor.org/stable/2706043>, acesso em 23.mar.2018 PASOLD, Cesar Luiz. Metodologia da Pesquisa Jurídica: teoria e prática. 13. ed. rev. São Paulo: Conceito Editorial, 2015.

PIRES, Maria Coeli Simões. Da proteção ao patrimônio cultural: o tombamento como principal instituto. Belo Horizonte: Del Rey, 1994.

RIVERO, Patricia Jimena; e MARTínEZ, Virginia Soledad. Cultura e identidade: Discusiones teóricasepistemológicas para la comprensión de la contemporaneidad. Revista de Antropología Experimental. Deposito legal: J-154-2003 no 16, 2016. Texto 8: 109-121. ISSN: 1578-4282. Universidad de Jaén (España). Disponível em:

<http://revistaselectronicas.ujaen.es/index.php/rae>, acesso em 03.abr.2018.

SARLET, Ingo Wolfgang. A eficácia dos direitos fundamentais: uma teoria geral dos direitos fundamentais na perspectiva constitucional. Porto Alegre: Livraria do Advogado, 2009.

SOARES, Inês Virgínia Prado. Direito ao (do) Patrimônio Cultural Brasileiro. Belo Horizonte: Fórum, 2009. 


\title{
EL MODELO AGROINDUSTRIAL DE PRODUCCIÓN DE ALIMENTOS POST-MODERNO Y SUS PROBLEMAS SOCIOAMBIENTALES. HACIA UN CAMBIO DE PARADIGMA
}

\author{
"En el mundo hay recursos suficientes para cubrir las \\ necesidades de todos los hombres, pero no para satisfacer su \\ codicia".
}

Mahatma Gandhi

\section{Mariana Moreno Kuhnke ${ }^{1}$}

\section{INTRODUCCIÓN}

La biotecnología y los agrotóxicos asociados a ella, que conforman el actual modelo agroindustrial de producción de alimentos, se vienen desarrollado desde hace varias décadas, sin haberse visto resueltas aún las controversias que los acompañan.

El problema es que el impacto de este modelo sobre la salud humana y el medio ambiente se agudiza cada día porque la naturaleza comienza a no ser capaz de soportarlos y las injusticias sociales se hacen más evidentes; la sociedad creada es una clara sociedad de riesgo. El tiempo acucia para el ser humano, y como defiende el profesor REAL FERRER, la naturaleza va a seguir existiendo sin la humanidad.

El objetivo del trabajo es analizar el actual modelo agroindustrial de producción de alimentos y sus impactos para concluir que es clara la evidencia de que el límite del conocimiento humano crea una sociedad de riesgos, y que los únicos instrumentos con los que cuenta el derecho para combatir estos riesgos son los principios de prevención y precaución, siendo este último el más importante en el desarrollo de este trabajo. Por este motivo, y antes de que se convierta en una sociedad de catástrofe, se necesita un cambio de paradigma, a través del Principio de Sostenibilidad, por el que se alcance la conciencia del ser humano como parte de la naturaleza y se instaurare una forma sostenible y respetuosa de utilizar de los recursos. Al mismo tiempo, se entiende necesario concebir un modo de producción de alimentos justo (ambiental,

\footnotetext{
${ }^{1}$ Maestría en Ciência Jurídica por Universidade do Vale do Itajaí - Brasil. Maestría en "Derecho Ambiental y de la Sostenibilidad" por la Universidad de Alicante - España. Licenciada en Derecho por la Universidad de Granada - España. E-mail: m.morenokuhnkehs@gmail.com
} 
social y económicamente) para todos los seres humanos; un modo de vida que no desemboque en la destrucción ambiental ni en el deterioro de la salud de agricultores, vecinos y/o consumidores de acuerdo con el principio de sostenibilidad.

La elección de esta temática se justifica en que es un asunto de gran actualidad, controvertido como ninguno, ya que confronta grandes intereses económicos y tiene graves consecuencias humanas y ambientales.

La metodología utilizada ha sido la inductiva con las técnicas del referente, de la revisión bibliográfica y del concepto operacional.

\section{EL MODELO AGROINDUSTIAL DE PRODUCCIÓN DE ALIMENTOS}

\subsection{Antecedentes: del Capitalismo Industrial al Post-moderno}

Como describiera Fritjof CAPRA ${ }^{2}$, surgió en el S. XVI, con la Revolución Científica, de la mano de pensadores como COPÉRNICO, GALILEO GALILEI, DESCARTES, BACON y NEWTON, el pensamiento racional que supuso una ruptura con la concepción del mundo medieval. Fue DESCARTES el que instauró como método de investigación la descripción matemática de la naturaleza y el método analítico de razonamiento. Este método fue aceptado como único método de conocimiento por todas las ramas de las ciencias, incluso las sociales; a partir de ese momento se negó el carácter racional de las formas de conocimiento que no se pautaran por sus principios y reglas epistemológicas ${ }^{3}$, y se disociaron ser humano y naturaleza.

La razón tomó un aspecto subjetivo e instrumental, entendiéndose la razón humana como instrumento de dominación y de emancipación simultáneamente.

Por la alteración del discurso racionalizador el modelo capitalista industrial, amparándose en el ideal desarrollista, se consiguió legitimar la dominación y transformación de la naturaleza con finalidad únicamente productiva (el ser humano como ya dijera Descartes, debe "someter a la naturaleza", viéndose separado de ella e incluso superior a la misma ${ }^{4}$ ); se mercantiliza la

\footnotetext{
${ }^{2}$ CAPRA, Fritjof. El punto crucial. Editorial Troquel, Buenos Aires, 1992, p, 27.

${ }^{3}$ SANTOS, Boaventura de Sousa. Um discurso sobre as ciências na transição para uma ciência pós-moderna. Estud. av., São Paulo, v.2, n.2, Ago. 1988, p.48. Disponible en: <http://www.scielo.br/scielo.php?script=sci_arttext\&pid=S0103-40141988000200007>. Último acesso: 29-01-2017.

${ }^{4}$ ALCANTARINO JARDINI GOMES, Ana Carolina. (Re)pensar a humanidade e a natureza: a crise ecológica no pensamento moderno ocidental. XXIV Congresso Nacional Do CONPEDI - UFMG/FUMEC/Dom Helder Câmara. Disponible en <http://www.conpedi.org.br/publicacoes/66fsl345/j0duvo2k>. Último acceso: 28-01-2017.
} 
naturaleza y la educación, la religión, la política e incluso la vida.

Así, el capitalismo vació al hombre de toda moral religiosa, cambiándola, como dice WEBER ${ }^{5}$, por una ética que consiste en "ganar dinero y siempre más dinero" como lo único trascendente en sí mismo, llegando a "cosificar" al ser humano que queda convertido en mano de obra, vale lo que produce o lo que tiene. Ya $\mathrm{HABERMAS}^{6}$ sostuvo que el aumento de la producción y de la población tiene dos grandes limitaciones: a) el abastecimiento con recursos finitos (agua potable, suelo, alimentos y materias primas no renovables); b) la capacidad de los sistemas ecológicos de absorber la contaminación.

\subsection{La "Revolución Verde"}

Así, en los años 20 en los Estados Unidos se comenzó a experimentar cruzando distintos tipos de maíz y obteniendo híbridos, en algunos casos estériles, que garantizarían un mayor lucro a las empresas. Posteriormente, en los años 40, se produjo la llamada "revolución verde". Con los avances tecnológicos nacieron las plantas transgénicas, utilizadas sobre todo en dos de sus variantes, es decir, resistentes a los herbicidas creados específicamente para ellas $(\mathrm{Ht})$ y letales para insectos $(\mathrm{Bt})$.

Acompañando a la ingeniería genética comenzó a crecer también la industria química; en el año 1940 fueron creadas más de 200 sustancias químicas para su uso en la lucha contra los insectos, "malas hierbas", roedores y otros organismos que se describen actualmente como "plagas" ${ }^{7}$. Su único objetivo era eliminar unas pocas plantas o insectos. Así, después de la Segunda Guerra Mundial, se comenzó a usar el DDT (utilizado como arma de guerra) como insecticida cuando se comenzó la era de los agrotóxicos ${ }^{8}$. La industria química encontró en la agricultura un nuevo mercado ${ }^{9}$.

Nace la agro-industria conforme al ideal de desarrollismo capitalista, que combina el cultivo extensivo de plantas transgénicas con el uso de fertilizantes, herbicidas y pesticidas

\footnotetext{
${ }^{5}$ WEBER, Max. A Ética Protestante e o Espírito do Capitalismo. Tradução: José Marcos Mariani de Macedo. Edição Antônio Flávio Pierucci São Paulo: Companhia das Letras, 2004, p. 46.

${ }^{6}$ HABERMAS, Jürgen. A crise de legitimação no capitalismo tardio. 2. ed. São Paulo: Tempo Brasileiro, 2002, p. 58.

${ }^{7}$ CARSON, Rachel. Primavera silenciosa. Editorial Crítica. Barcelona, 2010, p.8.

${ }^{8}$ CARSON, Rachel. Primavera silenciosa. Editorial Crítica. Barcelona, 2010, p. 21.

${ }^{9}$ LONDRES, Flávia. Agrotóxicos no Brasil: um guia para ação em defesa da vida. Rio de Janeiro: AS-PTA - Assessoria e Serviços a Projetos em Agricultura Alternativa, 2012, p. 17.
} 
(agrotóxicos ${ }^{10}$ ), de los cuales en 2012 170,3 millones de hectáreas eran cultivos con biotecnología aplicada, con una tasa anual de crecimiento del $6 \%{ }^{11}$.

El surgimiento de este modelo se argumentó necesario para acabar con el hambre en el mundo, pero la realidad es que no hace falta aumentar la producción de alimento; hoy en día una tercera parte de la producción mundial de alimentos, con la que se podría alimentar a las personas que se mueren de hambre, se tira a la basura, es decir, el modelo no se justifica.

Así, lo que en un principio era una forma de acabar con el hambre en el mundo, se terminó convirtiendo en una industria millonaria que no encuentra rival ni oposición. Se empezó a comprender, tan solo unas décadas después ${ }^{12}$, que este modelo traía como consecuencia la puesta en peligro del equilibro del medio ambiente, la salud humana y la seguridad alimentaria (foodsafety y foodsecurity) ${ }^{13}$. Estos impactos ya fueron advertidos en los años 40 o $60^{14}$.

\subsection{Consecuencias del modelo Agroindustrial}

Las empresas que integran el agro-negocio, a través de la concentración de la tierra, la producción agropecuaria y forestal a gran escala, el monocultivo, el uso intensivo de agrotóxicos, hormonas, transgénicos, despreciando los aspectos socio-culturales de los pueblos del campo y expropiándolos, solo buscan la continua acumulación de capital ${ }^{15}$.

Se puede afirmar, entonces, que los impactos del sistema de producción agroalimentario se dan en el ámbito social, de la salud humana y el medio ambiente; los impactos ambientales, antes o después, siempre van a repercutir en el ser humano y en todos los seres humanos, incluso a los que lo producen o se lucran con él ${ }^{16}$.

\footnotetext{
10 BRASIL. Ley № 7.802, de 11 de julio de 1989, define agrotóxicos en su artículo 2으, I, a e b, como los “productos y los agentes de procesos físicos, químicos o biológicos, destinados al uso en los sectores de producción, almacenamiento y mejora de productos agrícolas, en los pastos, en la protección de bosques, nativas o sembradas, y de otros ecosistemas y también ambientes urbanos, hídricos e industriales, cuya finalidad sea alterar la composición de la flora o la fauna, con el fin de preservarla de los daños que pudieran causarles seres vivos considerados nocivos", y como las "sustancias y productos, empleados como defoliantes, desecantes, estimuladores e inhibidores de crecimiento".

${ }^{11}$ JAMES, Clive. Global Status of Commercialized Biotech/GM Crops: 2012. ISAAA Brief No. 44. ISAAA: Ithaca, Nueva York. 2012 , p. 1.

${ }^{12}$ CARSON, Rachel. Primavera silenciosa. Editorial Crítica. Barcelona, 2010.

13 "Foodsafety" hace referencia a la seguridad de los alimentos para la salud humana en cuanto alimentos de calidad y sin peligro; mientras que "foodsecurity" se refiere a la garantía de que toda la población mundial tenga acceso a alimentos.

${ }^{14}$ CARSON, Rachel. Primavera silenciosa. Editorial Crítica. Barcelona, 2010.

${ }^{15}$ CARVALHO, Horácio Martins de. A expansão do capitalismo no campo e a desnacionalização do agrário no Brasil. Revista da Associação Brasileira de Reforma Agrária (ABRA), edição especial, jun. 2013.

${ }^{16}$ BECK, Ulrich. La sociedad de riesgo. Hacia una nueva modernidad. Ediciones Paidós Ibérica, Barcelona. 1998, p. 43.
} 


\subsubsection{Sociales}

La "revolución verde" supuso la separación del hombre de la tierra. Dice PoLANY" que la función económica de la tierra es solo una de sus muchas funciones vitales, no siendo, entonces, la separación natural sino que está destinada a satisfacer las necesidades del mercado, favoreciendo el fortalecimiento de las estructuras de latifundios.

Por otro lado, la introducción en el campo de maquinaria agrícola, con el fin de aumentar la productividad y reducir los costes, supuso que los trabajadores del campo se quedaran sin trabajo y se desplazaron a las ciudades, lo que provocó, y aún hoy en día sigue provocando, desempleo y pobreza (tan solo en EEUU 3 millones de granjas han sido eliminadas desde $1945^{18}$ ). Ahora, para los tradicionales pequeños agricultores y en general para los más pobres, acceder de nuevo a la tierra es casi imposible, pues compiten con los mercados (no gozan de igualdad de oportunidades, capacidad económica y tampoco el Estado los protege, sino que fomenta el capitalismo).

Además, el modelo pone gravemente en riesgo la soberanía alimentaria por la posibilidad de la que gozan las grandes compañías de patentar las semillas, de forma que los agricultores deben de comprarlas todos los años, suponiendo esto un coste adicional. Para reducir costes en el control de la compra de semillas, se han desarrollado plantas genéticamente modificadas en las que se ha incluido el "gen terminator", que anula su capacidad reproductiva. Esto supone que cuando las cosechas no salen bien, y los agricultores no tienen ya reserva de semillas, quedan en la más profunda ruina.

A este problema hay que añadir el hecho de que los monocultivos de transgénicos, incluso los convencionales donde se utilizan agrotóxicos, han hecho imposible la coexistencia con otro tipo de cultivos, que se contaminan de agrotóxicos y por polinización cruzada, y supone un enorme coste económico para los agricultores que se ven obligados a comercializar sus productos como convencionales.

Además, lo que en principio era la promesa de un cultivo que precisaba de menos agrotóxicos acaba siendo un cultivo que ve las dosis de agrotóxicos incrementadas porque las "plagas" generan resistencia, entre otros motivos. En 2008 Brasil se convirtió en el mayor consumidor de agrotóxicos, ascendiendo la cantidad a 5,2 litros de agrotóxicos por persona al año.

\footnotetext{
${ }^{17}$ POLANYI, Karl. La gran transformación. Los orígenes políticos y económicos de nuestro tiempo, FCE, México, 2003, p. 238.

${ }^{18}$ CAPRA, Fritjof. El punto crucial. Editorial Troquel, Buenos Aires, 1992, p. 138.
} 


\subsubsection{A la salud humana}

El modelo afecta a la salud de los trabajadores del campo por el contacto constante con los agrotóxicos $^{19}$. Y es que, cuando se aplica el plaguicida,

solamente alcanza el organismo "blanco" aproximadamente el 1\%, mientras que el 25 \% es retenido en el follaje, el 30 \% llega al suelo y el $44 \%$ restante es exportado a la atmósfera y a los sistemas acuáticos por escorrentía y lixiviación ${ }^{20}$. A través del aire, agua o suelo, los compuestos se transportan, entrando muy frecuentemente en contacto con gran variedad de organismos, incluyendo los seres humanos.

Según estudios recientes de la Organización Internacional del Trabajo (OIT) y de la Organización mundial de la salud (OMS), se estima que los agrotóxicos causan anualmente alrededor de 2 y 5 millones de casos de intoxicación agudas y crónicas en trabajadores, de las que 40.000 llevan a la muerte, debido al uso indiscriminado de los pesticidas ${ }^{21}$. Sólo en Brasil, en 2011, se registraron 5.253 casos de intoxicación por agrotóxicos de uso agrícola, con 188 muertes (contribución de la epidemiologia).

La intoxicación por el contacto directo con los agrotóxicos afecta también a las poblaciones (normalmente muy pobres) que se encuentran en medio de miles de hectáreas de campo de cultivo y que son rociadas constantemente con ellos.

En cuanto a la salud de los consumidores, se estima que está viéndose afectada también por la utilización de los agrotóxicos, tanto por el consumo directo ${ }^{22}$ (un tercio de los alimentos que consumen los brasileños está contaminado con agrotóxicos ${ }^{23}$ ) como por su presencia en agua (incluso de la de lluvia ${ }^{24}$ ), aire o animales. Se ha llegado a encontrar presencia de los mismo en la leche materna ${ }^{25}$ y en la carne de pingüinos antárticos ${ }^{26}$.

\footnotetext{
${ }^{19} \mathrm{CHONCHOL}$, Jacques. A soberania alimentar. Estudos Avançados, São Paulo, v. 55, n. 19, p. 33-48, Set-dez. 2005 , p. $33-34$. Disponible en: <http://www.scielo.br/scielo.php?script=sci_arttext\&pid=S0103-40142005000300003>. Último acceso: 30-012017.

${ }^{20}$ BRADY, N. y WEIL, R. Soils and chemical pollution. The Nature and Properties of Soils. Prentiss Hall Intnal, 1996, Chapter 18.

${ }^{21}$ OIT. Datos disponibles en: <http://www.ilo.org/global/about-the-ilo/newsroom/news/WCMS_008027/lang--en/index.htm>. Último acceso: 29-01-2017.

${ }^{22}$ FERREIRA CARNEIRO, Fernando, GIRALdo da Silva Augusto, Lia, Rigotto, Raquel Maria, Friedrich, Karen e Campos Búrigo, André (org.). Dossiê ABRASCO: um alerta sobre os impactos dos agrotóxicos na saúde. Rio de Janeiro: EPSJV; São Paulo: Expressão Popular, 2015, p. 59-65

${ }^{23}$ FERREIRA CARNEIRO, Fernando, GIRALdo da Silva Augusto, Lia, Rigotto, Raquel Maria, Friedrich, Karen e Campos Búrigo, André (org.). Dossiê ABRASCO: um alerta sobre os impactos dos agrotóxicos na saúde. P. 56.

${ }^{24}$ FERREIRA CARNEIRO, Fernando, GIRALdo da Silva Augusto, Lia, Rigotto, Raquel Maria, Friedrich, Karen e CAmpos BúRIgo, André (org.). Dossiê ABRASCO: um alerta sobre os impactos dos agrotóxicos na saúde. P. 66 y ss.

${ }^{25}$ FERREIRA CARNEIRO, Fernando, GIRALdo da SILVA Augusto, Lia, Rigotto, Raquel Maria, Friedrich, Karen e CAmpos BúRIgo, André (org.). Dossiê ABRASCO: um alerta sobre os impactos dos agrotóxicos na saúde. P. 72 y ss.

${ }^{26}$ BECK, Ulrich. Sociedade de risco: rumo a outra modernidade. 2. ed. Tradução de Sebastião Nascimento. São Paulo: 34, 2011. P, 34.
} 
Por otro lado, se tienen que tener en cuenta los riesgos intrínsecos a la manipulación genética, por el riesgo derivado de la falta de control que el profesional tiene sobre las técnicas y los métodos que utiliza en el momento de insertar en el genoma del organismo receptor un gen ajeno a él; el método requiere de que se inserten numerosas copias del gen exógeno en el organismo sin saber cómo, dónde o cuántas copias (o partes de ellas) exactamente se van a terminar colocando a lo largo de la cadena del ADN del órgano receptor ${ }^{27}$, ni tampoco cuál será la reacción del mismo ni de sus diferentes perfiles metabólicos, si expresará las funciones deseadas o si anulará su expresión ${ }^{28}$.

Si estas complicaciones se dan en manipulaciones genéticas simples, ¿cuáles podrían ser los riesgos cuando se introduce en un organismo receptor hasta 5 transgenes?

En este sentido, aunque hay aún mucha discusión científica acerca de los riesgos para la salud humana, parece ser que los estudios que se han hecho hasta ahora tratan sobre riesgos a corto plazo sin reparar en los efectos acumulados que puede tener el consumo de OMG. Para rebatirlos, en el libro "Lavouras transgénicas" ${ }^{29}$ se identifican varios estudios ignorados por la ciencia hegemónica que indican serios desordenes consecuencia del consumo de los OMG (sin el agrotóxico), como interacción de las proteínas Bt con las células de los mamíferos (estudios detectan la toxina Bt en fetos y recién nacidos) ${ }^{30}$, alergenicidad ${ }^{31}$, pudiendo convertirse en alergias crónicas, entre otros. Derivados del consumo de agrotóxicos se pueden mencionar neuropatías, inmuno-toxicidad, alteraciones endócrinas, alteraciones del sistema reproductor, del desarrollo y del crecimiento y producción de neoplasias ${ }^{32}$.

\footnotetext{
${ }^{27}$ LATHAM, J., WILSON, A., STEINBRECHER, R. The Mutational Consequences of Plant Transformation. Journal of Biomedicine and Biotechnology. 2006, Article ID 25376. Disponible en: <www.ncbi.nlm.nih.gov/pmc/articles/PMC1559911>. Último acceso: 2209-2016.

${ }^{28}$ EL-HANI, C., "Between the cross and the sword: the crisis of the gene concept", Genet. Mol. Biol., Vol. 30, no2, Sao Paulo, 2007. Disponible en: <www.scielo.br/ > Último acceso: 23-09-2016.

${ }^{29}$ FERMENT, G., MELGAREJO, L., BIANCONI FERNANDES, G., FERRAZ, J.M. Lavouras transgénicas - riscos e incertezas: mais de 750 estudos desprezados pelos órgaos reguladores de OGMs. Brasilia: Ministério do Desenvolvimento Agrário. Disponible en: <https://issuu.com/centrodetecnologiasalternativasdazo/docs/lavouras_transgenicas_riscos_e_ince>. Último acceso: 20-092016.

${ }^{30}$ ARIS, A., LEBLANC, S. Maternal and fetal exposure to pesticides associated to genetically modified foods in Eastern Townships of Quebec, Canada. Reprod. Toxicol, 31(4): 528-33, 2011. Disponible en: <https://www.ncbi.nlm.nih.gov/pubmed/21338670>. Último acceso: 31-01-2017.

${ }^{31}$ FERMENT, G., MELGAREJO, L., BIANCONI FERNANDES, G., FERRAZ, J.M. Lavouras transgénicas - riscos e incertezas: mais de 750 estudos desprezados pelos órgaos reguladores de OGMs, p. 286.

32 FERREIRA CARNEIRO, Fernando, GIRALDO DA SILVA AUGUSTO, Lia, RIGOTTO, Raquel Maria, FRIEDRICH, Karen e CAMPOS BÚRIGO, André (org.). Dossiê ABRASCO: um alerta sobre os impactos dos agrotóxicos na saúde. P. 78.
} 


\subsubsection{Ambientales}

Los problemas ambientales que el modelo agroindustrial genera son muchos $\mathrm{y}$ de importancia muy significativa.

Así, el número de hectáreas de suelo utilizadas para el cultivo de alimento y de agrocombustibles crece todos los años de forma alarmante. En el año 2000 , el 48,5\% del hábitat del bosque de latifolio seco tropical/ subtropical había sido transformado para atender las necesidades humanas ${ }^{33}$. Y es que aunque varía entre una región y otra, la causa principal de la deforestación es la expansión de la agricultura ${ }^{34}$, ya que la erosión del suelo consecuencia de las técnicas de cultivo insostenible hace que tengan que buscarse nuevas zonas de cultivo ${ }^{35}$.

Así, la cantidad y agresividad con la que atacan los agrotóxicos tanto a los organismos "blanco" como al resto de organismos hacen temer por la pérdida irreversible de gran variedad de especies y ecosistemas enteros; la abundancia de las especies estudiadas ha decaído un $58 \%$ entre 1970 y $2012^{36}$.

Por otro lado, la agroindustria ha venido luchando por el monocultivo de tan solo algunas variedades de plantas. Por ejemplo, en algunas regiones del Tercer Mundo ha habido una erradicación intencional de algunas semillas y variedades de plantas nativas de las que se alimentaba la población con la excusa de su bajo aporte nutritivo comparado con las variedades comercialmente deseadas. Lo que en realidad se perseguía era erradicar aquellas incompatibles con el cultivo de las especies comerciales. Estas plantas nativas han venido siendo tratadas desde entonces como "malas hierbas" y combatidas con agrotóxicos. Algunas de ellas, como la "bathua", se han demostrado ricas, por ejemplo, en Vitamina $\mathrm{A}$ y de elevado valor nutricional ${ }^{37}$. Posteriormente se experimentó genéticamente con el arroz, el famoso arroz dorado, para que aportara mayor cantidad de vitamina A a niños de Africa y Asia que tenían graves deficiencias de esta vitamina y se estaban quedando ciegos. También el anteriormente mencionado gen terminator puede llevar a una reducción de la biodiversidad cuando por polinización cruzada

\footnotetext{
${ }^{33}$ HOEKSTRA, A.Y. and T.O. WIEDMANN. 2014. Humanity's unsustainable environmental footprint. Science 344 (6188): $1114-1117$. Doi: 10.1126/science.1248365. Disponible en : < https://www.ncbi.nlm.nih.gov/pubmed/24904155>. Último acceso: 29-01-2017.

${ }^{34}$ GIBBS, H.K., RUESCH, A.S., ACHARD, F., CLAYTON, M.K., HOLMGREN, P., RAMANKUTTY, N. and J.A. FoleY. Tropical forests were the primary sources of new agricultural land in the 1980s and 1990s. 2010. Proceedings of the National Academy of Sciences 107(38): 16732-16737. Doi: 10.1073/pnas.0910275107. Disponible en: <https://www.ncbi.nlm.nih.gov/pubmed/20807750>. Último acceso: 20-01-2017.

${ }^{35}$ WWF. 2016. Informe Planeta Vivo 2016. Riesgo y resiliencia en el Antropoceno. P. 53.

${ }^{36}$ WWF. 2016. Informe Planeta Vivo 2016. Riesgo y resiliencia en el Antropoceno. P, 12.

${ }^{37}$ SHIVA, Vandana. Monoculturas da mente: perspectivas da biodiversidade e da biotecnologia. São Paulo: Gaia, 2003, p. 38-42.
} 
podrían verse "infectadas" especies silvestres cuya capacidad reproductiva podría verse anulada.

Además, según la FAO, para la agricultura se extrae entorno al $70 \%$ de las aguas de los acuíferos $^{38}$. Esto, evidentemente, ejerce una enorme presión sobre el recurso y los organismos dependientes de él, que es aún más alarmante cuando se piensa en que toda esa agua que se gastó en generar un producto que va a ser tirado a la basura (en los países desarrollados se tira entorno al $40 \%$ de la comida), podría haberse dejado en el medio o empleado con algún otro objetivo.

\section{CRÍTICA AL DESARROLLISMO CAPITALISTA}

La crítica debe hacerse, por lo tanto, al origen y base de la mayoría de los problemas de la humanidad que es el modelo de sociedad, el modelo desarrollista, desarrollo por el desarrollo en mismo, capitalista y consumista. Como dijera LATOUCHE, "pasa a tener valor existencial aquello que puede ser racionalmente medido, principalmente medido de forma económica" 39.

En esta línea, el desarrollo material es lo único importante, y se mantiene como modelo sostenido por las ideas de (i) progreso que aporta a los individuos "la máxima felicidad que puede aportar una sociedad" y (ii) crecimiento económico que "es el motor que el desarrollo es el necesario para el desarrollo social, psíquico y moral" ${ }^{40}$. Al mismo tiempo, el PIB nacional (que es un indicador meramente económico) es tomado como indicador de bien-estar, sin tener en cuenta el número de personas en situación de pobreza.

Para perpetuar este modelo, son necesarios tres ingredientes: "la publicidad, que crea el deseo de consumir; el crédito, que proporciona los medios; y la obsolescencia acelerada y programada de los productos" ${ }^{41}$.

En este sentido, el desarrollo material ha demostrado ser un concepto subdesarrollado que crea subdesarrollo intelectual (dificultad de pensar sistemáticamente los problemas fundamentales y globales ${ }^{42}$ ), psíquico (lógica cuantitativa y materialista) y moral (el individualismo

\footnotetext{
${ }^{38}$ FAO. Disponible en: <http://www.fao.org/fileadmin/user_upload/newsroom/docs/SOLAW\%20factsheet-es.pdf>. Último acceso: 27-01-2017.

${ }^{39}$ LATOUCHE, Serge. Pequeno Tratado de decrescimento sereno. São Paulo: WMF Martins Fontes, 2009, p.28-29.

${ }^{40}$ MORIN, Edgar; KERN, Anne Brigitte. Terra Pátria. São Paulo: Sulina, 1995, p.78.

${ }^{41}$ LATOUCHE, Serge. Pequeno Tratado de decrescimento sereno. São Paulo: WMF Martins Fontes, 2009, p.17.

${ }^{42}$ ALCANTARINO JARDINI GOMES, Ana Carolina. (Re)pensar a humanidade e a natureza: a crise ecológica no pensamento moderno ocidental. XXIV Congresso Nacional Do CONPEDI - UFMG/FUMEC/Dom Helder Câmara. Disponible en <http://www.conpedi.org.br/publicacoes/66fsl345/j0duvo2k>. Último acceso: 28-01-2017.
} 
exacerbado despoja al ser humano de la solidaridad) ${ }^{43}$ siendo la economía y las políticas impuestas las que determinan lo que el ser humano debe alcanzar, que no es ni siquiera para sí mismo sino para el sistema.

Para mantenerse el modelo hace uso de las retóricas de la ocultación, justificación y descualificación. Con la retórica de la ocultación se respalda en las instituciones científicas; su funcionamiento se puede reducir a la máxima "uso racional o uso seguro de los agrotóxicos", traspasando la responsabilidad por los casos de intoxicación a las víctimas, alegando que no adoptaron de seguridad recomendados. Es prueba de la disociación entre ética y la práctica científica. Con la retórica de la justificación se presenta como necesario aquello que es económica e ideológicamente oportuno, esta es la tesis del "mal necesario"; esta narrativa se vuelve aún más frágil cuando el aumento del consumo de los agrotóxicos se correlaciona con el aumento del consumo de medicamentos como forma de combatir los efectos crónicos de las intoxicaciones de trabajadores y consumidores, comúnmente no asociadas al contacto con los agrotóxicos ${ }^{44}$. Por último, con la retórica de la descualificación se le quita legitimidad a aquellos que son críticos y defienden el interés público, acusados de oscurantismo y frecuentemente criminalizados, y hasta coartados personal y/o profesionalmente ${ }^{45}$. Así, las tres retóricas se refuerzan entre sí y legitiman la guerra contra la vida que ya denunciara en su día CARSON.

Por otro lado, para que el mundo occidental pueda mantener este modelo, los costes se externalizan siendo los países "del Sur" (países subdesarrollados o en vías de desarrollo), los empleados, las generaciones futuras y la naturaleza los que tienen que soportarlos. Cabe poner como ejemplo que países como Brasil, países en vías de desarrollo, son los que producen la soja y el maíz transgénicos destinados a la alimentación del ganado europeo.

Este modelo ejerce tal presión que la naturaleza ya no es capaz de absorber los impactos. Se están sobrepasando los llamados "límites de seguridad" de las actividades humanas ${ }^{46}$, los límites planetarios. "El marco de los límites planetarios está constituido por nueve alteraciones del funcionamiento del sistema Tierra producidas por los seres humanos":" 1 . integridad de la

\footnotetext{
${ }^{43}$ MORIN, Edgar. A via para o futuro da humanidade. Rio de Janeiro: Bertrand Brasil, 2013, p.31-32.

${ }^{44}$ Según la Organización Mundial de la salud, por cada caso notificado, hay 50 casos de intoxicación por agrotóxicos que no son notificados en FERREIRA CARNEIRO, Fernando, GIRALDO DA SILVA AUGUSTO, Lia, RIGOTTO, Raquel Maria, FRIEDRICH, Karen e CAMPOS BÚRIGO, André (org.). Dossiê ABRASCO: um alerta sobre os impactos dos agrotóxicos na saúde. P. 32.

${ }^{45}$ FERREIRA CARNEIRO, Fernando, GIRALDO DA SILVA AUGUSTO, Lia, RIGOTTO, Raquel Maria, FRIEDRICH, Karen e CAMPOS BÚRIGO, André (org.). Dossiê ABRASCO: um alerta sobre os impactos dos agrotóxicos na saúde. P. 33.

${ }^{46}$ CROWARDS, T.M. 1998. Safe minimum standards: costs and opportunities. Ecological Economics 25: 303-314. Doi: 10.1016/S0921-8009(97)00041-4. Disponible en: <http://www.citeulike.org/user/cbniles/author/Crowards:TM>. Último acceso: 28-01-2017.
} 
biosfera; 2. cambio climático; 3. acidificación del océano; 4. cambio del uso del suelo; 5 . uso insostenible del agua dulce; 6. perturbación de los flujos biogeoquímicos (aportes de nitrógeno y fósforo a la biosfera); 7. carga atmosférica de aerosoles; 8. contaminación generada por nuevas sustancias; y 9. agotamiento del ozono de la estratósfera" ${ }^{47}$. A día de hoy, los límites se han superado en los subsistemas $1,2,4$ y 6 (el 5 está muy cerca del límite) ${ }^{48}$.

\section{SOCIEDAD DE RIESGO Y EL PRINCIPIO DE PRECAUCIÓN}

Se hace evidente que se está viviendo en una sociedad de riesgo, en la que el riesgo ya no proviene de las incontrolables fuerzas de la naturaleza, sino que es el propio ser humano quien lo crea con los avances tecnológicos y científicos. Comprende Beck ${ }^{49}$ en este sentido que, la sociedad de riesgo en la que se vive actualmente "no es una sociedad de catástrofe" aún, pero el acuciante "riesgo comporta un mensaje (político) de urgencia en la acción transformadora".

Las armas con las que actualmente cuenta el derecho para combatir el riesgo son los principios de prevención y de precaución, ambos aceptados por la comunidad internacional y recogidos en la Declaración de Rio de Janeiro de 1992 en sus principios $17^{50}$ y $15^{51}$ respectivamente, por la Convención sobre la Diversidad Biológica de $1992^{52}$ (en su preámbulo) y su Protocolo de Cartagena sobre Seguridad de la Biotecnología del $2000^{53}$ (en casi idénticos términos). A pesar de ser un principio de derecho internacional, hay aún mucho reparo en aplicar el principio de precaución, tanto que la Corte Internacional de Justicia aún no se ha pronunciado al respecto y en demasiados países del mundo la legislación interna aún no lo prevé.

Lo fundamental en la prevención es el peligro, mientras que lo fundamental para la

\footnotetext{
${ }^{47}$ ROCKSTRÖM, J., STEFFEN, W., NOONE, K., PERSSON, Å., CHAPIN, III, F.S., LAMBIN, E.F., LENTON, T.M., SCHEFFER, M., FOLKE, C., SCHELLNHUBER, H.J. et al. 2009b. A safe operating space for humanity. Nature. 461(7263): 472-475. Doi: 10.1038/461472a;pmid:19779433. Disponible en: <https://www.ncbi.nlm.nih.gov/pubmed/19779433>. Último acceso: 30-012017.

${ }^{48}$ WWF. 2016. Informe Planeta Vivo 2016. Riesgo y resiliencia en el Antropoceno. P. 61.

${ }^{49}$ BECK, Ulrich. A Europa Alemã: a crise do euro e as novas perspectivas de poder. 1a ed. São Paulo: Paz e Terra, 2015, p. 46-50.

${ }^{50}$ ONU. "Deberá emprenderse una evaluación del impacto ambiental, en calidad de instrumento nacional, respecto de cualquier actividad propuesta que probablemente haya de producir un impacto negativo considerable en el medio ambiente y que esté sujeta a la decisión de una autoridad nacional competente". Disponible en: < http://www.un.org/spanish/esa/sustdev/agenda21/riodeclaration.htm > . Último acceso: 16-01-2017.

${ }^{51}$ ONU. "Con el fin de proteger el medio ambiente, los Estados deberán aplicar ampliamente el criterio de precaución conforme a sus capacidades. Cuando haya peligro de daño grave o irreversible, la falta de certeza científica absoluta no deberá utilizarse como razón para postergar la adopción de medidas eficaces en función de los costos para impedir la degradación del medio ambiente". Disponible en: < http://www.un.org/spanish/esa/sustdev/agenda21/riodeclaration.htm > . Último acceso: 16-012017.

${ }^{52}$ CBD. Disponible en: < https://www.cbd.int/doc/legal/cbd-es.pdf > . Último acceso: 20-01-2017

${ }^{53}$ CBD. Disponible en: < http://bch.cbd.int/protocol/text/ >. Último acceso: 20-01-2017
} 
precaución es el riesgo. La diferencia está en la previsibilidad de que se materialice el daño, siendo el peligro un riesgo extremadamente alto y el riesgo un peligro no comprobado ${ }^{54}$.

Para poder aplicar el principio de precaución es necesaria la existencia de incertidumbre científica (que se puede traducir también en falta de resultados definitivos o de consenso científico) acerca del riesgo que se genera para la salud humana y/o el medio ambiente. Así, la falta de certeza científica, no se puede utilizar como excusa por parte del sector económico o del poder político para no actuar ${ }^{55}$.

Además, los análisis de riesgos en los que se basen las decisiones de la aceptabilidad del riesgo deben basarse en los mejores datos científicos disponibles, de los estudios más recientes y en los "principios de excelencia, de independencia, de transparencia e de objetividad". En este sentido, cabe preguntarse, ¿quién analiza los riesgos de la biotecnología? Y ¿qué metodología se utilizan? Se debe intentar no caer en la falacia de la autoridad ${ }^{56}$.

La determinación de la aceptabilidad del riesgo, que tradicionalmente es asignada a los científicos, defiende $\mathrm{BECK}^{57}$, debe contar con la participación popular; debe introducirse la ciencia en el ámbito de decisión pública. En este sentido deben cumplirse los derechos previstos en el Principio 10 Declaración de Rio de Janeiro de 1992 sobre el Medio Ambiente y el Desarrollo ${ }^{58}$ y en el Convenio de Aarhus de $1998^{59}$ : derecho a la información ambiental, a la participación en temas ambientales y el acceso a la justicia ambiental. Y es que "la obligación de tolerar, de soportar, nos da el derecho de saber" ${ }^{\prime 60}$; la aceptabilidad y la gestión del riesgo son cuestiones de gobernanza. Merecen aquí especial atención los más desfavorecidos pues la desigualdad en los riesgos es algo evidente que menoscaba sus derechos humanos, y la pobreza fragiliza la participación ${ }^{61}$.

\footnotetext{
${ }^{54}$ CORBALAN TEBAR, Wellington Boigues. Críticas à concepção (eco)absolutsta do princípio da precaução: uma releitura à luz do procedimento de tomada de decisões. XXIV Congresso Nacional Do CONPEDI - UFMG/FUMEC/Dom Helder Câmara. Disponible en < http://www.conpedi.org.br/publicacoes/66fsl345/j0duvo2k>. Último acceso: 28-01-2017.

${ }^{55}$ ALBUQUERQUE, Leticia, y FABRE, Roger. A sociedade de risco e o debate em torno do alcance do princípio da precaução. XXIV Congresso Nacional Do CONPEDI - UFMG/FUMEC/Dom Helder Câmara. Disponible en <http://www.conpedi.org.br/publicacoes/66fsl345/8g6821fe>. Último acceso: 28-01-2017.

${ }^{56}$ FREITAS, Juarez. Sustentabilidade: direito ao futuro. 2. ed. Belo Horizonte: Fórum, 2012, p. 145.

${ }^{57}$ BECK, Ulrich. Sociedade de risco: rumo a outra modernidade. 2. ed. Tradução de Sebastião Nascimento. São Paulo: 34, 2011. P. 69-71.

${ }^{58}$ ONU. Disponible en: <http://www.un.org/spanish/esa/sustdev/agenda21/riodeclaration.htm > . Último acceso: 16-01-2017.

${ }^{59}$ Comisión Económica de las Naciones Unidas para Europa. Convenio de Aarhus, de 25 de noviembre de 2005, sobre acceso a la información, participación pública en la toma de decisiones y acceso a la justicia en materia de medio ambiente. Disponible en: <http://www.prtr-es.es/data/images/Convenci\%C3\%B3n\%20Aarhus-27D036D47C1C7FE9.pdf>. Última consulta: 23-09-2016.

${ }^{60}$ JEAN RESTAND citado por CARSON, Rachel en FERREIRA CARNEIRO, Fernando, GIRALDO DA SILVA AUGUSTO, Lia, RIGOTTO, Raquel Maria, FRIEDRICH, Karen e CAMPOS BÚRIGO, André (org.). Dossiê ABRASCO: um alerta sobre os impactos dos agrotóxicos na saúde. P. 25.

${ }^{61}$ Consejo de Derechos Humanos de la ONU, 1998. Resolución 2006/9 de la Subcomisión para la Promoción y Protección de los Derechos Humanos, con su propuesta de principios orientadores "Extrema Pobreza y Derechos Humanos: los derechos de los
} 
No hay que perder de vista que la cautela (precaución) no significa la negación de una actividad, pero si dar trascendencia a los análisis de la complejidad de los riesgos y dotar de mecanismos a las instituciones para hacerles frente, debiendo poder suspender una actividad hasta que se demuestre que el riesgo que supone es aceptable.

En vistas de las consecuencias prácticas que deberían discurrir de la mencionada teoría y en vistas de lo que acontece en el sector agroalimentario, se puede afirmar que el principio de precaución es sistemáticamente inobservado en los países que forman el continente americano, tanto del norte como del sur. Al contrario, en el marco de la UE se puede llegar a considerar que los primeros indicios de la aplicación del principio de precaución se están dando, cuando en el año 2015, y mediante la Directiva 2015/412 ${ }^{62}$, la UE permitió a los Estados Miembro prohibir el cultivo de OMG en su territorio. Esta facultad puede haber sido concebida como resolución a la controversia y problemas que ha generado esta actividad en estados como Francia o Alemania en los últimos años. En el año 2016 mediante la Decisión de Ejecución 2016/321 ${ }^{63}$, 19 Estados Miembro hicieron uso de tal facultad.

Como ya dijera Habermas, el capitalismo industrial consumista está topándose con los límites de los recursos naturales; es el momento en que la humanidad decida cómo va a vivir en el futuro, tiene la opción de metamorfosear ${ }^{64}$, de cambiar su forma de vida y su relación con la naturaleza. En este marco, Morín ${ }^{65}$ confía en el ser humano, defendiendo que lo positivo de la globalización es que se han sentado las estructuras de una sociedad-mundo, que considere a la Tierra su patria y la proteja.

\section{SOSTENIBILIDAD Y SOCIOAMBIENTALISMO COMO GUÍAS PARA UN NUEVO MODELO AGROALIMENTARIO}

Desarrollo sostenible fue utilizado por primera vez como concepto en el Informe "Nuestro Futuro Común"66 (conocido como el Informe Brundtland), publicado en 1987 por la World

\footnotetext{
pobres".

62 Unión Europea. Directiva 2015/412 del Parlamento Europeo y del Consejo, de 11 de marzo de 2015, por la que se modifica la Directiva 2001/18/CE/CE en lo que respecta a la posibilidad de que los Estados miembros restrinjan o prohíban el cultivo de organismos modificados genéticamente (OMG) en su territorio, DO L 68 de 13.3.2015.

${ }^{63}$ Unión Europea. Decisión de Ejecución 2016/321 de la Comisión, de 3 de marzo de 2016, por la que se adapta el ámbito geográfico de la autorización de cultivo del maíz (Zea mays L.) modificado genéticamente MON 810 (MON- $\varnothing \varnothing 81 \varnothing-6)$

${ }^{64}$ MORIN, Edgar. A via para o futuro da humanidade. Rio de Janeiro: Bertrand Brasil, 2013, p.39-40.

${ }^{65}$ MORIN, Edgar. A via para o futuro da humanidade. Rio de Janeiro: Bertrand Brasil, 2013, p.35-36.

${ }^{66}$ Informe de World Commission on Environment and Development. Informe Brundtland, "Our Common Future". Disponible en
} 
Commission on Environment and Development de las Naciones Unidas. Definía como desarrollo sostenible "...el desarrollo que satisface las necesidades del presente, sin comprometer la capacidad de las futuras generaciones de satisfacer sus propias necesidades".

Aunque el mismo concepto lleve implícito un "compromiso de solidaridad con las generaciones futuras", que implica una visión integrada de los sistemas económico, social y ambiental, los críticos lo entienden como un simple atributo de un tipo de desarrollo. Algunos autores advierten que si no se analiza en profundidad el concepto puede llegar a servir de base de afianzamiento para el pensamiento elitista y conservador dejando de promover cualquier alteración estructural.

Así, algunos de los críticos con el concepto como SouzA ${ }^{67}$ prefieren hablar de sostenibilidad como un proyecto de sociedad que observe al ciudadano informado y participativo, siendo, además, el proceso de consecución de objetivos transparente y constructivo. Así, el principio evolucionó, requiriendo ahora el análisis del medio ambiente siendo la desigualdad social y la pobreza consecuencia, a la vez responsable, de la degradación ambiental ${ }^{68}$.

Aunque la sostenibilidad fue, según REAL FERRER, inicialmente construida a partir de una triple dimensión (ambiental, social y económica) le debe ser añadida la tecnológica, pues es la inteligencia humana individual y colectiva, acumulada y multiplicada la que podrá asegurar un futuro más sostenible ${ }^{69}$.

La única solución es la edificación de un sistema de valores respetuosos con la dignidad del ser humano y "de la naturaleza" por su valor intrínseco, y no por su valor productivo. Sostiene REAL FERRER que para solucionar esto hay que hacer una redefinición ética capar de reorientar los procesos en verdaderos procesos civilizatorios basados en valores positivos. Ciencia, junto con egoísmo extremo solo crea barbarie.

Así, el Principio de Sostenibilidad, según FreITAS ${ }^{70}$, estaría constituido por 10 elementos básicos: (i) es un principio constitucional de aplicación directa e inmediata; (ii) exige resultados

$<$ http://www.un-documents.net/our-common-future.pdf $\geq$. Último acceso: 29-01-2017.

67 SOUZA, Maria Claudia da Silva Antunes de, DE CARVALHO BOTEGA, João Luiz. Sustentabilidade, sociedade de risco e alimentos transgênicos: disputas definitórias e o Projeto de Lei no. 4.148/08. XXIV Congresso Nacional Do CONPEDI - UFMG/FUMEC/Dom Helder Câmara. Disponible en <http://www.conpedi.org.br/publicacoes/66fsl345/8g6821fe>. Último acceso: 28-01-2017.

${ }^{68}$ FLORES, Guilherme N.; VIEIRA, Ricardo Stanziola. Expectativas da governança socioambiental na política nacional de resíduos sólidos: reflexões sobre a sustentabilidade e as consequências da globalização na geração de resíduos. Revista Direito Ambiental e Sociedade, v. 3, n. 1, 2013, p.49.

${ }^{69}$ REAL FERRER, Gabriel. Calidad de vida, medio ambiente, sostenibilidad y ciudadanía. Construímos juntos el futuro? Revista NEJ Eletrônica, v. 17, n. 3, 2012.

${ }^{70}$ FREITAS, Juarez. Sustentabilidade: direito ao futuro. 2. ed. Belo Horizonte: Fórum, 2012. p. 50. 
justos no solo efectos jurídicos, reclama eficacia; (iii) exige, además, eficiencia; (iv) su objetivo es volver el medio ambiente limpio; (v) presupone probidad en las relaciones públicas y privadas; (vi), (vii), (viii) implica prevención, precaución y solidaridad intergeneracional; (ix) implica el reconocimiento de la responsabilidad solidaria del Estado de y de la sociedad; y $(x)$ todos los elementos anteriores deben converger para que se dé un bienestar duradero y multidimensional.

La dimensión social y la ambiental del paradigma de la Sostenibilidad se verán tratadas en conjunto, porque el hombre es parte de la naturaleza, porque para vivir, el ser humano necesariamente crea un impacto que debe repensarse y disminuirse todo lo posible, sin que ello invada los límites del derecho a la dignidad y demás derechos fundamentales y sociales. Se justifica, por tanto, la existencia a la dimensión social del Principio de la Sostenibilidad"71.

Intentar atajar el problema en sus simples manifestaciones va a llevar siempre al fracaso; por ello hay que ir a la base, se debe reedificar el sistema de valores, debiendo entenderse que el ser humano es miembro de la comunidad de la Tierra en iguales términos que cualquier otro ser vivo, parte de un sistema interdependiente y no superior a los demás seres vivos. Debe haber, así, un cambio en la concepción de la dignidad y la vida, haciendo estos derechos extensivos a todos los seres vivos (justicia inter-especies) con los que se comparte el planeta Tierra (justicia trasespacial), incluso con aquellos que aún no hayan nacido (justicia intergeneracional).

Cabe aclarar que el entendimiento del ser humano como parte de la naturaleza y reconocer su valor intrínseco no significa dejar de tener cultivos, pesca o ganadería, pero que hay que ser responsables con la forma en que se hace uso de los recursos, debiendo garantizarse el buen funcionamiento de los sistemas ecológicos y en mantenimiento de la vida.

Por otro lado, es necesaria la creación de una institución de ciencia democratizada, es decir, a disposición del interés común y que ante los riesgos permita a la población ejercitar sus derechos de saber y participar en la toma de decisiones, debiendo ser el principio de precaución la guía y el fundamento de estos derechos ${ }^{72}$; la ciencia debe reconocer la complejidad y empoderar a la ciudadanía.

\footnotetext{
${ }^{71}$ SCHMITT SIQUEIRA GARCIA, Denise, SIQUEIRA GARCIA, Heloise. Dimensão social do princípio da sustentabilidade: uma análise do mínimo existencial ecológico en SouzA, Maria Claudia da Silva Antunes de, SIQUEIRA GARCIA, Heloise (org.). Lineamentos sobre sustentabilidade segundo Gabriel Real Disponible en: <http://siaibib01.univali.br/pdf/Lineamentos\%20sobre\%20Sustentabilidade\%20segundo\%20Gabriel\%20Real\%20Ferrer\%20\%20E-book.pdf>. Último acceso: 27-01-2017.

${ }^{72}$ FeRreiRA CARNeIRO, Fernando, GiRAldo da Silva Augusto, Lia, Rigotto, Raquel Maria, Friedrich, Karen e Campos Búrigo, André (org.). Dossiê ABRASCO: um alerta sobre os impactos dos agrotóxicos na saúde. P.30.
} 
La libertad de elección debe ser, por lo tanto, verdadera (se considera por ejemplo que la libertad de elección de productos ecológicos no es verdadera, pues la sobrevalorización monetaria hace el acceso a estos productos imposible para muchas personas).

Poniendo un ejemplo de alternativas ya existentes y competitivas con el modelo agroindustrial, el Dossiê ABRASCo ${ }^{73}$ propone la agroecología como alternativa al actual modelo de producción de alimentos. Los autores defienden que los experimentos documentados ${ }^{74}$ que apoyan como alternativa viable a la agroecología son más que suficientes, superándose con ella las perspectivas del productivismo economicista basadas en el monocultivo extensivo químicodependientes. La agroecología se basa en la idea de que, en las zonas rurales biológicamente diversificados se mantienen las estructuras biológicas responsables del combate de las llamadas "plagas", lo que hace el uso de agroquímicos absolutamente prescindible.

La agroecología incorpora las dimensiones económicas, sociales, ambientales, culturales, políticas y éticas de la producción agrícola; analiza los ciclos minerales, transformaciones energéticas, procesos biológicos y relaciones socioeconómicas en conjunto ${ }^{75}$ (visión holística).

Los beneficios de este nuevo sistema de producción de alimentos sostenible son patentes tanto en términos de productividad como de costos y representa un potencial contaminador mucho menor, incluso irrelevante ${ }^{76}$. Aparte de las ventajas de este modelo en cuanto a la productividad con un bajo impacto ambiental, capaces de producir alimentos saludables y contribuir a la seguridad alimentaria y nutricional, hay que tener en cuenta también que tiene como premisa la repartición de las tierras y la producción descentralizada generadora de mucha mano de obra, que dinamiza la economía y abastece los mercados locales ${ }^{77}$.

En fin, para la consecución de estos objetivos, existe la urgente necesidad de que el ser humano vuelva a retomar una verdadera conciencia político-ciudadano, que hoy se asume existe por los aparentes sistemas democráticos ${ }^{78}$, obligando al Estado como agente regulador, y a través

\footnotetext{
${ }^{73}$ FERREIRA CARNEIRO, Fernando, GIRALDO DA SILVA AUGUSTO, Lia, RIGOTTO, Raquel Maria, FRIEDRICH, Karen e CAMPOS BÚRIGO, André (org.). Dossiê ABRASCO: um alerta sobre os impactos dos agrotóxicos na saúde. P. 31.

74 UNCTD - UNITED NATIONS CONFERENCE ON TRADE AND DEVELOPMENT. Trade and environment review 2013: wake up before it is too late: make agriculture truly sustainable now for food security in a changing climate. Geneva, 2013.

${ }^{75}$ ALTIERI, MA. Agroecologia: as bases científias da agricultura alternativa. Rio de Janeiro: PTA/Fase, 1989.

${ }^{76}$ DUNCK, Ellen Adeliane Fernandes M. Agrotóxicos: modelo produtivo como fonte de violência, Revista de Direito Agrario e Agroambiental, v. 1, n. 2, 2015. Disponible en: <http://www.indexlaw.org/index.php/rdaa/article/view/328/329>. Último acceso: 30-01-2017.

${ }^{77}$ LONDRES, Flávia. Agrotóxicos no Brasil: um guia para ação em defesa da vida. Rio de Janeiro: AS-PTA - Assessoria e Serviços a Projetos em Agricultura Alternativa, 2012, p.24.

${ }^{78}$ VARGAS BARBOSA, Caroline y RAMOS JORDÃO, Luciana. A produção de agrocombustíveis e o enlaço com a segurança e 
de la educación, de estímulos y duras sanciones, a que fomente nuevas formas de actividades y someta a las actuales a las premisas de la sostenibilidad para la preservación del medio ambiente y sus funciones vitales.

Debe construirse una gobernanza ambiental como conjunto de iniciativas, reglas, instancias y procedimientos que permiten a la sociedad orientar la conducta del Estado, de las empresas y de las personas conforme a un nuevo sistema de valores y objetivos a largo plazo, que velarán por el interés público ${ }^{79}$ y tendrán en cuenta las diversidades locales; la protección del medio ambiente debe tener un enfoque socio-ambientalista, es decir, debe contar con una mayor participación de la sociedad en la toma de decisiones y en la gestión ambiental ${ }^{80}$.

\section{CONCLUSIONES}

El pensamiento fragmentario introducido por Descartes ha tenido un impacto decisivo en la configuración de la sociedad post-moderna, donde se mercantiliza la naturaleza y la educación, la religión, la política e incluso la vida en aras del desarrollo capitalista.

Es este desarrollo desmedido el que, vacío de ética y valores, ha hecho de nuestra sociedad una sociedad de riesgos; riesgos inmensurables y creados por el propio hombre en sus conocimientos limitados. El modelo de agricultura post-moderno es un claro ejemplo de riesgos a los que el desarrollismo somete al Planeta en su conjunto, creando problemas sociales, de salud y al medio ambiente.

Así, el único instrumento con el que cuenta el derecho para hacer frente a estos riesgos es una aplicación estricta del principio de precaución, no para impedir cualquier actividad, sino para evitar la catástrofe a la que la humanidad se dirige. Esta aplicación implica unos exigentes análisis de riesgos y la necesaria participación de la sociedad en la aceptabilidad de los riesgos como manifestación de justicia ambiental y gobernanza ambiental, debiendo prestar especial atención a las personas más desfavorecidas que son las que más sufren las consecuencias del riesgo creado (desigualdad en el riesgo).

\footnotetext{
soberania alimentar. Disponible en < http://www.conpedi.org.br/publicacoes/66fsl345/7y8y67h7>. Último acceso: 28-01-2017.

${ }^{79}$ FLORES, Guilherme N.; VIEIRA, Ricardo Stanziola. Expectativas da governança socioambiental na política nacional de resíduos sólidos: reflexões sobre a sustentabilidade e as consequências da globalização na geração de resíduos. Revista Direito Ambiental e Sociedade, v. 3, n. 1, 2013, p.49.

${ }^{80}$ FLORES, Guilherme N.; VIEIRA, Ricardo Stanziola. Gestão integrada de resíduos sólidos urbanos à luz da Lei 12.305/2010: uma proposta para a solução da disposição final do lixo na Região Metropolitana da Foz do rio Itajaí. Revista Eletrônica Direito e Política, v. 5, 2010, p. 346-370.
} 
A través del paradigma de la Sostenibilidad (ambiental, social, económica y tecnológica) se va a intentar superar esta sociedad de riego, siendo para ello imprescindible un cambio en la ética y en el sistema de valores de la sociedad. Debe haber un cambio en la concepción de la dignidad y la vida, haciendo estos derechos extensivos a todos los seres vivos con los que se comparte el planeta Tierra, incluso con aquellos que aún no hayan nacido.

\section{BIBLIOGRAFÍA}

ALCANTARINO JARDINI GOMES, Ana Carolina. (Re)pensar a humanidade e a natureza: a crise ecológica no pensamento moderno ocidental. XXIV Congresso Nacional Do CONPEDI UFMG/FUMEC/Dom Helder Câmara. Disponible en <http://www.conpedi.org.br/publicacoes/66fsl345/j0duvo2k>. Último acceso: 28-01-2017. ALTIERI, MA. Agroecologia: as bases científias da agricultura alternativa. Rio de Janeiro: PTA/Fase, 1989.

ARIS, A., LEBLANC, S. Maternal and fetal exposure to pesticides associated to genetically modified foods in Eastern Townships of Quebec, Canada. Reprod. Toxicol, 31(4): 528-33, 2011. Disponible en: <https://www.ncbi.nlm.nih.gov/pubmed/21338670>. Último acceso: 31-01-2017.

BECK, Ulrich. La sociedad de riesgo. Hacia una nueva modernidad. Ediciones Paidós Ibérica, Barcelona. 1998.

BECK, Ulrich. A Europa Alemã: a crise do euro e as novas perspectivas de poder. 1a ed. São Paulo: Paz e Terra, 2015.

BRADY, N. y WEIL, R. Soils and chemical pollution. The Nature and Properties of Soils. Prentiss Hall Intnal, 1996.

OIT. Disponible en: <http://www.ilo.org/global/about-the ilo/newsroom/news/WCMS 008027/lang--en/index.htm>. Último acceso: 29-01-2017.

BRASIL. Ley № 7.802, de 11 de julio de 1989.

CAPRA, Fritjof. El punto crucial. Editorial Troquel, Buenos Aires, 1992, p, 27.

CARSON, Rachel. Primavera silenciosa. Editorial Crítica. Barcelona, 2010

CARVALHO, Horácio Martins de. A expansão do capitalismo no campo e a desnacionalização do 
agrário no Brasil. Revista da Associação Brasileira de Reforma Agrária (ABRA), edição especial, jun. 2013.

CBD. Disponible en: <https://www.cbd.int/doc/legal/cbd-es.pdf>. Último acceso: 27-01-2017

CBD. Disponible en: <http://bch.cbd.int/protocol/text/> Último acceso: 27-01-2017

CHONCHOL, Jacques. A soberania alimentar. Estudos Avançados, São Paulo, v. 55, n. 19, p. 33-48, Set-dez. 2005, p. 33-34. Disponible en:

<http://www.scielo.br/scielo.php?script=sci_arttext\&pid=S010340142005000300003>. Último acceso: 30-01-2017.

Comisión Económica de las Naciones Unidas para Europa. Convenio de Aarhus, de 25 de noviembre de 2005 , sobre acceso a la información, participación pública en la toma de decisiones y acceso a la justicia en materia de medio ambiente. Disponible en: <http://www.prtr-

es.es/data/images/Convenci\%C3\%B3n\%20Aarhus-27D036D47C1C7FE9.pdf>. Última consulta: 2309-2016.

Consejo de Derechos Humanos de la ONU, 1998. Resolución 2006/9 de la Subcomisión para la Promoción y Protección de los Derechos Humanos, con su propuesta de principios orientadores "Extrema Pobreza y Derechos Humanos: los derechos de los pobres".

CORBALAN TEBAR, Wellington Boigues. Críticas à concepção (eco)absolutsta do princípio da precaução: uma releitura à luz do procedimento de tomada de decisões. XXIV Congresso Nacional Do CONPEDI - UFMG/FUMEC/Dom Helder Câmara. Disponible en: <http://www.conpedi.org.br/publicacoes/66fsl345/j0duvo2k>. Último acceso: 28-01-2017. CROWARDS, T.M. 1998. Safe minimum standards: costs and opportunities. Ecological Economics 25: 303-314. Doi: 10.1016/S0921-8009(97)00041-4. Disponible en: <http://www.citeulike.org/user/cbniles/author/Crowards:TM>. Último acceso: 28-01-2017. DUNCK, Ellen Adeliane Fernandes M. Agrotóxicos: modelo produtivo como fonte de violência. Revista de Direito Agrario e Agroambiental, v. 1, n. 2, 2015. Disponible en: <http://www.indexlaw.org/index.php/rdaa/article/view/328/329>. Último acceso: 30-01-2017. EL-HANI, C. Between the cross and the sword: the crisis of the gene concept. Genet. Mol. Biol., Vol. 30, no2, Sao Paulo, 2007. Disponible en: <www.scielo.br/>. Último acceso: 23-09-2016. FAO. Disponible en: 
<http://www.fao.org/fileadmin/user_upload/newsroom/docs/SOLAW\%20factsheet-es.pdf>. Último acceso: 27-01-2017.

FERMENT, G., MELGAREJO, L., BIANCONI FERNANDES, G., FERRAZ, J.M. Lavouras transgénicas riscos e incertezas: mais de 750 estudos desprezados pelos órgaos reguladores de OGMs. Brasilia: Ministério do Desenvolvimento Agrário. Disponible en: < https://issuu.com/centrodetecnologiasalternativasdazo/docs/lavouras_transgenicas_riscos_e_inc e>. Último acceso: 20-09-2016.

FERREIRA CARNEIRO, Fernando, GIRALDO DA SILVA AUGUSTO, Lia, RIGOTTO, Raquel Maria, FRIEDRICH, Karen e CAMPOS BÚRIGO, André (org.). Dossiê ABRASCO: um alerta sobre os impactos dos agrotóxicos na saúde. Rio de Janeiro: EPSJV; São Paulo: Expressão Popular, 2015. FLORES, Guilherme N.; VIEIRA, Ricardo Stanziola. Gestão integrada de resíduos sólidos urbanos à luz da Lei 12.305/2010: uma proposta para a solução da disposição final do lixo na Região Metropolitana da Foz do rio Itajaí. Revista Eletrônica Direito e Política, v. 5, 2010.

FLORES, Guilherme N.; VIEIRA, Ricardo Stanziola. Expectativas da governança socioambiental na política nacional de resíduos sólidos: reflexões sobre a sustentabilidade e as consequências da globalização na geração de resíduos. Revista Direito Ambiental e Sociedade, v. 3, n. 1, 2013. FREITAS, Juarez. Sustentabilidade: direito ao futuro. 2. ed. Belo Horizonte: Fórum, 2012. GIBBS, H.K., RUESCH, A.S., ACHARD, F., CLAYTON, M.K., HOLMGREN, P., RAMANKUTTY, N. and J.A. FOLEY. Tropical forests were the primary sources of new agricultural land in the 1980s and 1990s. 2010. Proceedings of the National Academy of Sciences 107(38): 16732-16737. Doi: 10.1073/pnas.0910275107. Disponible en: <https://www.ncbi.nlm.nih.gov/pubmed/20807750>. Último acceso: 20-01-2017.

HABERMAS, Jürgen. A crise de legitimação no capitalismo tardio. 2. ed. São Paulo: Tempo Brasileiro, 2002.

HOEKSTRA, A.Y. and T.O. WIEDMANN. 2014. Humanity's unsustainable environmental footprint. Science 344 (6188): 1114-1117. Doi: 10.1126/science.1248365. Disponible en : < https://www.ncbi.nlm.nih.gov/pubmed/24904155>. Último acceso: 29-01-2017. JAMES, Clive. Global Status of Commercialized Biotech/GM Crops: 2012. ISAAA Brief No. 44. ISAAA: Ithaca, Nueva York. 2012. 
LATHAM, J., WILSON, A., STEINBRECHER, R. The Mutational Consequences of Plant Transformation. Journal of Biomedicine and Biotechnology. 2006, Article ID 25376. Disponible en: <www.ncbi.nlm.nih.gov/pmc/articles/PMC1559911>. Último acceso: 22-09-2016. LATOUCHE, Serge. Pequeno Tratado de decrescimento sereno. São Paulo: WMF Martins Fontes, 2009.

LONDRES, Flávia. Agrotóxicos no Brasil: um guia para ação em defesa da vida. Rio de Janeiro: ASPTA - Assessoria e Serviços a Projetos em Agricultura Alternativa, 2012.

MORIN, Edgar; KERN, Anne Brigitte. Terra Pátria. São Paulo: Sulina, 1995.

MORIN, Edgar. A via para o futuro da humanidade. Rio de Janeiro: Bertrand Brasil, 2013.

ONU. http://www.un.org/spanish/esa/sustdev/agenda21/riodeclaration.htm

POLANYI, Karl. La gran transformación. Los orígenes políticos y económicos de nuestro tiempo. FCE, México, 2003.

REAL FERRER, Gabriel. Calidad de vida, medio ambiente, sostenibilidad y ciudadanía. Construímos juntos el futuro? Revista NEJ - Eletrônica, v. 17, n. 3, 2012.

ROCKSTRÖM, J., STEFFEN, W., NOONE, K., PERSSON, Å., CHAPIN, III, F.S., LAMBIN, E.F., LENTON, T.M., SCHEFFER, M., FOLKE, C., SCHELLNHUBER, H.J. et al. 2009b. A safe operating space for humanity. Nature. 461(7263): 472-475. Doi: 10.1038/461472a;pmid:19779433. Disponible en: <https://www.ncbi.nlm.nih.gov/pubmed/19779433>. Último acceso: 30-01-2017.

SANTOS, Boaventura de Sousa. Um discurso sobre as ciências na transição para uma ciência pósmoderna. Estud. av., São Paulo, v.2, n.2, Ago. 1988.

SHIVA, Vandana. Monoculturas da mente: perspectivas da biodiversidade e da biotecnologia. São Paulo: Gaia, 2003.

SCHMITT SIQUEIRA GARCIA, Denise, SIQUEIRA GARCIA, Heloise. Dimensão social do princípio da sustentabilidade: uma análise do mínimo existencial ecológico en SOUZA, Maria Claudia da Silva Antunes de, SIQUEIRA GARCIA, Heloise (org.). Lineamentos sobre sustentabilidade segundo Gabriel Real Ferrer. Disponible en:

<http://siaibib01.univali.br/pdf/Lineamentos\%20sobre\%20Sustentabilidade\%20segundo\%20Gabri el\%20Real\%20Ferrer\%20-\%20E-book.pdf>. Último acceso: 27-01-2017. 
SOUZA, Maria Claudia da Silva Antunes de. Sustentabilidade, sociedade de risco e alimentos transgênicos: disputas definitórias e o Projeto de Lei no. 4.148/08. XXIV Congresso Nacional Do CONPEDI - UFMG/FUMEC/Dom Helder Câmara. Disponible en <http://www.conpedi.org.br/publicacoes/66fsl345/8g6821fe>. Último acceso: 28-01-2017. UNIÓN EUROPEA. Directiva 2015/412 del Parlamento Europeo y del Consejo, de 11 de marzo de 2015, por la que se modifica la Directiva 2001/18/CE/CE en lo que respecta a la posibilidad de que los Estados miembros restrinjan o prohíban el cultivo de organismos modificados genéticamente (OMG) en su territorio.

UNIÓN EUROPEA. Decisión de Ejecución 2016/321 de la Comisión, de 3 de marzo de 2016, por la que se adapta el ámbito geográfico de la autorización de cultivo del maíz (Zea mays L.) modificado genéticamente MON 810 (MON- $\varnothing \varnothing 81 \varnothing-6)$.

UNCTD - UNITED NATIONS CONFERENCE ON TRADE AND DEVELOPMENT. Trade and environment review 2013: wake up before it is too late: make agriculture truly sustainable now for food security in a changing climate. Geneva, 2013.

VARGAS BARBOSA, Caroline y RAMOS JORDÃO, Luciana. A produção de agrocombustíveis e o enlaço com a segurança e soberania alimentar. XXIV Congresso Nacional Do CONPEDI UFMG/FUMEC/Dom Helder Câmara. Disponible en <http://www.conpedi.org.br/publicacoes/66fsl345/7y8y67h7>. Último acceso: 28-01-2017. WEBER, Max. A Ética Protestante e o Espírito do Capitalismo. Tradução: José Marcos Mariani de Macedo. Edição Antônio Flávio Pierucci São Paulo: Companhia das Letras, 2004.

World Commission on Environment and Development. Informe Brundtland, "Our Common Future". Disponible en <http://www.un-documents.net/our-common-future.pdf $\geq$. Último acceso: 29-01-2017.

WWF. 2016. Informe Planeta Vivo 2016. Riesgo y resiliencia en el Antropoceno. 


\title{
A CONCESSÃO DE USO ESPECIAL PARA FINS DE MORADIA NA COMPETÊNCIA LEGISLATIVA E OS BENS IMÓVEIS DOS ESTADOS E DOS MUNICÍPIOS
}

\author{
Mônani Menine Pereira ${ }^{1}$
}

\section{INTRODUÇÃO}

Somente em Florianópolis/SC, milhares de pessoas residem há muito tempo em pelo menos 31 (trinta e uma) comunidades irregulares instaladas em terras públicas ${ }^{2}$. Isso se dá, evidente, por conta da histórica e grave crise habitacional que assola o país, que força um fluxo cada vez maior de pessoas a se direcionar e se concentrar nos grandes centros urbanos.

Existe necessidade de se assegurar os bens imóveis públicos, como patrimônio coletivo. Mas, da ocupação irregular e desordenada do espaço público também decorrem conseqüências sociais, econômicas e ambientais, especialmente pela costumeira falta de condições básicas de infraestrutura naqueles locais.

Para o bem do desenvolvimento sustentável, que pressupõe também o planejamento territorial das áreas urbanas, o Poder Público deve solucionar as ocupações irregulares consolidadas em seus próprios imóveis, assegurando os recursos naturais, através da preservação ambiental, sem olvidar a dignidade dos ocupantes pela efetivação do direito social de moradia.

É necessário então recorrer aos instrumentos gerais da Política Urbana, com destaque para a concessão de uso especial para fins de moradia prevista no $\S 1$ o do art. 183 da Constituição Federal.

O presente artigo, cuja parte do tema foi objeto de outro ensaio que será encaminhado para publicação ${ }^{3}$, traz breve reflexão acerca da regulamentação da concessão de uso especial para fins moradia e a competência legislativa em face dos imóveis dos Estados e dos Municípios.

\footnotetext{
${ }^{1}$ Graduado em Direito pela Universidade do Vale do Itajaí - UNIVALI - SC. Pós-graduado em Direito Civil e Processo Civil pelo Complexo de Ensino Superior de Santa Catarina - CESUSC - SC. Pós-graduado em Direito e Gestão Judiciária para Magistrados pela Universidade Federal do Estado de Santa Catarina - UFSC - SC. Mestrando em Ciência Jurídica pela Universidade do Vale do Itajaí - UNIVALI - SC. Juiz de Direito da Vara Criminal da Comarca de Tijucas - SC. E-mail: mmp17928@gmail.com.

2 THOMÉ, Leonardo. Habitação precária: mais de 50 mil pessoas vivem em 64 comunidades irregulares de Florianópolis. Jornal Hora de Santa Catarina. Florianópolis, 20 agosto de $2016 . \quad$ Disponível em http://horadesantacatarina.clicrbs.com.br/sc/geral/noticia/2016/08/mais-de-50-mil-pessoas-vivem-em-64-comunidadesirregulares-de-florianopolis-7300817.html. Acesso em: 20 de janeiro de 2017.

3 PEREIRA. Mônani Menine. A limitação temporal na regulamentação da concessão de uso especial para fins de moradia.
} 
Dividido em três partes, na primeira será apresentado o tratamento legislativo reservado à concessão de uso especial para fins de moradia, desde a previsão constitucional até as tentativas de se regulamentar o referido instituto jurídico.

Na segunda parte, as normas que tratam da concessão de uso especial para fins de moradia serão analisadas segundo a competência legislativa prevista na Constituição Federal.

E na derradeira, serão lançadas considerações acerca de dispositivos da Medida Provisória n. 2.220, de 04 de setembro de 2001 que cuidam do instituto da concessão de uso especial para fins de moradia e que, reconhecidos como norma geral produzida no âmbito da competência legislativa concorrente, extrapolam os limites daquela competência.

A investigação, o tratamento dos dados e a elaboração do relato desta pesquisa são realizados com base no método dedutivo, com pesquisa bibliográfica referenciada ao final ${ }^{4}$.

\section{A CONCESSÃO DE USO ESPECIAL PARA FINS DE MORADIA NO ORDENAMENTO JURÍDICO BRASILEIRO}

A Constituição Federal apresentou o instituto da concessão de uso especial para fins de moradia. Como prescrição aquisitiva de um direito que vai além da simples habitação ${ }^{5}$ em imóvel público, o § 1ㅇ do art. 183 da Constituição Federal cuida da concessão de uso:

Art. 183. Aquele que possuir como sua área urbana de até duzentos e cinquenta metros quadrados, por cinco anos, ininterruptamente e sem oposição, utilizando-a para sua moradia ou de sua família, adquirir-lhe-á o domínio, desde que não seja proprietário de outro imóvel urbano ou rural.

$\S 1$ 은 0 título de domínio e a concessão de uso serão conferidos ao homem ou à mulher, ou a ambos, independentemente do estado civil. (g.n.) ${ }^{6}$

Embora prevista na alínea " $\mathrm{h}$ " do inciso V do art. 4ำ do Estatuto da Cidade (Lei Federal n.

\footnotetext{
4 “MÉTODO DEDUTIVO: base lógica da dinâmica da Pesquisa Científica que consiste em estabelecer uma formulação geral e, em seguida, buscar as partes do fenômeno de modo a sustentar a formulação geral". PASSOLD, Cesar Luiz. Metodologia da Pesquisa Jurídica: Teoria e Prática. 12 ed. rev. São Paulo: Conceito Editorial, 2011. p .86).

${ }^{5}$ Sobre a distinção entre o direito à moradia e direito de habitação, Sergio Iglesias Nunes de Souza disserta que "a partir do momento em que se objetiva a análise doutrinária e jurisprudencial das consequências jurídicas oriundas do direito à moradia e de habitação para o indivíduo ou para a coletividade, a distinção entre ambos ganha, para nós, certa relevância, para se distinguir o cunho pessoal do primeiro e do patrimonial do segundo, sem, porém, olvidar-se do seu forte liame teleológico e seu caráter de complementaridade". SOUZA, Sergio Iglesias Nunes de. Direito à moradia e de habitação: Análise comparativa e seu aspecto teórico e prático com os direitos da personalidade. 3a ed. rev. atual. e amp. São Paulo: Editora Revista dos Tribunais, 2013. p. 117.

6 BRASIL. Constituição Federal. Presidência da República: Casa Civil - Subchefia para Assuntos Jurídicos. Brasília, DF. Disponível em: <http://www.planalto.gov.br>. Acesso em: 20 janeiro de 2017.
} 
10.257/01), os artigos 15, 16, 17, 18, 19 e 20 do mesmo diploma legal, que regulamentariam a concessão especial de uso para fins de moradia, foram vetados pelo Presidente da República. Constam das razões do veto:

O instituto jurídico da concessão de uso especial para fins de moradia em áreas públicas é um importante instrumento para propiciar segurança da posse - fundamento do direito à moradia - a milhões de moradores de favelas e loteamentos irregulares. Algumas imprecisões do projeto de lei trazem, no entanto, riscos à aplicação desse instrumento inovador, contrariando o interesse público".

O caput do art. 15 do projeto de lei assegura o direito à concessão de uso especial para fins de moradia àquele que possuir como sua área ou "edificação urbana" de até duzentos e cinquenta metros quadrados situada em imóvel público. A expressão "edificação urbana" no dispositivo visaria a permitir a regularização de cortiços em imóveis públicos, que no entanto é viabilizada pela concessão a título coletivo, prevista no art. 16. Ela se presta, por outro lado, a outra leitura, que poderia gerar demandas injustificadas do direito em questão por parte de ocupantes de habitações individuais de até duzentos e cinquenta metros quadrados de área edificada em imóvel público.

Os arts. 15 a 20 do projeto de lei contrariam o interesse público sobretudo por não ressalvarem do direito à concessão de uso especial os imóveis públicos afetados ao uso comum do povo, como praças e ruas, assim como áreas urbanas de interesse da defesa nacional, da preservação ambiental ou destinadas a obras públicas. Seria mais do que razoável, em caso de ocupação dessas áreas, possibilitar a satisfação do direito à moradia em outro local, como prevê o art. 17 em relação à ocupação de áreas de risco.

O projeto não estabelece uma data-limite para a aquisição do direito à concessão de uso especial, o que torna permanente um instrumento só justificável pela necessidade imperiosa de solucionar o imenso passivo de ocupações irregulares gerado em décadas de urbanização desordenada.

Por fim, não há no art. 18 a definição expressa de um prazo para que a Administração Pública processe os pedidos de concessão de direito de uso que, previsivelmente, virão em grande número a partir da vigência deste instrumento. Isto traz o risco de congestionar o Poder Judiciário com demandas que, num prazo razoável, poderiam e deveriam ser satisfeitas na instância administrativa.

Pelas razões expostas, propõe-se o veto aos arts. 15 a 20 do projeto de lei. "Em reconhecimento à importância e validade do instituto da concessão de uso especial para fins de moradia, o Poder Executivo submeterá sem demora ao Congresso Nacional um texto normativo que preencha essa lacuna, buscando sanar as imprecisões apontadas. ${ }^{7}$

Porém, cerca de dois meses depois da publicação do Estatuto da Cidade (e do veto), o Presidente editou a Medida Provisória n. 2.220, de 04 de setembro de 2001, que dispõe sobre a concessão de uso especial de que trata o $\S 10$ do art. 183 da Constituição e dá outras providências:

Art. $1^{\circ}$ Aquele que, até 30 de junho de 2001, possuiu como seu, por cinco anos, ininterruptamente e sem oposição, até duzentos e cinquenta metros quadrados de imóvel público situado em área

\footnotetext{
7 BRASIL. Mensagem de veto n. 730, de 10 de julho de 2001. Presidência da República: Casa Civil - Subchefia para Assuntos Jurídicos. Brasilia, DF. Disponível em <http://www.planalto.gov.br/ccivil_03/leis/Mensagem_Veto/2001/Mv730-01.htm. >. Acesso em: 20 janeiro de 2017.
} 
urbana, utilizando-o para sua moradia ou de sua família, tem o direito à concessão de uso especial para fins de moradia em relação ao bem objeto da posse, desde que não seja proprietário ou concessionário, a qualquer título, de outro imóvel urbano ou rural.

$\S 1^{\circ}$ A concessão de uso especial para fins de moradia será conferida de forma gratuita ao homem ou à mulher, ou a ambos, independentemente do estado civil.

$\S 2^{\circ} \mathrm{O}$ direito de que trata este artigo não será reconhecido ao mesmo concessionário mais de uma vez.

$\S 3^{\circ}$ Para os efeitos deste artigo, o herdeiro legítimo continua, de pleno direito, na posse de seu antecessor, desde que já resida no imóvel por ocasião da abertura da sucessão.

Art. $2^{\circ}$ Nos imóveis de que trata o art. $1^{\circ}$, com mais de duzentos e cinquenta metros quadrados, que, até 30 de junho de 2001, estavam ocupados por população de baixa renda para sua moradia, por cinco anos, ininterruptamente e sem oposição, onde não for possível identificar os terrenos ocupados por possuidor, a concessão de uso especial para fins de moradia será conferida de forma coletiva, desde que os possuidores não sejam proprietários ou concessionários, a qualquer título, de outro imóvel urbano ou rural.

$\S 1^{\circ} \mathrm{O}$ possuidor pode, para o fim de contar o prazo exigido por este artigo, acrescentar sua posse à de seu antecessor, contanto que ambas sejam contínuas.

$\S 2^{\circ}$ Na concessão de uso especial de que trata este artigo, será atribuída igual fração ideal de terreno a cada possuidor, independentemente da dimensão do terreno que cada um ocupe, salvo hipótese de acordo escrito entre os ocupantes, estabelecendo frações ideais diferenciadas.

$\S 3^{\circ} \mathrm{A}$ fração ideal atribuída a cada possuidor não poderá ser superior a duzentos e cinquenta metros quadrados.

Art. $3^{\circ}$ Será garantida a opção de exercer os direitos de que tratam os arts. $\mathbf{1}^{\circ}$ e $\mathbf{2}^{\circ}$ também aos ocupantes, regularmente inscritos, de imóveis públicos, com até duzentos e cinquenta metros quadrados, da União, dos Estados, do Distrito Federal e dos Municípios, que estejam situados em área urbana, na forma do regulamento.

Art. $4^{\circ}$ No caso de a ocupação acarretar risco à vida ou à saúde dos ocupantes, o Poder Público garantirá ao possuidor o exercício do direito de que tratam os arts. $1^{\circ} \mathbf{2}^{\circ}$ em outro local.

Art. $5^{\circ}$ É facultado ao Poder Público assegurar o exercício do direito de que tratam os arts. $\mathbf{1}^{\circ} \mathrm{e}$

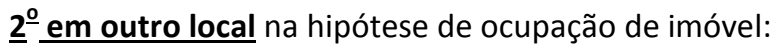

I - de uso comum do povo;

II - destinado a projeto de urbanização;

III - de interesse da defesa nacional, da preservação ambiental e da proteção dos ecossistemas naturais;

IV - reservado à construção de represas e obras congêneres; ou

V - situado em via de comunicação.

Art. $6^{\circ}$ O título de concessão de uso especial para fins de moradia será obtido pela via administrativa perante o órgão competente da Administração Pública ou, em caso de recusa ou omissão deste, pela via judicial. 
$\S 1^{\circ}$ A Administração Pública terá o prazo máximo de doze meses para decidir o pedido, contado da data de seu protocolo.

$\S 2^{\circ}$ Na hipótese de bem imóvel da União ou dos Estados, o interessado deverá instruir o requerimento de concessão de uso especial para fins de moradia com certidão expedida pelo Poder Público municipal, que ateste a localização do imóvel em área urbana e a sua destinação para moradia do ocupante ou de sua família.

$\S 3^{0}$ Em caso de ação judicial, a concessão de uso especial para fins de moradia será declarada pelo juiz, mediante sentença.

$\S 4^{\circ} \mathrm{O}$ título conferido por via administrativa ou por sentença judicial servirá para efeito de registro no cartório de registro de imóveis.

Art. $7^{\circ} \mathrm{O}$ direito de concessão de uso especial para fins de moradia é transferível por ato inter vivos ou causa mortis.

Art. $8^{\circ}$ O direito à concessão de uso especial para fins de moradia extingue-se no caso de:

I - o concessionário dar ao imóvel destinação diversa da moradia para si ou para sua família; ou

II - o concessionário adquirir a propriedade ou a concessão de uso de outro imóvel urbano ou rural.

Parágrafo único. A extinção de que trata este artigo será averbada no cartório de registro de imóveis, por meio de declaração do Poder Público concedente.

Art. $9^{\circ}$ É facultado ao Poder Público competente dar autorização de uso àquele que, até 30 de junho de 2001, possuiu como seu, por cinco anos, ininterruptamente e sem oposição, até duzentos e cinquenta metros quadrados de imóvel público situado em área urbana, utilizando-o para fins comerciais.

$\S 1^{\circ}$ A autorização de uso de que trata este artigo será conferida de forma gratuita.

$\S 2^{\circ} \mathrm{O}$ possuidor pode, para o fim de contar o prazo exigido por este artigo, acrescentar sua posse à de seu antecessor, contanto que ambas sejam contínuas.

$\S 3^{\circ}$ Aplica-se à autorização de uso prevista no caput deste artigo, no que couber, o disposto nos arts. $4^{\circ}$ e $5^{\circ}$ desta Medida Provisória. (g.n. $)^{8}$

Referida norma tanto não foi convertida em lei como permanece em vigor por força do disposto no art. 2ㅇ da Emenda Constitucional n. 32, de 11 de setembro de 2001:

Art. $2^{\circ}$ As medidas provisórias editadas em data anterior à da publicação desta emenda continuam em vigor até que medida provisória ulterior as revogue explicitamente ou até deliberação definitiva do Congresso Nacional. (g.n.) ${ }^{9}$

Mais recentemente foi editada a Medida Provisória n. 759, de 22 de dezembro de 2016, que alterou os arts. 1ํ, 2ํ e 9ㅇda Medida Provisória n. 2.220/01:

\footnotetext{
8 BRASIL. Medida Provisória n. 2.220, de 04 de setembro de 2001.Dispõe sobre sobre a concessão de uso especial de que trata o $\S$ $1^{\circ}$ do art. 183 da Constituição, cria o Conselho Nacional de Desenvolvimento Urbano - CNDU e dá outras providências. Presidência da República: Casa Civil - Subchefia para Assuntos Jurídicos. Brasília, DF. Disponível em: <http://www.planalto.gov.br>. Acesso em: 20 janeiro de 2017.

9 BRASIL. Constituição Federal. Presidência da República: Casa Civil - Subchefia para Assuntos Jurídicos. Brasília, DF. Disponível em: <http://www.planalto.gov.br>. Acesso em: 20 janeiro de 2017.
} 
Art. 66. A Medida Provisória no 2.220, de 4 de setembro de 2001, passa a vigorar com as seguintes alterações:

"Art. 10 Aquele que, até 22 de dezembro de 2016, possuiu como seu, por cinco anos, ininterruptamente e sem oposição, até duzentos e cinquenta metros quadrados de imóvel público situado em área com características e finalidade urbana, e que o utilize para sua moradia ou de sua família, tem o direito à concessão de uso especial para fins de moradia em relação ao bem objeto da posse, desde que não seja proprietário ou concessionário, a qualquer título, de outro imóvel urbano ou rural.

Art. 2ㅇ Nos imóveis de que trata o art. 1으, com mais de duzentos e cinquenta metros quadrados, ocupados até 22 de dezembro de 2016, por população de baixa renda para sua moradia, por cinco anos, ininterruptamente e sem oposição, onde não for possível identificar os terrenos ocupados por possuidor, a concessão de uso especial para fins de moradia será conferida de forma coletiva, desde que os possuidores não sejam proprietários ou concessionários, a qualquer título, de outro imóvel urbano ou rural.

Art. 9o É facultado ao Poder Público competente conceder autorização de uso àquele que, até $\mathbf{2 2}$ de dezembro de 2016, possuiu como seu, por cinco anos, ininterruptamente e sem oposição, até duzentos e cinquenta metros quadrados de imóvel público situado em área características e finalidade urbana para fins comerciais." (g.n. $)^{10}$

Assim, as disposições infraconstitucionais ainda estão totalmente disciplinadas na Medida Provisória 2.220/01 (com as alterações da Medida Provisória n. 759/16) que, em resumo, permite:

(i) a concessão de uso especial para fins de moradia ao homem ou mulher que, até 22 de dezembro de 2016, possuía como seu, por cinco anos ininterruptos e sem oposição, até duzentos e cinquenta metros quadrados de imóvel público situado em área com característica e finalidade urbana, desde que o utilize para sua moradia ou de sua família e que não seja proprietário ou concessionário, a qualquer título, de outro imóvel urbano ou rural (art. 1ํ);

(ii) a concessão de uso especial para fins de moradia, de forma coletiva, à população de baixa renda que, até 22 de dezembro de 2016, possuía como seu, por cinco anos ininterruptos e sem oposição, até duzentos e cinquenta metros quadrados de imóvel público situado em área com característica e finalidade urbana, desde que não sejam proprietários ou concessionários, a qualquer título, de outro imóvel urbano ou rural (art. 2º);

(iii) a concessão de uso especial para fins de moradia aos ocupantes, regularmente inscritos, de imóveis públicos com até duzentos e cinquenta metros quadrados situados em área

\footnotetext{
${ }^{10}$ BRASIL. Medida Provisória n. 759, de 22 de dezembro de 2016. Dispõe sobre a regularização fundiária rural e urbana, sobre a liquidação de créditos concedidos aos assentados da reforma agrária e sobre a regularização fundiária no âmbito da Amazônia Legal, institui mecanismos para aprimorar a eficiência dos procedimentos de alienação de imóveis da União, e dá outras providências. Presidência da República: Casa Civil - Subchefia para Assuntos Jurídicos. Brasília, DF. Disponível em: <http://www.planalto.gov.br>. Acesso em: 20 janeiro de 2017.
} 
urbana (art. 3ㅇ); e

(iv) a concessão de uso especial para fins de moradia, em local distinto, à população de baixa renda que, até 22 de dezembro de 2016, possuía como seu, por cinco anos ininterruptos e sem oposição, até duzentos e cinquenta metros quadrados de imóvel público situado em área com característica e finalidade urbana, desde que não sejam proprietários ou concessionários, a qualquer título, de outro imóvel urbano ou rural (art. 4우).

\section{A MEDIDA PROVISÓRIA 2.220/01 COMO NORMA GERAL}

O caput do art. 182 da Constituição Federal ${ }^{11}$ cuida das normas gerais de desenvolvimento urbano, editadas pela União para serem executadas pelo Poder Público Municipal.

Art. 182. A política de desenvolvimento urbano, executada pelo Poder Público municipal, conforme diretrizes gerais fixadas em lei, tem por objetivo ordenar o pleno desenvolvimento das funções sociais da cidade e garantir o bem- estar de seus habitantes. (g.n.)

Aquelas diretrizes gerais da política urbana, precisamente em função da regulamentação do caput do art. 182 da Carta Maior, estão delineadas no art. 2o do Estatuto da Cidade.

Art. $2^{\circ}$ A política urbana tem por objetivo ordenar o pleno desenvolvimento das funções sociais da cidade e da propriedade urbana, mediante as seguintes diretrizes gerais:

I - garantia do direito a cidades sustentáveis, entendido como o direito à terra urbana, à moradia, ao saneamento ambiental, à infra-estrutura urbana, ao transporte e aos serviços públicos, ao trabalho e ao lazer, para as presentes e futuras gerações;

II - gestão democrática por meio da participação da população e de associações representativas dos vários segmentos da comunidade na formulação, execução e acompanhamento de planos, programas e projetos de desenvolvimento urbano;

III - cooperação entre os governos, a iniciativa privada e os demais setores da sociedade no processo de urbanização, em atendimento ao interesse social;

IV - planejamento do desenvolvimento das cidades, da distribuição espacial da população e das atividades econômicas do Município e do território sob sua área de influência, de modo a evitar e corrigir as distorções do crescimento urbano e seus efeitos negativos sobre o meio ambiente;

V - oferta de equipamentos urbanos e comunitários, transporte e serviços públicos adequados aos interesses e necessidades da população e às características locais;

$\mathrm{VI}$ - ordenação e controle do uso do solo, de forma a evitar:

\footnotetext{
${ }^{11}$ José Afonso da Silva entende que "a referência a "diretrizes gerais fixadas em lei", no art. 182, se liga também à competência indicada nos arts. 21, XX e 24, I, e § 10. Quer dizer, as diretrizes do desenvolvimento urbano, mencionadas no art. 21, XX, devem ser veiculadas mediante lei federal de normas gerais, de que cogitam o art. 24, I e $\S 1 \mathfrak{Q}^{\prime \prime}$. SILVA. José Afonso. Direito Urbanístico Brasileiro. São Paulo: Malheiros. 2008, p. 65.
} 
a) a utilização inadequada dos imóveis urbanos;

b) a proximidade de usos incompatíveis ou inconvenientes;

c) o parcelamento do solo, a edificação ou o uso excessivos ou inadequados em relação à infraestrutura urbana;

d) a instalação de empreendimentos ou atividades que possam funcionar como pólos geradores de tráfego, sem a previsão da infra-estrutura correspondente;

e) a retenção especulativa de imóvel urbano, que resulte na sua subutilização ou não utilização;

f) a deterioração das áreas urbanizadas;

g) a poluição e a degradação ambiental;

h) a exposição da população a riscos de desastres.

VII - integração e complementaridade entre as atividades urbanas e rurais, tendo em vista o desenvolvimento socioeconômico do Município e do território sob sua área de influência;

VIII - adoção de padrões de produção e consumo de bens e serviços e de expansão urbana compatíveis com os limites da sustentabilidade ambiental, social e econômica do Município e do território sob sua área de influência;

IX - justa distribuição dos benefícios e ônus decorrentes do processo de urbanização;

X - adequação dos instrumentos de política econômica, tributária e financeira e dos gastos públicos aos objetivos do desenvolvimento urbano, de modo a privilegiar os investimentos geradores de bem-estar geral e a fruição dos bens pelos diferentes segmentos sociais;

XI - recuperação dos investimentos do Poder Público de que tenha resultado a valorização de imóveis urbanos;

XII - proteção, preservação e recuperação do meio ambiente natural e construído, do patrimônio cultural, histórico, artístico, paisagístico e arqueológico;

XIII - audiência do Poder Público municipal e da população interessada nos processos de implantação de empreendimentos ou atividades com efeitos potencialmente negativos sobre o meio ambiente natural ou construído, o conforto ou a segurança da população;

XIV - regularização fundiária e urbanização de áreas ocupadas por população de baixa renda mediante o estabelecimento de normas especiais de urbanização, uso e ocupação do solo e edificação, consideradas a situação socioeconômica da população e as normas ambientais;

XV - simplificação da legislação de parcelamento, uso e ocupação do solo e das normas edilícias, com vistas a permitir a redução dos custos e o aumento da oferta dos lotes e unidades habitacionais;

XVI - isonomia de condições para os agentes públicos e privados na promoção de empreendimentos e atividades relativos ao processo de urbanização, atendido o interesse social;

XVII - estímulo à utilização, nos parcelamentos do solo e nas edificações urbanas, de sistemas operacionais, padrões construtivos e aportes tecnológicos que objetivem a redução de impactos ambientais e a economia de recursos naturais; 
XVIII - tratamento prioritário às obras e edificações de infraestrutura de energia, telecomunicações, abastecimento de água e saneamento. (g.n.) ${ }^{12}$

Importa destacar que a Constituição Federal elevou o direito urbanístico como ramo próprio do Direito, desvinculando-o do administrativo ${ }^{13}$, com a conseqüente alteração do regime jurídico da produção de suas normas.

Carlos Ari Sundfel ${ }^{14}$, a propósito, afirma que:

[...] o direito urbanístico surge, então, como direito da política de desenvolvimento urbano em três sentidos: a) como conjunto de normas que disciplinam a fixação dos objetivos da política urbana (exemplo: normas constitucionais; b) como conjunto de textos normativos em que estão fixados os objetivos da política urbana (os planos urbanísticos, por exemplo); c) como conjunto de normas em que estão previstos e regulados os instrumentos de implementação da política urbana (o próprio Estatuto da Cidade, entre outros). (g.n.)

As normas de direito urbanístico ${ }^{15}$, enfim, têm um regramento constitucional próprio, sujeitas que estão ao regime da competência legislativa concorrente.

Mesmo que a Lei Federal 10.257/01 não possa ser considerada como um "Código Urbanístico" $^{16}$ - tanto que o Projeto de Lei no 775/83, que deu origem às discussões que resultaram no Estatuto da Cidade, era chamado de "Lei do Desenvolvimento Urbano"-, existem indisfarçáveis normas de direito urbanístico naquele texto.

Inegável, de fato, que alguns institutos jurídicos presentes no Estatuto da Cidade (art. 4으, inc. V) têm relação intima e direta com aquele ramo do direito. José Afonso da Silva ${ }^{17}$ destaca alguns:

12 BRASIL. Lei Federal n. 10.257, de 10 de julho de 2001. Regulamenta os arts. 182 e 183 da Constituição Federal, estabelece diretrizes gerais da política urbana e dá outras providências. Presidência da República: Casa Civil - Subchefia para Assuntos Jurídicos. Brasília, DF. Disponível em: <http://www.planalto.gov.br>. Acesso em: 20 janeiro de 2017.

${ }^{13}$ Predomina na doutrina, contudo, entendimento de que o direito urbanístico é parte do direito administrativo, sob o fundamento de que as normas de direito urbanístico constituem-se em normas administrativas, especiais ou não. A propósito, vide RABELLO. Sonia. Direito Urbanístico e Direito Administrativo: imbricações e inter-relações. Revista de Direito da Cidade. Revista Jus Navigandi, vol. $01 . \quad$ n. 01 ISSN 2317-7721. Disponível em <http://www.epublicacoes.uerj.br/index.php/rdc/article/viewFile/10492/8264>. Acesso em: 20 janeiro de 2017. Já José Afonso da Silva sustenta que "ainda é prudente considerá-lo como uma disciplina de síntese, ou ramo multidisciplinar do Direito, que aos poucos vai configurando suas próprias instituições". (SILVA. José Afonso. Direito Urbanístico Brasileiro. São Paulo: Malheiros. 2008, p. 44).

${ }^{14}$ SUNDFELD. Carlos Ari. O Estatuto da Cidade e suas diretrizes gerais. In, DALLARI, Adilson Abreu; FERRAZ, Sérgio (Coord.). Estatuto da Cidade: comentários à Lei Federal n. 10.257/2010. São Paulo: Malheiros. 2002. p. 49.

${ }^{15}$ José Afonso da Silva destaca que "o direito urbanístico no Brasil forma-se de um conjunto de normas que compreende normas gerais, de competência legislativa da União (CF, art. 24, l, e § 10), hoje consubstanciadas no Estatuto da Cidade (Lei 10.257/2001); normas suplementares de cada Estado (CF, art. 24, I, § 20) de pouca expressão; normas municipais, também de caráter suplementar (CF, art. 30, II e VIII, e 182) - agora, por força do Estatuto da Cidade, com mais unidade substancial". (SILVA. José Afonso. Direito Urbanístico Brasileiro. São Paulo: Malheiros. 2008, p. 44).

${ }^{16}$ Países como Espanha (Lei de Regimen del Suelo y Ordenación Urbana, de 1956, reformulada em 1975 e 1992), Itália (Legge Urbanistica, de 1942, reformulada em 1967 e 1977), França (Code de l'Urbanisme et de l'Habitation, de 1954, reformulado em 1973) e Alemanha (Bundesbaugesetz - Lei Federal de Ordenação Urbanística, de 1960), há muito, tocados pela necessidade do planejamento territorial, tem assegurado a unidade do direito urbanístico em seu ordenamento jurídico.

${ }^{17}$ SILVA. José Afonso. Direito Urbanístico Brasileiro. São Paulo: Malheiros. 2008, p. 45-46. 
23. Embora os princípios informadores do direito urbanístico, acima indicados, ainda careçam de elaboração cientifica mais precisa, já é possível, no entanto, perceber a formação de certas instituições e institutos que já delineiam sua estrutura.

24. Assim, o conjunto de normas que configura a ordenação jurídica dos espaços habitáveis dá origem a verdadeiras instituições de direito urbanístico, como: o planejamento urbanístico (traduzido formalmente em planos urbanísticos), o parcelamento do solo urbano ou urbanizável, o zoneamento de uso do solo, a ocupação do solo, o reparcelamento. Em cada uma dessas instituições encontramos institutos jurídico-urbanísticos, como: o arruamento, o loteamento, o desmembramento, a outorga onerosa do direito de construir, as operações urbanas consorciadas, o direito de superfície, o direito de preempção, a transferência do direito de construir, a regularização fundiária, os índices urbanísticos (taxa de ocupação do solo, coeficiente de aproveitamento do solo, recuos, gabaritos).

25. Por outro lado, há procedimentos próprios do direito urbanístico, como o do planejamento urbano, o do zoneamento, o do arruamento e o do loteamento, modos pelos quais se realizam na prática as instituições correspondentes.

Por isso, em que pese entendimento contrário ${ }^{18}$, a doutrina pacificamente reconhece no Estatuto da Cidade normas gerais de direito urbanístico ${ }^{19}$, editadas pela União no âmbito da competência legislativa concorrente.

Art. 24. Compete à União, aos Estados e ao Distrito Federal legislar concorrentemente sobre:

I - direito tributário, financeiro, penitenciário, econômico e urbanístico;

$\S 1$ ㅇN No âmbito da legislação concorrente, a competência da União limitar-se-á a estabelecer normas gerais. (g.n.) ${ }^{20}$

Adilson Abreu Dallari e Daniela Campos Libório Di Sarno ${ }^{21}$ afirmam que:

[...] é muito significativo que o Estatuto da Cidade, dispondo sobre normas gerais do Direito Urbanístico, tenha sido editado pela União na competência que lhe dá o art. 24, inciso I, da Constituição Federal, para editar normas gerais de Direito Urbanístico. A inferência imediata que se deve retirar disso é que o Estatuto da Cidade não é uma lei federal, no sentido de ser uma lei aplicável apenas ao aparelho administrativo da União: o Estatuto da Cidade é uma lei nacional, que estabelece normas gerais de observância obrigatória por todos os jurisdicionados do estado brasileiro.

\footnotetext{
${ }^{18}$ DIAS, Mauricio Leal; RIBEIRO, Taíse Spotto Lima. O Estatuto da Cidade (Lei no 10.257/01) é norma geral de Direito Urbanístico ou diretriz geral da política urbana? Revista Jus Navigandi, Teresina, ano 9, n. 312, 15 de maio de 2004. Disponível em: <https://jus.com.br/artigos/5193>. Acesso em: 20 janeiro de 2017.

${ }^{19}$ Por todos, Carlos Ari Sundfel assevera que "para informar todo o trabalho de produção - e posterior interpretação e aplicação das múltiplas cadeias normativas do direito urbanístico brasileiro, o Estatuto da Cidade decidiu fixar, em seu art. 20, as diretrizes gerais da política urbana. Para tanto, valendo-se das competências recebidas dos arts. 21, XX e 24, I, da Constituição Federal, pelo que essas diretrizes tem o status de normas gerais nacionais, sendo, portanto, vinculativas para todos os entes da Federação, especialmente os Municípios." (SUNDFELD. Carlos Ari. O Estatuto da Cidade e suas diretrizes gerais. In, DALLARI, Adilson Abreu; FERRAZ, Sérgio (Coord.). Estatuto da Cidade: comentários à Lei Federal n. 10.257/2010. São Paulo: Malheiros. 2002. p. 53).

${ }^{20}$ BRASIL. Constituição Federal. Presidência da República: Casa Civil - Subchefia para Assuntos Jurídicos. Brasília, DF. Disponível em: <http://www.planalto.gov.br>. Acesso em: 20 janeiro de 2017.

${ }^{21}$ DALLARI, Adilson Abreu e Daniela Campos Libório Di Sarno. Direito Urbanístico e Ambiental. Belo Horizonte: Fórum, 2011, p. 30.
} 
E não poderia ser diferente, uma vez que o Estatuto da Cidade regulamenta não apenas o artigo 182, mas também o artigo 183 e seus parágrafos da Constituição Federal. Reside neste último dispositivo, aliás, o assento constitucional da concessão de uso especial para fins de moradia.

Enfaticamente, a concessão de uso especial para fins de moradia é instituto jurídico do direito urbanístico, previsto no Estatuto da Cidade (art. 4으, inc. V, "h") como um dos instrumentos para execução da política urbana.

Assim, a previsão da concessão de uso especial para fins de moradia no Estatuto da Cidade decorre da regulamentação do art. 183 e seus parágrafos na forma do $\S 10$ do art. 24, ambos da Constituição Federal, ou seja, por norma geral.

A propósito das normas gerais (ou nacionais) válidas para todo Estado Federal, convém inicialmente distingui-las das normas federais, dedicadas apenas para a pessoa jurídica de direito público que as instituiu.

Hélio do Valle Pereira ${ }^{22}$ disserta:

[...] a distinção entre leis nacionais e leis federais. Aquelas são relativas à atribuição legislativa da União como ente que congrega todas as pessoas políticas, estabelecendo normas a eles comuns ( $p$. ex., direito penal, normas gerais tributárias). As leis federais referem-se à regulamentação de situações que envolvem exclusivamente a União, como pessoa pública equiparada às demais (v.g., estatuto de seus servidores, criação de imposto federal). (g.n.).

Segundo Geraldo Ataliba ${ }^{23}$, as leis gerais seriam então:

[...] leis que não se circunscrevem ao âmbito de qualquer pessoa política, mas os transcendem aos três. Não se confundem com a lei federal, estadual ou municipal e tem seu campo próprio e específico, excludente das outras três e reciprocamente. Quer dizer, da mesma forma que dominam o próprio campo constitucional, em caráter privativo, prevalecendo - em razão de delimitação constitucional, e não da hierarquia - sobre tentativas das demais leis que lhes invadir esta faixa, não podem estender-se validamente aos objetos próprios da legislação federal, estadual ou municipal.

Como lei federal pode-se exemplificar a de n. 11.481, que alterou a Lei Federal n. 9.636/98 (que cuida da regularização e administração de bens imóveis da União), e que disciplina a concessão de uso especial para fins de moradia em imóveis daquele ente federado.

Art. $2^{\circ}$ A Lei $n^{\circ} 9.636$, de 15 de maio de 1998, passa a vigorar acrescida dos seguintes artigos:

\footnotetext{
${ }^{22}$ PEREIRA, Hélio do Valle. Manual da Fazenda Pública em juízo. 2 ed. Rio de Janeiro: Renovar, 2006. p. 7, nota de rodapé.

${ }^{23}$ ATALIBA, Geraldo. Regime constitucional e leis nacionais e federais. In CLEVE, Clémerson Merlin. BARROSO, Luis Roberto (org). Doutrinas Essenciais de Direito Constitucional. São Paulo: Saraiva, 2011. v. IIII, p. 291.
} 
"Seção VIII

Da Concessão de Uso Especial para Fins de Moradia

Art. 22-A. A concessão de uso especial para fins de moradia aplica-se às áreas de propriedade da

União, inclusive aos terrenos de marinha e acrescidos, e será conferida aos possuidores ou ocupantes que preencham os requisitos legais estabelecidos na Medida Provisória $\mathrm{n}^{\circ} \underline{\mathbf{2} .220}$, de 4 de setembro de 2001. (g.n.) ${ }^{24}$

Por esta, percebe-se que tanto em relação aos imóveis da União existe lei federal específica, como que a concessão de uso especial para fins de moradia continua regulamentada pela Medida Provisória n. 2.220/01.

E propriamente às normas gerais, merece destaque inicial a condensação de estudos elaborados por diversos autores, apresentada por Diogo de Figueiredo Moreira Neto, antes de definir o que são "normas gerais" para o sistema constitucional de repartição de competência legislativa:

Sintetizando-as, a partir dessas características, as normas gerais seriam institutos que:

a) estabelecem princípios, diretrizes, linhas mestras e regras jurídicas (BÜHLER, MAUNS, BURDEAU, PONTES, PINTO FALCÃO, CLÁUDIO PACHECO, SHAID MALUF, JOSÉ AFONSO DA SILVA, PAULO DE BARROS CARVALHO, MARCO AURÉLIO GRECCO);

b) não podem entrar em pormenores ou detalhas nem, muito menos, esgotar o assunto legislado (MATZ, BÜHLER, MAUNZ, PONTES, MANOEL GONÇALVES FERREIRA FILHO, PAULO DE BARROS CARVALHO E MARCO AURÉLIO GRECCO);

c) devem ser regras nacionais, uniformemente aplicáveis a todos os entes públicos (PINTO FALCÃO, SOUTO MAIOR BORGES, PAULO DE BARROS CARVALHO, CARVALHO PINTO e ADILSON ABREU DALLARI);

e) só cabem quando preencham lacunas constitucionais ou disponham sobre áreas de conflito (PAULO DE BARROS CARVALHO e GERALDO DE ATALIBA);

f) devem referir-se a questões fundamentais (PONTES e ADILSON ABREU DALLARI);

g) são limitadas, no sentido de não poderem violar a autonomia dos Estados (PONTES, MANOEL GONÇALVES FERREIRA FILHO, PAULO DE BARROS CARVALHO e ADILSON ABREU DALLARI);

h) não são normas de aplicação direta (BURDEAU e CLÁUDIO PACHECO). ${ }^{25}$

A partir desse compêndio, Diogo de Figueiredo Moreira Neto sustenta que as normas gerais

\footnotetext{
${ }^{24}$ BRASIL. Lei Federal n. 11.481, de 31 de maio de 2007. Dá nova redação a dispositivos das Leis nos 9.636 , de 15 de maio de 1998 , 8.666, de 21 de junho de 1993, 11.124, de 16 de junho de 2005, 10.406, de 10 de janeiro de 2002 - Código Civil, 9.514, de 20 de novembro de 1997, e 6.015, de 31 de dezembro de 1973, e dos Decretos-Leis $\mathrm{n}^{\text {os }} 9.760$, de 5 de setembro de 1946, 271 , de 28 de fevereiro de 1967, 1.876, de 15 de julho de 1981, e 2.398, de 21 de dezembro de 1987; prevê medidas voltadas à regularização fundiária de interesse social em imóveis da União; e dá outras providências e dá outras providências. Presidência da República: Casa Civil - Subchefia para Assuntos Jurídicos. Brasília, DF. Disponível em: <http://www.planalto.gov.br>. Acesso em: 20 janeiro de 2017.

${ }^{25}$ MOREIRA NETO, Diogo de Figueiredo. Competência concorrente limitada. Revista de informação legislativa, a. 25, n. 100 , out./dez. 1988, p. 149-150.
} 
seriam um tertium genius, que se situa entre ao que refere como normas-princípios e normas "particularizantes" 26 .

Segundo o doutrinador, como os princípios, as normas gerais estabeleceriam diretrizes e orientações e, ao tratar das questões fundamentais, não admitiriam particularizações. A distinção se dá quando, enquanto os princípios vedam ao legislador e aplicador agir contra o valor tutelado, as normas gerais, além de conter aquela carga negativa, aplicam-se concretamente às relações e situações específicas, seja na competência administrativa federal ou, quando o Estado ou Município não tenha exercitado sua competência concorrente ou a exercida em contrariedade com o valor nelas declarado, também na competência executiva estadual ou municipal.

De outro lado, conforme o jurista, as normas gerais não se aproximam das normas particularizantes em razão do valor jurídico, que naquelas seria apenas abstrata e diretamente referido, enquanto nestas estaria intrinsecamente ligado à relação ou situação jurídica concretamente tutelada pela norma e nela definida. Ademais, enquanto as normas gerais teriam como destinatários o legislador estadual ou municipal, a norma particularizante é produzida ao agente que irá praticar o ato.

Porém, como bem demonstra Ricardo Marcondes Martins ${ }^{27}$, a distinção há muito proposta por Diogo de Figueiredo Moreira Neto entre normas gerais e princípios "ao menos nos dias de hoje, mostra-se insustentável":

Vigora, na Teoria Geral do Direito, a terceira fase do conceito de princípios jurídicos: estes têm a estrutura qualitativa de normas jurídicas e podem, independente da edição de uma regra jurídica, regular as relações intersubjetivas. Tanto as regras quanto os princípios são normas jurídicas e, nesse sentido, passíveis de aplicação direta no mundo fenomênico. consistindo ambos em manifestações irredutíveis do deôntico. Sem embargo, possuem diferença estrutural: princípios são normas que ordenam que se realize algo na maior medida possível, são, nesse sentido, mandados de optimização realizáveis de acordo com as circunstâncias fáticas e jurídicas; regras são normas que exigem um cumprimento pleno, sendo somente cumpridas ou descumpridas, são, nesse sentido, determinações no campo das possibilidades fáticas e jurídicas. Fica afastada, com os avanços da Teoria Geral do Direito, a concepção de que as normas gerais são um terceiro gênero normativo na medida em que

\footnotetext{
${ }^{26}$ Acerca da categoria "normas particularizantes", Diogo de Figueiredo Moreira Neto a propõe na busca de um conceito para normas gerais: "Ao distinguirmos, ainda, a categoria das normas, as normas gerais, cumpre-nos diferenciá-la das demais normas que antes formavam a integridade dessa categoria dessarte tripartida. Seriam normas gerais as que, numa primeira abordagem, avizinham-se das normas-princípios, gozassem de maior abstração e menor pormenorização, ao passo que remanesceriam como normas, tout court, normas específicas, particularizantes ou de aplicação, as que, devendo reger próxima e diretamente os atos jurídicos, seriam menos abstratas e mais pormenorizantes". (MOREIRA NETO, Diogo de Figueiredo. Competência concorrente limitada. Revista de informação legislativa, a. 25, n. 100, out./dez. 1988, p. 153).

${ }^{27}$ MARTINS, Ricardo Marcondes. As normas gerais de direito urbanístico. Revista de Direito Administrativo, n. 239, jan./mar. 2005, Rio de Janeiro. p. 72.
} 
cai por terra a afirmação de que as normas gerais diferenciar-se-iam dos princípios pelo fato de caracterizarem imediatamente as relações da vida real. Necessária, assim, uma conceituação de normas gerais que atenda as concepções hoje vigorantes.

Ricardo Marcondes Martins ${ }^{28}$ defende que as normas gerais possuem um elemento formal, conforme a classificação de Norberto Bobbio, sendo "necessária e imperativamente, normas com destinatário universal e ação universal”29, bem como um conteúdo material, ainda que não preciso ou previamente fixado pelo texto constitucional:

Cada matéria suscitada deve ser examinada pelo legislador federal e submetida à ponderação que leve em conta todas as circunstâncias fáticas e jurídicas, devendo considerar, por exemplo, o momento histórico, as aspirações sociais, a incidência do princípio da igualdade. Dessa ponderação o legislador concluirá qual princípio constitucional apresenta maior peso e qual é afastado e em que medida é afastado. O resultado da ponderação dá com precisão os limites materiais do poder legiferante federal para editar normas gerais. Estas poderão ou não ser editadas, poderão ser mais ou menos minuciosas, tudo dependerá da dimensão do princípio da segurança jurídica diante das circunstâncias fáticas e jurídicas envolvidas.

A propósito, José Afonso da Silva ${ }^{30}$ pondera que o Estatuto da Cidade assume "as características de uma lei geral de direito urbanístico, talvez com um certo casuísmo exagerado".

Surge então primeiro e inevitável questionamento: o tratamento legislativo até o momento reservado à concessão de uso especial para fins de moradia está adequado aos termos propostos no $\S 1$ ㅇ do art. 24 da Constituição Federal?

É preciso lembrar inicialmente que a concessão especial de uso para fins de moradia do imóvel público, à exemplo da usucapião especial urbana, tem requisitos delineados no texto constitucional (§1으 c/c caput do art. 183).

Da Constituição Federal, de fato, já é possível extrair que ultimada a ocupação ininterrupta para fins de moradia pelo decurso do prazo de cinco anos, sem oposição, da área urbana de até duzentos e cinquenta metros quadrados, deve o Poder Público regularizar a situação. Surge aí o direito de o ocupante reclamar, judicial ou administrativamente, a concessão de uso especial para fins de moradia.

De outro lado, a previsão da concessão de uso especial para fins de moradia na alínea " $\mathrm{h}$ " do inciso $V$ do art. 4ㅇ do Estatuto da Cidade, como instrumento para execução da política urbana

\footnotetext{
${ }^{28}$ MARTINS, Ricardo Marcondes. As normas gerais de direito urbanístico. Revista de Direito Administrativo, n. 239, jan./mar. 2005, Rio de Janeiro. p. 77.

${ }^{29}$ MARTINS, Ricardo Marcondes. As normas gerais de direito urbanístico. Revista de Direito Administrativo, n. 239, jan./mar. 2005, Rio de Janeiro. p. 73.

${ }^{30}$ SILVA. José Afonso. Direito Urbanístico Brasileiro. São Paulo: Malheiros. 2008, p. 69.
} 
(tal como a usucapião especial urbana), ressalta a relevância do instituto jurídico, mesmo diante do veto dos artigos 15, 16, 17, 18, 19 e 20 do mesmo diploma legal.

Entrementes, é na Medida Provisória n. 2.220, de 04 de setembro de 2001, editada em razão daquele veto, que se encontra a regulamentação da concessão de uso especial para fins de moradia.

Como já dito, a medida provisória referida permanece em vigor em razão do disposto no art. 20 da Emenda Constitucional n. 32, de 11 de setembro de 2001, ou seja, com força de lei que Ihe é atribuída enquanto não revogada expressamente por outra medida provisória ou deliberação definitiva do Congresso Nacional. Tal peculiaridade, de certa forma, ofusca a natureza jurídica efêmera daquela norma, tornando-a compatível, como se estima, com as leis ${ }^{31}$.

Adite-se inexistir qualquer óbice constitucional (exceto as vedações materiais insertas nos $\S \S 10$ e 2 o do art. 62 , no $\S 20$ do art. 25), no âmbito da competência legislativa concorrente, à edição de normas gerais, pela União, por meio de medidas provisórias. Basta referir a conhecido julgamento do Supremo Tribunal de Federal em matéria ambiental (ADIn 3.035-3/PR, Rel. Min. Gilmar Mendes. j. 06/04/2005), que tratou da inconstitucionalidade de norma estadual que vedava a comercialização de organismos geneticamente modificados, onde se assentou a impossibilidade da lei estadual afastar a aplicação de normas nacionais, entre as quais, à época, a Medida Provisória n. 131/2003.

Ressalta-se, por fim, que a Medida Provisória n. 2.220, de 04 de setembro de 2001, foi lançada antes das alterações promovidas pela Emenda Constitucional n. 32, que restringiu, sobremaneira, o alcance e a efetividade desta sui generis espécie normativa. Logo, ao tempo em que editada a Medida Provisória n. 2.220 não existiam as vedações sobre a matéria hoje ventiladas no $\S 10$ do art. 62 da Constituição Federal que, aliás, não inibiriam a regulamentação do $\S 1$ 음o art. 183.

Formalmente, por isso, estima-se que a Medida Provisória 2.220/01 (com as alterações da Medida Provisória n. 759/16), editada em razão do veto aos artigos 15, 16, 17, 18, 19 e 20 do Estatuto da Cidade, possa ser admitida como norma geral da União no âmbito da competência legislativa concorrente.

\footnotetext{
${ }^{31}$ Sem embargo da dissensão doutrinária quanto a "natureza jurídica" das medidas provisórias, trata-se de ato normativo que, embora não envolva em si um processo legislativo, tem a vocação de deflagrar um (art. 59, inc. V da Constituição Federal), e que desde quando editada passa a ser considerada com status de lei.
} 
Ainda assim, o conteúdo de alguns dispositivos da Medida Provisória 2.220/01 aparenta invadir a esfera privativa e específica das leis estaduais e municipais, mesmo diante da competência legislativa concorrente já afirmada.

\section{A MEDIDA PROVISÓRIA 2.220/01 E OS BENS IMÓVEIS DOS ESTADOS E DOS MUNICÍPIOS}

Em que pese a dificuldade em se identificar as normas gerais de que trata o § 1 o do art. 24 da Constituição Federal no Estatuto da Cidade (tanto mais pelo regramento detalhado de alguns institutos jurídicos), é necessário, no enquadramento daquelas normas, analisar a adequação com a Constituição Federal, no caso, sua inter-relação com as normas da política urbana e com as competências constitucionais atribuídas aos entes federativos.

Por isso, adverte José Afonso da Silva, ao tratar da competência constitucional para estabelecer normas gerais de direito urbanístico, que essas "se revelam como mecanismos limitadores da autonomia dos Estados e Municípios - razão por que hão de ser compreendidas em sentido estrito" ${ }^{32}$.

A competência legislativa concorrente, no âmbito do direito urbanístico, está assim definida no texto constitucional:

Art. 24. Compete à União, aos Estados e ao Distrito Federal legislar concorrentemente sobre:

I - direito tributário, financeiro, penitenciário, econômico e urbanístico;

$\S 1$ 을 No âmbito da legislação concorrente, a competência da União limitar-se-á a estabelecer normas gerais.

§ 2으 A competência da União para legislar sobre normas gerais não exclui a competência suplementar dos Estados.

§ 3으 Inexistindo lei federal sobre normas gerais, os Estados exercerão a competência legislativa plena, para atender a suas peculiaridades.

§ 4으 A superveniência de lei federal sobre normas gerais suspende a eficácia da lei estadual, no que lhe for contrário (g.n.) ${ }^{33}$

À União compete editar normas gerais - cuja aproximação de um conceito já foi tratado no afã de assegurar o desenvolvimento harmônio e coerente. E os limites dessa competência são os interesses regionais e locais, diante da necessidade do respeito às peculiaridades dos espaços (e

\footnotetext{
32 SILVA. José Afonso. Direito Urbanístico Brasileiro. São Paulo: Malheiros. 2008, p. 65.

${ }^{33}$ BRASIL. Constituição Federal. Presidência da República: Casa Civil - Subchefia para Assuntos Jurídicos. Brasília, DF. Disponível em: <http://www.planalto.gov.br>. Acesso em: 20 janeiro de 2017.
} 
bens!) administrados pelos Estados e pelos Municípios.

Aos Estados, no âmbito da competência legislativa concorrente com a União, cabe a elaboração de normas urbanísticas suplementares para atender suas regiões. Na ausência de lei nacional sobre o assunto, assumem a competência plena até a superveniência de norma da União, que suspende a eficácia da norma estadual no que for contrária à lei nacional. Devem observar, porém, as limitações impostas tantos pelas normas gerais estabelecidas pela União, como pela competência dos Municípios na ordenação do solo urbano.

Já os Municípios, de fato, não foram referidos no artigo 24 da Constituição Federal. Isso, porém, não Ihes deslegitima a, tal como os Estados, ingressar no exercício da competência concorrente para suplementar legislação federal e/ou estadual em assunto de interesse local, nos termos do art. 30, incisos I e II da Constituição Federal:

\section{Art. 30. Compete aos Municípios: \\ I - legislar sobre assuntos de interesse local; \\ II - suplementar a legislação federal e estadual no que couber; (g.n.) $)^{34}$}

Destacados os aspectos da competência legislativa concorrente, é necessário ressaltar que não importa indevida interferência, por si só, a possibilidade conferida pela norma geral editada pela União para concessão de uso especial para fins de moradia de bens em imóveis de outros entes federativos.

Como visto, trata-se de norma nacional que regulamenta e dá efetividade à dispositivo constitucional de reconhecido apelo social, sendo que "é função das normas gerais servir como instrumento de uniformização, para a realização de valores e objetivos fundamentais, como a segurança jurídica e a própria preservação da estrutura do Estado Federal" ${ }^{35}$.

A relevância do instituto da concessão especial para fins de moradia, conforme Maria Sylvia Zanella Di Pietro ${ }^{36}$, se revela quando "atende ao evidente interesse social, na medida em que se insere como instrumento de regularização da posse de milhares de pessoas das classes mais pobres, em regra faveladas, contribuindo para ampliar a função social inerente à propriedade

\footnotetext{
${ }^{34}$ BRASIL. Constituição Federal. Presidência da República: Casa Civil - Subchefia para Assuntos Jurídicos. Brasília, DF. Disponível em: $<$ http://www.planalto.gov.br>. Acesso em: 20 janeiro de 2017.

${ }^{35}$ REZENDE. Renato Monteiro de. Normas gerais revisitadas: A competência legislativa em matéria ambiental. Textos para Discussão 121. fev. 2013. p. 29. Disponível em <https://www12.senado.leg.br/publicacoes/estudos-legislativos/tipos-deestudos/textos-para-discussao/td-121-normas-gerais-revisitadas-a-competencia-legislativa-em-materia-ambiental>. Acesso em: 20 janeiro de 2017.

${ }^{36}$ DI PIETRO, Maria Sylvia Zanella. Concessão de uso especial para fins de moradia: MP 2.220, de 4/9/2001. In: DALLARI, Adilson Abreu; FERRAZ, Sérgio (Coord.). Estatuto da cidade: comentários à Lei Federal 10.257/2001. São Paulo: Malheiros, 2002. p. 160.
} 
pública".

Assim, a ausência da regulamentação da concessão de uso especial para fins de moradia por norma geral transformaria o instituto jurídico em verdadeira quimera.

Pondere-se, contudo, que se é viável que lei nacional inclua os bens imóveis dos Estados e dos Municípios, não existe permissivo para que a norma geral inviabilize a própria aplicabilidade permanente de instrumento para execução da política urbana, invadindo assim a competência dos entes federados a ela vinculados para regularizar a ocupação.

Nesse sentido, ao impor no caput dos artigos 10 e 2은 uma limitação temporal para o exercício do direito à concessão especial para fins de moradia não contemplada no texto constitucional, a Medida Provisória Medida Provisória 2.220/01 negou a projeção para o futuro da norma.

Art. 1ㅇ Aquele que, até 22 de dezembro de 2016, possuiu como seu, por cinco anos, ininterruptamente e sem oposição, até duzentos e cinquenta metros quadrados de imóvel público situado em área com características e finalidade urbana, e que o utilize para sua moradia ou de sua família, tem o direito à concessão de uso especial para fins de moradia em relação ao bem objeto da posse, desde que não seja proprietário ou concessionário, a qualquer título, de outro imóvel urbano ou rural.

Art. 2ㅇ Nos imóveis de que trata o art. 1으, com mais de duzentos e cinquenta metros quadrados, ocupados até 22 de dezembro de 2016, por população de baixa renda para sua moradia, por cinco anos, ininterruptamente e sem oposição, onde não for possível identificar os terrenos ocupados por possuidor, a concessão de uso especial para fins de moradia será conferida de forma coletiva, desde que os possuidores não sejam proprietários ou concessionários, a qualquer título, de outro imóvel urbano ou rural ${ }^{37}$ (g.n.).

Estima-se que a previsão infraconstitucional de uma data limite para a contagem retroativa do prazo dos cinco anos (até 22 de dezembro de 2016), além de esvaziar o conteúdo da garantia constitucional daquele instrumento jurídico, interfere na autonomia dos Estados e os Municípios para promover a regularização fundiária das invasões em seus próprios bens.

Ora, como poderiam os Estados e os Municípios, ainda que sobre os próprios imóveis, contrariar a limitação temporal prevista na normal geral editada pela União no âmbito da competência concorrente? Como poderiam conceder o uso especial para fins de moradia àqueles

\footnotetext{
${ }^{37}$ BRASIL. Medida Provisória n. 759, de 22 de dezembro de 2016. Dispõe sobre a regularização fundiária rural e urbana, sobre a liquidação de créditos concedidos aos assentados da reforma agrária e sobre a regularização fundiária no âmbito da Amazônia Legal, institui mecanismos para aprimorar a eficiência dos procedimentos de alienação de imóveis da União, e dá outras providências. Presidência da República: Casa Civil - Subchefia para Assuntos Jurídicos. Brasília, DF. Disponível em: <http://www.planalto.gov.br>. Acesso em: 20 janeiro de 2017.
} 
que completaram o prazo de cinco anos de ocupação após 22 de dezembro de 2011?

Orlando Gomes ${ }^{38}$ pondera que:

[...] a concessão de uso especial para fins de moradia é um instrumento importante para as ações governamentais no campo da regularização fundiária e para a garantia do direito social previsto pelo art. 6o da Constituição Federal. As normas urbanísticas e o Plano Diretor devem ter instrumentos capazes de auxiliar nessa missão, que é assegurar o direito à moradia e, consequentemente, a dignidade da pessoa humana.

Regis Fernandes de Oliveira, ao comentar a limitação temporal da Medida Provisória 2.220/01 que regulamentou a concessão de uso especial para fins de moradia, afirma que "as leis devem ter caráter geral, abstrato e impessoal, projetando-se para o futuro e inovando no ordenamento jurídico, o que não é possível com a MP que trata deste instituto." ${ }^{39}$

Por seu turno, Luiz Carlos Alvarenga ${ }^{40}$ destaca que:

[...] a eficácia social da concessão de uso especial para fins de moradia seria maior não fosse o limite temporal de cinco anos estabelecido no art. 1 o da MedProv 2.220/2001, limite este que expira em '30.06.2001'[...]. A Constituição trouxe em seu bojo princípios que são instrumentos balizadores para interpretação e aplicação das relações jurídicas, devendo todos os institutos invariavelmente estar em consonância com eles [...]. Uma interpretação condizente com os princípios constitucionais é no sentido de exigir, a exemplo do que ocorre na usucapião especial urbana, apenas cinco anos de posse ininterrupta, sem a necessidade de completar esses cinco anos até '30.06.2001'. O limite temporal estabelecido pelo art. 1으 da MedProv 2.220/2001 é deveras desarrazoado e não encontra fundamento no ordenamento jurídico estabelecido pela Constituição Federal de 1988.

Nesse sentido, entende-se que a implícita vedação à concessão de uso especial para fins de moradia aos ocupantes que completaram o período cinco anos de posse ininterrupta e sem oposição após 22 de dezembro de 2011, em norma geral editada pela União, interfere diretamente na autonomia dos Estados e dos Municípios.

A imposição de um prazo prescricional para o reconhecimento do direito de ocupação previsto na norma geral tolhe dos Estados e dos Municípios a possibilidade de manejar importante instituto jurídico do direito urbanístico, concedendo aos ocupantes o uso especial para fins de moradia.

Por extensão, inviabiliza os Estados e os Municípios de solucionar as ocupações irregulares consolidadas em seus próprios imóveis, comprometendo a preservação ambiental, a proteção do

\footnotetext{
${ }^{38}$ GOMES, Orlando. Direitos Reais. 21 ed. rev. atual. por Luiz Edson Fachin. Rio de Janeiro: Forense, 2012.

${ }^{39}$ OLIVEIRA, Regis Fernandes de. Comentários ao Estatuto da Cidade. 2 ed. rev. atual. São Paulo: Revista dos Tribunais, 2005, p. 78.

${ }^{40}$ ALVARENGA, Luiz Carlos. A concessão de uso especial para fins de moradia como instrumento de regularização fundiária e acesso à moradia. Revista de Direito imobiliário, ano 31, №. 65, jul./dez., 2008, p. 65.
} 
espaço público, o planejamento territorial das áreas urbanas e, principalmente, nega a dignidade dos ocupantes através da efetivação do direito social de moradia.

\section{CONSIDERAÇÕES FINAIS}

O Poder Público deve solucionar as ocupações irregulares consolidadas em seus próprios imóveis, a fim de garantir a preservação ambiental, a proteção do espaço público e, principalmente, assegurar a dignidade dos ocupantes através da efetivação do direito social de moradia.

A Constituição Federal prevê a concessão de uso especial para fins de moradia em imóveis públicos, instituto jurídico do direito urbanístico, elencado no Estatuto da Cidade e regulamentado na Medida Provisória 2.220/01 como um dos instrumentos para execução da política urbana.

Como instituto do direito urbanístico, a previsão da concessão de uso especial para fins de moradia no Estatuto da Cidade e na Medida Provisória 2.220/01 decorre da regulamentação do art. 183 e seus parágrafos na forma do $\S 10$ do art. 24, ambos da Constituição Federal, ou seja, por normas gerais editadas pela União no âmbito da competência legislativa concorrente.

Porém, embora a Constituição Federal tenha disponibilizado relevante instituto jurídico, a Medida Provisória 2.220/2001 incluiu uma limitação temporal à concessão especial para fins de moradia que interfere na autonomia dos Estados e os Municípios para promover a regularização fundiária das invasões em seus próprios bens, na medida em que, extrapolando os limites do arts. $183, \S 1$ 으 e $24, \S 1$, ambos da Constituição Federal, veda concessão de uso aos ocupantes que completaram o período cinco anos de posse ininterrupta e sem oposição após 22 de dezembro de 2011.

\section{REFERÊNCIAS DAS FONTES CITADAS}

ALVARENGA, Luiz Carlos. A concessão de uso especial para fins de moradia como instrumento de regularização fundiária e acesso à moradia. Revista de Direito imobiliário, ano 31, no. 65, jul./dez., 2008.

ATALIBA, Geraldo. Regime constitucional e leis nacionais e federais. In CLEVE, Clémerson Merlin. BARROSO, Luis Roberto (org). Doutrinas Essenciais de Direito Constitucional. São Paulo: Saraiva, 
2011. v. IIII.

BRASIL. Constituição Federal. Presidência da República: Casa Civil - Subchefia para Assuntos Jurídicos. Brasília, DF. Disponível em: <http://www.planalto.gov.br>. Acesso em: 20 janeiro de 2017.

BRASIL. Lei Federal n. 11.481, de 31 de maio de 2007. Dá nova redação a dispositivos das Leis nos 9.636, de 15 de maio de 1998, 8.666, de 21 de junho de 1993, 11.124, de 16 de junho de 2005, 10.406, de 10 de janeiro de 2002 - Código Civil, 9.514, de 20 de novembro de 1997, e 6.015, de 31 de dezembro de 1973, e dos Decretos-Leis $\mathrm{n}^{\mathrm{os}} 9.760$, de 5 de setembro de 1946, 271, de 28 de fevereiro de 1967, 1.876, de 15 de julho de 1981, e 2.398, de 21 de dezembro de 1987; prevê medidas voltadas à regularização fundiária de interesse social em imóveis da União; e dá outras providências e dá outras providências. Presidência da República: Casa Civil - Subchefia para Assuntos Jurídicos. Brasília, DF. Disponível em: <http://www.planalto.gov.br>. Acesso em: 20 janeiro de 2017.

BRASIL. Medida Provisória n. 2.220, de 04 de setembro de 2001. Dispõe sobre a concessão de uso especial de que trata o $\S 1^{\circ}$ do art. 183 da Constituição, cria o Conselho Nacional de Desenvolvimento Urbano - CNDU e dá outras providências. Presidência da República: Casa Civil Subchefia para Assuntos Jurídicos. Brasília, DF. Disponível em: <http://www.planalto.gov.br>. Acesso em: 20 janeiro de 2017.

BRASIL. Medida Provisória n. 759, de 22 de dezembro de 2016. Dispõe sobre a regularização fundiária rural e urbana, sobre a liquidação de créditos concedidos aos assentados da reforma agrária e sobre a regularização fundiária no âmbito da Amazônia Legal, institui mecanismos para aprimorar a eficiência dos procedimentos de alienação de imóveis da União, e dá outras providências. Presidência da República: Casa Civil - Subchefia para Assuntos Jurídicos. Brasília, DF. Disponível em: <http://www.planalto.gov.br>. Acesso em: 20 janeiro de 2017.

BRASIL. Mensagem de veto n. 730, de 10 de julho de 2001. Presidência da República: Casa Civil Subchefia para Assuntos Jurídicos. Brasilia, DF. Disponível em < http://www.planalto.gov.br/ccivil_03/leis/Mensagem_Veto/2001/Mv730-01.htm. >. Acesso em: 20 janeiro de 2017.

DALLARI, Adilson Abreu; DI SARNO, Daniela Campos Libório. Direito Urbanístico e Ambiental. Belo Horizonte: Fórum, 2011. 
DIAS, Mauricio Leal; RIBEIRO, Taíse Spotto Lima. O Estatuto da Cidade (Lei no 10.257/01) é norma geral de Direito Urbanístico ou diretriz geral da política urbana?. Revista Jus Navigandi, Teresina, ano 9, n. 312, 15 de maio de 2004. Disponível em: <https://jus.com.br/artigos/5193>. Acesso em: 20 janeiro de 2017

DI PIETRO, Maria Sylvia Zanella. Concessão de uso especial para fins de moradia: MP 2.220, de 4/9/2001. In: DALLARI, Adilson Abreu; FERRAZ, Sérgio (Coord.). Estatuto da cidade: comentários à Lei Federal 10.257/2001. São Paulo: Malheiros, 2002.

GOMES, Orlando. Direitos Reais. 21. ed. rev. atual. por Luiz Edson Fachin. Rio de Janeiro: Forense, 2012.

MOREIRA NETO, Diogo de Figueiredo. Competência concorrente limitada. Revista de informação legislativa, a. 25, n. 100, out./dez. 1988.

OLIVEIRA, Regis Fernandes de. Comentários ao Estatuto da Cidade. 2 ed. rev. atual. São Paulo: Revista dos Tribunais, 2005.

PASSOLD, Cesar Luiz. Metodologia da Pesquisa Jurídica: Teoria e Prática. 12 ed. rev. São Paulo: Conceito Editorial, 2011.

PEREIRA, Hélio do Valle. Manual da Fazenda Pública em juízo. 2 ed. Rio de Janeiro: Renovar, 2006.

RABELLO. Sonia. Direito Urbanístico e Direito Administrativo: imbricações e inter-relações.

Revista de Direito da Cidade. Revista Jus Navigandi, vol. 01. n. 01, ISSN 2317-7721. Disponível em <http://www.e-publicacoes.uerj.br/index.php/rdc/article/viewFile/10492/8264>. Acesso em: 20 janeiro de 2017.

SILVA. José Afonso. Direito Urbanístico Brasileiro. São Paulo: Malheiros. 2008.

SOUZA, Sergio Iglesias Nunes de. Direito à moradia e de habitação: Análise comparativa e seu aspecto teórico e prático com os direitos da personalidade. 3 a ed. rev. atual. e amp. São Paulo: Editora Revista dos Tribunais, 2013.

SUNDFELD. Carlos Ari. O Estatuto da Cidade e suas diretrizes gerais. In, DALLARI, Adilson Abreu; FERRAZ, Sérgio (Coord.). Estatuto da Cidade: comentários à Lei Federal n. 10.257/2010. São Paulo: Malheiros. 2002.

THOMÉ, Leonardo. Habitação precária: mais de 50 mil pessoas vivem em 64 comunidades irregulares de Florianópolis. Jornal Hora de Santa Catarina. Florianópolis, 20 janeiro de 2017. 
Disponível em http://horadesantacatarina.clicrbs.com.br/sc/geral/noticia/2016/08/mais-de-50mil-pessoas-vivem-em-64-comunidades-irregulares-de-florianopolis-7300817.html. Acesso em: 20 de janeiro de 2017. 


\title{
LA PARTICIPACIÓN CIUDADANA COMO ELEMENTO NECESARIO PARA UNA GESTIÓN SOSTENIBLE DEL RECURSO HÍDRICO. ACERCAMIENTO A LAS LEGISLACIONES BRASILEÑA Y COLOMBIANA
}

\author{
Nathalia Alzate Mora ${ }^{1}$
}

\section{INTRODUCCIÓN}

El agua es un elemento indispensable para la existencia en la tierra por ser necesaria para satisfacer las necesidades básicas de cualquier ser humano como saciar la sed, alimentarse, asearse y mantener su entorno en buenas condiciones. Además, para las niñas y los niños contar con agua potable en sus hogares marca la diferencia en su desarrollo personal y social, en sus niveles de nutrición y en la posibilidad de asistir a la escuela. En consecuencia, el estudio sobre la forma en que se gestiona el recurso hídrico resulta clave para asegurar un uso sostenible del mismo.

En este orden de ideas, el objeto de este trabajo es identificar los espacios de participación ciudadana en los procesos de gestión del agua en las legislaciones de Brasil y Colombia; con el objetivo de analizar cuál es la composición de dichos espacios, y si responden a los estándares internacionales sobre la materia.

El problema central de esta investigación está enfocado a sentar las bases para establecer si los mecanismos de participación ciudadana para la gestión del agua existentes en las dos legislaciones analizadas, son suficientes frente a las demandas actuales de inclusión en la toma de decisiones medioambientales. Este tema encuentra justificación en la crisis mundial actual que estamos viviendo en torno a la distribución del agua, pues a pesar de los avances que se han dado en los últimos años sobre acceso a este recurso, que se corresponden con las metas propuestas en los Objetivos de Desarrollo del Milenio (odm), todavía 748 millones de personas no disfrutan de una buena fuente de agua potable y 2.500 millones no gozan de buenas instalaciones de

\footnotetext{
${ }^{1}$ Abogada de la Universidad del Rosario de Colombia, Magister en Derechos Humanos y Democratización del derecho de la Universidad Externado de Colombia, y Magister en Derecho Ambiental y de la Sostenibilidad de la Universidad de Alicante España. Actualmente trabaja en la Corte Constitucional de Colombia. nathalia.alzate@gmail.com
} 
saneamiento $^{2}$. Además, el agua es un instrumento indispensable para el desarrollo de múltiples actividades que generan beneficios para toda la población de un país, siendo pues uno de los motores y obstáculos -en los casos de escasez o inequidad en la prestación- del desarrollo para la mayoría de ellos. Frente a este panorama, garantizar una sostenibilidad económica, ambiental y social en el manejo del agua solo es posible si se tienen en cuenta los intereses de todos los ciudadanos en especial de aquellos menos favorecidos, para lo cual es necesario que existan garantías de participación en los procesos correspondientes.

Así pues, a continuación se presentan (i) algunos antecedentes internacionales sobre el principio de participación en la toma de decisiones que afectan al ambiente, y su relación con la sostenibilidad; (ii) consideraciones sobre la participación ciudadana en la gestión del recurso hídrico, haciendo énfasis en los ordenamientos jurídicos de Colombia y Brasil para, finalmente; (iii) concluir las observaciones encontradas.

En cuanto a la metodología, se utilizó la lógica inductiva mediante la búsqueda y análisis de bibliografía sobre el tema.

\section{LOS PRINCIPIOS DE PARTICIPACIÓN CIUDADANA Y DE SOSTENIBILIDAD EN EL ÁMBITO INTERNACIONAL}

La sostenibilidad ha sido una preocupación constante en la mayoría de tratados y declaraciones internacionales sobre el medio ambiente. Desde el Informe Brundtland ${ }^{3}$ de 1987 y la toma de conciencia sobre los efectos que tienen nuestras actividades en el planeta que éste provocó, se viene hablando también de la necesidad de incluir a la ciudadanía en la toma de decisiones ambientales para poder garantizar un entorno sostenible. Así, las notas introductorias del Informe resaltan la importancia de la participación de todos los actores, esto es individuos, colectivos de personas, instituciones, comunidad científica, entre otros, en todos los niveles para una salvaguarda efectiva del ambiente; y concluye pidiendo un esfuerzo común y nuevas pautas de comportamiento tanto para la administración como por parte de los administrados, pues los

\footnotetext{
${ }^{2}$ ORGANIZACIÓN DE LAS NACIONAES UNIDAS, World Water Assesment Program. Informe de las Naciones Unidas sobre los recursos hídricos en el mundo 2015. Agua para un mundo sostenible. Datos y Cifras. UNESCO. WWAP. UN WATER. [en línea]. Disponible en: http://www.unesco.org/new/fileadmin/MULTIMEDIA/HO/SC/images/WWDR2015Facts_Figures_SPA_web.pdf>. Consulta: 30/07/2016.

${ }^{3}$ En este apartado no pretendo ser exhaustiva con la presentación de los antecedentes a nivel internacional. Por ejemplo, antes del Informe Brundtland, le Declaración de Estocolmo sobre el Medio Humano de 1972 ya había hablado sobre educación en materia ambiental, que es sin duda un elemento necesario para la participación ciudadana. También es posible encontrar referencias sobre el tema en la Carta Mundial de la Naturaleza de Nairobi de 1982, entre otros.
} 
cambios en la forma de entender la protección del ambiente, los valores sociales y los propósitos que se plantea el informe dependen en gran medida de la realización de amplias campañas de educación, debates y participación ciudadana. Se trata entonces de Sostenibilidad como un concepto amplio que contiene distintas dimensiones y que, por ende, va más allá de la simple concepción económica del "desarrollo sostenible"; en efecto, al incluir el tema de la participación ciudadana como un presupuesto necesario y transversal para el avance en la protección del ambiente se está haciendo alusión a una dimensión social de la Sostenibilidad.

En este mismo sentido, la Declaración de Río sobre Medio Ambiente y Desarrollo de 1992 sentó las bases de los derechos al acceso a la información en materia ambiental; a la participación y a la justicia ambiental elementos que, desde entonces son reconocidos como los tres pilares básicos para lograr un desarrollo sostenible. Igualmente, su agenda 21 reconoce la necesidad de contar con mecanismos para la participación adecuada de personas y grupos en la formulación y aplicación de leyes y reglamentos sobre el medio ambiente y el desarrollo, con el fin de poder adoptar marcos jurídicos eficaces. Asimismo, la Declaración de Johannesburgo de 2001, que fue producto de la Cumbre Mundial del Desarrollo Sostenible llevada a cabo ese mismo año, reconoció en el punto 23 que para lograr un desarrollo sostenible es indispensable contar con una amplia participación social en la formulación de políticas, la adopción de decisiones y la aplicación a todos los niveles; y en el punto 27 estableció el compromiso de fortalecer y mejorar la gobernanza en todos los planos para poder cumplir con la Agenda 21, así como con los objetivos establecidos en la Declaración del Milenio y el Plan de Acción de Johannesburgo.

Recientemente, en la Cumbre del Milenio celebrada en Nueva York en 2015 se adoptó la Agenda 2030 para el Desarrollo Sostenible que es la continuación de un plan de acción trazado por la comunidad internacional desde el año 2000 para alcanzar ciertas metas propuestas sobre este tema. La agenda del 2000, también conocida como Objetivos de Desarrollo del Milenio (ODM), es un hito a nivel internacional en cuanto a compromisos conjuntos para mejorar la calidad de vida de todas las personas, el cuidado del medio ambiente, y avanzar en la igualdad de género, entre otros $^{4}$. El plazo para su cumplimiento venció a finales del 2015, y aunque no se lograron alcanzar todas las metas propuestas, en muchos ámbitos se logró un importante avance. Sin embargo, no nos detendremos aquí en sus resultados.

\footnotetext{
${ }^{4}$ En concreto, los ODM eran ocho: (i) erradicar la pobreza extrema y el hambre, (ii) lograr la enseñanza primaria universal, (iii) promover la igualdad entre los sexos y el empoderamiento de la mujer, (iv) reducir la mortalidad de los niños menores de 5 años, (v) mejorar la salud materna, (vi) combatir el VIH/SIDA, la malaria y otras enfermedades, (vii) garantizar la sostenibilidad del medio ambiente, y (viii) fomentar una alianza mundial para el desarrollo.
} 
Pues bien, este tipo de agendas son una apuesta la acción global y conjunta para la construcción de un mundo más igualitario a futuro, así como un instrumento de corrección de algunos temas que son claves para la sostenibilidad. La agenda 2030 y sus Objetivos de Desarrollo Sostenible (ODS) constituyen un plan mucho más amplio y específico que el que le presidió, pues de 8 metas principales, pasaron a proponerse 17, dentro de las que encontramos algunos puntos importantes en cuanto a la participación de la sociedad civil, tema que sólo se tuvo en cuenta en los ODM en lo que tiene que ver con la igualdad de género. Además, el objetivo número 6 está dedicado a trazar propuestas sobre la forma de garantizar la disponibilidad de agua, su gestión sostenible y el saneamiento para todos, hecho que da cuenta de la importancia que ha ido ganando en los últimos años la preocupación por el agua a nivel internacional. Específicamente, la meta 6.b señala que se debe apoyar y fortalecer la participación de las comunidades locales en la gestión del agua y el saneamiento.

De otra parte, en ámbito Interamericano la participación como base de la sostenibilidad ha sido igualmente desarrollada. El documento fundacional de la Organización de los Estados Americanos -OEA- como organismo regional de la ONU fue suscrito en la ciudad de Bogotá en 1948 y actualmente cuenta con varios protocolos adicionales ${ }^{5}$. Consciente de la importancia de la vinculación de la ciudadanía en el objetivo de alcanzar un desarrollo integral, la Carta señala en su artículo 34 que uno de los objetivos básicos de los Estados miembros es garantizar la plena participación de sus pueblos en las decisiones relativas a su propio desarrollo. Asimismo, la Unidad de Desarrollo Sostenible y Medio Ambiente de la OEA presentó en Washington en el año 2001 la Estrategia Interamericana para la Promoción de la Participación Pública en la Toma de Decisiones sobre Desarrollo Sostenible (ISP), cuya elaboración le había sido encomendada en la Conferencia Cumbre sobre Desarrollo Sostenible de Santa Cruz de la Sierra, Bolivia, en 1996. El documento final fue producto de cerca de tres años de trabajo en un proceso abierto y participativo, en el que organizaciones de la sociedad civil y el sector púbico de los 34 Estados miembro realizaron estudios técnicos, encuentros y consultas, generando un flujo de ideas y opiniones en torno a los aspectos que deben observarse en el diseño, ejecución y evaluación de proyectos y políticas sobre el desarrollo sostenible y el medio ambiente.

\footnotetext{
${ }^{5}$ En efecto, la Carta ha sido reformada en varias ocasiones: Protocolo de Buenos Aires (27 de febrero de 1967), Protocolo de Cartagena de Indias (5 de diciembre de 1985), Protocolo de Washington (14 de diciembre de 1992), y Protocolo de Managua (10 de junio de 1993).
} 
La ISP incluye siete principios básicos sobre participación pública, a saber: (i) proactividad ${ }^{6}$; (ii) inclusión ${ }^{7}$; (iii) responsabilidad compartida ${ }^{8}$; (iv) apertura a través de todo el proceso ${ }^{9}$; (v) acceso $^{10}$; (vi) transparencia ${ }^{11} \mathrm{y}$, (vii) respeto por los aportes del público ${ }^{12}$. Al mismo tiempo, incluye varias recomendaciones de política para su implementación, dentro de las cuales se destacan la de crear y fortalecer mecanismos formales e informales de intercambio y acceso a la información para la sociedad civil en los diferentes grupos que ésta abarca y en todos los niveles del gobierno. También señala la importancia de crear, expandir y poner en práctica marcos legales y regulatorios adecuados que aseguren la participación de la sociedad civil en las decisiones sobre el desarrollo sostenible.

Por último, cabe mencionar el Proyecto de ciudadanía ambiental global (GEC) que se basa en las Declaraciones de Río y de Johannesburgo, previamente reseñadas; en la Iniciativa Latinoamericana y Caribeña para el Desarrollo Sustentable (ILAC) que tiene entre sus principales objetivos estimular la participación activa del sector privado y de las entidades de la sociedad civil para promover acciones que conduzcan a actividades productivas sostenibles y a la conservación y el uso sostenible de los bienes comunes. En la Estrategia del Programa de las Naciones Unidas para el Medio Ambiente -PNUMA- para América Latina y el Caribe 2003-2005, que contiene un área de acción específicamente dedicada a la promoción de la integración de los grupos mayores de la sociedad civil en la acción ambiental, y apoyar la educación, así como el fomento del interés por el ambiente. En el proyecto participaron Argentina, Chile, Costa Rica, Cuba, Ecuador, México y Perú.

Dentro de sus principales objetivos se encontraba la formación en Latinoamérica de una ciudadanía consciente de sus derechos y responsabilidades ambientales, así como la promoción de la participación social organizada mediante la educación para la comprensión de las

\footnotetext{
${ }^{6}$ En tanto es necesario que la ciudadanía y los gobiernos maximicen su compromiso mediante la implementación de iniciativas propias, ayudando así a enriquecer los procesos.

${ }^{7}$ Se refiere a la necesidad de garantizar una participación plena de todas las personas en igualdad de oportunidades, especialmente de las mujeres, los jóvenes, la población indígena, las minorías étnicas, entre otros.

${ }^{8}$ Implica que tanto los gobiernos como la sociedad civil deberían compartir de forma equitativa los compromisos, costos y beneficios del desarrollo.

${ }^{9}$ Este principio apuesta por el dinamismo en todas las etapas previas a la adopción de proyectos, políticas o programas, en el sentido que, si la participación es extensa y continua, nuevas ideas y conocimientos se generarán al mismo tiempo que las decisiones se legitiman y se enriquecen los resultados.

${ }^{10}$ Poder acceder oportunamente a la información, al proceso político y al sistema judicial es un requisito indispensable para poder participar.

${ }^{11}$ Este principio busca generar relaciones productivas entre el gobierno y la sociedad civil, así como una participación significativa en la toma de decisiones, mediante la garantía de que ambas partes sean confiables y transparentes.

${ }^{12}$ Trata de asegurar que las contribuciones derivadas de los procesos participativos sean evaluadas y consideradas adecuada y oportunamente, pues de lo contrario éstos no serían efectivos ni eficientes.
} 
responsabilidades ciudadanas en torno al cuidado del medio ambiente; también planeaba generar interés por los temas medio ambientales y crear un cambio en la conducta individual y social respecto al mismo.

Este proyecto evidencia el reconocimiento a nivel latinoamericano de la necesidad de formar ciudadanos interesados por la participación en los procesos de toma de decisiones en materia medio ambiental, y de incentivar la búsqueda y el acceso de una información de calidad, que permita crear relaciones productivas y transparentes.

En suma, este breve repaso por algunos de los instrumentos internacionales y regionales que promueven el desarrollo sostenible dan cuenta de su innegable relación con el ejercicio de la participación ciudadana. Si bien la mayoría de documentos reseñados no tienen fuerza vinculante por tratarse de declaraciones o agendas de trabajo, lo cierto es que actualmente constituyen el marco de referencia básico para esta materia, y se ven reflejados en mayor o menor medida en las legislaciones nacionales.

\section{PARTICIPACIÓN CIUDADANA EN LA GESTIÓN DEL AGUA}

La gestión del recurso hídrico es un asunto trascendental para el desarrollo económico y social de cualquier país. Actualmente resulta innegable que el acceso al agua es un presupuesto necesario para la garantía de varios derechos humanos como la vida, la salud, la educación, y la seguridad alimentaria, así como para la prestación de servicios básicos como el saneamiento y el abastecimiento de agua potable domiciliaria. Por ello, la participación de la ciudadanía es clave para garantizar políticas justas y equitativas que atiendan a los principios de transparencia y no discriminación.

En este sentido, $<<$ [n]o cabe duda de que el derecho fundamental a un medio ambiente sano y equilibrado hace parte de la preservación de los recursos naturales, siendo esencial la conservación del agua. Muy fundamental para la sobrevivencia humana. Que, a través de un cambio de paradigma, a través de las dimensiones que orientan al fenómeno de la sostenibilidad hará un futuro amplio para el entorno natural $>>^{13}$. El agua como elemento del ambiente puede ser considerada entonces un derecho fundamental, pero es también un recurso natural escaso,

\footnotetext{
${ }^{13}$ SOUZA, Maria Cláudia da Silva Antunes de y PAVAN, Kamilla. Sustentabilidade, meio ambiente e água: uma questão de sobrevivencia. Traducción propia. XXV Encontro Nacional do Compedi - Brasília/DF. Direto e sustentabilidade II, 2016, p. 336. Disponible en: <http://www.conpedi.org.br/publicacoes/y0ii48h0/dzoq9f77/4aF1HOT08DIXm7Cl.pdf>Consulta: 12/01/2017.
} 
pues <<pese a que dos terceras partes de la superficie terrestre se encuentran cubiertas por agua, solo el $2,5 \%$ corresponde a agua dulce $>>^{14} \mathrm{Y}$ aunque esto puede sonar como una cifra muy pequeña, el agua que existe en la Tierra es suficiente para abastecer a la población mundial, por lo tanto, los problemas relacionados con el abastecimiento de agua no tratan sobre la disponibilidad, el reto está en la gobernanza del recurso, esto es, la manera en que se distribuye, se utiliza y se maneja ${ }^{15}$.

Antes bien, $<<$ el derecho de acceso al agua, no puede de manera alguna privilegiar a algún grupo o ser destinado exclusivamente a una institución, sea ella pública o privada, teniendo en cuenta que se trata de un derecho natural conferido a todos. Es un derecho que solamente puede ser concretado mediante la cooperación solidaria e intergeneracional entre los Estados y la sociedad, y que tiene, como beneficiarios, a las generaciones presentes y futuras ${ }^{16}>{ }^{17}$. En este contexto, el fortalecimiento de los espacios de participación ciudadana resulta fundamental para generar una buena distribución, uso y aprovechamiento del mismo.

\subsection{Breve aproximación a las legislaciones colombiana y brasileña}

Actualmente la mayoría de países han consagrado en sus constituciones el principio participativo. Por ejemplo, la Constitución Política de 1988 de Brasil señala en su artículo 1 que la República Federal del Brasil es un Estado Democrático de Derecho, afirmación de la que se desprenden consecuencias como el respeto por la dignidad humana, garantías de inclusión y pluralismo, así como de participación. Además, en su artículo 187 garantiza la posibilidad de los productores, trabajadores, así como sectores de comercialización, almacenamiento y transportes participen en la planificación de la política agrícola del país. También es importante mencionar el artículo 231 numeral 3 que le reconoce a los pueblos indígenas el derecho a ser oídos antes de

\footnotetext{
${ }^{14}$ SHIKLOMANOV, 1999. Citado por: ZAMUDIO RODRÍGUEZ, Carmen. Gobernabilidad sobre el recurso hidrico en Colombia: entre avances y retos. Revista Gestión y Ambiente, 15(3), 2012, p. $108 . \quad$ Disponible en: http://search.proquest.com/docview/1677587303 ?accountid=17192. Consulta: 06/06/2016.

${ }^{15}$ ORGANIZACIÓN DE LAS NACIONAES UNIDAS, World Water Assesment Program. Informe de las Naciones Unidas sobre los recursos hídricos en el mundo 2015. Agua para un mundo sostenible. Datos y Cifras. UNESCO. WWAP. UN WATER. Disponible en: http://www.unesco.org/new/fileadmin/MULTIMEDIA/HO/SC/images/WWDR2015Facts_Figures_SPA_web.pdf. Consulta: $30 / 07 / 2016$

${ }^{16}$ CANOTILHO, José Joaquim Gomes. LEITE, José Rubens Morato. Direito Constitucional Ambiental Brasileiro. São Paulo: Saraiva. 2007. p. 292.

${ }^{17}$ SOUZA, Maria Cláudia da Silva Antunes de; GHILARDI Hilariane Teixeira. La evaluación ambiental estratégica en la gestión de planificación de recursos hídricos: una necesidad para el equilibrio del medio ambiente. [Traducción propia. XXV Encontro Nacional do Compedi - Brasília/DF. Direto e sustentabilidade II Disponible en: http://www.conpedi.org.br/publicacoes/y0ii48h0/q923c0e2/3t761UPW49g20kUP.pdf p. 17. Consulta: 12/01/2017.
} 
que se tomen decisiones sobre el "aprovechamiento de los recursos hidráulicos, incluido el potencial energético, la búsqueda y extracción de las riquezas minerales" en sus territorios.

A su turno, la Constitución Política de Colombia de 1991 señala en su artículo 1 que Colombia es un Estado Social de Derecho, lo que significa que es un Estado democrático que reconoce derechos individuales y colectivos, y que promueve la inclusión y la participación de todas las personas en igualdad de condiciones. Asimismo, el artículo 2 señala que uno de los fines esenciales del Estado es facilitar la participación de todos en las decisiones que los afectan y en la vida económica, política, administrativa y cultural de la nación; respecto a la participación en las decisiones que pueden afectar al ambiente el artículo 79 señala que todas las personas tienen derecho a ello. Por último, destacar que más de 50 disposiciones constitucionales establecen bases, mecanismos, instancias, y canales de participación en las diferentes funciones del Estado.

Pues bien, dichos postulados constitucionales tienen efecto directo en la forma en que se desarrolla legalmente la planeación sobre el agua. Brasil cuenta con una Política Nacional de Recursos Hídricos (PNRH) que está consagrada en la ley 9.433 del 8 de enero de 1997. Esta norma "modernizó la gestión del agua haciendo uso de normas e instrumentos implementados en diversos países; le dio importancia a la participación de los usuarios y la sociedad civil en la gestión buscando legitimidad y adopción real de las políticas (Porto y Porto, 2008); y puso como prioridad considerar los usos múltiples del agua restándole importancia al sector energético en la gestión del agua (Borsoi y Torres, 2010)."18 En efecto, en su artículo 1ㅇ que contiene los fundamentos de la PNRH señala el numeral VI que la gestión de los recursos hídricos debe ser descentralizada y contar con la participación del Poder Público, los usuarios y las comunidades.

En concordancia con lo anterior, dicha legislación contempla como principal espacio de participación para los particulares los Comités de Cuenca Hidrográfica, que según el artículo 39 de la ley 9.433 de 1997, deben ser compuestos por representantes $<<$ - -de la Unión; II - de los Estados de Distrito Federal cuyos territorios se sitúen, total o parcialmente en sus respectivas áreas de actuación; III - de los Municipios situados, en todo o en parte, en su área de actuación; IV - de los usuarios de las aguas de su área de actuación y; $\mathrm{V}$ - de las entidades civiles de recursos hídricos

\footnotetext{
${ }^{18}$ ROJAS PADILLA, Johnny Harold; PÉREZ RINCÓN, Mario Alejandro; MALHEIROS, Tadeu Fabricío; MADERA PARRA, Carlos Arturo; PROTA, Mariza Guimaråles; y DOS SANTOS, Raquel. Análisis comparativo de modelos e instrumentos de gestión integrada del recurso hídrico en Suramérica: Ios casos de Brasil y Colombia. En: Ambi-Agua, Taubaté, v. 8, n. 1, 2013, p. 82. Disponible en: http://dx.doi.org/10.4136/ambi-agua.971. Consulta: 10/07/2016.
} 
con actuación comprobada en la cuenca $>>^{19}$. Dentro de sus competencias señaladas en el artículo $38^{20}$ de la misma ley se encuentran, entre otras, las de promover debates sobre las cuestiones relacionadas con los recursos hídricos y articular la actuación de las entidades intervinientes; arbitrar en primera instancia administrativa, los conflictos relacionados con los recursos hídricos; y aprobar el Plan de Recursos Hídricos de la Cuenca. Esta última es sin duda una de las más importantes, ya que la participación en los procesos de planeación es clave para poder tener incidencia sobre las decisiones que se adoptan, y por ende, en la forma que se gestiona el recurso.

Sobre estos Comités, la Agencia Nacional de Aguas de Brasil ${ }^{21}$, señala que:

[...] difieren de otras formas de participación previstas en las demás políticas públicas, pues tienen atribución legal para deliberar sobre la gestión del agua, función que comparten con el poder público. [...] Una de las atribuciones más relevantes de los comités es establecer un conjunto de mecanismos y de reglas, decididas colectivamente, de forma que los diferentes intereses sobre los usos del agua de la cuenca sean discutidos y negociados democráticamente en ámbito público, con transparencia en el proceso decisorio, buscando prevenir y dirimir conflictos.

Ahora bien, es clara la importancia de éste órgano y las funciones que desempeña, que dotan de una evidente legitimidad a las decisiones que adopte sobre el agua, sin embargo, en principio la ciudadanía de a pie no tiene cabida en el mismo, ya que según la consagración legal solo pueden hacer parte del mismo, usuarios de la cuenca y asociaciones civiles de recursos hídricos que actúen en la misma. Por el momento no es posible detenerse en la pertinencia de una legitimidad más amplia para pertenecer a este tipo de órganos, sin embargo, es un aspecto que debe tenerse en cuenta para el estudio de la eficacia de la participación ciudadana. Cabe mencionar también, que para que los Comités puedan funcionar, deben estar debidamente financiados por el Estado situación que puede generar una indebida dependencia de la voluntad

\footnotetext{
${ }^{19}$ BRASIL. Constituição (1988). Constituição da República Federativa do Brasil. Brasília, DF, Senado, 1998.

20 “Art. 38. Compete aos Comitês de Bacia Hidrográfica, no âmbito de sua área de atuação:

I - promover o debate das questões relacionadas a recursos hídricos e articular a atuação das entidades intervenientes; II - arbitrar, em primeira instância administrativa, os conflitos relacionados aos recursos hídricos; III - aprovar o Plano de Recursos Hídricos da bacia; IV - acompanhar a execução do Plano de Recursos Hídricos da bacia e sugerir as providências necessárias ao cumprimento de suas metas; V - propor ao Conselho Nacional e aos Conselhos Estaduais de Recursos Hídricos as acumulações, derivações, captações e lançamentos de pouca expressão, para efeito de isenção da obrigatoriedade de outorga de direitos de uso de recursos hídricos, de acordo com os domínios destes; VI - Estabelecer os mecanismos de cobrança pelo uso de recursos hídricos e sugerir os valores a serem cobrados;VII - (VETADO); VIII - (VETADO); IX - estabelecer critérios e promover o rateio de custo das obras de uso múltiplo, de interesse comum ou coletivo. (...)"

${ }^{21}$ BRASIL, Agência Nacional de Águas. O Comitê de Bacia Hidrográfica: o que é e o que faz? / Agência Nacional de Águas. -- Brasília: SAG, 2011. [en línea] < http://www.ana.gov.br/bibliotecavirtual/arquivos/20120809150432 Volume 1.pdf> [Consulta: 10/01/2017]. Traducción propia, el texto original es el siguiente: “(...)diferem de outras formas de participação previstas nas demais políticas públicas, pois têm como atribuição legal deliberar sobre a gestão da água fazendo isso de forma compar- tilhada com o poder público. (...)Uma das atribuições mais relevantes dos comi- tês é estabelecer um conjunto de mecanismos e de regras, decididas coletivamente, de forma que os diferentes interesses sobre os usos da água na bacia sejam discutidos e negociados democraticamente em ambiente público, com transparência no processo decisório, buscando prevenir e dirimir conflitos."
} 
política que éste tenga para activar estos espacios. Esto puede generar dificultades en la práctica que deriven en una simple consagración formal del espacio, que diste de ser eficaz en términos de verdadera participación ciudadana.

De esta forma, la legislación de Brasil ha articulado entonces espacios de participación en la toma de decisiones sobre el agua, que lleva ya algún tiempo funcionando y que dan cuenta de la necesidad de involucrar a la población civil en la toma de decisiones ambientales. Así, como consecuencia del tiempo transcurrido desde la implementación de la PNRH en 1997, la legislación brasileña cuenta con una estructura más sólida en comparación con la inmensa dispersión normativa colombiana, producto de la ausencia de una ley específica sobre aguas, sin perjuicio del proceso de transición hacia una gestión integrada del recurso hídrico -GIRH- que comenzó en los últimos años, a partir de 2010.

En concordancia con lo anterior, la nueva política de GIRH colombiana tiene diversos instrumentos para la planificación, ordenación y manejo de las cuencas hidrográficas y acuíferos, regulados en el Decreto 1640 de 2012. Esta norma creó en su artículo 48 el Consejo de Cuenca que es $<<$ la instancia consultiva y representativa de todos los actores que viven y desarrollan actividades dentro de la cuenca hidrográfica >>. Su composición está contenida en la Resolución 509 de 2013 del Ministerio de Ambiente y Desarrollo Sostenible, e incluye una amplia representación de varios sectores de la sociedad pues son miembros del Consejo máximo tres representantes de: las comunidades indígenas tradicionalmente asentadas en la cuenca; las comunidades negras asentadas en la cuenca que hayan ocupado tradicionalmente zonas rurales ribereñas de acuerdo con sus prácticas de producción; las organizaciones que asocien o agremien campesinos; las organizaciones que asocien o agremien sectores productivos; personas prestadoras de servicios de acueducto y alcantarillado; organizaciones no gubernamentales cuyo objeto exclusivo sea la protección del medio ambiente y los recursos naturales renovables; las Juntas de Acción Comunal; instituciones de educación superior; municipios con jurisdicción en la cuenca, departamentos con jurisdicción en la cuenca, y los demás que resulten del análisis de actores. El Consejo participará en las fases del plan de ordenación y manejo de la cuenca, de acuerdo a lo que se considere en la estrategia de socialización y participación del mismo.

Como se ve, es un órgano nuevo que se conformará particularmente en cada cuenca y por ende no disponemos de mayores datos concretos sobre su eficacia. Por ahora diremos que es uno de los órganos evidentemente con mayor participación ciudadana en lo referente a la gestión del 
agua, en el que convergen múltiples intereses e incluso cosmovisiones por lo que, resulta razonable tener por lo menos, dudas en cuanto a su funcionalidad y eficacia. Es así como -aunque aún no están del todo claras o determinadas cuáles van a ser sus funciones, y la manera en que participará en los procesos de planeación-, podemos advertir que si lo que se pretende es concentrar en un solo documento las observaciones que tengan los diferentes actores del Consejo de Cuenca, ello va a ser un verdadero desafío porque no solo se trata de coordinar las ideas que cada sector representado tenga sobre determinados temas, a esto hay que añadirle los diferentes tiempos de deliberación y toma de decisiones que manejan, por ejemplo las comunidades indígenas y campesinas, que por regla general tienen unas costumbres ancestrales ostensiblemente diferentes a nuestra cultura moderna, que cada vez va más rápido y procura tomar decisiones en los menores lapsos posibles.

En suma, tanto el derecho colombiano como el brasileño han dedicado regulaciones importantes sobre la participación ciudadana en la gestión del recurso hídrico, que como vimos, es absolutamente necesaria para garantizar una sostenibilidad tanto ambiental como social respecto al manejo de las aguas. Ahora bien, pese a esta consagración legal, en la práctica suelen aparecer inconvenientes que impiden afirmar que los procesos participativos son completamente eficaces y que, en efecto, las opiniones de los ciudadanos se ven reflejadas en las decisiones que se adoptan. Sin embargo, por limitaciones de tiempo y espacio para la realización de este trabajo no podremos ahondar en el tema, que puede seguir adelantándose a futuro, pues es no solo interesante sino necesario realizar un diagnóstico del funcionamiento de este tipo de espacios.

\section{CONSIDERACIONES FINALES}

El principio de participación ciudadana en materia medioambiental ha sido una preocupación constante a nivel internacional. Así pues, vimos como diversos tratados internacionales relacionados con el medio ambiente lo han incluido dentro de sus textos dando cuenta de la necesidad de involucrar a los particulares en las decisiones sobre este tema en aras de conseguir una sostenibilidad ambiental, económica y social. Ahora bien, el objetivo que persigue la participación ciudadana es poder incidir en la toma de decisiones sobre los aspectos que afectan los derechos de todas las personas y en la protección del medio ambiente, meta que es difícil de cumplir. Por ello es necesario que las legislaciones nacionales avancen hacia una mayor inclusión de la ciudadanía en estos procesos. 
Lo anterior en tanto la ausencia de mecanismos y espacios de participación eficaces puede generar verdaderas injusticias hídricas que afectan directamente los derechos de las personas más vulnerables. En consecuencia, el fortalecimiento de los espacios participativos es una tarea que no da espera, y que puede jugar un papel importante para afrontar las desigualdades que generan la inequitativa distribución del recurso y el mal uso del mismo.

Finalmente, hace falta un cambio de mentalidad a nivel de la ciudadanía y de la Administración en torno al tema que estamos tratando. Así pues, es urgente crear conciencia sobre la importancia de involucrarse en este tipo de procesos, y la necesidad de reclamar mejores espacios con mayores garantías, para poder incidir en la toma de decisiones que marcan las pautas de cómo se manejará el recurso hídrico en los años siguientes. Para lograr despertar este tipo de demandas en la ciudadanía, es necesario adoptar un rol activo socialmente, y demandar del Estado mejores y mayores espacios para la expresión de las preocupaciones ciudadanas.

De igual forma, es necesario que la Administración no asimile estos procesos a simples formalidades, o como algo que dilata la toma de decisiones, debe pues, garantizar el derecho de todos los ciudadanos de participar, y crear espacios educativos para incentivar conciencia y fomentar una actitud activa, para afrontar entre todos los retos que la época en la que estamos viviendo nos impone. La educación, la transparencia y el acceso a la información, son herramientas claves en la búsqueda de un manejo sostenible de las aguas al interior de cualquier país. Por ello, vale la pena seguir estudiando el tema para poder proponer alternativas, y revisar otros modelos, incluso ancestrales y comunitarios de gestión del recurso hídrico, que son generalmente más participativos, y de donde es posible extraer lecciones importantes para hacer frente a la problemática señalada en este trabajo.

\section{REFERENCIAS DE LAS FUENTES CITADAS}

BRASIL. Constituição (1988). Constituição Da República Federativa Do Brasil. Brasília, df, senado, 1998. Disponible en:

<http://www2.Congreso.Gob.Pe/Sicr/Cendocbib/Con4_Uibd.Nsf/Db0906178f38c78105257d9a006 d1b77/\$File/Constitución_Brasil.Pdf>. Consulta: 04/01/2017.

BRASIL. Lei № 9.433, De 08 De Janeiro De 1997. Lei de Gestão de Recursos Hídricos; Lei da Política Nacional de Recursos Hídricos; Lei das Águas. Câmara dos Deputados. Disponible en 
<http://www2.Camara.Leg.Br/Legin/Fed/Lei/1997/Lei-9433-8-Janeiro-1997-374778-NormaPI.Html>. Consulta: 04/01/2017.

BRASIL, Agência Nacional de Águas. 0 comitê de bacia hidrográfica: o que é e o que faz? Brasília: SAG, 2011. Disponible:

<http://www.ana.gov.br/bibliotecavirtual/arquivos/20120809150432_volume_1.pdf>. Consulta: $10 / 01 / 2017$.

COLOMBIA. Constitución Política, 1991. Bogotá: Consejo Superior de la Judicatura, 2017. 161p.

COLOMBIA. Ministerio De Ambiente Y Desarrollo Sostenible. Decreto no. 1640. (02, Agosto, 2012). Por medio del cual de reglamentan los instrumentos para la planificación, ordenación y manejo de las cuencas hidrográficas y acuíferos, y se dictan otras disposiciones. Disponible en:

<http://www.minambiente.gov.co/images/normativa/decretos/2012/dec_1640_2012.pdf>. Consulta: 04/01/2017.

COLOMBIA. Ministerio de Ambiente y Desarrollo Sostenible. Resolución no. 0509. (21, mayo, 2013). Por la cual se definen los lineamientos para la conformación de los consejos de cuenca y su participación en las fases del plan de ordenación de la cuenca, y se dictan otras disposiciones. Disponible en:

<http://www.minambiente.gov.co/images/gestionintegraldelrecursohidrico/pdf/cuencashidrograficas/resolucion-0509-de-2013.pdf>. Consulta: 04/01/2017.

ORGANIZACIÓN DE LAS NACIONAES UNIDAS, World Water Assesment Program. Informe de las Naciones Unidas sobre los recursos hídricos en el mundo 2015. Agua para un mundo sostenible. Datos y Cifras. UNESCO. WWAP. UN WATER. [en línea]. Disponible en: <http://www.unesco.org/new/fileadmin/MULTIMEDIA/HQ/SC/images/WWDR2015Facts_Figures_ SPA_web.pdf>. Consulta: 30/07/2016.

ROJAS PADILLA, Johnny Harold; PÉREZ RINCÓN, Mario Alejandro; MALHEIROS, Tadeu Fabricío; MADERA PARRA, Carlos Arturo; PROTA, Mariza Guimaråles; y DOS SANTOS, Raquel. Análisis comparativo de modelos e instrumentos de gestión integrada del recurso hídrico en suramérica: los casos de Brasil y Colombia. Ambi-Agua. Taubaté, v. 8, n. 1, p. 82. 2013. Disponible en: <http://dx.doi.org/10.4136/ambi-agua.971>. Consulta: 10/07/2016.

SOUZA, Maria Cláudia Da Silva Antunes de; PAVAN, Kamilla. Sustentabilidade, Meio Ambiente E Água: Uma Questão De Sobrevivencia. XXV Encontro Nacional Do Compedi - Brasília/DF. Direto E 
Sustentabilidade li. 2016. Disponible:

<http://www.conpedi.org.br/publicacoes/y0ii48h0/dzoq9f77/4af1hot08dixm7ci.pdf>. Consulta: $12 / 01 / 2017$.

SOUZA, Maria Cláudia Da Silva Antunes de; GHILARDI, Hilariane Teixeira. La Evaluación Ambiental Estratégica En La Gestión De Planificación De Recursos Hídricos: Una Necesidad Para El Equilibrio Del Medio Ambiente. XXV Encontro Nacional Do Compedi - Brasília/DF. Direto E Sustentabilidade li. Disponible:

<http://www.conpedi.org.br/publicacoes/y0ii48h0/q923c0e2/3t761upw49g20kup.pdf>. Consulta: $12 / 01 / 2017-$

ZAMUDIO RODRÍGUEZ, Carmen. Gobernabilidad sobre el recurso hídrico en Colombia: entre avances y retos. Revista Gestión y Ambiente, 15(3). Disponible:

<http://search.proquest.com/docview/1677587303?accountid=17192>. Consulta: 06/06/2016. 


\title{
O STATUS JURÍDICO DIFERENCIADO DA LEI DO PLANO DIRETOR
}

\author{
Sérgio Laguna Pereira ${ }^{1}$
}

\section{INTRODUÇÃO}

A Constituição Federal de 1988, ao estabelecer um capítulo específico para disciplinar a política de desenvolvimento e expansão urbana, trouxe novos e significativos contornos para o Direito Urbanístico. Definiu-se de maneira clara e direta as funções do planejamento urbano, ${ }^{2}$ distribuiu-se competências legislativas e administrativas entre os entes da federação ${ }^{3}$ e, ainda, colocou-se à disposição do Poder Público uma série de instrumentos adequados às finalidades constitucionalmente estabelecidas. ${ }^{4}$

Para que se alcance os objetivos constitucionais, definiu-se, ainda, um protagonista: o plano diretor. Esse plano, que deve ser aprovado por meio de lei e que precisa contar com intensa participação social no seu processo de elaboração, tem a função de fixar as diretrizes gerais da disciplina urbanística. ${ }^{5}$

Nesse contexto, o problema que se coloca no presente artigo é saber qual o status jurídiconormativo do plano diretor - e de que modo ele se inter-relaciona com as demais leis municipais de direito urbanístico. Ao ser definido como "instrumento básico da política de desenvolvimento e expansão urbana", o plano diretor está no mesmo plano normativo das demais leis urbanísticas municipais, podendo ser livremente alterado ou revogado por leis supervenientes,

\footnotetext{
${ }^{1}$ Mestrando em Ciência Jurídica na Universidade do Vale do Itajaí (UNIVALI). Especialista em Advocacia Pública pela AVM Faculdades Integradas e Instituto para o Desenvolvimento Democrático. Graduado em Ciências Jurídicas e Sociais pela Universidade Federal do Rio Grande do Sul. Procurador do Estado de Santa Catarina. E-mail: laguna@pge.sc.gov.br

${ }^{2} \mathrm{O}$ art. 182, caput, da Constituição prevê que "A política de desenvolvimento urbano, executada pelo Poder Público municipal, conforme diretrizes gerais fixadas em lei, tem por objetivo ordenar o pleno desenvolvimento das funções sociais da cidade e garantir o bem-estar de seus habitantes". (BRASIL. Constituição da República Federativa do Brasil, de 05 de outubro de 1988. Disponível em: <https://www.planalto.gov.br/ccivil_03/constituicao/constituicao.htm>. Acesso em: <19.02.2017>.

${ }^{3} \mathrm{O}$ art. 24, I, da Constituição prevê a competência concorrente entre União, Estados e Distrito Federal para legislar sobre direito urbanístico; o art. 30, I, II, VIII e IX, a seu turno, prevê que compete aos Municípios: legislar sobre assuntos de interesse local; suplementar a legislação federal e a estadual no que couber; promover, no que couber, adequado ordenamento territorial, mediante planejamento e controle do uso, do parcelamento e da ocupação do solo urbano; promover a proteção do patrimônio histórico-cultural local, observada a legislação e a ação fiscalizadora federal e estadual. (BRASIL. Constituição da República Federativa do Brasil de 1988, de 05 de outubro de 1988.)

${ }^{4}$ SUNDFELD, Carlos Ari. O Estatuto da Cidade e suas Diretrizes Gerais. In: DALLARI, Adilson Abreu; FERRAZ, Sérgio (Org.). Estatuto da Cidade: Comentários à Lei Federal 10.257/2001. 4. ed. São Paulo: Malheiros, 2008. pp. 52-53

${ }^{5}$ De acordo com o art. 182, § 10, “O plano diretor, aprovado pela Câmara Municipal, obrigatório para cidades com mais de vinte mil habitantes, é o instrumento básico da política de desenvolvimento e expansão urbana". (BRASIL. Constituição da República Federativa do Brasil, de 05 de outubro de 1988)
} 
independentemente de procedimento específico? A resposta a essa questão é relevante para a segurança jurídica no âmbito normativo do direito urbanístico.

Na primeira seção, examinar-se-á no que consiste o plano diretor e, em linhas gerais, o papel que é a ele atribuído no que concerne à densificação dos conceitos de função social da cidade e do direito à cidade sustentável. Logo adiante, na segunda seção, será analisado o peculiar processo de elaboração do plano diretor, o qual demanda participação social qualificada, aspecto em que ele se diferencia do processo legislativo comum. Na terceira seção, o foco será a análise do precedente firmado pelo Supremo Tribunal Federal (STF) no Recurso Extraordinário (RE) 607.940/DF, no qual se estabeleceu tese de repercussão geral que prevê que as leis urbanísticas específicas devem ser compatíveis com as diretrizes do plano diretor. Por fim, na quarta seção, serão analisadas as consequências jurídicas da aplicação da tese de repercussão geral do STF no que se refere ao status jurídico-normativo do plano diretor.

Recorrendo à pesquisa bibliográfica, o que inclui a análise de precedente do STF, o presente trabalho terá base lógico-investigativa apoiada no método indutivo ${ }^{6}$, tendo sido utilizadas, ainda, as técnicas do referente ${ }^{7}$, da categoria ${ }^{8}$ e do conceito operacional ${ }^{9}$.

\section{O PLANO DIRETOR COMO INSTRUMENTO BÁSICO DE ORDENAÇÃO DA CIDADE}

A política de desenvolvimento urbano, propugnada pelo Movimento Nacional de Reforma Urbana e incorporada pela Constituição de 1988, produziu significativa mudança mediante o rompimento "com diversos padrões que, até então, dominavam a concepção jurídica de propriedade e cidade". ${ }^{10} \mathrm{~A}$ cidade passou a ser um espaço cultural e coletivo, em que se propõem os princípios da justiça social, da função social da cidade e da propriedade.

Consoante prescreveu o art. 182, $\S 1$ 으, da Constituição Federal, o plano diretor, a ser

\footnotetext{
${ }^{6}$ MÉTOdo INDUTIVO: base lógica da dinâmica da Pesquisa Científica que consiste em "pesquisar as partes de um fenômeno e coleciona-las de modo a ter uma percepção ou conclusão geral" (PASOLD, Cesar Luiz. Metodologia da Pesquisa Jurídica: Teoria e Prática. 13ed.rev. Florianópolis: Conceito Editorial, 2015, p. 91).

${ }^{7}$ REFERENTE: "explicitação prévia dos motivos, objetos e produto desejado, delimitando o alcance temático e de abordagem para uma atividade intelectual, especialmente para uma pesquisa" (PASOLD, Cesar Luiz. Metodologia da Pesquisa Jurídica: Teoria e Prática. p. 58).

${ }^{8}$ CATEGORIA: “a palavra ou expressão estratégica à elaboração e/ou à expressão de uma ideia" (PASOLD, Cesar Luiz. Metodologia da Pesquisa Jurídica: Teoria e Prática. p. 27).

${ }^{9}$ CONCEITO OPERACIONAL: "definição para uma palavra ou expressão, com o desejo de que tal definição seja aceita para os efeitos das ideias que expomos" (PASOLD, Cesar Luiz. Metodologia da Pesquisa Jurídica: Teoria e Prática. p. 39)

${ }^{10}$ PINHEIRO, Gabriele Araújo; RODRIGUES, Wagner de Oliveira. Direito fundamental à cidade sustentável e os dilemas do planejamento urbano no Estado Democrático de Direito. Revista da Faculdade de Direito da Universidade de São Paulo, São Paulo, v. 106/107, 2011/2012. p. 378
} 
previsto em lei municipal, constitui o instrumento básico da política de desenvolvimento e de expansão urbana. ${ }^{11}$ É a partir dele que deverão ser estruturados os esforços do Poder Público à satisfação do direito a cidades sustentáveis, tendo em conta direitos à moradia, ao trabalho, à educação, à saúde e ao saneamento ambiental, à infraestrutura urbana, ao transporte e aos serviços públicos etc ${ }^{12}$, disciplinando-se, em diretrizes gerais ${ }^{13}$, "os processos de produção e fruição do espaço urbano" ${ }^{14}$.

O plano diretor, em sua vertente política, tem a função de atuar como verdadeiro instrumento de intervenção social, "reconhecendo a cidade como espaço de realizações da sociedade e prescrevendo caminhos para o seu desenvolvimento justo e sustentável” ${ }^{15}$. Daí porque se diz que, mais do que um instrumento técnico, o plano diretor consubstancia um “instrumento sociopolítico em que se define o conteúdo para o exercício de direitos individuais de propriedade imobiliária urbana". ${ }^{16}$

A noção de plano diretor se inter-relaciona diretamente com o conceito de função social da cidade e com a definição de direito à cidade. Trata-se, por certo, de conceitos que demandam uma densificação jurídica, pois eles não podem ser aferidos desde logo. A Constituição, não obstante, trouxe o ponto de partida:

O capítulo específico previsto na Constituição alude à política urbana como meio para atingir determinados fins. Dentre esses fins não está, ao menos não expressamente, a realização de um "direito a cidades sustentáveis". Também não se alude à realização de algum direito específico por intermédio da política urbana. Em vez disso, o art. 182 da Constituição prevê que a política urbana "tem por objetivo ordenar o pleno desenvolvimento das funções sociais da cidade e garantir o bemestar de seus habitantes". Daí se extrai que o texto constitucional dispôs sobre uma disciplina objetiva da função pública urbanística, não fundada em direito ou direitos subjetivos. Conquanto se aluda ao bem-estar dos habitantes das cidades, não há a delimitação de posições jurídicas exigíveis. ${ }^{17}$

\footnotetext{
${ }^{11}$ BRASIL. Constituição da República Federativa do Brasil, de 05 de outubro de 1988.

${ }^{12}$ FRANCISCO, Caramuru Afonso. Estatuto da Cidade comentado. 1ạ ed. São Paulo: Juarez de Oliveira, 2001. p. 241

13 "Transposta para a fonte legislativa, significa preceitos indicadores, preceitos que fixam esquemas gerais, linhas básicas, balizas em determinadas matérias; preceitos norteadores da efetivação de uma política. Tais prescrições norteadoras dirigem-se, em tese, a outros legisladores, a administradores ou ao intérprete em geral" (MEDAUAR, Odete. A força vinculante das diretrizes da política urbana. In: FINK, Daniel Roberto (Org.). Temas de direito urbanístico 4. São Paulo: Ministério Público do Estado de São Paulo, 2005. p. 17)

${ }^{14}$ PIRES, Maria Coeli Simões. A função social no direito urbanístico e na política urbana: uma nova ordem de sustentabilidade das cidades. In: PEREIRA, Flavio Henrique Unes; Dias, Maria Tereza Fonseca (Org.). Cidadania e Inclusão Social: Estudos em Homenagem à Professora Miracy Barbosa de Sousa Gustin. Belo Horizonte: Editora Fórum, 2008. p. 385

${ }^{15}$ FERREIRA, Gabriel Luis Bonora Vidrih. Plano Diretor e Inclusão Social no Espaço Urbano. Revista de Direitos Difusos, Rio de Janeiro, v. 46, 2008. p. 29

${ }^{16}$ SANTOS, Juliana Cavalcanti dos. A função social da propriedade urbana sob o ponto de vista do Estatuto da Cidade. In: ALVIM, José Manoel de Arruda; CAMBLER, Everaldo Augusto (Org.). Estatuto da Cidade. São Paulo: Revista dos Tribunais, 2014. p. 573

${ }^{17}$ REISDORFER, Guilherme F. Dias. Definição e concretização do direito à cidade: entre direitos e deveres fundamentais. Revista de Direito Administrativo Contemporâneo, São Paulo, ano 3, v. 19, 2015. p. 178
} 
O objetivo primordial da política urbana, não obstante, não é apenas delimitar posições jurídicas exigíveis do Estado, relativas a direitos subjetivos específicos. Ela tem relação com a própria estruturação do ambiente urbano como um todo ${ }^{18}$, visando à concretização de um direito fundamental à cidade. Os direitos fundamentais - em especial os econômicos, sociais e culturais não são efetivados em abstrato, mas eles devem ser materializados no tempo e no espaço, ou seja, no meio urbano. Portanto, a efetiva apropriação do espaço urbano pelos cidadãos, de forma democrática e sustentável - visando atender à presente e às futuras gerações -, é condição para a efetividade dos direitos fundamentais. ${ }^{19}$

Nessa ordem de ideias, o programa constitucional urbanístico se estrutura em três vertentes: planejamento urbano, gestão democrática e solidarismo. No que tange aos dois primeiros aspectos, trata-se de deveres impostos ao Poder Público, o qual deve promover o planejamento urbano mediante um processo democratizado. Por outro lado, no que tange ao solidarismo, reconhece-se que há uma dimensão da estruturação urbana que demanda um comprometimento e uma atuação dos próprios cidadãos, que devem compatibilizar suas iniciativas sociais e econômicas com as diretrizes de desenvolvimento definidas no plano diretor. ${ }^{20}$

Portanto, a formulação de um plano, tal como é o plano diretor, consiste na concatenação de um conjunto de medidas, "que se posicionam numa relação indissolúvel de complementaridade e dependência recíprocas". ${ }^{21} \mathrm{Em}$ primeiro lugar, o plano tem como função inventariar a atual realidade urbana quanto à ocupação do espaço, seja do ponto de vista fático, seja sob o prisma jurídico. Compete ao plano, também, promover a conformação do território. "Trata-se de uma função conatural a todos os planos, já que todos eles pretendem programar, influenciar e organizar a ocupação e transformação do território e desenvolver harmoniosamente as diferentes parcelas do espaço". ${ }^{22}$ Por fim, a terceira função do básica do plano é a conformação do direito de propriedade do solo, o que se viabiliza mediante o estabelecimento de prescrições “que vão tocar a própria essência do direito de propriedade, através da classificação do uso e

\footnotetext{
${ }^{18}$ REISDORFER, Guilherme F. Dias. Definição e concretização do direito à cidade: entre direitos e deveres fundamentais. p. 178

${ }^{19} \mathrm{O}$ direito à cidade não constitui um conceito fechado. Ele diz respeito a um conjunto de necessidades humanas relacionadas à estruturação do espaço urbano; é um feixe de posições jurídicas de direito fundamentais. Trata-se, portanto, de uma construção histórica, própria de cada tempo e lugar. Embora muitos relacionem o direito à cidade com o direito à moradia, a isso ele não se restringe. Ele pressupõe o atendimento de condições mais amplas e não relacionadas a posições jurídicas individuais específicas. Logo, a realização do direito à cidade passa pela construção de um ambiente urbano sadio para a coletividade, que não realize apenas direitos individuais dos moradores, mas sim um conjunto de direitos coletivos como infraestrutura urbana, serviços essenciais e meio ambiente equilibrado.

${ }^{20}$ REISDORFER, Guilherme F. Dias. Definição e concretização do direito à cidade: entre direitos e deveres fundamentais. p. 179

${ }^{21}$ CORREIA, Fernando Alves. Manual de Direito do Urbanismo. 4a ed., Coimbra: Almedina, 2012. p. 362

${ }^{22}$ CORREIA, Fernando Alves. Manual de Direito do Urbanismo. p. 366
} 
destino do solo, da divisão do território em zonas e da definição dos parâmetros a que deve obedecer a ocupação, uso e transformação de cada uma delas". ${ }^{23}$

É de se destacar, ademais, que a elaboração do plano diretor deve compreender todo o território, não apenas as zonas urbanas; ainda que se trate de competência legislativa municipal, ela não é excludente, porque no plano ou nas leis específicas decorrentes "hão de ser observados os parâmetros urbanísticos de interesse nacional ou regional, fixados em lei federal ou estadual, bem como as normas federais ou estaduais de proteção ambiental”. ${ }^{24}$

\section{A GESTÃo DEMOCRÁtICA URBANÍSTICA E O PROCEDIMENTO ESPECIAL DE APROVAÇÃO DO PLANO DIRETOR}

A gestão democrática da política urbana constitui diretriz fundamental a ser observada no processo de elaboração do plano diretor, o qual há de contar com uma participação social qualificada, o que o difere, substancialmente, do processo legislativo convencional.

As leis municipais, via de regra, decorrem de procedimento legislativo que se estabelece em três etapas básicas: (1) a iniciativa, com a submissão de projeto de lei à Câmara Municipal ${ }^{25}$; (2) a tramitação e aprovação do projeto de lei pela Câmara Municipal; e (3) a sanção e promulgação do projeto de lei pelo Chefe do Poder Executivo Municipal.

No caso dos planos diretores, entretanto, há uma disciplina especial que prevê uma participação social mais intensa, que não se esgota com o sistema de democracia representativa que se opera indiretamente por meio de representantes eleitos (no caso, vereadores ou Prefeito Municipal). ${ }^{26}$

De um lado, o art. 29, XII, da Constituição prevê a "cooperação das associações

\footnotetext{
${ }^{23}$ CORREIA, Fernando Alves. Manual de Direito do Urbanismo. p. 366

${ }^{24}$ DUTRA, Fábio. Plano Diretor e a proteção do meio ambiente. In: Revista de Direito do Tribunal de Justiça do Estado do Rio de Janeiro, Rio de Janeiro, v. 70, p.13-22, 2007. pp. 19-20

${ }^{25}$ A Constituição não dispõe diretamente sobre o processo legislativo municipal. Tal tarefa está confiada à Lei Orgânica do Município. Não obstante, há parâmetros a serem adotados. O primeiro deles é a iniciativa popular, prevista expressamente no art. 29, XIII. O segundo parâmetro, originário da jurisprudência do STF, é o de que Estados, Distrito Federal e Municípios têm o dever de observar em suas Constituições ou Leis Orgânicas, tanto quanto possível, simetria com as regras de processo legislativo federal (cf. MENDES, Gilmar Ferreira; COELHO, Inocêncio Mártires; BRANCO, Paulo Gustavo Gonet. Curso de Direito Constitucional. 4. ed. São Paulo: Saraiva, 2009. p. 861-862). Daí se poder afirmar que a iniciativa de lei, em âmbito municipal, é normalmente conferida ao Prefeito Municipal e aos vereadores, admitida, ainda, a iniciativa popular, nos termos e condições previstas no referido art. 29, XIII, Constituição. (BRASIL. Constituição da República Federativa do Brasil, de 05 de outubro de 1988).

${ }^{26}$ Cf. SILVA, José Afonso da. Curso de Direito Constitucional Positivo. 37ạed., Malheiros: São Paulo, 2014. pp. 139-140
} 
representativas no planejamento municipal", ${ }^{27}$ o que é tido como indicativo claro da necessidade de democratização do processo de planejamento urbano (que não pode se restringir a uma perspectiva exclusivamente tecnocrática) ${ }^{28} 29$. E isso há de incluir, naturalmente, o processo de elaboração do plano diretor, haja vista o protagonismo que ele exerce nas políticas de desenvolvimento e expansão urbana.

Por outro lado, é o Estatuto da Cidade ${ }^{30}$ que, de forma mais minuciosa, estabelece em seu art. 40, $\S 4$ 으, que, no processo de elaboração do plano diretor e na fiscalização de sua implementação, os Poderes Legislativo e Executivo municipais devem garantir: (i) a promoção de audiências públicas e debates com a participação da população e de associações representativas dos vários segmentos da comunidade, (ii) a publicidade quanto aos documentos e informações produzidos; (iii) o acesso de qualquer interessado aos documentos e informações produzidos.

A participação popular no processo de elaboração do plano diretor, tal como disciplinada no Estatuto da Cidade, constitui assim um elemento fundamental na democratização da gestão urbana, em especial no que tange ao objetivo de "fortalecer o elo entre a cidade real, a cidade ideal e a cidade possível de se realizar" ${ }^{31}$. A legitimação do plano diretor, nesse contexto, não decorre apenas de sua veiculação por meio de lei em sentido formal, mas sim de um prévio e qualificado processo participativo de elaboração (inclusive na fase pré-legislativa) em que a população, e as entidades representativas da sociedade civil organizada, possa participar diretamente da definição das mais diversas questões municipais, observadas as suas peculiaridades, demandas e interesses específicos. ${ }^{32}$ Trata-se de um processo decisório aberto em que se promove o efetivo exercício da cidadania. ${ }^{33}$

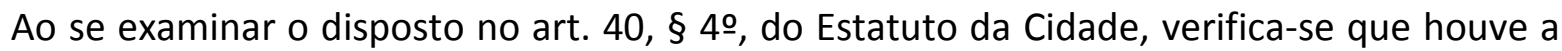

\footnotetext{
${ }^{27}$ BRASIL. Constituição da República Federativa do Brasil, de 05 de outubro de 1988.

${ }^{28}$ GONDIM, Linda Maria de Pontes; LIMA, Martônio Mont'alverne Barreto; MOREIRA, Sandra Mara Vale. Democracia, tecnocracia e política: encontros e desencontros na elaboração do plano diretor participativo. In: Revista Interesse Público, Porto Alegre, v. 35 , 2006. pp. 281-282

29 “[...] até o surgimento das novas diretrizes proveniente da Constituição Federal e do Estatuto da Cidade, o Plano Diretor era visto apenas como um documento técnico, que descartava as práticas sociais do cotidiano da cidade. Nesta nova concepção, o Plano Diretor assume a função política de interferir no processo de desenvolvimento local, compreendendo e integrando os fatores que condicionam a situação do Município" (FERREIRA, Gabriel Luis Bonora Vidrih. Plano Diretor e Inclusão Social no Espaço Urbano. p. 35)

30 BRASIL. Lei n. 10.257, de 10 de julho de 2001. Disponível em: <http://www.planalto.gov.br/ccivil_03/leis/LEIS_2001/L10257.htm>. Acesso em: <19.02.2017>.

${ }^{31}$ GONDIM, Linda Maria de Pontes; LIMA, Martônio Mont'alverne Barreto; MOREIRA, Sandra Mara Vale. Democracia, tecnocracia e política: encontros e desencontros na elaboração do plano diretor participativo. pp. 269-270

32 GONDIM, Linda Maria de Pontes; LIMA, Martônio Mont'alverne Barreto; MOREIRA, Sandra Mara Vale. Democracia, tecnocracia e política: encontros e desencontros na elaboração do plano diretor participativo. pp. 281-282

${ }_{33}$ MUKAI, Toshio. O Estatuto da Cidade. In: CARDOSO, José Eduardo Martins; QUEIROZ, João Eduardo Lopes; SANTOS, Márcia Walquiria Batista dos (Org.). Direito Administrativo Econômico. São Paulo: Editora Atlas, 2011. p. 1425
} 
definição de que a democratização do processo de elaboração do plano diretor deve se dar em três aspectos distintos. Em primeiro lugar, há previsão de que deve ser conferida absoluta publicidade aos documentos e informações que embasam o processo de discussão e elaboração do plano diretor; trata-se, por certo, de uma atuação ativa, consubstanciada no dever do Poder Público (aqui compreendido tanto o Legislativo quanto o Executivo) de tornar públicas as informações relacionadas ao processo, seja por meio físico ou digital, mesmo antes de ser instado a fazê-lo. ${ }^{34}$ Um segundo aspecto, por outro lado, diz respeito ao dever do Poder Público de prestar informações que the sejam requeridas. Esse dever possibilita que qualquer interessado possa requerer tais informações e obtê-las em prazo razoável. E, por fim, o Estatuto da Cidade estabelece que o Poder Público tem o dever de criar as oportunidades de manifestação da sociedade, o que se dá através da realização de audiências públicas e debates em que sejam postos à apreciação e explicitados, em linguagem acessível ${ }^{35}$, os aspectos técnicos do projeto. ${ }^{36}$

Assim, deve-se compreender que a disciplina do Estatuto da Cidade prevê que não apenas haja participação popular no processo de elaboração do plano diretor, mas também que essa participação deve ser informada, qualificada, instruída. Devem ser divulgadas com antecedência necessária as informações a serem discutidas pelos interessados em audiências; deve haver a divulgação dos comentários e sugestões formulados, bem como resposta fundamentada a quaisquer comentários e contribuições. ${ }^{37} \mathrm{O}$ caráter substancial - e não apenas formal - que se espera desse processo colaborativo de elaboração do plano diretor exige que as contribuições sejam efetivamente consideradas pelo gestor, o qual, para rejeitá-las, deve expor as razões que o justificam. O objetivo é que desse processo, após um debate amplo e qualificado, possa resultar um plano diretor mais adequado às necessidades e especificidades dos diferentes grupos sociais que integram o espaço urbano.

Veja-se que é tão relevante e grave esse dever do Poder Público de promover processos decisórios abertos em relação à elaboração do plano diretor que o art. 52, VI, do Estatuto da Cidade dispôs que, se o Prefeito Municipal não vier a promover as audiências, debates ou não conferir a devida publicidade prevista no art. 40, § 4ำ, tal omissão o sujeita, no limite, à sanção por

\footnotetext{
${ }^{34}$ CÂMARA, Jacintho Arruda. Plano Diretor. In: DALLARI, Adilson Abreu; FERRAZ, Sérgio (Org.). Estatuto da Cidade: Comentários à Lei Federal 10.257/2001. 4. ed. São Paulo: Malheiros, 2014. p. 339

${ }^{35}$ SOUZA, Guilherme Carvalho e. A importância da gestão democrática das cidades para a formulação de políticas públicas no âmbito municipal: a criação do plano diretor. Revista Brasileira de Direito Municipal, Belo Horizonte, v. 12, n. 42, 2011. p. 96

${ }^{36}$ GASPARINI, Diogenes. Aspectos jurídicos do plano diretor. In: Revista Interesse Público, Porto Alegre, v. 31, 2005. pp. 18-19

${ }^{37}$ CÂMARA, Jacintho Arruda. Plano Diretor. In: DALLARI, Adilson Abreu; FERRAZ, Sérgio (Org.). Estatuto da Cidade: Comentários à Lei Federal 10.257/2001. p. 339
} 
improbidade administrativa. $^{38}$

Uma questão interessante que se coloca é a seguinte: caso não seja promovida ou observada a participação social no processo de elaboração do plano diretor, haveria alguma consequência jurídica?

Observe-se, quanto a esse aspecto, que o art. $40, \S 50$, do projeto de lei que resultou no Estatuto da Cidade previa expressamente a nulidade da lei que instituir o plano diretor em desacordo com o disposto no $\S 4$ 으 do mesmo artigo (logo, sem o processo participativo de elaboração do plano diretor). No entanto, esse dispositivo foi vetado pelo então Presidente da República, ao fundamento de que violaria a autonomia municipal para dispor sobre regras relacionadas ao processo legislativo. ${ }^{39}$

Assim, parte da doutrina considera que esse veto inviabiliza qualquer conclusão a respeito da nulidade do plano diretor em que não for observada a participação popular no processo de elaboração. ${ }^{40}$ Há quem considere que o veto fragilizou, sobremodo, as exigências do art. 40, § 4으, pois não impôs consequências jurídicas à sua inobservância ${ }^{41}$, salvo a já referida hipótese de improbidade administrativa especificamente quanto ao Prefeito Municipal.

Não obstante, há razoáveis fundamentos para que se conclua em sentido diverso. Consoante adverte Eros Roberto Grau, "texto e norma não se superpõe", pois "o processo legislativo termina no momento do texto - a norma virá depois, produzida no bojo de um outro processo, a interpretação" ${ }^{42}$. Daí porque se diz que a intepretação é uma "atividade que se presta a transformar disposições (textos, enunciados) em normas" ${ }^{43}$.

Logo, a circunstância de ter sido vetado o dispositivo do Estatuto da Cidade - que, de modo expresso, atribuía vício de nulidade ao plano diretor que fosse instituído sem observância do processo participativo de elaboração -, não conduz necessariamente à conclusão de que tal vício

\footnotetext{
${ }^{38}$ CÂMARA, Jacintho Arruda. Plano Diretor. In: DALLARI, Adilson Abreu; FERRAZ, Sérgio (Org.). Estatuto da Cidade: Comentários à Lei Federal 10.257/2001. p. 339

39 “"'Reza o § 50 do art. 40 que é 'nula a lei que instituir o plano diretor em desacordo com o disposto no § 40’. Tal dispositivo viola a Constituição, pois fere o princípio federativo que assegura a autonomia legislativa municipal. Com efeito, não cabe à União estabelecer regras sobre processo legislativo a ser obedecido pelo Poder Legislativo municipal, que se submete tão-somente, quanto à matéria, aos princípios inscritos na Constituição do Brasil e na do respectivo Estado-membro, consoante preceitua o caput do art. 29 da Carta Magna. O disposto no $\S 50$ do art. 40 do projeto é, pois, inconstitucional e, por isso, merece ser vetado." (BRASIL. Presidência da República. Mensagem de Veto n. 730, de 10 de julho de 2001. Disponível em:< http://www.planalto.gov.br/ccivil_03/leis/Mensagem_Veto/2001/Mv730-01.htm> Acesso em: <19.02.2017>

${ }^{40}$ GASPARINI, Diogenes. Aspectos jurídicos do plano diretor. p.19

${ }^{41}$ BUCCI, Maria Paula Dallari. Gestão Democrática da Cidade. In: DALLARI, Adilson Abreu; FERRAZ, Sérgio (Org.). Estatuto da Cidade: Comentários à Lei Federal 10.257/2001. 4. ed. São Paulo: Malheiros, 2014. p. 357

${ }^{42}$ GRAU, Eros Roberto. Direito Posto e Direito Pressuposto. 7ạed., São Paulo: Malheiros, 2008. p. 317

${ }^{43}$ GRAU, Eros Roberto. Ensaio e Discurso sobre a Interpretação/Aplicação do Direito. 4åed., São Paulo: Malheiros, 2006. p 84
} 
inexiste. Isto porque tal efeito jurídico pode perfeitamente ser obtido por outros fundamentos, tal como o princípio democrático ínsito à gestão urbana, notadamente o art. 29, XII, da Constituição, que prevê a cooperação de entidades representativas no planejamento municipal. Além disso, não seria razoável interpretar que as disposições do Estatuto da Cidade, editadas na legítima competência da União para dispor sobre normas gerais em matéria urbanística, sejam desprovidas de qualquer vinculatividade. A literalidade do art. 40, § 4으, do Estatuto da Cidade é muito clara no sentido de que, no processo de elaboração do plano diretor, os "Poderes Legislativo e Executivo garantirão" a promoção de audiências, publicidade, etc. Logo, não se trata de mera faculdade, mas sim de requisito de validade do processo.

Em favor da tese da nulidade, destaca-se precedente do Tribunal Regional Federal da 4a Região em relação ao plano diretor do Município de Florianópolis/SC. ${ }^{44}$ Ao fundamento de que durante o processo de elaboração do plano diretor não foi assegurada uma participação informada da população, pois não houve a realização de audiências públicas legítimas em que os interessados pudessem ser devidamente ouvidos e tivessem suas sugestões e encaminhamentos considerados e efetivamente analisados, decidiu-se que o Município deveria refazer o processo. Concluiu-se, basicamente, que não tem validade jurídica um plano diretor em que a fase de audiências públicas e debates foi precária ou em que a sociedade não foi devidamente informada e instruída durante o processo.

Nesse contexto, afigura-se inegável que a observância do processo decisório aberto de elaboração do plano diretor constitui dever das autoridades municipais, sendo que uma das consequências possíveis em razão do descumprimento desse procedimento é a própria nulidade da lei de plano diretor que não o observe.

\section{A TESE DE REPERCUSSÃO GERAL FIRMADA PELO STF NO RECURSO EXTRAORDINÁRIO №}

\subsection{0}

\footnotetext{
${ }^{44}$ BRASIL. Tribunal Regional Federal da 4ạ Região. Acórdão da Apelação e Reexame Necessário n. 5021653-98.2013.404.7200, Relatora Desembargadora Federal Salise Monteiro Sanchotene, Terceira Turma. Porto Alegre, 27 de maio de 2005. Disponível em: <https://goo.gl/eSj1OV >. Acesso em: <19.02.2017>.
} 
O precedente firmado pelo STF no RE $607.940,{ }^{45}$ o qual fora julgado sob o rito da repercussão geral, tem sido exaltado por parte da doutrina como um leading case relativamente ao tema dos condomínios fechados. Isto porque a base para a controvérsia jurídica posta à apreciação do STF consistia na Lei Complementar Distrital (LCD) $710 / 2005,{ }^{46}$ que dispõe sobre Projetos Urbanísticos com Diretrizes Especiais para Unidades Autônomas e dá outras providências. ${ }^{47} \mathrm{~A}$ partir disso, tem-se afirmado que esse precedente é responsável por pacificar o entendimento sobre se os Municípios dispõem de competência legislativa para regular, sem amparo em normas gerais federais, a matéria específica dos condomínios fechados. ${ }^{48}$

No entanto, é necessário ressaltar que o tema dos condomínios fechados assumiu caráter secundário na discussão estabelecida no aludido precedente; o que se debateu naquele julgado, em verdade, foi a relação entre plano diretor e leis urbanísticas específicas. ${ }^{49}$

$\mathrm{Na}$ ação direta de inconstitucionalidade ajuizada pelo Ministério Público do Distrito Federal e Territórios (MPDFT) perante o Tribunal de Justiça do Distrito Federal e Territórios (TJDFT), na qual o parâmetro de controle era a Lei Orgânica do Distrito Federal (LODF), sustentou-se duas teses básicas. A primeira tese é a de que somente no plano diretor de ordenamento territorial (PDOT) ou nos planos diretores locais (PDL) ${ }^{50}$, elaborados com a efetiva participação da sociedade e dos órgãos de planejamento territorial, poderia ser disciplinada a questão dos loteamentos fechados. Portanto, não se admitiria uma disciplina em lei específica que seja isolada e desvinculada de estudos urbanísticos globais. A segunda tese, a qual mais diretamente dizia respeito ao conteúdo material da LCD 710/2005, era no sentido de que tal diploma normativo

${ }^{45}$ BRASIL. Supremo Tribunal Federal. Acórdão do Recurso Extraordinário n. 607.940. Relator: Min. Teori Zavascki, Tribunal Pleno. Brasília, 29 de outubro de 2015. Disponível em: <https://goo.gl//hSoTT>. Acesso em: <19.02.2017>.

${ }^{46}$ DISTRITO FEDERAL. Lei Complementar Distrital n. 710, de 08 de setembro de 2005. Disponível em: <https://goo.gl/MOSI3a>. Acesso em: $<19.02 .2017>$.

${ }^{47}$ É pertinente observar que ao Distrito Federal são atribuídas, a um só tempo, competências reservadas aos Estados e Municípios, nos termos do art. 32, § 1으, da Constituição Federal. Assim, embora o art. 182 da Constituição estabeleça que o plano diretor deva ser previsto em lei municipal, no caso específico a competência é distrital. (BRASIL. Constituição da República Federativa do Brasil, de 05 de outubro de 1988)

${ }^{48}$ DANTAS, Marcelo Buzaglo. Considerações sobre Loteamento Fechado. In: Direito, Desenvolvimento Urbano e Meio Ambiente [recurso eletrônico] / coordenadores Paulo de Tarso Brandão, Davi do Espírito Santo; organizadores Maria Cláudia Silva Antunes de Souza, Gilson Jacobsen - Dados eletrônicos. Itajaí: UNIVALI, 2016. Disponível em: <http://www.univali.br/ppcj/ebook>. Acesso em <19.02.2017>. p. 199-201

${ }^{49}$ VIOTTO, Aline; TAVOLARI, Bianca. As disputas pela interpretação constitucional do plano diretor / Disputes over the constitutional interpretation of the master plan. In: Revista Direito e Práxis, [s.I.], v. 7, n. 14, 8 jun. 2016. Universidade de Estado do Rio de Janeiro. p. 562

${ }^{50} \mathrm{O}$ plano diretor de ordenamento territorial (PDOT), nos termos do art. 317 da LODF, abrange todo espaço físico do território do Distrito Federal e tem a função de regular a localização dos assentamentos humanos e das atividades econômicas e sociais da população. Os planos diretores locais (PDLs), a seu turno, são previstos no art. 319 da LODF e, referindo-se a cada núcleo urbano (ou regiões administrativas que compõem o DF), regulam o direito ao uso e ocupação do solo, com objetivo de ordenar o desenvolvimento urbano, mediante adensamento de áreas já urbanizadas ou ocupação por urbanização de novas áreas. (DISTRITO FEDERAL. Lei Orgânica do Distrito Federal, de 08 de junho de 1993. Disponível em: <https://goo.gl/MQ2MCN>. Acesso em: $<19.02 .2017>$ ). 
relativizaria o acesso ao ecossistema urbano, desigualando a distribuição dos ônus urbanísticos decorrentes de sua ocupação e incentivando a segregação social a partir da ocupação fragmentada do território. Pedia-se, assim, a inconstitucionalidade de todo o diploma normativo impugnado.

O TJDFT julgou improcedente a ação. ${ }^{51}$ O Conselho Especial do Tribunal, no votocondutor $^{52}$, concluiu que a própria LODF prevê outros instrumentos a serem utilizados para disciplinar o ordenamento territorial, não se configurando, em consequência, a alegada exclusividade dos planos diretores quanto ao trato da matéria. Assim, seria possível que a matéria dos condomínios fechados viesse a ser disciplinada em lei específica e que, se houver eventual incompatibilidade entre o plano diretor e a lei específica, ela haveria de ser apurada em instâncias ordinárias, e não em uma ação direta de inconstitucionalidade distrital, cujo parâmetro de controle a ser tomado é somente a LODF, e não os planos diretores.

Foi no contexto dessa decisão do Tribunal local que houve, então, a interposição do RE 607.940. A tese recursal, a qual fora obviamente adaptada para que se tivesse por parâmetro o art. 182, §§ 1ㅇ e 2으, da Constituição, questionava a possibilidade de edição de "projetos urbanísticos isolados e desvinculados da exigência constitucional do plano diretor" ${ }^{\prime 53}$.

O STF, a partir de proposta do Ministro Ayres Britto, afetou a matéria ao rito dos recursos extraordinários com repercussão geral, tendo consignado que o tema versava sobre “obrigatoriedade do plano diretor como instrumento da política de ordenamento urbano" ${ }^{54}$. Evidentemente, não era a descrição mais adequada para a controvérsia, já que não se discutia no recurso se o plano diretor era obrigatório (o que, inclusive, era premissa da tese recursal), mas sim se a legislação específica que fora editada pelo Distrito Federal era constitucionalmente compatível.

Quando do início do julgamento do RE pelo STF, o Ministro Teori Zavascki, relator, ao votar

\footnotetext{
${ }^{51}$ DISTRITO FEDERAL. Tribunal de Justiça do Distrito Federal e Territórios. Acórdão n. 310.389 na Ação Direta de Inconstitucionalidade n. 2007.00.2.006486-7. Relator Desembargador Dácio Vieira, Conselho Especial. Brasília, 15 de abril de 2008. Disponível em: <https://goo.gl/qV0Ln4> Acesso em: 19.02.2017.

52 DISTRITO FEDERAL. Tribunal de Justiça do Distrito Federal e Territórios. Acórdão n. 310.389 na Ação Direta de Inconstitucionalidade n. 2007.00.2.006486-7.

${ }^{53}$ BRASIL. Ministério Público do Distrito Federal e Territórios. Petição de Razões do Recurso Extraordinário n. 607.940. Disponível em: <https://goo.gl/6oLKp9>. Acesso em: <19.02.2017>.

${ }^{54}$ BRASIL. Supremo Tribunal Federal. Acórdão de Repercussão Geral no Recurso Extraordinário n. 607.940, Plenário Virtual, Relator Ministro Ayres Britto. Brasília, 09 de dezembro de 2010. Disponível em: <https://goo.gl/9sLbzk>. Acesso em: $<19.02 .2017>$.
} 
pelo desprovimento do recurso ${ }^{55}$, considerou que, embora a Constituição determine que seja o plano diretor instrumento básico, geral e fundamental da política de desenvolvimento e expansão urbana, tal circunstância não conduziria, necessariamente, à conclusão de que todas as formas de parcelamento, uso ou ocupação do solo devam estar inteiramente disciplinadas na lei do plano diretor. Entendeu que haveria determinados modos de aproveitamento do solo urbano que, pelas suas singularidades, admitiriam disciplina jurídica autônoma.

Até aí o STF pouco inovava na ordem jurídica, já que apenas se limitava a afirmar que o plano diretor não esgota a disciplina urbanística local - traça-lhe, apenas, as diretrizes gerais -, o que pode ser complementado por leis urbanísticas específicas, em plena conformidade com o que a doutrina há muito já afirmava. ${ }^{56}$

A discussão, contudo, tomou outros rumos a partir de voto-vista apresentado pelo Ministro Dias Toffoli. ${ }^{57}$ Mesmo considerando que a lei distrital, no caso específico, não violava o art. 182, §§ 1 을 e ${ }^{\circ}$, da Constituição Federal, o Ministro concluiu que os municípios e o Distrito Federal podem legislar sobre programas e projetos específicos de ordenamento do espaço urbano, desde que o façam "por meio de leis que sejam compatíveis com as diretrizes do plano diretor".

A conclusão do voto do Ministro Dias Toffoli gerou um interessante debate entre os Ministros, trazendo, no entanto, algumas perplexidades. O Ministro Roberto Barroso, percebendo as implicações da tese, questionou se não se estaria hierarquizando o plano diretor em relação às demais leis urbanísticas. ${ }^{58}$ Advertiu o Ministro que, se o plano diretor é aprovado sob a forma de lei em sentido formal, de acordo com a dogmática convencional, leis supervenientes, de igual hierarquia, poderiam promover alterações no plano diretor, o que, entretanto, seria excepcionado se adotada a tese proposta pelo Ministro Dias Toffoli.

Após intensa discussão, contudo, preponderou mesmo o entendimento de que as leis urbanísticas específicas hão de ser compatíveis com o plano diretor. Conforme consignou o Ministro Dias Toffoli, "[...] as outras leis têm que seguir esse instrumento básico. Do ponto de vista formal, pode ser uma lei de igual hierarquia, específica, mas, do ponto de vista material, ela tem que ser uma norma, no seu conteúdo material, que seja compatível com a política global de

\footnotetext{
${ }^{55}$ BRASIL. Supremo Tribunal Federal. Acórdão no Recurso Extraordinário n. 607.940. pp. 15-29

${ }^{56}$ GASPARINI, Diogenes. Aspectos jurídicos do plano diretor. p. 25

${ }^{57}$ BRASIL. Supremo Tribunal Federal. Acórdão no Recurso Extraordinário n. 607.940. pp. 48-52

${ }^{58}$ BRASIL. Supremo Tribunal Federal. Acórdão no Recurso Extraordinário n. 607.940. p. 54-58 
desenvolvimento de uma cidade." ${ }^{59}$

Portanto, houve acordo entre os Ministros no sentido de que, mesmo se tratando de leis municipais ou distritais de igual hierarquia, o conteúdo material do plano diretor haveria de preponderar, somente podendo ser tidas como válidas as leis específicas que com ele fossem compatíveis. Justificou-se, assim, um status jurídico-normativo diferenciado ao plano diretor, seja porque a Constituição Ihe atribuiu a condição de instrumento básico de ordenação da cidade, seja porque a ele é atribuído um processo de elaboração em que ocorre uma participação social qualificada.

É bem verdade que, na conclusão do julgamento do RE 607.940, os Ministros Edson Fachin, Ricardo Lewandowski e Marco Aurélio votaram vencidos. No entanto, tal circunstância não ocorreu porque eles estivessem em desacordo em relação à tese de repercussão geral que fora adotada, mas sim porque, quanto ao caso específico da LCD 710/2005, concluíram que ela não tinha compatibilidade com o plano diretor do DF, que não previu, como diretriz geral, qualquer possibilidade de constituição de loteamentos fechados que fragmentem o espaço urbano.

Ocorre, no entanto, que preponderou o entendimento de que não era possível, em sede extraordinária, o exame pelo STF da compatibilidade entre o plano diretor local e a lei urbanística específica, ambas normas de âmbito distrital, pois incidiria na hipótese a Súmula 280 do STF. ${ }^{60}$ Em suma, se o STF poderia afirmar em tese que as leis urbanísticas específicas devem ser compatíveis com o plano diretor, ele não poderia chegar à minúcia de fazer o confronto de compatibilidade entre o conteúdo material do plano diretor do Distrito Federal e a LCD 710/2005, pois o recurso extraordinário somente se viabiliza quando a norma jurídica tida como parâmetro de controle estiver diretamente prevista na Constituição.

\section{CONSEQUÊNCIAS JURÍDICAS DA TESE DE REPERCUSSÃO GERAL: O STATUS JURÍDICO DIFERENCIADO DO PLANO DIRETOR}

A tese de repercussão geral firmada pelo STF, analisada na seção anterior, implica significativas consequências jurídicas no que concerne ao status jurídico-normativo do plano diretor.

\footnotetext{
${ }^{59}$ BRASIL. Supremo Tribunal Federal. Acórdão no Recurso Extraordinário n. 607.940. p. 57

${ }^{60}$ BRASIL. Supremo Tribunal Federal. Súmula 280: "Por ofensa a direito local não cabe recurso extraordinário". Disponível em: < https://goo.gl/5mq8Q5>. Acesso em <19.02.2017>.
} 
Já se afirmou no presente artigo a relevância da função exercida pelo plano diretor na ordenação urbana, a qual está diretamente implicada com a materialização da função social da cidade e do direito à cidade sustentável. Também já se ressaltou que a instituição do plano diretor exige, como requisito para sua validade, uma participação social efetiva no seu processo de elaboração. Resta, portanto, esmiuçar a questão sobre o que se deve entender a respeito da tese firmada pelo STF no sentido de que as leis urbanísticas específicas devem ser compatíveis com as diretrizes do plano diretor.

O precedente do STF criou uma espécie de controle de compatibilidade. As leis urbanísticas específicas, para a sua validade, devem ser compatíveis com o plano diretor, o qual tem a função de fixar diretrizes gerais. Se o plano diretor é aprovado por meio de lei em sentido formal, seja ela complementar ou ordinária ${ }^{61}$, outras leis urbanísticas, mesmo que formalmente veiculadas na forma de lei de mesma hierarquia, não terão o condão de derrogar a lei do plano diretor. Não se aplica, no caso, os critérios convencionais de cronologia e especialidade para a resolução do problema da sucessão de leis no tempo. Há, na hipótese, uma reserva material atribuída diretamente pela Constituição.

A partir de uma leitura atenta dos argumentos que embasaram a decisão do STF no RE 607.940, verifica-se que houve basicamente a adoção de dois fundamentos que justificam essa reserva material atribuída ao plano diretor.

O primeiro é o fato de que a própria Constituição, no art. 182, caput e $\S 1$ 으, previu que o plano diretor é o instrumento básico da política de desenvolvimento e de expansão urbana, e deve ser veiculado sob a forma de lei. A ele são atribuídas as diretrizes gerais da política urbana, de modo que há uma evidente centralidade em suas disposições. Nessa perspectiva, se a política de desenvolvimento urbano pressupõe planejamento, há que se pressupor também que haja um documento que, de forma coerente e sistemática, fixe os rumos da política urbanística local. Eis a função do plano diretor.

Por outro lado, não se pode ignorar que o plano diretor, consoante fundamentos constitucional e legal já assinalados, também foi dotado de um processo de elaboração de intensa participação social. Logo, seria tornar sem qualquer efetividade essa participação social se fosse

\footnotetext{
${ }^{61}$ Observe-se que a Constituição exige apenas que o plano diretor seja aprovado por meio de lei (art. 182, § 1ㅇ). Ela não prevê que seja lei complementar ou lei ordinária, de modo que o status normativo da lei pode ser definido pela respectiva Lei Orgânica, seja lei complementar, seja lei ordinária. O que não é possível é que o plano diretor seja instituído por ato normativo diverso de lei em sentido formal.
} 
possível a alteração ou derrogação do plano diretor por qualquer lei específica que não observe tal rito procedimental.

Se for o caso, a alteração do plano diretor, como observou o Ministro Roberto Barroso ${ }^{62}$, há de observar o mesmo procedimento específico de elaboração; deve ser conferido à alteração do plano, tal como no processo originário de elaboração, a mesma exigência de ampla publicidade e de audiências públicas, com vistas à participação popular em um processo decisório aberto. É importante sublinhar esse aspecto. O plano diretor não constitui um diploma normativo imutável. Antes, ao contrário, o próprio Estatuto da Cidade prevê que ele deve ser objeto de revisão periódica. ${ }^{63} \mathrm{O}$ importante é que essa revisão, e mesmo alterações mais episódicas, contem sempre com o processo de participação social que o qualifica à condição de instrumento básico da política de desenvolvimento e de expansão urbana.

Quanto à reserva material que a tese do STF atribuiu ao plano diretor, deve-se reconhecer, não obstante, que não se trata inovação absoluta no sistema constitucional brasileiro. Há ao menos um outro caso em que leis de conteúdo específico não podem ser derrogadas por leis supervenientes de mesma hierarquia: veja-se a relação entre o plano plurianual, a lei de diretrizes orçamentárias e a lei orçamentária anual. ${ }^{64}$ Mesmo que todas essas leis se revistam do mesmo status normativo - e cronologicamente uma suceda à outra -, é da lógica do sistema que a lei de diretrizes orçamentárias há de ser compatível com o plano plurianual e, do mesmo modo, a lei orçamentária há de observar a lei de diretrizes orçamentárias.

Esse arranjo jurídico-normativo não é exclusividade brasileira. A mesma solução jurídica já foi adotada em Portugal, cujo sistema jurídico é muito similar ao brasileiro. A Constituição da República Portuguesa traz a previsão de uma categoria normativa denominada "leis de valor reforçado". ${ }^{65}$ São, em geral, leis orgânicas, lei de autorização, leis de bases, leis das grandes

\footnotetext{
${ }^{62}$ BRASIL. Supremo Tribunal Federal. Acórdão no Recurso Extraordinário n. 607.940. p. 67

${ }^{63}$ Art. 39, § 3으, do Estatuto da Cidade: "A lei que instituir o plano diretor deverá ser revista, pelo menos, a cada dez anos". (BRASIL. Lei $\mathbf{n}$. 10.257, de 10 de julho de 2001)

64 “[...] as três leis orçamentárias compõem um sistema harmônico. O plano plurianual teria como função permitir o planejamento da atividade estatal a longo prazo, enunciando prioridades e metas referentes a quatro exercícios financeiros. [...] A lei de diretrizes orçamentárias, por sua vez, destina-se a servir como preparativo para a elaboração do projeto de lei orçamentária anual, a ser realizada pelo Poder Executivo. Sua função principal é a fixação de parâmetros para a elaboração das propostas orçamentárias dos Poderes Legislativo e Judiciário, bem como do Ministério Público. [...] Por fim, a lei orçamentária anual rege concretamente a realização das despesas efetuadas pelo Estado ao longo de cada exercício financeiro." (BARROSO, Luis Roberto; MENDONÇA, Eduardo. O Sistema Constitucional Orçamentário. In: Tratado de Direito Financeiro / coordenadores Ives Gandra da Silva Martins, Gilmar Ferreira Mendes, Carlos Valder do Nascimento. São Paulo: Saraiva, 2013. pp. 239-240)

${ }^{65}$ Cf. Artigo 112, item 3: "Têm valor reforçado, além das leis orgânicas, as leis que carecem de aprovação por maioria de dois terços, bem como aquelas que, por força da Constituição, sejam pressuposto normativo necessário de outras leis ou que por outras devam ser respeitadas". (PORTUGAL. Constituição da República Portuguesa, de 2 de abril de 1976. Disponível em:
} 
opções dos planos de desenvolvimento econômico e social, entre outras.

Segundo José Joaquim Gomes Canotilho, essas leis adquirem o caráter de leis de valor reforçado pela função constitucional que desempenham. $O$ autor sugere quatro critérios de identificação (que, em verdade, podem ser tomados também como características) das leis de valor reforçado ${ }^{66}$ :

a) O critério do fundamento material de validade: "uma lei é reforçada relativamente a outra ou outras quando apresenta um conteúdo de natureza paramétrica que deve servir de pressuposto à disciplina normativa estabelecida por estes outros actos legislativos"

b) O critério da capacidade derrogatória: "Uma lei é reforçada relativamente a outra quando pode derrogar esta sem por ela ser suscetível de ser derrogada"

c) O critério da forma e especificidades procedimentais: "traduz a ideia de que uma lei tem o caráter de lei reforçada porque, nos termos constitucionais, como tal é considerada, beneficiando de forma e procedimento especiais também constitucionalmente estabelecidos"

d) O critério da parametricidade aferido por um processo judicial e fiscalização: as leis reforçadas se "beneficiam [...] de um processo de fiscalização judicial tendente a assegurar o valor paramétrico ou competencial [...] e a possibilitar a desaplicação ou eliminação de outras leis em desconformidade com elas.

Veja-se que, em conformidade com a tese firmada em repercussão geral pelo STF, pode-se atribuir aos planos diretores todas as quatro características que, segundo o modelo português descrito, são atribuídas às leis de valor reforçado.

O plano diretor possui status jurídico-normativo qualificado em razão da matéria que ele disciplina (diretrizes gerais da política de desenvolvimento e expansão urbana); ele não pode ser derrogado por outras leis urbanísticas específicas (já que estas, mesmo quando de igual hierarquia, devem ser com ele compatíveis, sob pena de invalidade); o plano diretor possui uma especificidade procedimental (tendo em vista a exigência de um processo de elaboração com participação social qualificada); e, por fim, pode-se afirmar, como decorrência das características anteriores, a possibilidade de que o controle de compatibilidade entre o plano diretor e a legislação urbanística específica possa ser realizado pelo Poder Judiciário.

\section{CONSIDERAÇÕES FINAIS}

Presentemente, ainda não é possível afirmar que há sedimentado consenso doutrinário ou

\footnotetext{
$<$ http://www.tribunalconstitucional.pt/tc/crp.html>. Acesso: <19.02.2017>

${ }^{66}$ CANOTILHO, José Joaquim. Direito Constitucional. 6. ed.rev., Coimbra: Almedina, 1993. pp. 862-863
} 
jurisprudencial relativamente às consequências que devem ser atribuídas à questão do status jurídico-normativo do plano diretor. A questão é nova e ainda não foi devidamente enfrentada. Não obstante, trata-se de questão relevante - que possui sentidas consequências jurídicas no plano urbanístico, especialmente no que diz respeito à segurança jurídica, pois afeta a própria aferição da validade de leis municipais. Portanto, a questão merece ser aprofundada pela doutrina.

A considerar o problema suscitado nesse artigo, considera-se que o precedente firmado pelo STF no RE 607.940 constitui relevante paradigma a ser considerado, pois afirma, em tese de repercussão geral, a exigência de que os programas e projetos urbanísticos específicos devem ser compatíveis com o plano diretor.

No presente estudo, procurou-se, ainda que de modo breve, examinar os fundamentos que justificam a tese do STF - conferindo relevo jurídico ao plano diretor, seja em razão da matéria que ele disciplina, seja em decorrência do processo de participação social próprio da sua elaboração -, assim como houve a proposição, inspirada em contribuição do direito português, de características e consequências jurídicas desse status normativo diferenciado.

Pretendeu-se demonstrar que, se afirma o STF que as leis urbanísticas específicas devem ser compatíveis com o plano diretor, o qual tem a função de traçar as diretrizes gerais da política de desenvolvimento e expansão urbana, conferiu-se uma reserva material a esse diploma normativo. Logo, é consequência de tal atributo o impedimento de que o plano diretor seja derrogado por leis que, mesmo que possuindo a mesma hierarquia e que tenham sido posteriormente editadas, não observem o caráter democrático que marca o seu processo de elaboração; além disso, há a possibilidade de que o Poder Judiciário, no controle da validade de leis, realize o controle de compatibilidade de leis urbanísticas específicas com o plano diretor, devendo declarar, quando for o caso, a nulidade de leis que sejam com ele incompatíveis.

\section{REFERÊNCIAS DAS FONTES CITADAS}

BARROSO, Luis Roberto; MENDONÇA, Eduardo. O Sistema Constitucional Orçamentário. In: MARTINS, Ives Gandra da Silva; MENDES, Gilmar Ferreira; NASCIMENTO, Carlos Valder do (coords.). Tratado de Direito Financeiro. São Paulo: Saraiva, 2013.

BRASIL. Constituição da República Federativa do Brasil, de 05 de outubro de 1988. Disponível em: 
<http://www.planalto.gov.br/ccivil_03/constituicao/constituicao.htm>. Acesso em: <19.02.2017>.

BRASIL. Lei n. 10.257, de 10 de julho de 2001. Disponível em:

<http://www.planalto.gov.br/ccivil_03/leis/LEIS_2001/L10257.htm>. Acesso em: <19.02.2017>.

BRASIL. Ministério Público do Distrito Federal e Territórios. Petição de Razões do Recurso

Extraordinário n. 607.940. Disponível em: <https://goo.gl/6oLKp9>. Acesso em: <19.02.2017>.

BRASIL. Presidência da República. Mensagem de Veto n. 730, de 10 de julho de 2001. Disponível em:<http://www.planalto.gov.br/ccivil_03/leis/Mensagem_Veto/2001/Mv730-01.htm> Acesso em: $<19.02 .2017>$.

BRASIL. Supremo Tribunal Federal. Acórdão de Repercussão Geral no Recurso Extraordinário n. 607.940, Plenário Virtual, Relator Ministro Ayres Britto. Brasília, 09 de dezembro de 2010.

Disponível em: <https://goo.gl/9sLbzk>. Acesso em: <19.02.2017>.

BRASIL. Supremo Tribunal Federal. Acórdão do Recurso Extraordinário n. 607.940. Relator: Min. Teori Zavascki, Tribunal Pleno. Brasília, 29 de outubro de 2015. Disponível em: <https://goo.gl/lhSoTT>. Acesso em: <19.02.2017>.

BRASIL. Supremo Tribunal Federal. Súmula 280: “Por ofensa a direito local não cabe recurso extraordinário". Disponível em: < https://goo.gl/5mq8Q5>. Acesso em <19.02.2017>.

BRASIL. Tribunal Regional Federal da 4ạ Região. Acórdão da Apelação e Reexame Necessário n. 5021653-98.2013.404.7200, Relatora Desembargadora Federal Salise Monteiro Sanchotene, Terceira Turma. Porto Alegre, 27 de maio de 2005. Disponível em: <https://goo.gl/eSj1OV>. Acesso em: $<19.02 .2017>$.

BUCCI, Maria Paula Dallari. Gestão Democrática da Cidade. In: DALLARI, Adilson Abreu; FERRAZ, Sérgio (Org.). Estatuto da Cidade: Comentários à Lei Federal 10.257/2001. 4. ed. São Paulo: Malheiros, 2014.

CÂMARA, Jacintho Arruda. Plano Diretor. In: DALLARI, Adilson Abreu; FERRAZ, Sérgio (Org.). Estatuto da Cidade: Comentários à Lei Federal 10.257/2001. 4. ed. São Paulo: Malheiros, 2014.

CANOTILHO, José Joaquim. Direito Constitucional. 6. ed., Coimbra: Almedina, 1993. 
CORREIA, Fernando Alves. Manual de Direito do Urbanismo. 4. ed., Coimbra: Almedina, 2012. DANTAS, Marcelo Buzaglo. Considerações sobre Loteamento Fechado. In: BRANDÃO, Paulo de Tarso; ESPÍRITO SANTO, Davi (coords.). SOUZA, Maria Cláudia da Silva Antunes de; JACOBSEN, Gilson (orgs.). Direito, Desenvolvimento Urbano e Meio Ambiente. Itajaí: UNIVALI, 2016. Disponível em: <http://www.univali.br/ppcj/ebook>. Acesso em 19.02.2017. pp. 199-201 DISTRITO FEDERAL. Lei Complementar Distrital n. 710, de 08 de setembro de 2005. Disponível em: <https://goo.gl/MOSI3a>. Acesso em: <19.02.2017>.

DISTRITO FEDERAL. Lei Orgânica do Distrito Federal, de 08 de junho de 1993. Disponível em: <https://goo.gl/MQ2MCN>. Acesso em: <19.02.2017>.

DISTRITO FEDERAL. Tribunal de Justiça do Distrito Federal e Territórios. Acórdão n. 310.389 na Ação Direta de Inconstitucionalidade n. 2007.00.2.006486-7. Relator Desembargador Dácio Vieira, Conselho Especial. Brasília, 15 de abril de 2008. Disponível em: <https://goo.gl/qV0Ln4> Acesso em: $<19.02 .2017>$.

DUTRA, Fábio. Plano Diretor e a proteção do meio ambiente. Revista de Direito do Tribunal de Justiça do Estado do Rio de Janeiro, Rio de Janeiro, v. 70, pp.13-22, 2007.

FERREIRA, Gabriel Luis Bonora Vidrih. Plano Diretor e Inclusão Social no Espaço Urbano. Revista de Direitos Difusos, Rio de Janeiro, v. 46, pp. 29-39, 2008.

FRANCISCO, Caramuru Afonso. Estatuto da Cidade comentado. 1. ed. São Paulo: Juarez de Oliveira, 2001.

GASPARINI, Diogenes. Aspectos jurídicos do plano diretor. In: Revista Interesse Público, Porto Alegre, v. 31, p.13-37, 2005.

GONDIM, Linda Maria de Pontes; LIMA, Martônio Mont'alverne Barreto; MOREIRA, Sandra Mara Vale. Democracia, tecnocracia e política: encontros e desencontros na elaboração do plano diretor participativo. In: Revista Interesse Público, Porto Alegre, v. 35, p.269-289, 2006.

GRAU, Eros Roberto. Direito Posto e Direito Pressuposto. 7. ed., São Paulo: Malheiros, 2008. GRAU, Eros Roberto. Ensaio e Discurso sobre a Interpretação/Aplicação do Direito. 4. ed., São Paulo: Malheiros, 2006. 
MEDAUAR, Odete. A força vinculante das diretrizes da política urbana. In: FINK, Daniel Roberto (Org.). Temas de direito urbanístico 4. São Paulo: Ministério Público do Estado de São Paulo, 2005.

MENDES, Gilmar Ferreira; COELHO, Inocêncio Mártires; BRANCO, Paulo Gustavo Gonet. Curso de Direito Constitucional. 4. ed. São Paulo: Saraiva, 2009.

MUKAI, Toshio. O Estatuto da Cidade. In: CARDOSO, José Eduardo Martins; QUEIROZ, João Eduardo Lopes; SANTOS, Márcia Walquiria Batista dos (Org.). Direito Administrativo Econômico. São Paulo: Editora Atlas, 2011.

PASOLD, Cesar Luiz. Metodologia da Pesquisa Jurídica: Teoria e Prática. 13. ed.rev. Florianópolis: Conceito Editorial, 2015.

PINHEIRO, Gabriele Araújo; RODRIGUES, Wagner de Oliveira. Direito fundamental à cidade sustentável e os dilemas do planejamento urbano no Estado Democrático de Direito. In: Revista da Faculdade de Direito da Universidade de São Paulo, São Paulo, v. 106/107, pp. 373-387, $2011 / 2012$.

PIRES, Maria Coeli Simões. A função social no direito urbanístico e na política urbana: uma nova ordem de sustentabilidade das cidades. In: PEREIRA, Flavio Henrique Unes; Dias, Maria Tereza Fonseca (Org.). Cidadania e Inclusão Social: Estudos em Homenagem à Professora Miracy Barbosa de Sousa Gustin. Belo Horizonte: Editora Fórum, pp. 377-405, 2008.

PORTUGAL. Constituição da República Portuguesa, de 2 de abril de 1976. Disponível em: <http://www.tribunalconstitucional.pt/tc/crp.html>. Acesso: <19.02.2017>

REISDORFER, Guilherme F. Dias. Definição e concretização do direito à cidade: entre direitos e deveres fundamentais. In: Revista de Direito Administrativo Contemporâneo, São Paulo, Ano 3, v. 19, p.177-197, 2015.

SANTOS, Juliana Cavalcanti dos. A função social da propriedade urbana sob o ponto de vista do Estatuto da Cidade. In: ALVIM, José Manoel de Arruda; CAMBLER, Everaldo Augusto (Org.). Estatuto da Cidade. São Paulo: Revista dos Tribunais, pp. 537-596, 2014.

SILVA, José Afonso da. Curso de Direito Constitucional Positivo. 37. ed., Malheiros: São Paulo, 2014.

SOUZA, Guilherme Carvalho e. A importância da gestão democrática das cidades para a 
formulação de políticas públicas no âmbito municipal: a criação do plano diretor. In: Revista Brasileira de Direito Municipal, Belo Horizonte, v. 12, n. 42, pp. 85-104, 2011.

SUNDFELD, Carlos Ari. O Estatuto da Cidade e suas Diretrizes Gerais. In: DALLARI, Adilson Abreu; FERRAZ, Sérgio (Org.). Estatuto da Cidade: Comentários à Lei Federal 10.257/2001. 4. ed. São Paulo: Malheiros, 2008. pp. 45-62

VIOTTO, Aline; TAVOLARI, Bianca. As disputas pela interpretação constitucional do plano diretor / Disputes over the constitutional interpretation of the master plan. In: Revista Direito e Práxis, [s.l.], v. 7, n. 14, pp. 531-566, 8 jun. 2016. Universidade de Estado do Rio de Janeiro. 


\title{
OS DESASTRES AMBIENTAIS: DICOTOMIA ENTRE OS FATORES NATURAIS E ANTROPOGÊNICOS
}

\author{
Tatiana C. dos Reis Filagrana ${ }^{1}$
}

\section{INTRODUÇÃO}

Os desastres estão presentes ao longo da evolução histórica da sociedade. Nos primórdios dos tempos, mais precisamente, no Medievo, os desastres eram caracterizados como "obras divinas", "destinos", pois Deus estaria enviando "sinais" às pessoas como forma de castigo.

Na realidade não eram analisadas todas as circunstancias em que os desastres ocorriam, a vulnerabilidade daquela determinada região, por exemplo, e o quanto aquela população estava contribuindo para a ocorrência dos mesmos.

O caso da cidade romana Pompéia, localizada nas proximidades do vulcão Vesúvio, o que atesta a vulnerabilidade da região, por estar numa área de risco expressivo, que acabou sendo soterrada pelo mesmo, em 24 de agosto de 79 d.c., em decorrência de um terremoto que cobriu a cidade inteira, bem como as cidades de Herculano e Stabia, com suas lavas vulcânicas, pedras incandescentes e poeira.

Temos, no artigo de Guerdan, Revista História Viva:

De repente, ouve-se uma explosão. Espanto! Num instante, todos estão na rua. Espetáculo alucinante, o topo do Vesúvio havia se partido em dois. Uma coluna de fogo escapa dali. É uma erupção! De início, todos se assustam e se interpelam. Havia pelo menos 900 anos que o vulcão não dava sinais de vida. Dizia-se que ele estava extinto. Logo depois é a agitação. Em volta começa a desabar uma chuva de projéteis: pedras-polmes, lapíli e, às vezes, pedaços de rochas - fragmentos arrancados do topo da montanha e da tampa de lava resfriada que obstruía a cratera. [...]

Durante todo o dia 24 e todo o dia 25, e ainda no dia 26, a chuva de cinzas não parou. Quando, enfim, na aurora do dia 27, o sol reapareceu, o Vesúvio tinha mudado de forma. Ele possuía agora um topo duplo e, no lugar da antiga cratera, um cone havia se formado. Quanto aos habitantes de

\footnotetext{
${ }^{1}$ Mestranda do Curso de Ciência Jurídica, da instituição Universidade do Vale do Itajaí - UNIVALI. Especialização em D. Processual Civil e D. Civil pela UNIASSELVI. Graduação em Direito pela Universidade Ritter dos Reis/RS (2004). Coordenadora do Curso de Pós Graduação em D. de Família e Sucessões - Uniasselvi. Autora do livro: Responsabilidade Civil em Casos de Alienação Parental. Possui artigos jurídicos na área de D. de Família publicados. . Advogada desde 2005. Professora na instituição de ensino UNIASSELVI - FAMEBLU e FAMEG (Curso de Direito). Orientadora e examinadora de Banca de Trabalho de Conclusão de Curso (Graduação).Professora no Curso de Pós Graduação em D de Família na Faculdade CESUSC (Florianópolis/SC). Participante de Congressos Jurídicos de Direito de Família, como palestrante (Brasil e Portugal). Email: filagrana32@gmail.com
} 
Pompéia, $80 \%$ deles - 16 mil numa população de 20 mil - jaziam a vários metros de profundidade. A cidade estava morta, mas uma morte que a tornaria imortal.

Assim, o objetivo dessa pesquisa é analisar de uma forma mais precisa a ocorrência dos desastres e a ligação destes com os atos praticados pela sociedade.

Salutar mencionar que os desastres não são acontecimentos novos, pelo contrário, contudo, o estudo preventivo destes ainda é precário, conseguimos apenas traçar os riscos com maior precisão quando as catástrofes já s sucederam.

Conforme menciona Carvalho ${ }^{2}$

Sempre houve catástrofes na história humana. Contudo, tais eventos vão adquirindo, na evolução social, sentidos diversos ao longo do processo histórico. No medievo, os desastres eram atribuídos, assim como os riscos, a razões divinas, estando ligados diretamente a uma ideia de destino.

Num segundo momento histórico, há o deslocamento desta semântica em direção à ideia de progresso. [...]

Um terceiro momento efetua a convergência destas racionalidades históricas para lidar com o risco dos desastres, tendo esses não apenas como fomento do medo, resultado inexorável do progresso, mas, principalmente, como fonte de ponderação para processos de tomada de decisão em contextos de racionalidade limitada.

Apresenta-se como problemática da pesquisa até que ponto os atos praticados pela sociedade influenciam na formação dos desastres, ou, se os mesmos decorrem apenas de eventos naturais, utilizando como metodologia a pesquisa qualitativa através de analise bibliográfica.

Em face desses questionamentos, o presente estudo apresenta três tópicos, iniciando com as noções introdutórias a respeito do tema escolhido para pesquisa.

No primeiro tópico, analisa-se o conceito de meio ambiente, sendo que em seus subtítulos, estão elencados os princípios basilares à pesquisa que se propõe.

No segundo tópico, faz-se um estudo pertinente à origem e características dos desastres. Os fatores que os impulsionam, aborda-se os reflexos decorrentes de fenômenos naturais e também promovidos pelas condutas lesivas da sociedade ao meio ambiente. Não deixando de apontar a vulnerabilidade referente ao local que sucedem tais desastres.

Por fim, referente ao terceiro tópico, este irá tratar a respeito dos causadores dos desastres, ou seja, o cerne da presente pesquisa. Enfrenta a discussão a respeito de quais seriam

\footnotetext{
${ }^{2}$ CARVALHO, Délton Winter de. DAMACENA, Fernanda Dalla Libera. Direito dos Desastres. Porto Alegre: Livraria do Advogado, 2013
} 
os fatores causadores dos desastres, ou seja, fatores naturais ou fatores antropogênicos.

\section{CONCEITO DE MEIO AMBIENTE}

Primeiramente, é de suma importância conceituarmos o que seria meio ambiente, tendo em vista que não podemos simplesmente afirmar que os desastres interferem para que tenhamos um meio ambiente saudável, sendo que não sabemos ao certo o seu conceito.

Ressalta-se que são inúmeros os conceitos que são atribuídos ao meio ambiente, um deles refere-se à definição do art 3ํ, I, da Lei n. 6.938/81 - Lei da Política Nacional do Meio Ambiente. ${ }^{3}$. Vejamos.

Art. 3 Para fins previstos nesta Lei, entende-se por:

I- Meio ambiente, o conjunto de condições, leis, influencias e interações d ordem física, química e biológica, que permite, abriga e rege a vida em todas suas formas.

Analisa-se que a Constituição Federal manteve o conceito trazido pela Lei n. 6.938/81, ampliando-o no sentido tutelar o meio ambiente natural e artificial. Colaciona-se.

Art. 225. Todos têm direito ao meio ambiente ecologicamente equilibrado, bem de uso comum do povo e essencial à sadia qualidade de vida, impondo-se ao Poder Público e à coletividade o dever de defendê-lo e preservá-lo para as presentes e futuras gerações.

Portanto, pondera-se que não há um conceito especifico para meio ambiente, tendo em vista que a Lei e a Constituição Federal não delimitam tal definição, mas resta claro que tudo o que nos circunda, trata-se de meio ambiente.

\subsection{Princípios do Direito Ambiental}

Os princípios tratados aqui, assim, como todos os demais princípios constituem a base de todo e qualquer ramo do Direito e, no Direito Ambiental não poderia ser diferente. No presente artigo analisaremos os princípios basilares do Direito Ambiental, atinentes à esta pesquisa.

De acordo com Amado ${ }^{4}$ os princípios são conceituados:

Os princípios são normas jurídicas que fundamentam o sistema jurídico, com maior carga de abstração, generalidade e indeterminação que as regras, não regulando situações fáticas

\footnotetext{
${ }^{3}$ FIORILLO, Celso Antônio Pacheco. Curso de direito ambiental brasileiro. 16. ed. São Paulo: Saraiva, 2015.

${ }^{4}$ AMADO, Frederico Augusto Di Trindade. Direito Ambiental Esquematizado. 7. ed. rev e atual. Rio de Janeiro: Forense; São Paulo: Método, 2016.
} 
diretamente, carecendo de intermediação para aplicação concreta. Devem ser pesados com outros princípios em cada caso concreto, à luz da ponderação casual (Princípio da Proporcionalidade).

Salutar mencionarmos o entendimento de $\mathrm{Mello}^{5}$ onde este entende que: "Os princípios jurídicos constituem o mandamento nuclear do sistema normativo, já que além de servirem de critério para a interpretação de todas as normas jurídicas eles têm a função de integrar e de harmonizar todo o ordenamento jurídico transformando-o efetivamente em um sistema."

Assim sendo, observa-se que os princípios são de suma importância no sentido de serem fontes e influenciarem a criação de outras fontes.

\subsubsection{Princípio da Prevenção}

Entende-se por prevenção o ato de prevenir os danos ambientais que poderão advir em decorrência de determinadas atividades que, fatalmente poderão ser de extrema lesividade ao meio ambiente.

O art. 225 da Carta Magna deixa claro que cabe ao Poder Público e da coletividade o dever de proteger e preservar o meio ambiente para as presentes e futuras gerações ${ }^{6}$.

No mesmo sentido, temos a Declaração Universal sobre o Meio Ambiente que já consagrou desde 1972 o princípio da prevenção ao estabelecer que "Deve-se pôr fim à descarga de substâncias tóxicas ou de outros materiais e, ainda, à liberação de calor em quantidades ou concentrações tais que o meio ambiente não tenha condições para neutralizá-las, a fim de não se causar danos graves ou irreparáveis aos ecossistemas. Deve-se apoiar a justa luta dos povos de todos os países contra a contaminação". ${ }^{7}$

Colacionamos o entendimento de Benjamim ${ }^{8}$, onde o mesmo destaca que a prevenção é mais importante do que a responsabilização do dano ambiental.

Analisa-se que o princípio da prevenção se refere à certeza cientifica, tendo em vista as atividades humanas a serem licenciadas e, principalmente seu impacto junto ao meio ambiente.

\footnotetext{
${ }^{5}$ MELLO, Celso Antônio Bandeira de. Elementos de Direito Administrativo. São Paulo: Revista dos Tribunais, 1980.

${ }^{6}$ FIORILLO, Celso Antônio Pacheco. Curso de direito ambiental brasileiro. 4. ed. São Paulo: Saraiva, 2003.

${ }^{7}$ FARIAS, Talden Queiroz. Princípios gerais do direito ambiental. Disponível em:

<http://www.ambitojuridico.com.br/site/index.php?n_link=revista_artigos_leitura\&artigo_id=1543> Acesso em 25 de fevereiro de 2017.

${ }^{8}$ BENJAMIN, Antônio Herman de Vasconcellos (coord). Dano ambiental: prevenção, reparação e repressão. São Paulo: Revista dos Tribunais, 1993
} 
Antunes $^{9}$ assevera que o princípio da prevenção é aplicado em relação aos impactos ambientais conhecidos e dos quais se possa estabelecer as medidas necessárias para prever e evitar os danos ambientais.

Destarte, analisa-se que o princípio da prevenção é um dos mais importantes do Direito Ambiental, estando presente nas legislações ambientais e na Carta Magna.

\subsubsection{Princípio da Precaução}

Salienta-se que apesar deste princípio não estar previsto de forma expressa na Carta Magna, mas o mesmo foi previsto pela primeira vez na Declaração do Rio de Janeiro sobre Meio Ambiente e Desenvolvimento que o consagrou inclusive no âmbito internacional.

Amado $^{10}$ expõe o Princípio da Precaução, de acordo com a Declaração do Rio de Janeiro:

Princípio 15 que "De modo a proteger o meio ambiente, o princípio da precaução deve ser amplamente observado pelos Estados, de acordo com suas capacidades. Quando houver ameaça de danos sérios ou irreversíveis, a ausência de absoluta certeza científica não deve ser utilizada como razão para postergar medidas eficazes e economicamente viáveis para prevenir a degradação ambiental".

Analisa-se que, ao contrário do Princípio da Prevenção, o da Precaução relaciona-se com o risco que, embora desconhecido, tem-se uma ação antecipada; já em relação ao Princípio da Prevenção há uma certeza de risco certo, inobstante ambos estarem interligados.

Acompanhando FIORILLO ${ }^{11}$, citando o entendimento de Nelson Nery Jr, temos que:

O princípio da precaução refere-se ao conteúdo e a intensidade de proteção ambiental. Significa que a política do ambiente não se limita à eliminação ou redução da poluição já existente ou iminente, mas assegura que a poluição é combatida na sua incipiência e que os recursos naturais são utilizados numa base de produção sustentada. Este princípio reveste-se de vários aspectos diferentes, tais como a manutenção da poluição a um nível tão baixo quanto possível, a redução dos materiais residuais, a proibição da deterioração significativa do ambiente, a redução dos riscos conhecidos, mas muito improváveis.

No mesmo sentido, entende Nogueira ${ }^{12}$

\footnotetext{
${ }^{9}$ ANTUNES, Paulo de Bessa. Política Nacional do Meio Ambiente - PNMA: Comentários à Lei 6.938, de 31 de agosto de 1981 . Rio de Janeiro: Lumen Juris, 2005.

${ }^{10}$ AMADO, Frederico Augusto Di Trindade. Direito Ambiental Esquematizado. 7. ed. rev e atual. Rio de Janeiro: Forense; São Paulo: Método, 2016.

${ }^{11}$ FIORILLO, Celso Antônio Pacheco. Curso de direito ambiental brasileiro. 16. ed. São Paulo: Saraiva, 2015.

${ }^{12}$ NOGUEIRA, Ana Carolina Casagrande. O conteúdo jurídico do princípio da precaução no direito ambiental brasileiro. FERREIRA, Heline Sivini; LEITE, José Rubens Morato (orgs). Estado de direito ambiental: tendências: aspectos constitucionais e diagnósticos. Rio de Janeiro: Forense Universitária, 2004, p 198.
} 
O "princípio de precaução", por sua vez, é apontado, pelos que defendem seu status de novo princípio jurídico-ambiental, como um desenvolvimento e, sobretudo, um reforço do princípio da prevenção. Seu fundamento seria, igualmente, a dificuldade ou impossibilidade de reparação da maioria dos danos ao meio ambiente, distinguindo-se do princípio da prevenção por aplicar-se especificamente às situações de incerteza científica.

Deste modo, temos que este princípio refere-se ao fato de que, mesmo não tendo a certeza de que determinada atividade irá apresentar riscos ao meio ambiente, mas devemos nos precaver, não arriscar de modo algum, eis que existe um perigo potencial, mesmo sendo este abstrato.

\subsubsection{Princípio do Poluidor - Pagador}

Caracteriza-se este princípio pelo fato de que todo o poluidor deverá arcar com os ônus de seus atos que tem como consequência a degradação do meio ambiente, compensando o dano que causou junto ao meio ambiente.

Como afirma Machado ${ }^{13}$, ao causar uma degradação ambiental o indivíduo invade a propriedade de todos os que respeitam o meio ambiente e afronta o direito alheio.

Ademais, a Declaração do Rio de Janeiro sobre Meio Ambiente e Desenvolvimento também dispôs sobre o princípio do poluidor-pagador ao estabelecer no Princípio 16 que "Tendo em vista que o poluidor deve, em princípio, arcar com o custo decorrente da poluição, as autoridades nacionais devem procurar promover a internacionalização dos custos ambientais e o uso de instrumentos econômicos, levando na devida conta o interesse público, sem distorcer o comércio e os investimentos internacionais". ${ }^{14}$

No mesmo sentido, Antunes ${ }^{15}$ “O princípio do poluidor-pagador foi introduzido pela Organização para a Cooperação e Desenvolvimento Econômico - OCDE em 26 de maio de 1972 por meio da Recomendação C (72) 128 do Conselho Diretor, que trata da relação entre as políticas ambiental e econômica."

O princípio do poluidor-pagador protege o meio ambiente no sentido de que obriga o empreendedor a incluir em seus custos os danos que sua atividade venha, porventura causar.

\footnotetext{
${ }^{13}$ MACHADO, Paulo Affonso Leme Machado. Direito ambiental brasileiro. 9. ed. São Paulo: Malheiros, 2001, p. 47

${ }^{14}$ AMADO, Frederico Augusto Di Trindade. Direito Ambiental Esquematizado. 7. ed. rev e atual. Rio de Janeiro: Forense; São Paulo: Método, 2016

${ }^{15}$ ANTUNES, Paulo de Bessa. Direito ambiental. 4. ed. Rio de Janeiro: Lumen Juris, 2000
} 


\subsubsection{Princípio da Vedação ao Retrocesso Ecológico}

Este princípio decorre do direito de que todos temos em desfrutar de um meio ambiente ecologicamente equilibrado, proibindo-se assim, o retrocesso.

Analisa-se que a Conferência das Nações Unidas sobre o Meio Ambiente Humano, consagrou por meios dos princípios 1 e 2 :

O homem tem o direito fundamental à liberdade, à igualdade e ao desfrute de condições de vida adequadas em um meio ambiente de qualidade tal que lhe permita levar uma vida digna e gozar de bem-estar, tendo a solene obrigação de proteger e melhorar o meio ambiente para as gerações presentes e futuras. A este respeito, as políticas que promovem ou perpetuam o apartheid, a segregação racial, a discriminação, a opressão colonial e outras formas de opressão e de dominação estrangeira são condenadas e devem ser eliminadas. (Princípio 1).

Os recursos naturais da terra incluídos o ar, a água, a terra, a flora e a fauna e especialmente amostras representativas dos ecossistemas naturais devem ser preservadas em benefício das gerações presentes e futuras, mediante uma cuidadosa planificação ou ordenamento (Princípio 2).

Colacionando o entendimento de Amado $^{16}$, temos que:

De acordo com este princípio, especialmente voltado ao Poder Legislativo, é defeso o recuo dos patamares legais da proteção ambiental, salvo temporariamente em situações calamitosas, pois a proteção ambiental deve ser crescente, não podendo retroagir, máxime quando os índices de poluição no Planeta Terra crescem a cada ano.

Observa-se a tamanha importância deste princípio que, inclusive o Superior Tribunal de Justiça o reconheceu, ao julgar o Recurso Especial n.302.906, de 26.08.2010, vejamos:

[...] O exercício jus variandi, para flexibilizar restrições urbanístico-ambientais contratuais, haverá de respeitar o ato jurídico perfeito e o licenciamento do empreendimento, pressuposto geral que, no Direito Urbanístico, como no Direito Ambiental, é decorrência da crescente escassez de espaços verdes e dilapidação da qualidade de vida das cidades. Por isso mesmo, submete-se ao princípio da não regressão (ou, por terminologia, princípio da proibição do não retrocesso), garantia de que os avanços urbanístico-ambientais conquistados no passado não serão diluídos, destruídos ou negados pela geração atual ou pelas seguintes [...]

Logo, de acordo com o mencionado acima, temos que o princípio da vedação ao retrocesso ecológico está intimamente ligado ao princípio da dignidade da pessoa humana, tendo em vista que o mesmo preserva a vida sadia o que importa em se ter uma vida com dignidade.

\footnotetext{
${ }^{16}$ AMADO, Frederico Augusto Di Trindade. Direito Ambiental Esquematizado. 7. ed. rev e atual. Rio de Janeiro: Forense; São Paulo: Método, 2016.
} 


\section{DESASTRES: ORIGEM E CARACTERÍSTICAS}

A sociedade tem passado por inúmeras mudanças, e, consequentemente, o desenvolvimento social acaba trazendo consigo inúmeros riscos ao meio ambiente, tendo em vista que a globalização influencia o capitalismo. E, assim, a sociedade industrial tornou-se uma sociedade de risco, onde seus efeitos colaterais são extremamente danosos ao meio ambiente.

Salutar mencionarmos que, atualmente, as leis ambientais buscam um equilíbrio ecológico, para que a sociedade tenha uma vida saudável, até porque, usufruir de um meio ambiente saudável e equilibrado é direito de todos, devendo ser preservado não somente pelo Estado, mas também pela própria sociedade.

Segundo o entendimento de Carvalho ${ }^{17}$

Assim, a sociedade atual se posiciona em uma situação de autodestruição (self-endangered). As ameaças decorrentes da sociedade industrial são de natureza tecnológica, política e, acima de tudo, ecológica. Enquanto na sociedade industrial pode-se dizer que há uma certa previsibilidade das consequências negativas dos processos produtivos capitalistas, nas sociedades de risco (que não deixa de tratar-se de uma sociedade industrial, porem potencializada pelo desenvolvimento tecnocientífico) há um incremento no grau de incerteza quanto às consequências das atividades e tecnologias empregadas nos processos econômicos. Dessa forma, essa nova estrutura social apresenta riscos transtemporais (efeitos ilimitados temporalmente), de alcance global e potencialidade catastrófica.

Importante analisar os impactos ambientais trazidos pelos desastres que são, em grande parte de difícil reparação, tendo em vista a extensão dos danos causados. Neste sentido, os desastres podem ser causados por inúmeros fatores, sejam por fenômenos da natureza: deslizamentos, enxurradas, tsunamis, erupções vulcânicas, entre outros. $E$, também por atos da própria sociedade que, agindo com total displicência às determinações legais, acabam "agredindo" o meio ambiente, gerando consequências catastróficas, como por exemplo, a poluição dos rios, os gases tóxicos das indústrias que são lançados na atmosfera, sem o menor cuidado, os derramamentos de petróleo nas aguas dos rios, dentre outros.

Pertinente às origens dos desastres pode-se verificar que os mesmos não são fatos recentes, ao contrário, sempre existiram, a diferença é que antes, os mesmos eram tratados como se fossem "castigos divinos", não era feito um estudo aprofundado a respeito de suas verdadeiras causas, como no caso da erupção do vulcão Vesúvio, que dizimou a cidade de Pompéia.

\footnotetext{
${ }^{17}$ CARVALHO, Délton Winter de. DAMACENA, Fernanda Dalla Libera. Dano Ambiental Futuro: A responsabilização civil pelo risco ambiental. 2. ed. rev, atual. e ampl. Porto Alegre: Livraria do Advogado, 2013.
} 
Cita-se alguns dos maiores desastres que ocorreram no Brasil e no mundo onde suas consequências geram reflexos até os dias de hoje. Temos: em Bophal, na madrugada do dia 03 de dezembro de 1984, onde o vazamento de Metil Isocianato da empresa da Union Carbide Corporation, fábrica de pesticidas americana instalada na Índia que matou mais de 2000 pessoas e feriu ou incapacitou mais 200.000; a contaminação radioativa em Chernobyl, oriunda da explosão do reator n. 04 da central nuclear de Chernobyl, na Ucrânia, no dia 26 de abril de 1986, pelo menos 14 países da Europa foram contaminados com o Césio 137, que foi carregado pela atmosfera; a contaminação com o Césio 137, em Goiânia, no Brasil, em 1987; o furacão Katrina, em 2005, nos Estados Unidos; vazamento de petróleo no Golfo do México, em 2010; o acidente nuclear de Fukushima, em 2011, causado por deslocamento das placas tectônicas que ensejaram ondas de até 10 metros de altura. Todas as usinas foram desligadas, contudo a de Fukushima, por uma falha no resfriamento elétrico, causou um dos maiores acidentes nucleares da história. Não podemos de forma alguma esquecermos o caso de Mariana, município de Minas Gerais, ocorrido recentemente, em 2015, onde após o rompimento de uma barragem (Fundão) da mineradora Samarco, que é controlada pela Vale e pela BHP Billiton, liberou cerca de 62 milhões de metros cúbicos de rejeitos de mineração, que eram formados, principalmente, por óxido de ferro, água e lama.

Salutar mencionarmos Carvalho ${ }^{18}$ onde o mesmo assevera:

Na Sociedade Pós-Industrial, apresentada ao mundo pela explosão do reator de Chernobyl, tem- se a normalização dos perigos, nu processo de ocultação das causalidades que envolvem os riscos abstratos. Contudo, a atualidade nos está trazendo a uma normalização das consequências daquela formatação social, isto é, está-se diante da concretização dos riscos negligenciados, numa normalização dos desastres.

Os desastres estão presentes cada vez mais em nossa vida, tendo em vista que os riscos têm aumentado muito também. A vulnerabilidade tangente à localização das cidades e o desrespeito às leis vigentes de proteção ao meio ambiente são grandes causadores desses desastres. Não podemos apenas colocar a responsabilidade nos fenômenos naturais ou, como antes eram considerados, "castigos divinos", mas sim, analisarmos o que a sociedade tem feito para a ocorrência de tais desastres.

Beck $^{19}$ cita que:

\footnotetext{
${ }^{18}$ CARVALHO, Délton Winter de. DAMACENA, Fernanda Dalla Libera. Direito dos Desastres. Porto Alegre: Livraria do Advogado, 2013

${ }^{19}$ BECK, Urlrich, De la sociedad industrial a la del riesgo: cuestiones de supervivência, estrutura social e ilustracion ecológica.
} 
As instituições da sociedade industrial desenvolvida (politica, direito, ciências da técnica, empresas industriais) dispõem de um amplo arsenal para a normalização dos perigos que não são calculáveis. Este processo de normalização dos perigos, segundo o autor, leva a uma depreciação da magnitude destes, forçando a um "anonimato casual e jurídico".

Os desastres são catástrofes que geram lesões ao meio ambiente irreparáveis ou de difícil reparação. O modelo capitalista que vivemos hoje, traz como consequência uma produção industrial em larga escala, sendo que tais empresas acabam gerando uma poluição enorme ao meio ambiente.

\section{Menciona Damacena ${ }^{20}$}

[...] a evolução tecnológica e científica da Sociedade Contemporânea ocorrida, pincipalmente, após a industrialização, desencadeia a ampliação da capacidade de intervenção do homem sobre a natureza, havendo, em quase todos os desastres denominados naturais, algum fator antropogênico. Esta situação, por evidente, ocasiona, ao direito e à teoria da responsabilidade, uma maior dificuldade do que se trata de "act of God" e o que seria decorrente de "act of Man", para fins de delimitação da previsibilidade ou não de um evento e, consequentemente, da incidência destes fenômenos como excludente de responsabilidade (especialmente civil e administrativa) de entes públicos e privados.

As alterações climáticas que estamos acompanhando, em grande parte, estão ocorrendo em decorrência desta mudança brusca de comportamento social, no sentido de que, produzindo cada dia mais, para suprir as necessidades da sociedade, não se tem uma atenção especial ao meio ambiente, à preservação do mesmo. Tais mudanças climáticas contribuem para a ocorrência de tsunamis, enchentes, dentre outras.

Magalhães ${ }^{21}$, remonta em seu artigo a seguinte afirmação, citando:

Quando o aquecimento global foi detectado, alguns cientistas ainda acreditavam que o fenômeno poderia ser causado por eventos naturais, como a erupção de vulcões, aumento ou diminuição da atividade solar e movimento dos continentes. Porém, com o avanço da ciência, ficou provado que as atividades humanas são as principais responsáveis pelas mudanças climáticas que já vêm deixando vítimas por todo o planeta. Hoje não resta dúvida. O homem é o principal responsável por este problema. E é ele que precisa encontrar soluções urgentes para evitar grandes catástrofes.

Assim, analisa-se que os desastres possuem uma vinculação tanto com os fenômenos naturais, quanto com os fatores humanos, à medida em que podemos classificá-los como desastres naturais e desastres antropogênicos. Sendo os desastres naturais, aqueles que ocorrem

\footnotetext{
Revista Occidente, n. 150, 1993, p. 28.

${ }^{20}$ DAMACENA, Fernanda Dalla Libera. Dano Ambiental Futuro: A responsabilização civil pelo risco ambiental. 2. ed. rev, atual. e ampl. Porto Alegre: Livraria do Advogado, 2013.

${ }^{21}$ GREENPEACE. Mudanças climáticas, o que são? Disponível em <http://p2-raw.greenpeace.org/brasil/greenpeace-brasil-clima/entenda/o-que-sao> Acessado em 25 de fevereiro de 2017.
} 
de acordo com os fatores naturais: geofísicos, meteorológicos, hidrológicos, climatológicos e biológicos. $^{22}$

Pertinente aos desastres antropogênicos, os mesmos são formados por fatores humanos, podemos apontar os tecnológicos e sociopolíticos. ${ }^{23}$

Preleciona Aragão ${ }^{24}$

A preponderância do caráter hibrido dos desastres decorre do fato de estes fenômenos serem designados como catástrofes muito mais pelos resultados do que por suas causas. Assim, mesmo que um evento eminentemente natural tenha desencadeado uma serie de sinistros, a dimensão da catástrofe será atingida por fatores humanos de amplificação, vulnerabilidade, agravamento ou cumulação. Assim, os riscos naturais podem potencializar os riscos antropogênicos, bem como estes detêm condições de amplificar aqueles.

Sendo assim, os desastres são consequências do complexo de fatores: naturais e antropológicos, que juntos geram as catástrofes de danos irreparáveis.

\section{OS DESASTRES AMBIENTAIS: CAUSADOS PELOS FATORES NATURAIS OU INFLUENCIADOS PELOS ATOS DA SOCIEDADE?}

Os desastres ambientais são consequências de fatores climáticos e dos riscos que a sociedade cria ao longo dos tempos. Incialmente, como já citamos, os desastres eram tidos como "obras divinas", onde os riscos estavam intrinsecamente ligados ao destino.

Observa Carvalho ${ }^{25}$, citando Luhmann:

Percebe-se assim que sempre houve catástrofes na história humana. Contudo, tais eventos vão adquirindo, na evolução social, sentidos diversos ao longo do processo histórico. No medievo os desastres eram atribuídos, assim como os riscos, a razoes divinas, estando ligados diretamente a uma ideia de destino.

E, continua o mesmo autor:

Num segundo momento histórico, há o deslocamento desta semântica em direção à ideia de progresso. A partir do iluminismo e da modernidade, os desastres passaram a consistir em eventos que servem de importante ponto de partida evolutivo, exigindo reflexões, tomadas de decisão e, acima de tudo, antecipação pelos governantes, gestores privados e população em geral. Um marco

\footnotetext{
${ }^{22}$ VOS, Femke; RODRIGUEZ, Jose; BELOW, Regina; GUHA- SAPIR, D. Annual Disaster Statiscal Review 2009: the numbersand trendes. Brussels: CRED, 2010.

${ }^{23}$ PORFIRIEV, Boris N. Definition and delineatin of desastres. In: What is a Disaster? E. L. Quarantelli (ed) New York: Routledge, 2010, p. 64.

${ }^{24}$ ARAGÃO, Alexandra. Princípio da Precaução: manual de instruções. Revista do CEDOUA. N. 22, ano XI, 2008.

${ }^{25}$ CARVALHO, Délton Winter de. DAMACENA, Fernanda Dalla Libera. Direito dos Desastres. Porto Alegre: Livraria do Advogado, 2013.
} 
histórico neste sentido consiste no terremoto que atingiu a cidade de Lisboa em 1755 que, seguido de múltiplo focos de incêndio e um tsunami, destruí a cidade lusitana inteira. Este consiste no primeiro desastre moderno, uma vez que foi a partir de sua ocorrência que, apesar de católicos e protestantes verem no destino e na mão de Deus a resposta para esta ocorrência catastrófica, durante as fases de resposta e de recuperação, os cidadãos passaram a demandar mais do governo e começaram a se ver como agentes de transformação do meio ambiente.

Os desastres ambientais estão ligados a dois fatores, de forma sistemática, naturais e antropogênicos, eis que, os primeiros trazem como causas os fenômenos climáticos, capazes de modificar o sistema ambiental, como por exemplo, terremotos, maremotos, tsunamis e vulcões. O segundo fator refere-se à interferência do homem na natureza, temos como exemplos, as contaminações químicas e desastres tecnológicos. Entretanto, podemos observar que, mesmo os desastres que ocorrem como consequência de fatores naturais, estes têm uma ligação com o fator antropogênico, à medida em que, o homem contribui para essa mudança climática que estamos vivenciando, impulsionando assim, a ocorrência dos destes ambientais.

Mas afinal, como podem ser conceituados os desastres?

Carvalho ${ }^{26}$ conceitua desastres da seguinte forma:

Os desastres consistem, conceitualmente, em cataclismo sistêmico de causas que, combinadas, adquirem consequências catastróficas. Por tal razão, o sentido de desastres ambientais (naturais e humanos) é concebido a partir da combinação entre eventos de causas e magnitudes especificas. Em outras tintas, trata-se de fenômenos compreendidos a partir de causas naturais, humanas ou mistas sucedidas por eventos de grande magnitude, irradiando danos e perdas significativas ambiental e social.

Conveniente mencionarmos que um evento natural pode ser agravado pelo fator antropogênico, à medida em que determinadas atitudes humanas, como por exemplo, a poluição dos rios, acaba potencializando os riscos, causando, por consequência desastres maiores ainda. Não se quer dizer que os desastres também não estão ligados à vulnerabilidade das regiões, mas, as condutas lesivas da sociedade amplificam seus efeitos.

Cita-se o entendimento de Aragão ${ }^{27}$ a respeito desta ampliação de efeitos dos desastres em decorrência das condutas lesivas ao meio ambiente, provocadas pela sociedade:

A preponderância do caráter hibrido dos desastres decorre do fato de estes fenômenos serem designados como catástrofes muito mais pelos resultados do que por suas causas. Assim, mesmo que um evento eminentemente natural tenha desencadeado uma serie de sinistros, a dimensão de

\footnotetext{
${ }^{26}$ CARVALHO, Délton Winter de. DAMACENA, Fernanda Dalla Libera. Direito dos Desastres. Porto Alegre: Livraria do Advogado, 2013.

${ }^{27}$ ARAGÃO, Alexandra. Princípio da Precaução: manual de instruções. Revista do CEDOUA. N. 22, ano XI, 2008.
} 
catástrofe será atingida por fatores humanos de amplificação, vulnerabilidade, agravamento ou cumulação. Assim, os riscos naturais podem ser potencializar os riscos antropogênicos, bem como estes detêm condições de amplificar aqueles.

Damacena $^{28}$ ressalta a respeito dessa dicotomia de fatores causadores dos desastres ambientais:

[..] Não obstante a relevância das distinções conceituais acima, a grande maioria dos desastres decorre de uma sinergia de fatores naturais e antropogênicos (desastres mistos ou híbridos), sem que possa ser percebida uma prevalência de um destes, mas sim uma combinação de fatores híbridos num fenômeno de grandes proporções.

Assim, podemos apontar como uma das causas dos desastres ambientais o crescimento populacional, que, não restando outra alternativa, acabam ocupando áreas de risco, desequilibrando sensivelmente o meio ambiente, deixando-o mais vulnerável. Por óbvio, que ao adentrarmos nesta questão, trava-se também uma discussão entre Direito de Moradia e Princípio da Dignidade da Pessoa Humana, eis que todos temos o direito ao meio ambiente saudável e equilibrado, e também o direito à moradia, relacionado ao Princípio da Dignidade da Pessoa Humana. Entretanto, como não será alvo de nossa pesquisa, trataremos de forma sucinta, colacionado o entendimento de Dantas, que expôs com muita propriedade a respeito desse assunto.

Manifesta-se Dantas ${ }^{29}$ a respeito:

Ocorre que a ocupação humana, com vistas a garantir uma vida digna, muitas vezes se dá com sacrifício ao meio ambiente ecologicamente equilibrado. É o que historicamente aconteceu no Brasil com a ocupação de áreas de preservação permanente como encostas, topos de morro, entorno de reservatórios de agua naturais e artificiais, entre outros.

No mesmo sentido, temos a análise de Carvalho ${ }^{30}$

As decisões de ocupação do solo também consistem em fatores de incremento dos riscos e custos decorrentes dos desastres. A ocupação de áreas de risco é um fator determinante para a ocorrência ou agravamento de um evento à condição de desastre. É a partir da ocupação de áreas especialmente vulneráveis que se tem uma intensificação das probabilidades e magnitudes de riscos de inundações, deslizamentos, terremotos, incêndios, entre outros. Este fator de agravamento de riscos catastróficos é especialmente relevante no caso brasileiro, uma vez que os desastres ambientais, cada vez mais constantes no País, apresentam relação direta com a ocupação irregular de áreas de preservação permanente - APP (vegetação em topo e encostas de morros, nas margens

\footnotetext{
${ }^{28}$ DAMACENA, Fernanda Dalla Libera. Dano Ambiental Futuro: A responsabilização civil pelo risco ambiental. 2. ed. rev, atual. e ampl. Porto Alegre: Livraria do Advogado, 2013.

${ }^{29}$ DANTAS, Marcelo Buzaglo. Direito Ambiental de Conflitos: o direito ao meio ambiente ecologicamente equilibrado e os casos de colisão com outros direitos fundamentais. Rio de Janeiro: Lumen Juris, 2015

${ }^{30}$ CARVALHO, Délton Winter de. DAMACENA, Fernanda Dalla Libera. Direito dos Desastres. Porto Alegre: Livraria do Advogado, 2013
} 
dos rios, lagos e lagoas artificiais etc.). Neste sentido, os deslizamentos ocorridos no vale do rio Itajaí em 2008 e na zona serrana do Rio de Janeiro em 2011 têm ligação importante, porém não exclusiva, com o estado de conservação da vegetação natural nos topos dos morros, nas encostas e mesmo nos sopés.

As mudanças climáticas também contribuem para ampliar os riscos, envolvendo a ocorrência de desastres. Entretanto, neste ponto temos que há uma influência antropogênica bastante considerável, tendo em vista os gases emitidos na atmosfera pelas indústrias contribuem e muito para o aquecimento global, gerando mais riscos ao meio ambiente.

Seguimos o entendimento de Guiddens ${ }^{31}$ a respeito, a emissão desses gases produzidos, em parte pela indústria moderna, causa o aquecimento da Terra, com consequências devastadoras para o futuro.

Assim, temos que, os desastres ambientais não são somente consequências de fenômenos naturais, mas sim, da dicotomia entre fenômenos naturais e fenômenos antropogênicos, eis que a sociedade acaba contribuindo para a geração e riscos à formação dos desastres. O crescimento populacional é um problema ao equilíbrio do meio ambiente, pois as pessoas acabam, sem ter outra alternativa, construindo suas residências em lugares impróprios para moradia, outrossim, temos a emissão de gases poluentes na atmosfera que desequilibra e muito o clima da Terra, causando chuvas, consequentemente desmoronamentos e assim, por diante, aliado à vulnerabilidade da região gerando riscos consideráveis, capazes de gerar desastres ao meio ambiente.

A responsabilidade pelos desastres é do Estado, eis que tem o dever de informar e fiscalizar as condutas lesivas praticadas contra o meio ambiente, conforme preconiza a Carta Magna, mas também é dever da sociedade proteger o meio ambiente para si e para as gerações futuras.

Todos temos o direito ao meio ambiente equilibrado e o Estado tem o dever de proporcionar tal direito e nós como sociedade, pensarmos no dia de amanhã. Como queremos viver em nosso Planeta?

\section{CONSIDERAÇÕES FINAIS}

O presente trabalho teve como objetivo fazer uma análise a respeito dos desastres ambientais, ou seja, se os mesmos seriam consequências predominantemente, de fatores naturais

\footnotetext{
${ }^{31}$ GUIDEDENS, Anthony. The Politics of Climate Change. Cambridge: Polity Press, 2009.
} 
ou se as condutas da sociedade também seriam tão lesivas a ponto de tornarem-se causas dos desastres, ou seja, os fatores antropogênicos.

Para essa análise foram pesquisados os entendimentos de inúmeros autores, para que se tivesse um aprofundamento maior a respeito do tema.

O meio ambiente equilibrado e saudável é um direito de toda a sociedade, contudo, essa mesma sociedade, em dado momento acaba praticando atos que lesam o meio ambiente, gerando enormes desastres. Quanto mais graves as condutas lesivas, maiores os riscos ao meio ambiente e, consequentemente, mais graves os desastres.

A potencialização dos riscos gerando desastres ambientais consistem: nas condições econômicas modernas; no crescimento populacional e tendência demográfica; decisões acerca da ocupação do solo; infraestrutura verde e construída e mudanças climáticas. ${ }^{32}$

Pertinente à responsabilidade é de suma importância mencionarmos que, em decorrência da dicotomia existente entre os fatores naturais e antropogênicos, causadores dos desastres, temos que a sociedade é responsável pelas condutas lesivas que praticam ao meio ambiente, bem como o Estado, eis que tem o dever de fiscalizar e, se assim, não o faz, também é responsável por omissão.

Porém, o ponto principal deste trabalho é identificar os fatores causadores dos desastres o que concluímos que não existe apenas um fator causador, mas um conjunto de fatores, sendo um deles consequência do outro, ou seja, as mudanças climáticas são mais constantes à medida em que a sociedade pratica mais condutas lesivas ao meio ambiente, criando mais riscos.

\section{REFERÊNCIAS DAS FONTES CITADAS}

AMADO, Frederico Augusto Di Trindade. Direito Ambiental Esquematizado. 7. ed. rev e atual. Rio de Janeiro: Forense; São Paulo: Método, 2016.

ANTUNES, Paulo de Bessa. Direito ambiental. 4. ed. Rio de Janeiro: Lumen Juris, 2000.

. Política Nacional do Meio Ambiente - PNMA: Comentários à Lei 6.938, de 31 de agosto de 1981. Rio de Janeiro: Lumen Juris, 2005.

ARAGÃO, Alexandra. Princípio da Precaução: manual de instruções. Revista do CEDOUA. N. 22,

${ }^{32}$ FARBER, Daniel; CHEN, Jim, VERCHICK, Robert R.M.; SUN, Lisa Grow. Disaster Law and Policy. New York: Aspen Publishers, 2010 
ano XI, 2008.

BECK, Urlrich, De la sociedad industrial a la del riesgo: cuestiones de supervivência, estrutura social e ilustracion ecológica. Revista Occidente, n. 150, 1993, p. 28.

BENJAMIN, Antônio Herman de Vasconcellos (coord). Dano ambiental: prevenção, reparação e repressão. São Paulo: Revista dos Tribunais, 1993.

CARVALHO, Délton Winter de. DAMACENA, Fernanda Dalla Libera. Direito dos Desastres. Porto Alegre: Livraria do Advogado, 2013.

. Dano Ambiental Futuro: A responsabilização civil pelo risco ambiental. 2. ed. rev, atual. e ampl. Porto Alegre: Livraria do Advogado, 2013.

DANTAS, Marcelo Buzaglo. Direito Ambiental de Conflitos: o direito ao meio ambiente ecologicamente equilibrado e os casos de colisão com outros direitos fundamentais. Rio de Janeiro: Lumen Juris, 2015.

FARBER, Daniel; CHEN, Jim, VERCHICK, Robert R.M.; SUN, Lisa Grow. Disaster Law and Policy. New York: Aspen Publishers, 2010.

FARIAS, Talden Queiroz. Princípios gerais do direito ambiental. Disponível em:

<http://www.ambitojuridico.com.br/site/index.php?n_link=revista_artigos_leitura\&artigo_id=154 3> Acesso em 25 de fevereiro de 2017.

FIORILLO, Celso Antônio Pacheco. Curso de direito ambiental brasileiro. 4. ed. São Paulo: Saraiva, 2003.

Curso de direito ambiental brasileiro. 16. ed. São Paulo: Saraiva, 2015.

GUERDAN, René. A Tragédia de Pompéia. Revista História Viva, São Paulo. Disponível em:

<http://www2.uol.com.br/historiaviva/reportagens/a_tragedia_de_pompeia.html>. Acesso em 25 de fevereiro de 2017.

GUIDEDENS, Anthony. The Politics of Climate Change. Cambridge: Polity Press, 2009.

GREENPEACE. Mudanças climáticas, o que são? Disponível em

<http://p2-raw.greenpeace.org/brasil/greenpeace-brasil-clima/entenda/o-que-sao> Acessado em 25 de fevereiro de 2017. 
LUHMANN, Niklas. Risk: a sociological theory. New Jersey: Aldine transaction, 2008, p. 8 e segs. MACHADO, Paulo Affonso Leme Machado. Direito ambiental brasileiro. 9. ed. São Paulo: Malheiros, 2001, p. 47.

MAGALHÃES, Gregory Ferreira. Catástrofes climáticas mundiais. Contraindicações das ações humanas ou ordem natural? Disponível em:

<http://www.ambitojuridico.com.br/site/index.php?n_link=revista_artigos_leitura\&artigo_id=489 0>. Acesso em 25 de fevereiro de 2017.

MELLO, Celso Antônio Bandeira de. Elementos de Direito Administrativo. São Paulo: Revista dos Tribunais, 1980.

MUKAI, Toshio. Direito ambiental sistematizado. 10. ed. rev e atual. Rio de Janeiro: Forense, 2016.

NOGUEIRA, Ana Carolina Casagrande. O conteúdo jurídico do princípio da precaução no direito ambiental brasileiro. FERREIRA, Heline Sivini; LEITE, José Rubens Morato (orgs). Estado de direito ambiental: tendências: aspectos constitucionais e diagnósticos. Rio de Janeiro: Forense Universitária, 2004, p 198.

PORFIRIEV, Boris N. Definition and delineatin of desastres. In: What is a Disaster? E. L. Quarantelli (ed) New York: Routledge, 2010, p. 64.

VOS, Femke; RODRIGUEZ, Jose; BELOW, Regina; GUHA- SAPIR, D. Annual Disaster Statiscal Review 2009: the numbersand trendes. Brussels: CRED, 2010. 


\title{
SISTEMAS URBANOS DE DRENAGEM SUSTENTÁVEL COMO ALTERNATIVAS DE CONTROLE DE INUNDAÇÕES
}

\author{
Ximena Cardozo Ferreira ${ }^{1}$
}

\section{INTRODUÇÃO}

O tema do controle de inundações, em que pese bastante recorrente nos cenários europeu e norte-americano, encontra ainda escasso desenvolvimento no Brasil, cujo ordenamento jurídico não conta com disposições específicas, sendo necessário recorrer aos aportes da legislação setorial esparsa ${ }^{2}$.

Diante disso, tampouco são muito desenvolvidas por aqui as alternativas para enfrentamento do problema das inundações, centrando-se nelas o objeto do presente artigo.

Seu objetivo, circunscrito aos limites editoriais, é apresentar uma visão geral de algumas tipologias mais conhecidas e utilizadas ao redor do mundo do que aqui chamaremos de Sistemas Urbanos de Drenagem Sustentável (SUDS), apontando para sua possível contribuição à sustentabilidade das cidades.

Quanto à metodologia empregada, registra-se que foi utilizado o método indutivo e as técnicas do referente, do conceito operacional e da pesquisa bibliográfica ${ }^{3}$.

\section{INSTRUMENTOS DE CONTROLE DE INUNDAÇÕES}

\subsection{Medidas estruturais e não estruturais}

Uma adequada gestão do risco de inundações pressupõe a utilização de um conjunto de medidas de naturezas diversas para o enfrentamento das causas e dos agravantes das inundações.

De fato, nessa seara não há solução única possível, haja vista que nenhuma das alternativas

\footnotetext{
${ }^{1}$ Mestre em Derecho Ambiental y de la Sostenibilidad pela Universidade de Alicante (Espanha). Mestranda em Ciência Jurídica pela UNIVALI (Itajaí/SC). Especialista em Direito Ambiental Nacional e Internacional pela Universidade Federal do Rio Grande do Sul (UFRGS).Promotora de Justiça do Estado do Rio Grande do Sul. E-mail: xiferreira76@gmail.com

${ }^{2}$ Cujo aporte mais expressivo e recente é o da Lei da Política Nacional de Proteção e Defesa Civil.

${ }^{3}$ PASOLD, Cesar Luiz. Metodologia da pesquisa jurídica: teoria e prática. 13 ed. Florianópolis: Conceito Editorial, 2015.
} 
existentes tem o condão de, por si só, solucionar o problema das inundações. Pelo contrário: somente a associação de diversas medidas, tanto de natureza estrutural como não estrutural pode oferecer um bom resultado na seara do controle dos riscos.

\section{Safira De La Sala e Eliane Guaraldo ${ }^{4}$ precisam os conceitos:}

As medidas estruturais intensivas são as que se referem a alterações que modificam diretamente os corpos d'água, como retificações e canalizações; já as medidas estruturais extensivas afetam o sistema hidrológico como um todo, sem constituir intervenções diretas sobre os corpos d'água - por exemplo, através da captação da água de chuva, criação de áreas verdes e a utilização de pisos permeáveis.

As medidas não estruturais, por sua vez, referem-se àquelas medidas onde "o homem busca uma convivência harmônica com o rio, através da elaboração de planos de uso e ocupação e zoneamentos de áreas de risco à inundação, sistemas de alerta e seguros-enchente" (Botelho, 2011, p. 94), que, perceba-se, dizem respeito aos diferentes momentos de gestão de desastres (prevenção, durante e pós-desastres). ${ }^{5}$

\subsection{Medidas estruturais intensivas e extensivas}

A figura abaixo registra alguns exemplos de utilização de medidas estruturais para controle de inundações:

Figura 1 - Exemplos de medidas estruturais (extensivas e intensivas)

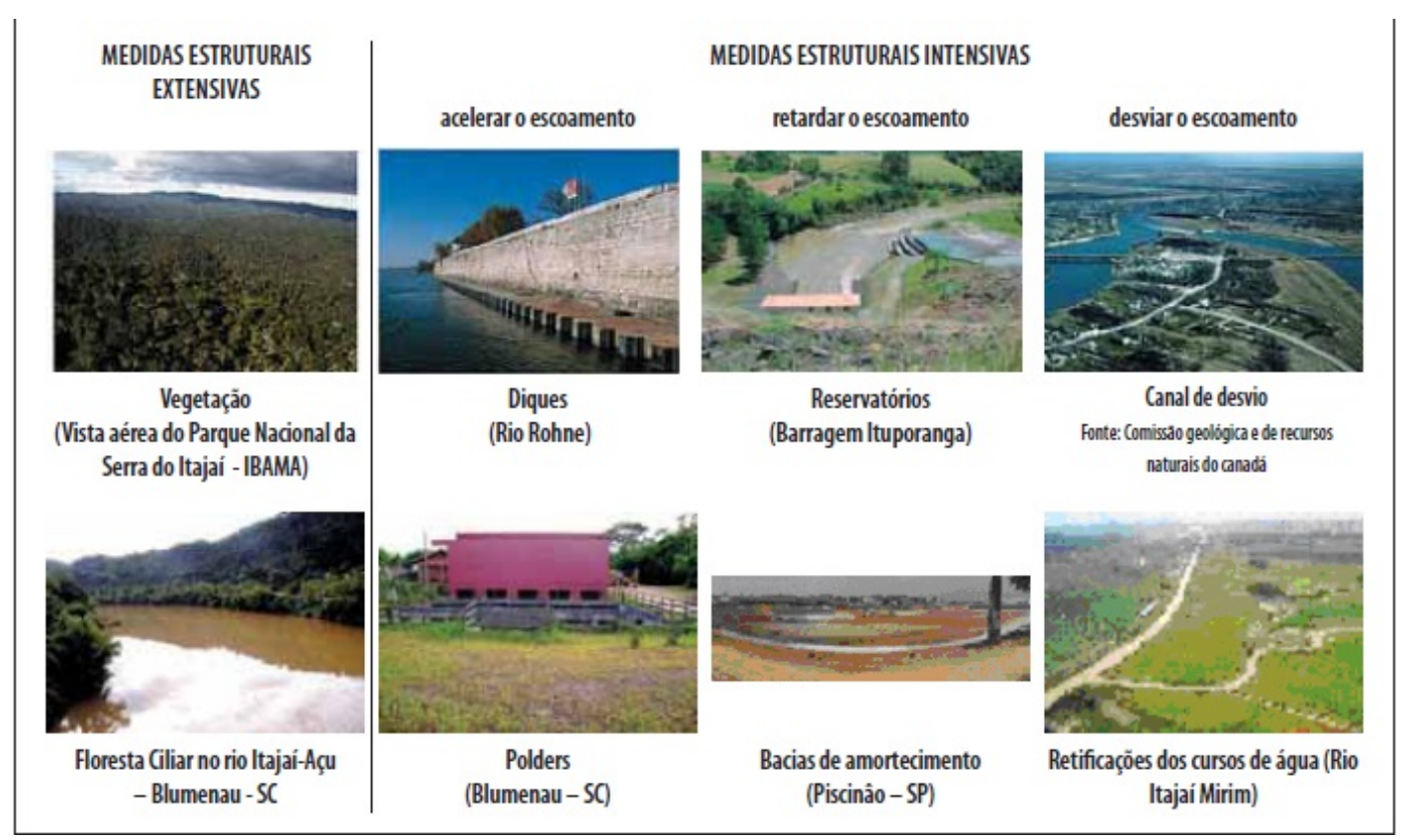

\footnotetext{
${ }^{4}$ Na página 363 do artigo "Planos Diretores de Redução de Risco de Desastres: Comentários ao art. 42-A do Estatuto da Cidade", publicado na Revista de Direito Ambiental, vol. 75, Jul - Set /2014, pp. 355 - 372.

${ }^{5}$ A referência, segundo a bibliografia citada pelas autoras, diz respeito a BOTELHO, R. G. M. Bacias hidrográficas urbanas. In: GUERRA, A. J. T. (org.) Geomorfologia urbana. Rio de Janeiro: Bertran Brasil, 2011. pp. 71-115.
} 
(Fonte: PINHEIRO, Adilson. Enchente e Inundação ${ }^{6}$ )

Tucci distingue as medidas que podem ser adotadas para controle das inundações entre medidas através das quais o homem "modifica o rio" ${ }^{7}$ e outras com as quais ele "convive com o rio":

As medidas de controle de inundações podem ser classificadas em estruturais, quando o homem modifica o rio, e em não-estruturais, quando o homem convive com o rio. No primeiro caso, estão as medidas de controle através de obras hidráulicas, tais como barragens, diques e canalização, entre outras. No segundo caso, encontram-se medidas do tipo preventivo, tais como zoneamento de áreas de inundação, alerta e seguros. ${ }^{8}$

No presente artigo serão analisadas algumas tipologias de medidas estruturais, notadamente as chamadas extensivas que - ao invés de atuar diretamente nos cursos d'água agem em nível de bacia hidrográfica, interferindo de alguma forma no ciclo hidrológico. Nesse mote, elegemos os inovadores Sistemas Urbanos de Drenagem Sustentável como alternativas ao enfrentamento do problema das inundações.

\section{SISTEMAS URBANOS DE DRENAGEM SUSTENTÁVEL}

Ao longo das últimas décadas - notadamente na Europa e nos Estados Unidos - vêm sendo desenvolvidos estudos acerca do que se convencionou chamar "sistemas urbanos de drenagem sustentável" ${ }^{9}$ - ou SUDS, como doravante os denominaremos.

A urbanização ${ }^{10}$ impermeabiliza o solo, reduzindo a capacidade de infiltração da água e aumentando o volume e a velocidade de escoamento, sobrecarregando os sistemas tradicionais de drenagem e ocasionando o aumento da temperatura ambiente.

Assim, a filosofia dos SUDS é justamente reproduzir, da forma mais fiel possível, o ciclo hidrológico natural anterior à ação antrópica: a ideia é minimizar os impactos da urbanização

\footnotetext{
${ }^{6}$ In: SANTOS, Rozely Ferreira dos. (org.). Vulnerabilidade Ambiental - Desastres naturais ou fenômenos induzidos? Brasília: MMA, 2007. p. 102

${ }^{7}$ Quando o especialista refere que as medidas estruturais "modificam o rio", está seguramente se referindo a medidas estruturais intensivas.

${ }^{8}$ Em capítulo de livro denominado "Inundações Urbanas", p. 20. Disponível em: <http://4ccr.pgr.mpf.mp.br/institucional/gruposde-trabalho/encerrados/residuos/documentos-diversos/outros_documentos_tecnicos/curso-gestao-do-terrimorio-e-manejointegrado-das-aguas-urbanas/drenagem1.PDF>. Acesso em: 29 dez. 2016.

${ }^{9} \mathrm{Na}$ Espanha é usada a expressão sistemas urbanos de drenaje sostenible (SUDs), aqui adotada, enquanto que em outros locais os mesmos equipamentos se denominam BMPs (Best Management Practices) ou WSUD (Water Sensitive Urban Design), entre outras acepções.

${ }^{10}$ Que contempla mais de $80 \%$ dos brasileiros atualmente.
} 
tanto no que concerne à qualidade quanto à quantidade do escoamento. Mas não apenas para isso servem os SUDS: como veremos, os sistemas tem a dupla função de reduzir os riscos associados ao impacto das águas e, ao mesmo tempo, promover integração paisagística (com valores sociais e ambientais, portanto).

Os objetivos dos SUDS podem ser assim elencados ${ }^{11}$ :

- Proteger los sistemas naturales: proteger y mejorar el ciclo del agua en entornos urbanos.

- Integrar el tratamiento de las aguas de lluvia en el paisaje: maximizar el servicio al ciudadano mejorando el paisaje con la integración de cursos y/o láminas de agua en el entorno.

- Proteger la calidad del agua: proteger la calidad de las aguas receptoras de escorrentías urbanas.

- Reducir volúmenes de escorrentía y caudales punta: reducir caudales punta procedentes de zonas urbanizadas mediante elementos de retención y minimizando áreas impermeables.

- Incrementar el valor añadido minimizando costes: minimizar el coste de las infraestructuras de drenaje al mismo tiempo que aumenta el valor del entorno.

A estes objetivos se poderia acrescentar o da preservação dos sistemas de drenagem tradicionais, haja vista que a redução do escoamento, com a retenção de águas através de outras estruturas, evita a sobrecarga do sistema instalado (em regra geral subdimensionado).

Pode ser esperado, ademais, um impacto positivo em estações de tratamento de efluentes porventura existentes, haja vista que a implantação de SUDS pressupõe a redução do carregamento de poluentes, ínsito ao escoamento superficial ${ }^{12}$.

De fato, esclarece Arturo Trapote Jaume ${ }^{13}$ que em períodos de tempo seco, diversos contaminantes vão se acumulando em pavimentos e nos telhados (sedimentos, matéria orgânica, nutrientes, microrganismos patogênicos, metais entre outros). Com a chuva, são arrastados pelo escoamento superficial até a rede de drenagem e - direta ou indiretamente - acabam chegando aos cursos hídricos. Os impactos negativos dessas descargas nos corpos hídricos são importantes: diminuição do oxigênio dissolvido (risco de mortalidade de espécies aquáticas), aumento de

\footnotetext{
${ }^{11}$ Como fazem PERALES MOMPARLER, S. e ANDRÉS-DOMÉNECH, I. no artigo LOS SISTEMAS URBANOS DE DRENAJE SOSTENIBLE: UNA ALTERNATIVA A LA GESTIÓN DEL AGUA DE LLUVIA, p. 4. Disponível em: <http://ovacen.com/wpcontent/uploads/2015/05/gestion-del-agua-en-el-planeamiento.pdf> Acesso em: 4 jul. 2016.

${ }^{12}$ No Brasil, atualmente, muito pouco ou nada se fala sobre a questão da contaminação das águas: o escoamento superficial é visto como problema relacionado a alagamentos e inundações (no que concerne a quantidade de água, portanto), mas ainda não é visto como fator contaminante. Na Europa, entretanto, o tema já é tratado de forma ampla, como se vê da Diretiva Marco de Água e da implantação de SUDS que tem por objetivo primordial a manutenção da qualidade das águas.

${ }^{13}$ TRAPOTE JAUME, Arturo. SISTEMAS URBANOS DE DRENAJE SOSTENIBLE (SUDS): IMPLICACIONES HIDROLÓGICO-HIDRÁULICAS Y AMBIENTALES. In: BRANDÃO, P. T.; ESPÍRITO SANTO, D. (coord.); SOUZA, M. C. S. A.; JACOBSEN, G. (org.). Direito, desenvolvimento urbano e meio ambiente [recurso eletrônico]. Itajaí: UNIVALI, 2016. pp.115-137. Disponível em: $\langle$ www.univali/ppcj/ebook>. Acesso em: 4 jan. 2017.
} 
nutrientes (risco de eutrofização), contaminação por patogênicos e elementos tóxicos (riscos à saúde e à cadeia trófica), bem como o aumento dos custos de tratamento da água.

A principal característica dos SUDS, contudo, reside na infiltração: através da promoção ou maximização da captação da água da chuva é possível reter na origem (evitando ou reduzindo o escoamento superficial) e também preservar a qualidade das águas. Nos últimos anos, portanto, inúmeros sistemas vêm sendo aplicados no mundo (notadamente em países da Europa, nos Estados Unidos, no Japão e na Austrália) visando justamente o aumento da capacidade de infiltração da água da chuva.

O Grupo de Investigação de Tecnologia da Construção da Escola de Caminhos, Canais e Portos de Santander (GITECO), da Universidade de Cantábria/Espanha ${ }^{14}$, divide os SUDS segundo suas características em:

Sistemas de infiltración o control en origen:

- Superficies permeables

- Pozos y zanjas de infiltración

- Depósitos de infiltración

Sistemas de transporte permeable

- Drenes filtrantes o drenes franceses

- Cunetas verdes

- Franjas filtrantes

Sistemas de tratamiento pasivo

- Depósitos de detención

- Estanques de retención

- Humedales artificiales

Apresentaremos, a seguir, breve identificação15 das tipologias de SUDS conhecidas e em utilização, aportando exemplos ilustrativos.

\subsection{Telhados e terraços verdes ${ }^{16}$}

\footnotetext{
${ }^{14}$ Artigo SISTEMAS URBANOS DE DRENAJE SOSTENIBLE. SUDS, p. 11. Disponível em: <http://docplayer.es/11160333-Sistemasurbanos-de-drenaje-sostenible-suds.html>. Acesso em: 5 jul. 2016.

${ }^{15}$ Descrições extraídas de MOMPARLER, S. P. e ANDRÉS-DOMÉNECH, I. LOS SISTEMAS URBANOS..., p. 6-8. Os nomes atribuídos às tipologias receberam tradução livre da autora ou, no caso do item 2.1, optou-se pela denominação pela qual a tipologia é conhecida e utilizada no Brasil.

${ }^{16}$ Essa é uma tipologia de SUDS que se encontra em utilização - de forma bastante pontual - no Brasil, aliada ao uso - também
} 
Sistemas com cobertura vegetal que são aplicáveis a telhados e terraços, de forma a interceptar e reter as águas pluviais, reduzindo o volume de escoamento. Também tem a função de retenção de contaminantes e funcionam como isolante térmico, compensando o efeito de "ilha de calor" decorrente da urbanização.

Figura 2 - Componentes de telhados e terraços verdes

\section{Componentes do telhado verde}

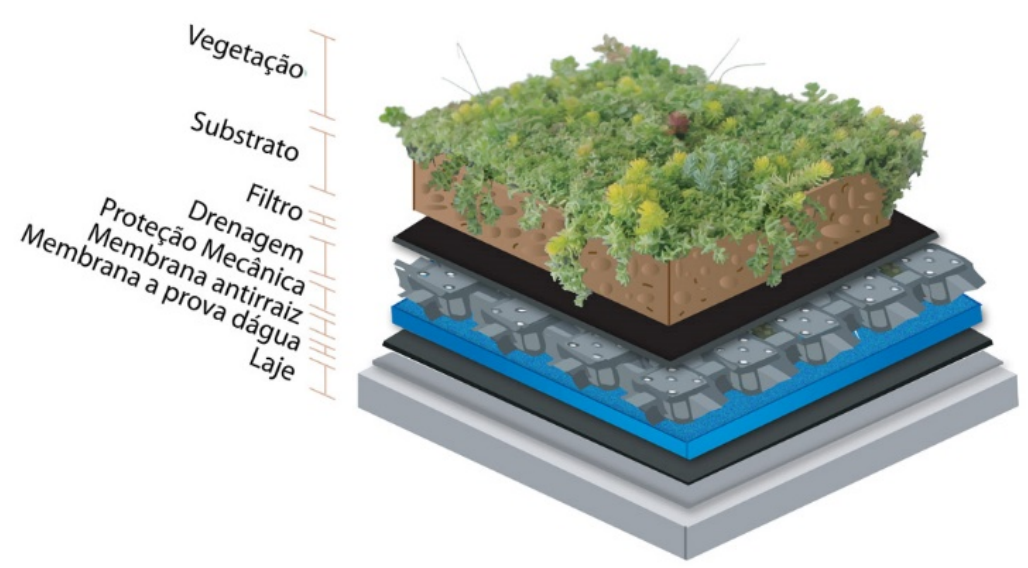

(Fonte: Internet ${ }^{17}$ )

Figura 3 - Fotografias de exemplos de terraços e telhados verdes (Chicago, Estados Unidos)

pontual - de pisos permeáveis em estacionamentos. Além dessas poderíamos citar a construção de "piscinões" (reservatórios de retenção de água) como em Santo André/SP. Vide ZUFFO, A. C. Vulnerabilidade Ambiental..., p. 120.

${ }^{17}$ Disponível em: <http://2030studio.com/wp-content/uploads/2015/02/telhado-verde-camadas2.jpg>. Acesso em: 4 jul. 2016. 

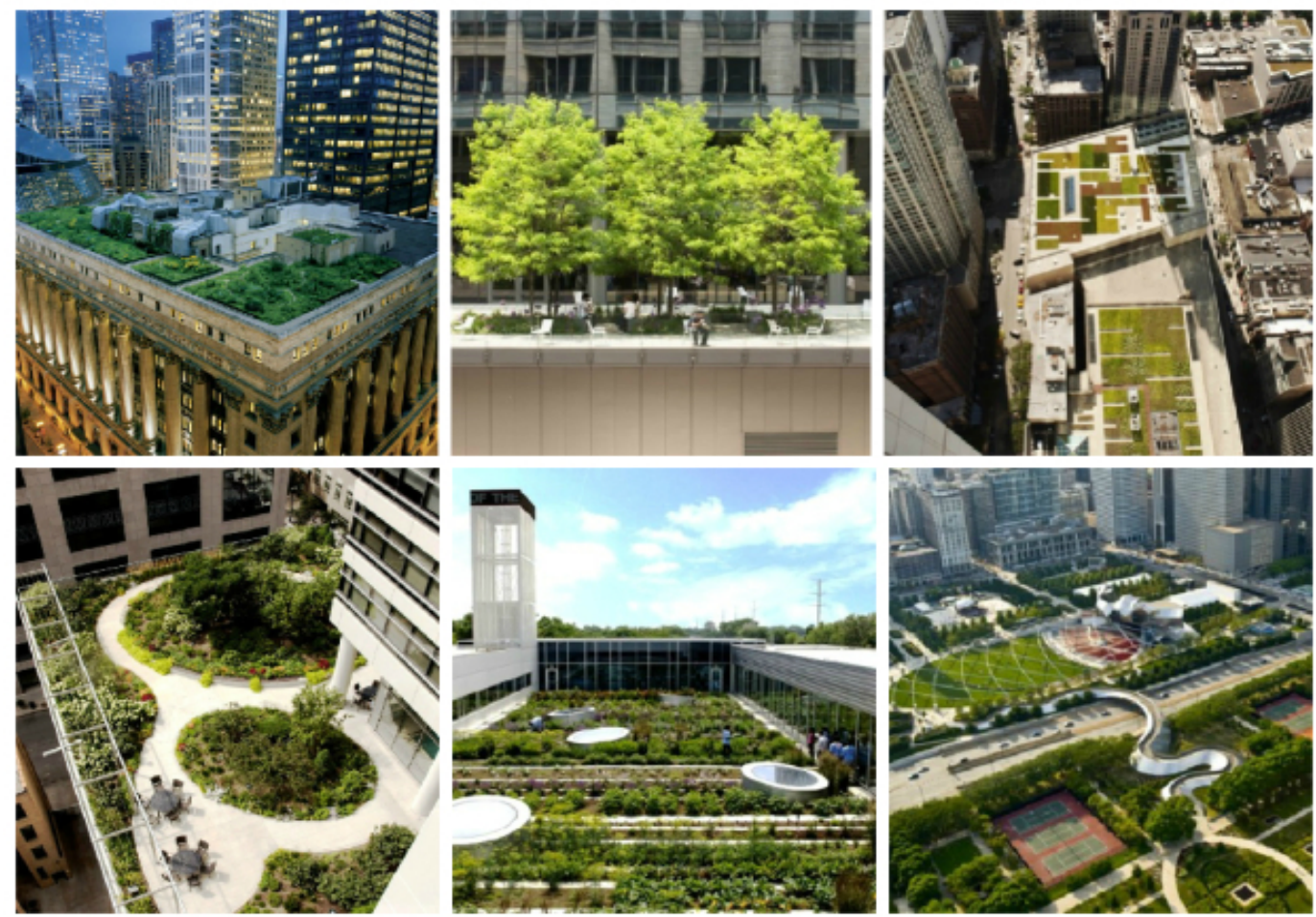

(Fonte: Internet ${ }^{18}$ )

\subsection{Superfícies permeáveis}

São obtidas através da implantação de pavimentos que permitem a infiltração de água ou mesmo a captação de água para posterior reutilização ou evacuação. Os mais conhecidos no Brasil são os chamados "bloquetos", que formam os pisos intertravados. Nestes, a água pode infiltrar pelas juntas ou mesmo pela presença de gramíneas, conforme o modelo aplicado.

Figura 4 - Fotografias de superfícies permeáveis com pisos intertravados

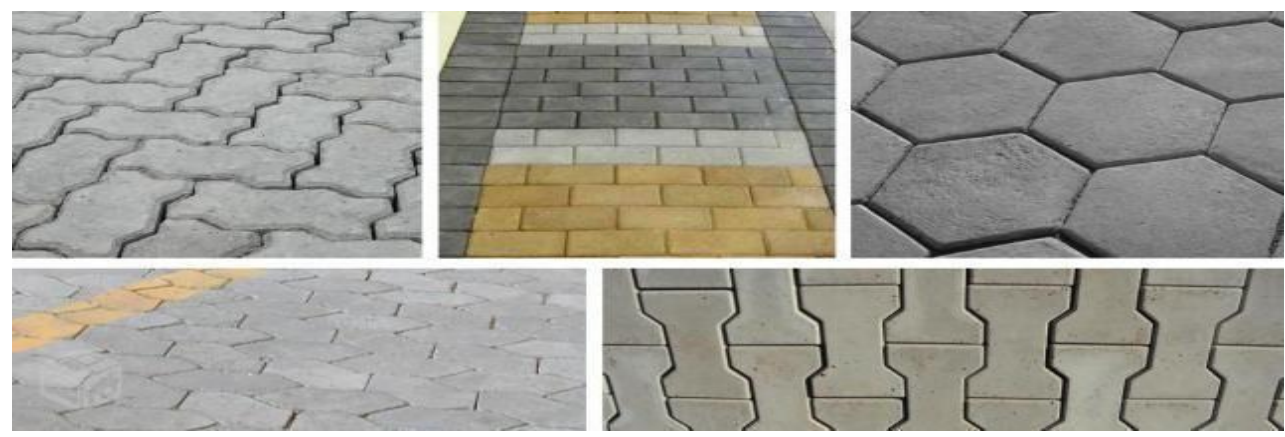

(Fonte: Internet ${ }^{19}$ )

\footnotetext{
${ }^{18}$ Disponível em: <http://sustentarqui.com.br/wp-content/uploads/2015/08/telhados-verdes-em-chigaco-624x468.jpg>. Acesso em: 4 jul. 2016.

${ }^{19}$ Disponível em: <http://img.olx.com.br/images/22/223528027055348.jpg>. Acesso em: 4 jul. 2016.
} 
Figura 12 - Fotografias de superfície permeável de piso intertravado com gramíneas

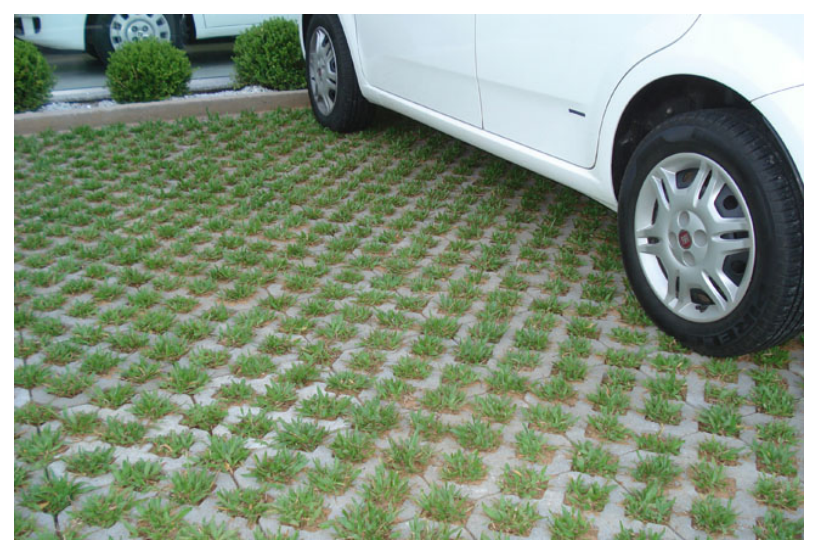

(Fonte: Internet ${ }^{20}$ )

\subsection{Faixas ou tiras filtrantes}

Faixas de solo cobertas com vegetação, de largura variável e com pequena inclinação. São instaladas entre uma superfície impermeável e o meio receptor do escoamento (curso d'água ou rede de drenagem). Permitem, além da infiltração e a consequente redução do escoamento, a sedimentação das partículas contaminantes.

\section{Figura 5 - Fotografia de faixa filtrante contígua a uma rodovia}

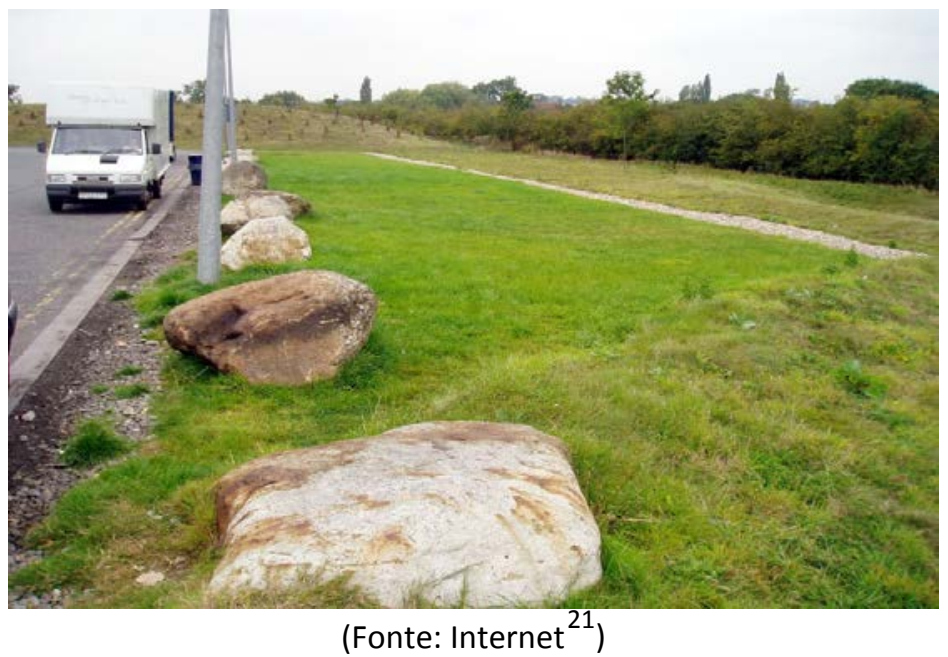

\subsection{Poços ou valas de infiltração}

Poços e valas pouco profundos (1 a $3 \mathrm{~m}$ ) recheados de material filtrante, que receberão o escoamento superficial ocorrido em áreas contíguas impermeabilizadas. A concepção técnica deve prever a completa absorção do escoamento gerado por um temporal, por exemplo.

\footnotetext{
${ }^{20}$ Disponível em: <http://ecodhome.com.br/blog/wp-content/uploads/produtos_8_4.jpg>. Acesso em: 4 jul. 2016.

${ }^{21}$ Disponível em: <http://drenajeurbanosostenible.org/wp-content/gallery/franjas-filtrantes/c-7_-_filtration_-_filter_strips.jpg>. Acesso em: 4 jul. 2016.
} 


\section{Figura 6 - Esquema de poço e fotografia de vala de infiltração}

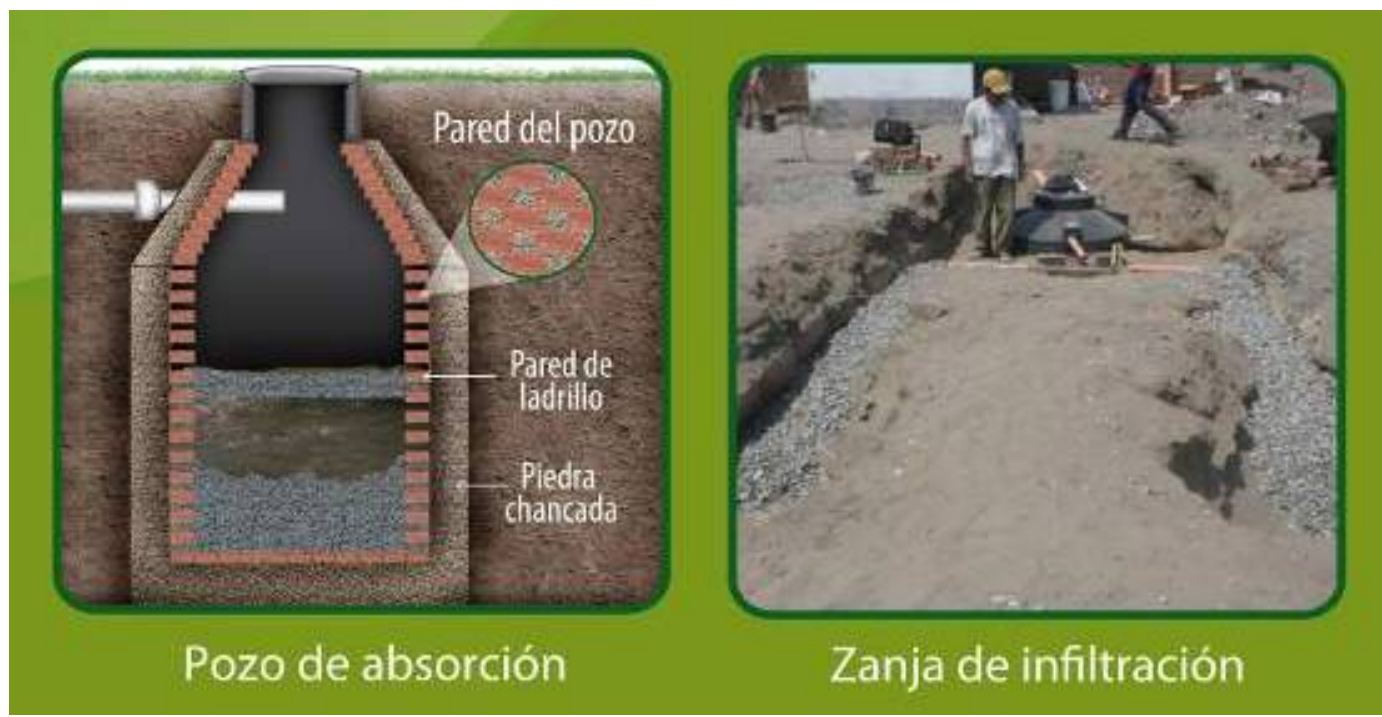

(Fonte: Internet ${ }^{22}$ )

\subsection{Drenos filtrantes}

Valas pouco profundas recheadas de material filtrante, com ou sem conduto inferior de transporte, destinadas a captar e filtrar o escoamento de superfícies impermeáveis contíguas com a finalidade de transportá-las a jusante. Podem permitir a infiltração e diminuição dos volumes de escoamento.

Figura 7 - Fotografia de dreno filtrante entre duas superfícies impermeáveis

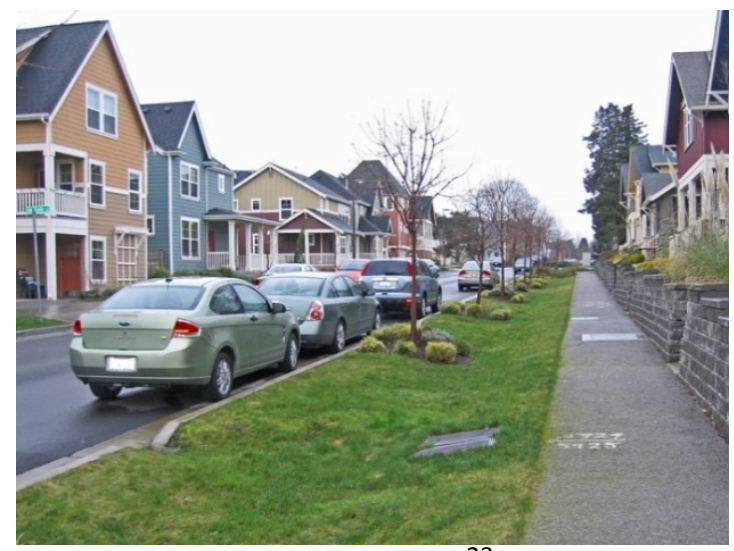

(Fonte: Internet ${ }^{23}$ )

\subsection{Valas verdes}

São canais superficiais lineares amplos e com inclinação, desenhados para armazenar e

\footnotetext{
${ }^{22}$ Disponível em: <http://www.leer-mas.com/lallave/news43/img/biodigestor-percolacion.jpg>. Acesso em: 4 jul. 2016.

${ }^{23}$ Disponível em: <http://www.rnlagos.com/dev/wp-content/uploads/2012/01/drenaje-sostenible.jpg>. Acesso em: 4 jul. 2016.
} 
transportar o escoamento superficial em baixas velocidades, permitindo a sedimentação de partículas contaminantes. Também podem permitir a infiltração para camadas inferiores.

\section{Figura 8 - Fotografia de uma vala verde}

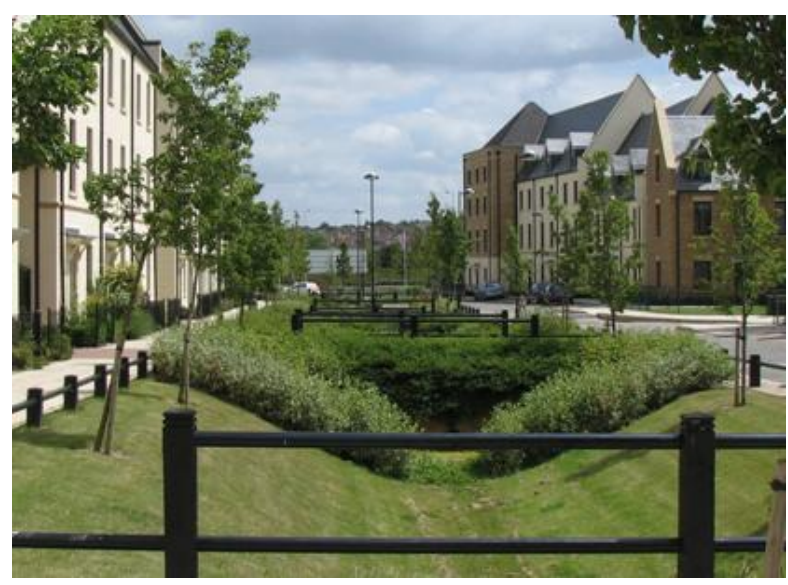

(Fonte: Internet ${ }^{24}$ )

\subsection{Depósitos de infiltração}

Depressões vegetadas do terreno, desenhadas para armazenar e infiltrar gradualmente o escoamento de água gerado em superfícies contíguas. O fluxo, então, de superficial passa a subterrâneo, permitindo também a eliminação de contaminantes mediante filtros, adsorção ${ }^{25} \mathrm{e}$ transformações biológicas.

\section{Figura 9 - Fotografia de um depósito de infiltração}

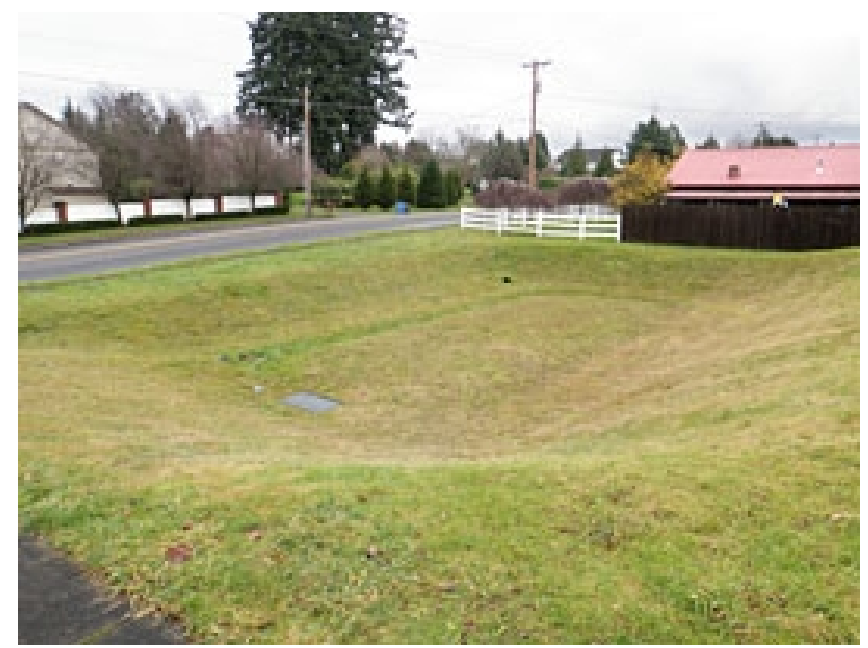

\footnotetext{
${ }^{24}$ Disponível em: <http://www.weetwood.net/_images/services_sw_drainage_2.jpg>. Acesso em: 4 jul. 2016.

25 “Adsorver: adesão (fixação) de moléculas de um fluido (o adsorvido) a uma superfície sólida (o adsorvente). Na adsorção, as moléculas ou íons de uma substância ficam retidos (fixados) na superfície de sólidos por interações químicas e físicas. Um ótimo exemplo de substância adsorvente é o carvão ativado. Ele é usado nas Estações de Tratamento de Água (ETA's) para retirar impurezas contaminantes como material orgânico, gases e partículas menores. A água, após passar pelos filtros de carvão ativado, sai límpida e sem cheiro." Disponível em: <http://mundoeducacao.bol.uol.com.br/quimica/adsorver-absorver-qualdiferenca.htm>. Acesso em: 5 jul. 2016.
} 
(Fonte: Internet ${ }^{26}$ )

\subsection{Depósitos superficiais de detenção}

Depósitos superficiais desenhados para armazenamento temporário de volumes de escoamento gerados a montante, reduzindo os fluxos de água em momentos de pico ${ }^{27}$. Também enfrentam a contaminação mediante sedimentação. Podem ser instalados em "zonas mortas" ou ser associados a outros usos (recreativos ou esportivos, por exemplo).

Figura 10 - Fotografia de um depósito superficial de detenção

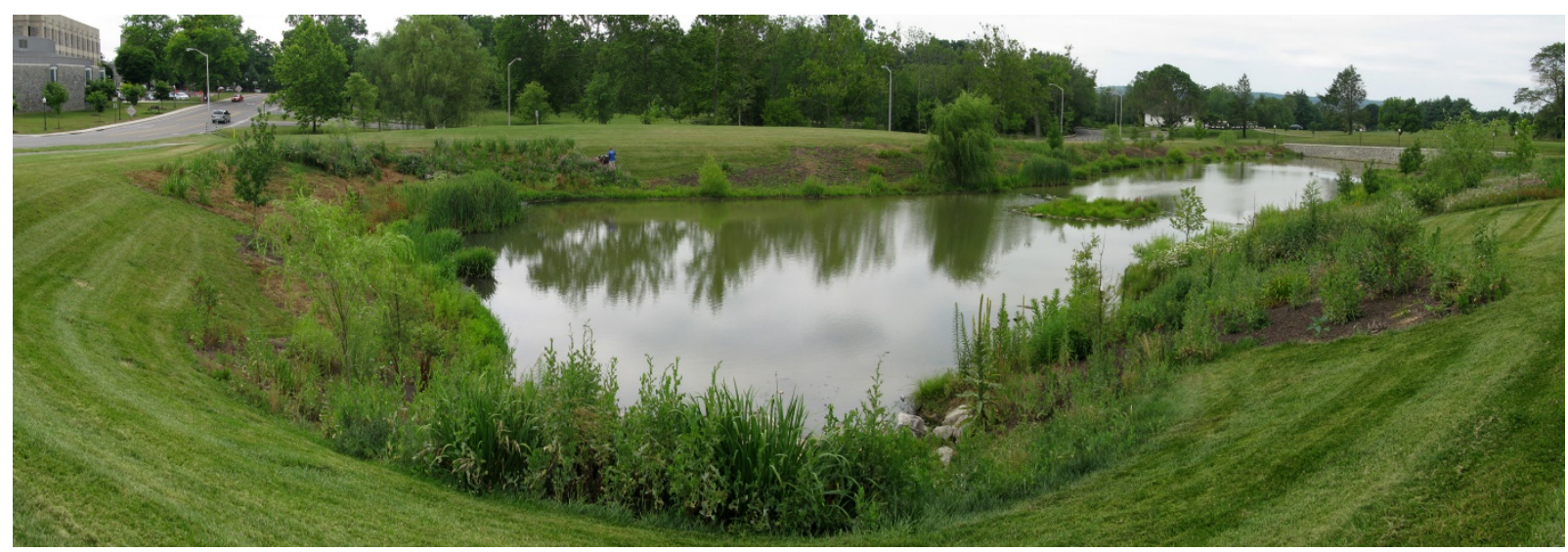

(Fonte: Internet ${ }^{28}$ )

\subsection{Depósitos de detenção enterrados}

Na ausência de superfície livre, os mesmos depósitos de detenção podem ser construídos no subsolo. Também podem ser aplicados nos casos em que as condições do meio não recomendam a instalação a céu aberto. Normalmente construídos de concreto armado ou plástico.

Figura 11 - Fotografia de material plástico utilizado em depósito de detenção

\footnotetext{
${ }^{26}$ Disponível em: <http://drenajeurbanosostenible.org/wp-content/gallery/depositos-infiltracion/infiltrationbasin1.jpg>. Acesso em: 4 jul. 2016.

${ }^{27}$ Chamados caudales punta na Espanha.

${ }^{28}$ Disponível em: <https://jsancheztapetillo.files.wordpress.com/2015/08/img_3824.jpg>. Acesso em: 4 jul. 2016.
} 


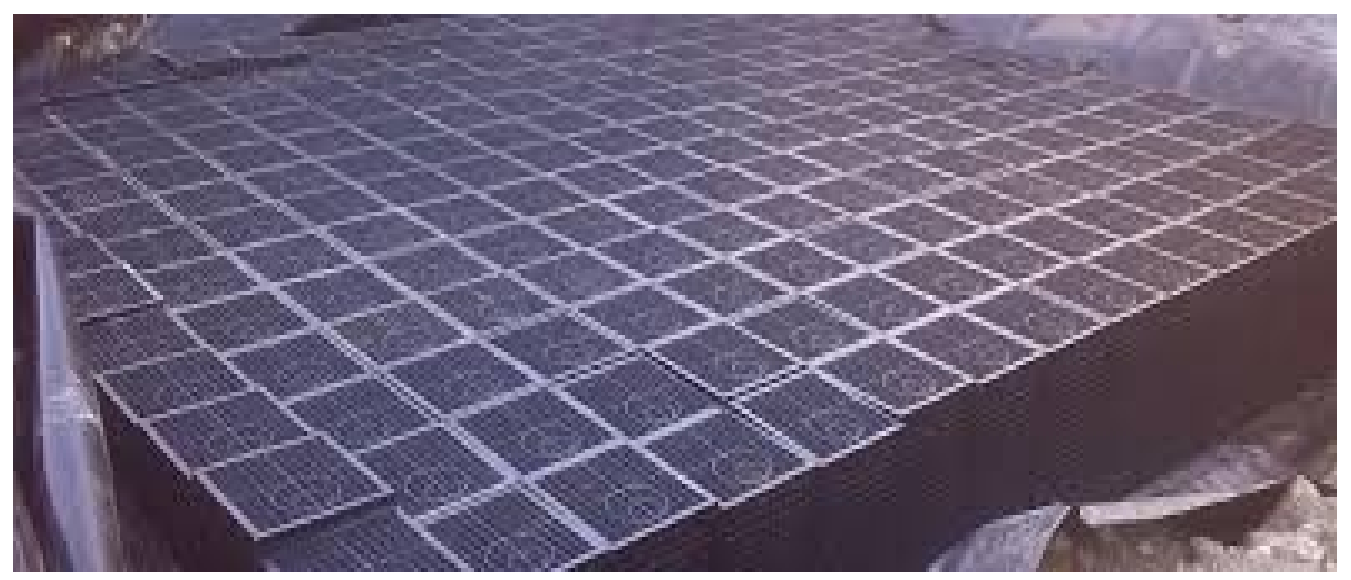

(Fonte: Internet ${ }^{29}$ )

Figura 12 - Fotografia de depósito fabricado em concreto armado

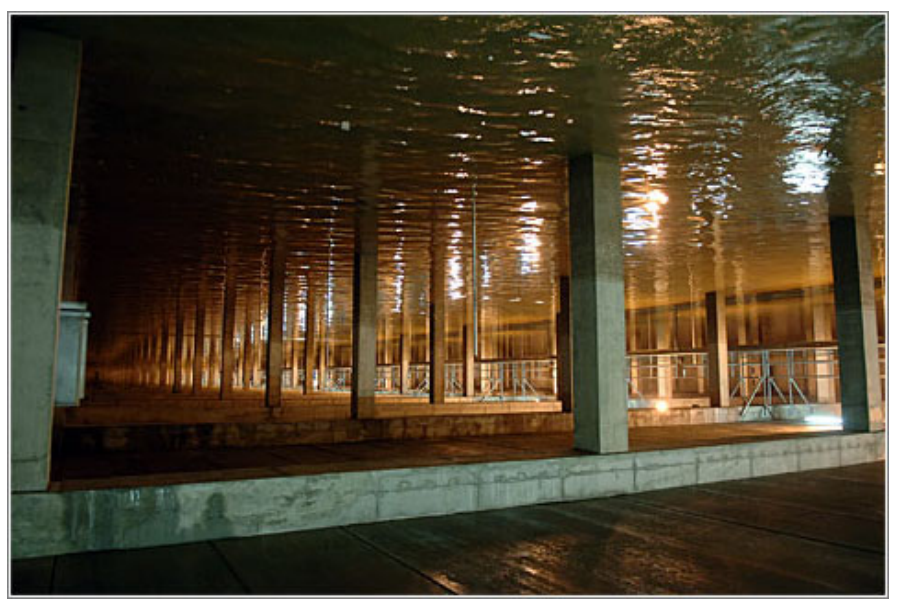

(Fonte: Internet ${ }^{30}$ )

\subsection{Lagoas de retenção}

Lagoas artificiais com lâmina permanente de água (de profundidade entre 1,2 e 2 metros) com vegetação aquática, tanto emergente como submersa. Servem para longos períodos de retenção de escoamento (2-3 semanas) e promovem a sedimentação e absorção de nutrientes pela vegetação. Preveem um volume adicional de armazenamento para redução dos fluxos em

\footnotetext{
29 Disponível em: <https://encrypted-tbn1.gstatic.com/images?q=tbn:ANd9GcSTYJZXrFwZOd0cljHLXWlswUEQ1BiwqhLNid2FkxKVVwOPJa9dw>. Acesso em: 3 jul. 2016.

${ }^{30}$ Disponível em: <http://www.microsiervos.com/images/estanques-tormentas.jpg>. Acesso em: 4 jul. 2016.
} 
momentos de pico.

Figura 13 - Fotografia de uma lagoa de retenção

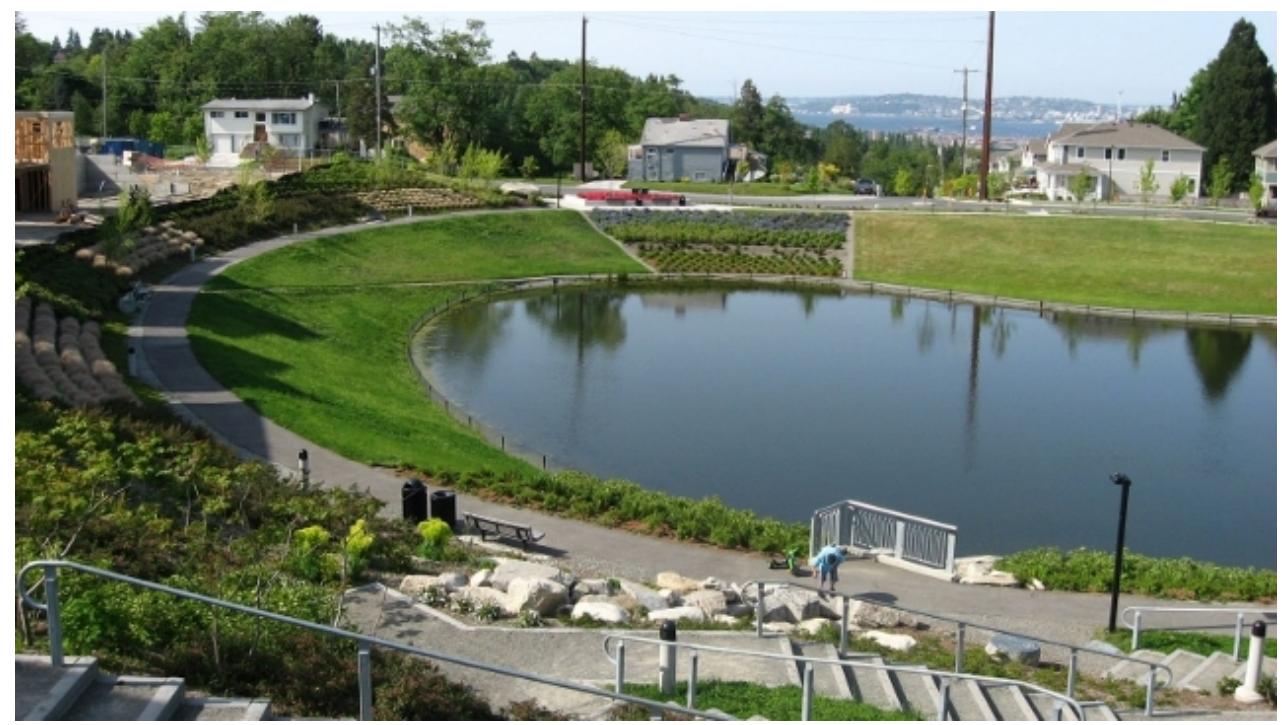

(Fonte: Internet ${ }^{31}$ )

\subsection{Wetlands (áreas úmidas/banhados)}

Artificialmente instalados como os anteriores, de forma a substituir uma área úmida natural, mas com menor profundidade e maior densidade de vegetação emergente. Possuem grande potencial ecológico, estético, educacional e recreativo.

Neste ponto cumpre referir uma experiência espanhola recente: no primeiro semestre de 2015 foi inaugurado na cidade de Alicante (Comunidade Valenciana) o primeiro parque inundável da Espanha ${ }^{32}$. Localizado no bairro Playa de San Juan, palco de inundações a cada chuva expressiva, este sistema urbano de drenagem sustentável - da tipologia wetland - reproduz com perfeição uma área úmida.

O parque diz-se inundável porque foi projetado para recolher as águas das riadas otoñales (enchentes de outono) típicas de Alicante. De fato, além de contar com lâmina d'água permanente, tem capacidade de acolhimento de 45 mil metros cúbicos de água. Caso superado o volume, as águas podem ser desviadas diretamente ao mar. A água recolhida, por seu turno, pode

31 Disponível em: <http://drenajeurbanosostenible.org/wp-content/gallery/estanques-retencion/retention-pond-seattle-highpoint-neighborhood.jpg>. Acesso em: 4 jul. 2016.

32 Há notícias de implantação de parques inundáveis em Santiago do Chile (disponível em: <http://www.lacasadejuana.cl/\#!INUNDANDO-SANTIAGO-El-agua-en-la-construcci\%C3\%B3n-de-una-mejorciudad/c20ln/57350bca0cf284cf21412071>. Acesso em: 5 jul. 2016) e proposta de implantação de parque inundável multiuso no município de Camboriú, no estado brasileiro de Santa Catarina (disponível em: <http://www.aderbalmachado.com.br/opiniao/2015-11-21/Parque_inundavel_necessario_e_renegado>. Acesso em: 5 jul. 2016). 
ser encaminhada a uma estação de tratamento para reutilização ou mesmo direcionada (se de boa qualidade) para utilização no regadio urbano. Os 30 mil metros quadrados de parque incluem, além dos tanques, uma cascata de quatro metros de altura, bancos para sentar, trilhas para passear e miradores para ver o próprio parque ou as montanhas ao redor. Além disso, está conectado a outra área verde através de uma ponte ${ }^{33}$.

Figura 14 - Fotografia do Parque Inundável “La Marjal” (Alicante, Espanha)

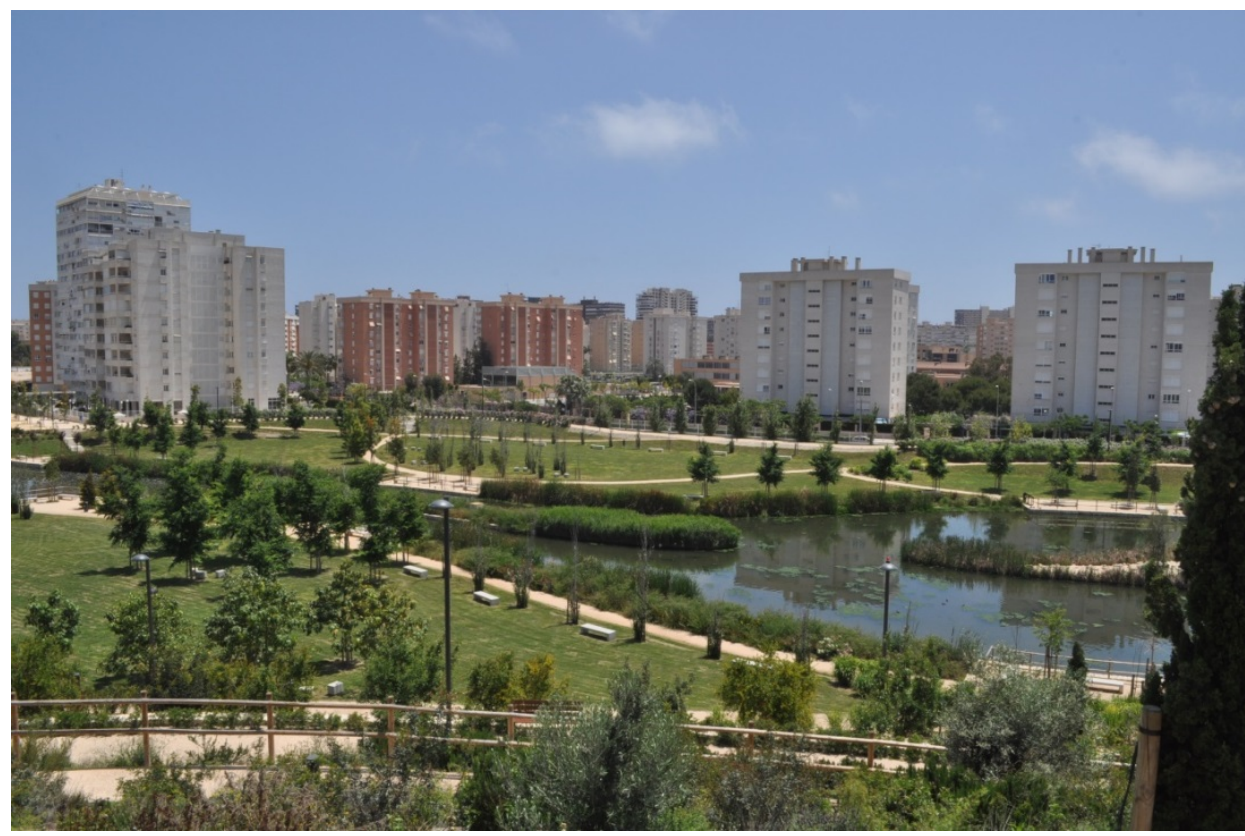

(Fonte: fotografia da autora, obtida em visita ao local em 20 de maio de 2016.)

O mais interessante desse empreendimento é que ele alia o objetivo do controle de inundações a funções paisagísticas, estéticas e recreativas, transformando-se num ponto nobre da

\footnotetext{
${ }^{33}$ Informações colhidas em: <http://www.porahinoes.es/2015/04/parque-urbano-inundable-la-marjal/>. Acesso em: 5 jul. 2016.
} 
cidade - inclusive com valorização imobiliária do entorno ${ }^{34}$. De ponderar que há registro de armazenamento de 3,5 milhões de litros de água no primeiro outono (outubro-novembro de 2015), bem como notícia de visualização no parque de exemplares de Martim Pescador, uma ave protegida que nunca antes havia sido vista nas cercanias de Alicante ${ }^{35}$.

\section{DA POSSÍVEL CONTRIBUIÇÃO DOS SUDS À SUSTENTABILIDADE DAS CIDADES}

Da análise das tipologias apresentadas, extrai-se que o que distingue os SUDS dos sistemas tradicionais de drenagem urbana não é, seguramente, apenas a estética.

Ana Abellán ${ }^{36}$ elenca como diferença essência a própria visão que se tem da água de escoamento: enquanto no sistema tradicional ela é vista como um inconveniente a eliminar, nos SUDS passa a ser um recurso com diversas utilidades, como recargas de aquíferos ou aporte de valor paisagístico ${ }^{37}$, entre outros.

Além disso, destaca a mesma autora que a drenagem sustentável não apenas gere o volume de escoamento (através da evacuação, da infiltração e da evapotranspiração), ocupandose também da carga contaminante que as águas carregam ao escoar - com ganhos, então, não apenas no aspecto quantitativo, mas também qualitativo.

À guisa de conclusão, cumpre registrar as conclusões do GITECO acerca dos SUDS:

Los SUDS se presentan como un elemento integrador ciudad-naturaleza muy importante que ha de ser considerado como una herramienta más a la disposición de los encargados del diseño urbano.

Con la implantación de SUDS se da solución a los problemas ocasionados por las aguas pluviales relativos a la cantidad; disminuyendo el riesgo de inundaciones localizadas gracias a la laminación ofrecida por estos sistemas, controlando la punta del caudal y aumentado el tiempo de concentración correspondiente.

Los SUDS proporcionan beneficios adicionales a los ofrecidos por los sistemas de drenaje convencional, como el tratamiento natural de las aguas pluviales, obteniendo unas calidades aptas para su vertido directo a los medios receptores, sin necesidad de pasar por las depuradoras y evitando la contaminación difusa de los medios naturales.

\footnotetext{
34 Maiores informações sobre o parque, inclusive com vídeos e plantas do projeto, disponíveis em: <http://www.aguasdealicante.es/ParqueLaMarjal>. Acesso em: 4 jul. 2016.

35 Conforme notícia disponível em: <http://www.laverdad.es/alicante/201601/02/parque-inundable-marjal-almaceno20160102190253.html>. Acesso em: 5 jul. 2016.

${ }^{36}$ Artigo Drenaje urbano sostenible disponível em: <http://www.iagua.es/blogs/ana-abellan/drenaje-urbano-sostenible>. Acesso em: 4 jul. 2016.

${ }^{37}$ Este é uma característica dos SUDS que, segundo a autora, nunca se verá em sistemas tradicionais de drenagem.
} 
Con el uso de SUDS se revaloriza el entorno urbano como consecuencia de la posibilidad de recuperar zonas de frágil equilibrio, como son las que tienen un déficit en recursos hídricos por la sobreexplotación que sufren, mediante la valorización de las aguas de lluvia en la recuperación de acuíferos y humedales en vías de desaparición.

Además, todo lo anteriormente dicho repercute de forma positiva apreciable en los costes económicos de construcción, gestión y mantenimiento del drenaje urbano, aspecto que habría de ser tomado en consideración por todos los participantes en el diseño urbano para una pausada reflexión.

Los SUDS no implican la eliminación de los sistemas de drenaje tradicionales, pueden ser un complemento y nunca una competencia para estos sistemas.

Es fundamental establecer la diferenciación entre tratamiento cuantitativo y cualitativo de las aguas, y asignar costes y beneficios en cada caso para obtener una visión integral de la mejor solución posible.

Un buen funcionamiento requiere un buen mantenimiento, al igual que sucede con todos los sistemas de drenaje convencional.

Los SUDS son sistemas que funcionan en cadena, por esta razón, es necesario integrar el diseño urbano en su globalidad para dar una respuesta correcta a todo el conjunto. ${ }^{38}$

Assim, da análise do sistema proposto e de suas tipologias, verificam-se todos os benefícios que podem derivar de sua implantação. A intenção dos SUDS é, portanto, compatibilizar o desenvolvimento urbano com a natureza, gerando cidades mais sustentáveis.

Afinal, no dizer de Ricardo Stanziola Vieira, a sustentabilidade consiste em "buscar responder aos anseios contemporâneos sobre os riscos do crescimento econômico desenfreado, em prol de prevenir e melhorar a vivência humana qualitativa no planeta" ${ }^{39}$.

No cenário nacional, segundo Juarez Freitas, a sustentabilidade, ao mesmo tempo:

(a) é princípio ético-jurídico, direta e imediatamente vinculante (do qual são inferíveis regras), que determina o oferecimento de condições suficientes para o bem-estar das atuais e futuras gerações, (b) é valor constitucional supremo (critério axiológico de avaliação de políticas e práticas) e (c) é objetivo fundamental da República (norte integrativo de toda interpretação e aplicação do Direito) ${ }^{40}$.

Nesse sentir, defendemos a necessidade de adoção da sustentabilidade como razão de decidir, como critério valorativo e como diretriz básica para adoção de posturas políticoadministrativas.

\footnotetext{
${ }^{38}$ BAYON, Joseba Rodriguez et al. SISTEMAS URBANOS DE DRENAJE SOSTENIBLE. SUDS, pp. 19-20. Disponível em: <http://docplayer.es/11160333-Sistemas-urbanos-de-drenaje-sostenible-suds.html>. Acesso em: 5 jul. 2016.

${ }^{39}$ VIEIRA, R. S.; MAFRA, J. R. A SUSTENTABILIDADE NO CONTEXTO GLOBAL E NO BRASIL: COMPREENDENDO A EXPERIÊNCIA NO CUMPRIMENTO DOS OBJETIVOS DO MILÊNIO APRAZADOS PARA 2015. In: RIBEIRO; COUTO; SARLET. (Org.). DIREITO E SUSTENTABILIDADE II - XXIV CONGRESSO NACIONAL DO CONPEDI - UFMG/FUMEC/DOM HELDER CÂMARA. 1ed. Florianópolis: CONPEDI, 2015, v. 1, p. 119-145.

${ }^{40}$ FREITAS, Juarez. Sustentabilidade: direito ao futuro. 2. ed. Belo Horizonte: Fórum. 2012. p. 117.
} 


\section{CONSIDERAÇÕES FINAIS}

Numa tradição de ocupação do espaço através da exploração de recursos naturais que, baseada em sua abundância, sempre pressupôs que seriam infinitos, o Brasil impactou negativamente seu território e suas espécies durante a imensa maioria dos mais de 500 anos transcorridos desde o seu "descobrimento", sem qualquer preocupação com a transgeracionalidade do direito ao meio ambiente ou com a própria sustentabilidade de seu desenvolvimento - conceitos cunhados somente a partir da década de 70 (há menos de 50 anos, portanto).

Para além das preocupações atinentes à remediação dos danos causados pelos desastres, bem como a criação de sistemas de alertas para pessoas que já estejam sob risco iminente - que nos impelem a desenvolver cidades com capacidade de resiliência - cumpre envidar esforços no sentido da prevenção e redução do risco de danos causados por eventos extremos.

Para tanto, impende investir em cidades mais sustentáveis, planejando cidades ambientalmente integradas às regiões nas quais estão inseridas e também lançando mão de das mais modernas medidas estruturais, como os aqui expostos sistemas urbanos de drenagem sustentável.

\section{REFERÊNCIA DAS FONTES CITADAS}

ABELLÁN, Ana. Drenaje urbano sostenible. Disponível em: <http://www.iagua.es/blogs/anaabellan/drenaje-urbano-sostenible>. Acesso em: 4 jul. 2016.

BAYON, Joseba Rodriguez et al. SISTEMAS URBANOS DE DRENAJE SOSTENIBLE. SUDS. Disponível em: <http://docplayer.es/11160333-Sistemas-urbanos-de-drenaje-sostenible-suds.html>. Acesso em: 5 jul. 2016.

BOTELHO, R. G. M. Bacias hidrográficas urbanas. In: GUERRA, A. J. T. (org.) Geomorfologia urbana. Rio de Janeiro: Bertran Brasil, 2011. pp. 71-115.

DE LA SALA, Safira; e GUARALDO, Eliane. Planos Diretores de Redução de Risco de Desastres: Comentários ao art. 42-A do Estatuto da Cidade. Revista de Direito Ambiental, vol. 75, Jul Set/2014, pp. 355 - 372. 
FREITAS, Juarez. Sustentabilidade: direito ao futuro. 2. ed. Belo Horizonte: Fórum. 2012.

PASOLD, Cesar Luiz. Metodologia da pesquisa jurídica: teoria e prática. 13 ed. Florianópolis: Conceito Editorial, 2015.

PERALES MOMPARLER, S. e ANDRÉS-DOMÉNECH, I. Los sistemas urbanos de drenaje sostenible: una alternativa a la gestión del agua de lluvia. Disponível em: <http://ovacen.com/wpcontent/uploads/2015/05/gestion-del-agua-en-el-planeamiento.pdf> Acesso em: 4 jul. 2016. PINHEIRO, Adilson. Enchente e Inundação. In: SANTOS, Rozely Ferreira dos. (org.). Vulnerabilidade Ambiental - Desastres naturais ou fenômenos induzidos? Brasília: MMA, 2007. pp. 95-106. TRAPOTE JAUME, Arturo. SISTEMAS URBANOS DE DRENAJE SOSTENIBLE (SUDS): IMPLICACIONES HIDROLÓGICO-HIDRÁULICAS Y AMBIENTALES. In: BRANDÃO, P. T.; ESPÍRITO SANTO, D. (coord.); SOUZA, M. C. S. A.; JACOBSEN, G. (org.). Direito, desenvolvimento urbano e meio ambiente [recurso eletrônico]. Itajaí: UNIVALI, 2016. pp.115-137.

TUCCI, Carlos. E. M. Inundações Urbanas. Disponível em:

<http://4ccr.pgr.mpf.mp.br/institucional/grupos-de-trabalho/encerrados/residuos/documentosdiversos/outros_documentos_tecnicos/curso-gestao-do-terrimorio-e-manejo-integrado-dasaguas-urbanas/drenagem1.PDF>. Acesso em: 29 dez. 2016.

VIEIRA, R. S.; MAFRA, J. R. A SUSTENTABILIDADE NO CONTEXTO GLOBAL E NO BRASIL: COMPREENDENDO A EXPERIÊNCIA NO CUMPRIMENTO DOS OBJETIVOS DO MILÊNIO APRAZADOS PARA 2015. In: RIBEIRO; COUTO; SARLET. (Org.). Direito e Sustentabilidade II - XXIV Congresso Nacional do CONPEDI - UFMG/FUMEC/DOM HELDER CÂMARA. 1ed. Florianópolis: CONPEDI, 2015 , v. 1, p. 119-145. 


\title{
A RELATIVIZAÇÃO DA COISA JULGADA EM MATÉRIA AMBIENTAL
}

\author{
Andrey Cunha Amorim ${ }^{1}$
}

\section{INTRODUÇÃO}

A relativização da coisa julgada constitui tema que vem despertando o interesse da doutrina e da jurisprudência pátrias. Como corolário da segurança jurídica, o caráter definitivo da sentença forma um dos pilares do estado democrático de direito, em prol da estabilidade das relações jurídicas. Nenhuma sociedade pode desenvolver-se sem que os seus integrantes tenham garantida uma solução definitiva para os seus conflitos de interesses. O presente artigo importa-se com a coisa julgada material, ou seja, quando a sentença põe fim ao processo com o julgamento do mérito, impossibilitando, em regra, o ajuizamento de uma nova demanda para a discussão do mesmo pedido e causa de pedir. Esta impossibilidade é absoluta ou pode ser relativizada? Este é o problema a ser resolvido.

Há quem defenda a completa imutabilidade da sentença transitada em julgado, entendendo que a coisa julgada se constituiu em direito fundamental, o qual só pode ser restringido nas estritas hipóteses legais, como no caso da ação rescisória. Não é esta, no entanto, a conclusão do presente artigo. De fato, a segurança jurídica é um direito fundamental. Todavia, ainda assim, os direitos fundamentais não são absolutos, podendo ser relativizados diante do confronto com outros direitos fundamentais. E a solução deste confronto pode dar-se também pela via judicial, quando a restrição não vem prevista em lei. A presente pesquisa trouxe alguns exemplos, como a colisão entre a segurança jurídica e o direito à identidade genética, debatido à exaustão pelo Supremo Tribunal Federal, no caso do RE n. 363.889, cujo relator foi o Min. Dias Toffoli, oportunidade em que prevaleceu o direito à identidade genética.

Com relação aos direitos individuais, o novo Código de Processo Civil tratou do tema da relatividade da coisa julgada, prevendo-a expressamente em alguns casos, via ação rescisória. Embora o leque tenha sido alargado (prova nova e título fundado em lei julgada inconstitucional),

\footnotetext{
${ }^{1}$ Aluno do curso de Mestrado em Ciências Jurídicas da UNIVALI, com área de concentração em Direito, Desenvolvimento Urbano e Meio Ambiente. Artigo científico de conclusão da disciplina Meio Ambiente Natural e Artificial, ministrada pelo Professor Marcelo Dantas
} 
a ação rescisória ainda está condicionada a determinado lapso temporal. Esta solução não atende adequadamente aos conflitos entre direitos, como a colisão entre a segurança jurídica e o direito à identidade genética, persistindo a problemática. No que alude aos direitos coletivos, embora a coisa em julgado tenha diferentes efeitos, dependendo da modalidade do direito em jogo (coletivo stricto sensu, difuso ou individual homogêneo), ainda assim deve-se admitir a sua relativização fora das hipóteses legalmente previstas (Lei de Ação Civilm Pública e Código do Consumidor).

O exemplo clássico pode ser extraído da matéria ambiental. Assim como no caso do direito à identidade genética, de um lado pode estar o direito à segurança jurídica e de outro o direito a um meio ambiente saudável. Este confronto, evidentemente, deve ser dirimido em prol do meio ambiente, porque constitui um direito muito mais importante e socialmente relevante, cuja proteção é condição de sobrevivência da própria humanidade, pouco importando quais os limites legais estatuídos para os direitos difusos ou coletivos. Até porque, como concluiu a presente pesquisa, por exemplo, a mutabilidade dos efeitos de uma sentença transitada em julgado, que permitisse a poluição do planeta como um todo, levando a sua destruição, não serviria para nada. "Preservar-se-ia a coisa julgada para quem?"

\section{A COISA JULGADA E A SEGURANÇA JURÍDICA}

O homem vive em sociedade. Consequentemente, a existência de conflitos de interesses é inevitável. Qualificados estes conflitos por uma pretensão resistida, uma das partes interessadas pode levá-los ao exame do Poder Judiciário, a fim de dirimi-los. Depois de garantido o devido processo legal, esse mesmo Judiciário deve exarar sentença, dizendo com quem está a razão. Inconformada, a parte sucumbente pode interpor recurso, evidentemente. Depois de examinados todos os eventuais recursos, transitada em julgado, em regra, a sentença não pode mais ser modificada, adquirindo o status daquilo que se denominou tecnicamente de coisa julgada. Enfim, sem incursionar pelo dissídio doutrinário segundo o qual a coisa julgada é um efeito ou uma qualidade da decisão ${ }^{2}$, diferença inócua para o que pretende este artigo, o fato é que a coisa julgada deve ser entendida como a imutabilidade da sentença transitada em julgado, em outras e mais simples palavras, incialmente.

Eis o conceito entabulado por José Frederico Marques:

\footnotetext{
${ }^{2}$ LIEBMAN, Enrico Túlio. Eficácia e Autoridade da Sentença e outros escritos sobre a Coisa Julgada. Rio de Janeiro: Forense, 2006. P. 23.
} 
A coisa julgada é qualidade dos efeitos da prestação jurisdicional entregue com o julgamento final da res in judicium deducta, tornando-os imutáveis entre as partes. Com a sentença definitiva não mais sujeita a reexames recursais, a res judicanda se transforma em res judicata, e a vontade concreta da lei, afirmada no julgado, dá ao imperativo jurídico, ali contido, a força e a autoridade de Lex especialis entre os sujeitos da lide que a decisão compôs. ${ }^{3}$

Com efeito, o instituto da coisa julgada tem origem no princípio constitucional da segurança jurídica, cuja existência forma um dos pilares do estado democrático de direito, ajudando a construir a estabilidade e a paz nas relações jurídicas. Seu desiderato não é outro senão a proteção e a preservação das expectativas das pessoas que compõem a sociedade, permitindo-Ihes a organização e o planejamento das suas vidas. ${ }^{4}$

Por exemplo, uma sentença imutável não pode sofrer a alteração posterior do seu comando, simplesmente por que a jurisprudência evoluiu e, agora, passados anos do seu trânsito em julgado, os juízes vêm decidindo a mesma questão de outra maneira, atribuindo-lhe desfecho diferente. Imaginemos uma singela ação de cobrança, através da qual o seu autor recebeu determinado quantum, fruto da interpretação do comportamento dos juros sobre o valor da dívida. A sentença transitou em julgado, o autor recebeu o seu dinheiro e com ele fez uma casa. Anos depois o autor morreu e a casa ficou para os seus herdeiros. Todavia, nesse ínterim, o Poder Judiciário mudou a interpretação do direito que resultou na aplicação dos juros frente àquela dívida, diminuindo-a significativamente. É justo impor a alteração da sentença, determinando aos herdeiros a devolução do valor que seu pai recebeu? Sem estabilidade jurídica, como os herdeiros podem planejar e organizar as suas vidas?

Ao contrário, ainda, seguindo o mesmo exemplo, imagine-se que não foi a interpretação dos juízes que tenha sofrido alteração, mas o comando da própria lei. Quando do julgamento da ação a lei impunha determinado percentual de juros. Passados anos do trânsito em julgado da sentença, a lei restou alterada e aumentou este percentual. Os herdeiros podem cobrar do devedor original a diferença do valor? Seria justo? Sem uma solução definitiva a respeito do quantum pago, como o devedor pode prosseguir os seus negócios com absoluta segurança?

Na verdade, foi exatamente por isso que a própria Constituição Federal, no seu art. 5으, XXXVI, externando implicitamente o princípio da segurança jurídica, determinou que: "a lei não prejudicará o direito adquirido, o ato jurídico perfeito e a coisa julgada".

\footnotetext{
${ }^{3}$ MARQUES, José Frederico. Instituições de Direito Processual Civil. Campinas, Milenium, 1999. P. 343.

${ }^{4}$ DANTAS, B. Direito fundamental à previsibilidade das decisões judiciais. Revista Justiça e Cidadania, edição 149, janeiro de 2013.
} 
Os professores Nelson Nery Júnior e Rosa Maria de Andrade Nery traçaram interessante paralelo entre a coisa julgada e o estado democrático de direito, fruto da segurança jurídica que deve nortear as relações sociais:

\begin{abstract}
A segurança jurídica, trazida pela coisa julgada material, é manifestação do estado democrático de direito (CF 1으, caput). Entre o justo absoluto, utópico, e o justo possível, realizável, o sistema constitucional brasileiro a exemplo do que ocorre na maioria dos sistemas democráticos ocidentais, optou pelo segundo (justo possível), que é consubstanciado na segurança jurídica da coisa julgada material. Descumprir-se a coisa julgada é negar o próprio estado democrático de direito, fundamento da república brasileira. ${ }^{5}$
\end{abstract}

Em suma, viver em uma sociedade sem segurança jurídica seria o mesmo que eternizar os conflitos de interesses, sem apresentar-lhes uma solução absolutamente definitiva. A falta de deslinde definitivo equivaleria à ausência de qualquer solução, na medida em que solução temporária não é solução. O prejuízo coletivo seria extremo, diante da ausência de relações jurídicas definitivas. Assim, ao lado do direito adquirido e do ato jurídico perfeito, o instituto da coisa julgada representa o princípio da segurança jurídica, encarnando-o como forma de solução judicial definitiva dos conflitos de interesses, em prol da pacificação social e do estado democrático de direito.

\title{
2. OS EFEITOS DA COISA JULGADA
}

Sabidamente, os efeitos da coisa julgada podem ser de duas ordens: formal e material. (a) Formal quando produz efeitos dentro do processo apenas e (b) material quando a sentença julga o mérito da demanda, não permitindo o ajuizamento de nova ação, razão pela qual os seus efeitos espraiam-se para fora do processo, impedindo a constituição de um outro processo para discussão da mesma questão (efeito exterior ao processo). ${ }^{6}$

Não é difícil perceber, portanto, que os efeitos formais da coisa julgada são inerentes a toda e qualquer sentença, tenha ela decidido ou não o mérito da lide. Uma vez transitada em julgado, sem mais possibilidade de interposição de recurso, aquela sentença, dentro daquele determinado processo, em regra, não pode sofrer alteração.

Para clarear, eis a lição do mestre Vicente Greco Filho, a respeito dos efeitos formais da

\footnotetext{
${ }^{5}$ NERY JÚNIOR, Nelson; NERY, Rosa Maria de Andrade. Código de Processo Civil Comentado e Legislação Extravagante. 8. ed. São Paulo: Revista dos Tribunais, 2004. P. 863.

${ }^{6}$ DINAMARCO, Cândido Rangel. Relativizar a coisa julgada material. In Nova era do Processo Civil, São Paulo: Malheiros editores, 2004. PP. 221-222.
} 
sentença transitada em julgado:

Quando estiveram esgotados todos os recursos previstos na lei processual, ou porque foram todos utilizados e decididos, ou porque decorreu o prazo de sua interposição, ocorre a coisa julgada formal, que é a imutabilidade da decisão dentro do mesmo processo recursos ordinários ou extraordinários. Todas as sentenças, em certo momento, fazem coisa julgada formal. ${ }^{7}$

Sobre os efeitos formais da coisa julgada, também bem discorreu o incomparável Humberto Theodoro Júnior ${ }^{8}$ :

Decorre simplesmente da imutabilidade da sentença dentro do processo que foi proferida pela impossibilidade de interposição de recursos, quer porque a lei não mais os admite, quer porque se esgotou o prazo estipulado pela lei sem interposição pelo vencido, quer porque o recorrente tenha desistido do recurso interposto ou ainda tenha renunciado à sua interposição.

Por outro lado, na esteira do mesmo raciocínio, fácil notar que nem todas as sentenças podem gerar coisa julgada com efeitos materiais. Para produzir o efeito de imutabilidade para fora do processo, impedindo o ajuizamento da nova ação para discussão da mesma causa, a sentença tem que colocar fim ao processo, decidindo o mérito da lide. Portanto, a sentença que extingue o processo sem decisão do mérito, por exemplo, no que alude à coisa julgada, tem efeito apenas de ordem formal. Não gera efeitos materiais e, em consequência, nova ação, através de novo processo, pode discutir a mesma questão, a qualquer tempo.

Eis novamente a lição do professor Theodoro Júnior ${ }^{9}$ :

No sistema do Código, a coisa julgada material só diz respeito ao julgado da lide, de maneira que não ocorre quando a sentença é apenas terminativa (não incide sobre o mérito da causa). Assim, não transitam em julgado, materialmente, as sentenças que anulam o processo e as que decretam sua extinção, sem cogitar da procedência ou improcedência da ação. Tais decisórios geram apenas coisa julgada formal. Seu efeito se faz sentir apenas nos limites do processo. Não solucionam o conflito de interesses estabelecidos entre as partes e, por isso, não impedem que a lide volte a ser posta em juízo em nova relação processual.

A propósito, veja-se o ensinamento de Teresa Arruda Alvim Wambier e José Miguel Garcia Media, quando escrevem sobre os efeitos materiais da coisa julgada, resumindo tudo o que vimos até agora:

A coisa julgada é instituto cuja função é a de estender ou projetar os efeitos da sentença indefinidamente para o futuro. Com isso, pretende-se zelar pela segurança extrínseca das relações jurídicas, de certo modo em complementação ao instituto da preclusão, cuja função primordial é garantir a segurança intrínseca do processo, pois que assegura a irreversibilidade das situações

\footnotetext{
${ }^{7}$ GRECO FILHO, Vicente Greco. Direito Processual Civil Brasileiro, vol. 2, 14. ed., Saraiva, 2000. p. 246

${ }^{8}$ THEODORO JÚNIOR, Humberto. Curso de Direito Processual Civil. Forense, 48. ed., 2008. p. 603

${ }^{9}$ THEODORO JÚNIOR, Humberto. Curso de Direito Processual Civi. p. 596
} 
jurídicas cristalizadas endoprocessualmente. Esta segurança extrínseca das relações jurídicas gerada pela coisa julgada material traduz-se na impossibilidade de que haja outra decisão sobre a mesma pretensão. [...] "a coisa julgada, enquanto fenômeno decorrente de princípio ligado ao Estado Democrático de Direito, convive com outros princípios fundamentais igualmente pertinentes. Ademais, como todos os atos oriundos do Estado, também a coisa julgada se formará se presentes pressupostos legalmente estabelecidos. Ausentes estes, de duas, uma: (a) ou a decisão não ficará acobertada pela coisa julgada, ou (b) embora suscetível de ser atingida pela coisa julgada, a decisão poderá, ainda assim, ser revista pelo próprio Estado, desde que presentes motivos preestabelecidos na norma jurídica, adequadamente interpretada. ${ }^{10}$

Pois bem, dentro do raciocínio até agora esposado, para efeito do tema proposto neste artigo, importa a partir de agora apenas a coisa julgada material, até porque o efeito formal é consequência do trânsito em julgado de qualquer sentença. Para haver coisa julgada material, imperioso antes a existência do seu efeito formal: o trânsito em julgado da sentença. Na verdade, a relativização da coisa julgada está relacionada ao seu efeito material, porque atinente aos limites extrínsecos ao processo. Ora, se a presente pesquisa tem o objetivo de investigar se é possível, em alguns casos, a repetição de nova ação para a discussão de questão já decidida, evidente que a relativização da coisa julgada diz respeito aos seus efeitos materiais, já que a coisa julgada formal, puramente considerada, não impede a propositura de nova ação, além de inerente ao seu efeito material.

\section{A RELATIVIZAÇÃO DA COISA JULGADA}

Já vimos que a coisa julgada decorre do princípio da segurança jurídica, cujo conteúdo impõe a estabilidade das decisões judiciais. Este princípio, no entanto, não é absoluto e admite exceções. Contra as sentenças transitadas em julgado pode ser ajuizada ação rescisória, por exemplo, cabível em hipóteses estreitas, é verdade, mas cabível, desde que observado certo limite temporal, conforme o antigo (art. 485) e o novo Código de Processo Civil (art. 966). Todavia, a doutrina moderna tem entendido que, mesmo fora dos limites da ação rescisória, excepcionalmente, a coisa julgada pode ser relativizada, desde que a sentença seja absolutamente injusta, teratológica ou inconstitucional, contrariando direitos mais relevantes do que o da segurança das relações jurídicas, em tese.

Essa matéria não é pacífica, todavia. De fato, há quem defenda a completa imutabilidade

\footnotetext{
${ }^{10}$ WAMBIER, Teresa Arruda Alvim; MEDINA, José Miguel Garcia. O Dogma da Coisa Julgada: hipóteses de relativização. São Paulo: Revista dos Tribunais, 2003. p 21-22.
} 
da sentença transitada em julgado, sob o argumento que a segurança jurídica é um direito fundamental, previsto por via transversa pelo art. 5ㅇ, XXXVI, da Constituição Federal. Pior do que permitir a alteração da sentença consolidada é admitir a possibilidade desta alteração fora dos limites impostos expressamente pela lei. Porquanto, defendem alguns, que a modificação da coisa julgada só pode dar-se por intermédio da ação rescisória, nos limites e prazos estabelecidos pela lei. Fora destas hipóteses, impossível qualquer alteração da sentença que produziu coisa julgada material. Se o próprio legislador admitiu, via ação rescisória, a possibilidade de desconstituição da coisa julgada, em consequência todas as demais hipóteses não previstas na lei não podem ser admitidas, sob pena de severo afronta à segurança jurídica e à própria legalidade.

O prof. Didier Jr. ${ }^{11}$, por exemplo, é uma das vozes mais abalizadas que defende a imutabilidade absoluta da coisa julgada:

Permitir a revisão da coisa julgada por um critério atípico é perigosíssimo. Esquecem os adeptos dessa corrente que, exatamente por essa especial característica do direito litigioso, àquele que pretende rediscutir a coisa julgada bastará alegar que ela é injusta/desproporcional/inconstitucional. E, uma vez instaurado o processo, o resultado é incerto: pode o demandante ganhar ou perder. Ignora-se esse fato [...] É por isso que a ação rescisória ... é típica e tem um prazo para ser ajuizada... A coisa julgada é instituto construído ao longo dos séculos e reflete a necessidade humana de segurança. Ruim com ela, muito pior sem ela. Relativizar a coisa julgada por critério atípico é exterminá-la.

No entanto, a relativização da coisa julgada, ainda assim, encontra respaldo na maioria da doutrina nacional. Tem defensores de peso como Humberto Theodoro Júnior e Cândido Rangel Dinamarco, dentre outros. De fato, o princípio da segurança jurídica não pode ser encarado de forma absoluta. Se ele é um direito fundamental, por certo outros direitos de igual quilate também existem. E, no confronto entre eles, qual deve prevalecer?

Por exemplo, o que vale mais, a segurança jurídica ou o direito que alguém tem de ter a sua filiação biológica identificada? A segurança jurídica ou o direito coletivo a um meio ambiente equilibrado? Se a própria lei, quando julgada inconstitucional de forma abstrata, retira-se do universo jurídico como se nunca tivesse existido, por que a sentença transitada em julgado, fundamentada na mesma lei inconstitucional, não pode ter seus efeitos relativizados? Há ainda outros exemplos, como a sentença que fixou injusta indenização contra o Estado, a expropriação indevida e por ai vai. Estes comandos devem ser imutáveis?

Com a ajuda de Antônio Carlos de Araújo Cintra e Ada Pellegrine Grinover, ensina o prof.

\footnotetext{
${ }^{11}$ DIDIER JÚNIOR, Fredie. Curso de Direito Processual Civil. Vol. II, 5. Ed., Salvador: Podivm, 2009. P. 447
} 
Cândido Rangel Dinamarco ${ }^{12}$, que foi quem criou a expressão "relativização da coisa julgada":

Por outro lado, segundo parte da doutrina mesmo as sentenças de mérito cobertas pela autoridade da coisa julgada material podem ser revistas em casos excepcionalíssimos, nos quais se relativiza a coisa julgada a bem da prevalência de valores humanos, políticos, morais etc. de envergadura maior do que aqueles que tiverem sido objeto da decisão. A relativização da coisa julgada material é uma tese extremamente polêmica, que nasceu no seio do Superior Tribunal de Justiça (Min. José Delgado) e que, mesmo entre os que a aceitam, só é defendida para casos realmente extraordinários. Essa tese parte da premissa de que nenhum valor constitucional é absoluto, devendo todos eles ser sistematicamente de modo harmonioso e, consequentemente, aplicando-se à coisa julgada o princípio da proporcionalidade, utilizado para o caso de colisão entre princípios constitucionais. [...] Assim, segundo parte da doutrina seria possível desconsiderar a coisa julgada, em processo próprio, para que prevaleça outro bem constitucionalmente tutelado, de índole material.

Na mesma toada segue o prof. Humberto Theodoro Jr. ${ }^{13}$ :

Em passado recente, a intangibilidade da coisa julgada se revestia de uma mística auréola de santidade, como, entre muitos, registrava José Luiz Vazquez Sotelo. Escassos, pois, eram, aqui e alhures, ensaios que se voltavam, por exemplo, para o problema da desconformidade de uma sentença transitada em julgado e a Constituição. E o que prevalecia, mesmo no transcendente domínio da ordem constitucional, era o critério de somente contemporizar com o rompimento da res iudicata nos acanhados limites da ação rescisória. Dessa maneira, até mesmo as ofensas à Lei Maior, quando cometidas pela sentença contra a qual não se pudesse manejar a rescisória, tornarse-iam perenes e irrecorríveis, mercê da intransponibilidade da barreira criada pela coisa julgada. Ergueram-se, no entanto, vozes de inconformismo no seio da doutrina constitucional contra esse exagero de santificação de um fenômeno que haveria de conduzir a sentença a um nível de autoridade superior ao da própria Constituição... A tese que vem ganhando corpo é a de que o fenômeno da inconstitucionalidade se reduz a uma relação de validade: se o ato de poder qualquer que seja ele é conforme à Constituição, vale; se não o é, não vale.

A jurisprudência brasileira tem evoluído na mesma velocidade da doutrina. No Superior Tribunal de Justiça, o ministro José Deolgado teve importante papel no desenvolvimento da teoria da relativização da coisa julgada. Segundo ele, "essas teorias sobre a coisa julgada devem ser confrontadas, na época contemporânea, se a coisa julgada ultrapassar os limites da moralidade, 0 círculo da legalidade, transformar fatos não verdadeiros em reais e violar princípios constitucionais, com as características do pleno Estado de Direito que convive impelido pelas linhas do regime democrático e que há de aprimorar as garantias e os anseios da cidadania"14. Vide

\footnotetext{
${ }^{12}$ CINTRA, Antônio Carlos de Araújo. GRINOVER, Ada Pellegrini. DINAMARCO, Cândido Rangel. Teoria Geral do Processo. P. $327-$ 328

${ }^{13}$ THEODORO, Humberto Júnior. Prefácio escrito para a obra $\mathbf{O}$ dogma da coisa julgada: hipóteses de relativização. São Paulo: RT, 2003.

${ }^{14}$ DEOLGAdO, José. Pontos Polêmicos das Ações de Indenização de Áreas Naturais Protegidas - Efeitos da Coisa Julgada e os Princípios Constitucionais. Revista de Processo, ano 26, v. 103, São Paulo: Editora Revista dos Tribunais, 2001. PP. 9-36
} 
vários precedentes do STJ, no sentido de que não faz coisa julgada a questão referente ao domínio em sede de ação expropriatória, por exemplo ${ }^{15}$.

Mas foi no Supremo Tribunal Federal, numa ação de investigação de paternidade, que a matéria ganhou destacado deslinde.

\section{O JULGAMENTO DO RE 363.889, DO STF}

O julgamento do RE n. 363.889, do STF, cujo relator foi o Min. Dias Toffoli, chamou a atenção para a questão da relativização da coisa julgada.

É um caso de investigação de paternidade, ajuizada no Distrito Federal, cuja sentença de primeiro grau declarou improcedente o pedido exordial por carência das provas, transitando em julgado. Naquela época o exame de DNA era inacessível e dispendioso, razão pela qual o juiz negou a sua produção pela assistência judiciária, inclusive. Vinte anos depois o mesmo réu ajuizou nova ação de investigação de paternidade, com o mesmo pedido e causa de pedir, invocando lei distrital nova, que garantiu o DNA para os hipossuficientes, em razão do avanço tecnológico, acessibilidade e redução de custos. O juiz entendeu possível a ação, afastando a coisa julgada em face do confronto do princípio da segurança dos atos judiciais com o direito fundamental de filiação (identidade genética) e assistência jurídica integral. O Tribunal de Justiça do Distrito Federal, no entanto, reformou a decisão de primeiro grau e julgou extinta a ação, reconhecendo justamente a imutabilidade da coisa julgada como princípio absoluto. Houve recurso extraordinário ao STF, o qual entendeu, por maioria de votos, que a coisa julgada deveria ser relativizada, sob o argumento de que não se pode impor óbices processuais ao direito fundamental de identidade genética, nos casos de ação de investigação de paternidade julgada improcedente por falta de provas, máxime em razão da certeza emanada da conclusão do exame de DNA. Embora não conste da ementa, o STF ainda deixou claro que a assistência judiciária integral não foi observada na hipótese e este também é um outro direito fundamental que confronta com a coisa julgada, podendo relativizá-la. De fato, o acórdão do STF elencou o direito à paternidade como fundamental. Decidiu que o direito à segurança jurídica não é absoluto e deve ceder quando em conflito com outros direitos de igual ou maior importância. A discussão foi muito interessante. No seu voto vencedor o Ministro Dias Toffoli fez um paralelo com a evolução

\footnotetext{
${ }^{15}$ REsp 621.403/PR, Rel. Min. Luiz Fux, DJ 02.05.2005; AgRg no REsp 512.481/SP, Rel. Min. Francisco Falcão, DJ de 06.12.2004.
} 
do direito à paternidade no Brasil. Esclareceu que no passado, por exemplo, os filhos advindos de relações extraconjugais não podiam ser reconhecidos e, caso admitida como absoluta a coisa julgada, eventual sentença que reconheceu esta impossibilidade, uma vez transitada em julgado, fora das hipóteses de ação rescisória, jamais poderia ser modificada, mesmo depois da evolução constitucional a respeito.

Os Ministros Marco Aurélio e César Peluso foram vencidos e expuseram argumentos igualmente interessantes, calcados na importância da segurança das decisões judiciais, fruto justamente da estabilidade que decorre do instituto da coisa julgada. Argumentaram que a parte poderia ter recorrido da decisão original de primeiro grau, que lhe negou acesso ao DNA e não o fez. Disseram que o exame de DNA não é obrigatório e que nova ação, portanto, seria inócua. Anotaram que a estabilidade dos atos judiciais é tão ou mais importante do que qualquer outro direito fundamental, fazendo um paralelo, inclusive, com o direito penal, ao exemplificar que a liberdade, por ser um direito fundamental, autorizaria a mutabilidade das sentenças penais condenatórias.

Prevaleceu, no entanto, o entendimento da relativização da coisa julgada, quando em confronto com o direito de identidade genética, em prol da conclusão de que a forma não pode ser mais importante do que o conteúdo, sendo atribuída repercussão geral ao caso, em razão da sua importância.

Este foi um julgamento emblemático, cujo desfecho demonstrou a evolução jurisprudencial do tema envolvendo a relativização da coisa julgada.

Eis a ementa do RE 363.889 , do STF:

EMENTA. RECURSO EXTRAORDINÁRIO. DIREITO PROCESSUAL CIVIL E CONSTITUCIONAL. REPERCUSSÃO GERAL RECONHECIDA. AÇÃO DE INVESTIGAÇÃO DE PATERNIDADE DECLARADA EXTINTA, COM FUNDAMENTO EM COISA JULGADA, EM RAZÃO DA EXISTÊNCIA DE ANTERIOR DEMANDA EM QUE NÃO FOI POSSÍVEL A REALIZAÇÃO DE EXAME DE DNA, POR SER O AUTOR BENEFICÁRIO DA JUSTIÇA GRATUITA E POR NÃO TER O ESTADO PROVIDENCIADO A SUA REALIZAÇÃO. REPROPOSITURA DA AÇÃO. POSSIBILIDADE, EM RESPEITO À PREVALÊNCIA DO DIREITO FUNDAMENTAL À BUSCA DA IDENTIDADE GENÉTICA DO SER, COMO EMANAÇÃO DE SEU DIREITO DE PERSONALIDADE. 1. É dotada de repercussão geral a matéria atinente à possibilidade da repropositura de ação de investigação de paternidade, quando anterior demanda idêntica, entre as mesmas partes, foi julgada improcedente, por falta de provas, em razão da parte interessada não dispor de condições econômicas para realizar o exame de DNA e o Estado não ter custeado a produção dessa prova. 2. Deve ser relativizada a coisa julgada estabelecida em ações de investigação de paternidade em que não foi possível determinar-se a efetiva existência de vínculo genético a unir 
as partes, em decorrência da não realização do exame de DNA, meio de prova que pode fornecer segurança quase absoluta quanto à existência de tal vínculo. 3. Não devem ser impostos óbices de natureza processual ao exercício do direito fundamental à busca da identidade genética, como natural emanação do direito de personalidade de um ser, de forma a tornar-se igualmente efetivo o direito à igualdade entre os filhos, inclusive de qualificações, bem assim o princípio da paternidade responsável. 4. Hipótese em que não há disputa de paternidade de cunho biológico, em confronto com outra, de cunho afetivo. Busca-se o reconhecimento de paternidade com relação a pessoa identificada. 5. Recursos extraordinários conhecidos e providos.

\section{A RELATIVIZAÇÃO DA COISA JULGADA, O DIREITO INDIVIDUAL E O NOVO CPC}

Em tema de relativização da coisa julgada, atualmente, não se pode deixar de fazer um comentário, embora breve, a respeito do novo Código de Processo Civil, máxime em casos como o julgado acima pelo STF.

É certo que o argumento para a relativização da cosia julgada continua o mesmo: o confronto entre os direitos. No entanto, não se pode desconsiderar que há uma nítida resistência à possibilidade de relativização no novo CPC, cujo comando prevê a possibilidade de ação rescisória fundada em prova nova, com prazo de 2 anos contados a partir da descoberta desta prova (novidade), observado o prazo máximo de 5 anos (novidade também), contado do trânsito em julgado da decisão (art. 975, §2ำ, do CPC).

Ora, tomando como exemplo o exame de DNA, apresentando-se ele como uma prova nova, à luz do novo CPC, seria possível uma nova investigação de paternidade 10 anos, 15 ou 20 anos após o trânsito em julgado da decisão do primeiro processo, que negou a paternidade por falta de provas? O prazo máximo, agora expressamente previsto, no caso de prova nova, seria de 2 anos a partir da descoberta desta prova e de 5 anos a partir do trânsito em julgado da decisão definitiva, sem possibilidade de ajuizamento de outra ação uma vez ultrapassados estes prazos? E o direito fundamental de identidade genética, como fica?

Apenas para argumentar, o mesmo se pode dizer com relação à impugnação da sentença

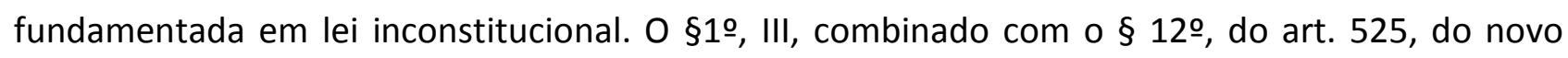
CPC, que trata da impugnação ao cumprimento de sentença, inovou ao deixar claro que a inexigibilidade do título executivo pode ocorrer quando fundamentado em ato inconstitucional declarado pelo STF, por força de controle difuso ou concentrado. No entanto, inovou mais ainda ao determinar, no seu $\S 15$, que se o julgamento do STF for proferido após o trânsito em julgado 
da decisão exequenda, caberá ação rescisória, cujo termo inicial será contado a partir da decisão do próprio STF. Se sobrevier decisão do STF, não será "automática" a desconstituição do título, havendo necessidade de ação rescisória, com alargamento do prazo.

Porquanto, em suma, o novo CPC aponta a ação rescisória como único instrumento possível para desconstituir a coisa julgada. Numa das hipóteses (prova nova) modifica o termo inicial do prazo de 2 anos, contado a partir do descobrimento de tal prova e estabelece o prazo máximo de 5 anos, a partir da data do trânsito em julgado (fora disso não há previsão sobre a possibilidade de alteração da sentença). Na outra hipótese (título fundado em lei julgada inconstitucional) não há prazo máximo, porém a hipótese depende de decisão do STF e não é de aplicação automática. Resta-nos esperar como vão se comportar a doutrina e a jurisprudência.

De qualquer forma, além do novo CPC, a matéria continua regulamentada em legislações esparsas, no que alude ao direito difuso e coletivo.

\section{A COISA JULGADA NAS AÇÕES COLETIVAS}

Doutrinariamente, sabe-se, a coisa julgada tem dois limites: a) tendente a matéria (pedido e causa de pedir); e b) referente às pessoas que serão afetadas (em princípio as partes). Na sistemática do CPC, relativa aos direitos individuais, a coisa julgada atinge a matéria apenas com relação a quem foi parte no processo. Portanto, se alguém ingressa com uma ação possessória contra outrem e tem o seu pedido julgado improcedente, por exemplo, uma vez transitada em julgado a decisão, fora os casos de ação rescisória, nova ação jamais poderá ser repetida, em regra, pelas partes. O processo coletivo, no entanto, tem outro enfoque, porque a coisa julgada pode abranger não só quem foi parte no processo, mas terceiros, razão pela qual ganhou regulamentação diversa, com efeitos distintos.

Para a compreensão da coisa julgada nas ações coletivas, imperioso esclarecer que o direito processual coletivo, atualmente, possui fundamento na Constituição Federal, na Lei da Ação Civil Pública (LACP) e no Código de Defesa do Consumidor (CDC). Nesse passo, embora a LACP classifique os direitos coletivos, lato sensu considerados, em direitos difusos e coletivos stricto sensu, o CDC ampliou este rol, para inserir também os direitos individuais homogêneos. Direito difuso é o que não se pode dividir e abrange um número indeterminado de pessoas (direito ao ar puro, p. ex.). Direito coletivo é que não se pode dividir, mas abrange um número determinado de 
pessoas, vinculados a um grupo, categoria ou classe (direito à qualidade de ensino de uma determinada escola, p. ex.). E, direito individual homogêneo é o que pode ser dividido e tem origem num fato determinado, atingindo pessoas determinadas que tenham relação com este fato (recall das peças de um tipo de veículo, p. ex.).

Esta classificação dos direitos coletivos é importante para diferenciar os efeitos da coisa julgada no processo coletivo, em especial quando discutidos via ação civil pública. A coisa julgada e a legitimidade para agir do processo coletivo são os principais pontos que lhe diferenciam do processo individual. No processo coletivo, a coisa julgada tem efeitos para além das partes porque a parte representa pessoas que não integram o processo (determinadas ou não). Em regra, portanto, a coisa julgada do processo coletivo tem os mesmos efeitos do processo individual, alcançando apenas as partes que compõem a relação processual. No entanto, ao contrário do processo individual, excepcionalmente, no processo coletivo, justamente porque é coletivo e abrange várias pessoas (determinadas ou não, partes no processo ou não) os efeitos da coisa julgada podem variar, dependendo do resultado do processo (secundum eventum litis), do sucesso das provas (secundum eventum probationis) e da classificação do direito em questão (difuso, coletivo ou individual homogêneo).

Segundo o art. 103 do CDC, nas ações coletivas, a sentença fará coisa julgada: a) erga omnes, quando se tratar de direitos difusos, salvo quando o pedido for julgado improcedente por falta de provas, hipótese em que qualquer legitimado (inclusive o original) poderá intentar nova ação, apresentando novas provas; b) ultra partes, quando versar sobre direito coletivo, limitada sempre ao grupo categoria ou classe, exceto se o pedido for julgado improcedente por insuficiência de provas, hipótese em que também qualquer legitimado, inclusive a própria parte, poderá oferecer nova demanda; e c) erga omnes, nos casos de direito individual homogêneo, apenas no caso de procedência do pedido, hipótese em que os efeitos da demanda beneficiam todos os titulares do direito, independentemente de serem ou não parte no feito (se a ação for julgada improcedente, pela certeza da convicção ou pela falta de provas, não interessa, os efeitos da sentença serão ultra partes, alcançando apenas quem fez parte da relação processual).

Com vagar, a respeito da coisa julgada em face das ações que visam proteger direitos individuais homogênios, Luiz Rodrigues Wambier ${ }^{16}$ explica:

\footnotetext{
${ }^{16}$ WAMBIER, Teresa Arruda Alvim. O Dogma da Coisa Julgada: hipóteses de relativização. São Paulo: Revista dos Tribunais, 2003. P. 296.
} 
$\mathrm{Na}$ procedência da ação coletiva em que se veiculam direitos individuais homogêneos, a imutabilidade da sentença se opera em relação a todos, que dela podem usufruir, mediante o aforamento das liquidações individuais; caso contrário, isto é, se o resultado for de improcedência, a imutabilidade alcança apenas aqueles que tenham participado do processo, como autores ou litisconsortes posteriores, diferentemente do que ocorre nas ações coletivas em que se promova a defesa de direitos coletivos ou difusos. Nestas últimas (que veiculam pretensões relativas a direitos coletivos ou difusos), a coisa julgada atinge os demais legitimados (entes coletivos do art. 82), mesmo que não tenham sido litisconsortes, de modo que a mesma demanda coletiva fica irremediavelmente obstada.

Já com relação aos direitos difusos e coletivos, o mesmo doutrinador enfatiza:

Referido autor ainda explica que: Já na defesa coletiva dos direitos difusos e coletivos em sentido estrito, se está diante de interesses metaindividuais, cuja titularidade cabe simultaneamente a cada um dos membros da comunidade ou do grupo, e ao próprio conjunto. Por isso tem sentido, quanto a esses direitos metaindividuais, a extensão erga omnes no caso de improcedência que não decorra de falta de provas, vedando-se a qualquer ente legitimado (para a ação coletiva nos termos do art. 82 do $C D C$ ) a defesa de idêntico direito, isto é, vedando-se que nova ação coletiva a respeito do mesmo direito (de que é titular a mesma comunidade ou grupo) seja posta em juízo. ${ }^{17}$

Em suma, segundo a determinação do art. 103 do CDC, quando se tratar de direitos difusos e coletivos, somente haverá a formação da coisa julgada quando a procedência ou improcedência da ação se der com suficiência de provas: nos direitos difusos a coisa julgada é erga omnis e nos coletivos é ultra partes. Se a improcedência, contudo, for pela insuficiência das provas apresentadas, não há que se falar em coisa julgada. Já quando cuidar a hipótese de direitos individuais homogêneos, sempre haverá a formação da coisa julgada, independentemente da procedência ou improcedência do pedido, inclusive por insuficiência de provas. A diferença é que no caso de procedência, a coisa julgada é erga omnis, alcançando todos os interessados, parte ou não no feito.

A professora Ada Pellegrini Grinover ${ }^{18}$ faz um único reparo, esclarecendo que:

[...] numa demanda coletiva que vise à retirada do mercado de produto considerado nocivo à saúde pública, a sentença rejeita o pedido julgando ação improcedente, por não considerar o produto danoso. A coisa julgada, atuando erga omnes, impede a renovação da ação (salvo na hipótese de insuficiência de provas), por parte de todos os entes e pessoas legitimados às ações coletivas. Mas não obsta a que o consumidor Caio, reputando-se lesado em sua saúde pelo produto, ajuíze ação pessoal indenizatória.

Todavia, prosseguindo, como se trata de direito coletivo lato sensu, a questão pode ser

\footnotetext{
${ }^{17}$ WAMBIER, Teresa Arruda Alvim. O Dogma da Coisa Julgada: hipóteses de relativização. São Paulo: Revista dos Tribunais, 2003. P. 301.

${ }^{18}$ GRINOVER, Ada Pelegrini. Código brasileiro de defesa do consumidor: comentado pelos autores do anteprojeto. 8. ed.. Rio de Janeiro: Forense Universitária, 2004. P. 931.
} 
enfrentada sob uma outra ótica: a relativização da coisa julgada, fora das hipóteses legalmente previstas. Como já examinado nas questões anteriores, dependendo da relevância do direito fundamental, em contraste com o direito de estabilização dos atos judiciais, pode haver a relativização da coisa julgada, em prol da modificação da sentença, como por exemplo nos casos envolvendo a aplicação do direito ambiental.

\section{A COISA JULGADA EM MATÉRIA AMBIENTAL}

No art. 225, da Constituição Federal, está disposto que todos têm direito ao meio ambiente ecologicamente equilibrado, o qual se constitui em bem de uso comum do povo e essencial à sadia qualidade de vida. Com a sua evolução, a relevância do direito ao meio ambiente é tamanha que hoje ele passou a ser tido como um direito difuso, indisponível e irrenunciável, essencial à sobrevivência humana, constituindo-se em direito fundamental, embora não esteja expressamente previsto como tal, no art. 5o da Constituição Federal. O meio ambiente não é mais um direito do Estado, apenas, mas da coletividade em geral (uso comum do povo), razão pela qual se ampliou a legitimação para a propositura de ações que visam à sua proteção, inclusive. Assim, ainda que se fale em bem privado ou público, os bens ambientais têm características difusas e coletivas, cuja utilização deverá sempre respeitar os conceitos de sustentabilidade, sabidamente.

Com efeito, a interpretação sistemática de que o direito ao meio ambiente equilibrado é um direito fundamental, só foi possível a partir do momento em que ele passou a ser entendido como consequência do direito à vida. Note-se, por exemplo, que o art. 225 , da Constituição Federal, mais do que a vida, garantiu a qualidade de vida. A Conferência das Nações Unidas sobre o Meio Ambiente, na Declaração de Estocolmo/72, por exemplo, ressaltou que o homem tem direito fundamental a "adequadas condições de vida, em um meio ambiente de qualidade". ${ }^{19}$

O prof. Paulo de Bessa Antunes escreveu:

A fruição de um meio ambiente saudável e ecologicamente equilibrado foi erigida em direito fundamental pela ordem jurídica constitucional vigente. Este fato, sem dúvida, pode se revelar um notável campo para a construção de um sistema de garantias da qualidade de vida dos cidadãos e do desenvolvimento econômico que se faça com respeito ao Meio Ambiente. ${ }^{20}$

\footnotetext{
${ }^{19}$ http://www.silex.com.br/leis/normas/estocolmo.htm

${ }^{20}$ ANTUNES, Paulo de Bessa. Direito Ambiental. 7. ed. Rio de Janeiro: editora Lumen Juris, 2005. P. 63.
} 
No mesmo norte segue o consagrado José Afonso da Silva ${ }^{21}$ :

O que é importante - escrevemos de outra feita - é que se tenha a consciência de que o direito à vida, como matriz de todos os demais direitos fundamentais do Homem, é que há de orientar todas as formas de atuação no campo da tutela do meio ambiente. [...] a tutela da qualidade do meio ambiente é instrumental no sentido de que, através dela, o que se protege é um valor maior: qualidade de vida.

Consequentemente, depois de compreendido como direito fundamental, a necessidade de preservação do meio ambiente trouxe profundas alterações de interpretação do sistema jurídico nacional como um todo, as quais até pouco tempo atrás eram inaceitáveis. Por exemplo, uma delas foi a limitação do uso do direito de propriedade. Hoje as pessoas já não podem mais dispor da sua propriedade como lhe parecer melhor, havendo uma série de restrições urbanísticas e ambientais em prol do bem comum.

A propósito, ainda sobre a importância do direito ambiental como fundamental, há quem classifique os direitos humanos como de primeira, segunda e terceira geração, segundo o grau da sua valoração para com o homem. Assim, o Supremo Tribunal Federal, outro exemplo, no julgamento do Mandado de Segurança n. 22.164/SP, ocorrido no distante ano de 1995, cujo relator foi o Ministro Celso de Mello, bem posicionou o direito ambiental como de terceira geração, fruto da sua essencialidade para a qualidade de vida das pessoas, colocando-o não como um direito individual de cada um, mas acima de tudo como um direito coletivo de todos. O caso versou sobre a possibilidade de desapropriação de imóvel rural situado no Pantanal, para fins de reforma agrária.

Eis parte da ementa:

A norma inscrita no art. 225 , parágrafo 4ํㅡ, da Constituição não atua, em tese, como impedimento jurídico a efetivação, pela União Federal, de atividade expropriatória destinada a promover e a executar projetos de reforma agrária nas áreas referidas nesse preceito constitucional, notadamente nos imóveis rurais situados no pantanal mato-grossense. A própria Constituição da República, ao impor ao Poder Público o dever de fazer respeitar a integridade do patrimônio ambiental, não o inibe, quando necessária a intervenção estatal na esfera dominial privada, de promover a desapropriação de imóveis rurais para fins de reforma agrária, especialmente porque um dos instrumentos de realização da função social da propriedade consiste, precisamente, na submissão do domínio a necessidade de o seu titular utilizar adequadamente os recursos naturais disponíveis e de fazer preservar o equilíbrio do meio ambiente (CF, art. 186, II), sob pena de, em descumprindo esses encargos, expor-se a desapropriação-sanção a que se refere o art. 184 da Lei Fundamental. A questão do direito ao meio ambiente ecologicamente equilibrado - direito de terceira geração -

\footnotetext{
${ }^{21}$ SILVA, José Afonso da. Curso de Direito Constitucional Positivo. 13. ed. São Paulo: Malheiros, 1997. P. 67.
} 
princípio da solidariedade - o direito a integridade do meio ambiente - típico direito de terceira geração - constitui prerrogativa jurídica de titularidade coletiva, refletindo, dentro do processo de afirmação dos direitos humanos, a expressão significativa de um poder atribuído, não ao indivíduo identificado em sua singularidade, mas, num sentido verdadeiramente mais abrangente, a própria coletividade social. Enquanto os direitos de primeira geração (direitos civis e políticos) - que compreendem as liberdades clássicas, negativas ou formais - realçam o princípio da liberdade e os direitos de segunda geração (direitos econômicos, sociais e culturais) - que se identifica com as liberdades positivas, reais ou concretas - acentuam o princípio da igualdade, os direitos de terceira geração, que materializam poderes de titularidade coletiva atribuídos genericamente a todas as formações sociais, consagram o princípio da solidariedade e constituem um momento importante no processo de desenvolvimento, expansão e reconhecimento dos direitos humanos, caracterizados, enquanto valores fundamentais indisponíveis, pela nota de uma essencial inexauribilidade.

$\mathrm{Na}$ esteira desse raciocínio, sendo o direito ambiental um direito fundamental à sobrevivência humana, pode-se pensar que, fruto do progresso social e tecnológico, por exemplo, uma nova lei pode ser melhor e mais perfeita do ponto de vista ambiental. Sob a égide da lei anterior, determinada situação ambiental pode ser regular. Todavia, com base na nova lei, a situação pode inverter-se. E é ai que vem a pergunta: considerando os conceitos de ato jurídico perfeito e direito adquirido, a lei nova não pode retroagir? Há direito adquirido à perpetuação da poluição? O empreendedor que tem uma situação consolidada pode continuar poluindo? $\mathrm{O}$ meio ambiente como direito fundamental não é mais relevante do que o direito à segurança jurídica? 0 ato jurídico perfeito ou o direito adquirido, neste caso, justificam a manutenção da situação poluidora?

O mesmo se diga com relação à coisa julgada em matéria ambiental. Devido a sua natureza difusa e coletiva, os efeitos da sentença não estão limitados às partes, conforme estudado nos limites das ações coletivas, o que não deixa de ser uma forma de relativização da coisa julgada, não só em matéria ambiental, mas em sede de todos os direitos difusos e coletivos. Mas é preciso ir além. Ora, se a mitigação da coisa julgada ocorresse apenas nos expressos casos previstos em lei, como resolver-se-ia a seguinte situação: O MP ajuizou uma ação civil pública ambiental, que foi julgada improcedente com base nas provas produzidas nos autos, as quais naquele momento, de acordo com a tecnologia existente, apontaram a não ocorrência do dano ambiental. Posteriormente, transitada em julgado a decisão, novos estudos e novas tecnologias vieram a demonstrar a ocorrência de dano ambiental no local, o que não foi possível anteriormente, já passados os dois anos para a propositura da rescisória, a contar da descoberta da nova prova. Com base no art. 16 da Lei da Ação Civil Pública, como a sentença de improcedência se deu com fundamento na prova dos autos, ter-se-ia a coisa julgada material com efeitos erga omnis, o que 
impediria a propositura de nova ação civil pública. Assim, em nome do princípio da segurança das decisões judiciais, com base na coisa julgada, a poluição poderia continuar eternamente a ocorrer, perpetuando-se um verdadeiro direito de poluir? É claro que não!

A única saída possível é a relativização da coisa julgada em matéria ambiental. Tal qual a investigação de paternidade, agora com muito mais razão, porque o meio ambiente é um direito muito mais importante e socialmente relevante do que a identidade genética, haveria um confronto entre os direitos. De um lado o direito à segurança jurídica e de outro o direito a um meio ambiente saudável. Este confronto, evidentemente, deve ser dirimido em prol do meio ambiente, cuja proteção é condição de sobrevivência da própria humanidade.

Uma outra situação deve ser objeto de comentário, também em forma de exemplo prático. Imagine-se a descoberta de um poderoso inseticida, apto a matar pragas que infestam as lavouras e que, por isso, começou a ser largamente utilizado como defensor agrícola. Logo no início foi ajuizada ação civil pública cujo objeto era a paralização do seu uso, porque agredia sobremaneira o meio ambiente. Ocorreu, porém, que uma perícia concluiu sem sombra de qualquer dúvida que o referido inseticida mal nenhum causava ao ecossistema. Com base nesta prova o juiz julgou improcedente a ação, cuja sentença, depois de confirmada pelo Tribunal de Justiça, transitou em julgado, fazendo coisa julgada. Pois bem, passados mais de 10 anos, descobriu-se que o mesmo inseticida provoca grandes estragos ambientais, causando, inclusive, deformidades nas pessoas que comeram, por anos, os alimentos que ele visava "proteger". Pergunta-se: em nome da coisa julgada e do princípio da segurança jurídica, este inseticida pode continuar sendo aplicado nas lavouras?

Por fim, um outro exemplo foi muito bem colocado pelo incomparável Hugo Nigro Mazzili:

Tomemos agora um exemplo ligado à questão ambiental. Uma ação civil pública pode hoje resultar em improcedência, não por falta de provas, mas porque o juiz, desconsiderando a perícia, erroneamente entendeu que o resíduo emitido pela chaminé da fábrica do réu não é poluente; antes, conclui a sentença, o resíduo é saudável ou pelo menos é inócuo para o homem. Formada a coisa julgada com eficácia erga omnes, e vencida a oportunidade da rescisória, será que a humanidade ficará eternamente condenada a suportar a produção daqueles resíduos altamente tóxicos e prejudiciais? Pode ainda ocorrer que a sentença tenha sido dada por corrupção do juiz, e, embora as provas da corrupção já fossem conhecidas, pode já ter decorrido o prazo decadencial de dois anos para propor a ação rescisória. O que fazer? Não nos parece que esses casos versem relação jurídica continuativa, ao menos nos termos em que estariam colocadas nossas hipóteses. A sentença teria reconhecido que aquele resíduo não era poluente, não por falta de provas de que o fosse, mas por erro de julgamento ou até por corrupção do magistrado. Com a continuação da produção do 
mesmo dano, a rigor não teríamos uma alteração nem na situação de fato nem de direito, mas simplesmente o prosseguimento da mesma atividade poluidora preexistente. Não teriam surgido novos conhecimentos científicos que demonstrassem ser a atividade poluente, nem se teriam descoberto novas provas, nem teria havido alteração no ordenamento jurídico vigente. Teria, então, toda a coletividade, de suportar eternamente a imutabilidade da coisa julgada? Ora, não se pode admitir coisa julgada ou direito adquirido contra direitos fundamentais da humanidade. A verdade suprajurídica é a de que não existe nem pode existir o direito de violar o meio ambiente e destruir as condições do próprio habitat do ser humano. Como admitir a formação de direitos adquiridos e coisa julgada em detrimento até mesmo de gerações que ainda nem nasceram?! Cabe lembrar a advertência de Mauro Cappelletti, no sentido de que, em matéria de conflitos transindividuais, os tradicionais limites subjetivos e objetivos da coisa julgada "caem como um castelo de cartas". 6 Não que devam ser simplesmente desconsideradas todas as leis processuais em vigor, rasgando-se o Código de Processo Civil e demais leis adjetivas; não é disso que se trata. Mas sim, é necessário aplicar, com cuidados redobrados, normas que foram concebidas antes para solucionar meros conflitos individuais que lides coletivas, em épocas nas quais até então ainda não se tinha sequer cogitado de processos coletivos e de suas peculiaridades e implicações. ${ }^{22}$

Em matéria ambiental, portanto, definitivamente, diante do caráter irrespondível de todos estes exemplos, os efeitos da coisa em julgado devem ser tidos como relativos, em nome de um princípio maior: a própria sobrevivência humana, sob pena de admitir-se a possibilidade do seu aniquilamento, consequentemente.

\section{CONSIDERAÇÕES FINAIS}

Verificada, portanto, a contradição entre um direito fundamental de natureza difusa, como o meio ambiente, com um outro que busca aperfeiçoar as relações jurídicas, levando estabilidade aos atos judiciais, sem dúvida que a melhor hermenêutica leva à conclusão sensata que se deve ficar com o meio ambiente sempre, relativizando-se a coisa julgada. Até porque, na verdade, de nada adiantaria a preservação da coisa julgada se não houver mais vida a preservar. Do que serviria a imutabilidade dos efeitos de uma sentença transitada em julgado, que permitisse a poluição do planeta como um todo, levando a sua destruição. Preservar-se-ia a coisa julgada para quem?

\section{REFERÊNCIAS DAS FONTES CITADAS}

\section{LIEBMAN, Enrico Túlio. Eficácia e Autoridade da Sentença e outros escritos sobre a Coisa}

\footnotetext{
${ }^{22}$ MAZILLI, Hugo Nigro. http://www.mazzilli.com.br/pages/artigos/mitigacj.pdf.
} 
Julgada. Rio de Janeiro: Forense, 2006.

MARQUES, José Frederico. Instituições de Direito Processual Civil. Campinas, Milenium, 1999.

DANTAS, B. Direito fundamental à previsibilidade das decisões judiciais. Revista Justiça e Cidadania, edição 149, janeiro de 2013.

NERY JÚNIOR, Nelson; NERY, Rosa Maria de Andrade. Código de Processo Civil Comentado e Legislação Extravagante. 8. ed. São Paulo: Revista dos Tribunais, 2004.

DINAMARCO, Cândido Rangel. Relativizar a coisa julgada material. In Nova era do Processo Civil, São Paulo: Malheiros editores, 2004.

GRECO FILHO, Vicente Greco. Direito Processual Civil Brasileiro. 14. ed., Saraiva, 2000, 2. v. THEODORO JÚNIOR, Humberto. Curso de Direito Processual Civil. 48. ed. São Paulo: Forense, 2008.

THEODORO JUNIOR, Humberto. Prefácio escrito para a obra $\mathbf{O}$ dogma da coisa julgada: hipóteses de relativização. São Paulo: RT, 2003.

WAMBIER, Teresa Arruda Alvim; MEDINA, José Miguel Garcia. O Dogma da Coisa Julgada: hipóteses de relativização. São Paulo: RT, 2003.

CINTRA, Antônio Carlos de Araújo. GRINOVER, Ada Pellegrini. DINAMARCO, Cândido Rangel. Teoria Geral do Processo.

DIDIER JÚNIOR, Fredie. Curso de Direito Processual Civil. 5. ed. Salvador: Podivm, 2009. 2. v. DEOLGADO, José. Pontos Polêmicos das Ações de Indenização de Áreas Naturais Protegidas Efeitos da Coisa Julgada e os Princípios Constitucionais. Revista de Processo, ano 26, v. 103, São Paulo: Editora Revista dos Tribunais, 2001.

GRINOVER, Ada Pelegrini. Código brasileiro de defesa do consumidor: comentado pelos autores do anteprojeto. 8. ed. Rio de Janeiro: Forense Universitária, 2004.

ANTUNES, Paulo de Bessa. Direito ambiental. 7. ed. Rio de Janeiro: editora Lumen Juris, 2005. SILVA, José Afonso da. Curso de Direito Constitucional Positivo. 13. ed. São Paulo: Malheiros, 1997.

MAZILLI, Hugo Nigro. http://www.mazzilli.com.br/pages/artigos/mitigacj.pdf. 
